\title{
PROPERTIES OF CHEMICAL EXPLOSIVES AND EXPLOSIVE SIMULANTS
}

Compiled and edited by

Brigitta M. Dobratz

December 15, 1972

Prepared for U.S. Atomic Energy Commission under contract No. W-7405-Eng-48

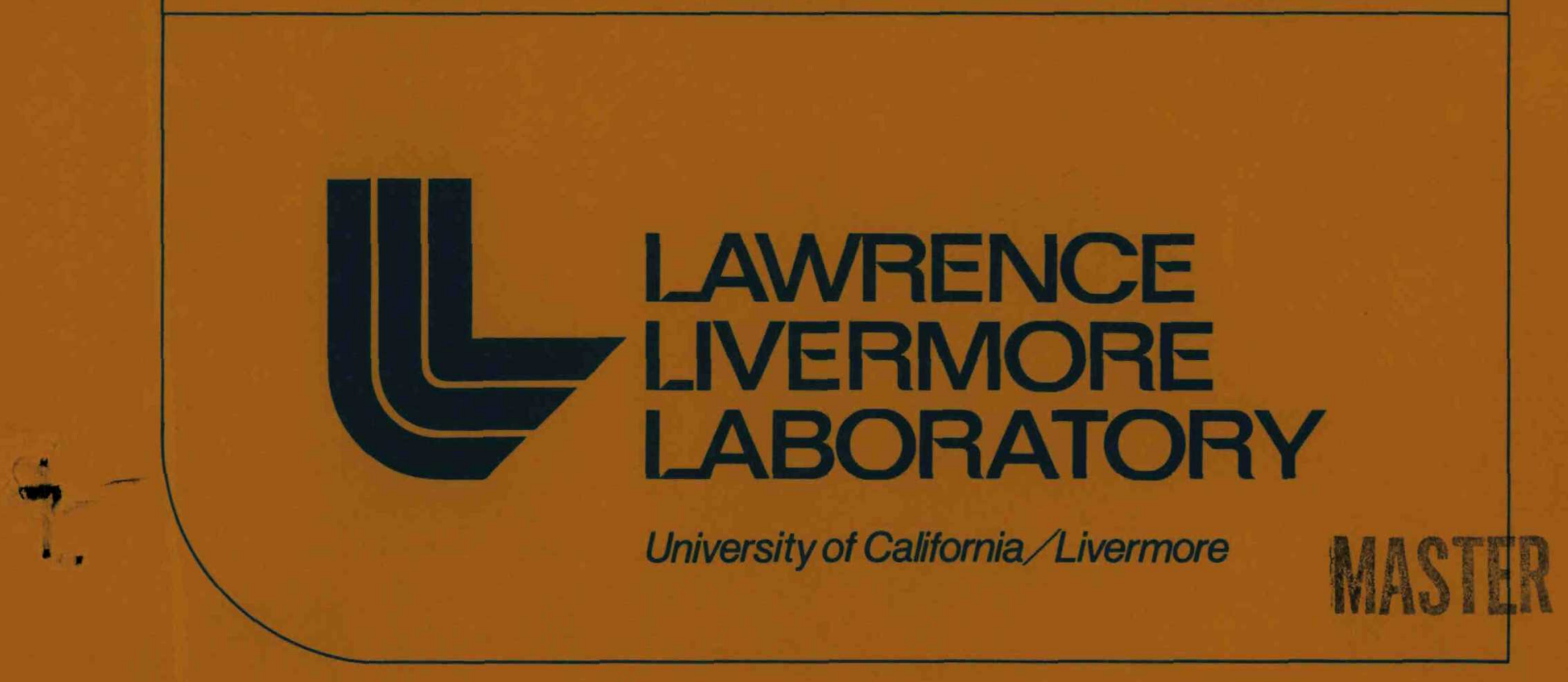

DISTRIBUTION OF THIS DOCUIMENT IS UNLIMITED

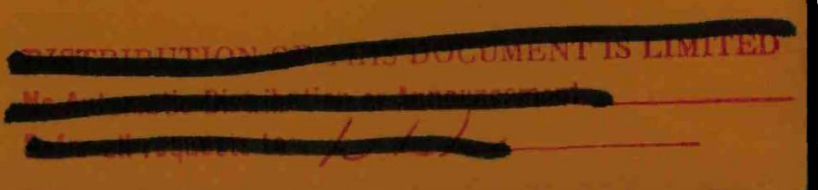




\section{DISCLAIMER}

This report was prepared as an account of work sponsored by an agency of the United States Government. Neither the United States Government nor any agency Thereof, nor any of their employees, makes any warranty, express or implied, or assumes any legal liability or responsibility for the accuracy, completeness, or usefulness of any information, apparatus, product, or process disclosed, or represents that its use would not infringe privately owned rights. Reference herein to any specific commercial product, process, or service by trade name, trademark, manufacturer, or otherwise does not necessarily constitute or imply its endorsement, recommendation, or favoring by the United States Government or any agency thereof. The views and opinions of authors expressed herein do not necessarily state or reflect those of the United States Government or any agency thereof. 


\section{DISCLAIMER}

Portions of this document may be illegible in electronic image products. Images are produced from the best available original document. 


\section{㢟 \\ LAMFENCE LNERMORE LABORATOFY

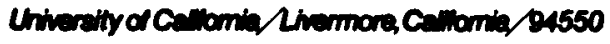

\section{UCRL-51319, Rev-, / \\ PROPERTIES OF CHEMICAL EXPLOSIVES AND EXPLOSIVE SIMULANTS}

\section{Compiled and edited by}

Brigitta M. Dobratz

MS. date: December 15, 1972

(Supersedes UCRL-6759, Vol. 1, and UCRL-14592)

This report was prepared as an account of work
sponsored by the United States Government. Neither
the United States nor the United States Atomic Energy
Commission, nor any of their employees, nor any of
their contractors, subcontractors, or their employees,
makes any warranty, express or implied, or assumes any
legal liability or responsibility for the accuracy, com.
pleteness or usefulness of any information, apparatus,
product or process disclosed, or represents that its use
would not infringe privately owned rights.


-

$\infty$ 


\section{Contents}

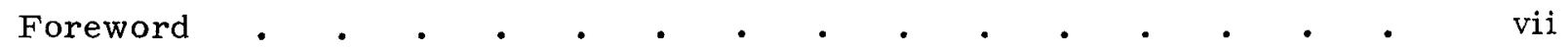

Conversion Factors

Glossary

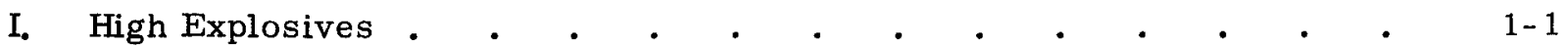

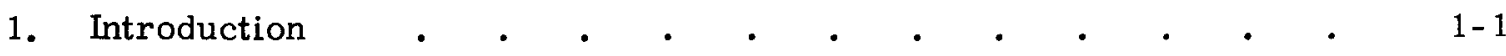

2. Manufacture . . . . . . . . . . . . .

Specifications $. \quad . \quad . \quad . \quad . \quad . \quad . \quad . \quad . \quad . \quad 2-1$

3. Names and Formulations . . . . . . . . . . . . . $3-1$

4. Physical Properties . . . . . . . . . . . . . . . . $4-1$

Physical State and Density $\quad . \quad$. $\quad . \quad . \quad . \quad . \quad . \quad .44-2$

Molecular Weight and Atomic Composition . . . . . 4-4

Melting Point, Boiling Point, and Vapor Pressure . . . 4-6

Crystallographic and Optical Properties . . . . . . . 4-9

References . . . . . . . . . . . . . $4-10$

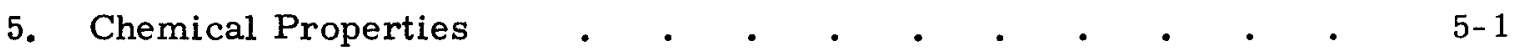

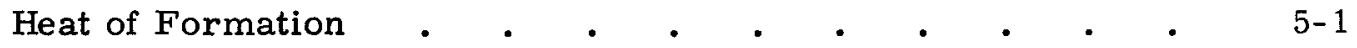

Heat of Detonation . . . . . . . . . . . . 5-

Compatibility . . . . . . . . . . .

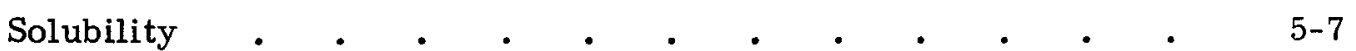

References . . . . . . . . . . . . 5-8

6. Thermal Properties . . . . . . . . . . 6-1

Thermal Conductivity . . . . . . . . . 6-1

Thermal Expansion . $. \quad . \quad . \quad . \quad . \quad . \quad . \quad . \quad .66-4$

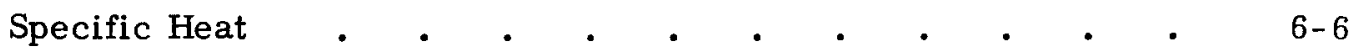

Thermal Stability . . . . . . . . . . 6-8

Thermal Stability of Larger Explosive Charges . . . 6-51

References . . . . . . . . . . . . 6 6-52

7. Mechanical Properties . . . . . . . . . . 7-1

Static Mechanical Properties . . . . . . . . 7-4

Initial Modulus . $. \quad . \quad . \quad . \quad . \quad . \quad . \quad . \quad .7-5$

Creep . . . . . . . . . . . . .

Stress-Strain Relationships . . . . . . . $7-8$

Failure Envelope . . . . . . . . . . $7-9$

Friction . . . . . . . . . . . 7-10

Complex Shear . . . . . . . . . . . . . . .

Dynamic Mechanical Properties . . . . . . . . . $7-15$

Compressive Stress-Strain and Tensile Strength • . .7-15

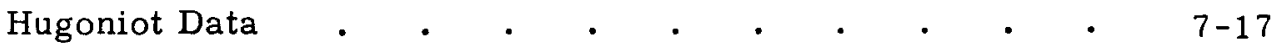

Sound Velocity $. \quad . \quad . \quad . \quad . \quad . \quad . \quad . \quad . \quad . \quad 7-21$ 
References . . . . . . . . . . . . . 7-23

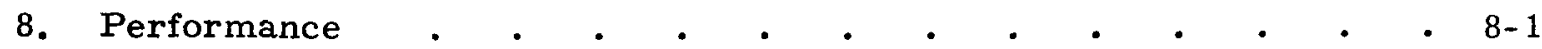

Detonation Velocity $. \quad . \quad . \quad . \quad . \quad . \quad . \quad . \quad . \quad . \quad$. $8-1$

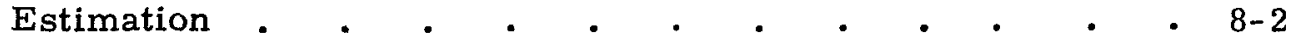

Equations . $. \quad . \quad . \quad . \quad . \quad . \quad . \quad . \quad . \quad . \quad .8-5$

Chapman-Jouguet Detonation Pressure . . . . . . $\quad$ 8-6

Cylinder Test Measurements of Explosive Energy . . . . 8-8

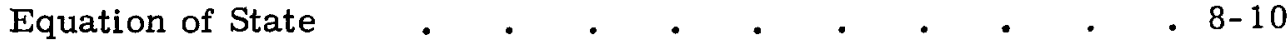

Detonation Energy $\quad . \quad . \quad . \quad . \quad . \quad . \quad . \quad . \quad . \quad .8-12$

References . . . . . . . . . . . . . . 8-14

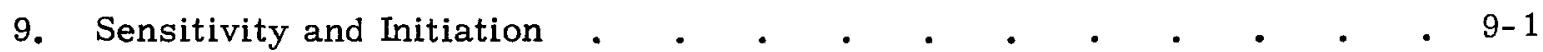

Drop Weight Test $•$ •

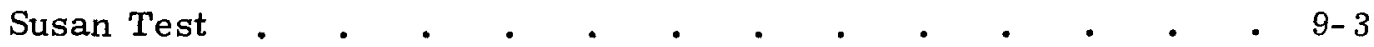

Comp B-3

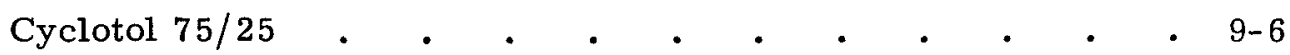

$\mathrm{LX}-02-1 \quad . \quad . \quad . \quad . \quad . \quad . \quad . \quad . \quad . \quad . \quad . \quad .9-7$

$\mathrm{LX}-04-1 \quad . \quad . \quad . \quad . \quad . \quad . \quad . \quad . \quad . \quad . \quad . \quad .9-8$

$\mathrm{LX}-07-2 \quad . \quad . \quad . \quad . \quad . \quad . \quad . \quad . \quad . \quad . \quad . \quad .9-9$

$\mathrm{LX}-09-0 \quad . \quad . \quad . \quad . \quad . \quad . \quad . \quad . \quad . \quad . \quad . \quad .9-10$

$\mathrm{LX}-10-0 \quad \cdot \quad \cdot \quad . \quad . \quad . \quad . \quad . \quad . \quad . \quad . \quad . \quad .9-11$

$\mathrm{LX}-11-0 \quad . \quad . \quad . \quad . \quad . \quad . \quad . \quad . \quad .9-12$

$\mathrm{LX}-14-0$. . . . . . . . . . . 9-13

Octol $75 / 25$. $\quad . \quad . \quad . \quad . \quad . \quad . \quad . \quad . \quad . \quad .9-14$

$\operatorname{PBX}-9010 . \quad . \quad . \quad . \quad . \quad . \quad . \quad . \quad .9-15$

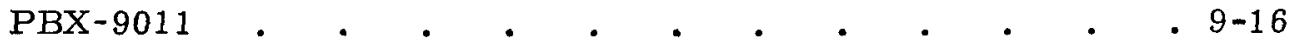

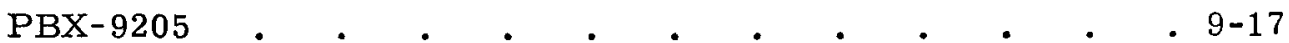

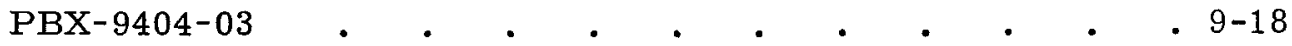

$\mathrm{PBX}-9501 . \quad . \quad . \quad . \quad . \quad . \quad . \quad . \quad .9-19$

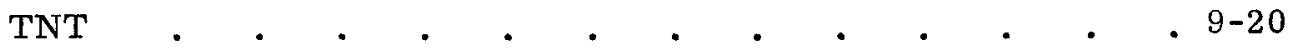

$\mathrm{XTX}-8003 . \quad . \quad . \quad . \quad . \quad . \quad . \quad . \quad .9-21$

Skid Test $. \quad . \quad . \quad . \quad . \quad . \quad . \quad . \quad . \quad . \quad . \quad . \quad \cdot 9-22$

Gap Test . . . . . . . . . . . . . $9-26$

Shock Initiation . . . . . . . . . . . . 9-29

Critical Energy . . . . . . . . . . . $9-29$

Initial Shock Pressure . . . . . . . . . 9-30

References . . . . . . . . . . . . . 9-32

10. Electrical Properties . . . . . . . . . . . . . $10-1$

Dielectric Constant . . . . . . . . . . . 10-1

References . . . . . . . . . . . . . 10-3

11. Toxicity

- 11-1

References . . . . . . . . . . . . . $111-2$ 
II. Mock Explosives

12. Introduction

13. Names and Formulations

14. Physical Properties

References

15. Thermal Properties

Thermal Conductivity and Specific Heat

Thermal Expansion

References

16. Mechanical Properties

Static Mechanical Properties

Initial Modulus

Tension Creep

Failure Envelope

Friction

Dynamic Mechanical Properties

Compressive Stress-Strain

Hugoniot Data

References

III. Code Designations

LLL Code Designations

Formulations in Production (LX Code)

Research Explosives (RX Code)

LASL Code Designations

IV. Data Sheets: Collected Properties of Explosives and

Energetic Materials

V. Bibliography

Chemical Analysis

General Reference Works

Health and Safety

Initiation and Sensitivity

Mechanical and Physical Properties

Performance

Radiation Effects

Thermal Properties 
a

-

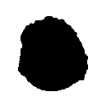




\section{Foreword}

This handbook presents information and data for high explosives of interest to programs of Lawrence Livermore Laboratory. The loose-leaf format is designed to permit easy revision and updating as new information and data become available. Thus, additions and corrections are welcomed by the compiler.

High Explosives (HE) are divided into two classes: initial detonating or primary explosives and noninitiating or secondary HEs. The primary HEs, such as azides and fulminates, are extremely sensitive to ignition by heat, shock, and electrical discharge; ignition goes to high-order detonation even for milligram quantities. Their use is therefore limited to squibs and starting materials for low-energy detonators. Since primary explosives have little application here, their properties have been specifically excluded from this compilation. Hereafter, secondary explosives are designated as HEs. Since many of the secondary high explosives (which are formulated and manufactured within the AEC complex) are mixtures, the properties of the additives and binders used have been included.

The data are the most up-to-date and accurate available to the knowledge of the compiler. Some data, however, can represent only a range, an approximation, or comparative values; this is especially true of explosive mixtures. Such cases are noted in the text as they occur. The sources of information include textbooks, journal articles, technical reports, memoranda, letters, and personal communications. Various schemes considered in the past to annotate the tables with the apposite references proved too cumbersome. However, an attempt is made in this revision and will be continued in subsequent revisions to provide precise references to the information and data presented. Data not specifically referenced were obtained from UCRL-14592 ${ }^{*}$; further information and additional references can be obtained from the compiler. References are listed at the end of each section.

The compilation consists of sections on high explosives and mock explosives, code designations, data sheets on individual materials, and a bibliography. A list of abbreviations precedes the section on high explosives. The data are given in the units (metric or English) in which they were reported originally. All values and units, however, are converted to the International System of Units (S.I.) ${ }^{\dagger}$; throughout this handbook the SI values are given in parentheses following the values in English or metric units. The units are given in the table below and on other tables and figures where used.

Reference to a company or product name in this compilation does not imply approval or recommendation of the product by the University of California or the U.S. Atomic Energy Commission to the exclusion of others that may be suitable.

\footnotetext{
*Properties of Chemical Explosives, Lawrence Livermore Laboratory, Rept. UCRL-14592 (1965).

$\dagger$ Metric Practice Guide, American Society for Testing and Materials, Philadelphia, E 380-70 (1970).
} 
CONVERSION FACTORS

Units and factors for conversion to SI system.

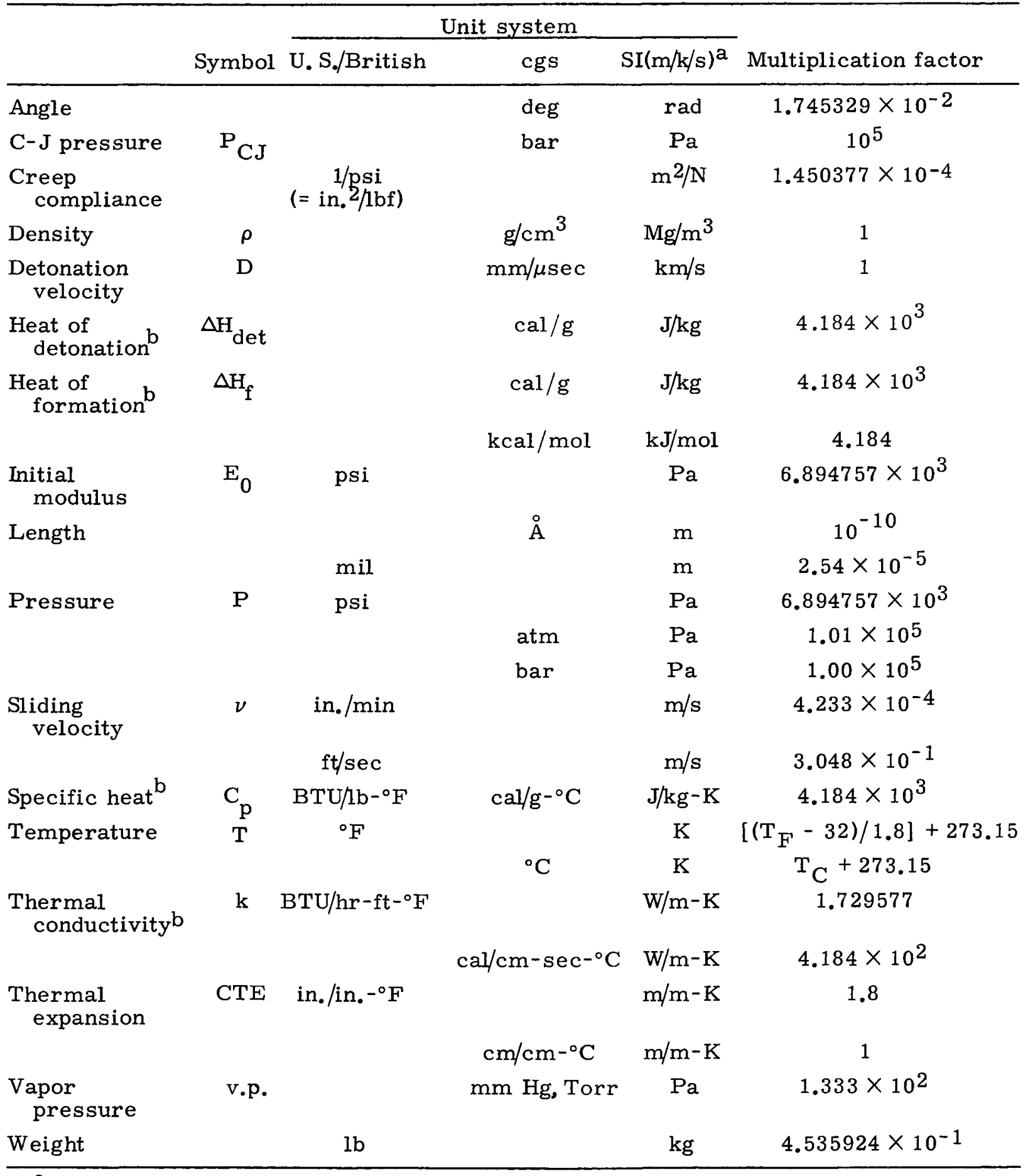

${ }^{a}$ In this column, the abbreviations used are those of the International System of Units (SI) ${ }^{2}$; in this system, degrees Kelvin $=\mathrm{K}$.

$\mathrm{b}_{\text {Thermochemical BTU or calorie. }}$ 


\section{Glossary}

AFNOL polymerization product of primarily DINOL and 4,4-dinitropimeloyl chloride

AWRE Atomic Weapons Research Establishment, U.K.

b.p. boiling point

BDNPA bis(2,2-dinitropropyl) acetal

BDNPF bis(2,2-dinitropropyl) formal

BEAF

1,2-ethanediol bisdifluoronitroacetate

BKW

Brinkley-Kistiakowski-Wilson (equation of state)

BTF

benzotrifuroxan

$c_{b}$

$\mathrm{c}_{\ell}$

$\mathrm{C}_{\mathrm{p}}$

$\mathrm{CAB}$

calculated bulk sonic velocity

calculated longitudinal velocity

specific heat

cellulose acetate butyrate

CEF

tris- $\beta$-chloroethyl phosphate

C J

Chapman-Jouguet

CTE

coefficient of thermal expansion

$\mathrm{D}$

detonation velocity

DATB

1,3-diamino-2,4,6-trinitrobenzene

dec.

decomposition

DFTNB

difluorotrinitrobenzene

DINOL

2,2,8,8-tetranitro-4,6-dioxa-1,9-nonane diol

DIPA M

$2,2^{\prime}, 4,4^{\prime}, 6,6^{\prime}$-diaminohexanitrobiphenyl, dipicramide

DMFA

dimethylformamide

DMSO dimethylsulfoxide

DNPA

2,2-dinitropropyl acrylate

DNPN

4,4-dinitropentanonitrile

DOP

$\mathrm{E}$

dioctylphthalate, di-(2-ethylh exyl)-phthalate

EDNP

energy

EGDN

ethyl 4,4-dinitropentanoate

$\mathrm{E}_{\mathrm{u}}$

ethylene glycol dinitrate

f

ultrasonic modulus

f.p.

coefficient of friction

FEFO

G

freezing point

bis(2-fluoro-2, 2-dinitroethyl) formal

$\mathrm{H}_{50}$

complex shear modulus

HE

drop weight sensitivity

HMX

high explosive

HNAB

$1,3,5,7$-tetranitro-1, 3, 5, 7 - tetrazacyclooctane

HNS

$2,2 ', 4,4 ', 6,6$ '-hexanitroazobenzene

HVD

$2,2 ', 4,4 ', 6,6$ '-hexanitrostilbene

$7 / 74$

high velocity detonation 


\begin{tabular}{|c|c|}
\hline JWL & Jones-Wilkins-Lee (equation of state) \\
\hline $\mathrm{K}$ & degrees Kelvin \\
\hline $\mathbf{k}$ & thermal conductivity \\
\hline LASL & Los Alamos Scientific Laboratory \\
\hline LLL & Lawrence Livermore Laboratory \\
\hline LVD & low velocity detonation \\
\hline m. p. & melting point \\
\hline MEK & methylethylketone \\
\hline MIBK & methylisobutylketone \\
\hline MW & molecular weight \\
\hline $\mathrm{N}$ & newton (pound-force) \\
\hline $\mathbf{n}$ & refractive index \\
\hline $\mathrm{NC}$ & nitrocellulose \\
\hline NG & nitroglycerine \\
\hline NM & nitromethane \\
\hline NOL & Naval Ordnance Laboratory \\
\hline NONA & nonanitroterphenyl \\
\hline NQ & nitroguanidine \\
\hline$P_{\mathrm{CJ}}$ & Chapman-Jouguet pressure \\
\hline PBX & plastic-bonded explosive \\
\hline PENTEK & pentaerythritol \\
\hline PETN & pentaerythritol tetranitrate \\
\hline PR & Poisson's ratio \\
\hline $\mathrm{R}$ & molecular refraction \\
\hline $\operatorname{RDX}$ & 1,3,5-trinitro-1, 3,5-triazacyclohexane \\
\hline RTV & room-temperature vulcanizing \\
\hline S. I. & Systeme Internationale (International System of Units) \\
\hline STP & standard temperature and pressure \\
\hline $\mathrm{T}$ & temperature \\
\hline $\mathrm{T}_{\mathrm{g}}$ & glass transition temperature \\
\hline TACOT & tetranitro-1, 2, 5, 6-tetrazadibenzocyclooctatetrene \\
\hline ТАТВ & 1,3,5-triamino-2, 4,6-trinitrobenzene \\
\hline TEF & tris- $\beta$-chloroethylphosphate \\
\hline Tetryl & $2,4,6$-trinitrophenylmethylnitramine \\
\hline THF & tetrahydrofuran \\
\hline TMD & theoretical maximum density \\
\hline TNM & tetranitromethane \\
\hline TNT & $2,4,6$-trinitrotoluene \\
\hline V & volume \\
\hline $\mathrm{v}$ & velocity \\
\hline v. p. & vapor pressure \\
\hline WLF & Williams-Landel-Ferry (shift equation) \\
\hline
\end{tabular}


$\alpha$

$\beta$

$\Delta \mathrm{H}_{\mathrm{det}}$

$\Delta \mathrm{H}_{\mathrm{f}}$

$\Gamma$

$\alpha$

$\beta$

$\epsilon$

$\nu$

$\rho$

linear coefficient of expansion

cubical coefficient of expansion

heat of detonation

heat of formation

adiabatic coefficient of expansion

linear CTE

cubical CTE

dielectric constant

sliding velocity

density 


\title{
PROPERTIES OF CHEMICAL EXPLOSIVES AND EXPLOSIVE SIMULANTS
}

\section{High Explosives}

\author{
1. INTRODUCTION
}

High explosives are metastable compounds or mixtures that can react rapidly to give gaseous products at high temperature and pressure. The attendant expansion of these products is the mechanism by which explosives do useful work. As with primary explosives, reaction can be initiated by shock and heat. High explosives, however, differ from primary explosives in three ways:

1. Small unconfined charges, even though ignited, will not usually detonate high-order.

2. Electrostatic ignition is very difficult (except in explosive dust clouds).

3. Ignition of any sort requires considerably larger shocks. 
1-2 


\section{MANUFACTURE}

Pure explosives are usually synthesized by sulfuric/nitric-acid nitration of organic compounds. The product is separated from the mixed acids by filtration, then worked free of impurities and dried.

TNT is one of the few pure explosives that can be fabricated directly by melting and casting into a desired shape. Most other materials must be diluted either with TNT (thereby castable) or with plastic (thereby pressable) before they can be fabricated into useful shapes.

The procedure used for fabricating castable, TNT-containing formulations is as follows: TNT is melted and the desired solid ingredients are added with stirring. The melt is precrystallized into a slurry, and vacuum is applied just before pouring into a mold. Cracking and variations in density and composition are minimized by careful control of the cooling rate.

Plastic-bonded explosives (PBX) are pressed from "molding" powders, which may be produced in several ways. A typical preparation is by the slurry technique: powdered explosive and water are agitated in a container equipped with cover, condenser, and stirrer. A lacquer composed of the plastic (together with a plasticizer, if required) dissolved in a suitable solvent is added to the slurry. The solvent is removed by distillation, causing the plastic phase to precipitate out onto the explosive as a coating. The plastic-explosive agglomerates into "beads" as the stirring and removal of solvent are continued. Finally, water is removed from the beads by filtering and drying, leaving the molding powder. Good molding powders have a high bulk density and are free-flowing and dustless.

PBX molding powder can be pressed into usable shapes by two methods: compression molding with steel dies, or hydrostatic or isostatic pressing. In the latter method the explosive is placed in rubber sacks and subjected to fluid pressure. With either method, consolidation of the molding powder to reasonable densities $(97 \%$ of theoretical) is obtained at pressures between 12,000 and $20,000 \mathrm{psi}$ (83 and $138 \mathrm{MPa}$ ) and molding temperatures between 25 and $120^{\circ} \mathrm{C}(298$ and $313 \mathrm{~K})$. An important and necessary feature of molding is the use of vacuum. The molding powder is normally evacuated to a pressure of less than $1000 \mu \mathrm{Hg}(133 \mathrm{~Pa})$ before pressing.

Both pressed and cast explosives are usually machined to final shape. Many intricate forms have been cut successfully. As a rule, the machining of explosives is similar to the machining of a conventional plastic, except that water is used as a cutting-tool coolant. New explosives are machined by remote control until their behavior under machining has been carefully evaluated.

\section{Specifications}

Manufacture and testing are controlled by specifications for production explosives. A list of pertinent specifications is given in Table 2-1. 
Table 2.1. Specifications for manufacture and testing.

\begin{tabular}{|c|c|c|}
\hline & $\begin{array}{l}\text { Specification } \\
\text { number }\end{array}$ & Title \\
\hline & & Explosives \\
\hline $\mathrm{BDNPA} / \mathrm{BDNP} P$ & WS- 1141 & $\begin{array}{l}\text { Weapons Specification for Mixture of } \\
\text { Bis }(2,2 \text {-dinitropropyl)acetal-Bis(2,2-dinitro-propyl) } \\
\text { formal. }\end{array}$ \\
\hline Comp B & MII_-C -401 & Military Specification for Composition B. \\
\hline Comp-B-3 & MIL-C-45113 & Military Specification for Composition B-3. \\
\hline FEFO & $R M-253202$ & $\begin{array}{l}\text { I I I Material Specification for I iquid Explosive } \\
\text { Bis (2,2-dinitro-2-fluoro-ethyl) formal (FEFO). }\end{array}$ \\
\hline HMX & MIL-H -45444 & Military Specification for HMX. \\
\hline HNAB & SS274590 & $\begin{array}{l}\text { Sandia Specification for Synthesis of HNAB (Hexa- } \\
\text { nitroaz obenzene). }\end{array}$ \\
\hline I X-04 & $\mathrm{RM}-252353$ & I I Material Specification for I X-04 Molding Powder. \\
\hline $\mathrm{LX}-07$ & RM-253379 & I I I Vaterial Specification for I X-07 Molding Powder. \\
\hline $\mathrm{LX}-09$ & R M-253200 & I I I Material Specification for I X-09 Molding Powder. \\
\hline $\mathrm{LX}-10$ & RM-253511 & I I I Material Specification for I X-10 Molding Powder. \\
\hline $\mathrm{LX}-13$ & RM-253520 & I I I General Specific ation for I X-13. (CRD) \\
\hline Octol & MII $-\mathrm{O}-45445$ & Military Specification for Octol. \\
\hline $\mathrm{PBX}-9007$ & $P A-P D-711$ & $\begin{array}{l}\text { Pic atinny Arsenal Purchase Description for Powder, } \\
\text { Volding Compound Explosive (PBX). (PBX-9007). }\end{array}$ \\
\hline PBX-9011 & $13 \mathrm{Y}-101030$ & $\begin{array}{l}\text { I ASI Material Specification for PBX-9011 Molding } \\
\text { Powder. }\end{array}$ \\
\hline PBX-9205 & $13 Y-103317$ & $\begin{array}{l}\text { I ASI Vaterial Specification for PBX-9205 Manufac- } \\
\text { tured by the Slurry Vethod. }\end{array}$ \\
\hline \multirow[t]{2}{*}{ PBX-9404 } & $13 Y-103159$ & $\begin{array}{l}\text { I ASI Vaterial Specification for PBX-9404 Moldıng } \\
\text { Powder. }\end{array}$ \\
\hline & $\mathrm{RM}-252336$ & $\begin{array}{l}\text { I I I Vaterial Specification for PBX-9404 Molding } \\
\text { Powder. }\end{array}$ \\
\hline PBX -9407 & $13 Y-109098$ & $\begin{array}{l}\text { I ASI Material Specification for PBX-9407 Molding } \\
\text { Powder. }\end{array}$ \\
\hline PBX-9501 & $13 y-109643$ & $\begin{array}{l}\text { I ASI Material Specification for PBX-9501 Molding } \\
\text { Powder. }\end{array}$ \\
\hline PETN & MII - P- 387 & $\begin{array}{l}\text { Ullitary Specific ation for Pentaerythritol Tetranitrate } \\
\text { (PFTN). }\end{array}$ \\
\hline $\operatorname{RDX}$ & MII - R-398 & Military Specification for RDY. \\
\hline Tetryl & JAN-T-339 & $\begin{array}{l}\text { Joint Army-Navy Specification for Tetryl } \\
\text { (Trinitrophenylmethylnitramine). }\end{array}$ \\
\hline TNT & MII - I-248 & Military Sper sfic ation for $\mathrm{TNT}$ \\
\hline \multirow[t]{2}{*}{$\mathrm{XTX}-8003$} & $13 Y-104481$ & $\begin{array}{l}\text { I ASI Material Specification for XTX-8003 Extrudable } \\
\text { Explosive. }\end{array}$ \\
\hline & & Binders \\
\hline Estane & $13 Y-101031$ & I ASI Material Specification for Estane $5740 \mathrm{X}-2$. \\
\hline $\begin{array}{l}\text { Fluoro- } \\
\quad \text { elastomer }\end{array}$ & R M-252988 & $\begin{array}{l}\text { LI I Material Specification for Uncured Fluoro- } \\
\text { elastomer Binder }\end{array}$ \\
\hline pDNPA & RM-253201 & $\begin{array}{l}\text { I I I Material Specification for 2,2-Dinitropropyl- } \\
\text { acrylate Polymer (pDNPA) Plastic Binder }\end{array}$ \\
\hline Polystyrene & MIL-P-55026 & $\begin{array}{l}\text { Military Specification for Polystyrene, Unmodified } \\
\text { (For Use as a Binder in Explosives). }\end{array}$ \\
\hline Sylgard & $13 Y-104480$ & $\begin{array}{l}\text { I ASI Material Specification for Dow Corning Resin } \\
93-022 \text { (Aerospace Grade Sylgard 182). }\end{array}$ \\
\hline
\end{tabular}

Explosive Parts and Testing

RM-253391 I I L Specification for Mechanical Properties Testing of Plastic-Bonded High Explosive Parts.

RM-252356 I.I L General Specifications for Plastic-Bonded High Explosives. 


\section{NAMES AND FORMULATIONS}

This section consists of Tables 3-1 through 3-4, which list the names and formulations of various explosives and energetic compounds.

Table 3-1. Pure explosive compounds.

\begin{tabular}{|c|c|c|c|}
\hline Material $^{\mathrm{a}}$ & Chemical name & Other designations & Color \\
\hline B'TE & $\begin{array}{l}\text { Benzotris- }[1,2,5] \text { oxadiazole- } \\
{[4,4,7]-\text { trioxide }}\end{array}$ & $\begin{array}{l}\text { Benzotrifuroxan, } \\
\text { hexanitrosobenzene }\end{array}$ & Buff \\
\hline DATB & $\begin{array}{l}\text { 1, } 3 \text {-Diamino- } 2,4,6-\text { trinitro- } \\
\text { benzene }\end{array}$ & & Yellow \\
\hline DIPAM & $\begin{array}{l}3,3 \text {-Diamino- } 2,2^{\prime}, 4,4^{\prime}, 6,6^{\prime}- \\
\text { hexamitrobiphenyl }\end{array}$ & $\begin{array}{l}\text { Hexanitrodiphenyl- } \\
\text { amine hexite, } \\
\text { dipicrylamine }\end{array}$ & - \\
\hline DNPA & 2,2-Dinitropropyl acrylate & & Off-white \\
\hline EDNP & Ethyl-4,4-dinitropentanoate & & Yellow \\
\hline FEFO & $\begin{array}{l}\text { Bis }(2-\text { fluoro-2, 2-dinitroethyl)- } \\
\text { formal }\end{array}$ & & Straw \\
\hline $\mathrm{HMX}$ & $\begin{array}{l}1,3,5,7 \text {-Tetranitro- } 1,3,5,7- \\
\text { tetraazacyclooctane }\end{array}$ & $\begin{array}{l}\text { Cyclotetramethylene } \\
\text { tetranitramine, } \\
\text { octogen }\end{array}$ & White \\
\hline HNAB & $\begin{array}{l}2,2^{\prime}, 4,4^{\prime}, 6,6^{\prime} \text {-Hexanitroazo- } \\
\text { benzene }\end{array}$ & & Orange \\
\hline HNS & $2,2^{\prime}, 4,4^{\prime}, 6,6^{\prime}$-Hexanitrostılbene & & Yellow \\
\hline NC $(12 \% N)^{b}$ & Partially nitrated cellulose & $\begin{array}{l}\text { Nitrocellulose } \\
\text { (lacquer grade), } \\
\text { cellulose trinitrate, } \\
\text { piroksilin }\end{array}$ & White \\
\hline $\begin{array}{l}\mathrm{NC}(13,35 \% \mathrm{~N} \\
\min )^{\mathrm{b}}\end{array}$ & Partially nitrated cellulose & $\begin{array}{l}\text { Nitrocellulose, } \\
\text { guncotton }\end{array}$ & White \\
\hline NG & $1,2,3$-Propanetriol trinitrate & Nitroglycerin & Clear \\
\hline $\mathrm{NM}$ & Nitromethane & & Clear \\
\hline NQ & Nitroguanidine & Aminomethaneamidine & White \\
\hline PE'TN & Pentaerythritol tetranitrate & Penthrite, TEN & White \\
\hline $\mathrm{RDX}$ & $\begin{array}{l}1,3,5 \text {-Trinitro- } 1,3,5 \text {-triaza- } \\
\text { cyclohexane, hexahydro- } \\
1,3,5 \text {-trinitro-s-triazıne }\end{array}$ & $\begin{array}{l}\text { Cyclotrimethylene } \\
\text { trinitramine, } \\
\text { hexogen cyclonite, Gh }\end{array}$ & White \\
\hline TACOT & $\begin{array}{l}\text { Tetranitro- } 1,2,5,6 \text {-tetraazad } 1- \\
\text { benzocyclooctatetrene }\end{array}$ & $\begin{array}{l}\text { Tetranitrodıbenzo- } \\
\text { 1, 3a, 4,6a- } \\
\text { tetraazapentalene }\end{array}$ & $\begin{array}{l}\text { Red- } \\
\text { orange }\end{array}$ \\
\hline TA TB & $\begin{array}{l}\text { 1, } 3,5 \text {-Triamino- } 2,4,6-\text { trinitro- } \\
\text { benzene }\end{array}$ & & $\begin{array}{l}\text { Bright } \\
\text { yellow }\end{array}$ \\
\hline "Tetryl & $\begin{array}{l}2,4,6 \text { - Trinitrophenylmethyl- } \\
\text { nitramine }\end{array}$ & & Yellow \\
\hline TNM & Tetranitromethane & & Clear \\
\hline "TNT & $2,4,6-\operatorname{Tr} ı$ nitrotoluene & Trotyl, T, tol & $\begin{array}{l}\text { Buff to } \\
\text { brown }\end{array}$ \\
\hline
\end{tabular}

\footnotetext{
${ }^{a}$ Properties of materials marked with asterisks are summarized in data sheets (Section IV).

${ }^{b}$ Nitrocellulose is not, strictly speaking, a single chemical compound. Different grades are commercially avallable, the grade denoting the degree of nitration. For this handbook we cite, where possible, data characteristic of lacquer-grade nitrocellulose $(12.0 \% \mathrm{~N})$ and guncotton $(13.35 \% \mathrm{~N}, \mathrm{~min})$. Lacquer-grade nitrocellulose is not an explosive but an energy-contributing plastic binder in PBX-9404. 
Table 3-2. Cast explosives: names and formulations.

\begin{tabular}{|c|c|c|c|c|}
\hline \multirow{3}{*}{$\frac{\text { Explosive }^{\mathrm{a}}}{\text { Baratol }}$} & \multicolumn{4}{|c|}{ Formulation $(w t \%)^{b}$} \\
\hline & \multirow{2}{*}{$\frac{\text { TNT }}{24}$} & \multirow[t]{2}{*}{ RDX } & \multicolumn{2}{|c|}{ Other ingredients } \\
\hline & & & $\mathrm{Ba}\left(\mathrm{NO}_{3}\right)_{2}$ & 76 \\
\hline Boracitol & 40 & & Boric acid & 60 \\
\hline *Comp B, Grade $A^{c}$ & 36 & 63 & Wax & 1 \\
\hline Comp B-3 & 40 & 60 & & \\
\hline$*$ Cyclotol $^{\mathrm{d}}$ & 25 & 75 & & \\
\hline \multirow[t]{3}{*}{$\mathrm{H}-6$} & 30 & 45 & Wax & 5 \\
\hline & & & $\mathrm{Al}$ & 20 \\
\hline & & & $\mathrm{CaCl}_{2}$ & 0.5 \\
\hline *Octol & 25 & & HMX & 75 \\
\hline *Pentolite ${ }^{d}$ & 50 & & PETN & 50 \\
\hline Tritonal & 80 & & $\mathrm{Al}$ & 20 \\
\hline
\end{tabular}

\footnotetext{
${ }^{a}$ Properties of materials marked with asterisks are summarized in data sheets (Section IV).

$\mathrm{b}_{\text {The weight percent values given in the table are nominal }}$ and subject to some variation.

${ }^{\mathrm{C}}$ Comp B, Grade A is formulated as a $60 / 40 \mathrm{RDX} / \mathrm{TNT}$ mixture, but high-quality castings usually are higher in RDX content due to the removal of a TNT-rich section at the top of the casting.

$\mathrm{d}_{\text {There are several cyclotols and pentolites. The most }}$ common cyclotol is RDX/TNT 75/25. The most common pentolite is PETN/TNT 50/50.
} 
Table 3-3. Plastic-bonded explosives: Names and formulations.

\begin{tabular}{|c|c|c|c|c|}
\hline \multirow[b]{2}{*}{ Explosive $^{a}$} & \multirow[b]{2}{*}{ Other designations } & \multicolumn{2}{|c|}{ Formulation } & \multirow[b]{2}{*}{ Color } \\
\hline & & Ingredient & $\mathrm{wt} \%$ & \\
\hline *LX-04-1 & PBHV-85/ 15 & $\begin{array}{l}\text { HMX } \\
\text { Viton A }\end{array}$ & $\begin{array}{l}85 \\
15\end{array}$ & Yellow \\
\hline$* L X-07-2$ & $\mathrm{RX}-04-\mathrm{BA}$ & $\begin{array}{l}\mathrm{HMX} \\
\text { Viton A }\end{array}$ & $\begin{array}{l}90 \\
10\end{array}$ & Orange \\
\hline$* \mathrm{LX}-09-0$ & $R X-09-C B$ & $\begin{array}{l}\text { HMX } \\
\text { pDNPA } \\
\text { FEFO }\end{array}$ & $\begin{array}{l}93 \\
4.6 \\
2.4\end{array}$ & Purple \\
\hline$L X-09-1$ & & $\begin{array}{l}\text { HMX } \\
\text { pDNPA } \\
\text { FEFO }\end{array}$ & $\begin{array}{r}93.3 \\
4.4 \\
2.3\end{array}$ & Purple \\
\hline$* \mathrm{LX}-10-0$ & RX-04-DE & $\begin{array}{l}\text { HMX } \\
\text { Viton A }\end{array}$ & $\begin{array}{r}95 \\
5\end{array}$ & $\begin{array}{l}\text { Blue-green spots } \\
\text { on white }\end{array}$ \\
\hline $\mathrm{LX}-10-1$ & & $\begin{array}{l}\text { HMX } \\
\text { Viton A }\end{array}$ & $\begin{array}{r}94.5 \\
4.5\end{array}$ & $\begin{array}{l}\text { Blue-green spots } \\
\text { on white }\end{array}$ \\
\hline$* L X-11-0$ & $\mathrm{RX}-04-\mathrm{PI}$ & $\begin{array}{l}\mathrm{HMX} \\
\text { Viton A }\end{array}$ & $\begin{array}{l}80 \\
20\end{array}$ & White \\
\hline$* \mathrm{LX}-14-0$ & & $\begin{array}{l}\text { HMX } \\
\text { Estane } \\
\quad 5702-\mathrm{F} 1\end{array}$ & $\begin{array}{r}95.5 \\
4.5\end{array}$ & $\begin{array}{l}\text { Violet spots } \\
\text { on white }\end{array}$ \\
\hline$* \mathrm{PBX}-9007$ & PBX-9007 Type B & $\begin{array}{l}\text { RDX } \\
\text { Polystyrene } \\
\text { Di(2-ethyl- } \\
\text { hexyl)- } \\
\text { phthalate } \\
\text { Rosin }\end{array}$ & $\begin{array}{l}90 \\
9.1 \\
0.5 \\
0.4\end{array}$ & $\begin{array}{l}\text { White or mottled } \\
\text { grayb }\end{array}$ \\
\hline$* \mathrm{PBX}-9010$ & & $\begin{array}{l}\text { RDX } \\
\text { Kel-F }\end{array}$ & $\begin{array}{l}90 \\
10\end{array}$ & White \\
\hline$* \mathrm{PBX}-9011$ & $X-0008$ & $\begin{array}{l}\text { HMX } \\
\text { Estane } \\
\quad 5740-\mathrm{X} 2\end{array}$ & 90 & Off-white \\
\hline$* P B X-9205$ & & $\begin{array}{l}\text { RDX } \\
\text { Palystyrene } \\
\text { Di(2-ethyl- } \\
\text { hexyl)- } \\
\text { phthalate }\end{array}$ & $\begin{array}{r}92 \\
6 \\
\\
2\end{array}$ & White \\
\hline$*$ PBX -9404 & PBX $-9404-03$ & $\begin{array}{l}\text { HMX } \\
\text { NC }(12.0 \% \text { N }) \\
\text { Tris }(\beta \text {-chloro- } \\
\text { ethyl)- } \\
\text { phasphate }\end{array}$ & $\begin{array}{r}94 \\
3 \\
\\
3\end{array}$ & White or blue \\
\hline * PBX -9407 & & $\begin{array}{l}\operatorname{RDX} \\
\text { Exon } 461\end{array}$ & $\begin{array}{r}94 \\
6\end{array}$ & White or black ${ }^{b}$ \\
\hline$*$ PBX-9501 & & $\begin{array}{l}\text { HMX } \\
\text { Estane } \\
\text { BDNPA } \\
\text { BDNPF }\end{array}$ & $\begin{array}{l}95 \\
2.5 \\
1.25 \\
1.25\end{array}$ & White \\
\hline
\end{tabular}

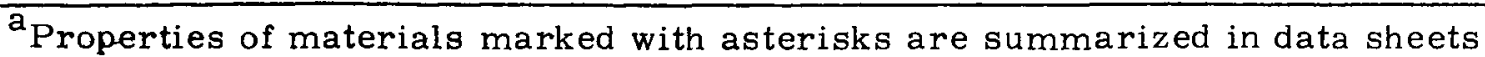
(Section IV).

$\mathrm{b}_{\text {Depending on graphite content. }}$ 
Table 3-4. Miscellaneous explosives: Names and formulations.

\begin{tabular}{|c|c|c|c|c|}
\hline \multirow[b]{2}{*}{ Explosive ${ }^{a}$} & \multirow[b]{2}{*}{ Other designations } & \multicolumn{2}{|l|}{ Formulation } & \multirow[b]{2}{*}{ Color } \\
\hline & & Ingredient & wt $\%$ & \\
\hline Comp C-4 & & $\begin{array}{l}\text { RDX } \\
\text { Di(2-ethylhexyl)- } \\
\text { sebacate } \\
\text { Polyisobutylene } \\
\text { Motor oil }\end{array}$ & $\begin{array}{l}91 \\
\\
5.3 \\
2.1 \\
1.6\end{array}$ & White \\
\hline$E L-506 A$ & & $\begin{array}{l}\text { PETN } \\
\text { Binder }\end{array}$ & $\begin{array}{l}85 \\
15\end{array}$ & Red \\
\hline$E L-506 C$ & & $\begin{array}{l}\text { PETN } \\
\text { Binder }\end{array}$ & $\begin{array}{l}63 \\
37\end{array}$ & Red \\
\hline$* \mathbf{L X}-01$ & NTN & $\begin{array}{l}\text { Nitromethane } \\
\text { Tetranitromethane } \\
1 \text {-Nitropropane }\end{array}$ & $\begin{array}{l}51.7 \\
33.2 \\
15.1\end{array}$ & Clear \\
\hline *LX-02-1 & EL-506 L-3 & $\begin{array}{l}\text { PETN } \\
\text { Butyl rubber } \\
\text { Acetyltributyl } \\
\text { citrate } \\
\text { Cab-O-Sil }\end{array}$ & $\begin{array}{r}73.5 \\
17.6 \\
6.9 \\
2.0\end{array}$ & Buff \\
\hline *LX-08 & & $\begin{array}{l}\text { PETN } \\
\text { Silicone rubber } \\
\text { Cab-O-Sil }\end{array}$ & $\begin{array}{r}63.7 \\
34.3 \\
2.0\end{array}$ & Blue \\
\hline $\mathrm{LX}-13$ & & $\begin{array}{l}\text { PETN } \\
\text { Silicone rubber }\end{array}$ & $\begin{array}{l}80 \\
20\end{array}$ & Green \\
\hline MEN-II & $\mathrm{RX}-01-\mathrm{AC}$ & $\begin{array}{l}\text { Nitromethane } \\
\text { Methanol } \\
\text { Ethylenediamine }\end{array}$ & $\begin{array}{r}72.2 \\
23.4 \\
4.4\end{array}$ & Clear \\
\hline$* \mathrm{XTX}-8003$ & Extex & $\begin{array}{l}\text { PETN } \\
\text { Silicone rubber }\end{array}$ & $\begin{array}{l}80 \\
20\end{array}$ & White \\
\hline
\end{tabular}

\footnotetext{
${ }^{a}$ Properties of materials marked with asterisks are summarized in data sheets (Section IV).
} 
Table 3-5. Additives and binders.

\begin{tabular}{|c|c|c|c|}
\hline Material $^{\mathrm{a}}$ & Chemical name & Other designation & Color \\
\hline $\mathrm{BDNPA} / \mathrm{BDNPF}$ & $\begin{array}{l}\text { Bis }(2,2 \text {-dinitropropyl) acetal/ } \\
\text { bis }(2,2 \text {-dinitropropyl) formal } 50 / 50 \mathrm{w} / \mathrm{o}\end{array}$ & & Straw \\
\hline Cab-O-Sil M-5 & & & White \\
\hline DOP & Di (2-ethylhexyl)-phthalate & dioctylphthalate & Clear \\
\hline Estane $5702-\mathrm{F} 1$ & & $\begin{array}{l}\text { polyurethane } \\
\text { solution system }\end{array}$ & $\begin{array}{l}\text { Light } \\
\text { amber }\end{array}$ \\
\hline Exon 461 & $\begin{array}{l}\text { Trifluorochloroethylene/ } \\
\text { vinylidine chloride copolymer }\end{array}$ & & White \\
\hline Kel-F 800 & Poly(trifluorochloroethylene) & & Off-white \\
\hline $\mathrm{Kel}-\mathrm{F} 3700$ & Poly(trifluorochloroethylene) & & Off-white \\
\hline Polystyrene & & & Clear \\
\hline Sylgard 182 & & Silicone resin & Light straw \\
\hline TEF & Tris- $\beta$-chloroethyl phos phate & & Clear \\
\hline Viton A & $\begin{array}{l}\text { Hexafluoropropylene/ } \\
\text { vinylidine fluoride } 1: 2\end{array}$ & . & White \\
\hline
\end{tabular}

\footnotetext{
${ }^{a}$ Properties of these materials are summarized in data sheets (Section IV).
} 


\section{PHYSICAL PROPERTIES}

This section contains information relating to selected physical constants and properties of HEs of interest. These properties are physical state and density (Table 4-1); molecular weight MW and atomic composition (Table 4-2); melting point m. p., boiling point b. p., and vapor pressure v.p. (Table 4-3 and Fig. 4-1); crystallographic and optical properties (Table 4-4).

Many properties are density-dependent. For calculations for mixtures, some useful auxiliary relationships between composition and density are as follows:

$$
\begin{aligned}
\rho(\mathrm{TMD}) & =\frac{\sum \mathrm{m}_{\mathrm{i}}}{\sum\left(\mathrm{m}_{\mathrm{i}} / \rho_{\mathrm{i}}\right)}=\frac{\sum\left(\mathrm{v}_{\mathrm{i}} \rho_{\mathrm{i}}\right)}{\sum \mathrm{v}_{\mathrm{i}}}, \\
\mathrm{v}_{\mathrm{i}} & =\mathrm{w}_{\mathrm{i}}\left(\rho_{0} / \rho_{\mathrm{i}}\right)=\frac{\mathrm{v}_{\mathrm{i}}}{\sum \mathrm{v}_{\mathrm{i}}}=\frac{100 \mathrm{~m}_{\mathrm{i}} / \rho_{\mathrm{i}}}{\sum\left(\mathrm{m}_{\mathrm{i}} / \rho_{\mathrm{i}}\right)}, \\
\mathrm{W}_{\mathrm{i}} & =\frac{100 \mathrm{v}_{\mathrm{i}} \rho_{\mathrm{i}}}{\sum\left(\mathrm{v}_{\mathrm{i}} \rho_{\mathrm{i}}\right)}=\frac{100 \mathrm{~m}_{\mathrm{i}}}{\sum \mathrm{m}_{\mathrm{i}}}, \\
\text { Void } \mathrm{v}_{\mathrm{i}} & =1-\left(\rho_{0} / \mathrm{TMD}\right),
\end{aligned}
$$

where TMD is theoretical maximum density, $m$ is mass, $v$ is volume, $W$ is weight percent, $\mathrm{V}$ is volume percent, $\rho$ is theoretical density, subscript $i$ designates the component, and $\rho_{0}$ is the actual density of the mixture. 
Physical State and Density

Table 4-1. Physical States and densities.

\begin{tabular}{|c|c|c|c|}
\hline \multirow[b]{2}{*}{ Material } & \multirow[b]{2}{*}{ Physical state } & $T_{M D}^{\mathrm{a}}, \rho$ & Nominal density, $\rho$ \\
\hline & & $\left(\mathrm{g} / \mathrm{cm}^{3}\left(\mathrm{Mg} / \mathrm{m}^{3}\right)\right)$ & $\left(\mathrm{g} / \mathrm{cm}^{3} \quad\left(\mathrm{Mg} / \mathrm{m}^{3}\right)\right)$ \\
\hline AFNOL & Liquid & 1.48 & 1.48 \\
\hline Baratol & Solid & 2.63 & $2.60-2.61$ \\
\hline $\mathrm{BDNPA} / \mathrm{BDNPF}{ }^{2}$ & Liquid & $1.383-1.397$ & - \\
\hline Boracitol & Solid & $\longrightarrow^{\mathrm{b}}$ & $1.53-1.54$ \\
\hline $\mathrm{BTF}$ & Solid & 1.901 & 1.87 \\
\hline $\mathrm{Cab}-\mathrm{O}-\mathrm{Sil}^{3}$ & Solid & 2.3 & 2.2 \\
\hline Comp B, Grade A & Solid & 1.74 & 1.71 \\
\hline Comp B-3 & Solid & 1.75 & 1.72 \\
\hline Comp C-4 & Puttylike solid & $\longrightarrow$ & 1.59 \\
\hline Cyclotol 75/25 & Solid & 1.77 & $1.75-1.76$ \\
\hline DA TB & Solid & 1.837 & 1.79 \\
\hline DIPA M ${ }^{4}$ & Solid & 1.79 & - \\
\hline DNPA & Solid & 1.47 & - \\
\hline DOP & Liquid & 0.9861 & - \\
\hline EDNP & Liquid & 1.28 & $\longrightarrow$ \\
\hline EL-506A & Solid & - & 1.48 \\
\hline$E L-506 C$ & Solid & - & 1.48 \\
\hline Estane $^{5}$ & Rubbery solid & - & 1.18 \\
\hline Exon $461^{6}$ & Solid & $\longrightarrow$ & 1.70 \\
\hline FEFO & Liquid & 1.607 & - \\
\hline $\mathrm{H}-6$ & Solid & - & 1.74 (cast) \\
\hline $\mathrm{HMX}$ & Solid & 1.900 & 1.89 \\
\hline $\mathrm{HNAB}-\mathrm{I}^{7}$ & Solid & $\begin{array}{l}1.795 \text { calc. } \\
1.799 \text { obs. }\end{array}$ & $\longrightarrow$ \\
\hline $\mathrm{HNAB}-\mathrm{II}^{7}$ & Solid & $\begin{array}{l}1.744 \text { calc. } \\
1.750 \text { obs. }\end{array}$ & - \\
\hline HNAB-III ${ }^{7}$ & Solid & $1.718 \mathrm{obs}$ & - \\
\hline $\mathrm{HNS}^{8,9}$ & Solid & 1.74 & 1.72 \\
\hline Kel-F $800^{10}$ & Solid & - & 2.02 \\
\hline Kel-F $3700^{10}$ & Solid & - & 1.85 \\
\hline$L X-01$ & Liquid & 1.23 & - \\
\hline LX -02 & Puttylike solid & 1.44 & $1.43-1.44$ \\
\hline $\mathrm{LX}-04$ & Solid & 1.889 & $1.860-1.870$ \\
\hline$L X-07$ & Solid & 1.892 & $1.860-1.870$ \\
\hline$L X-08$ & Puttylike solid & 1.439 & $\geq 1.42$ \\
\hline LX-09 & Solid & 1.867 & $1.837-1.845$ \\
\hline$L X-10-0$ & Solid & 1.896 & $1.858-1.868$ \\
\hline
\end{tabular}


Table 4-1. (continued)

\begin{tabular}{|c|c|c|c|}
\hline \multirow[b]{2}{*}{ Material } & \multirow[b]{2}{*}{ Physical state } & $\mathrm{TMD}^{\mathrm{a}}, \rho$ & Nominal density, $\rho$ \\
\hline & & $\left(\mathrm{g} / \mathrm{cm}^{3} \quad\left(\mathrm{Mg} / \mathrm{m}^{3}\right)\right)$ & $\left(\mathrm{g} / \mathrm{cm}^{3} \quad\left(\mathrm{Mg} / \mathrm{m}^{3}\right)\right)$ \\
\hline$L X-10-1$ & Solid & 1.895 & 1.870 \\
\hline $\mathrm{LX}-11$ & Solid & & $1.87-1.876$ \\
\hline$L X-13$ & $\begin{array}{l}\text { Putty curable to } \\
\text { rubbery solid }\end{array}$ & 1.558 & $\simeq 1.53$ \\
\hline $\mathrm{LX}-14$ & Solid & 1.849 & 1.834 \\
\hline MEN-II & Liquid & 1.017 & - \\
\hline $\mathrm{NC}(12.0 \% \mathrm{~N})$ & Solid & - & 1.58 \\
\hline $\mathrm{NC}(13.35 \% \mathrm{~N}, \mathrm{~min})$ & Solid & - & 1.58 \\
\hline$N G$ & Liquid & 1.59 & - \\
\hline $\mathrm{NM}$ & Liquid & $\begin{array}{l}1.13 \text { at } 20^{\circ} \mathrm{C} \\
(293 \mathrm{~K})\end{array}$ & - \\
\hline$N Q$ & Solid & 1.72 & 1.55 \\
\hline Octol & Solid & 1.83 & $1.80-1.82$ \\
\hline PBX-9007 & Solid & 1.697 & 1.66 \\
\hline PBX-9010 & Solid & 1.822 & 1.789 \\
\hline PBX-9011 & Solid & 1.795 & 1.770 \\
\hline PBX-9205 & Solid & 1.72 & 1.68 \\
\hline PBX-9404 & Solid & 1.865 & $1.831-1.844$ \\
\hline PBX -9407 & Solid & 1.81 & $1.60-1.62^{\mathrm{C}}$ \\
\hline PBX $-9501^{6}$ & Solid & 1.855 & 1.843 \\
\hline Pentolite 50/50 & Solid & 1.71 & 1.67 \\
\hline PETN & Solid & 1.77 & 1.76 \\
\hline Polystyrene ${ }^{12}$ & Solid & 1.12 & 1.05 \\
\hline $\operatorname{RDX}^{13}$ & Solid & 1.806 & - \\
\hline Sylgard $182^{14}$ & Liquid & 1.05 & - \\
\hline TACOT & Solid & 1.85 & 1.61 \\
\hline ТA TB & Solid & 1.938 & 1.88 \\
\hline TEF & Liquid & 1.425 & - \\
\hline Tetryl & Solid & 1.73 & 1.71 \\
\hline $\mathrm{TNM}$ & Liquid & $\begin{array}{l}1.650 \text { at } 13^{\circ} \mathrm{C} \\
(286 \mathrm{~K})\end{array}$ & - \\
\hline TNT & Solid & 1.654 & $\begin{array}{l}\text { Cast: } 1.5-1.6 \\
\text { Pressed: } 1.63-1.64\end{array}$ \\
\hline Viton $A^{15}$ & Rubbery solid & - & 1.815 \\
\hline $\mathrm{XTX}-8003$ & $\begin{array}{l}\text { Putty curable to } \\
\text { rubbery solid }\end{array}$ & 1.556 & $\simeq 1.53$ \\
\hline
\end{tabular}

\footnotetext{
Theoretical maximum density.

${ }^{\mathrm{b}} \mathrm{A}$ TMD value based on boric acid and TNT is 1.52; during the vacuum casting at over $80^{\circ} \mathrm{C}(353 \mathrm{~K})$, however, some of the boric acid breaks down to $\mathrm{B}_{2} \mathrm{O}_{3}$. This has the effect of increasing the TMD by an unpredictable amount.

${ }^{c}$ Nominal density in detonator and booster applications. 
Molecular Weight and Atomic Composition

Table 4-2. Molecular weights and atomic compositions. For materials that are pure chemical compounds, molecular weights and molecular formulas are given: for those that are mixtures, an arbitrary molecular weight of 100 is assigned, and an empirical formula corresponding to this weight is given. For such mixtures, the weight percentage of an element is given by the product of the atomic weight and its subscript in the empirical formula.

\begin{tabular}{|c|c|c|c|c|c|c|}
\hline \multirow[b]{2}{*}{ Explosive } & \multirow[b]{2}{*}{ MW } & \multicolumn{5}{|c|}{ Elemental composition } \\
\hline & & C & $\mathrm{H}$ & $\mathrm{N}$ & $\mathrm{O}$ & Other \\
\hline Baratol & 100 & 0.74 & 0.53 & 0.90 & 2.38 & $\mathrm{Ba} 0.29$ \\
\hline $\mathrm{BDNPA} / \mathrm{BDNPF}$ & 100 & & & & & \\
\hline Boracitol & 100 & 1.23 & 3.79 & 0.53 & 3.97 & В 0.97 \\
\hline $\mathrm{BTF}$ & 252.1 & 6 & 0 & 6 & 6 & \\
\hline $\mathrm{Cab}-\mathrm{O}-\mathrm{Sil}$ & 60.09 & & & & & \\
\hline Comp B, Grade $A^{a}$ & 100 & 2.03 & 2.64 & 2.18 & 2.67 & \\
\hline Comp B-3 ${ }^{b}$ & 100 & 2.05 & 2.51 & 2.15 & 2.67 & \\
\hline Comp C-4 & 100 & 1.82 & 3.54 & 2.46 & 2.51 & \\
\hline Cyclotol 75/25 & 100 & 1.78 & 2.58 & 2.36 & 2.69 & \\
\hline $\mathrm{DATB}$ & 243.1 & 6 & 5 & 5 & 6 & \\
\hline DIPAM & 454.1 & 12 & 6 & 8 & 12 & \\
\hline DNPA & 204.1 & 6 & 8 & 2 & 6 & \\
\hline DOP & 390.57 & 24 & 38 & & 4 & \\
\hline EDNP & 220.2 & 7 & 12 & 2 & 6 & \\
\hline$E L-506 A$ & 100 & 2.41 & 4.29 & 1.08 & 3.27 & \\
\hline$E L-506 C$ & 100 & 3.25 & 5.94 & 0.87 & 2.68 & \\
\hline Estane $5702 \mathrm{~F}-1$ & 100 & 5.137 & 7,500 & 0.187 & 1.758 & \\
\hline FEFO & 320.1 & 5 & 6 & 4 & 10 & F 2 \\
\hline Exon 461 & $(213.43)_{n}$ & 4 & 2 & & & $\begin{array}{rl}\mathrm{Cl} & 3 \\
\mathrm{~F} & 3\end{array}$ \\
\hline $\mathrm{H}-6$ & 100 & 1.890 & 2.590 & 1.612 & 2.009 & $\begin{array}{ll}\mathrm{Ca} & 0.0045 \\
\mathrm{Cl} & 0.0090 \\
\mathrm{Al} & 0.741\end{array}$ \\
\hline $\mathrm{HMX}$ & 296.2 & 4 & 8 & 8 & 8 & \\
\hline HNAB & 452.21 & 12 & 4 & 8 & 12 & \\
\hline HNS & 450.3 & 14 & 6 & 6 & 12 & \\
\hline Kel-F 3700 & $(116.48)_{\mathrm{n}}$ & 2 & & & & $\begin{array}{rl}\mathrm{Cl} & 1 \\
\mathrm{~F} & 3\end{array}$ \\
\hline$L X-01-0$ & 100 & 1.52 & 3.73 & 1.69 & 3.39 & \\
\hline $\mathrm{L} X-02-1$ & 100 & 2.77 & 4.86 & 0.93 & 2.99 & Si 0.03 \\
\hline LX $-04-1$ & 100 & 1.55 & 2.58 & 2.30 & 2.30 & F 0.52 \\
\hline$L X-07-2$ & 100 & 1.48 & 2.62 & 2.43 & 2.43 & F 0.35 \\
\hline$L X-08-0$ & 100 & 1.93 & 4.39 & 0.81 & 2.95 & Si 0.50 \\
\hline LX-09-0 & 100 & 1.43 & 2.74 & 2.59 & 2.72 & F 0.02 \\
\hline LX-09-1 & 100 & 1.425 & 2.735 & 2.592 & 2.721 & F 0.0144 \\
\hline & & $4-4$ & & & & $7 / 74$ \\
\hline
\end{tabular}


Table 4-2. (continued)

\begin{tabular}{|c|c|c|c|c|c|c|}
\hline \multirow[b]{2}{*}{ Explosive } & \multirow[b]{2}{*}{ MW } & \multicolumn{5}{|c|}{ Elemental composition } \\
\hline & & $\mathrm{C}$ & $\mathrm{H}$ & $\mathrm{N}$ & 0 & Other \\
\hline$L X-10-0$ & 100 & 1.42 & 2.66 & 2.57 & 2.57 & F 0.17 \\
\hline$L X-10-1$ & 100 & 1.410 & 2.663 & 2.579 & 2.579 & F 0.156 \\
\hline $\mathrm{LX}-11-0$ & 100 & 1.61 & 2.53 & 2.16 & 2.16 & $\mathrm{~F} 0.70$ \\
\hline \multicolumn{7}{|l|}{ LX-13 See XTX-8003 } \\
\hline $\mathrm{LX}-14$ & 100 & 1.521 & 2.917 & 2.587 & 2.658 & \\
\hline MEN-II & 100 & 2.06 & 7.06 & 1.33 & 3.10 & \\
\hline $\mathrm{NC}(12.0 \% \mathrm{~N})$ & 262.6 & 6 & 7 & 2.25 & 9.5 & \\
\hline $\mathrm{NC}(13.35 \% \mathrm{~N}, \mathrm{~min})$ & 274.1 & 6 & 7 & 2.5 & 10 & \\
\hline NG & 227.1 & 3 & 5 & 3 & 9 & \\
\hline NM & 61.0 & 1 & 3 & 1 & 2 & \\
\hline $\mathrm{NQ}$ & 104.1 & 1 & 4 & 4 & 2 & \\
\hline Octol & 100 & 1.78 & 2.58 & 2.36 & 2.69 & \\
\hline PBX-9007 & 100 & 1.97 & 3.22 & 2.43 & 2.44 & \\
\hline$P B X-9010$ & 100 & 1.39 & 2.43 & 2.43 & 2.43 & $\begin{array}{cc}\mathrm{Cl} & 0.09 \\
\mathrm{~F} & 0.26\end{array}$ \\
\hline PBX-9011 & 100 & 1.73 & 3.18 & 2.45 & 2.61 & \\
\hline PBX-9205 & 100 & 1.83 & 3.14 & 2.49 & 2.51 & \\
\hline PBX-9404 & 100 & 1.40 & 2.75 & 2.57 & 2.69 & $\begin{array}{rr}\mathrm{Cl} & 0.03 \\
\mathrm{P} & 0.01\end{array}$ \\
\hline PBX-9407 & 100 & 1.41 & 2.66 & 2.54 & 2.54 & $\begin{array}{rl}\mathrm{Cl} & 0.07 \\
\mathrm{~F} & 0.09\end{array}$ \\
\hline$P B X-9501$ & 100 & 1.47 & 2.86 & 2.60 & 2.69 & \\
\hline Pentolite $50 / 50$ & 100 & 2.33 & 2.37 & 1.29 & 3.22 & \\
\hline PETN & 316.2 & 5 & 8 & 4 & 12 & \\
\hline Polystyrene & $(104.15)_{n}$ & 8 & 8 & & & \\
\hline $\operatorname{RDX}$ & 222.1 & 3 & 6 & 6 & 6 & \\
\hline Sylgard 182 & $(74.16)_{n}$ & 2 & 6 & & 1 & Si 1 \\
\hline TACOT & 388.2 & 12 & 4 & 8 & 8 & \\
\hline TA TB & 258.2 & 6 & 6 & 6 & 6 & \\
\hline TEF & 285.5 & 6 & 12 & & 4 & $\begin{array}{cc}\mathrm{Cl} & 3 \\
\mathrm{P} & 1\end{array}$ \\
\hline Tetryl & 287.0 & 7 & 5 & 5 & 8 & \\
\hline TNM & 196.0 & 1 & 0 & 4 & 8 & \\
\hline TNT & 227.1 & 7 & 5 & 3 & 6 & \\
\hline Viton A & $(187.08)_{n}$ & 5 & 3.5 & & & F 6.5 \\
\hline XTX-8003 & 100 & 1.80 & 3.64 & 1.01 & 3.31 & Si 0.27 \\
\hline
\end{tabular}

\footnotetext{
${ }^{\mathrm{a}}$ Based on nominal composition of $63 \% \mathrm{RDX}, 36 \% \mathrm{TNT}$, and $1 \%$ wax. The wax was assumed to have the composition $\mathrm{CH}_{2}$.

${ }^{b}$ Based on nominal composition of RDX/TNT $60 / 40$. 
Table 4-3. Melting points m.p., boiling points b.p., and vapor pressures v. p.

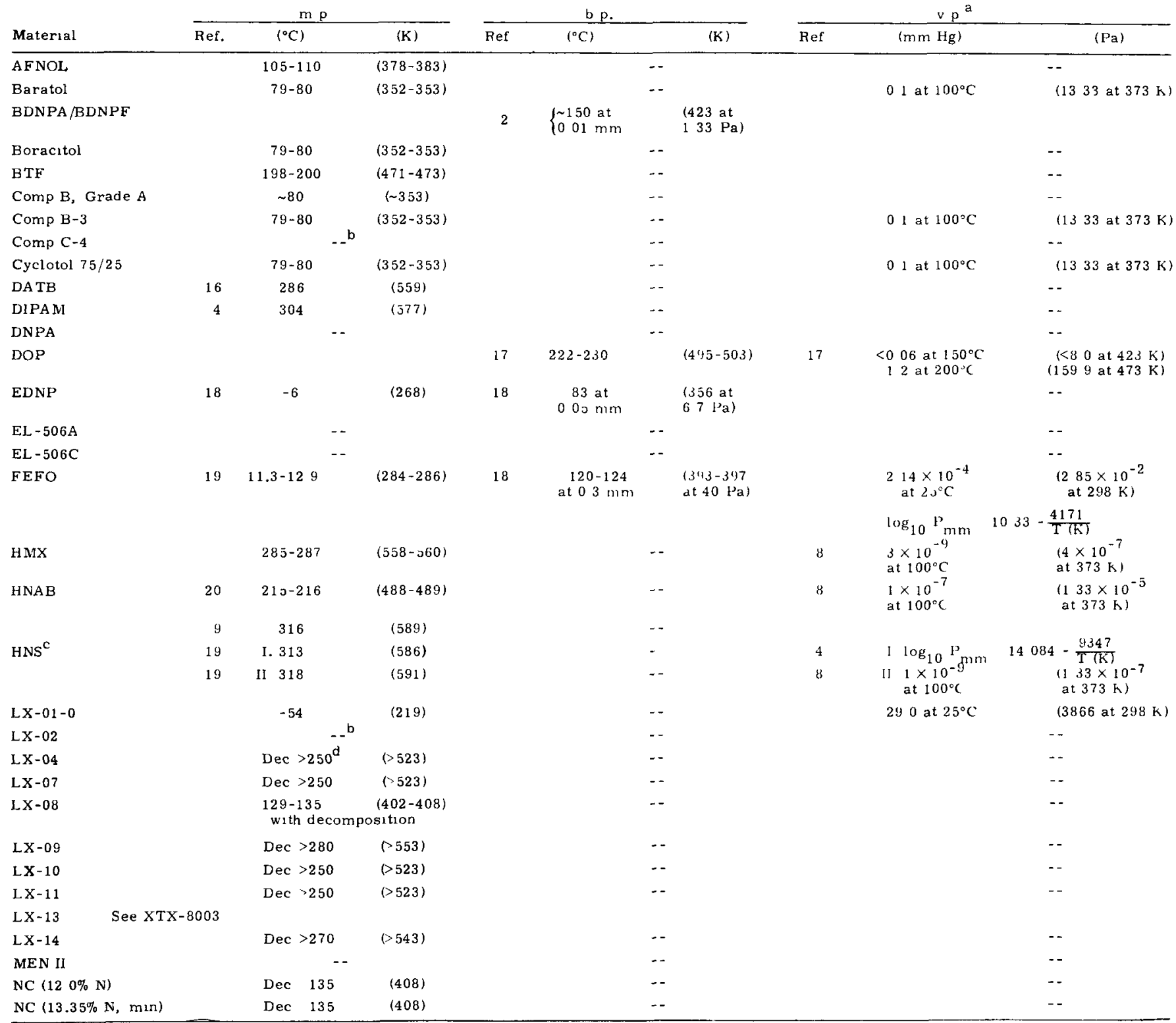


Table 4-3. (continued)

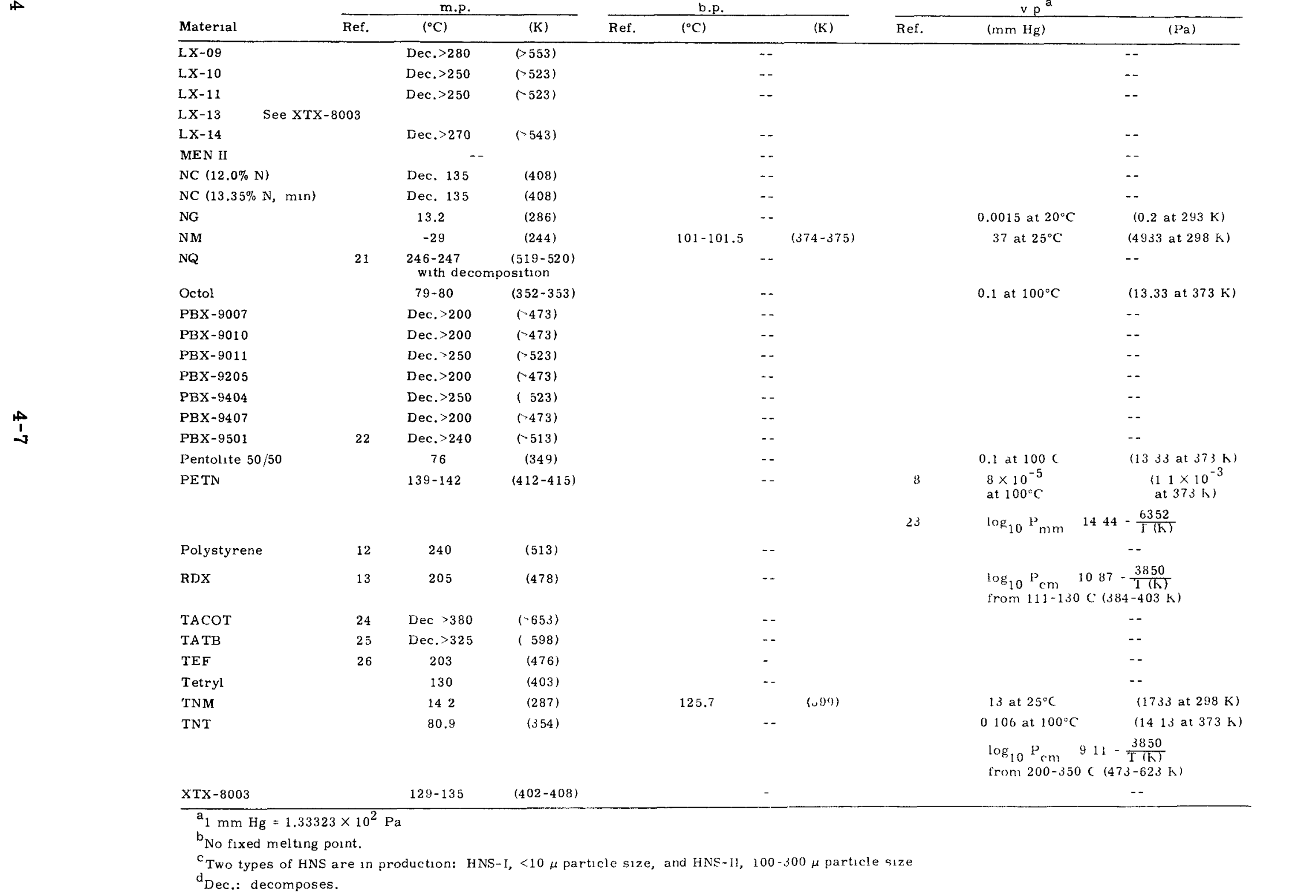




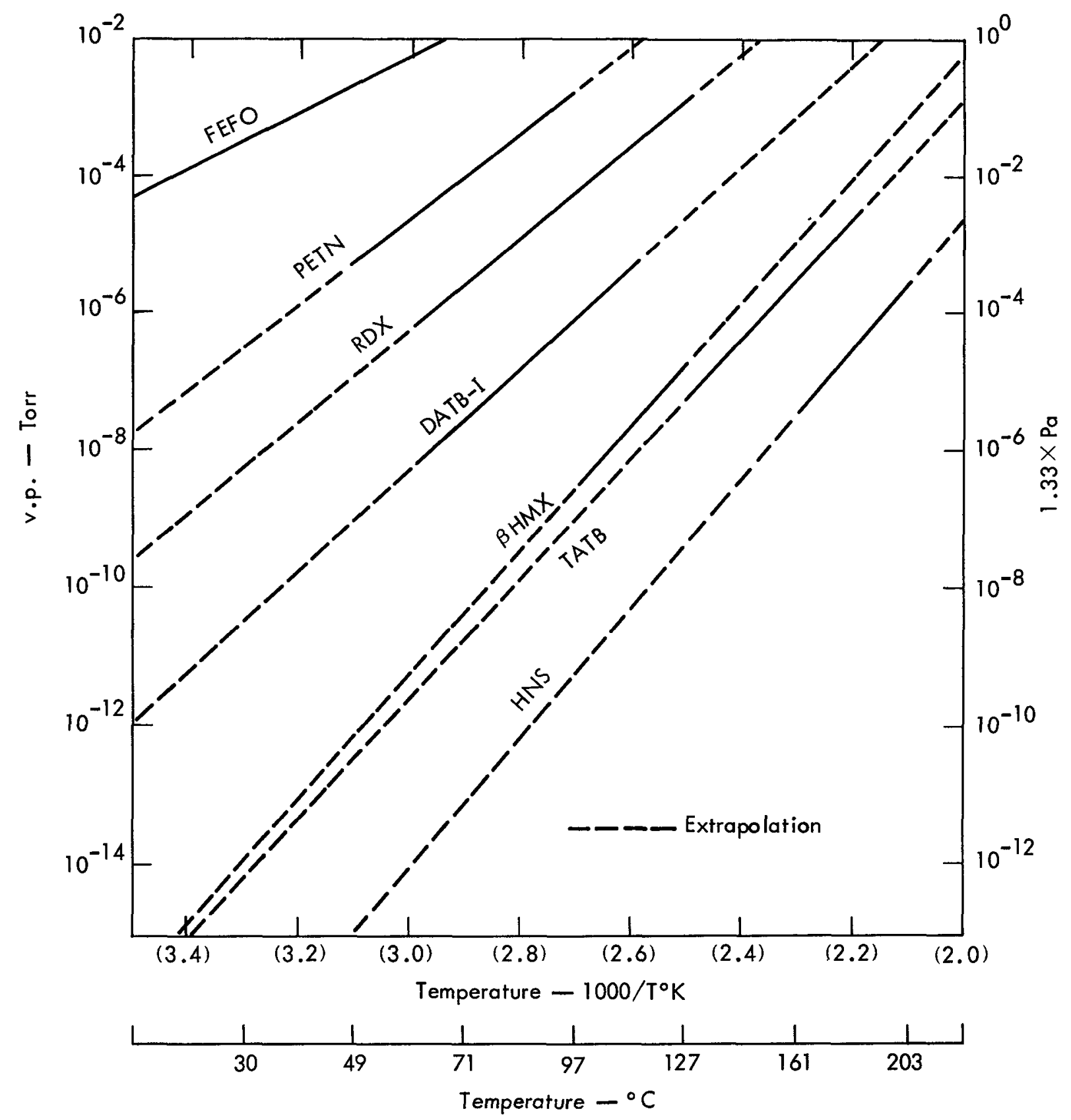

Fig. 4-1. Vapor pressure of FEFO, ${ }^{27}$ PETN, ${ }^{23}$ RDX, ${ }^{28}$ DATB-I, ${ }^{28} \beta$-HMX, ${ }^{28}$ TA TB, ${ }^{28}$ HNS. 29 Conversion factor: 1 Torr $=1.333 \times 10^{2} \mathrm{~Pa}$. 


\section{Crystallographic and Optical Properties}

Table 4-4. Crystallographic and optical properties. ${ }^{a}$

\begin{tabular}{|c|c|c|c|c|c|c|}
\hline Material & Polymorph & $\begin{array}{c}\text { Unit cell } \\
\text { dimension } \\
\left(\AA\left(10^{-1} \mathrm{~nm}\right)\right)\end{array}$ & $\begin{array}{l}\text { Crystal } \\
\text { structure }\end{array}$ & $\begin{array}{l}\text { Space } \\
\text { group }\end{array}$ & $\begin{array}{l}\text { Refractive } \\
\text { index } \\
n\end{array}$ & $\begin{array}{l}\text { Molecular } \\
\text { refraction } \\
\quad \mathrm{R}\end{array}$ \\
\hline $\mathrm{BDNPA}_{\mathrm{BDNPF}}{ }^{2}$ & & & & & $\begin{array}{c}1.462-1.464 \text { at } \\
25^{\circ} \mathrm{C}(298 \mathrm{~K})\end{array}$ & \\
\hline $\mathrm{BTF}^{29,30}$ & & $\begin{array}{l}a=9.92 \\
b=19.52 \\
c=6.52\end{array}$ & Orthorhomic & $\mathrm{Pna}_{1}$ & & \\
\hline $\mathrm{Cab}-\mathrm{O}-\mathrm{S}_{11^{3}}$ & & & Amorphous & & 1.46 & \\
\hline $\mathrm{DATB}{ }^{16}$ & I & $\begin{array}{l}a=7.30 \\
b=5.20 \\
c=11.63\end{array}$ & & Pc2 & & \\
\hline$D_{O P}^{17}$ & & & & & $\begin{array}{l}1.485 \text { at } 25^{\circ} \mathrm{C} \\
(298 \mathrm{~K})\end{array}$ & \\
\hline \multirow[t]{4}{*}{$\operatorname{HMX}^{31-35}$} & II $(\alpha)$ & $\begin{array}{l}a=15.14 \\
b=23.89 \\
c=5.91\end{array}$ & Orthorhombic & $F d d 2$ & $\begin{array}{l}\alpha-1.561-1.565 \\
\beta=1.562-1.566 \\
\gamma=1.72-1.74\end{array}$ & $\begin{array}{l}58 \text { calc. } \\
55.7 \text { obs. }\end{array}$ \\
\hline & $I(\beta)$ & $\begin{array}{l}a=6.54 \\
b=11.05 \\
c=8.70\end{array}$ & Monoclinie & $\mathrm{P} 2_{1} / \mathrm{c}$ & $\begin{array}{l}\alpha=1.589 \\
\beta=1.594 \\
\gamma=1.73\end{array}$ & $\begin{array}{l}58 \text { calc. } \\
56.1 \text { obs. }\end{array}$ \\
\hline & III $(\gamma)$ & $\begin{array}{l}a=10.95 \\
b=7.93 \\
c=14.61\end{array}$ & Monoclinic & $\begin{array}{l}\mathrm{Pc}_{1} \mathrm{P} 2 / \mathrm{c} \\
\mathrm{P} 2 / \mathrm{n}\end{array}$ & $\begin{array}{l}\alpha=1.537 \\
\beta=1.585 \\
\gamma=1.666\end{array}$ & $\begin{array}{l}58 \text { calc. } \\
55.4 \text { obs. }\end{array}$ \\
\hline & IV $(\delta)$ & $\begin{array}{l}a-7.66 \\
b=\frac{2.49}{c-32.49}\end{array}$ & Hexagonal & $\begin{array}{l}\mathrm{P} 6_{1} 22, \\
\mathrm{P}_{5} 22\end{array}$ & & $\begin{array}{l}58 \text { calc. } \\
55.9 \text { obs. }\end{array}$ \\
\hline \multirow[t]{2}{*}{$\mathrm{HNAB}^{7}$} & I & $\begin{array}{l}a=10.15 \\
b=8.26 \\
c-10.06\end{array}$ & & $\mathrm{P} 2_{1} / \mathrm{c}$ & & \\
\hline & II & $\begin{array}{l}a-10.63 \\
b-21.87 \\
c-7.59\end{array}$ & & $\mathrm{P} 2_{1} / \mathrm{a}$ & & \\
\hline $\mathrm{HNS}^{\mathrm{S}}$ & & $\begin{array}{l}a=20.93 \\
b-5.57 \\
c-14.67\end{array}$ & Orthorhombic & & & \\
\hline $\mathrm{Kel}-\mathrm{F} 800^{10}$ & & & & & 1.46 & \\
\hline $\mathrm{NQ}^{21}$ & & $\begin{array}{l}a-17.58 \\
b-24.84 \\
c-3.58\end{array}$ & Orthorhombic & Fdd2 & $\begin{array}{l}\mathrm{n}=16 \\
\alpha=1.526 \\
\beta=1.694 \\
\gamma=1.81\end{array}$ & $\begin{array}{l}25.2 \text { calc. } \\
22.2 \text { obs. }\end{array}$ \\
\hline \multirow[t]{2}{*}{ PETN $36-40$} & $\begin{array}{c}I(\alpha) \\
(\rho=1.778)\end{array}$ & $\begin{array}{l}a=9.38 \\
b=9.38 \\
c=6.71\end{array}$ & Tetragonal & $\mathrm{P}^{\overline{4} 2}{ }_{1} / \mathrm{c}$ & $\begin{array}{ll}\omega=1.558 & \text { in Na } \\
\epsilon=1.551 & \text { light }\end{array}$ & \\
\hline & $\begin{array}{l}\text { II }(\beta) \\
(\rho=1.716)\end{array}$ & $\begin{array}{l}a=13.22 \\
b=13.49 \\
c=6.83\end{array}$ & Orthorhombic & Pcnb & & \\
\hline Polystyrene & & $\begin{array}{l}a-21.90 \\
b=21.90 \\
c-6.63\end{array}$ & Rhombohedral & & $1.59-1.60$ & \\
\hline \multirow[t]{2}{*}{$\mathrm{RDX}^{13,40,41,42}$} & I & $\begin{array}{l}a=13.18 \\
b=11.57 \\
c=10.71\end{array}$ & Orthorhombic & Pbca & \multirow{2}{*}{$\left.\begin{array}{rl}\mathrm{n} & =8 \\
\alpha & =1.578 \\
\beta & =1.597 \\
\gamma & =1.602\end{array}\right\}$ at $20^{\circ} \mathrm{C}$} & $\begin{array}{l}43.7 \text { calc. } \\
41.4 \text { obs. }\end{array}$ \\
\hline & II & Unstable & & & & \\
\hline Sylgard $182^{14}$ & & & & & $\begin{array}{l}1.430 \text { at } 25^{\circ} \mathrm{C} \\
(298 \mathrm{~K})\end{array}$ & \\
\hline $\mathrm{TATB}^{43-44}$ & & $\begin{array}{l}a=9.01 \\
b=9.03 \\
c-6.81\end{array}$ & Triclinic & $P \overline{1}$ & $\begin{array}{l}\alpha=1.45 \\
\beta=2.3 \\
\gamma=3.1\end{array}$ & \\
\hline Tetryl 45 & & $\begin{array}{l}a=14.13 \\
b=7.37 \\
c=10.61\end{array}$ & Monoclınic & $\mathrm{P} 2_{1} / \mathrm{c}$ & $\begin{array}{l}\alpha=1.546 \\
\beta=1.632 \\
\gamma=1.74 \text { calc. }\end{array}$ & \\
\hline $\mathrm{TNT}^{46-50}$ & & $\begin{array}{l}a=14.99 \\
b=40.00 \\
c=6.10\end{array}$ & & & $\begin{array}{l}\mathrm{n}=16 \\
\alpha=1.543 \\
\beta=1.674 \\
\gamma=1.717\end{array}$ & $\begin{array}{l}44.3 \text { calc. } \\
49.6 \text { obs. }\end{array}$ \\
\hline
\end{tabular}

\footnotetext{
${ }^{\mathrm{a}}$ Refractive indexes and molecular refractions are at $5893 \AA$ and $25^{\circ} \mathrm{C}(589.3 \mathrm{~nm}$ and $298 \mathrm{~K})$.unless otherwise stated; $10 \AA=1 \mathrm{~nm}$.
} 


\section{References}

1. H. Hornig, Lawrence Livermore Laboratory, personal communication (1972).

2. M. Finger, Properties of Bis(2,2-dinitropropyl)acetal and Bis(2,2,-dinitropropyl) formal, Eutectic Mixture, Lawrence Livermore Laboratory, Rept. UCID-16088 (1972).

3. Cabot Corporation, Boston, Mass., Cab-O-Sil, Rept. Cgen-7 (no date).

4. E. E. Kilmer, J. Spacecr. Rockets 5, 1216-1219 (1968).

5. B. F. Goodrich Company, Cleveland, Ohio, Estane Polyurethane Materials, Service Bulletin 64-14; Estane Polyurethane Solution Systems, Service Bulletin TSR 64-18 (1964).

6. Firestone Plastics Company, Pottstown, Penn., Exon, Sales Service Bulletin No. 20 (1956).

7. E. J. Graeber, Sandia Laboratories, Albuquerque, N. Mex., personal communication (1972).

8. A. C. Schwartz, Application of Hexanitrostilbene (HNS) in Explosive Components, Sandia Laboratories, Albuquerque, N. Mex., Rept. SC-RR-710673 (1972).

9. K. G. Shipp, J. Org. Chem. 29, 2620-2623 (1964).

10. Minnesota Mining and Manufacturing Company, St. Paul, Minn., Kel-F Elastomer Properties and Applications (no date).

11. J. R. Humphrey, LX-10-1: A High-Energy Plastic-Bonded Explosive, Lawrence Livermore Laboratory, Rept. UCRL-51629 (1974).

12. J. Brandrup and E. H. Immergut, Eds., Polymer Handbook, Interscience, N. Y. (1966).

13. C. S. Choi and E. Prince, Acta Cryst. B28, 2857-2862 (1972).

14. Dow Corning, Hemlock, Mich., Information about Electronic Materials, Bulletin 07-123 (1964).

15. S. Dixon, D. R. Rexford, and J. S. Rugg, Ind. Eng. Chem. 49, 1687-1690 (1957).

16. J. R. Holden, Acta Cryst.. 22, 545-550 (1966).

17. Food Machinery Corporation, Ohio Apex Division, Nitro, W. Va., Plasticizers, Data Sheet (1955).

18. M. Finger, Lawrence Livermore Laboratory, personal communication (1972).

19. K. G. Shipp, U.S. Naval Ordnance Laboratory, White Oak, Md., personal communication (1965).

20. G. P. Sharnin, B. J. Buzykin, and K. Kh. Shakurova, J. Org. Chem. (USSR) $\underline{6}$ 1039-1041 (1970).

21. W. C. McCrone, Anal. Chem. 23, 205-206 (1951).

22. T. M. Benziger, X-0242: A High-Energy Plastic-Bonded Explosive, Los Alamos Scientific Laboratory, N. Mex., Rept. LA-4872-MS (1972).

23. F. T. Crimmins, The Vapor Pressure of Pentaerythritoltetranitrate (PETN) in the Temperature Range of 50 to 98 Degrees Centigrade, Lawrence Livermore Laboratory, Rept. UCRL-50704 (1969). 
24. E. I. Dupont de Nemours and Company, Technical Information on Military Specialties--TACOT (manufacturer's data sheet), E. I. DuPont de Nemours and Company, Inc., Wilmington, Del. (no date).

25. L. C. Smith, Los Alamos Scientific Laboratory, N. Mex., personal communication (1962).

26. Celanese Corporation, Chemical Division, New York, N. Y., Celluflex CEF, Products Bulletin N-46-2 (1955).

27. F. T. Crimmins, Lawrence Livermore Laboratory, personal communication (1969).

28. J. M. Rosen and C. Dickenson, J. Chem. Eng. Data 14, 120-124 (1969).

29. H. H. Cady, A. C. Larson, and D. T. Cromer, Acta Cryst. 20, 336-341 (1966).

30. E. N. Maslen, Acta Cryst. B24, 1170-1172 (1968).

31. H. H. Cady, A. C. Larson, and D. T. Cromer, Acta Cryst. 16, 617-623 (1963).

32. W. C. McCrone, Anal. Chem. 22, 1225-1226 (1950).

33. A. Filhol, Contribution to the Study of the Hexogen Molecule in the Crystalline and the Free State, Thesis, Université de Bordeaux, France (1971). (In French).

34. C. S. Choi and H. P. Boutin, Acta Cryst. B26, 1235-2340 (1970).

35. W. Selig, Explosivestoffe 17, 201-202 (1969).

36. J. E. Knoggs, Mineral. Mag. 20, 346-352 (1925).

37. A. D. Booth and F. J. Llewellyn, J. Chem. Soc. (London) 1947, 837-846 (1947).

38. J. Trotter, Acta Cryst. 16, 698-699 (1963).

39. H. H. Cady, Los Alamos Scientific Laboratory, N. Mex., personal communication (1972).

40. A. T. Bloomquist, Microscopic Examination of High Explosives and Boosters, Office of Scientific Research and Development, Rept. NDRC-B-3014 (AD-29944) (1957).

41. W. C. McCrone, Anal. Chem. 22, 954-955 (1950).

42. P. M. Harris, P. Reed, and R. E. Gluyas, Structures of Trinitro Aromatic Crystals and Related Substances, U.S. Dept. of Commerce, Rept. 156-104 (1959).

43. H. H. Cady, Microscope 14, 27 (1963).

44. H. H. Cady and A. C. Larson, Acta Cryst. 18, 485-496 (1965).

45. H. H. Cady, Acta Cryst. 23, 601-609 (1967).

46. W. C. McCrone, Anal. Chem. 21, 1583-1584 (1949).

47. F. G. J. May, B. W. Thorpe, and W. Connick, J. Cryst. Growth 5 , 312 (1969).

48. W. Connick, F. G. J. May, and B. W. Thorpe, Austr. J. Chem. 22, 2685-2688 (1969).

49. D. G. Grabar, F. C. Rauch, and A. J. Fanelli, J. Phys. Chem. 73, 3514-3516 (1969).

50. L. A. Burkhardt and J. H. Bryden, Acta Cryst. 7, 135-136 (1954). 
4- 12 


\section{CHEMICAL PROPERTIES}

This section gives information on heat of formation $\Delta H_{f}$, heat of detonation $\Delta H_{d e t}$, compatibility, and solubility.

\section{Heat of Formation}

Heat of formation $\Delta \mathrm{H}_{\mathrm{f}}$ refers to the enthalpy of the reaction

$$
\mathrm{aC}_{(\mathrm{s})}+\frac{\mathrm{b}}{2} \mathrm{H}_{2(\mathrm{~g})}+\frac{\mathrm{c}}{2} \mathrm{~N}_{2(\mathrm{~g})}+\frac{\mathrm{d}}{2} \mathrm{O}_{2(\mathrm{~g})}+\cdots \rightarrow \mathrm{C}_{\mathrm{a}} \mathrm{H}_{\mathrm{b}} \mathrm{N}_{\mathrm{c}} \mathrm{O}_{\mathrm{d}}
$$

at 1 atm $(101 \mathrm{kPa})$ and $298^{\circ} \mathrm{C}(571 \mathrm{~K})$. The sign convention is such that the $\Delta \mathrm{H}_{\mathrm{f}}$ is negative when the above reaction is exothermic. Tables 5-1 and 5-2 give heats of formation of various explosive materials and of additives and binders, respectively.

Table 5-1. Heats of formation, $\Delta \mathrm{H}_{\mathrm{f}}$, of explosives. ${ }^{1}$

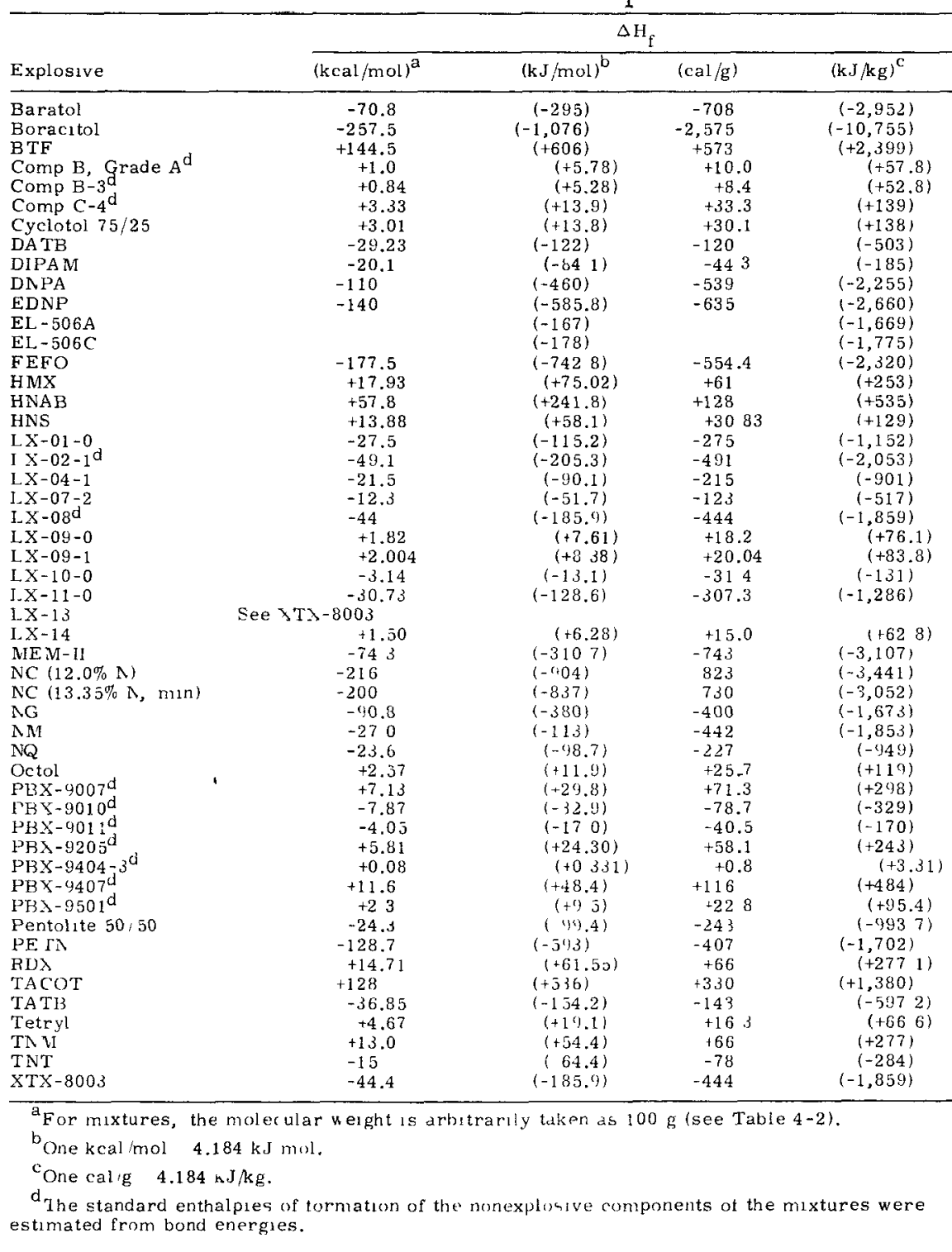


Table 5-2. Heats of formation, $\Delta \mathrm{H}_{\mathrm{f}}$, of additives and binders. ${ }^{1}$

\begin{tabular}{lcccr}
\hline Material & $\mathrm{kcal} / \mathrm{mol}$ & $(\mathrm{kJ} / \mathrm{mol})$ & $\mathrm{kcal} / \mathrm{g}$ & $(\mathrm{kJ} / \mathrm{kg})$ \\
\hline BDNPA/BDNPF & -46.38 & $(-194.1)$ & -0.464 & $(-1,941)$ \\
Cab-O-Sil $^{\mathrm{a}}$ & $-215: 94$ & $(-903.5)$ & -3.597 & $(-15.051)$ \\
DOP $^{\mathrm{b}}$ & -268.2 & $(-1,122)$ & -0.687 & $(-2,874)$ \\
Estane 5702 F-1 & -95 & $(-397)$ & -0.95 & $(-3,975)$ \\
Kel-F 3700 & -161 & $(-674)$ & -1.382 & $(-5,783)$ \\
Polystyrene & +18.9 & $(+79.1)$ & +0.181 & $(+757)$ \\
Sylgard 182 & -24.9 & $(-104.18)$ & -1.40 & $(-5,858)$ \\
TEF & -300 & $(-1,255)$ & -1.051 & $(-4,397)$ \\
Viton A & -332.7 & $(-1,392)$ & -1.778 & $(-7,439)$ \\
\hline
\end{tabular}

\footnotetext{
${ }^{\mathrm{a}}$ Calculation.

${ }^{b}$ Estimate.
}

\section{Heat of Detonation}

Heat of detonation $\Delta \mathrm{H}_{\mathrm{det}}$ refers to the change in enthalpy for the high-order detonation of the explosive. Initial and final states are taken at $25^{\circ} \mathrm{C}(298 \mathrm{~K})$ and $1 \mathrm{~atm}(101 \mathrm{kPa})$ pressure. The experimental values listed in Table 5-3 were determined in a detonation calorimeter; they are found to vary with density, size, and confinement of the charge as well as with calorimeter geometry. Therefore, application of these values of detonation energy to other situations represents only an approximation.

The maximum heat of detonation is a calculated value for the enthalpy of the reaction

$$
\text { Explosive } \rightarrow \text { Most Stable Products. }
$$

The order chosen for the most stable products is $\mathrm{H}_{2} \mathrm{O}, \mathrm{CO}_{2}, \mathrm{C}_{(\mathrm{s})}$, and $\mathrm{N}_{2}$ for $\mathrm{CHNO}$ explosives. If the explosive contains $\mathrm{F}$ and/or $\mathrm{Cl}$, then $\mathrm{HF}$ and/or $\mathrm{HCl}$ precedes $\mathrm{H}_{2} \mathrm{O}$ in the order. The values represent the upper limit of the chemical energy obtainable from an explosive.

In practice, the effective energy developed by a detonating high explosive is always smaller than the assumed thermodynamic maximum energy. The reason is that the actual shifting equilibrium along the adiabat until freeze-out occurs is not the one assumed here. Also, the actual entropy is higher than for $25^{\circ} \mathrm{C}(298 \mathrm{~K})$ and 1 atm (101 kPa) pressure. Such codes as RUBY, BKW, and TIGER are believed to give more realistic estimates of the true composition during expansion. 
Table 5.3. Heats of detonation, $\Delta \mathrm{H}_{\text {det }}$.

\begin{tabular}{|c|c|c|c|c|c|c|c|c|c|c|c|c|}
\hline \multirow[b]{3}{*}{ Explosive } & \multicolumn{4}{|c|}{ Max $\Delta H_{\text {det }}$ cilculated } & \multicolumn{4}{|c|}{ Experimcintal $\Delta$ It $_{\text {det }}$} & \multicolumn{4}{|c|}{ Experimental conditions } \\
\hline & \multicolumn{2}{|c|}{$\mathrm{H}_{2} \mathrm{O}_{(\ell)}$} & \multicolumn{2}{|c|}{${ }^{11}{ }_{2}{ }^{(1)}(\mathrm{g})$} & \multicolumn{2}{|c|}{$\mathrm{H}_{2} \mathrm{O}(\ell)$} & \multicolumn{2}{|c|}{$\mathrm{H}_{2} \mathrm{O}(\mathrm{g})$} & \multirow{2}{*}{$\begin{array}{c}\mathrm{T} \\
\left({ }^{\circ} \mathrm{C}(\mathrm{h})\right)\end{array}$} & \multirow{2}{*}{\multicolumn{2}{|c|}{$\begin{array}{l}\text { Diam } \\
(\mathrm{nn}(\mathrm{mm}))\end{array}$}} & \multirow{2}{*}{$\frac{\rho}{\left(\mathrm{Mg} / \mathrm{m}^{3}\right.}$} \\
\hline & $(\mathrm{kcal} / \mathrm{g})$ & $(\mathrm{MJ} / \mathrm{kg})^{\mathrm{a}}$ & $(\mathrm{kcal} \mathrm{g})$ & $(\mathrm{MJ} \mathrm{kg})^{\mathrm{a}}$ & $(\mathrm{k}<\mathrm{al} \mathrm{g})$ & $(1 \mathrm{lj} \mathrm{kg})^{\mathrm{a}}$ & $(\mathrm{kc} \overline{\mathrm{a}} \mathrm{L} / \mathrm{g})$ & $(\mathrm{MJ} \mathrm{kg})^{\mathrm{a}}$ & & & & \\
\hline Baratol $^{b}$ & 074 & $(310)$ & 072 & $\left(\begin{array}{lll}3 & 0 & 1\end{array}\right)$ & -- & -- & $\cdots$ & --- & -- & - & -- & - \\
\hline Boracitol $^{c}$ & 040 & $\left(\begin{array}{ll}1 & 67\end{array}\right)$ & 020 & $\left(\begin{array}{ll}0 & 84\end{array}\right)$ & - & --- & $\cdots$ & $-\quad-$ & -- & - & - &.- \\
\hline$B^{\prime} F^{1, d}$ & 169 & $\left(\begin{array}{ll}7 & 07\end{array}\right)$ & 169 & $\left(\begin{array}{ll}7 & 07\end{array}\right)$ & 141 & $\left\langle\begin{array}{ll}5 & 90\end{array}\right)$ & 141 & $(590)$ & $2 っ(298)$ & $1 / 2$ & $(127)$ & 186 \\
\hline Comp B, Grade A & 154 & $(644)$ & 140 & $(086)$ & -- & & $\cdots$ & & - - & - & - & -- \\
\hline $\operatorname{Comp~B-} 3^{1, c}$ & - 154 & $(644)$ & 140 & $\left(\begin{array}{ll}5 & 86\end{array}\right)$ & 120 & $\left(\begin{array}{ll}5 & 02\end{array}\right)$ & 112 & $\left(\begin{array}{ll}4 & 69\end{array}\right)$ & $25(2) 8)$ & $1 / 3$ & $\left(\begin{array}{ll}8 & 47\end{array}\right)$ & 169 \\
\hline Comp C-4 & 1. 59 & $(665)$ & 140 & $\left(\begin{array}{ll}5 & 86\end{array}\right)$ & - & -- & -- & --- & - & - & - & - \\
\hline Cyclotol $75 / 25$ & 157 & $\left(\begin{array}{ll}6 & 57\end{array}\right)$ & 144 & 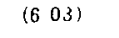 & & - & -- & $-\cdots$ & --- & - & $\cdots$ & $-\cdots$ \\
\hline $\mathrm{DATB}^{1}$ & 126 & $(527)$ & 115 & $(481)$ & 098 & $\left(\begin{array}{ll}4 & 10\end{array}\right)$ & 091 & $(381)$ & $25(238)$ & $1 / 3$ & $(847)$ & 180 \\
\hline DIPAM & 130 & $(565)$ & 127 & $(031)$ & -- & & - & $\ldots$ & -- - & -- & - & - \\
\hline DNPA & 106 & $(444)$ & 080 & $\left(\begin{array}{ll}3 & 57\end{array}\right)$ & -- & $\cdots$ & --- & -- & $-\cdots$ & -- & -- & - \\
\hline EDNP & 123 & $\left(\begin{array}{ll}5 & 15\end{array}\right)$ & 034 & $(393)$ & - & - & & $-\cdot$ & $\cdots$ & -- & - & $-\quad-$ \\
\hline $\mathrm{El}-506 \mathrm{~A}$ & 162 & $(678)$ & 138 & $(577)$ & -- & $-\cdots$ & - & $-\cdots$ & - & - & $\ldots$ & -- \\
\hline $\mathrm{EL}-506 \mathrm{C}$ & 141 & $(590)$ & 112 & $(469)$ & - & - & -- & -- & - - & -- & -- & -- \\
\hline $\mathrm{FEFO}$ & 145 & $\left(\begin{array}{ll}6 & 07\end{array}\right)$ & 13 & $(082)$ & 128 & $(536)$ & 121 & $(506$ & $25(298)$ & $1 / 2$ & $\left(\begin{array}{ll}12 & 7\end{array}\right)$ & I 61 \\
\hline $\mathrm{HMX}^{2}$ & 162 & $(678)$ & 148 & $\left(\begin{array}{ll}6 & 19\end{array}\right)$ & 148 & $\left(\begin{array}{ll}61\end{array}\right)$ & 137 & $\left(\begin{array}{ll}5 & 73\end{array}\right)$ & $25(298)$ & $1 / 2$ & $(127)$ & 189 \\
\hline HNAB & 147 & $(610)$ & 142 & $(594)$ & - & $-\quad-$ & -- & - & --- & & -- & - \\
\hline HNS & 142 & $(594)$ & 136 & $(06))$ & - & & -- & $-\cdots$ & $\cdots$ & - & & -- \\
\hline$I X-010$ & 172 & $\left(\begin{array}{ll}720 \\
2\end{array}\right)$ & 102 & $\left(\begin{array}{ll}6 & 36\end{array}\right)$ & -- & -- & -- & & --- & - & --- & $-\cdots$ \\
\hline$L X-021^{e}$ & 142 & $(594)$ & 116 & $(485)$ & - & - & -- & -- & -- & -- & $\ldots$ & $-\quad-$ \\
\hline I $X-041^{1}$ & 142 & $(004)$ & 131 & $(04)$ & 131 & $(54))$ & 125 & $\left(\begin{array}{ll}5 & 23\end{array}\right)$ & $24(297)$ & $1 / 3$ & $(847)$ & 188 \\
\hline $\begin{array}{llll}\mathrm{LX} & 07 & 2\end{array}$ & 143 & $(623)$ & 137 & $(073)$ & & & $\cdots$ & & - - & & -- & $-\cdots$ \\
\hline I X $08^{e} 1$ & 138 & $\left(82^{-}\right)$ & 177 & $(741)$ & - & & $\cdots$ & & $-\ldots$ & -- & $\ldots$ & --- \\
\hline $\mathrm{LX}$ oy 0 & 160 & $(66)$ & 146 & $\left(\begin{array}{lll}6 & 1 & 1\end{array}\right)$ & & -- & -- & - & & - & -- & --- \\
\hline LX $-09-1$ & 160 & $\left(\begin{array}{ll}6 & 6\end{array}\right)$ & 146 & $\left(\begin{array}{lll}6 & 1 & 1\end{array}\right)$ & - & $\cdots$ & $-\cdots$ & -- & --- & -- & -- & - \\
\hline LX 100 & 150 & $(641)$ & 142 & $(094)$ & -- & -- & --- & & -- & & $-\quad-$ & - \\
\hline I $X-11-0$ & 138 & $(077)$ & 128 & $\left(\begin{array}{ll}5 & 36\end{array}\right)$ & 123 & $\left(\begin{array}{lll}5 & 10\end{array}\right)$ & 116 & $\left(\begin{array}{ll}4 & 80\end{array}\right)$ & $25(298)$ & $1 / 2$ & $(127)$ & 188 \\
\hline $\operatorname{LX} 13$ & \multicolumn{2}{|c|}{ See YTY -800} & & & & & & & & & & \\
\hline I X 14 & 158 & 16331 & 143 & $\left(\begin{array}{ll}5 & 95\end{array}\right)$ & - & -- & - & -- & --- & -- & $-\cdots$ & --- \\
\hline VEN $I_{\mathbf{r}}$ & 138 & $(1,7)$ & 100 & $(43))$ & - & & $-\ldots$ & & -- & -- & - & $-\cdots$ \\
\hline$\Lambda C(120 \% \mathrm{~N}$ & 116 & $(480)$ & 102 & $(427)$ & & - & & & -- & -- & --- & \\
\hline $\mathrm{NC}(1335 \% \mathrm{~N}, \mathrm{~min})$ & 116 & $(480)$ & 102 & $(427)$ & & -- & & $\cdots$ & $\cdots$ & - & --- & $-\infty$ \\
\hline NG & 103 & $(66.5)$ & 148 & 1611 & - & & --- & & -- & -- & $\cdots$ & --- \\
\hline$v u^{2}$ & 162 & $(6-8)$ & 136 & $(06611)$ & 123 & $\left(\begin{array}{lll}0 & 1 & 0\end{array}\right)$ & 106 & $(444)$ & $20(298)$ & 12 & $(127)$ & 113 \\
\hline$\wedge Q$ & 106 & $(444)$ & 088 & $(368)$ & & -- & & -- & --- & -- & $-\cdots$ & --- \\
\hline Octol & 157 & $\left(\begin{array}{ll}6 & 07\end{array}\right)$ & 143 & $(08)$ & $\cdots$ & - & - & $-\cdots$ & $\cdots$ & - & --- & --- \\
\hline PBX 9007 & 106 & $(6) 33)$ & 13 & $(082)$ & & & -- & & & -- & --- & - \\
\hline PBX-9010 & 147 & $\left(\begin{array}{lll}6 & 1 & 0\end{array}\right)$ & 136 & $(06)$ & -- & -- & - & $\cdots$ & -- & -- & -- & --- \\
\hline PBX-9011 & 103 & $(640)$ & 136 & $\left(\begin{array}{lll}5 & 6 & 1\end{array}\right)$ & - & -- & --- & -- & - & - & --- & --- \\
\hline$P B X-9205$ & 146 & $\left(\begin{array}{lll}6 & 1 & 1\end{array}\right)$ & I 41 & $(590)$ & - & $\cdots$ & --- & -- & --- & -- & $-\cdots$ & -- \\
\hline$P B X-9404^{1}$ & $1>6$ & $\left(\begin{array}{ll}6 & 03\end{array}\right)$ & 142 & $\left(\begin{array}{ll}5 & 14\end{array}\right)$ & 138 & $(577)$ & 128 & $(036)$ & $20(298)$ & $1 / 3$ & $\left(\begin{array}{ll}8 & 47\end{array}\right)$ & 180 \\
\hline PBX -9407 & 160 & $(663)$ & 146 & $\left(\begin{array}{lll}6 & 1 & 1\end{array}\right)$ & & $\cdots$ & $\cdots$ & -- & --- & -- & $\cdots$ & --- \\
\hline PBX 9001 & 103 & $(66 v)$ & 144 & $\left(\begin{array}{ll}6 & 03\end{array}\right)$ & -- & & -- & - & $-\cdots$ & -- & $\cdots$ & --- \\
\hline Pentolite $000^{3} 0^{3}$ & 103 & $(640)$ & 140 & (o 86$)$ & 123 & $(515)$ & 116 & $\left(\begin{array}{ll}485 \\
8\end{array}\right)$ & $21(294)$ & 1 & $(254)$ & 165 \\
\hline$P E \mathrm{TN}^{4}$ & 165 & $\left(\begin{array}{ll}6 & 0\end{array}\right)$ & 101 & $\left(\begin{array}{ll}6 & 32\end{array}\right)$ & 149 & $\left(\begin{array}{ll}6 & 23\end{array}\right)$ & 137 & $(073)$ & $25(298)$ & $1 / 2$ & $(127)$ & 173 \\
\hline $\operatorname{RDX}^{5}$ & 162 & $\left(\begin{array}{lll}6 & 78\end{array}\right)$ & 148 & $\left(\begin{array}{lll}6 & 1 & 1\end{array}\right)$ & 151 & $(632)$ & 142 & $(594)$ & $23(296)$ & $1 / 3$ & $\left(\begin{array}{ll}8 & 47\end{array}\right)$ & 178 \\
\hline $\mathrm{TACOT}^{1}$ & 141 & $(030)$ & 135 & $(564)$ & 098 & $\left(\begin{array}{ll}4 & 10\end{array}\right)$ & 096 & $\left(\begin{array}{ll}4 & 02\end{array}\right)$ & $23(296)$ & $1 / 3$ & $(847)$ & 174 \\
\hline TA TB & 120 & $(002)$ & 108 & (4 52 ) & $\cdots$ & - & --- & $\cdots$ & --- & -- & $\cdots$ & --- \\
\hline Tetryl ${ }^{1}$ & 151 & $\left(\begin{array}{ll}6 & 32\end{array}\right)$ & 145 & $\left(\begin{array}{ll}6 & 07\end{array}\right)$ & 114 & $\left(\begin{array}{ll}4 & 77\end{array}\right)$ & 109 & $(456)$ & $21(294)$ & 1 & $(254)$ & 171 \\
\hline $\mathrm{TNM}^{\mathrm{d} f}$ & 055 & $\left(\begin{array}{ll}2 & 30\end{array}\right)$ & 055 & $\left(\begin{array}{ll}2 & 30\end{array}\right)$ & - & & - & --- & - - & -- & --- & $\cdots$ \\
\hline $1 N T^{2}$ & 141 & $(540)$ & 123 & $(540)$ & 109 & $(4>6)$ & 102 & $(427)$ & $25(298)$ & $1 / 2$ & $(127)$ & I 54 \\
\hline $\mathrm{XTX}-8003^{\mathrm{L}}$ & 188 & $(78)$ & 163 & $\left(\begin{array}{ll}7 & 07\end{array}\right)$ & 116 & $(480)$ & 100 & $\left(\begin{array}{ll}4 & 39\end{array}\right)$ & $25(298)$ & $1 / 2$ & $(127)$ & 155 \\
\hline
\end{tabular}




\section{Compatibility}

Many materials have been tested for compatibility with various HEs; those listed or mentioned in this section are the most commonly used at the LLL facility for explosive testing. In Tables 5-4 and 5-5, which list adhesives and fillers, those materials rated " $A$ " have been evaluated extensively; those rated " $B$ " have been screened for gross incompatibility only. If these materials are used as they are supplied, that is, in the prepackaged catalyst/resin system, they are satisfactory for use as indicated. It is understood that the adhesives will be used in minimum amounts, mixed according to supplier's instructions, and used only for limited times, that is, from two to three months during environmental testing.

The results of our compatibility tests are valid only for the specific batch/lot of HE and adhesive tested. For different HEs and later lots of adhesive, even from the same suppliers, the reactivity and compatibility tests must be repeated. The supplier may change or "improve" the material without notice; this could render the material incompatible.

The compilation is not to be regarded as complete; many other materials have been evaluated but are not commonly used and therefore not included here. Table 5-6 lists adhesive tapes found to be compatible with various HEs; any other tapes should be tested before use.

Table 5-4. Adhesives: Chemical reactivity and compatibility with various high explosives.

A, compatible; OK for long-term storage.

B, compatible; OK for short-term storage (less than 30 days).

Blank, compatibility has not been checked.

1 , bond strength equal to that of explosive.

2, bond strength less than that of explosive.

3 , no bond strength.

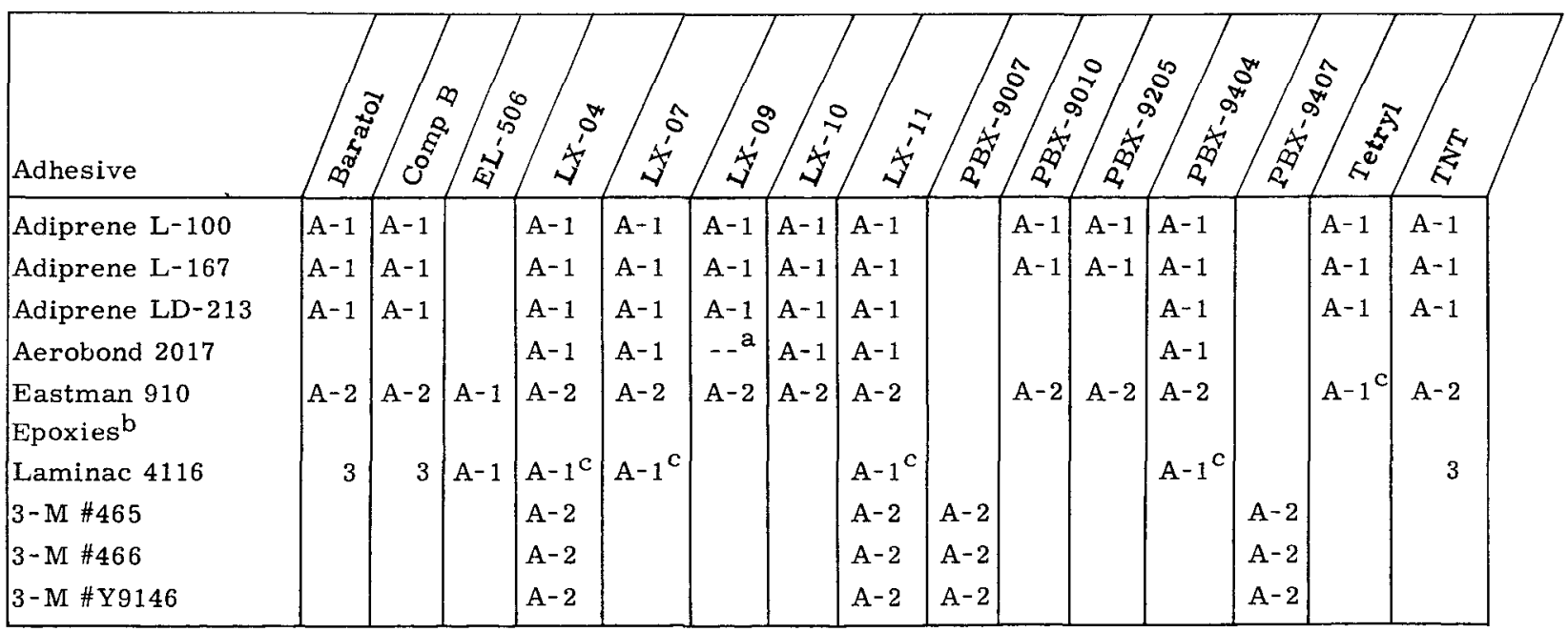

${ }^{a}$ Do not use Aerobond 2017 with LX-09. The cure of the adhesive is inhibited by the explosive.

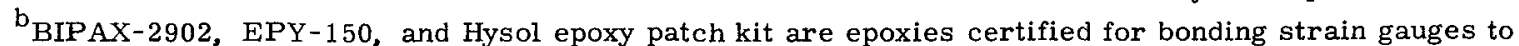
LX-04, LX-07, LX-09, LX-10, and PBX-9404.

${ }^{c}$ Does not meet environmental specifications. 
Table 5-5. Fillers and coatings: Chemical reactivity and compatibility.
A, compatible; OK for long-term stcrage.
B, compatible; OK for short-term storage (less than 30 davs).
1 , bond strength equal to that of explosive.
Blank, compatibility has not been
2 , bond strength less than that of explosive.
3 , no bond strength. checked.

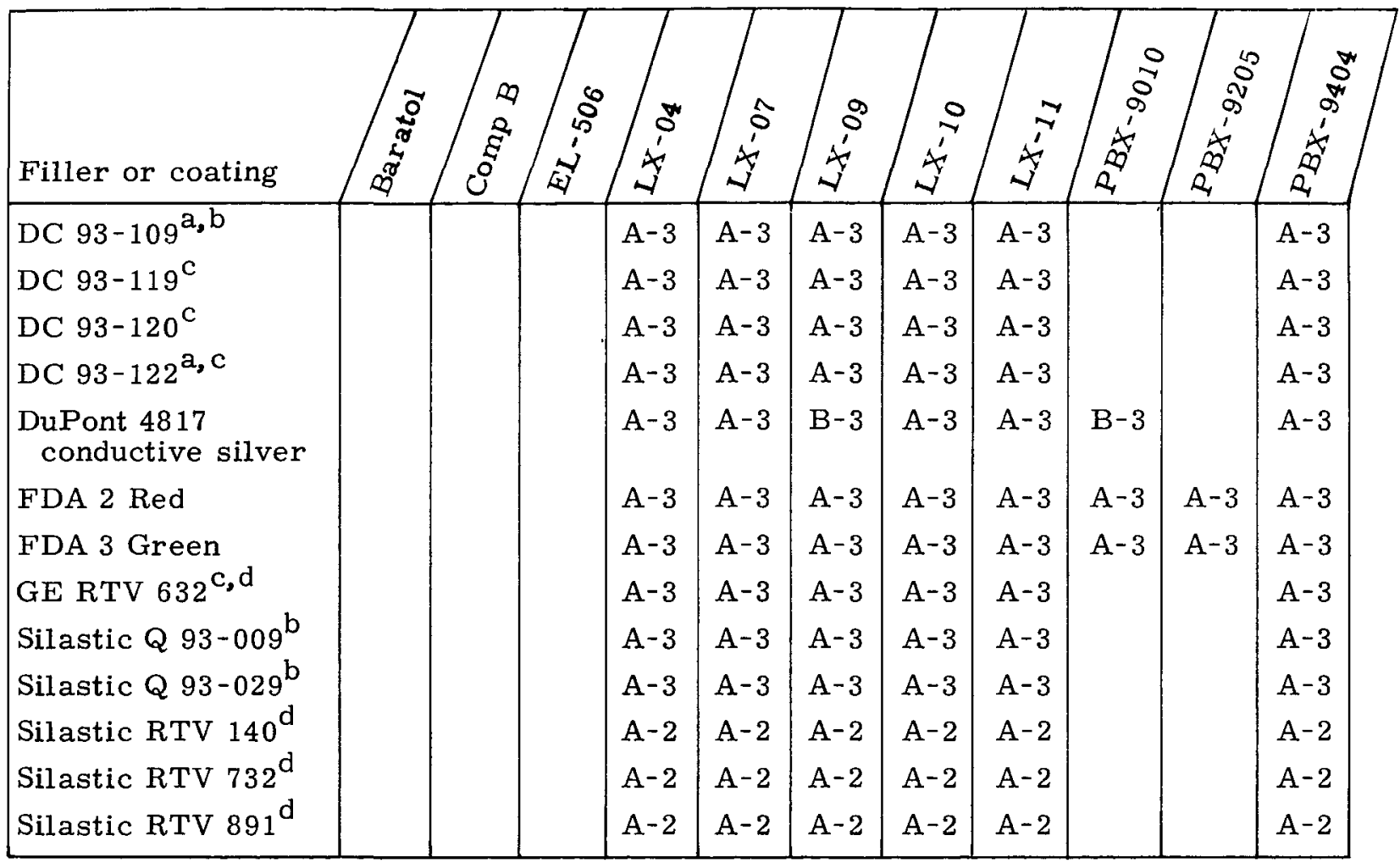

${ }^{a}$ Nonflowing RTV silicone rubber used mostly for potting spacers, detonators, and detonator cables.

${ }^{b}$ Do not attempt to use Nuocure 12, Nuocure 28, or Thermolite 12 catalysts with Silastic Q 93-109 or Q 93-029 when the material will be in contact with LX-09 or other formulations containing FEFO or DNPA.

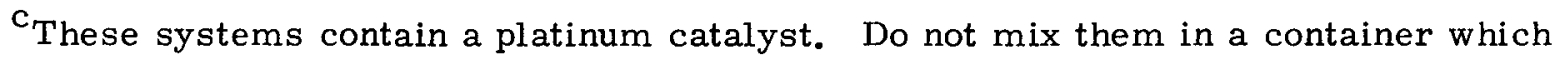
has been used to mix the more conventional RTV silicones, e.g., Silastic Q 93-009 and Q 93-029. The catalyst in these and similar RTV systems poisons the platinum catalyst and thus inhibits the cure.

${ }^{\mathrm{R}} \mathrm{RV}$ : room-temperature vulcanizing. 
Table 5-6. Adhesive tapes found to be compatible with various high explosives. Any tape not listed should be tested before use.

\begin{tabular}{|c|c|c|c|}
\hline Manufacturer & Trade name & Number & Color \\
\hline $3 \mathrm{M}$ & Scotch Brand Electrical Tape & $\# 33$ & Black \\
\hline $3 \mathrm{M}$ & Scotch Brand Mylar & $\# 56$ & Yellow \\
\hline $3 \mathrm{M}$ & Scotch Brand Electrical & $\# 57$ & Yellow \\
\hline $3 \mathrm{M}$ & Scotch Brand Masking & $\# 232$ & Tan \\
\hline $3 \mathrm{M}$ & Scotch Brand Photo Tape & $\# 235$ & Black \\
\hline $3 \mathrm{M}$ & $\begin{array}{l}\text { Scotch Brand Double Sided } \\
\text { Masking }\end{array}$ & $\# 400$ & Tan \\
\hline $3 \mathrm{M}$ & Scotch Brand Tape & $\# 420$ & Lead \\
\hline $3 \mathrm{M}$ & $\begin{array}{l}\text { Scotch Brand Double Sided } \\
\text { Masking }\end{array}$ & $\# 465$ & $\operatorname{Tan}$ \\
\hline $3 \mathrm{M}$ & $\begin{array}{l}\text { Scotch Brand Double Sided } \\
\text { Masking }\end{array}$ & $\# 466$ & $\operatorname{Tan}$ \\
\hline $3 \mathrm{M}$ & Scotch Brand Plastic & $\# 471$ & Yellow \\
\hline $3 \mathrm{M}$ & Scotch Brand Plastic & $\# 471$ & Red \\
\hline $3 \mathrm{M}$ & Scotch Brand Plastic & $\# 471$ & White \\
\hline $3 \mathrm{M}$ & Scotch Brand Cellophane Tape & $\# 600$ & Clear \\
\hline $3 \mathrm{M}$ & Scotch Brand Cellophane Tape & $\# 850$ & Clear \\
\hline $3 \mathrm{M}$ & Scotch Brand Magic Mending & $\# 810$ & Clear \\
\hline $3 \mathrm{M}$ & Scotch Filament Tape & $\# 880$ & Pearl \\
\hline $3 \mathrm{M}$ & $\begin{array}{l}\text { Scotch Brand Double Sided } \\
\text { Masking }\end{array}$ & \#Y9146 & Tan \\
\hline Behr-Manning & Bear Tape & $\# 4 / 1$ & Tan \\
\hline $\begin{array}{l}\text { Hampton Manufacturing } \\
\text { Company }\end{array}$ & Blue Cross Tape & ---- & Yellow \\
\hline Mystik Tape, Inc. & Mystic Tape & $\# 5803$ & Black \\
\hline Okonite Company & High Voltage Rubber Tape & --- & Brown \\
\hline Permacel & Permacel & $\# 29$ & Black \\
\hline Permacel & Permacel & $\# 32$ & Red \\
\hline Permacel & Permacel Cellophane Tape & --- & Clear \\
\hline $\begin{array}{l}\text { Saunders Engineering } \\
\text { Corporation }\end{array}$ & Teflon Tape & $\begin{array}{l}\text { \#S15 } \\
\text { \#S16 } \\
\text { \#S18 }\end{array}$ & Blue/brown \\
\hline $\begin{array}{l}\text { Technical Tape } \\
\text { Corporation }\end{array}$ & Tuck Tape & --- & Yellow \\
\hline $\begin{array}{l}\text { Technical Tape } \\
\text { Corporation }\end{array}$ & Tuck Tape & --- & Black \\
\hline
\end{tabular}


Table 5-7. Qualitative solubilities of pure explosives. Solubilities are expressed as follows, in terms of weight of substance dissolved at room temperature per $100 \mathrm{ml}$ of solvent: $i$ - insoluble (less than $0.1 \mathrm{~g}$ ), $\mathrm{sl}=$ slightly soluble $(0.1$ to $5 \mathrm{~g}), \mathrm{s}=$ soluble (over $5 \mathrm{~g}$ ).

\begin{tabular}{|c|c|c|c|c|c|c|c|c|c|c|c|c|c|c|c|c|c|c|c|c|}
\hline Solvent & BTF & DA TB & DIPAM & DNPA & EDNP & FEFO & HMX & $\mathrm{HNAB}^{6}$ & $\mathrm{HNS}^{7}$ & $\mathrm{NC}$ & $\mathrm{NG}^{8}$ & $\mathrm{NM}$ & $\mathrm{NQ}$ & PETN & RDX & $\mathrm{TACOT}^{9}$ & TATB & Tetryl & TNM & TNT \\
\hline Acetone & $\mathrm{s}$ & 1 & $\mathrm{~s}$ & $\mathbf{s}$ & $\mathrm{s}$ & $s$ & sl & $\mathrm{s}$ & sl & $\mathrm{s}$ & $\mathrm{s}$ & - & 1 & s & $\mathrm{s}$ & - & 1 & $\mathrm{~s}$ & - & s \\
\hline Benzene & $\mathbf{s}$ & 1 & - & - & - & - & - & - & - & - & $\mathrm{s}$ & - & 1 & sl & 1 & - & 1 & $\mathbf{s}$ & $\mathbf{s}$ & $\mathbf{s}$ \\
\hline Carbon disulfide & - & 1 & - & - & - & - & 1 & - & - & - & sl & - & 1 & 1 & 1 & - & 1 & 1 & - & sl \\
\hline Carbon tetrachloride & 1 & 1 & - & - & s & 1 & 1 & sl & - & 1 & sl & - & 1 & 1 & 1 & - & 1 & 1 & - & sl \\
\hline Chloroform & - & - & $\mathbf{s} 1$ & - & s & $s$ & 1 & $\mathrm{sl}$ & - & 1 & $\mathbf{s}$ & - & 1 & 1 & 1 & 1 & 1 & sl & - & $\mathbf{s}$ \\
\hline DMFA & s & $\mathrm{s}$ & $\mathrm{s}$ & - & s & $\mathrm{s}$ & sl & - & $\mathrm{s}$ & - & - & $\mathrm{s}$ & - & s & $\mathbf{s}$ & $\mathrm{sl}$ & 1 & - & - & $\mathbf{s}$ \\
\hline DMSO & s & $\mathrm{s}$ & s & - & s & $\mathbf{s}$ & $\mathrm{s}$ & - & - & - & - & $\mathbf{s}$ & - & $\mathbf{s}$ & $\mathbf{s}$ & sl & 1 & - & - & - \\
\hline Ethanol & s & 1 & - & - & $s$ & $\mathrm{~s}$ & - & - & - & $s$ & $s$ & s & sl & $x$ & sl & 1 & 1 & sl & $\mathrm{s}$ & sl \\
\hline Ethyl acetate & s & - & - & - & s & $\mathrm{s}$ & - & sl & - & - & $\mathrm{s}$ & - & 1 & $\mathbf{s}$ & 1 & - & 1 & $\mathbf{s}$ & - & $\mathbf{s}$ \\
\hline Ethyl ether & s & - & - & - & s & s & 2 & - & - & 1 & $\mathbf{s}$ & s & 1 & sl & 1 & - & 1 & sl & s & sl \\
\hline Nitric acid & - & - & $\mathrm{s}$ & - & - & - & - & - & - & - & $\mathbf{s}$ & - & sl & - & - & sl & - & $\mathbf{s}$ & - & $\mathbf{s}$ \\
\hline Sulfuric acid & - & - & - & - & - & - & - & - & - & - & $s$ & - & s & - & - & - & $\mathrm{si}^{10}$ & - & - & $\mathbf{s}$ \\
\hline Pyridine & $\mathrm{s}$ & - & - & - & s & s & sl & - & - & - & $\mathrm{s}$ & - & - & s & sl & sl & - & - & - & $\mathbf{s}$ \\
\hline Water & 1 & 1 & - & - & 1 & 1 & 1 & - & - & 1 & sl & s & 1 & 1 & 1 & 1 & 1 & 1 & sl & 1 \\
\hline
\end{tabular}

Table 5-8. Qualitative solubilities of additives and binders. Solubilities are expressed as follows, in terms of weight of substance dissolved at room temperature per $100 \mathrm{ml}$ of solvent: $\mathrm{i}$ a insoluble (less than $0.1 \mathrm{~g}$ ), $\mathrm{sl}=$ slightly soluble $(0.1$ to $5 \mathrm{~g}$ ), $\mathrm{s}=$ soluble (over $5 \mathrm{~g}$ ).

\begin{tabular}{|c|c|c|c|c|c|c|c|c|c|c|}
\hline Solvent & $\begin{array}{l}\text { BDNPA } \\
\text { BDNPF }_{1}\end{array}$ & $\mathrm{Cab}-\mathrm{O}-\mathrm{S}_{11}$ & $\mathrm{DOP}^{12}$ & $\begin{array}{l}\text { Estane } \\
5702-\mathrm{F} 13\end{array}$ & $\begin{array}{l}\text { Exon } \\
46114\end{array}$ & $\mathrm{Kel}-\mathrm{F}^{15}$ & Polystyrene $\mathrm{e}^{16}$ & $\begin{array}{c}\text { Sylgard } \\
182\end{array}$ & $\mathrm{TEF}^{17}$ & Viton A \\
\hline Acetone & - & - & - & s & - & s & - & - & - & s \\
\hline Benzene & $\mathrm{s}$ & - & - & - & - & - & $\mathrm{s}$ & - & s & - \\
\hline Dichloroethane & - & - & - & s & - & - & - & - & - & - \\
\hline DMFA & - & - & - & $\mathrm{s}$ & - & - & - & - & - & - \\
\hline DMSO & - & - & - & s & - & - & - & - & - & - \\
\hline Gasolıne & - & - & $\mathrm{s}$ & - & $s$ & - & - & - & - & - \\
\hline Glycerine & - & - & 1 & - & - & - & - & - & - & - \\
\hline MEK & - & - & - & s & s & $\mathrm{s}$ & - & - & s & s \\
\hline MIBK & - & - & - & $\mathbf{s}$ & - & s & - & - & s & s \\
\hline THF & - & - & - & s & - & s & - & - & - & s \\
\hline Toluene & $\mathrm{s}$ & - & - & - & s & 1 & s & - & $\mathrm{s}$ & - \\
\hline Water & 1 & - & 1 & - & - & - & - & - & 1 & - \\
\hline Xylene & - & - & - & - & s & - & - & - & s & - \\
\hline
\end{tabular}




\section{References}

1. D. L. Ornellas, Lawrence Livermore Laboratory, personal communication (1974).

2. D. L. Ornellas, J. Phys. Chem. 72, 2390-2394 (1968).

3. H. W. Sexton, Armament Research and Development Establishment, Fort Halstead, United Kingdom, personal communication (1956).

4. D. L. Ornellas, J. C. Carpenter, and S. R. Gunn, Rev. Sci. Inst. 37, 907-912 (1966).

5. A. Ya. Apin and Yu. A. Lebedev, Dokl. Akad. Nauk USSR 114, 819-821 (1957).

6. D. O'Keefe, Sandia Laboratories, Albuquerque, N. Mex., personal communication (1972).

7. K. G. Shipp, J. Org. Chem. 29, 2620-2623 (1964).

8. T. Urbanski, Chemistry and Technology of Explosives (McMillan, New York, 1964-1967), vols. 1-3.

9. W. Selig, Some Analytical Methods for Explosives and Explosive Simulants, Law rence Livermore Laboratory, Rept. UCRL-7873 Pts. 1-4 (1964-1973).

10. V. D. Gupta and B. L. Deopura, Mol. Phys. 19, 589-592 (1970).

11. M. Finger, Properties of Bis(2,2-dinitropropyl)acetal and Bis(2,2dinitropropyl)formal, Eutectic Mixture, Lawrence Livermore Laboratory, Rept. UCID-16088 (1972).

12. Food Machinery and Chemical Corporation, Ohio-Apex Division, Nitro, W. V., Plasticizers (no date).

13. B. F. Goodrich Company, Cleveland, Ohio, Estane Polyurethane Solution Systems, Service Bulletin, TSR 64-18 (1964).

14. Firestone Plastics Company, Pottstown, Pa., Exon, Sales Service Bulletin No. 20 (1956).

15. Minnesota Mining and Manufacturing Company, St. Paul, Minn., Kel-F Elastomer - Properties and Applications, Service Bulletin (no date).

16. J. Brandrup and E. H. Immergut, Eds., Polymer Handbook (Interscience, N. Y., 1966).

17. Celanese Chemical Corporation, New York, N.Y., Celluflex CEF, Product Bulletin N-46-2 (1955). 


\section{THERMAL PROPERTIES}

This section contains tables and information on thermal conductivity $\mathrm{k}$, coefficient of thermal expansion CTE, estimated specific heat $\mathrm{Cp}$, glass transition point $\mathrm{Tg}$, and thermal stability.

\section{Thermal Conductivity}

Measurements of thermal conductivity made $\mathrm{e}^{1}$ on an apparatus similar to that used at the National Bureau of Standards are included in Table 6-1. Thermal conductivities as a function of temperature are given in Fig. 6-1 for 8 explosives; the straight lines represent the best fit of the data.

Table 6-1. Thermal conductivities $\mathrm{k}$.

\begin{tabular}{|c|c|c|c|c|c|c|c|}
\hline \multirow[b]{2}{*}{ Explosive } & \multicolumn{4}{|c|}{$\mathbf{k}$} & \multicolumn{3}{|c|}{$\mathrm{T}$} \\
\hline & $\left(\mathrm{BTU} / \mathrm{hr}-\mathrm{ft}-{ }^{\circ} \mathrm{F}\right)^{1}$ & $\left(10^{-4}\right.$ & $\left.\mathrm{cal} / \mathrm{cm}-\mathrm{sec}-{ }^{\circ} \mathrm{C}\right)$ & $(W / m-K)^{a}$ & $\left({ }^{\circ} \mathrm{C}\right)$ & $\left({ }^{\circ} \mathrm{F}\right)$ & $(\mathrm{K})$ \\
\hline Baratol & & & 11.84 & $(0.4 .95)$ & $18-75$ & & $(291-348)$ \\
\hline Comp B-3 & & & 6.27 & $(0.262)$ & $18-72$ & & $(291-345)$ \\
\hline Comp C-4 & & & 6.22 & $(0.260)$ & & & \\
\hline DATB & & & 6.00 & $(0.251)$ & & & \\
\hline LX -04 & 0.22 & & 9.25 & $(0.380)$ & 21.1 & 70 & $(294)$ \\
\hline$L X-07$ & 0.23 & & & $(0.398)$ & & 70 & $(294)$ \\
\hline$L X-09$ & 0.25 & & & $(0.432)$ & & 70 & $(294)$ \\
\hline$L X-10$ & 0.25 & & & $(0.432)$ & & 70 & $(294)$ \\
\hline $\mathrm{LX}-11$ & 0.21 (est.) & & & $(0.363)(\mathrm{es}$ & st.) & 70 & $(294)$ \\
\hline $\mathrm{NC}(12.7 \% \mathrm{~N})$ & & & 5.5 & $(0.230)$ & & & \\
\hline PBX-9010 & & & $5.14^{2}$ & $(0.215)$ & & & \\
\hline PBX-9011 & 0.25 & & 10.0 & $(0.432)$ & & 70 & $(294)$ \\
\hline PBX-9404 & 0.25 & & 10.1 & $(0.432)$ & 21.1 & 70 & $(294)$ \\
\hline PBX-9501 & & & $10.8^{2}$ & $(0.451)$ & & & \\
\hline Polystyrene & & & $\begin{array}{l}2.51^{3} \\
2.78 \\
3.06\end{array}$ & $\begin{array}{l}(0.105) \\
(0.116) \\
(0.128)\end{array}$ & $\begin{array}{r}0 \\
50 \\
100\end{array}$ & & $\begin{array}{l}(273) \\
(323) \\
(373)\end{array}$ \\
\hline Sylgard 182 & & & $3.5^{4}$ & $(0.146)(\mathrm{cu}$ & ared) & & \\
\hline $\begin{array}{l}\text { Tetryl } \\
\qquad(\rho=1.53)\end{array}$ & & & 6.83 & $(0.286)$ & & & \\
\hline $\begin{array}{l}\text { TNT } \\
\quad(\rho=1.60)\end{array}$ & & & 6.22 & $(0.260)$ & $18-45$ & & $(291-318)$ \\
\hline
\end{tabular}




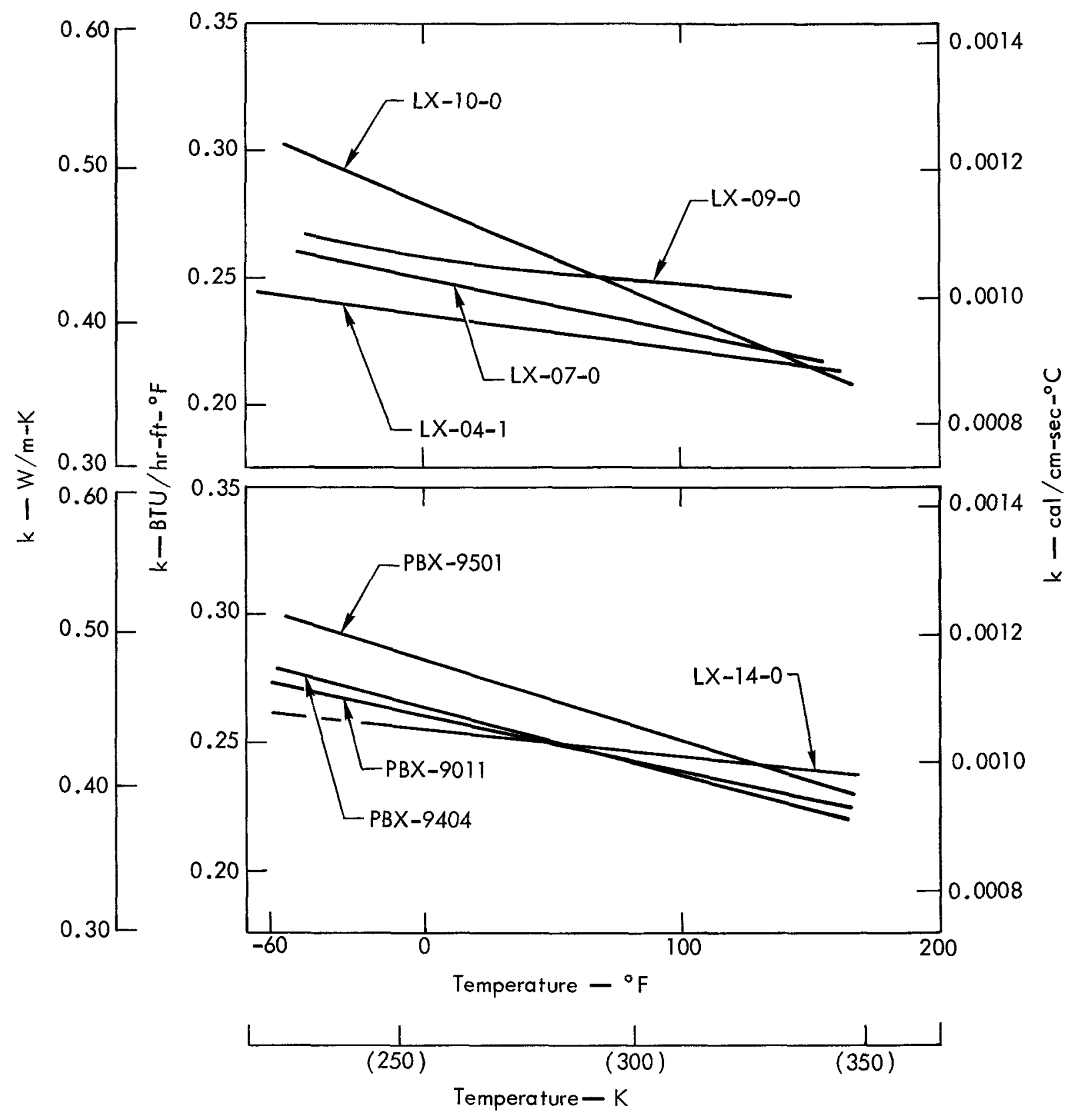

Fig. 6-1. Thermal conductivity $k$ as a function of temperature for $L X-04-1,{ }^{1} L X-07-0,5$ LX-09-0,6 LX-10-0, 5 LX-14-0, 7 PBX-9011, 5 PBX-9404, 1 and PBX-9501. 5

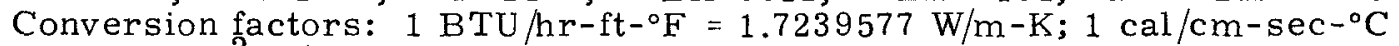
$=4.184 \times 10^{2} \mathrm{~W} / \mathrm{m}-\mathrm{K}$. 
The thermal conductivity data ${ }^{5}$ shown in Fig. 6-2 as a function of HMX content indicate the range of properties available with HMX/Viton explosives; see also the CTE data shown in Fig. 6-3 as a function of HMX content. Thermal conductivity $k$ increases with increasing HMX content; CTE decreases.

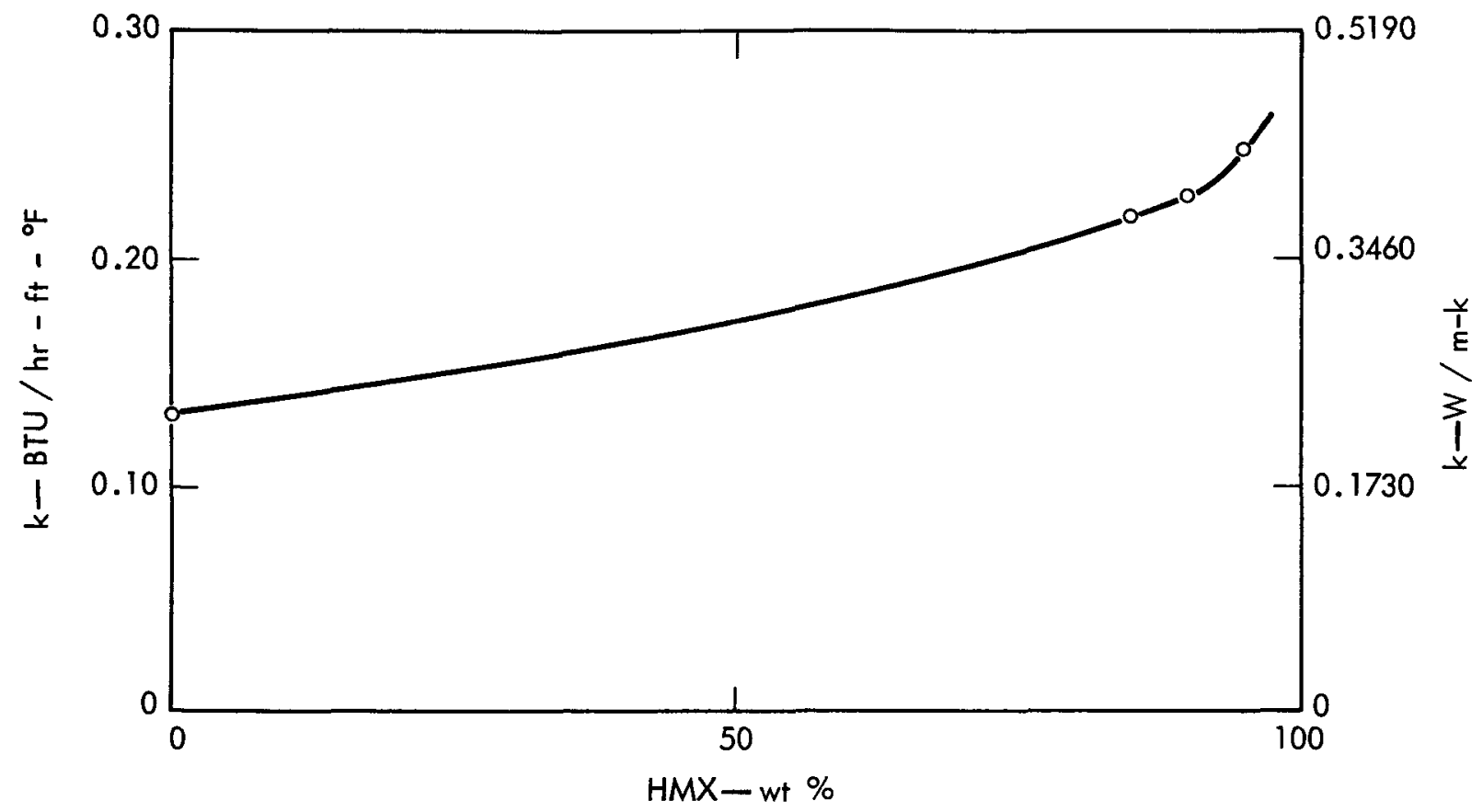

Fig. 6-2. Thermal conductivity $\mathrm{k}$ vs wt $\% \mathrm{HMX}$ for $\mathrm{HMX} /$ Viton systems at $70^{\circ} \mathrm{F}\left(21^{\circ} \mathrm{C}\right.$, $294 \mathrm{~K}$ ). Conversion factors: $1 \mathrm{BTU} / \mathrm{hr}-\mathrm{ft}-{ }^{\circ} \mathrm{F}=1.729577 \mathrm{~W} / \mathrm{m}-\mathrm{K}$;

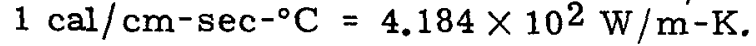




\section{Thermal Expansion}

Thermal expansion data were obtained by the use of bulk mercury dilatometers or a linear expansion apparatus; the two methods produce comparable results. ${ }^{6}$ Figure 6-3 shows CTE as a function of HMX content for HMX/Viton systems. Table 6-2 lists the measured linear $(\alpha)$ and cubic $(\beta)$ expansion coefficients of explosives and binders along with their glass transition temperatures and pressed densities. The cubic expansion coefficients $(\beta)$ can be calculated for isotropic materials as $\beta=3 \alpha$.

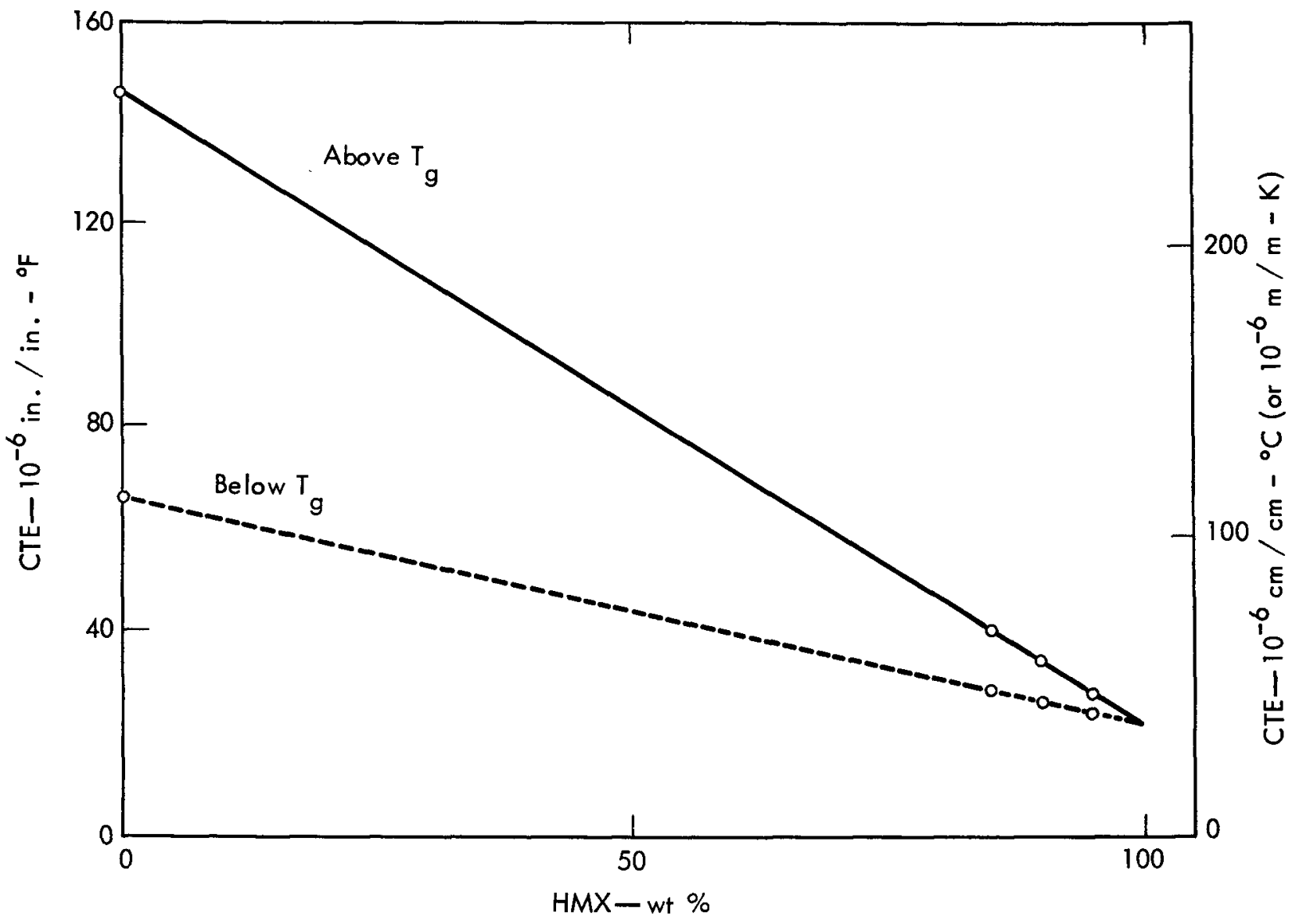

Fig. 6-3. Coefficients of thermal expansion CTE vs wt\% HMX for HMX/Viton systems. Conversion factor: 1 in. $/$ in. ${ }^{\circ} \mathrm{F}=1.8 \mathrm{~cm} / \mathrm{cm}^{-}{ }^{\circ} \mathrm{C}=1.8 \mathrm{~m} / \mathrm{m}-\mathrm{K}$. 
Table 6.2. Explosives and binders: Coefficients of thermal expansion CTE, glass transition temperatures $\mathrm{Tg}$, and pressed densities $\rho$.

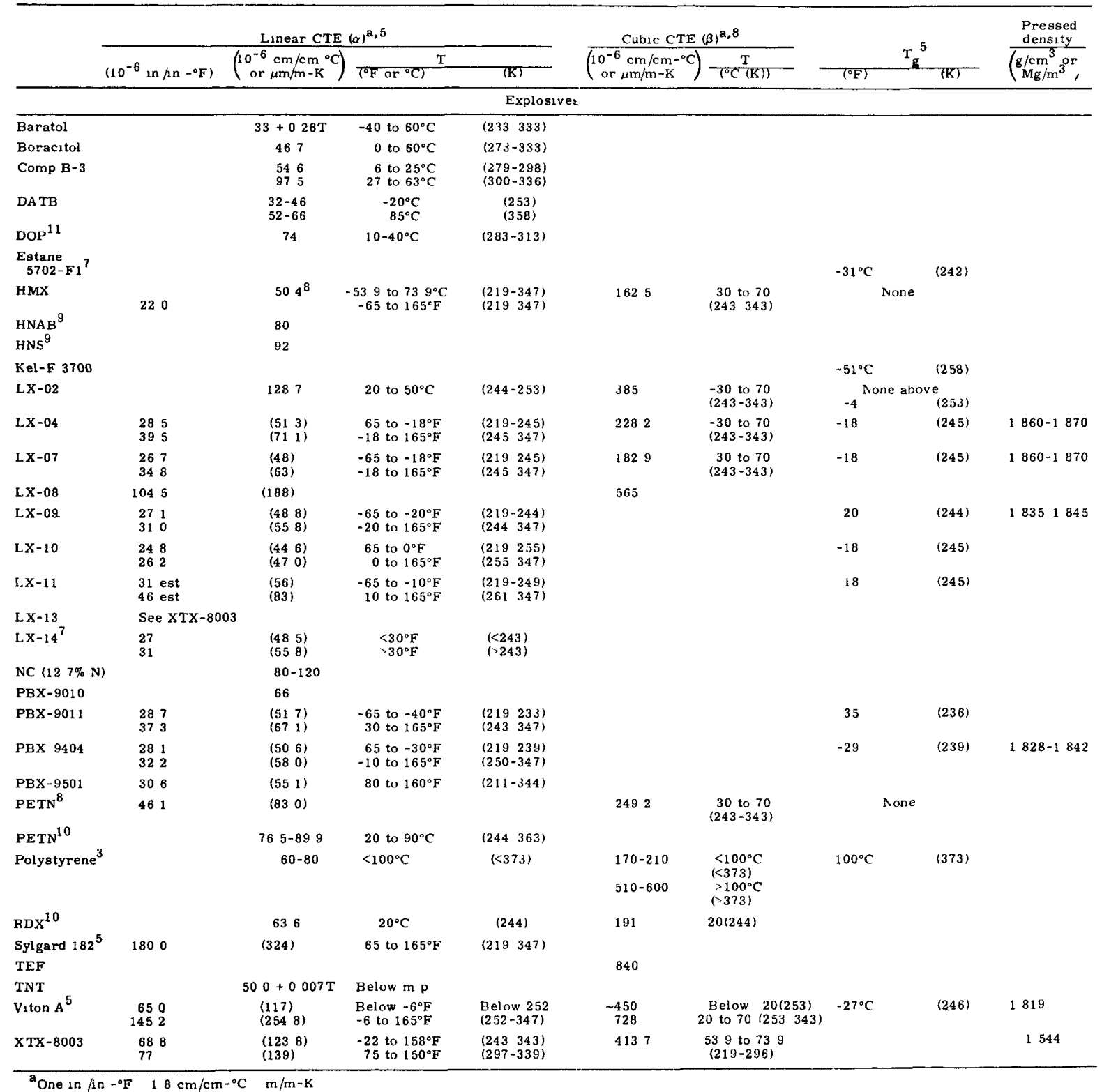




\section{Specific Heat}

Specific heats $\mathrm{C}_{\mathrm{p}}$ for the plastic components of plastic bonded explosives were estimated by means of the Kopp-Joule rule. Specific heat for the PBX was then calculated by applying the appropriate weight fractions to the specific heat of the components.

The estimates of specific heat $C_{p}$ listed in Table 6-3 are believed to be accurate to $\pm 5 \%$. Values for specific heat at temperatures other than $20^{\circ} \mathrm{C}(293 \mathrm{~K})$ for $\mathrm{HMX}-$ containing $\mathrm{PBX}$ can be estimated by the formula

$$
C_{p}(T)=C_{p}\left(T_{0}\right) \frac{C_{p}(T) H M X}{C_{p}\left(T_{0}\right) H M X},
$$

where $\mathrm{C}_{\mathrm{p}}(\mathrm{T})$ is the specific heat at a temperature other than $20^{\circ} \mathrm{C}(293 \mathrm{~K})$, and $\mathrm{C}_{\mathrm{p}}\left(\mathrm{T}_{0}\right)$ is the specific heat at $20^{\circ} \mathrm{C}(293 \mathrm{~K})$. Similarly, substitute RDX values into the formula for RDX-containing PBX. The specific heats of HMX and RDX as a function of temperature are included in Table 6-3.

Table 6-3. Specific heats $\mathrm{C}_{\mathrm{p}}$.

\begin{tabular}{|c|c|c|c|c|}
\hline \multirow[b]{2}{*}{ Explosive } & \multicolumn{2}{|c|}{$\mathrm{C}_{\mathrm{p}}$ (est.) at $20^{\circ} \mathrm{C}(293 \mathrm{~K})^{12}$} & \multicolumn{2}{|c|}{$C_{p}$, experimental } \\
\hline & $\left(\mathrm{cal} / \mathrm{g}-{ }^{\circ} \mathrm{C}\right)^{\mathrm{a}}$ & $(\mathrm{kJ} / \mathrm{kg}-\mathrm{K})^{\mathrm{b}}$ & $\left(\mathrm{cal} / \mathrm{g}-{ }^{\circ} \mathrm{C}\right)^{\mathrm{a}}$ & $(\mathrm{kJ} / \mathrm{kg}-\mathrm{K})^{\mathrm{b}}$ \\
\hline Baratol $^{13}$ & & & $\begin{array}{l}0.157 \text { at } 30^{\circ} \mathrm{C} \\
0.201 \text { at } 50^{\circ} \mathrm{C} \\
0.403 \text { at } 70^{\circ} \mathrm{C} \\
0.192 \text { at } 83-100^{\circ} \mathrm{C}\end{array}$ & $\begin{array}{l}(0.657 \text { at } 303 \mathrm{~K}) \\
(0.841 \text { at } 323 \mathrm{~K}) \\
(1.686 \text { at } 343 \mathrm{~K}) \\
(0.803 \text { at } 356-373 \mathrm{~K})\end{array}$ \\
\hline Comp B-3 $3^{13}$ & & & $\begin{array}{l}0.299 \text { at } 30^{\circ} \mathrm{C} \\
0.307 \text { at } 50^{\circ} \mathrm{C} \\
0.325 \text { at } 70^{\circ} \mathrm{C} \\
0.333 \text { at } 83-100^{\circ} \mathrm{C}\end{array}$ & $\begin{array}{l}(1.251 \text { at } 303 \mathrm{~K}) \\
(1.284 \text { at } 323 \mathrm{~K}) \\
(1.359 \text { at } 343 \mathrm{~K}) \\
(1.393 \text { at } 356-373 \mathrm{~K})\end{array}$ \\
\hline$D O P^{11}$ & & & $\sim 0.57$ at $50-150^{\circ} \mathrm{C}$ & $(2.385$ at $323-423 \mathrm{~K})$ \\
\hline $\mathrm{FEFO}^{14}$ & $\begin{array}{l}0.25\left(-73^{\circ} \mathrm{C}\right) \\
0.36\left(25^{\circ} \mathrm{C}\right) \\
0.47\left(127^{\circ} \mathrm{C}\right)\end{array}$ & $\begin{array}{l}(1.05)(200 \mathrm{~K}) \\
(1.51)(298 \mathrm{~K}) \\
(1.97)(400 \mathrm{~K})\end{array}$ & & \\
\hline $\mathrm{HMX}^{13}$ & & & $\begin{array}{l}0.265 \text { at } 20^{\circ} \mathrm{C} \\
0.267 \text { at } 30^{\circ} \mathrm{C} \\
0.271 \text { at } 50^{\circ} \mathrm{C} \\
0.278 \text { at } 70^{\circ} \mathrm{C} \\
0.286 \text { at } 90^{\circ} \mathrm{C} \\
0.295 \text { at } 110^{\circ} \mathrm{C} \\
0.302 \text { at } 130^{\circ} \mathrm{C} \\
0.312 \text { at } 150^{\circ} \mathrm{C}\end{array}$ & $\begin{array}{l}(1.109 \text { at } 293 \mathrm{~K}) \\
(1.117 \text { at } 303 \mathrm{~K}) \\
(1.133 \text { at } 323 \mathrm{~K}) \\
(1.163 \text { at } 343 \mathrm{~K}) \\
(1.197 \text { at } 363 \mathrm{~K}) \\
(1.234 \text { at } 383 \mathrm{~K}) \\
(1.264 \text { at } 403 \mathrm{~K}) \\
(1.305 \text { at } 423 \mathrm{~K})\end{array}$ \\
\hline $\mathrm{HNS}^{15}$ & 0.40 & $(1.67)$ & & \\
\hline$L X-02^{16}$ & 0.29 & $(1.21)$ & & \\
\hline LX -04 & 0.30 & $(1.25)$ & & \\
\hline LX -07 & 0.29 & $(1.21)$ & & \\
\hline $\mathrm{LX}-08$ & 0.28 & $(1.17)$ & & \\
\hline $\mathrm{LX}-09$ & 0.27 & (1.13) & & \\
\hline & & & -6 & $7 / 74$ \\
\hline
\end{tabular}


Table 6-3. (continued).

\begin{tabular}{|c|c|c|c|c|}
\hline \multirow[b]{2}{*}{ Explosive } & \multicolumn{2}{|c|}{$\mathrm{C}_{\mathrm{p}}$ (est.). at $20^{\circ} \mathrm{C}(293 \mathrm{~K})^{12}$} & \multicolumn{2}{|c|}{$\mathrm{C}_{\mathrm{p}}$, experimental } \\
\hline & $\left(\mathrm{cal} / \mathrm{g}-{ }^{\circ} \mathrm{C}\right)^{\mathrm{a}}$ & $(\mathrm{kJ} / \mathrm{kg}-\mathrm{K})^{\mathrm{b}}$ & $\left(\mathrm{cal} / \mathrm{g}-{ }^{\circ} \mathrm{C}\right)^{\mathrm{a}}$ & $(\mathrm{kJ} / \mathrm{kg}-\mathrm{K})^{\mathrm{b}}$ \\
\hline$L X-10$ & 0.28 & $(1.17)$ & & \\
\hline $\mathrm{LX}-11^{16}$ & 0.31 & $(1.26)$ & & \\
\hline $\mathrm{LX}-13$ & 0.27 & $(1.13)$ & & \\
\hline $\begin{array}{l}\mathrm{NC}^{17} \\
(13.35 \% \mathrm{~N}, \mathrm{~min})\end{array}$ & $\begin{array}{r}0.27 \\
\text { nin.) }\end{array}$ & $(1.13)$ & \multicolumn{2}{|c|}{$\left(1.84 \times 10^{-2}\right)+\left(7.64 \times 10^{-4} \mathrm{~T}\right)$ at $298-390 \mathrm{~K}$} \\
\hline \multicolumn{3}{|c|}{$\mathrm{NG}^{18}$} & 0.356 at $35-200^{\circ} \mathrm{C}$ & $(1.490$ at $308-473 \mathrm{~K})$ \\
\hline \multicolumn{3}{|l|}{$\mathrm{NM}^{19}$} & \multirow{2}{*}{\multicolumn{2}{|c|}{$\begin{aligned} \mathrm{C}_{\text {sat }}= & 104.4+\left(6.381 \times 10^{-2} \mathrm{t}\right) \\
& +\left(3.175 \times 10^{-4} \mathrm{t}^{2}\right)-\left(8.131 \times 10^{-7} \mathrm{t}^{3}\right) \\
& +\left(4.093 \times 10^{-9} \mathrm{t}^{4}\right) \mathrm{J} / \mathrm{mole}-{ }^{\circ} \mathrm{C}, \mathrm{t} \text { in }{ }^{\circ} \mathrm{C} \\
\mathrm{C}_{\mathrm{p}}= & 6+0.08 \mathrm{~T} \text { at } 200-460 \mathrm{~K}\end{aligned}$}} \\
\hline \multicolumn{3}{|l|}{$\mathrm{NQ}^{20}$} & & \\
\hline Octol & 0.27 & $(1.13)$ & & \\
\hline PBX-9007 & 0.28 & $(1.17)$ & & \\
\hline PBX-9010 & 0.27 & $(1.13)$ & \multicolumn{2}{|c|}{$0.247+0.00064 \mathrm{t}^{2}$ at $37-167^{\circ} \mathrm{C}(310-440 \mathrm{~K})$} \\
\hline PBX-9011 & 0.27 & $(1.13)$ & & \\
\hline PBX-9205 & 0.28 & $(1.17)$ & & \\
\hline PBX-9404 & 0.27 & $(1.13)$ & & \\
\hline PBX-9407 & 0.27 & $(1.13)$ & & \\
\hline PBX $-9501^{21}$ & 0.27 & $(1.13)$ & \multicolumn{2}{|c|}{$0.238+0.00079 \mathrm{~T}^{2}$ at $50-175^{\circ} \mathrm{C}(323-448 \mathrm{~K})$} \\
\hline \multicolumn{3}{|c|}{ Pentolite 50/50 0.26} & & \\
\hline \multicolumn{3}{|c|}{$\mathrm{PETN}^{12}$} & 0.26 at $20^{\circ} \mathrm{C}$ & $(1.088$ at $293 \mathrm{~K})$ \\
\hline \multicolumn{3}{|l|}{ Polystyrene ${ }^{3}$} & $\begin{array}{l}0.283 \text { at } 0^{\circ} \mathrm{C} \\
0.300 \text { at } 50^{\circ} \mathrm{C} \\
0.439 \text { at } 100^{\circ} \mathrm{C}\end{array}$ & $\begin{array}{l}(1.184 \text { at } 273 \mathrm{~K}) \\
(1.255 \text { at } 323 \mathrm{~K}) \\
(1.837 \text { at } 373 \mathrm{~K})\end{array}$ \\
\hline \multicolumn{3}{|l|}{$\operatorname{RDX}^{13}$} & $\begin{array}{l}0.274 \text { at } 20^{\circ} \mathrm{C} \\
0.278 \text { at } 30^{\circ} \mathrm{C} \\
0.285 \text { at } 50^{\circ} \mathrm{C} \\
0.289 \text { at } 70^{\circ} \mathrm{C} \\
0.290 \text { at } 90^{\circ} \mathrm{C} \\
0.293 \text { at } 110^{\circ} \mathrm{C}\end{array}$ & $\begin{array}{l}(1.146 \text { at } 293 \mathrm{~K}) \\
(1.163 \text { at } 303 \mathrm{~K}) \\
(1.192 \text { at } 323 \mathrm{~K}) \\
(1.209 \text { at } 343 \mathrm{~K}) \\
(1.213 \text { at } 363 \mathrm{~K}) \\
(1.236 \text { at } 383 \mathrm{~K})\end{array}$ \\
\hline \multicolumn{3}{|l|}{ Sylgard $182^{4}$} & \multicolumn{2}{|r|}{$(1.423$ at $298 \mathrm{~K})$} \\
\hline TA TB ${ }^{19}$ & 0.25 at $25^{\circ} \mathrm{C}$ & $(1.05$ at $298 \mathrm{~K})$ & & \\
\hline \multirow[t]{2}{*}{$\mathrm{TNT}^{22}$} & & & \multicolumn{2}{|c|}{$\begin{array}{l}C_{p}=15+0.19 \mathrm{~T} \text { at } 200-403 \mathrm{~K} \\
0.2463+\left(8.408 \times 10^{-4} \mathrm{t}\right) \\
\text { at } 25-68^{\circ} \mathrm{C}(298-341 \mathrm{~K})\end{array}$} \\
\hline & & & \multicolumn{2}{|c|}{$\begin{array}{l}0.4502+\left(8.018 \times 10^{-4} \mathrm{t}\right) \\
\text { at } 83-117^{\circ} \mathrm{C}(356-390 \mathrm{~K})\end{array}$} \\
\hline \multicolumn{3}{|l|}{ Viton $A^{23}$} & \multirow[t]{2}{*}{0.35} & $(1.464)$ \\
\hline $\mathrm{XTX}-8003^{16}$ & 0.27 & $(1.13)$ & & \\
\hline
\end{tabular}

\footnotetext{
${ }^{\mathrm{a}}$ Values are identical for $\mathrm{BTU} / \mathrm{lb}-{ }^{\circ} \mathrm{F}$ and $\mathrm{cal} / \mathrm{g}-{ }^{\circ} \mathrm{C}$.

${ }^{\mathrm{b}}$ Conversion factor: $1 \mathrm{cal} / \mathrm{g}-{ }^{\circ} \mathrm{C}=4.184 \mathrm{~kJ} / \mathrm{kg}-\mathrm{K}$.

${ }^{c^{C}} \mathrm{C}_{\text {sat }}=$ heat capacity at saturated liquid nitromethane under its own vapor pressure. $7 / 74 \quad 6-7$
} 


\section{Thermal Stability}

Thermal changes in materials can be measured in several ways, qualitatively and quantitatively. For HEs we generally use differential thermal analysis (DTA), thermogravimetric analysis (TGA), and tests (pyrolysis, CRT, or vacuum stability) that measure the amount of gas evolved when an $\mathrm{HE}$ is heated for a stated period of time at an elevated temperature. Heating rates are $10^{\circ} \mathrm{C} / \mathrm{min}$.

1. Differential thermal analysis (DTA). In the usual DTA analysis, identical containers are set up (one containing the sample and the other containing a standard reference substance) in identical thermal geometries with temperature sensors arranged so as to give both the temperature of each container and the difference in temperatures between containers. The data are displayed as a DTA thermogram in which the temperature difference is plotted against the temperature of the sample. The standard reference material chosen is one whose thermal behavior does not change rapidly. Such a plot is almost a straight line if the sample also has no rapidly changing thermal behavior (or if it is very similar to the standard material). Excursions above and below a background line are due to endo- or exothermic (heat-absorbing or heatreleasing) changes. The DTA analyses permit interpretation for phase changes, decomposition and kinetic information, melting points, thermal stability. Results are shown in Fig. 6-4. Sample sizes are of the order of $20 \mathrm{mg}$.

2. Pyrolysis. The sample is placed in a pyrolysis chamber which is then flushed with helium. When the air has been swept out, the temperature of the chamber is raised at a constant rate. Gas evolution is measured as a function of temperature by a bridge formed by two thermal conductivity cells. Data are included in Fig. 6-4, the right-hand ordinate showing the thermal conductivity response in millivolts $(\mathrm{mV}) .^{25}$ Sample sizes are of the order of $10 \mathrm{mg}$.

3. Thermogravimetric analysis (TGA). The objective in a TGA is to determine whether there are any weight changes in a sample, either when it is held at a fixed temperature or when its temperature is changed in a programmed linear fashion.

The data are generally plotted as weight vs temperature or time or as weight change vs temperature or time. The TGAs are useful for only a limited number of physical property investigations, e.g. vaporization phenomena, but they are extremely useful for obtaining information on chemical properties such as thermal stability and chemical reactions. They are also useful for obtaining kinetic data. Sample sizes are of the order of $10 \mathrm{mg}$.

The heating rate is held at $\sim 10^{\circ} \mathrm{C} / \mathrm{min}$ in nitrogen atmosphere, and weight loss is shown as a function of temperature in Fig. 6-5.26

4. LLL reactivity test (CRT). The sample is heated at $120^{\circ} \mathrm{C}(393 \mathrm{~K})$ for $22 \mathrm{hr}$. A two-stage chromatography unit is used to measure the individual volumes of $\mathrm{N}_{2}$, $\mathrm{NO}, \mathrm{CO}, \mathrm{N}_{2} \mathrm{O}$ and $\mathrm{CO}_{2}$ evolved per $0.25 \mathrm{~g}$ of explosive during this period. The test is used principally to determine the reactivity of explosives with other materials. When operated as a simple test of explosive stability, the results are expressed in terms of the sums of these volumes. Results are given in Table 6-4. 


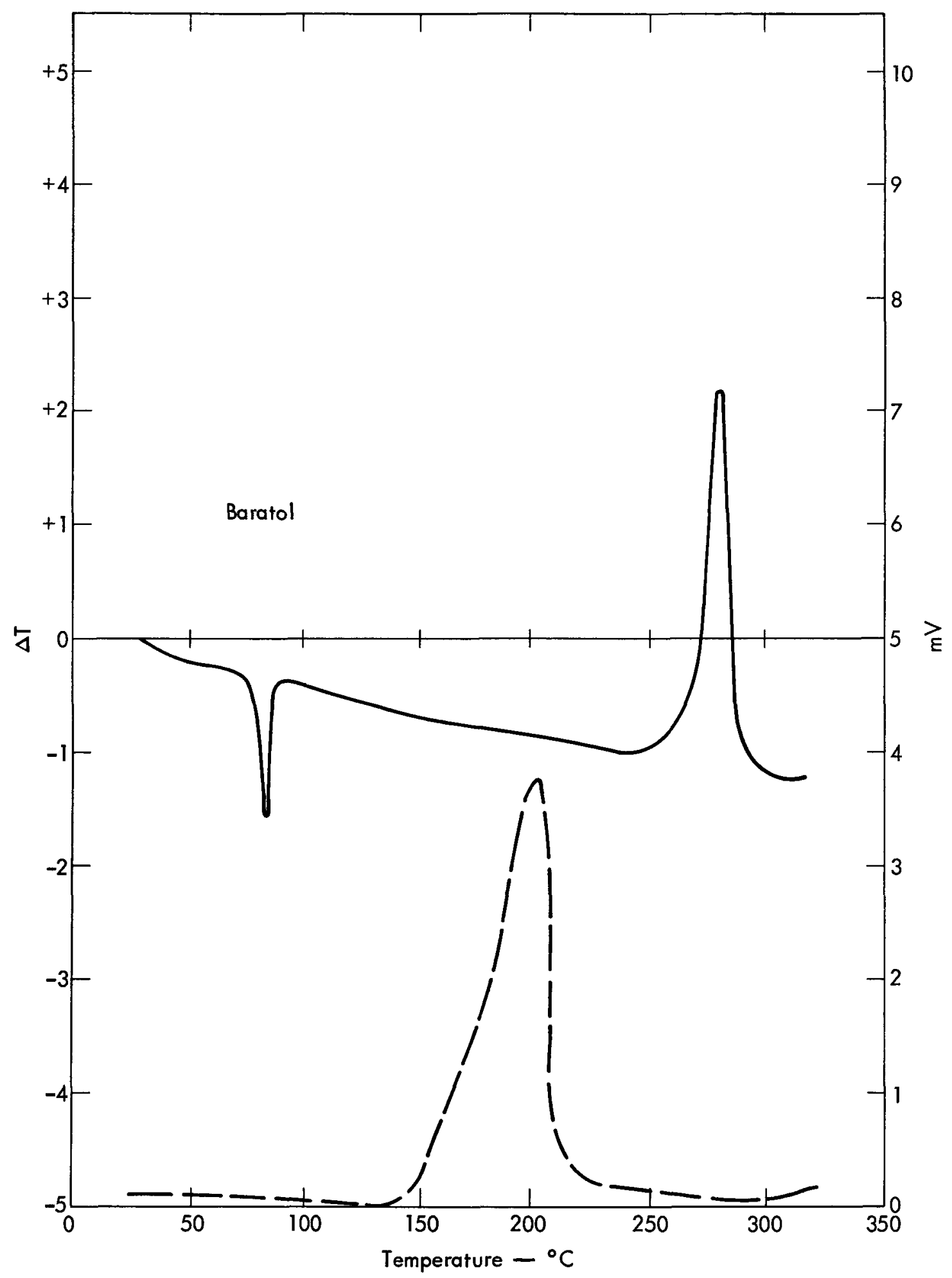

Fig. 6-4. (a) DTA curve (solid line) and pyrolysis (thermal conductivity) curve (dashed line) for baratol.24 


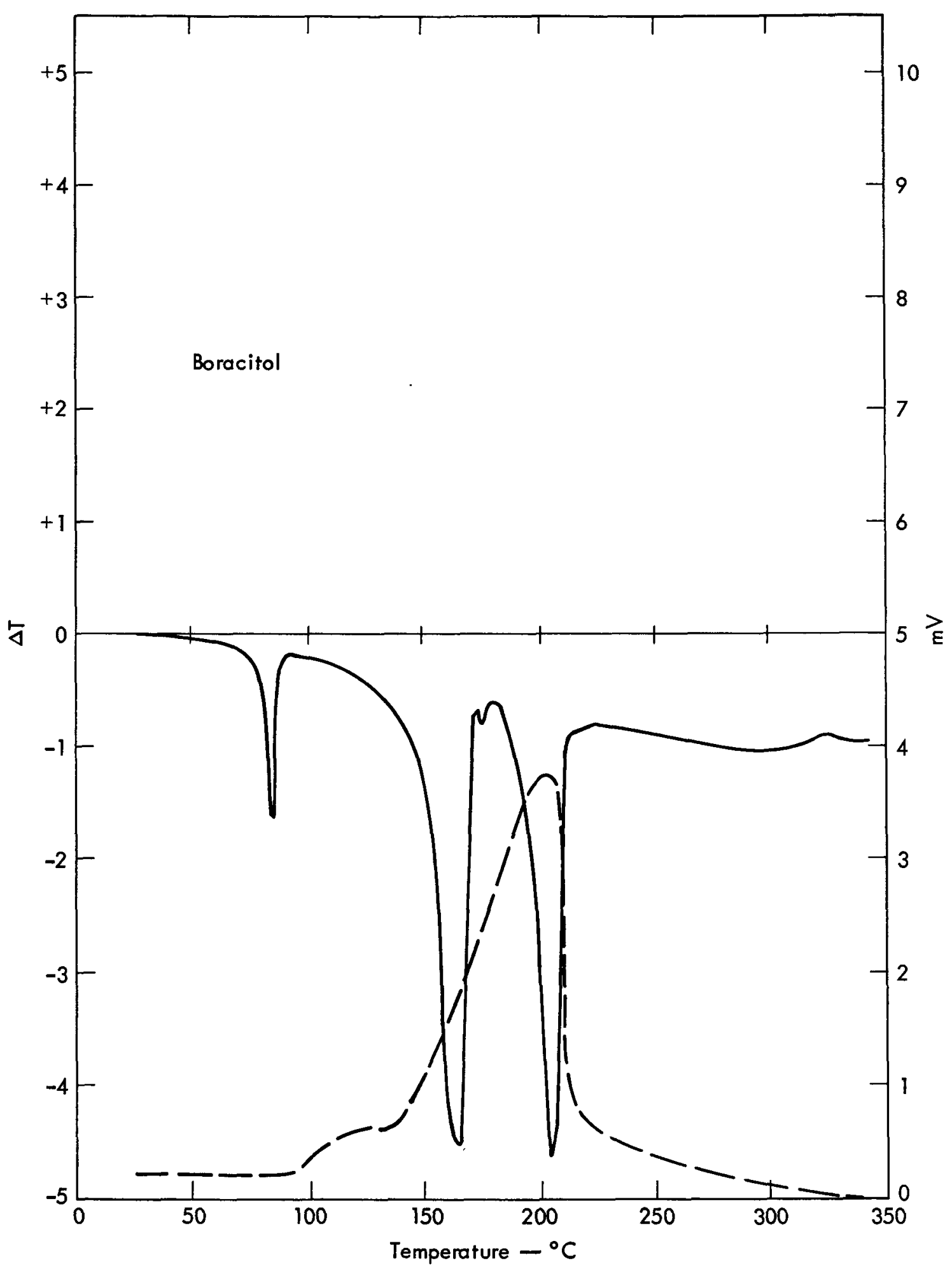

Fig. 6-4. (b) DTA curve (solid line) and pyrolysis (thermal conductivity) curve (dashed line) for boracitol. 24 


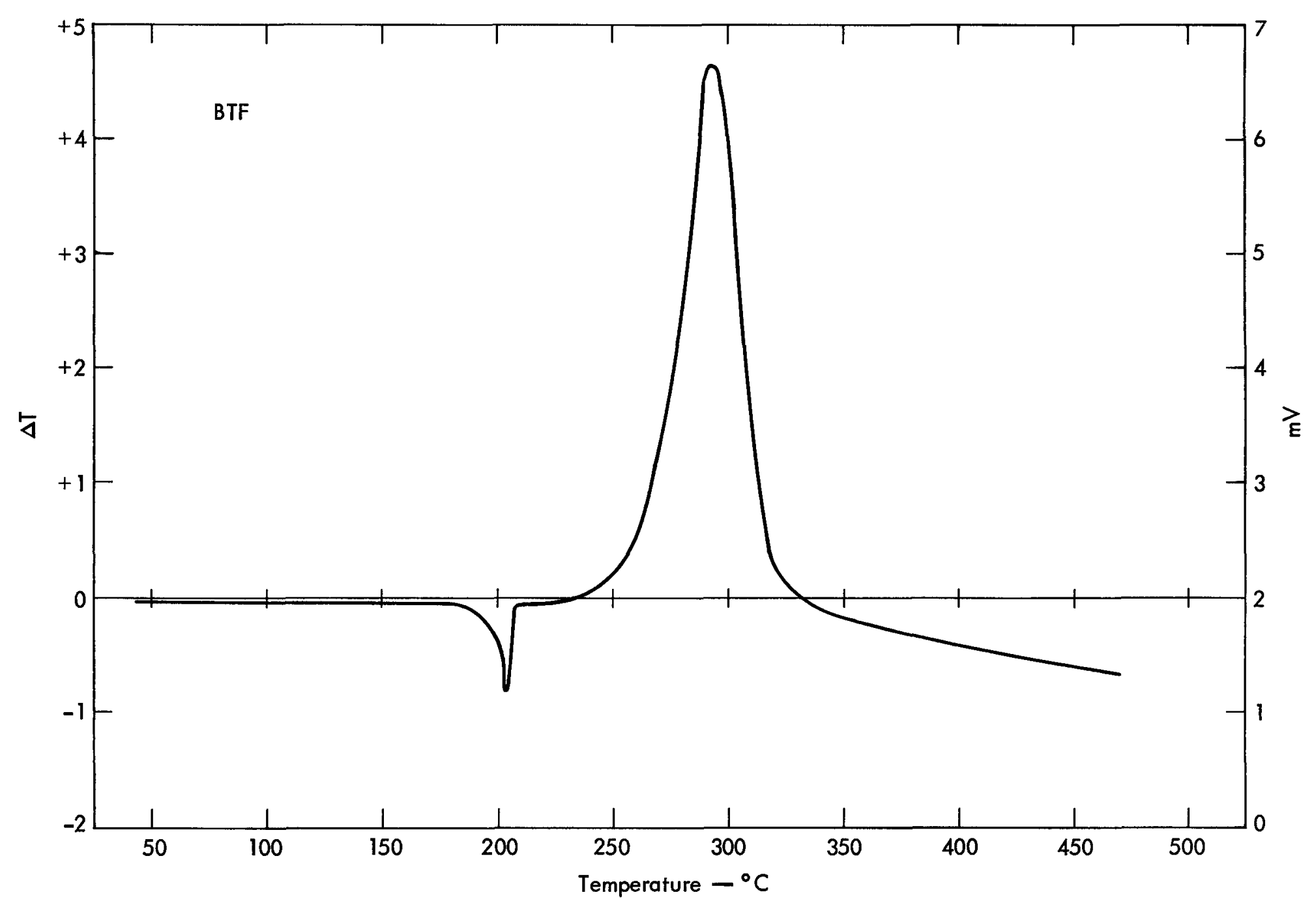

Fig. 6-4. (c) DTA curve for BTF, ${ }^{24}$ 


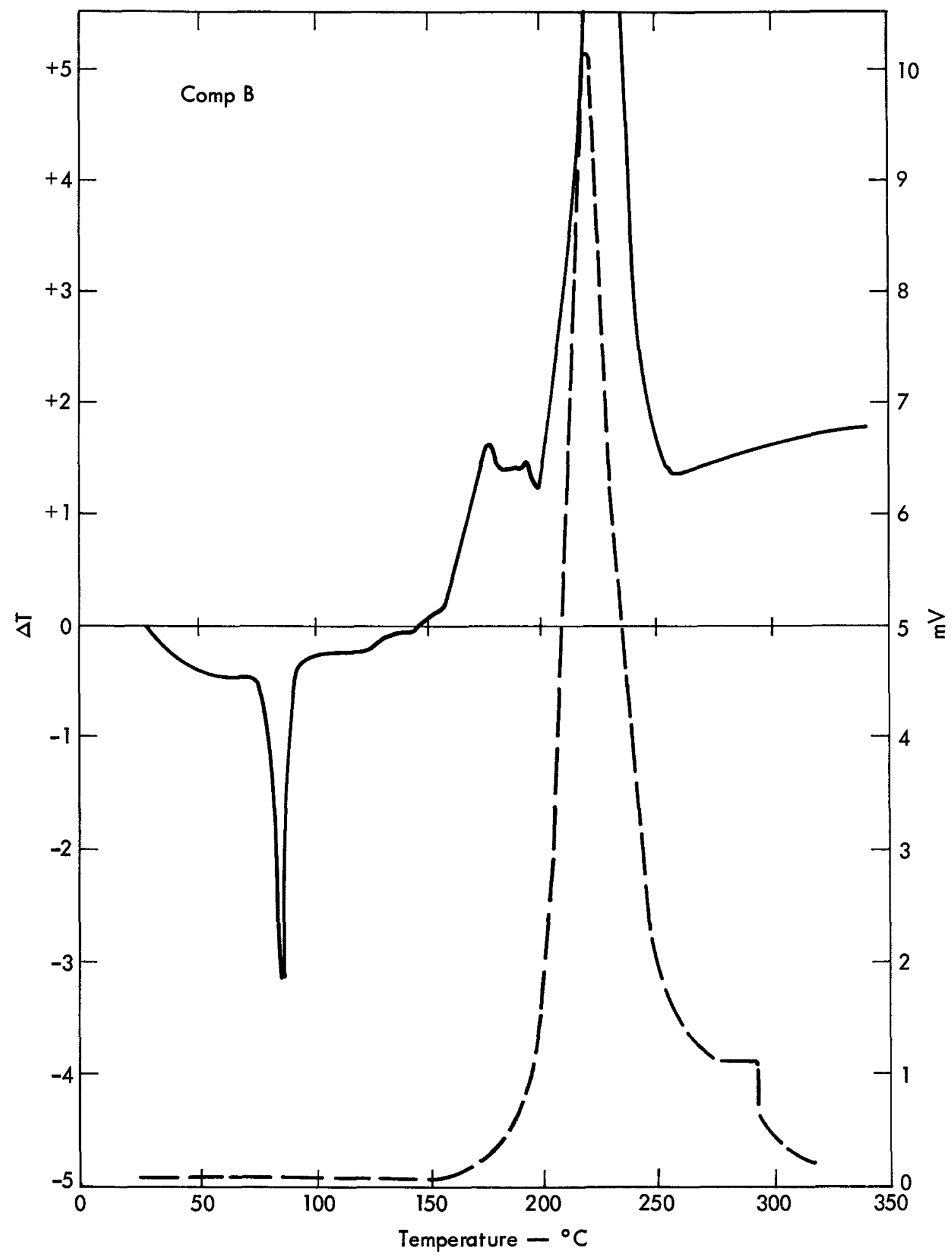

Fig. 6-4. (d) DTA curve (solid line) and pyrolysis (thermal conductivity) curve (dashed line) for Comp B.24 Melting points of both TNT and RDX are lowered. The melting endotherm for RDX is almost lost in the decomposition exotherm which starts at $\sim 150^{\circ} \mathrm{C}(423 \mathrm{~K})$. Comp B is less stable than its components separately. 


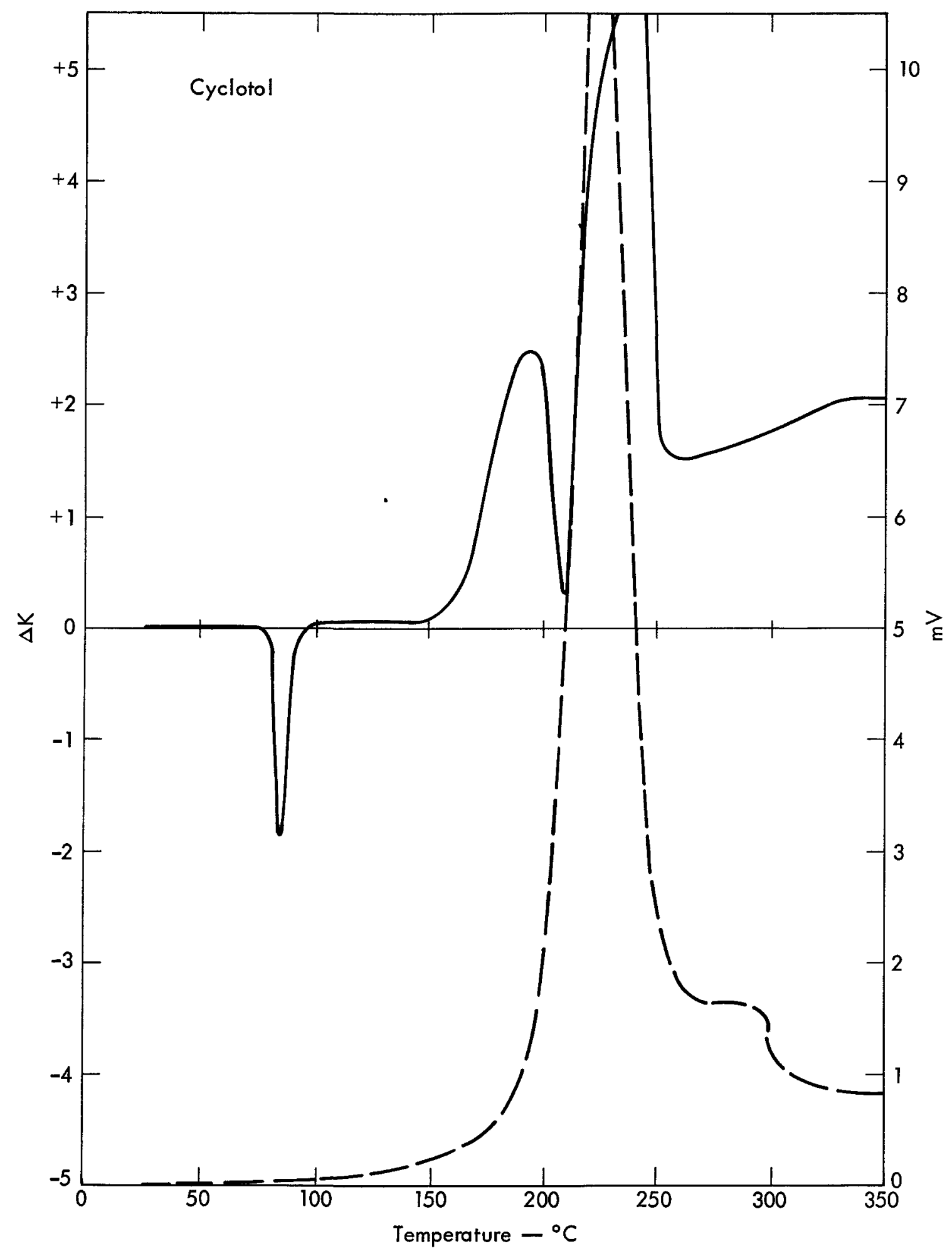

Fig. 6-4. (e) DTA curve (solid line) and pyrolysis (thermal conductivity) curve (dashed line) for cyclotol. 24 


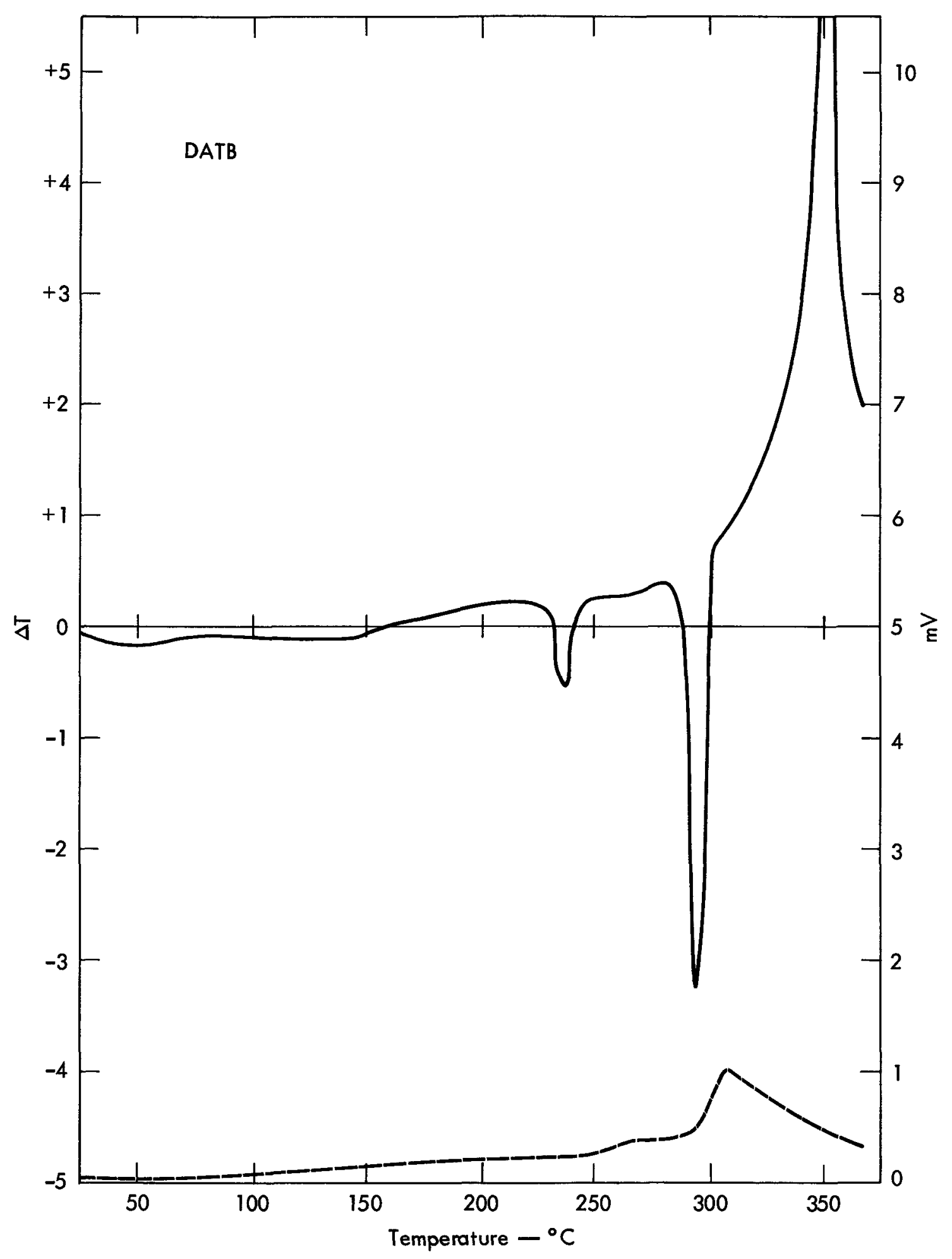

Fig. 6-4. (f) DTA curve (solid line) and pyrolysis (thermal conductivity) curve (dashed line) for DATB. 24 The endotherm starting at $\sim 220^{\circ} \mathrm{C}(493 \mathrm{~K})$ is due to the $\mathrm{I} \rightarrow$ II polymorphic transition. The melting point appears at $285^{\circ} \mathrm{C}(558 \mathrm{~K})$ 


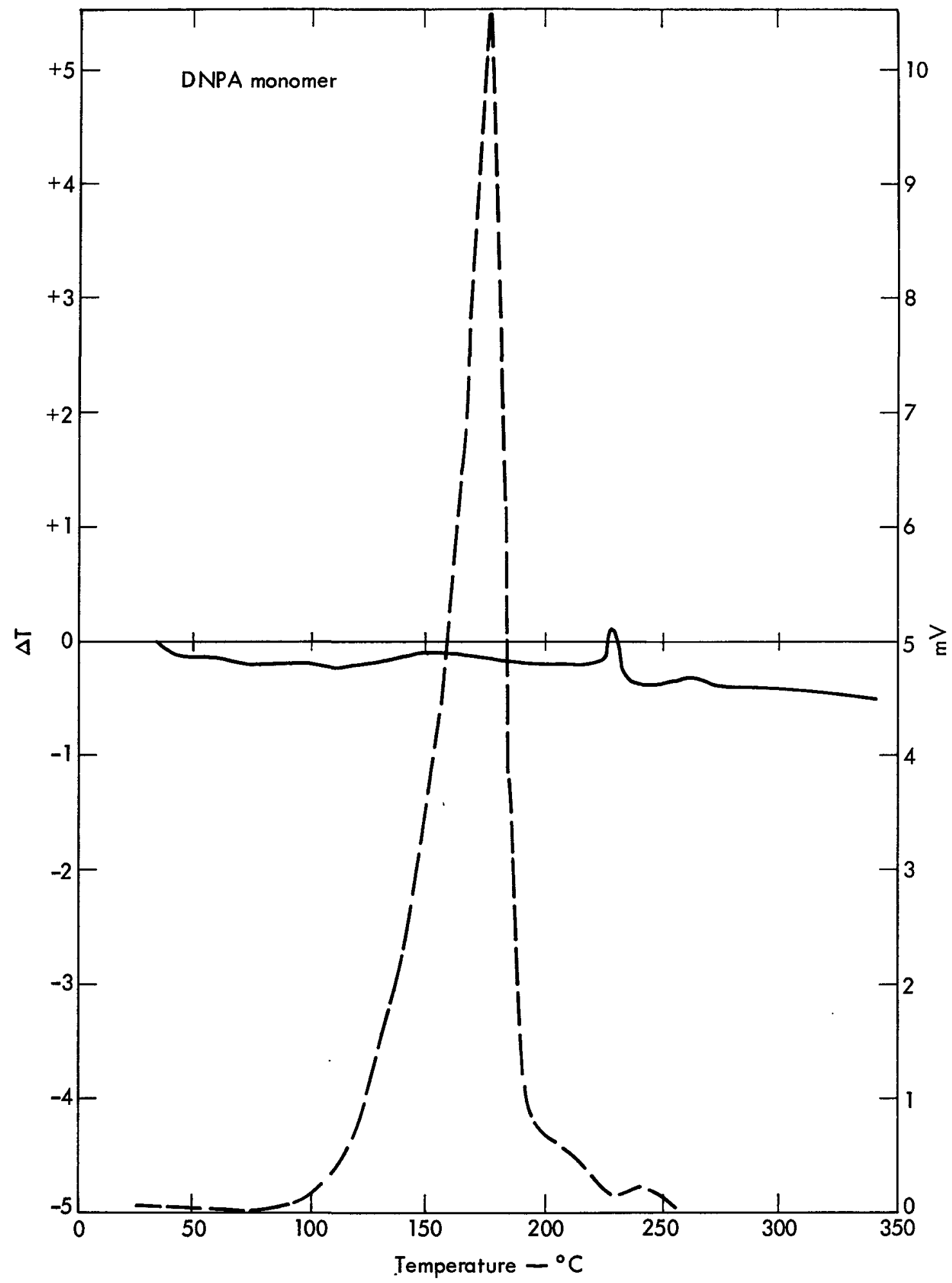

Fig. 6-4. (g) DTA curve (solid line) and pyrolysis (thermal conductivity) curve (dashed line) for DNPA monomer. 24 


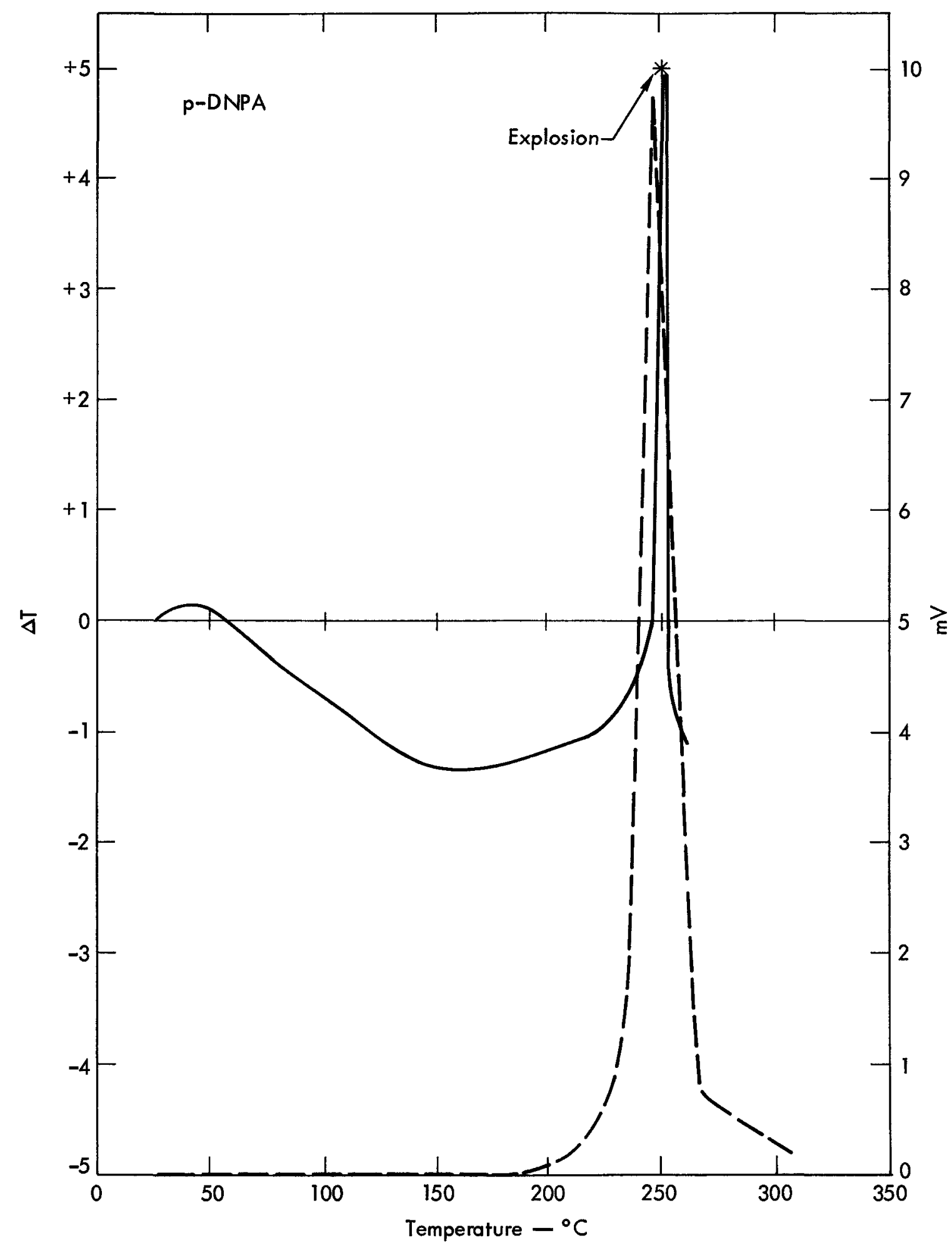

Fig. 6-4. (h) DTA curve (solid line) and pyrolysis (thermal conductivity) curve (dashed line) for p-DNPA. A mild explosion usually blows the sample thermocouple out of the cell at $250^{\circ} \mathrm{C}(523 \mathrm{~K})$. The small endotherm at $60^{\circ} \mathrm{C}(333 \mathrm{~K})$ is due to the second-order transition of the polymer. 


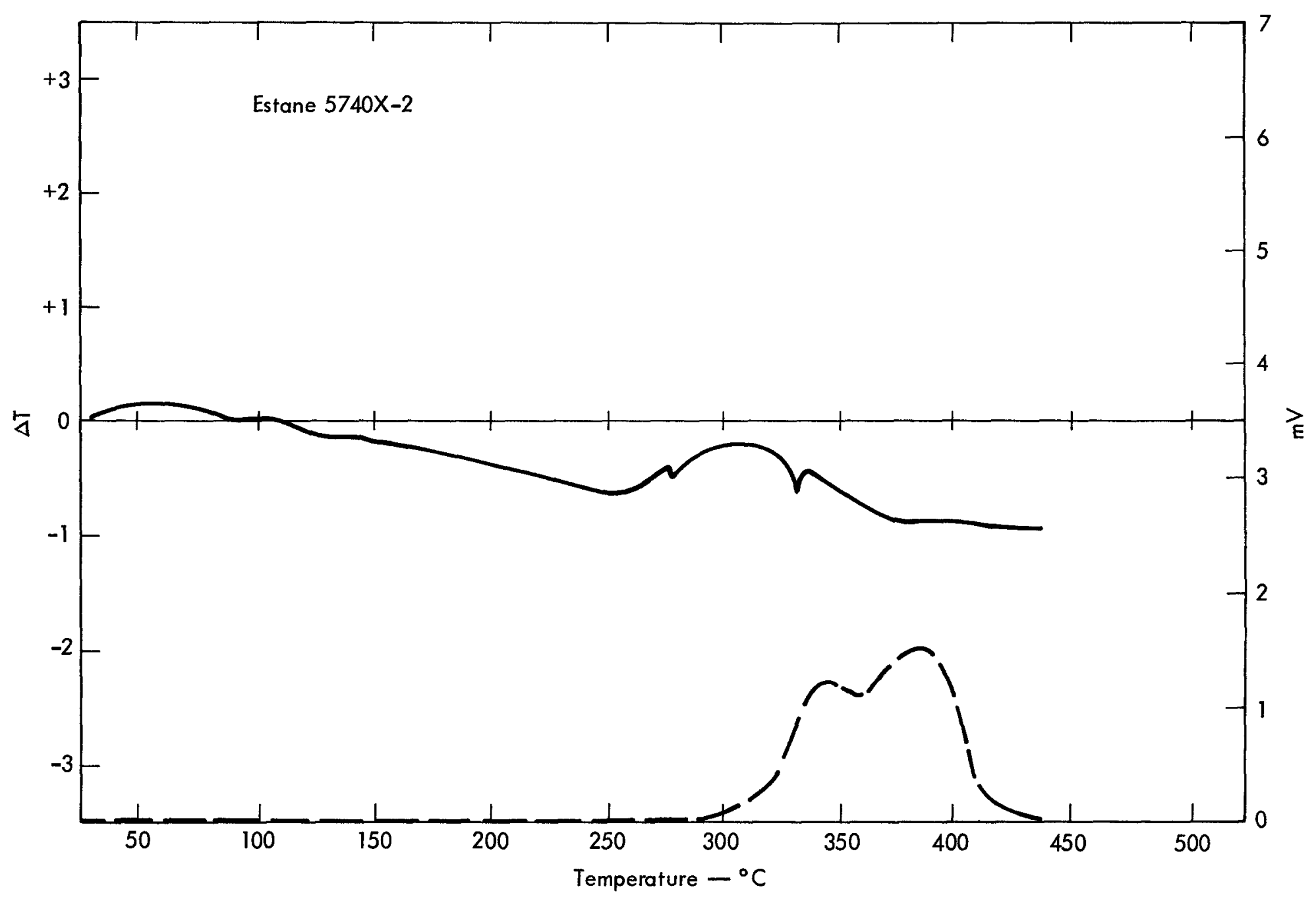

Fig. 6-4. (i) DTA curve (solid line) and pyrolysis (thermal conductivity) curve (dashed line) for Estane $5740 \mathrm{X}-2 .{ }^{24}$ 


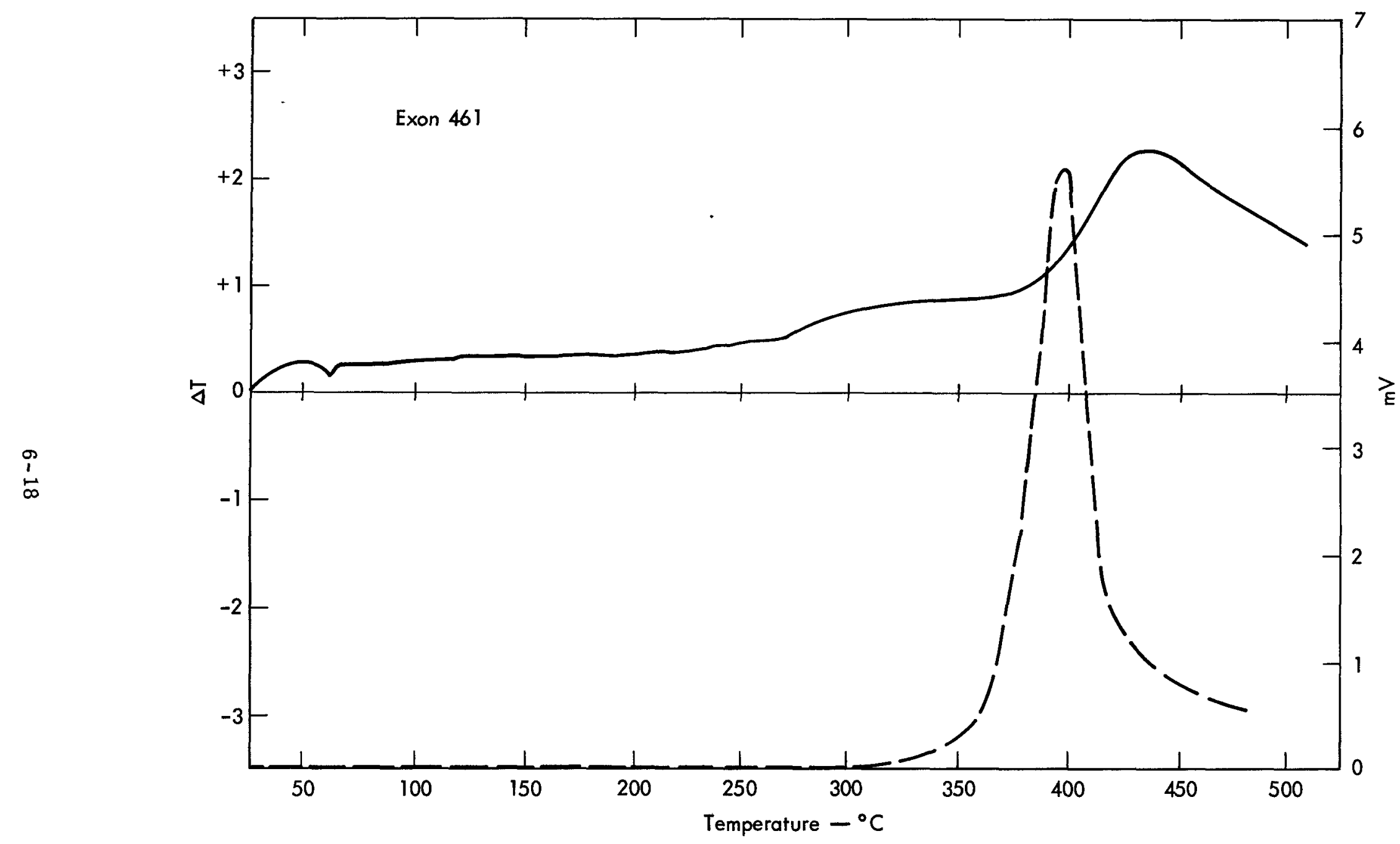

Fig. 6-4. (j) DTA curve (solid line) and pyrolysis (thermal conductivity) curve (dashed line) for Exon $461 .^{24}$ 
$\frac{\sqrt{7}}{2}$

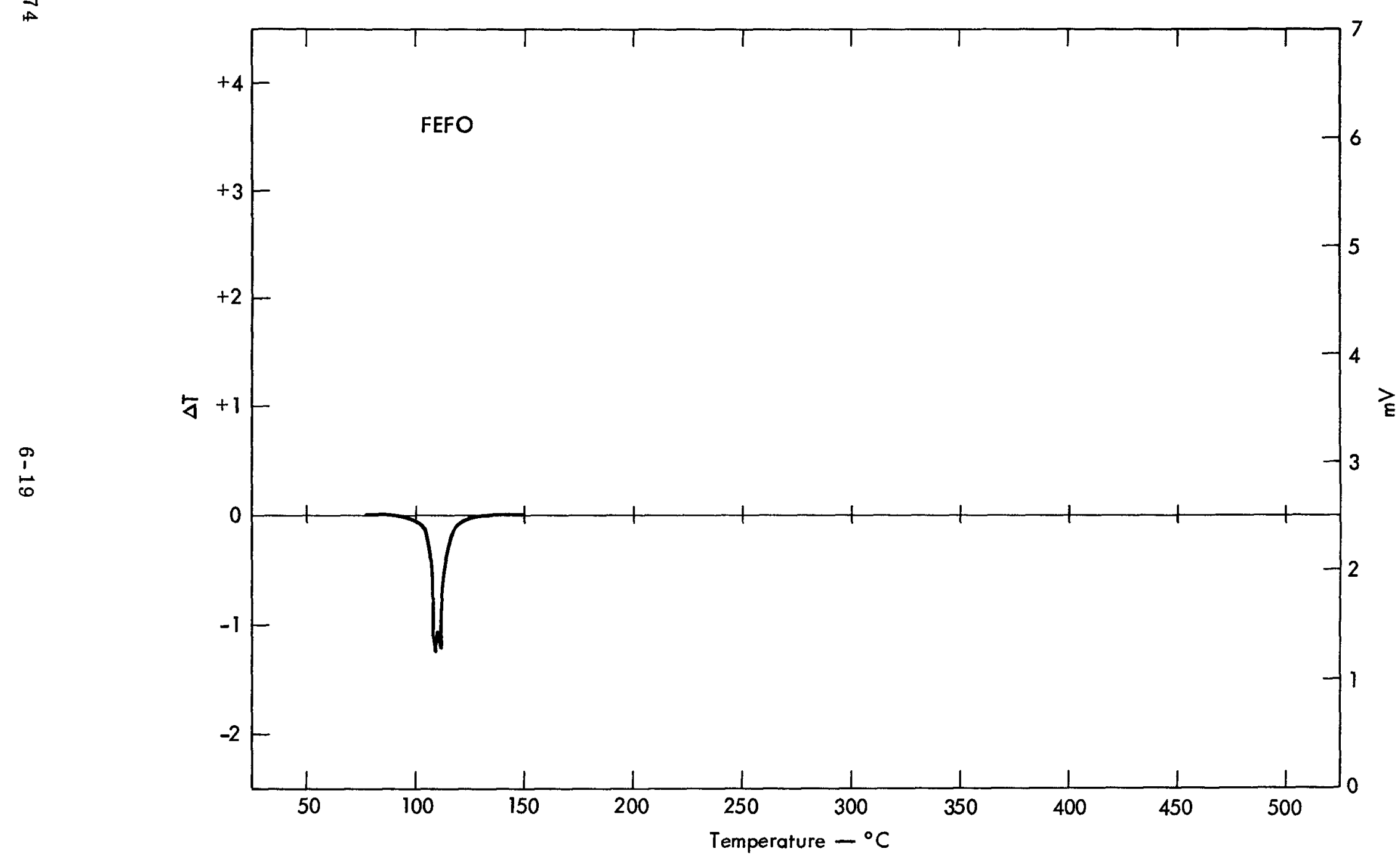

Fig. 6-4. (k) DTA curve for FEFO. ${ }^{24}$ 


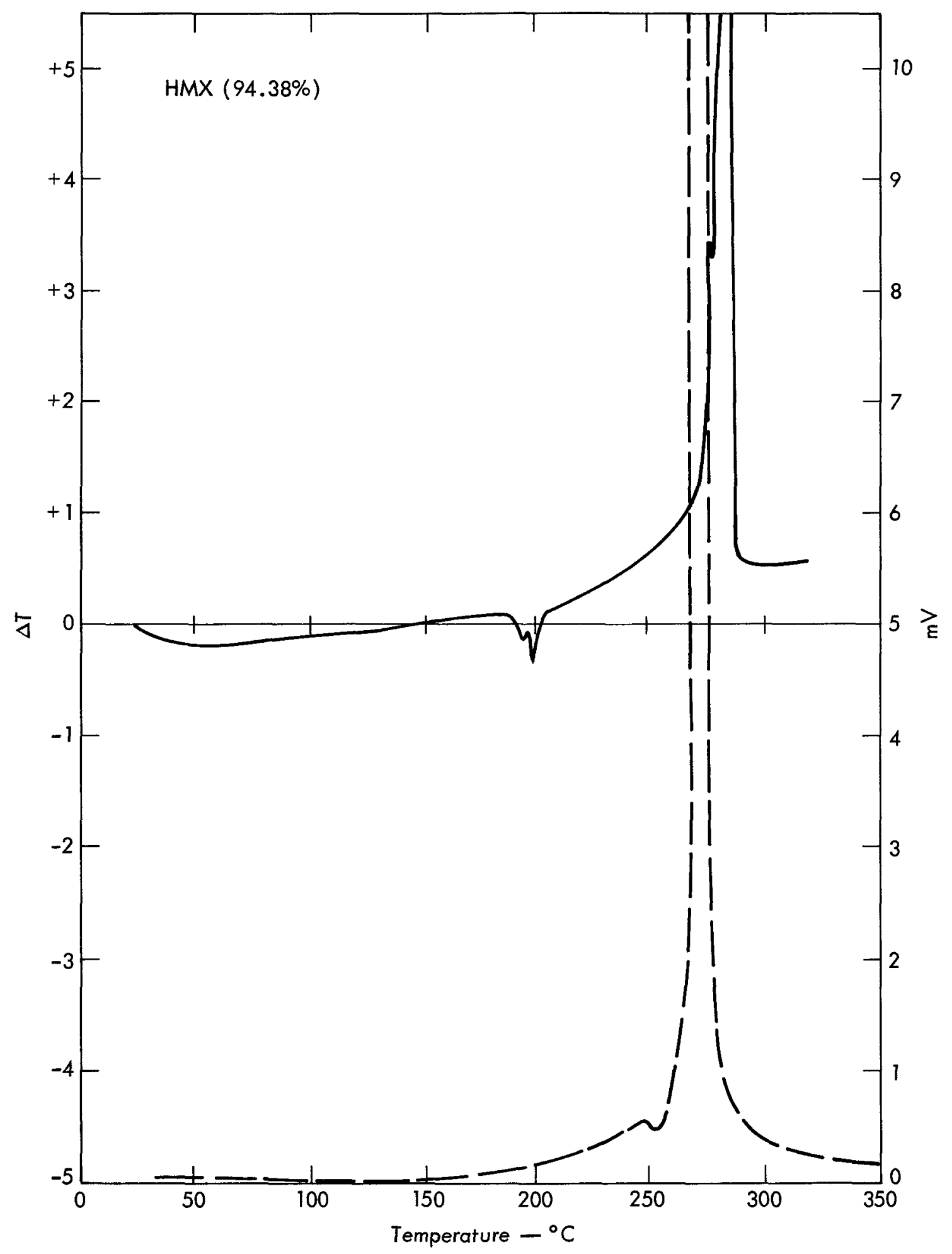

Fig. 6-4. (1) DTA curve (solid line) and pyrolysis (thermal conductivity) curve (dashed line) for HMX ( $94.38 \%$ Holston production grade).24 Melting point $275^{\circ} \mathrm{C}(548 \mathrm{~K})$. 


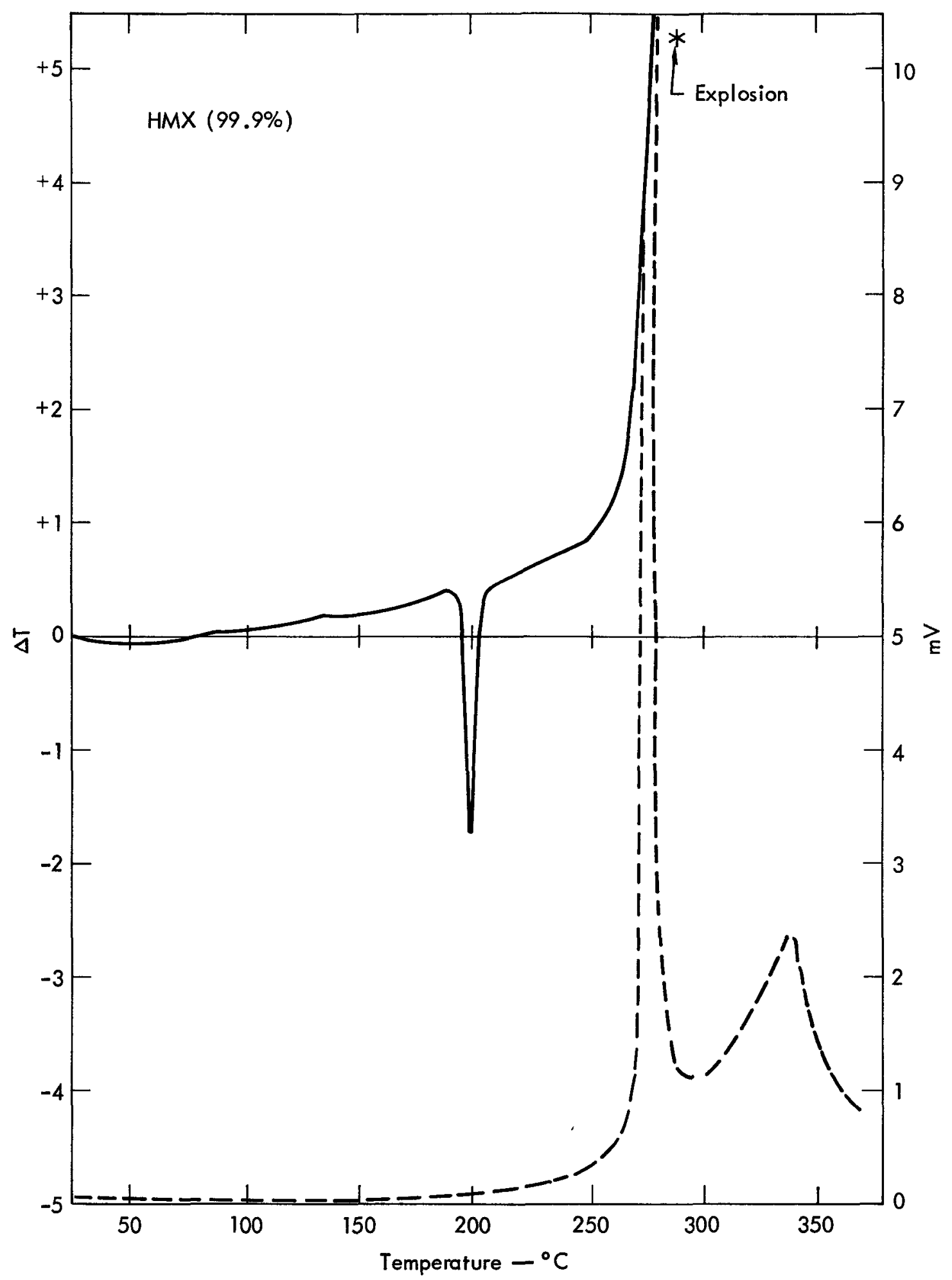

Fig. 6-4. (m) DTA curve (solid line) and pyrolysis (thermal conductivity) curve (dashed line) for HMX (99.9\% pure).24 Purified by extraction and crystallization of production-grade HMX. Dry $\beta-H M X$ of good purity does not show a $\beta \rightarrow \alpha$ transition. This sample shows a $\beta \rightarrow \alpha$ transition starting at $187^{\circ} \mathrm{C}(460 \mathrm{~K})$, but no melting point, so the endotherm does not show on the curve. 


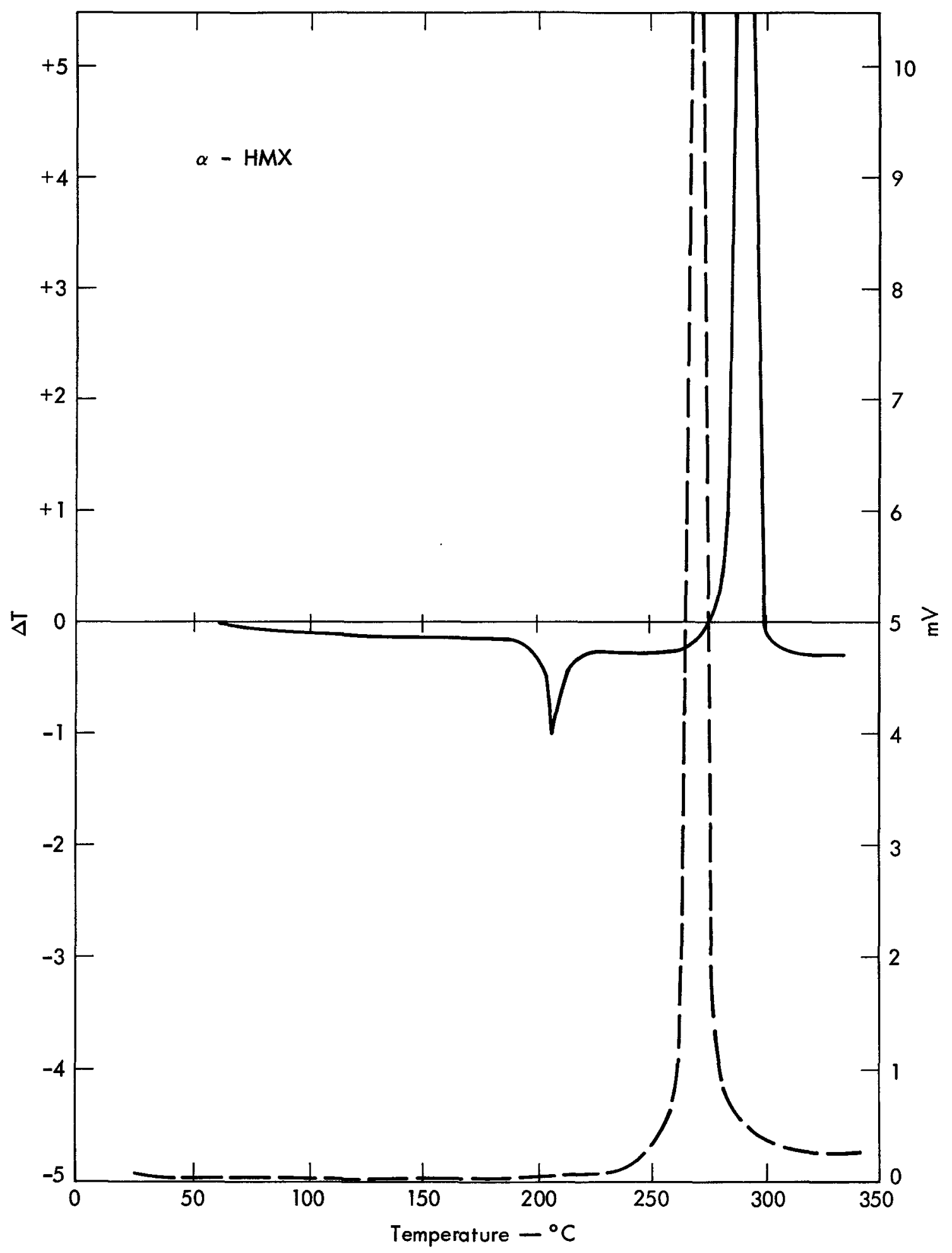

Fig. 6-4. (n) DTA curve (solid line) and pyrolysis (thermal conductivity) curve (dashed line) for $\alpha$-HMX. 24 Melting point $282^{\circ} \mathrm{C}(555 \mathrm{~K})$. 


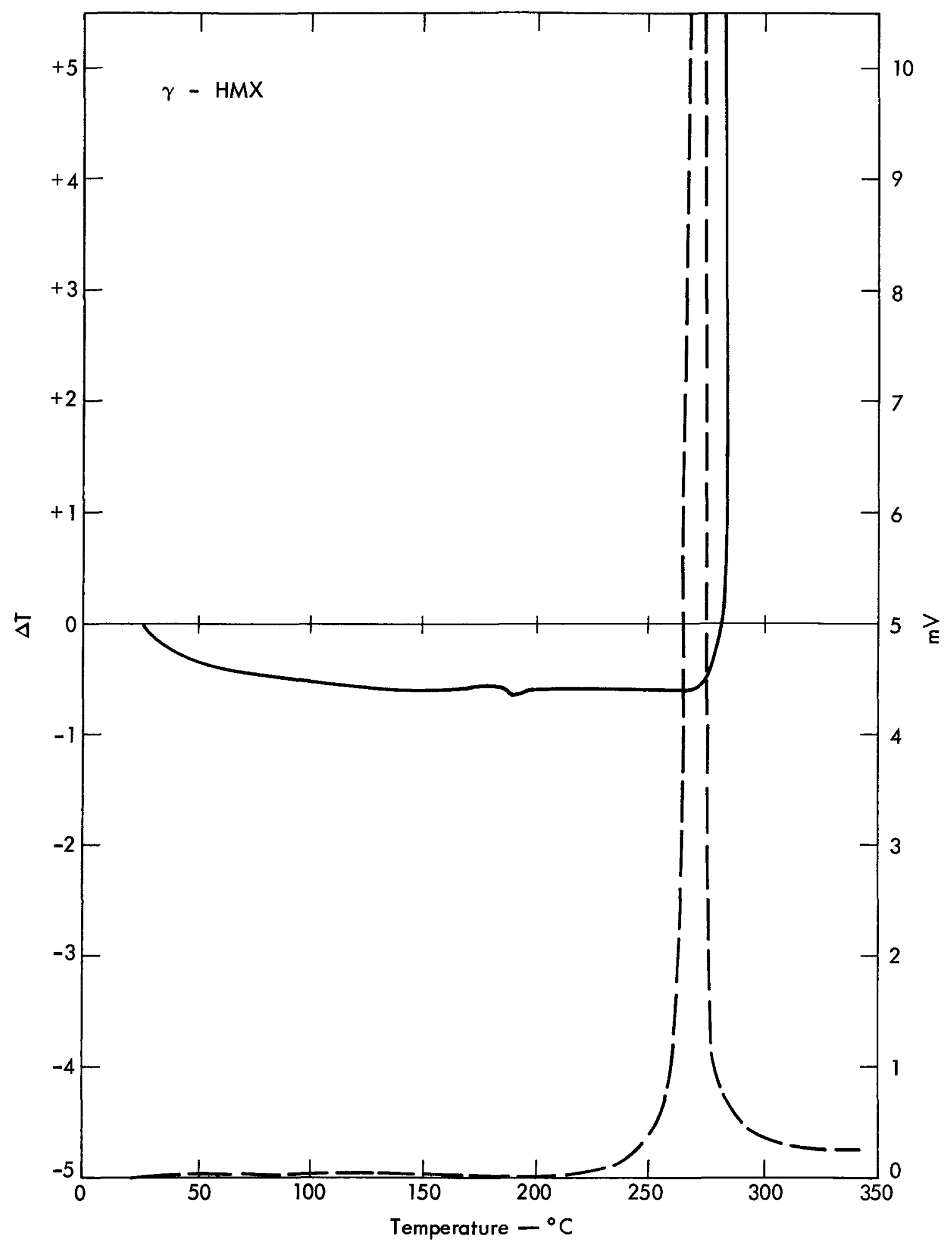

Fig. 6-4. (o) DTA curve (solid line) and pyrolysis (thermal conductivity) curve (dashed line) for $\gamma-\mathrm{HMX} .24$ A ppears to contain a small amount of $\beta-H M X$. 


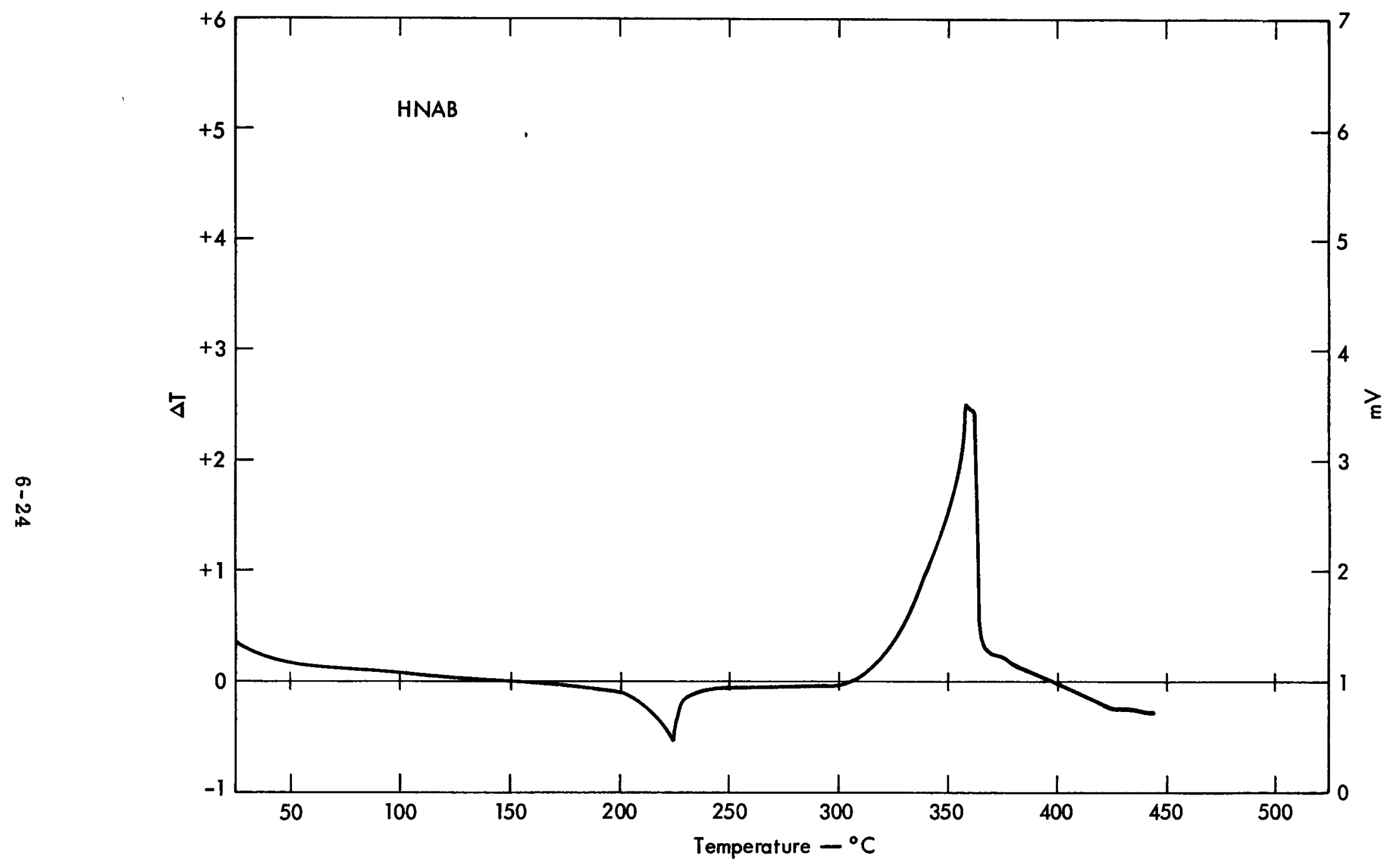

Fig. $6-4$. (p) DTA curve for HNAB. ${ }^{24}$

$\underset{n}{\sqrt[3]{n}}$ 
$\underset{2}{2}$

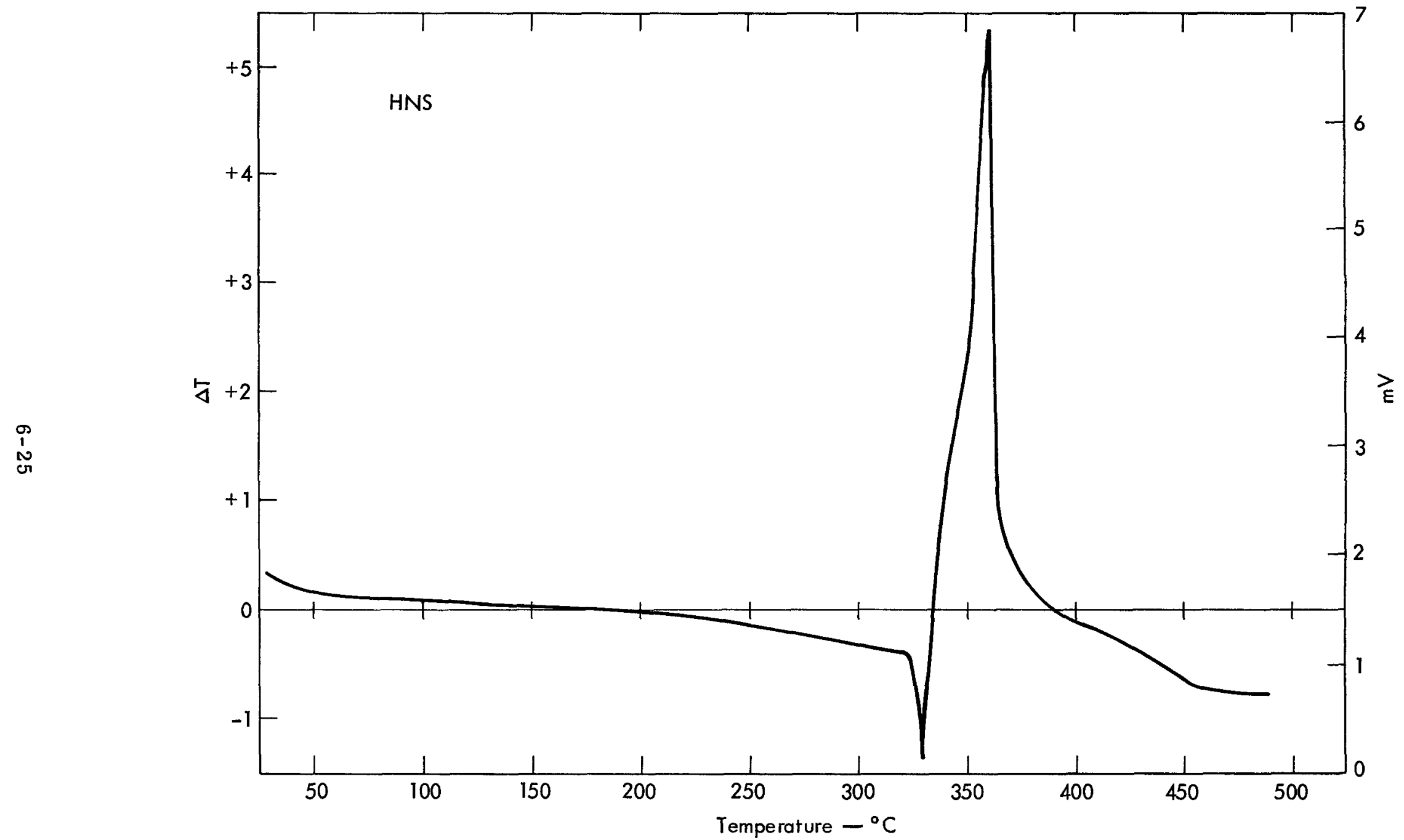

Fig. 6-4. (q) DTA curve for HNS. ${ }^{24}$ 


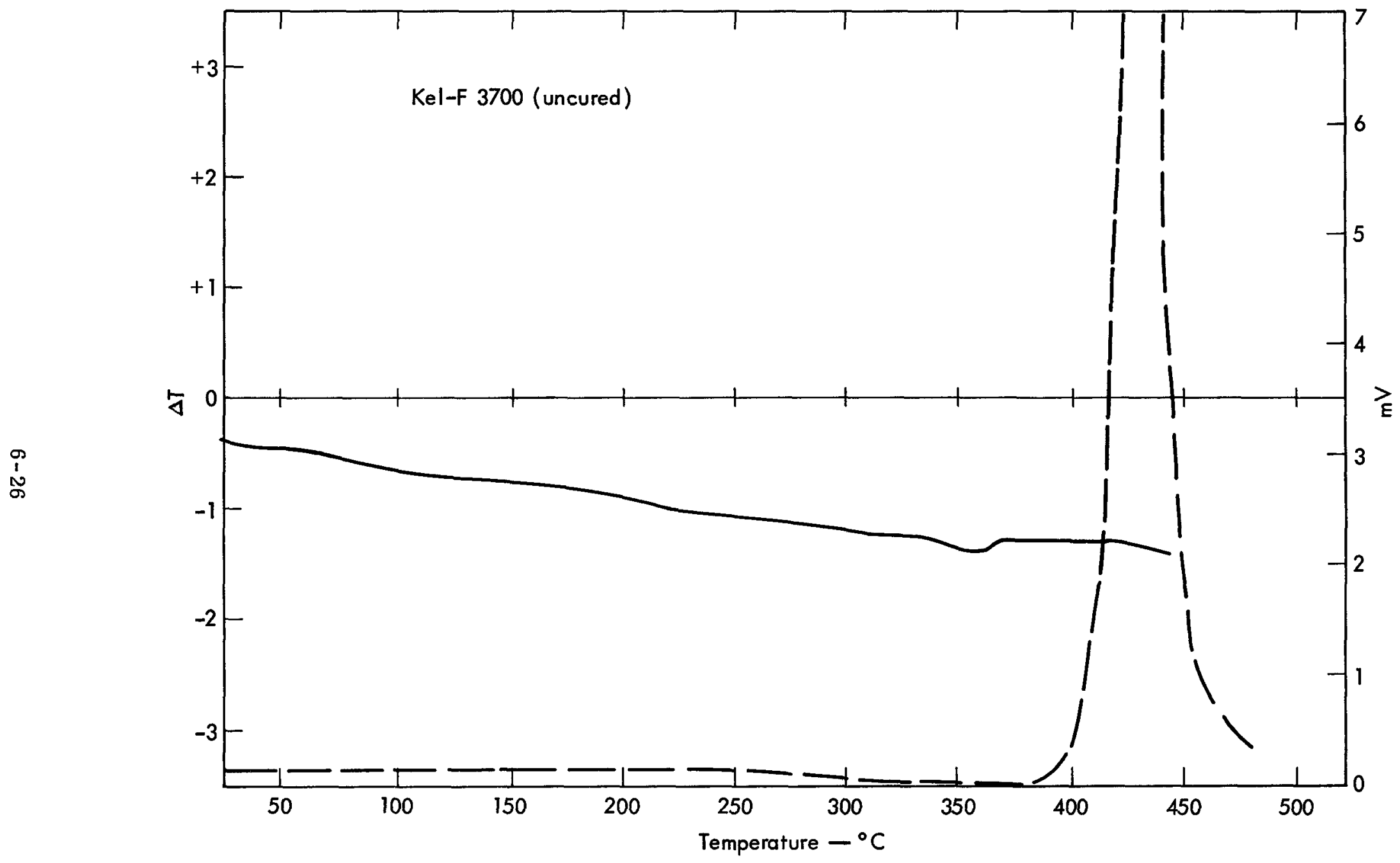

$\sim$ Fig. 6-4. (r) DTA curve (solid line) and pyrolysis (thermal conductivity) curve (dashed line) for Kel-F 3700 (uncured). ${ }^{24}$ Zero-line drift is due to low thermal conductivity of sample. 


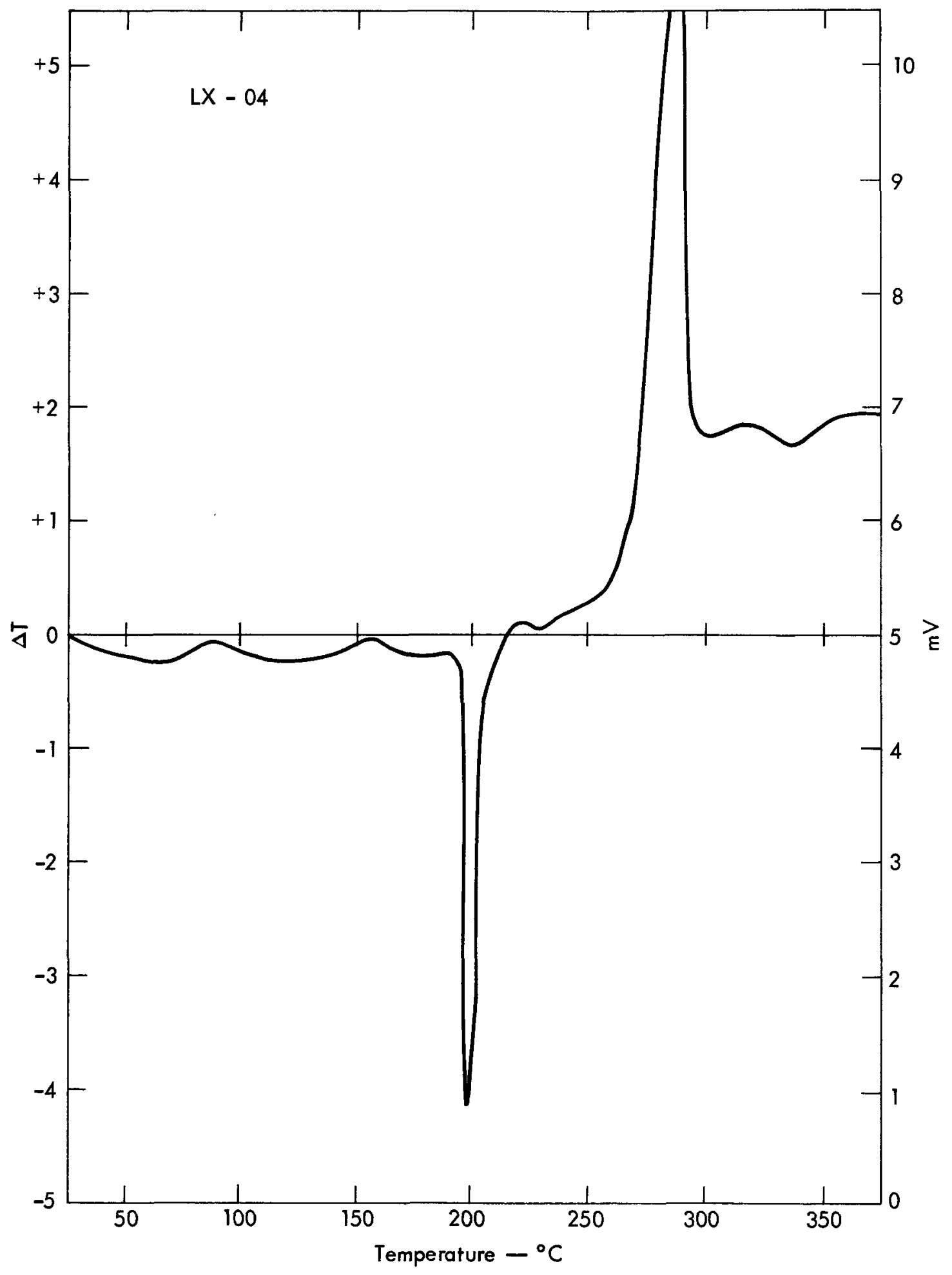

Fig. 6-4. (s) DTA curve for LX-04. ${ }^{24}$ 


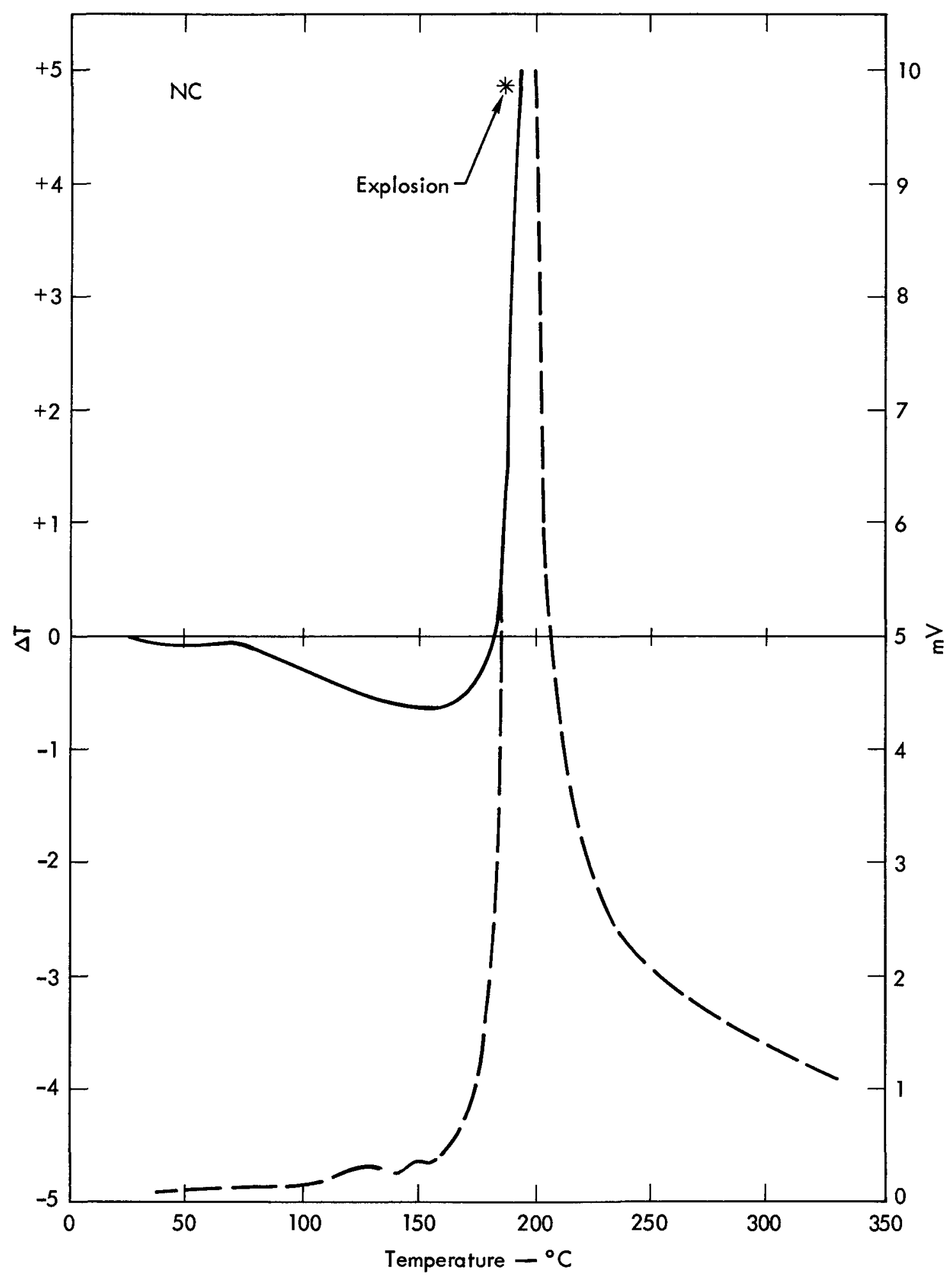

Fig. 6-4. (t) DTA curve (solid line) and pyrolysis (thermal conductivity) curve (dashed line) for NC.24 A mild explosion always blows the sample thermocouple out of the cell at $195-197^{\circ} \mathrm{C}(468-470 \mathrm{~K})$. 


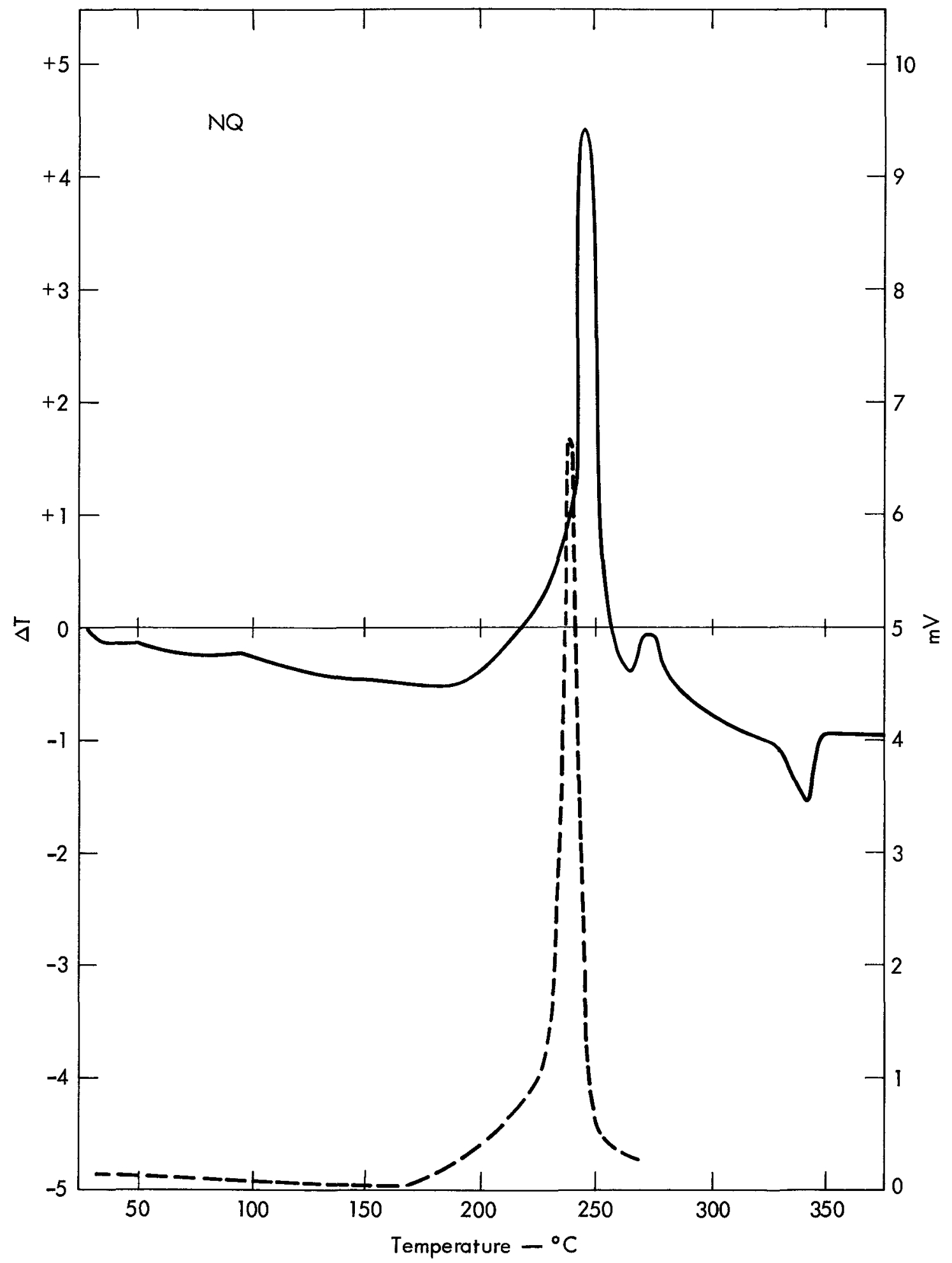

Fig. 6-4. (u) DTA curve (solid line) and pyrolysis (thermal conductivity) curve (dashed line) for NQ.24 


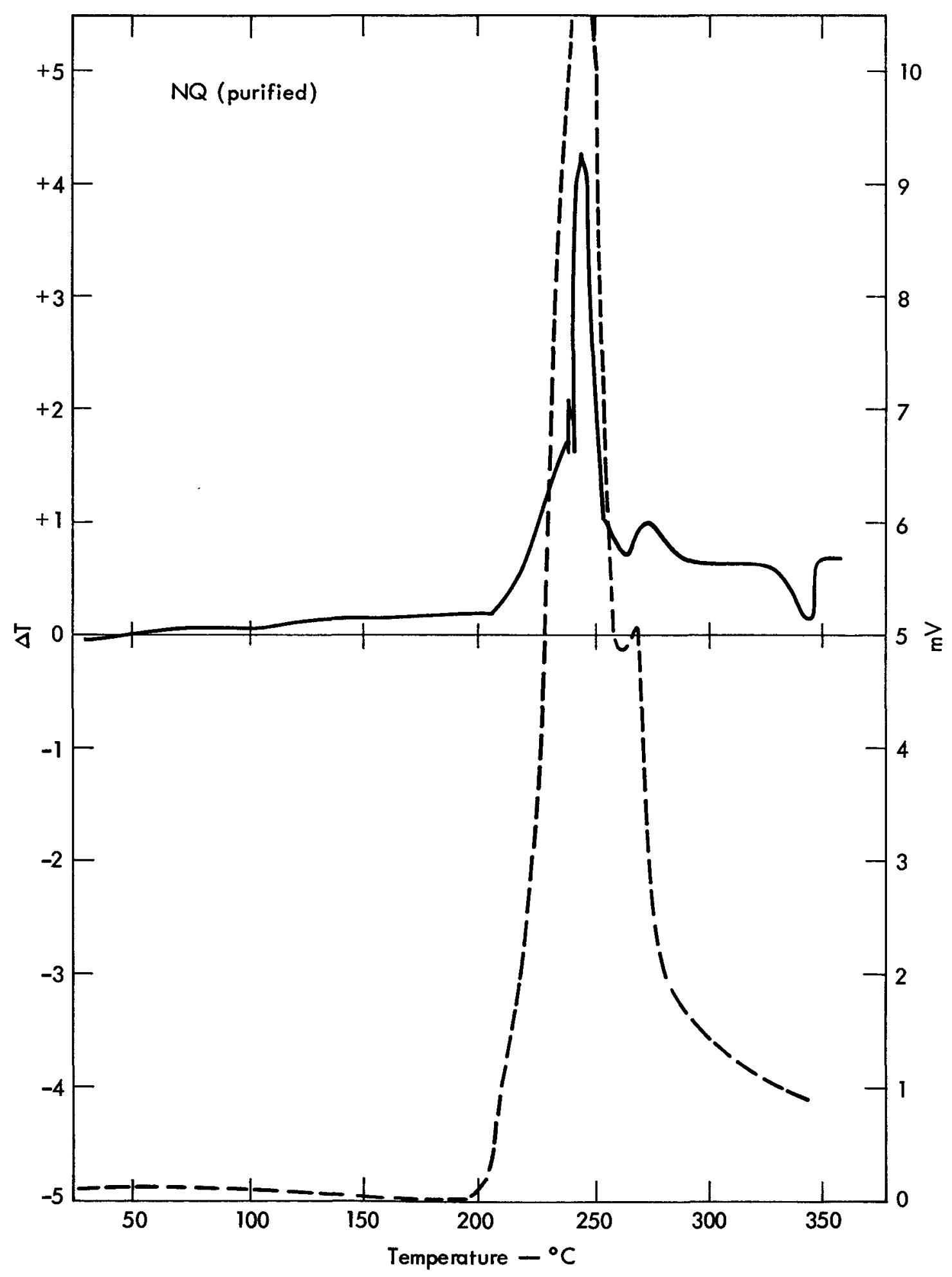

Fig. 6-4. (v) DTA curve (solid line) and pyrolysis (thermal conductivity) curve (dashed line) for $\mathrm{NQ}$ (purified).24 The melting point of the sample is superimposed on the decomposition exotherm. The decomposition in the liquid phase is extremely violent. 


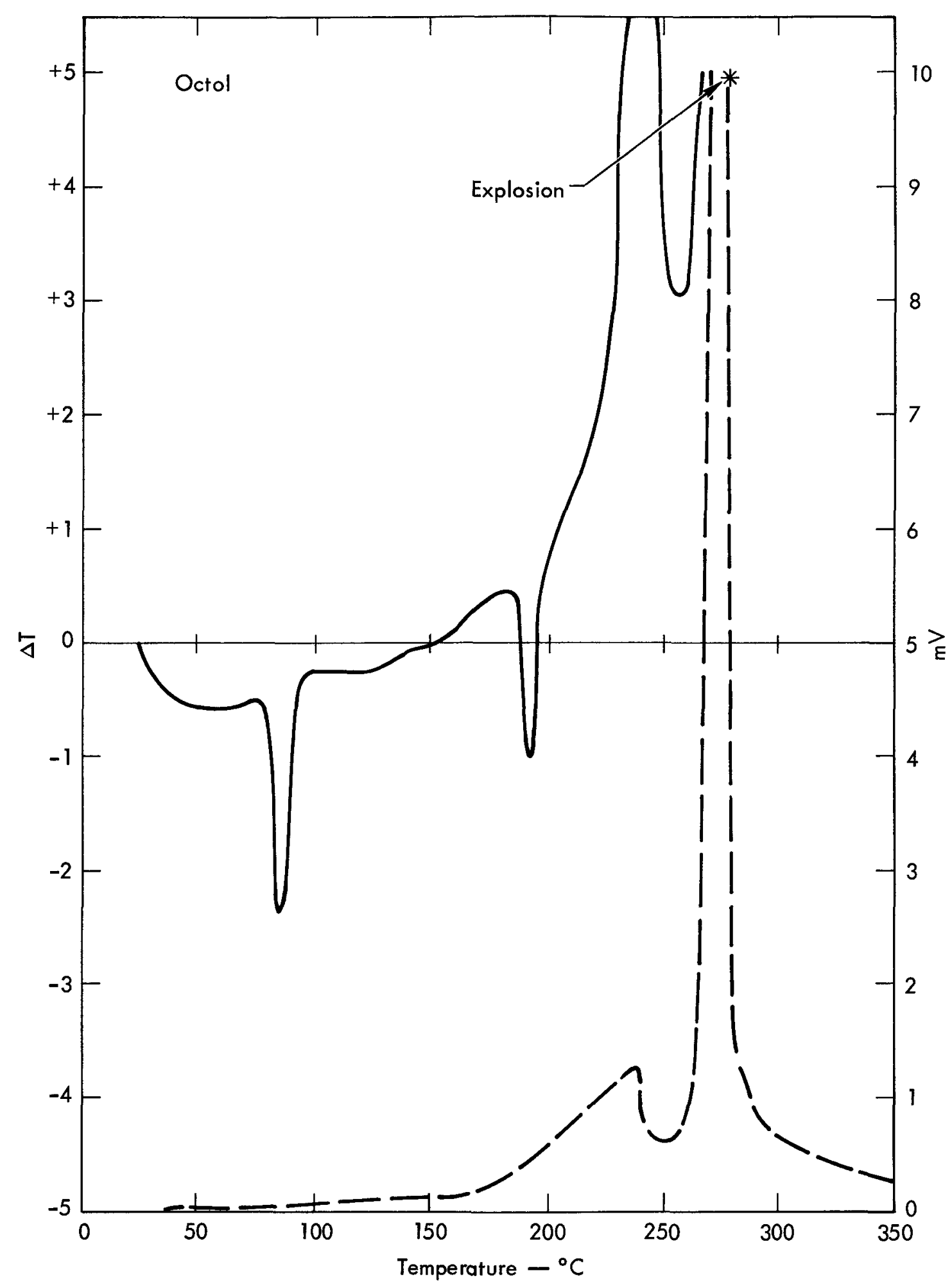

Fig. 6-4. (w) DTA curve (solid line) and pyrolysis (thermal conductivity) curve (dashed line) for octol.24 The endotherms were due to the melting of TNT and to the $\beta \rightarrow \delta$ transition of HMX. The pyrolysis curve shows an almost perfect volatilization curve for TNT before the HMX decomposition. 


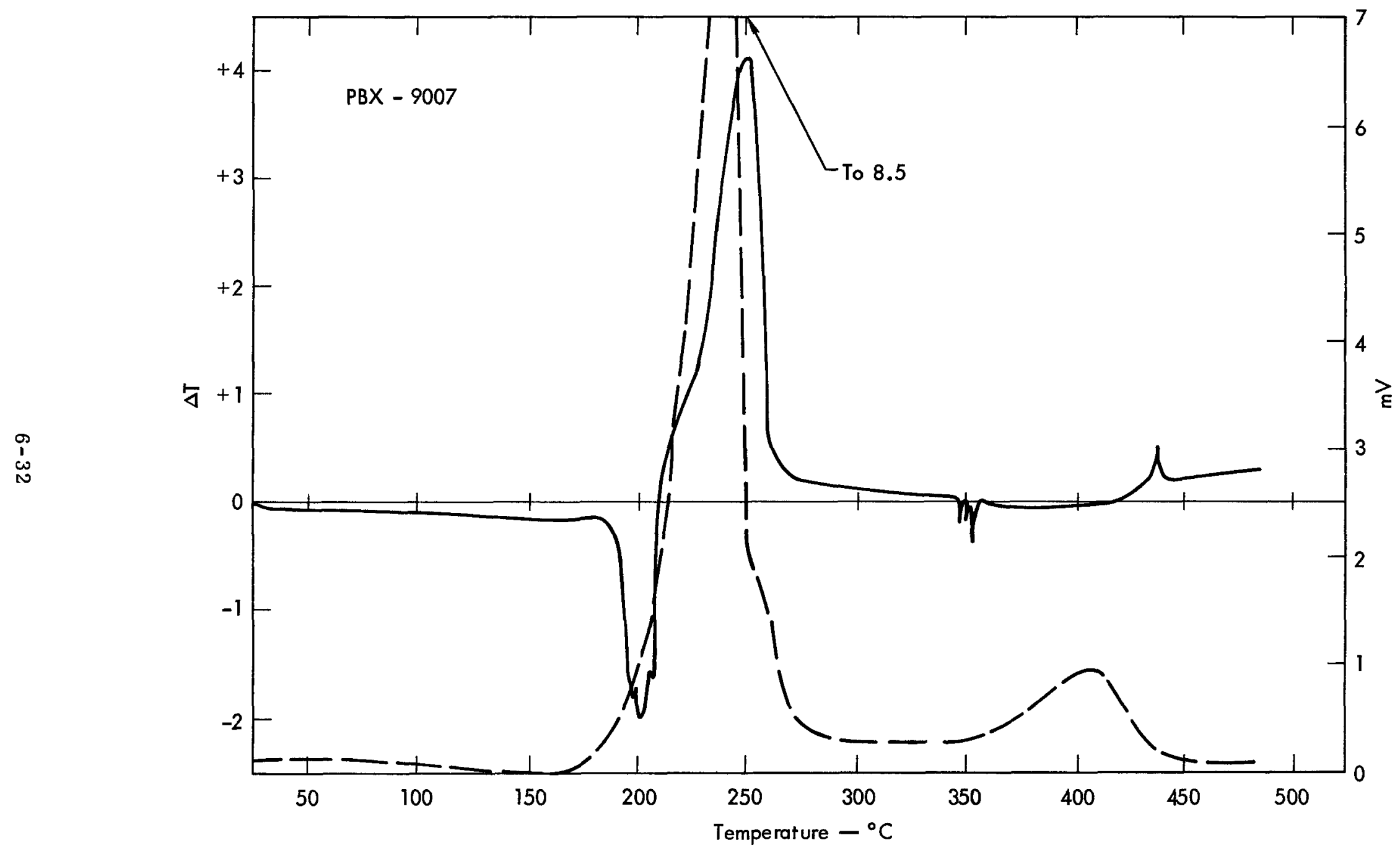

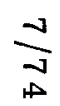

Fig. 6-4. (x) DTA curve (solid line) and pyrolysis (thermal conductivity) curve (dashed line) for PBX-9007. ${ }^{24}$ 


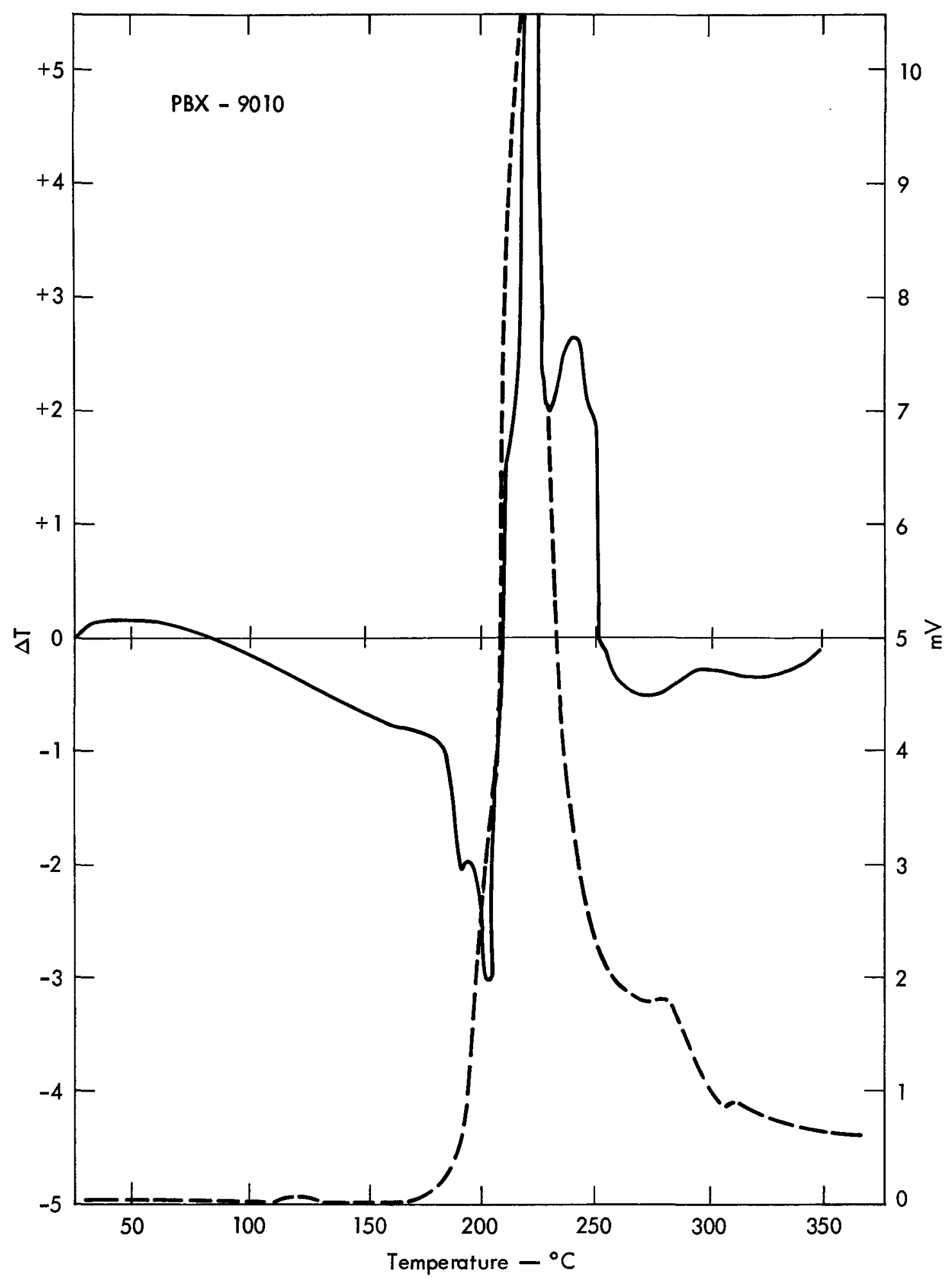

Fig. 6-4. (y) DTA curve (solid line) and pyrolysis (thermal conductivity) curve (dashed line) for PBX-9010.24 


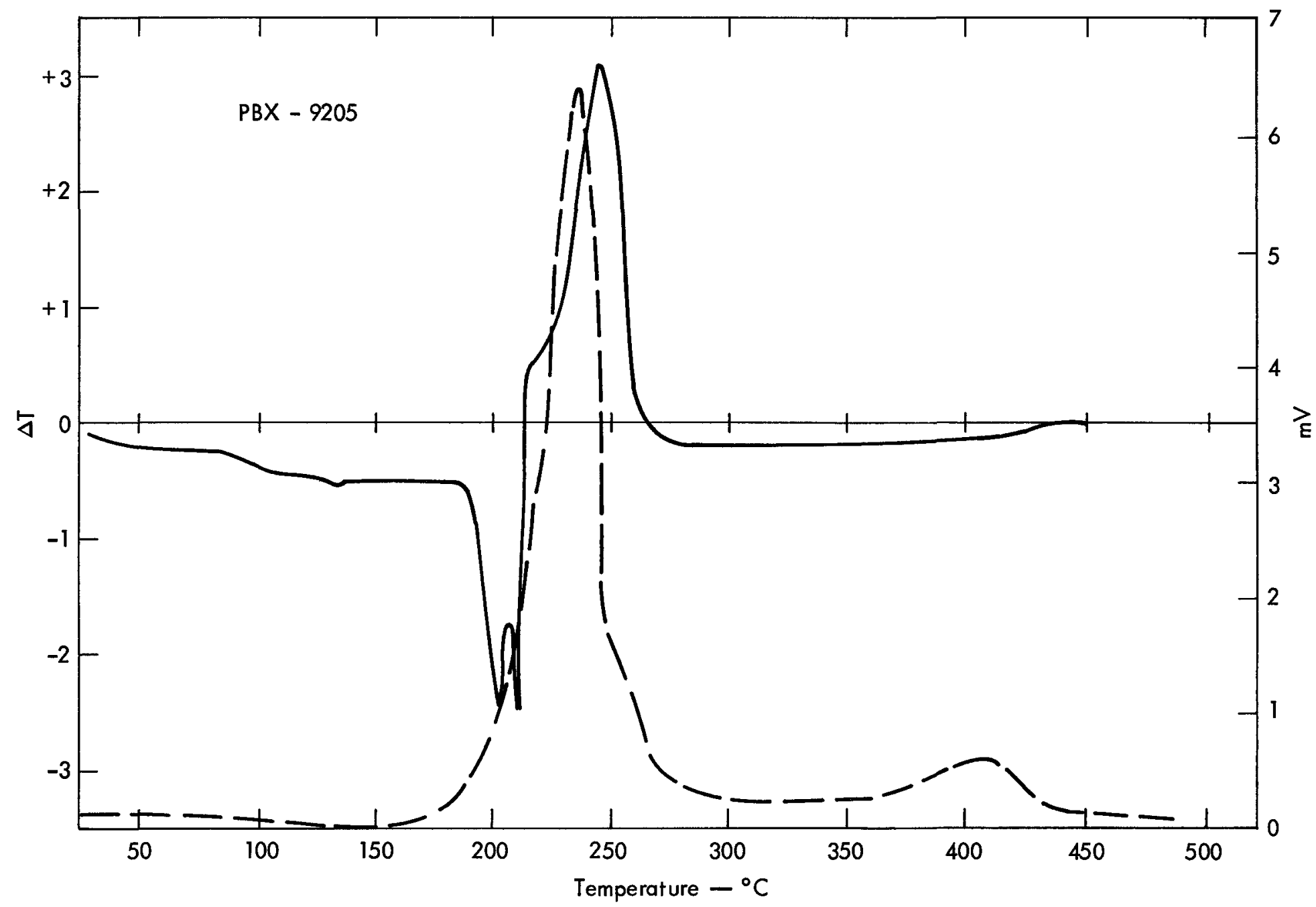




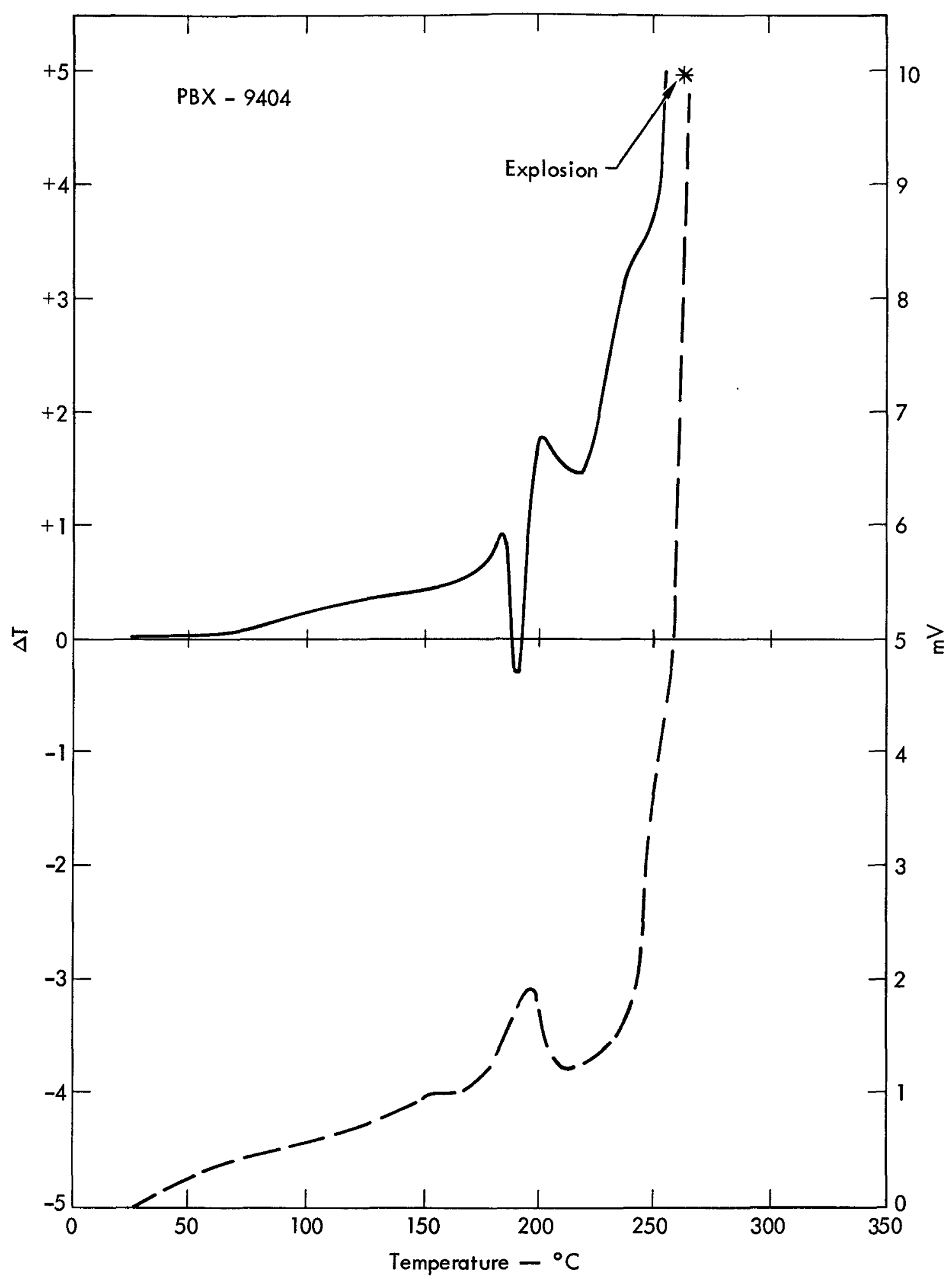

Fig. 6-4. (aa) DTA curve (solid line) and pyrolysis (thermal conductivity) curve (dashed line) for PBX-9404.24 Stabilized with diphenylamine. Solvent evolution and decomposition are integrated in the pyrolysis curve; however, the DTA curve shows that true decomposition begins at $\sim 75^{\circ} \mathrm{C}(348 \mathrm{~K})$. The HMX $\beta \rightarrow \delta$ transition is superimposed on the NC/CEF decomposition exotherm. Some samples of PBX-9404 show a small endotherm at $150^{\circ} \mathrm{C}$ $(423 \mathrm{~K})$. 


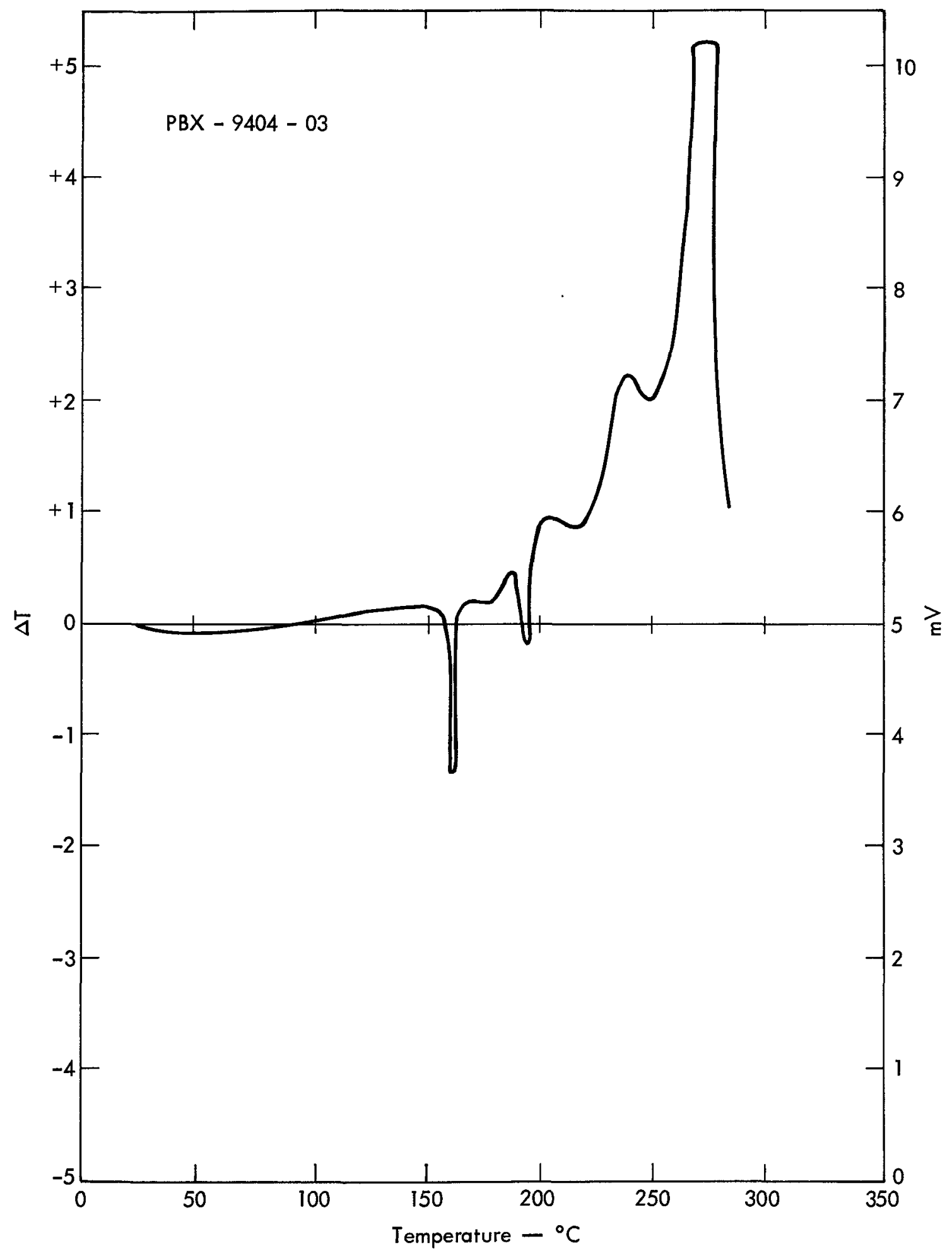

Fig. 6-4. (bb) DTA curve for PBX-9404-03. 24 


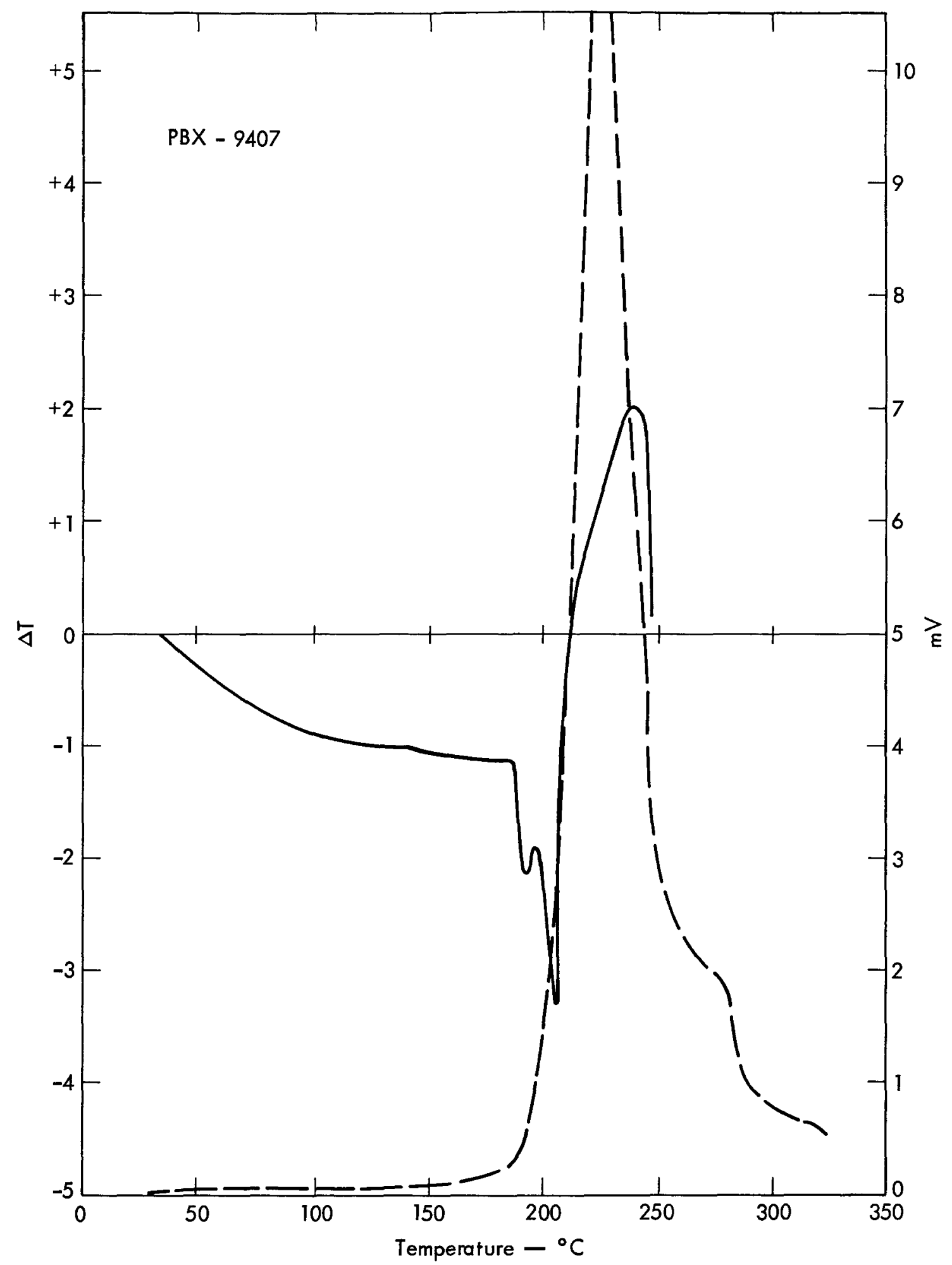

Fig. 6-4. (cc) DTA curve (solid line) and pyrolysis (thermal conductivity) curve (dashed line) for PBX-9407.24 


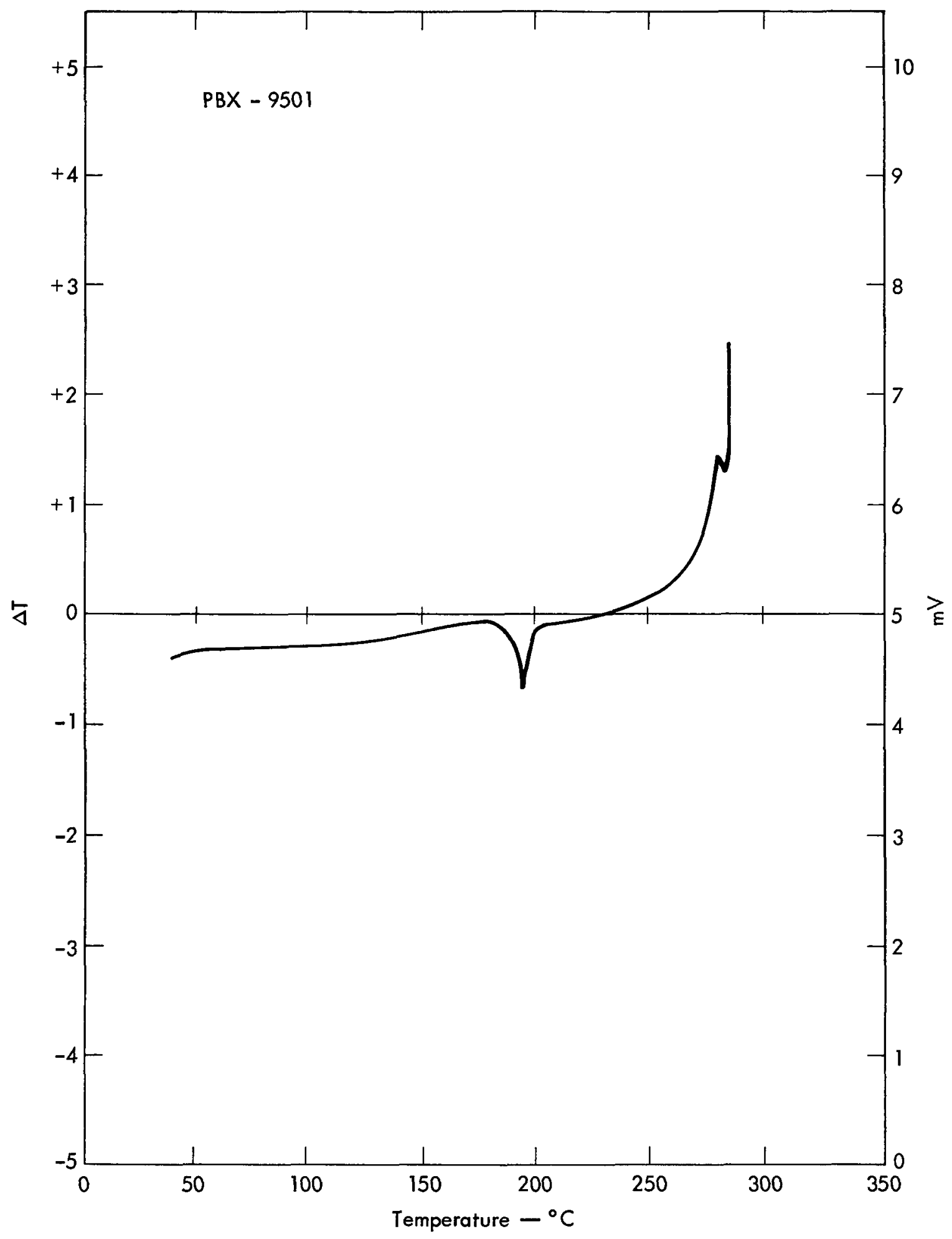

Fig. 6-4. (dd) DTA curve for PBX-9501. ${ }^{24}$ 


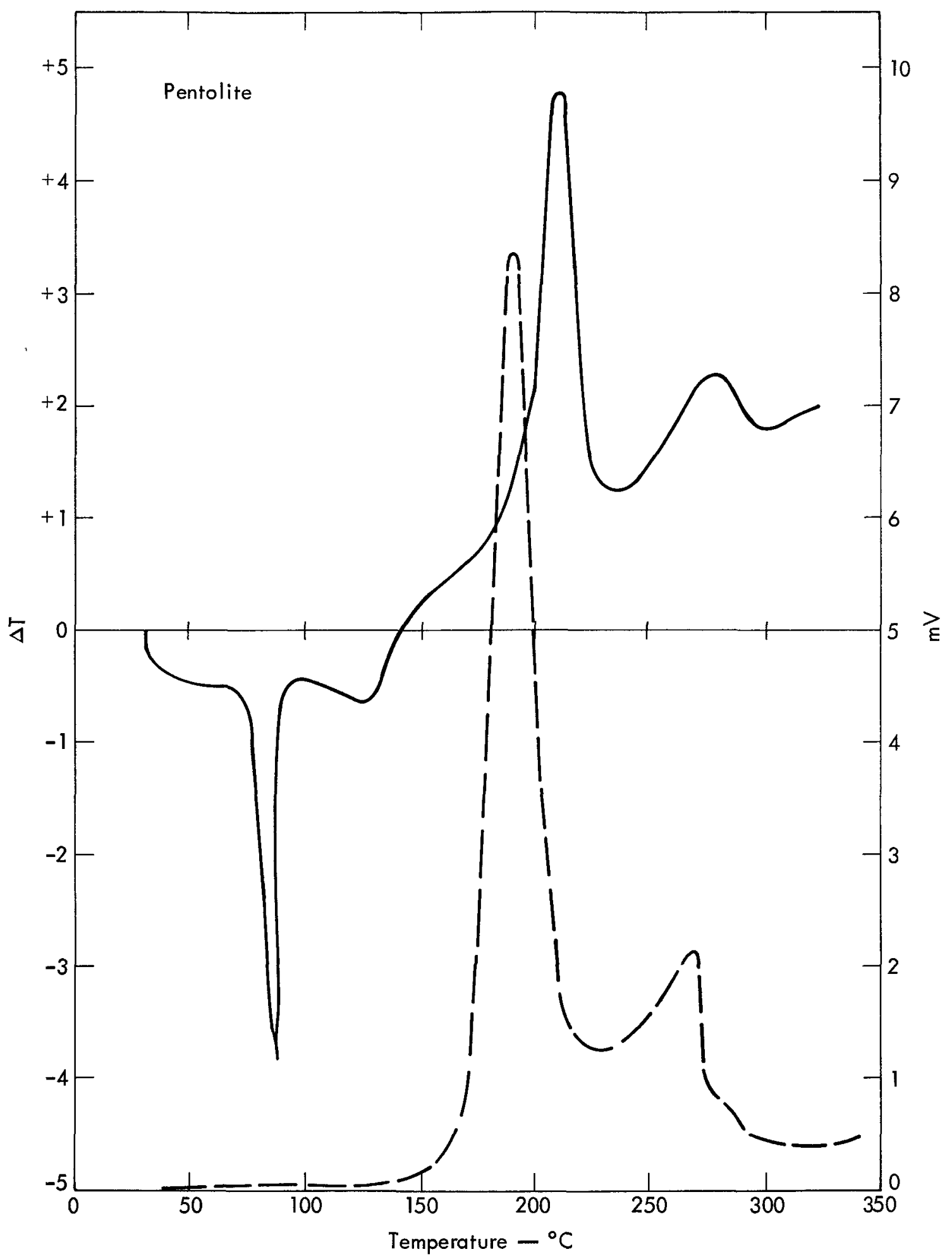

Fig. 6-4. (ee) DTA curve (solid line) and pyrolysis (thermal conductivity) curve (dashed line) for pentolite. 24 


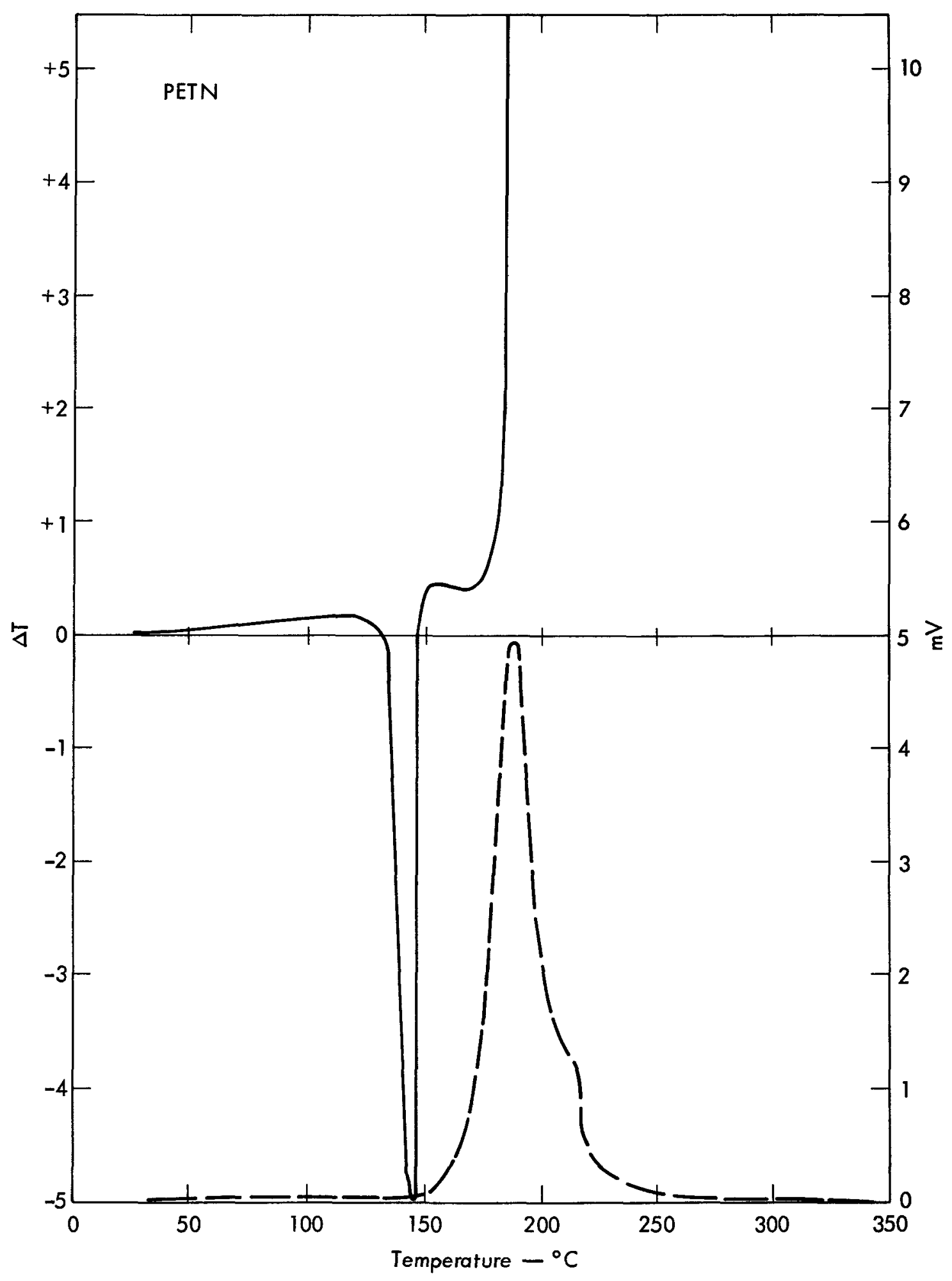

Fig. 6-4. (ff) DTA curve (solid line) and pyrolysis (thermal conductivity) curve (dashed line) for PETN.24 The small pyrolysis at $132^{\circ} \mathrm{C}(405 \mathrm{~K})$ represents a small evolution of trapped air from the imperfect crystal. 
$\frac{\sqrt{2}}{\sqrt{2}}$

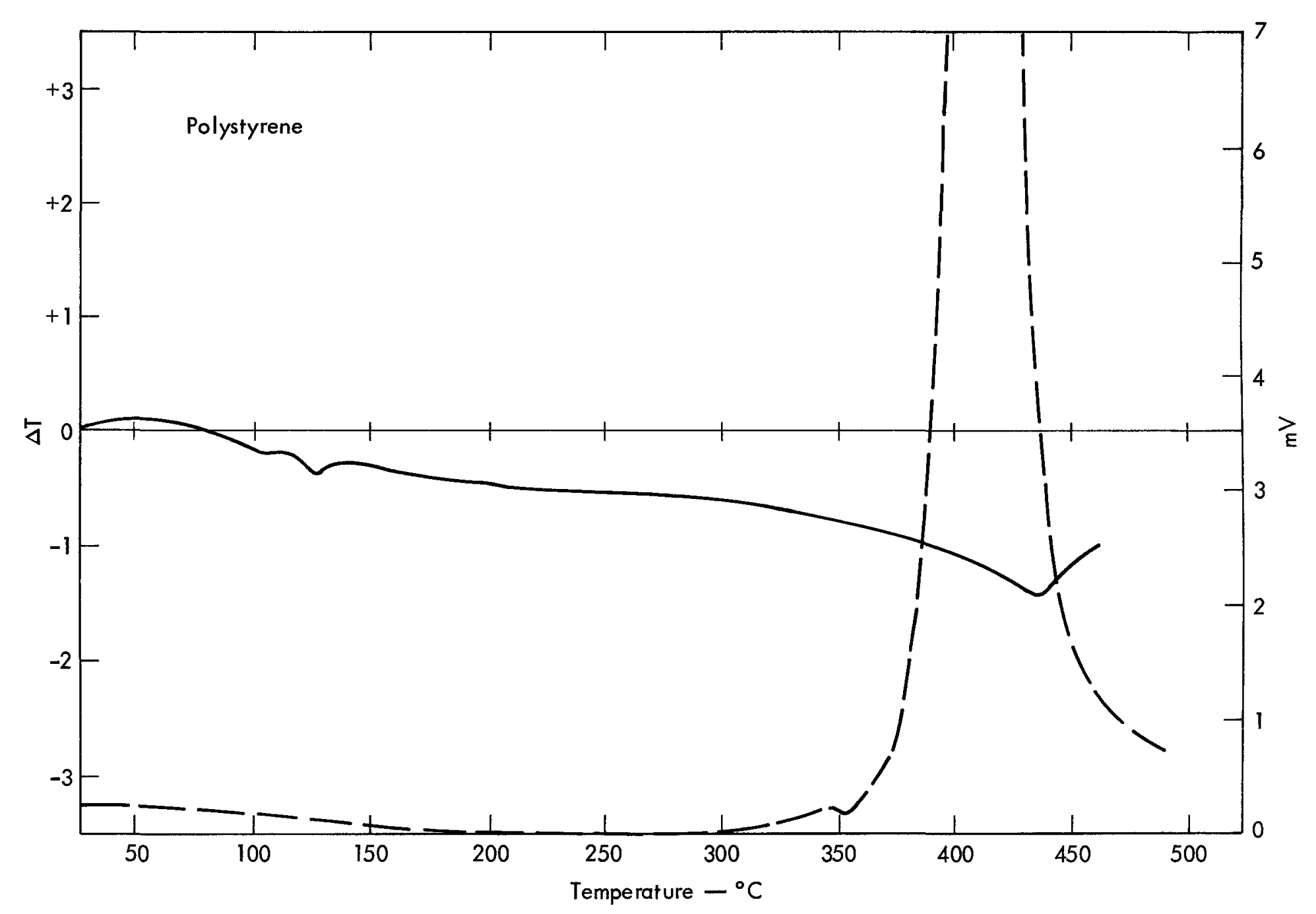

Fig. 6-4. (gg) DTA curve (solid line) and pyrolysis (thermal conductivity) curve (dashed line) for polystyrene. ${ }^{24}$ The ASTM softening point is $\sim 90-100^{\circ} \mathrm{C}(363-383 \mathrm{~K})$. 


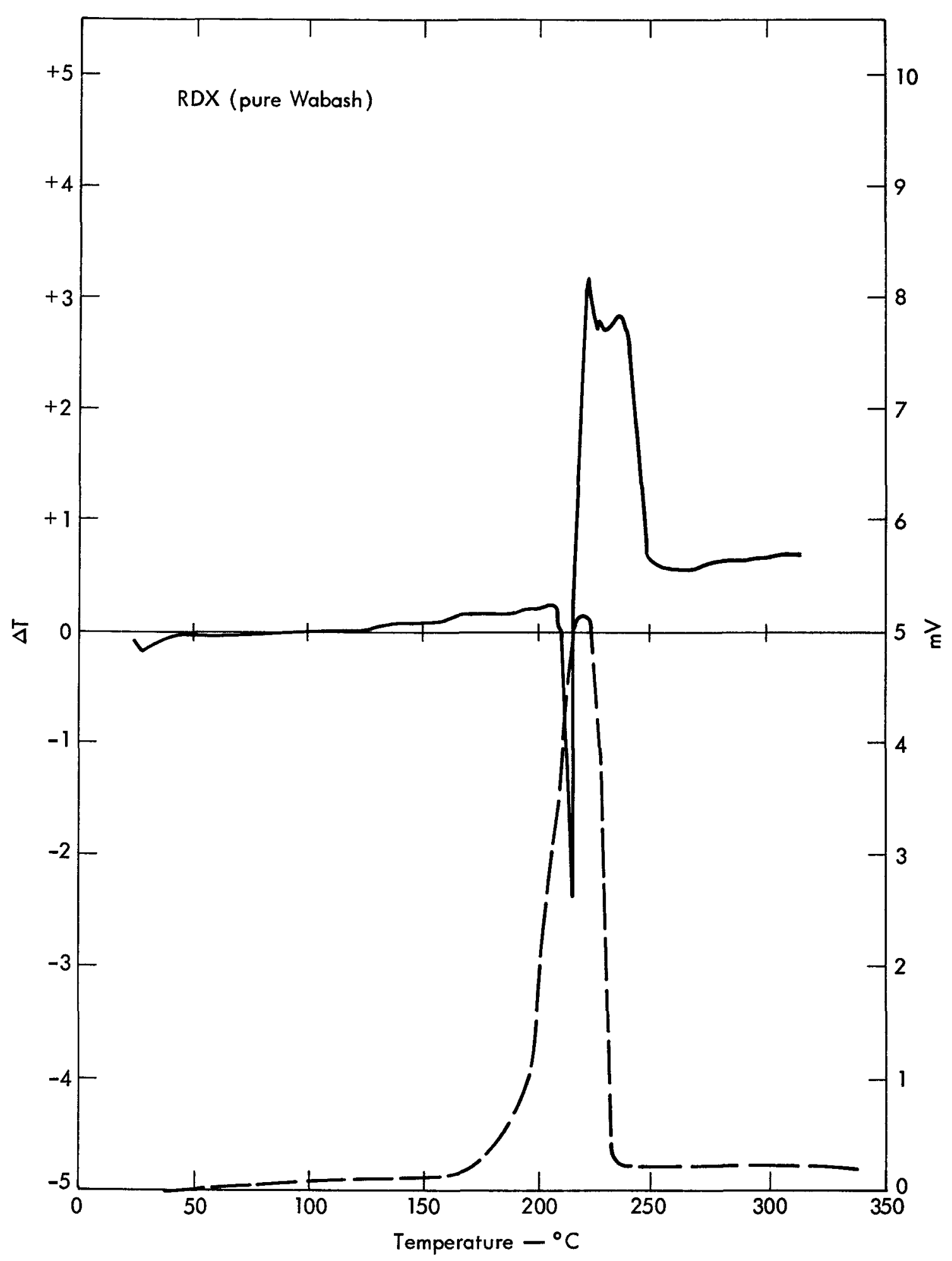

Fig. 6-4. (hh) DTA curve (solid line) and pyrolysis (thermal conductivity) curve (dashed line) for RDX (pure Wabash grade). 24 Gas evolution below the melting point is primarily sublimation. 


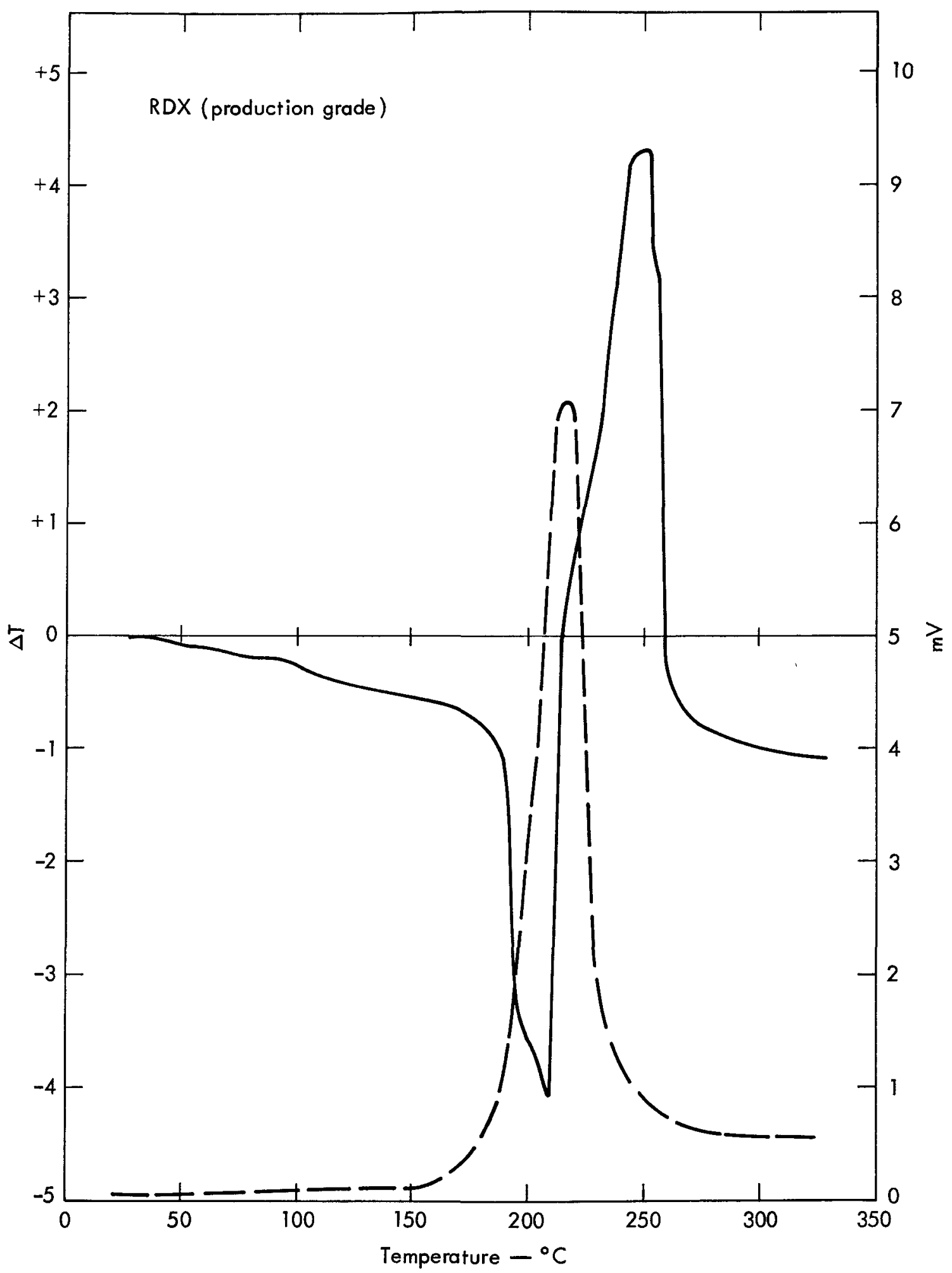

Fig. 6-4. (ii) DTA curve (solid line) and pyrolysis (thermal conductivity) curve (dashed line) for RDX (Holston production grade). 24 The sample contained several percent of HMX, which shows up as lowered melting point, broader endotherm, and lower gas-evolution temperature. 


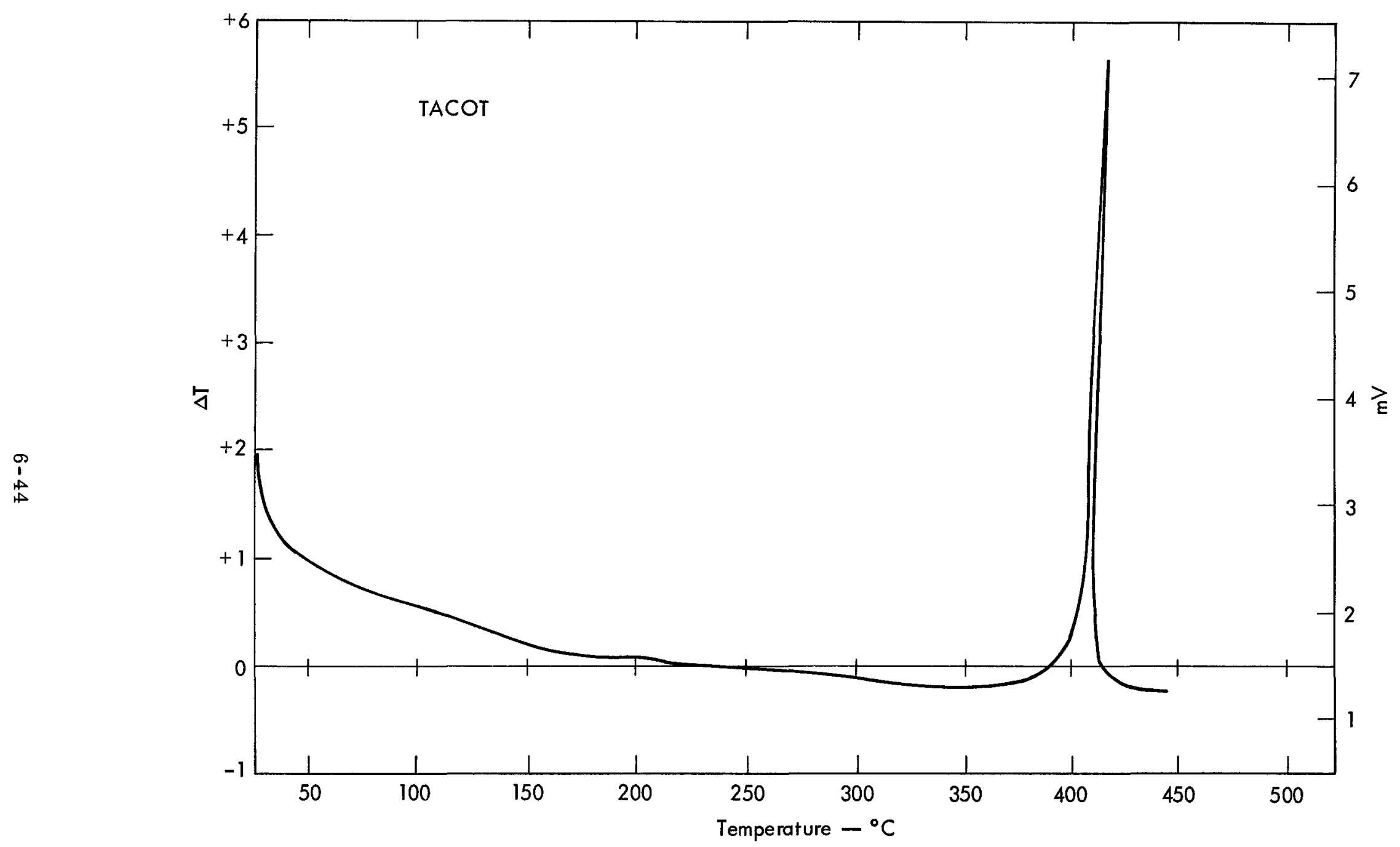

Fig. 6-4. (jj) DTA curve for TACOT. ${ }^{24}$ 


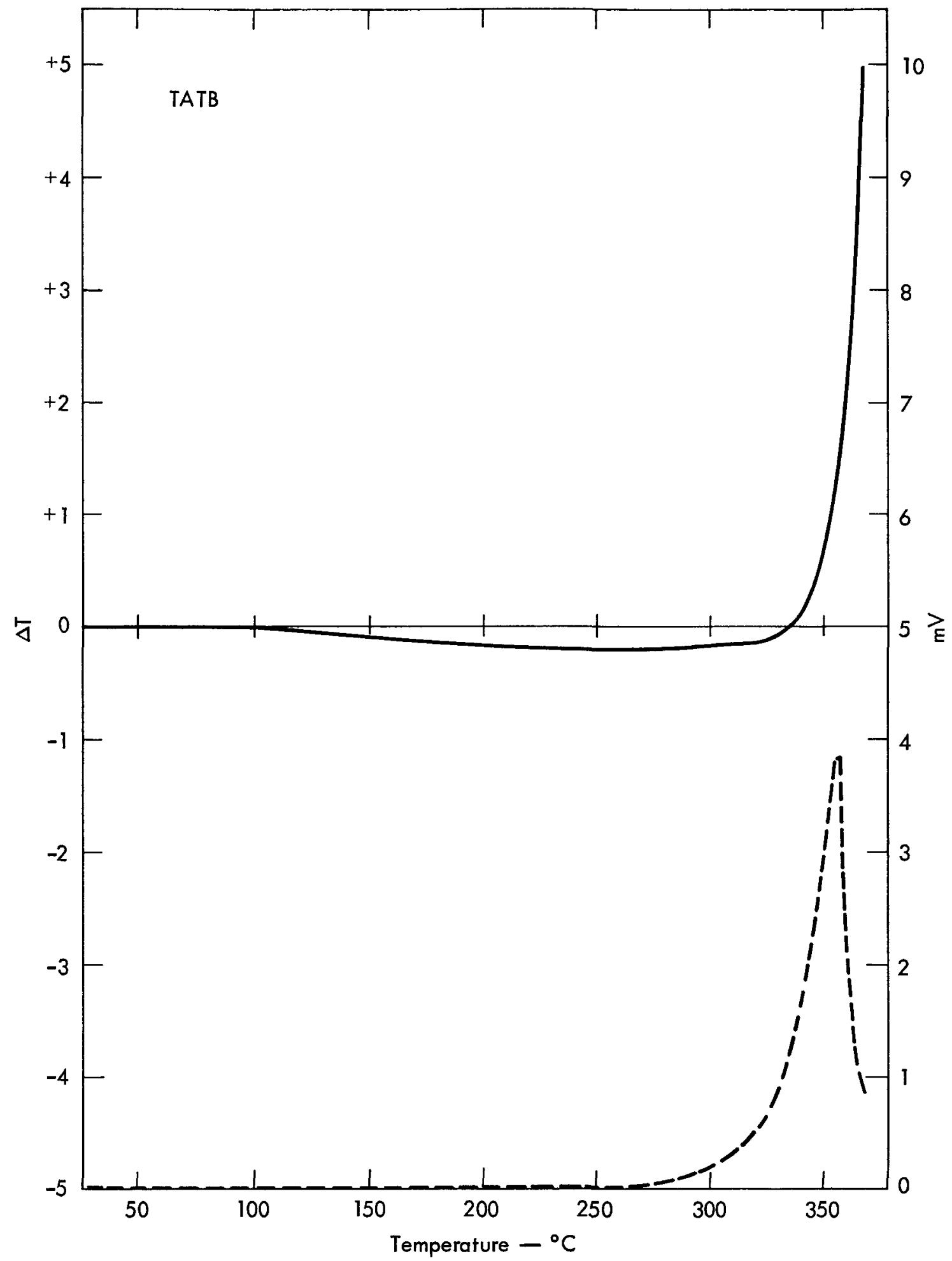

Fig. 6-4. (kk) DTA curve (solid line) and pyrolysis (thermal conductivity) curve (dashed line) for TATB. 24 The sample appears to be completely stable to at least $250^{\circ} \mathrm{C}(523 \mathrm{~K})$. 


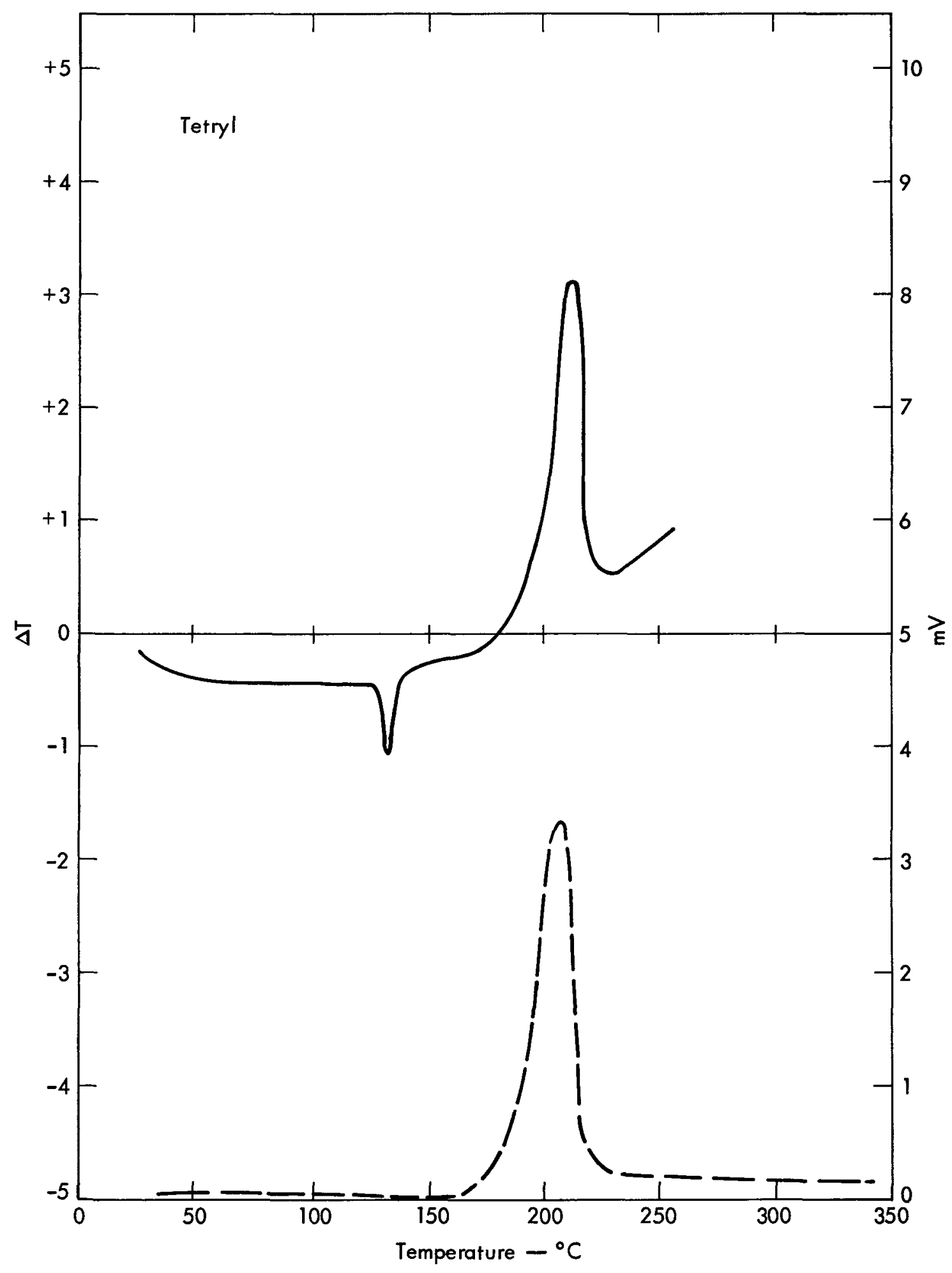

Fig. 6-4. (11) DTA curve (solid line) and pyrolysis (thermal conductivity) curve (dashed line) for tetryl.24 Reportedly melts at $130^{\circ} \mathrm{C}(403 \mathrm{~K})$ and explodes at $187^{\circ} \mathrm{C}(460 \mathrm{~K})$. This sample started to melt at $128^{\circ} \mathrm{C}(401 \mathrm{~K})$ but did not undergo rapid decomposition until about $198^{\circ} \mathrm{C}(471 \mathrm{~K})$. 


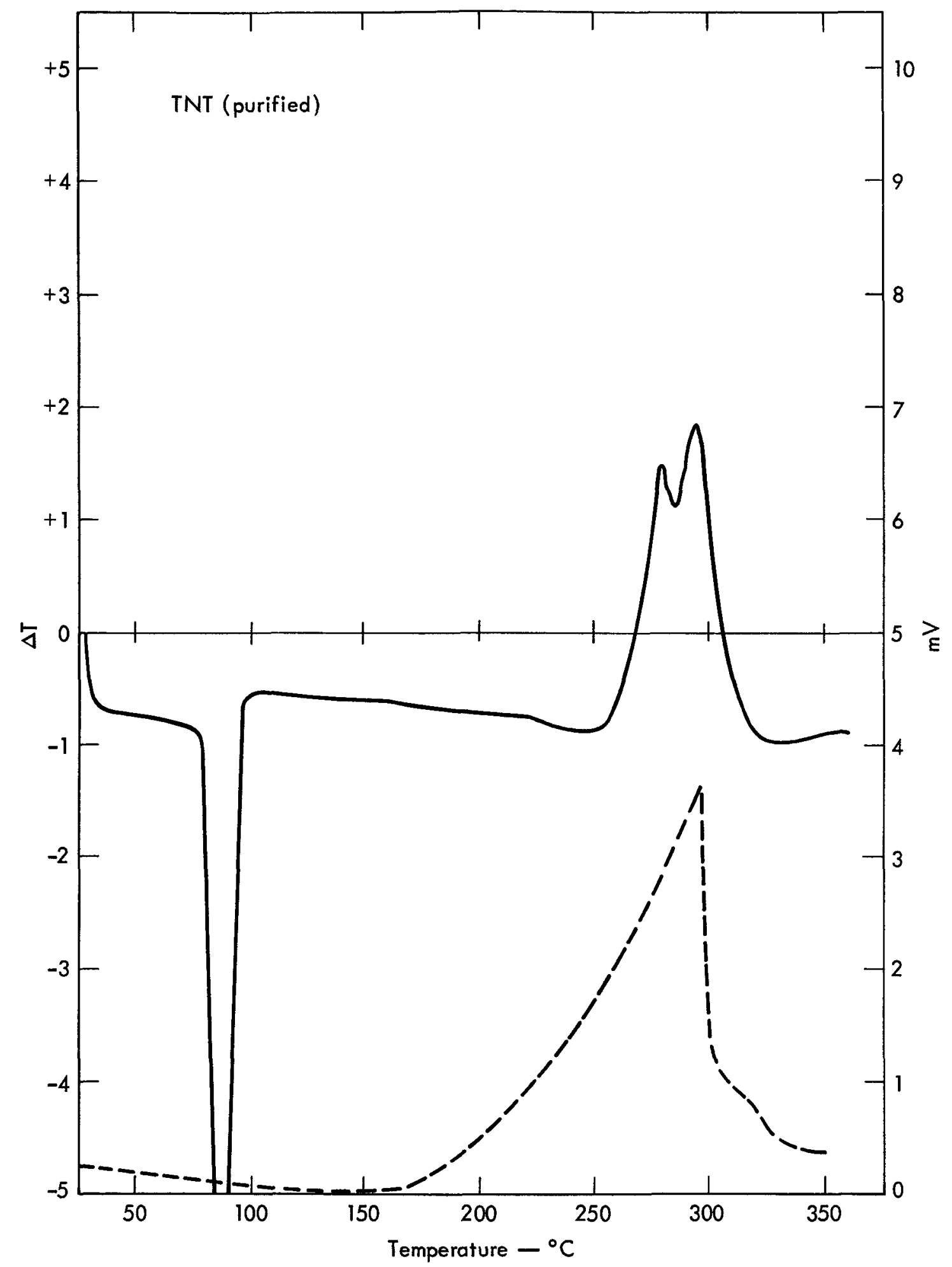

Fig. 6-4. (mm) DTA curve (solid line) and pyrolysis (thermal conductivity) curve (dashed line) for TNT (purified).24 


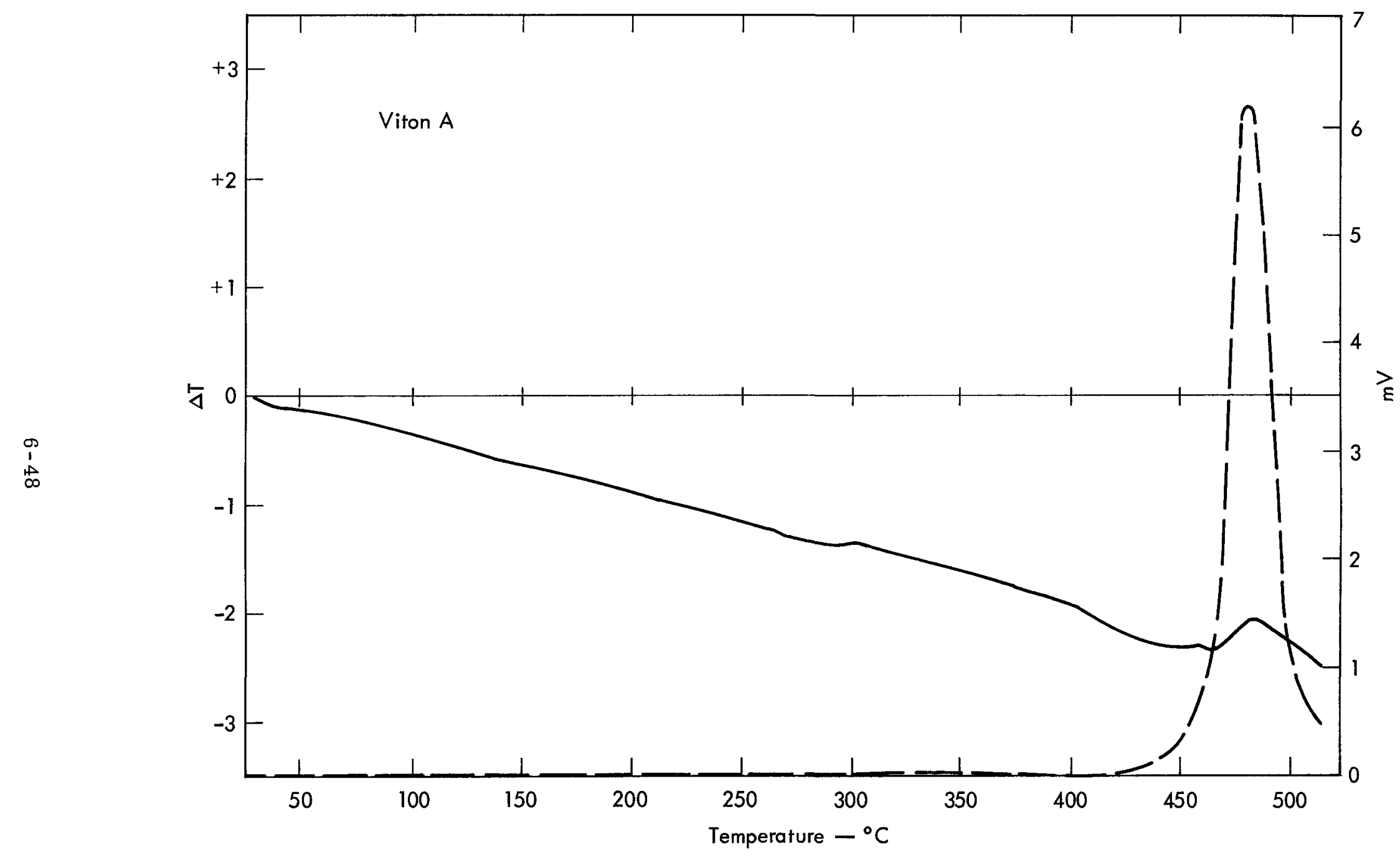



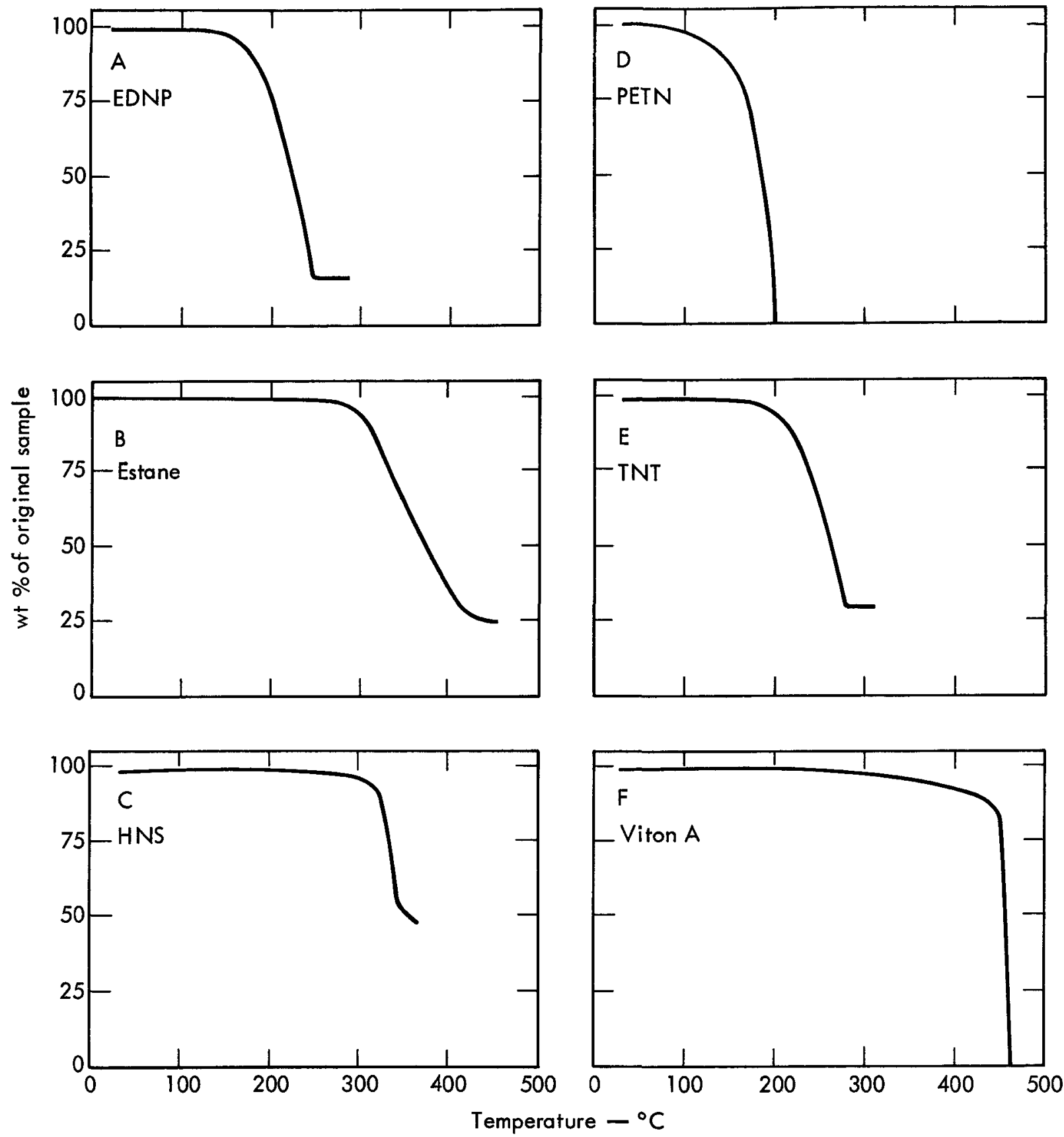

Fig. 6-5. TGA curves for explosives and binders. ${ }^{26}$ 
Table 6.4. Thermal stabilities of various explosives.

\begin{tabular}{|c|c|c|}
\hline Explosive & 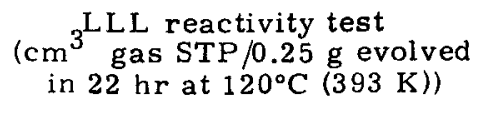 & $\begin{array}{l}\text { Vacuum stability test } \\
\left(\mathrm{cm}^{3} \text { gas STP/g evolved in }\right. \\
\left.48 \text { hr at } 120^{\circ} \mathrm{C}(393 \mathrm{~K})\right)\end{array}$ \\
\hline Baratol & $0.015-0.02$ & 0.19 \\
\hline Boracitol & - & $0.02-0.04$ \\
\hline BTF & $0.24-0.40$ & - \\
\hline BTF (purified) & 0.05 & - \\
\hline Comp B, Grade A & 0.051 & $0.05-0.16$ \\
\hline Comp B-3 & 0.033 & 0.27 \\
\hline Comp C-4 & 0.026 & - \\
\hline Cyclotol $75 / 25$ & $0.014-0.04$ & $0.25-0.94$ \\
\hline DATB & $<0.03$ & $<0.03$ \\
\hline DNPA & $0.04-0.06$ & - \\
\hline FEFO & $0.04-0.10$ & - \\
\hline $\mathrm{HMX}$ & $<0.01$ & 0.07 \\
\hline HNS & 0.01 & - \\
\hline$L X-01$ & $1.8^{\mathrm{a}}$ & - \\
\hline $\mathrm{LX}-02$ & $0.3-0.6$ & - \\
\hline $\mathrm{L} X-04$ & $0.01-0.04$ & - \\
\hline$L X-07-2$ & $0.01-0.04$ & - \\
\hline$L X-09-0$ & $0.03-0.07$ & - \\
\hline$L X-10-0$ & 0.02 & - \\
\hline $\mathrm{LX}-10-1$ & $0.04-0.06$ & - \\
\hline$L X-11$ & $0.01-0.04$ & - \\
\hline$L X-13$ & See XTX-8003 & . \\
\hline $\mathrm{L} X-14$ & 0.02 & 0.025 \\
\hline $\mathrm{NC}(12.0 \% \mathrm{~N})$ & $1.0-1.2$ & 5.0 \\
\hline NQ & $0.02-0.05$ & - \\
\hline Octol & - & 0.18 \\
\hline PBX-9007 & $0.03-0.07$ & - \\
\hline PBX -9010 & $0.02-0.04$ & $0.2-0.3^{c}$ \\
\hline PBX-9011 & 0.024 & - \\
\hline PBX-9205 & 0.025 & - \\
\hline PBX-9404 & $0.36-0.40$ & $3.2-4.9$ \\
\hline PBX-9407 & 0.06 & - \\
\hline$P B X-9501^{11}$ & 0.07 & 0.8 \\
\hline Pentolite $50 / 50$ & - & $3.0^{\mathrm{b}}$ \\
\hline PETN & $0.10-0.14$ & - \\
\hline $\operatorname{RDX}$ & $0.02-0.025$ & $0.12-0.9$ \\
\hline TACOT & - & - \\
\hline TATB & - & - \\
\hline Tetryl & 0.036 & - \\
\hline TNT & $0.00-0.012$ & $\sim 0.005$ \\
\hline $\mathrm{X} T \mathrm{~T}-8003$ & $<0.02^{\mathrm{b}}$ & - \\
\hline
\end{tabular}

${ }^{\mathrm{a}}$ Measured at $80^{\circ} \mathrm{C}(353 \mathrm{~K})$ because of the high volatility of the material

${ }^{b}$ Measured at $100^{\circ} \mathrm{C}(373 \mathrm{~K})$.

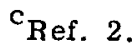


5. Vacuum stability test. The sample is heated for $48 \mathrm{hr}$ at $120^{\circ} \mathrm{C}(393 \mathrm{~K})$. A simple manometric system is used to measure the total volume of all gases evolved, including water and residual solvents. The results are expressed on the basis of $1 \mathrm{~g}$ of explosive. For reference purposes, $1 \mathrm{~cm}^{3}$ of evolved gas per gram of explosive represents about $0.2 \%$ decomposition (see Table 6-4).

\section{Thermal Stability of Larger Explosive Charges}

For large amounts of explosive, the results from small-scale thermal-stability tests are not strictly applicable. There is a maximum safe temperature that should not be exceeded for large charges: it is the point at which thermal energy from slow chemical decomposition is being given off at a rate greater than it can be dissipated. It is referred to as the self-heating temperature and is dependent on the amount of explosive, its environment, and the time it will be held at the elevated temperature. For example:

1. Twenty-five pounds $(11.34 \mathrm{~kg})$ of $\mathrm{LX}-04-1$ may be held at $190^{\circ} \mathrm{C}(463 \mathrm{~K})$ for no more than $10 \mathrm{~min}$ and at $220^{\circ} \mathrm{C}(493 \mathrm{~K})$ for no more than $1 \mathrm{~min}$.

2. Calculations indicate that $\sim 13,000 \mathrm{lb}$ ( $\sim 6$ tons) of molten TNT may be unsafe. Information on problems of this nature can be obtained from members of the Organic Materials Division. 


\section{References}

1. K. A. Peterman, Lawrence Livermore Laboratory, personal communication (1964).

2. A. Popolato, Los Alamos Scientific Laboratory, Albuquerque, N. Mex., personal communication (1974).

3. J. Brandrup and E. H. Immergut, Eds., Polymer Handbook, (Interscience, N. Y., 1960).

4. Dow Corning, Hemlock, Mich., Information About Electronic Materials, Dow Corning Bulletin 07-123 (May 1964).

5. R. L. Murray, Lawrence Livermore Laboratory, personal communication (1972).

6. W. G. Moen, Lawrence Livermore Laboratory, personal communication (1964).

7. W. H. Kirkwood, Lawrence Livermore Laboratory, personal communication (1974).

8. M. Finger, Lawrence Livermore Laboratory, personal communication (1965).

9. A. C. Schwartz, Application of Hexanitrostilbene (HNS) in Explosive Components, Sandia Laboratories, Albuquerque, N. Mex., Rept. SC-RR-710673 (1972).

10. H. H. Cady, J. Chem. Eng. Data 17, 369-371 (1972).

11. Food Machinery Corporation, Ohio Apex Division, Nitro, W. V., Plasticizers, Data Sheet (1955).

12. D. L. Ornellas, Lawrence Livermore Laboratory, personal communication (1974).

13. R. Velicky, C. Lenchitz, and W. Beach, Picatinny Arsenal, Dover, N. J., Rept. PA-TR-2504 (January 1949). Enthalpy data were plotted and $C_{p}$ was recalculated by D. L. Ornellas, Lawrence Livermore Laboratory (1974).

14. R. Shaw, Stanford Research Institute, Palo Alto, Calif., personal communication (1973).

15. S. Marantz and G. T. Armstrong, J. Chem. Eng. Data 13, 118-121 (1968).

16. D. G. Miller, Lawrence Livermore Laboratory, personal communication (1964).

17. L. J. Decker, J. R. Ward, and E. Freedman, Thermochim. Acta 8, 177-183 (1974).

18. Army Materiel Command, Properties of Explosives of Military Interest, U.S. Army Materiel Command, Rept. AMCP-706-177 (1967).

19. H. A. Berman and E. D. West, J. Chem. Eng. Data 14, 107-109 (1969).

20. G. Krien, H. Licht, and J. Zierath, Thermochim. Acta 6, 465-472 (1973).

21. T. W. Benziger, X-0242: A High-Energy Plastic Bonded Explosive, Los Alamos Scientific Laboratory, N. Mex., Rept. LA-4872-MS (1972).

22. H. Cady and W. Rogers, Los Alamos Scientific Laboratory, Los Alamos, N. Mex., Rept. LA-2696 (July 1962).

23. E. I. Du Pont de Nemours and Co., Service Bulletin, (no date).

24. R. N. Rogers, Los Alamos Scientific Laboratory, personal communication (1974).

25. R. N. Rogers, S. K. Yasuda, and J. Zinn, Anal. Chem. 32, 672-678 (1960).

26. B. Shroyer, Lawrence Livermore Laboratory, personal communication (1974). 


\section{MECHANICAL PROPERTIES}

High explosives are viscoelastic materials. Their mechanical properties are functions of time, temperature, and loading rate. In any one material they vary because of differences in raw material from one lot to another, differences in pressing conditions, and differences in the machining procedures used to fabricate the materials. Therefore, the data in this section are not intended to provide exact numerical values but rather to demonstrate general trends and to make comparisons between different materials. For more refined calculations to predict the behavior of materials, each individual lot of $\mathrm{HE}$ must be characterized.

To characterize materials over the entire temperature range from -65 to $165^{\circ} \mathrm{F}$ (219-347 K), it is necessary to make certain assumptions:

1. The material is homogeneous.

2. The material is isotropic.

3. Linear elastic and viscoelastic theory can be used to characterize explosives.

4. Poisson's ratio (PR) is independent of time and temperature. (Poisson's ratio for most solid HEs falls in the range from 0.25 to 0.30 .)

5. The material is thermorheologically simple (i.e., the time-temperature postulate holds).

6. The "failure envelope" (see Fig. 7-8) provides an adequate criterion of failure.

7. The material does not age. These assumptions have been explored experimentally and found to be reasonable.

The first step to be undertaken when looking for data on mechanical properties is to examine the time-scale of the specific problem. A schematic plot of stress vs time (Fig. 7-1) is useful for indicating the kind of data needed. 


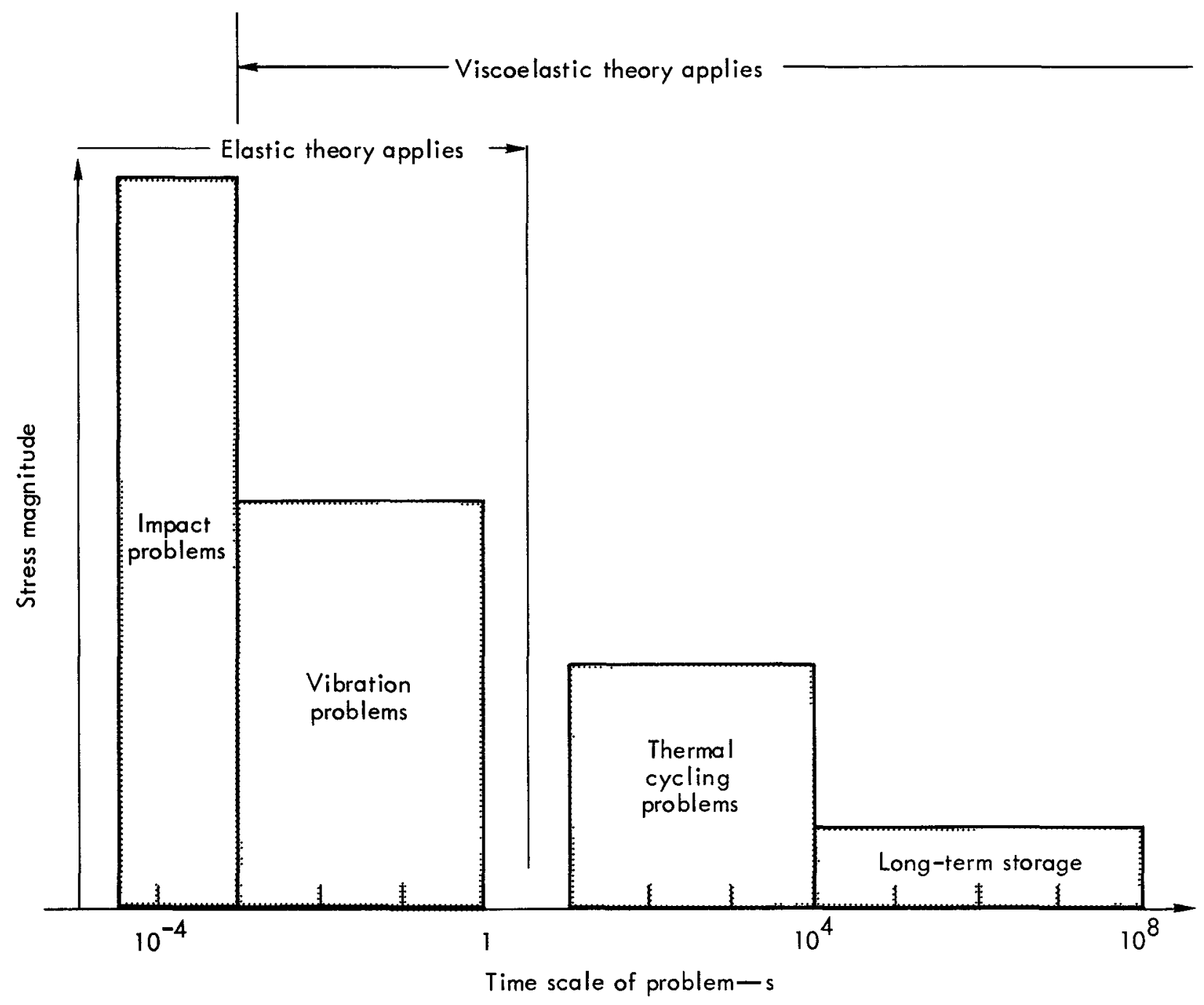

Fig. 7-1. The time-scale of the problem indicates the appropriate theory, which in turn indicates the kind of data to be collected. For elastic characterization, use initial modulus $\mathrm{E}_{0}$ as in Fig. 7-3 or $\nu$ as in Table 7-1. For viscoelastic characterization, use creep curves as in Figs. 7-4 to 7-6. Failure criteria apply to both characterizations (Fig. 7-8). 
Dynamic effects become important in a material when the time-scale of observation approaches the transit time of a wave velocity across a characteristic dimension of the sample. This shift from static to dynamic considerations is said to occur when the loading rate exceeds approximately $1 \mathrm{sec}^{-1}$. Static-dynamic stress-strain relationships in compression are shown in Fig. 7-2 for LX-04, LX-10, and PBX-9501.

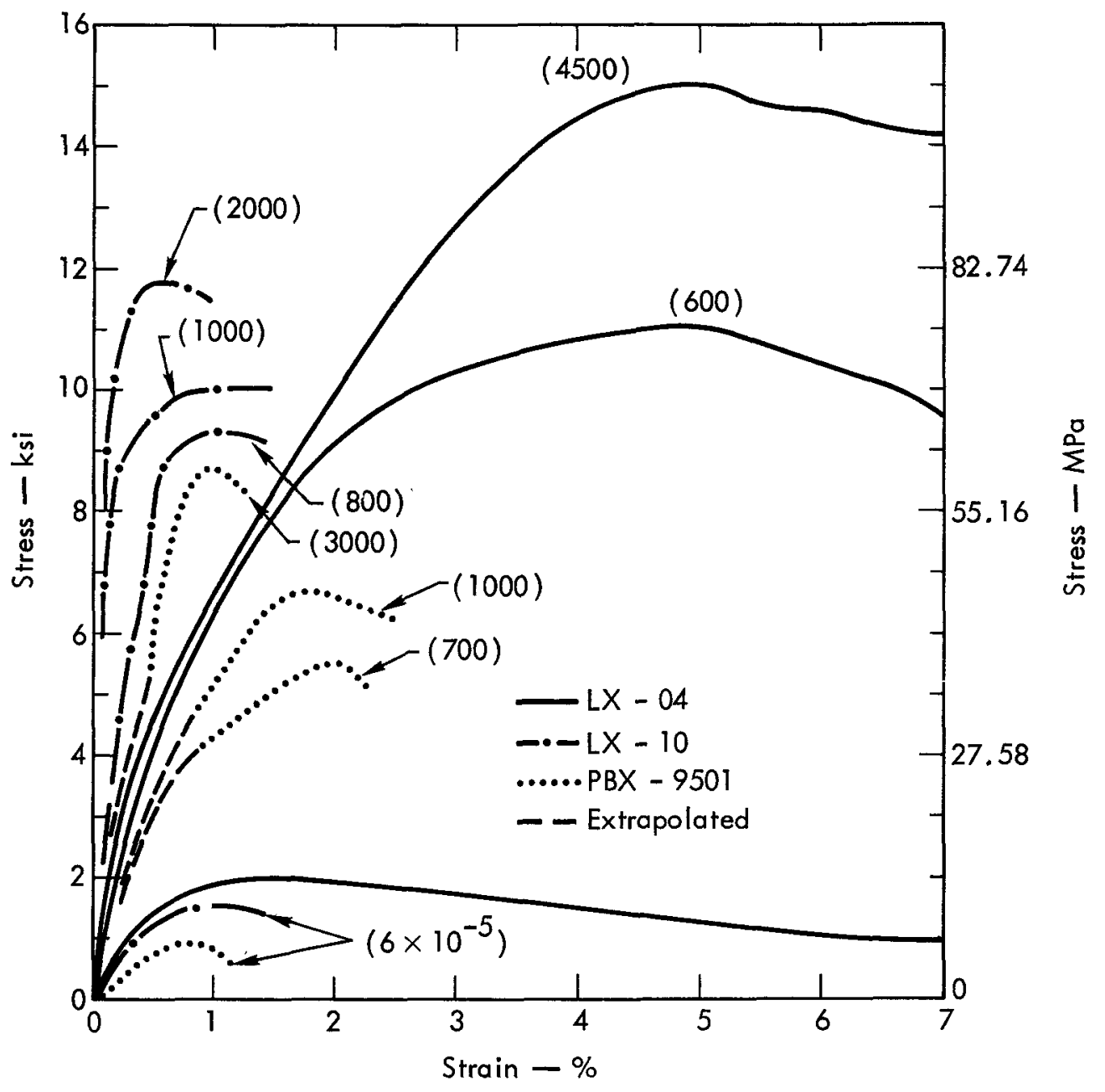

Fig. 7-2. Compressive stress-strain curves for LX-04, LX-10, and PBX-9501 at various strain rates. 1,2 Conversion factor: 1 psi $=6.894757 \mathrm{kPa}$. Numbers in parentheses are loading rates in $\mathrm{s}^{-1}$. 
Other considerations in the material properties are the crystallinity of the binder and the effects of adhesives. The crystallinity of the binder is controlled by its carbon content; increased crystallinity increases the stiffness of the material and decreases the temperature-sensitivity of the mechanical properties. When HE assemblies are joined together with adhesives, the compliance of the adhesive must be considered. Most adhesives used with HEs are stronger but more compliant than the explosive. If clean surfaces and recommended assembly procedures are used, the bond will usually be stronger than the HE. If the assembly is to be subjected to stress analysis, the adhesive bond should be modeled as a thermoviscoelastic material; however, data are not currently available to make this characterization. ${ }^{3}$

A series of codes for linear thermoviscoelastic analysis has been developed to predict thermal, mechanical, and failure behavior of HEs when subjected to arbitrary thermal and mechanical boundary conditions. 4 Members of the Nonmetallic Materials Group of W Division can supply copies of the codes and assist in generating a viscoelastic model of the problem to be analyzed. As noted above, different characterizations of material are required for different kinds of problems.

\section{Static Mechanical Properties}

In this section, experimental data are given for characterization of static mechanical properties: initial modulus $\mathrm{E}_{0}$ (Fig. 7-3), creep (Figs. 7-4 and 7-5), compression creep (Fig. 7-6), stress-strain data (Fig. 7-7), failure envelopes (Fig. 7-8), friction (Table 7-1 and Figs. 7-9 and 7-10), and complex shear (Fig. 7-11). The failure envelopes were obtained under isothermal, monotonically increasing tension loads. 


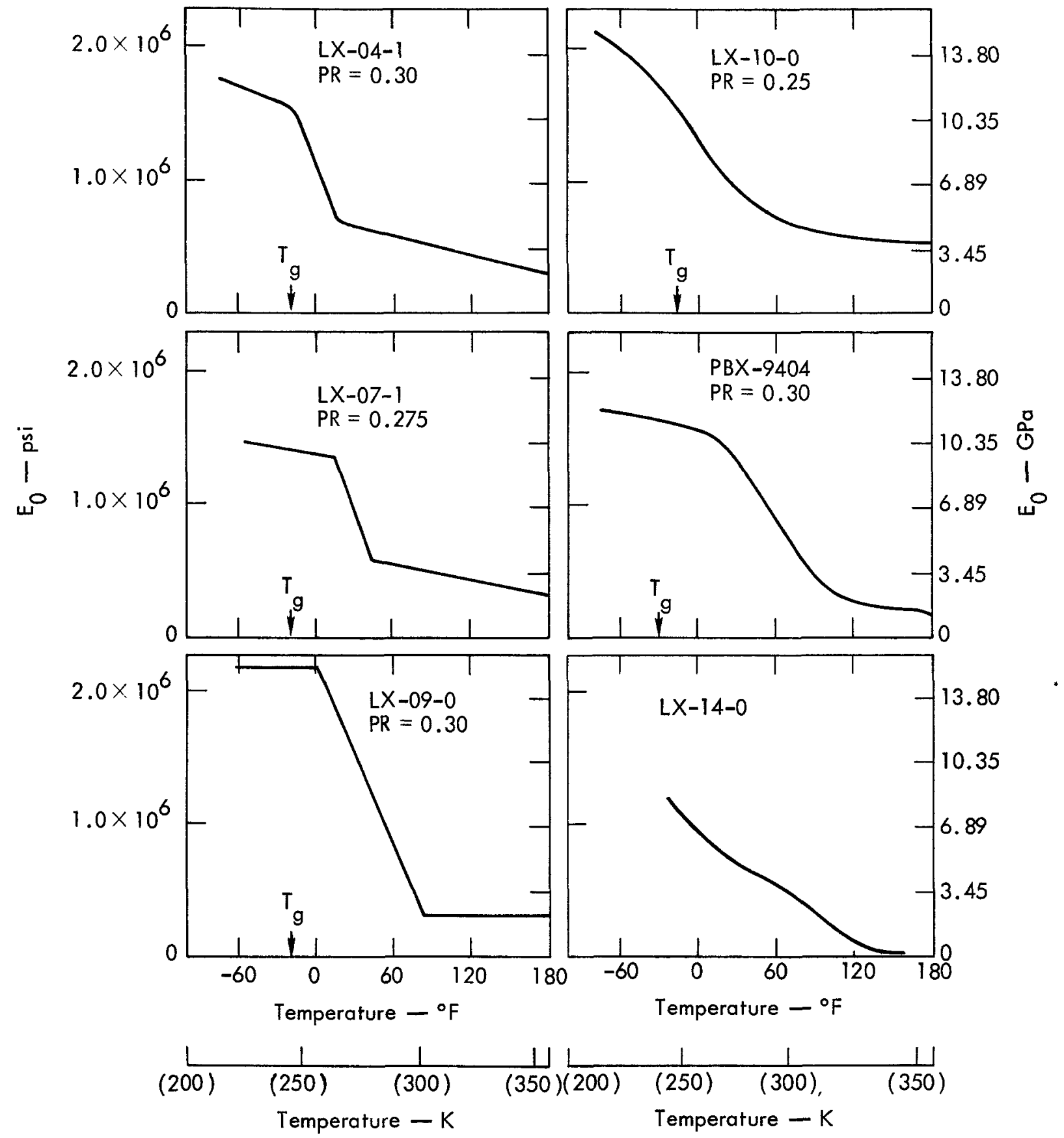

Fig. 7-3. Initial longitudinal modulus $E_{0}$ vs temperature for several explosives. PR, Poisson's ratio. Conversion factor: $1 \mathrm{psi}=6.894757 \mathrm{kPa}$. 


\section{Creep}
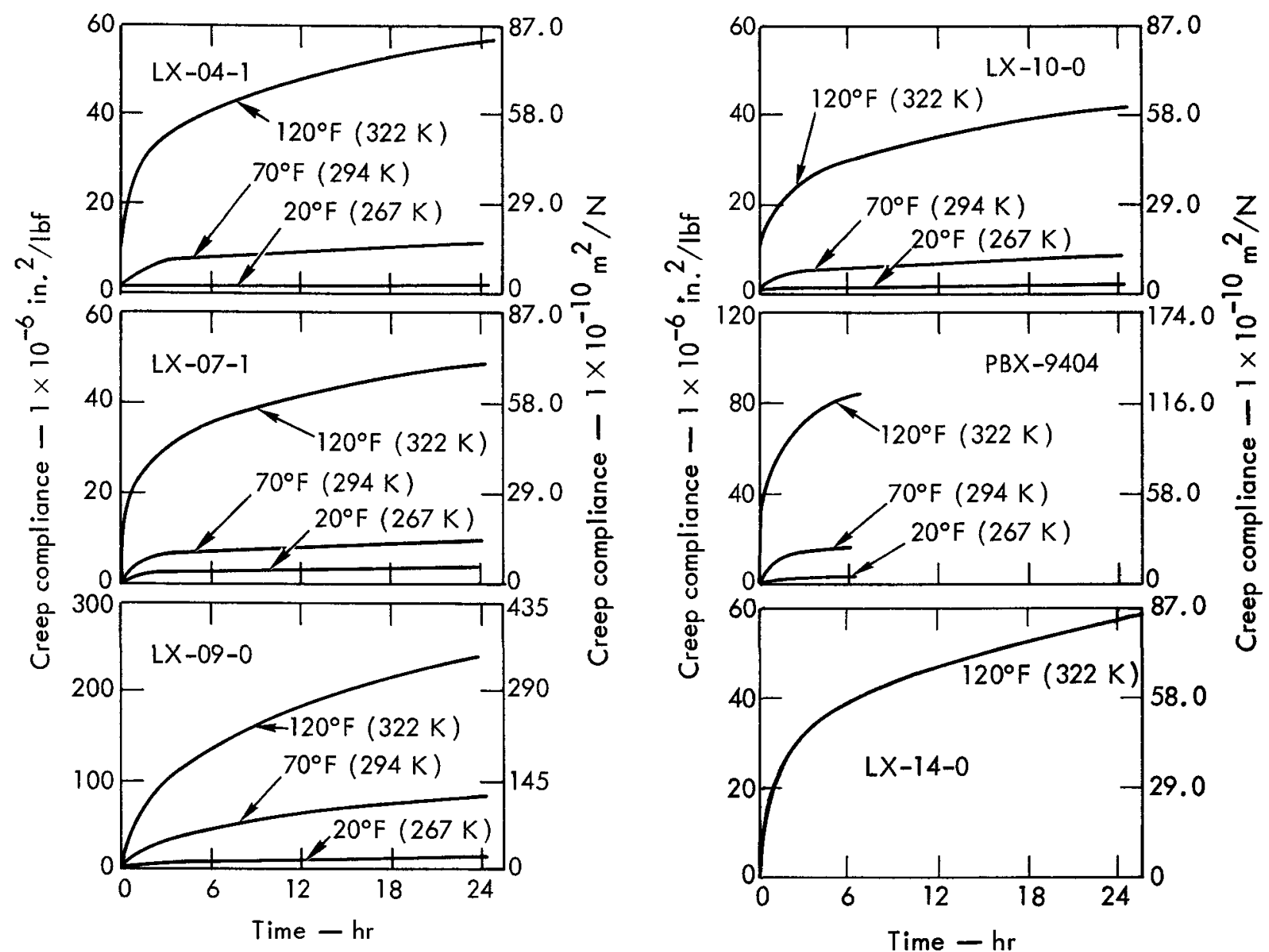

Fig. 7-4. Tension creep data for several explosives. Conversion factor: 1 in. ${ }^{2} / \mathrm{lbf}$ $=1.450377 \times 10^{-4} \mathrm{~m}^{2} / \mathrm{N}$. 


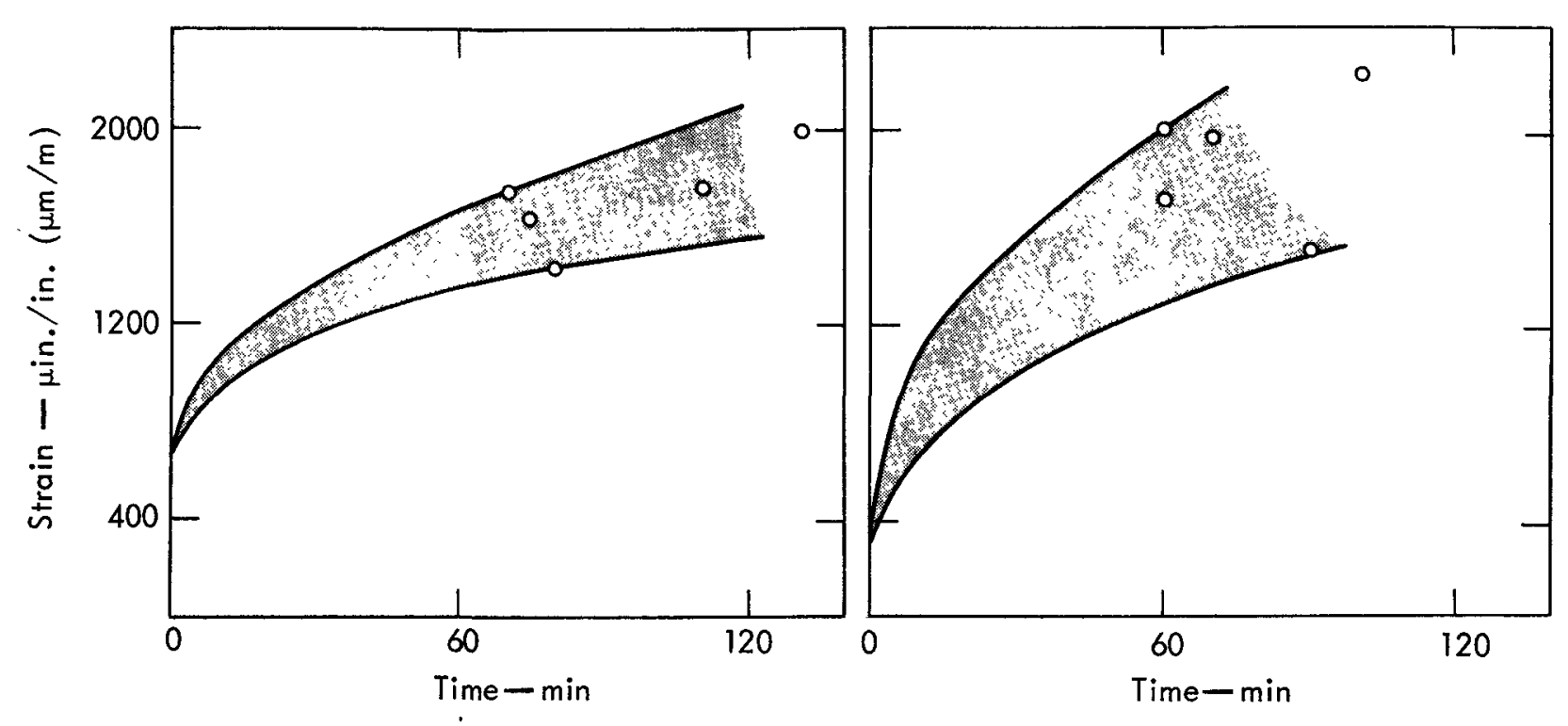

Fig. 7-5. Tension creep data for PBX-9501: left, at 100 psi $(689 \mathrm{kPa}), 70^{\circ} \mathrm{F}(294 \mathrm{~K})$; right, at $50 \mathrm{psi}(345 \mathrm{kPa}), 120^{\circ} \mathrm{F}(322 \mathrm{~K})$. The shaded area indicates the range; the points indicate rupture of the specimen.

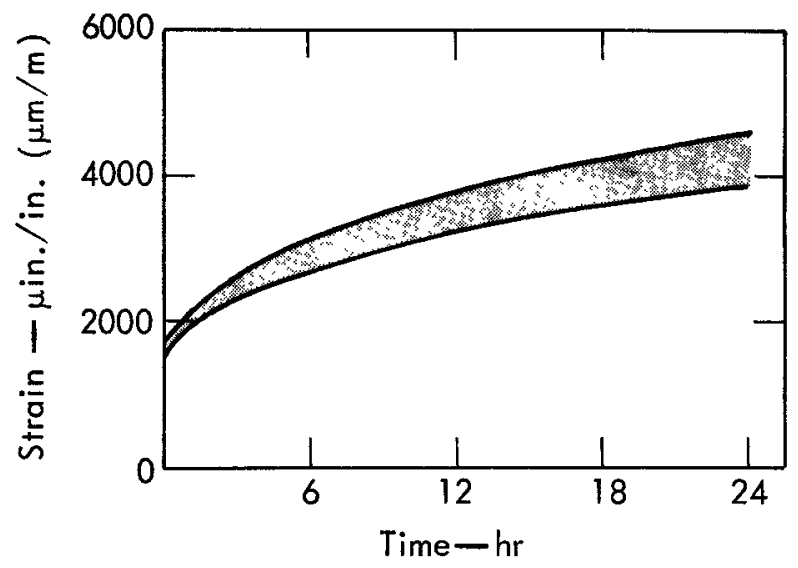

Fig. 7-6. Compression creep data for PBX-9501 at $100 \mathrm{psi}(689 \mathrm{kPa}), 120^{\circ} \mathrm{F}(322 \mathrm{~K})$. The shading indicates the range. 


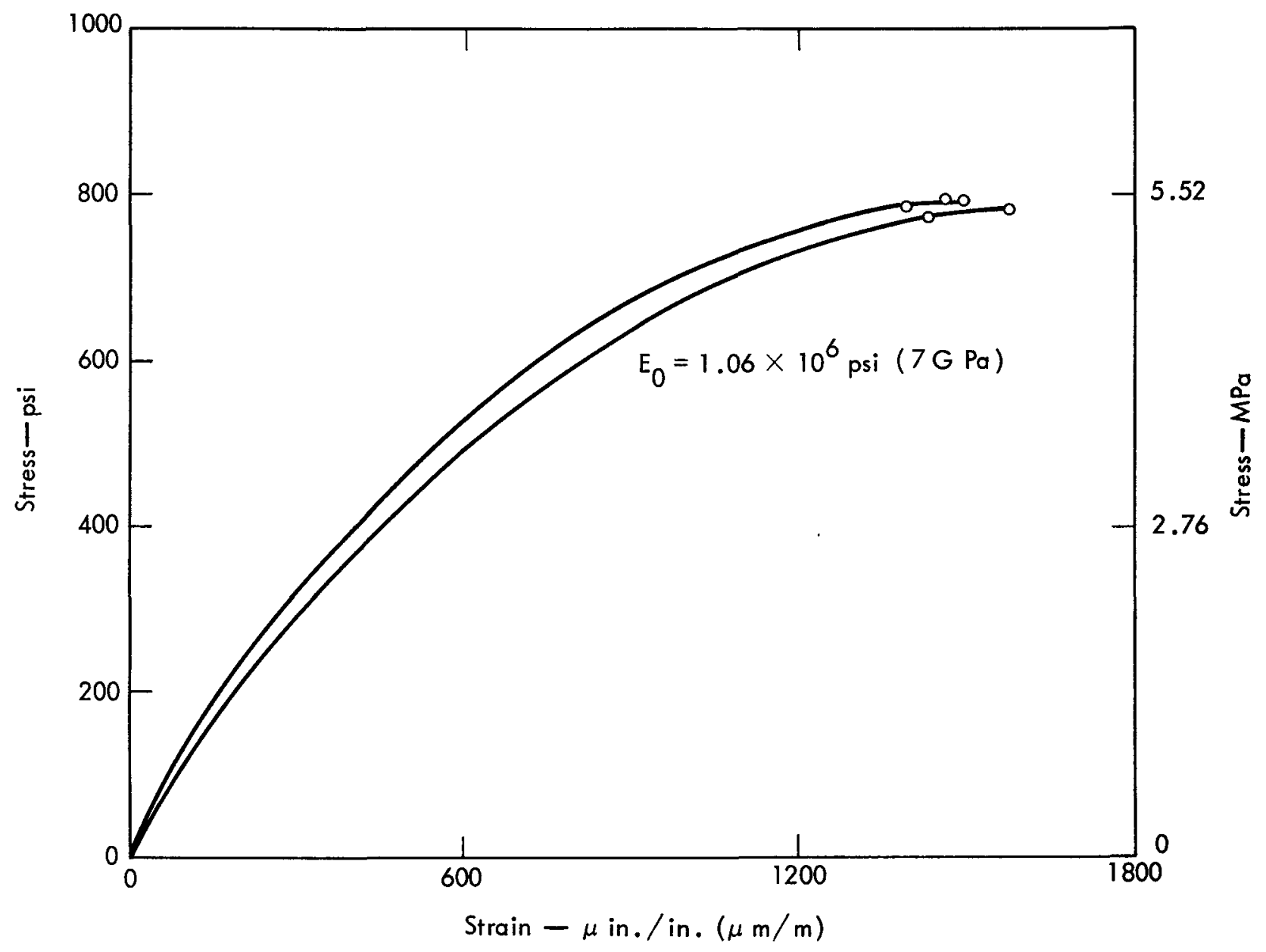

Fig. 7-7. Stress-strain data for PBX-9501. Crosshead velocity $0.005 \mathrm{in} / \mathrm{min}$ $(7.62 \mathrm{~mm} / \mathrm{s})$ at $-35^{\circ} \mathrm{F}(236 \mathrm{~K})$. The points indicate rupture of the specimen. 


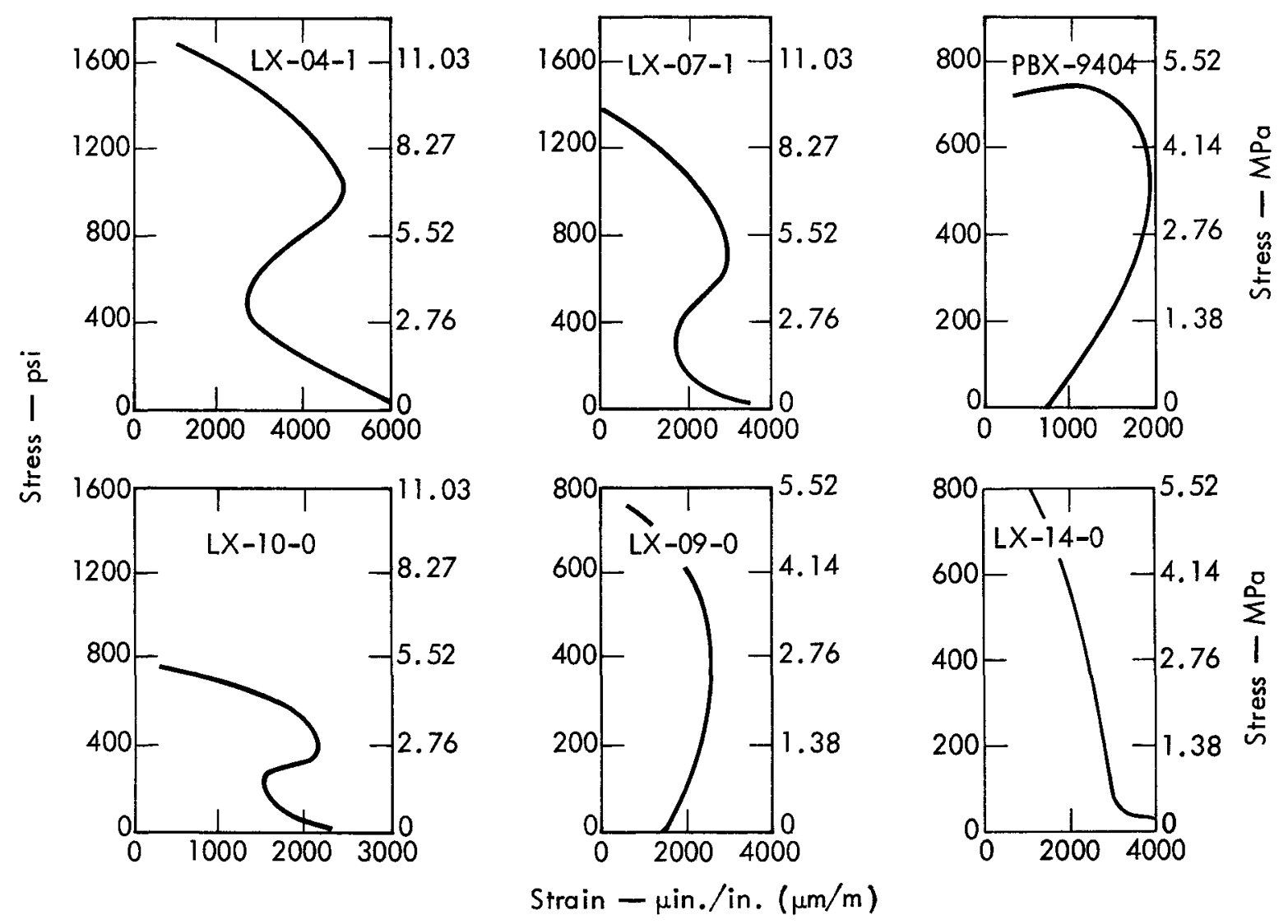

Fig. 7-8. Failure envelopes for several explosives. Conversion factor: 1 psi $=6.894757 \mathrm{kPa}$. 


\section{Friction}

Coefficients of friction $f$ were determined for several HEs sliding on themselves and on aluminum 6061-T6 as a function of sliding velocity $\nu$, at different pressures (loads), temperatures, and surface finishes (Table 7-1 and Fig. 7-9). It was found that the Williams-Landel-Ferry (WLF) ${ }^{5}$ shift equation could be used to correlate the effects of sliding velocity and temperature on $\mathrm{f}$; thus, a curve could be calculated for some reduced temperature $\mathrm{T}_{\mathrm{r}}$ (Fig. $7-10$ ).
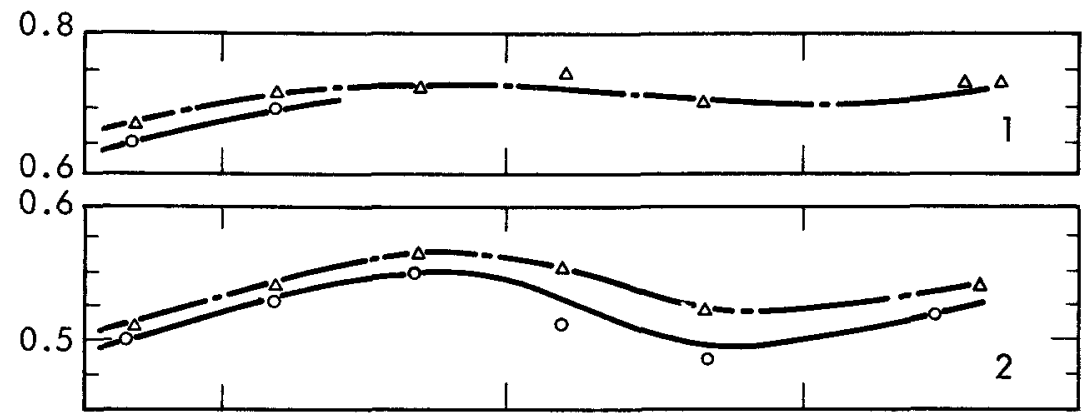

$P B X-9011$ on aluminum

4
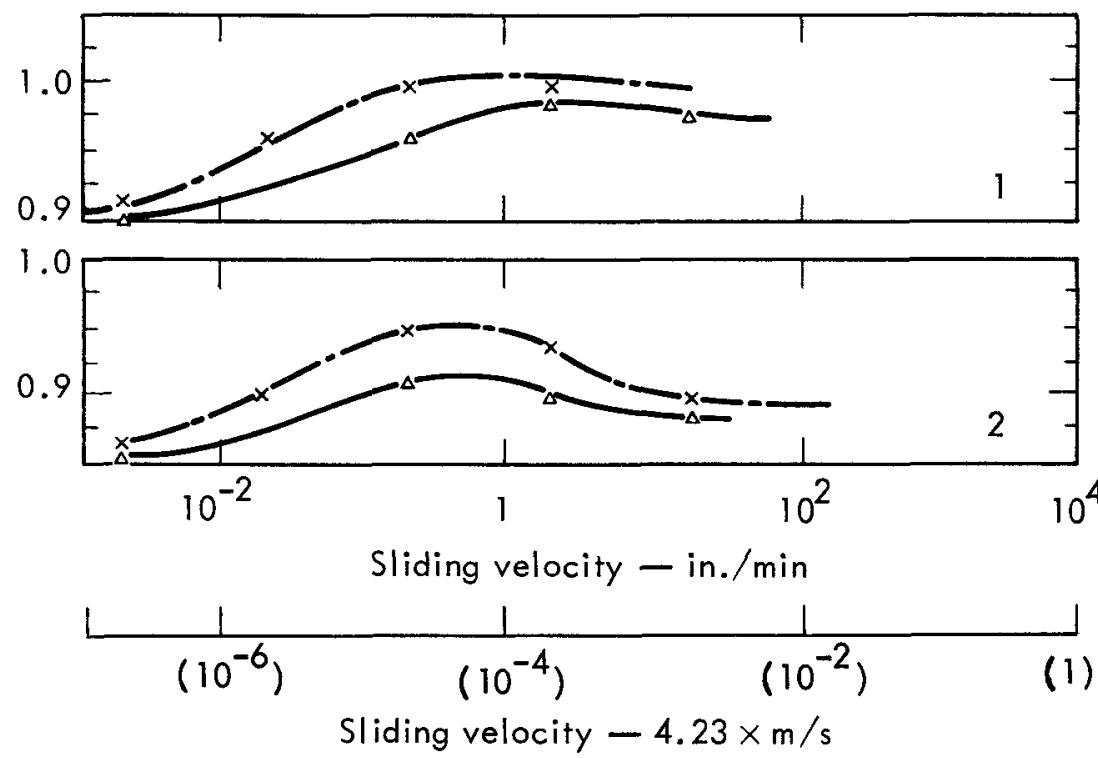

PBX-9011 on PBX-9011

$\times 125 \mathrm{psi}(0.86 \mathrm{MPa})$

$\triangle 250$ psi $(1.72 \mathrm{MPa})$

- 500 psi (3.45 MPa)

- $1000 \mathrm{psi}(6.89 \mathrm{MPa})$
1 Surface finish 125

2 Surface finish 32

Fig. 7-9. Coefficient of friction $\mathrm{f}$ as a function of sliding velocity $\nu$ for several explosives. 6 Conversion factor: $1 \mathrm{in} . / \mathrm{min}=4.233 \times 10^{-4} \mathrm{~m} / \mathrm{s}$. 

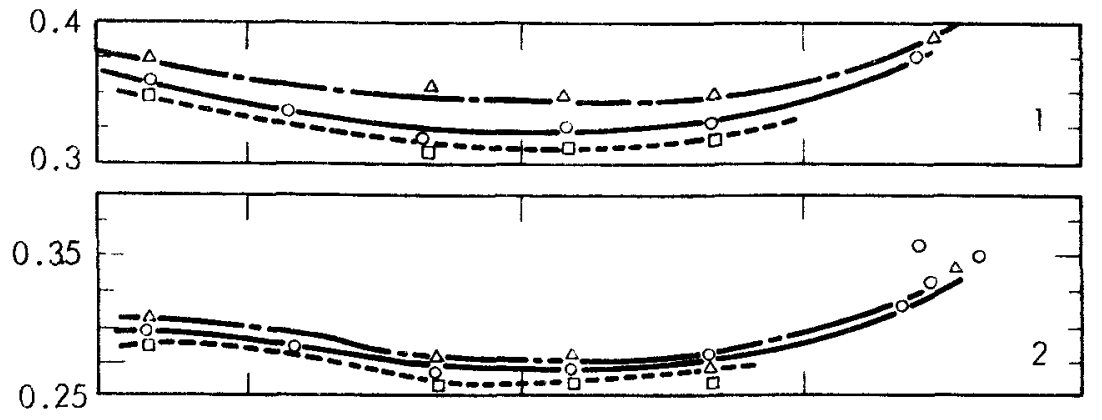

Comp B-3 on aluminum
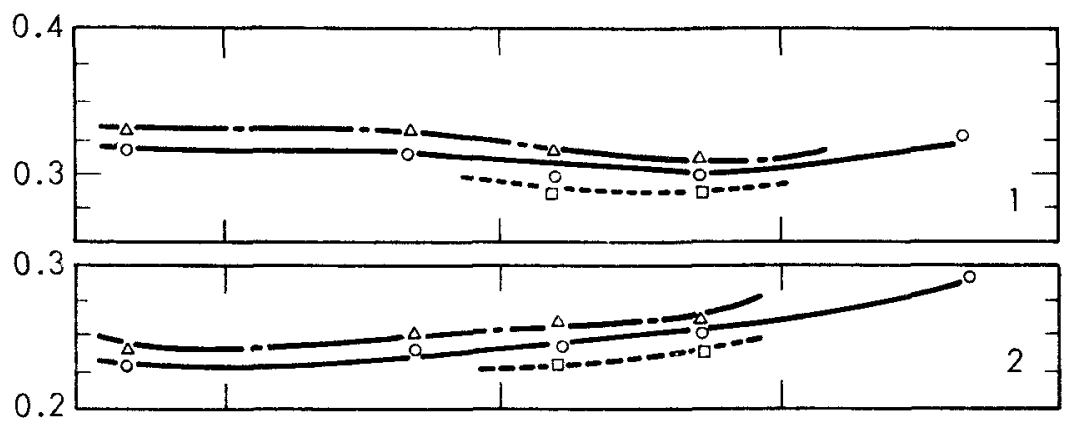

Comp B-3 on Comp B-3
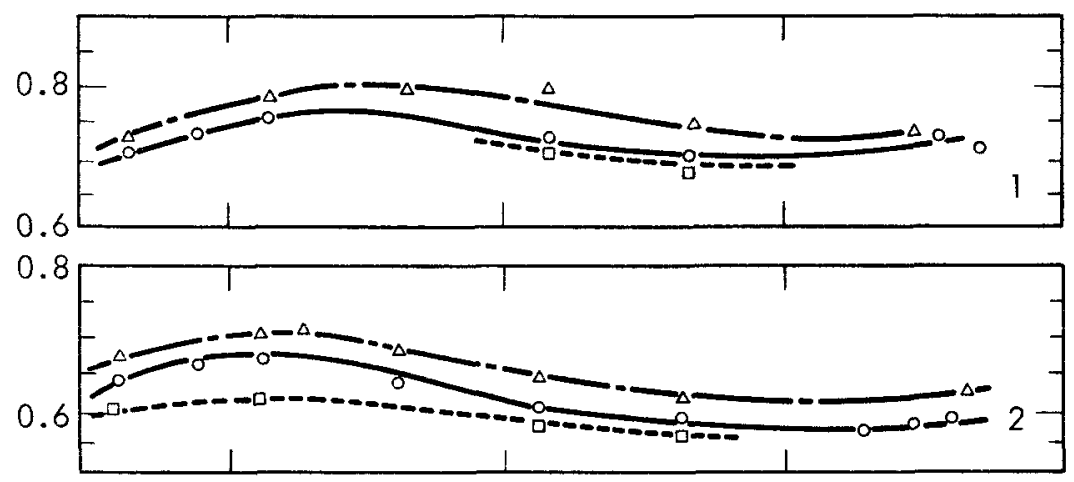

$L X-04-1$ on aluminum

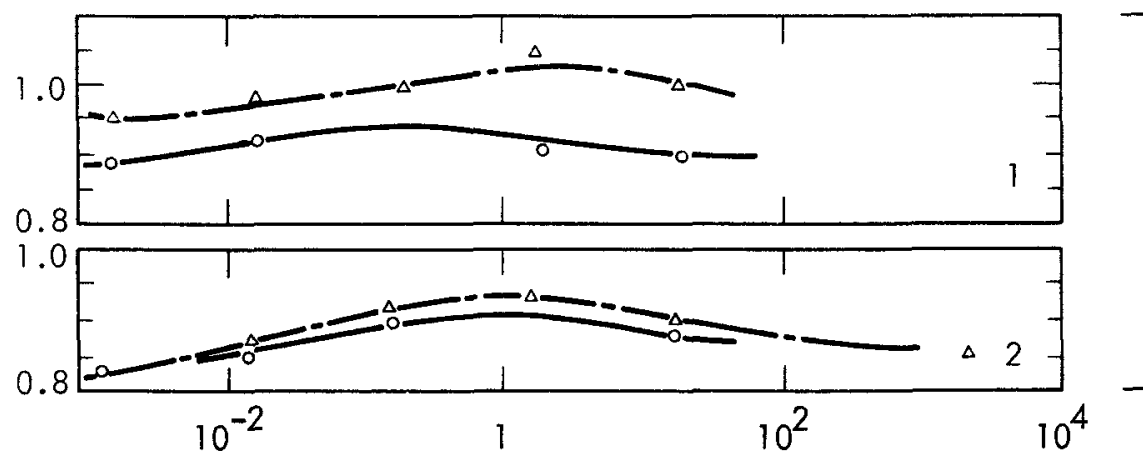

$L X-04-1$ on $L X-04-1$

$\frac{1}{\left(10^{-6}\right) \quad \text { Sliding velocity }- \text { in./min }}$

Sliding velocity $-4.23 \times \mathrm{m} / \mathrm{s}$

Fig. 7-9 (continued) 
Table 7-1. Coefficients of friction $f$ as functions of sliding velocity $\nu$ and pressure $P$ at room temperature. $a, 7$

\begin{tabular}{|c|c|c|c|c|c|c|c|c|c|c|c|c|c|c|c|}
\hline \multirow[b]{2}{*}{ Material $^{\mathbf{b}}$} & \multirow{2}{*}{$\frac{\nu=10^{-2}}{125} \frac{}{(0.86)}$} & \multicolumn{3}{|c|}{$\frac{\text { in. } / \min \left(4.23 \times 10^{-6}\right.}{P(\mathrm{psi}(\mathrm{MPa}))}$} & \multirow{2}{*}{ 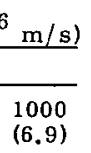 } & \multirow{2}{*}{ 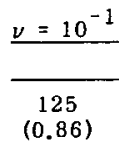 } & \multicolumn{3}{|c|}{$\frac{1 \mathrm{in} / \min \left(4.23 \times 10^{-5}\right.}{\mathrm{P}(\mathrm{psi}(\mathrm{MPa}))}$} & \multirow{2}{*}{ 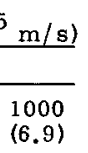 } & \multirow{2}{*}{$\frac{\nu=10^{0}}{\frac{125}{(0.86)}}$} & \multicolumn{3}{|c|}{$\frac{\text { in. } / \min \left(4.23 \times 10^{-4}\right.}{P(\mathrm{pgi}(\mathrm{MPa})}$} & \multirow{2}{*}{$\begin{array}{l}\mathrm{m} / \mathrm{s}) \\
\begin{array}{l}1000 \\
(6.9)\end{array}\end{array}$} \\
\hline & & $\begin{array}{c}250 \\
(1.7)\end{array}$ & $\begin{array}{c}500 \\
(3.5)\end{array}$ & $\begin{array}{r}750 \\
(5.2)\end{array}$ & & & $\begin{array}{c}250 \\
(1.7)\end{array}$ & $\begin{array}{c}500 \\
(3.5)\end{array}$ & $\begin{array}{c}750 \\
(5.2)\end{array}$ & & & $\begin{array}{c}250 \\
(1.7)\end{array}$ & $\begin{array}{c}500 \\
(3.5)\end{array}$ & $\begin{array}{c}750 \\
(5.2)\end{array}$ & \\
\hline $\begin{array}{l}\text { Comp B-3/Al } \\
1 \\
2\end{array}$ & & $\begin{array}{l}0.38 \\
0.31\end{array}$ & $\begin{array}{l}0.36 \\
0.30\end{array}$ & & $\begin{array}{l}0.35 \\
0.29\end{array}$ & & $\begin{array}{l}0.36 \\
0.28\end{array}$ & $\begin{array}{l}0.33 \\
0.27\end{array}$ & & $\begin{array}{l}0.31 \\
0.26\end{array}$ & & $\begin{array}{l}0.35 \\
0.27\end{array}$ & $\begin{array}{l}0.34 \\
0.265\end{array}$ & & $\begin{array}{l}0.31 \\
0.26\end{array}$ \\
\hline $\begin{array}{l}\text { Comp B-3/Comp B-3 } \\
\frac{1}{2}\end{array}$ & & $\begin{array}{l}0.33 \\
0.24\end{array}$ & $\begin{array}{l}0.32 \\
0.23\end{array}$ & & & & $\begin{array}{l}0.33 \\
0.25\end{array}$ & $\begin{array}{l}0.32 \\
0.24\end{array}$ & & & & $\begin{array}{l}0.32 \\
0.26\end{array}$ & $\begin{array}{l}0.31 \\
0.24\end{array}$ & & $\begin{array}{l}0.30 \\
0.23\end{array}$ \\
\hline $\begin{array}{l}\mathrm{LX}-04 / \mathrm{Al} \\
\quad 1 \\
2\end{array}$ & & $\begin{array}{l}0.75 \\
0.70\end{array}$ & $\begin{array}{l}0.72 \\
0.67\end{array}$ & 0.62 & & & $\begin{array}{l}0.81 \\
0.69\end{array}$ & $\begin{array}{l}0.76 \\
0.67\end{array}$ & 0.62 & & & $\begin{array}{l}0.80 \\
0.65\end{array}$ & $\begin{array}{l}0.74 \\
0.72\end{array}$ & $\begin{array}{l}0.73 \\
0.57\end{array}$ & \\
\hline $\begin{array}{l}\mathrm{LX}-04 / \mathrm{LX}-04 \\
1 \\
2\end{array}$ & & $\begin{array}{l}0.95 \\
0.86\end{array}$ & $\begin{array}{l}0.90 \\
0.83\end{array}$ & & & & $\begin{array}{l}0.98 \\
0.90\end{array}$ & $\begin{array}{l}0.93 \\
0.88\end{array}$ & & & & $\begin{array}{l}1.3 \\
0.94\end{array}$ & $\begin{array}{l}0.94 \\
0.91\end{array}$ & & \\
\hline $\begin{array}{l}\text { PBX-9011/Al } \\
\quad 1 \\
2\end{array}$ & & $\begin{array}{l}0.71 \\
0.58\end{array}$ & $\begin{array}{l}0.68 \\
0.52\end{array}$ & & & & $\begin{array}{l}0.73 \\
0.61\end{array}$ & 0.59 & & & & $\begin{array}{l}0.74 \\
0.62\end{array}$ & 0.59 & & \\
\hline $\begin{array}{l}\text { PBX-9011/PBX-9011 } \\
\quad 1 \\
2\end{array}$ & $\begin{array}{l}0.94 \\
0.90\end{array}$ & $\begin{array}{l}0.92 \\
0.87\end{array}$ & & & & $\begin{array}{l}0.98 \\
0.94\end{array}$ & $\begin{array}{l}0.95 \\
0.90\end{array}$ & & & & $\begin{array}{l}1.1 \\
0.95\end{array}$ & $\begin{array}{l}0.98 \\
0.92\end{array}$ & & & \\
\hline & $\nu=10^{1}$ & $\frac{\text { in. } / \mathrm{min}}{\mathrm{P}(\mathrm{p}}$ & $\frac{\mathrm{n}(4.23}{\mathrm{esi}(\mathrm{MI}}$ & $\frac{\times 10^{-3}}{\text { a)! }}$ & $\mathrm{m} / \mathrm{s})$ & $\nu=10^{2}$ & $\frac{\text { in. } / \mathrm{mir}}{\mathrm{P}(\mathrm{g}}$ & $\frac{n(4.23}{\operatorname{sic}(\mathrm{MF}}$ & $\frac{\times 10^{-2}}{\text { a) })}$ & $\mathrm{m} / \mathrm{s})$ & $\nu=10^{3}$ & $\frac{\text { in. } / \mathrm{mi}}{\mathrm{P}(\mathrm{r}}$ & $\frac{\mathrm{n}(4.23}{\mathrm{si}(\mathrm{MF}}$ & $\frac{\times 10^{-1}}{\mathrm{~Pa})}$ & $\mathrm{m} / \mathrm{s})$ \\
\hline Material $^{\mathrm{a}}$ & $\begin{array}{c}125 \\
(0.86)\end{array}$ & $\begin{array}{c}250 \\
(1.7)\end{array}$ & $\begin{array}{r}500 \\
(3.5)\end{array}$ & $\begin{array}{r}750 \\
(5.2)\end{array}$ & $\begin{array}{l}1000 \\
(6.9)\end{array}$ & $\begin{array}{c}125 \\
(0.86)\end{array}$ & $\begin{array}{c}250 \\
(1.7)\end{array}$ & $\begin{array}{c}500 \\
(3.5)\end{array}$ & $\begin{array}{c}750 \\
(5.2)\end{array}$ & $\begin{array}{l}1000 \\
(6.9)\end{array}$ & $\begin{array}{c}125 \\
(0.86)\end{array}$ & $\begin{array}{c}250 \\
(1.7)\end{array}$ & $\begin{array}{c}500 \\
(3.5)\end{array}$ & $\begin{array}{c}750 \\
(5.2)\end{array}$ & $\begin{array}{l}1000 \\
(6.9)\end{array}$ \\
\hline $\begin{array}{l}\text { Comp B-3/Al } \\
1 \\
2\end{array}$ & & $\begin{array}{l}0.35 \\
0.28\end{array}$ & $\begin{array}{l}0.34 \\
0.27\end{array}$ & & $\begin{array}{l}0.32 \\
0.27\end{array}$ & & $\begin{array}{l}0.37 \\
0.30\end{array}$ & $\begin{array}{l}0.35 \\
0.30\end{array}$ & & 0.34 & & $\begin{array}{l}0.39 \\
0.35\end{array}$ & $\begin{array}{l}0.38 \\
0.34\end{array}$ & & \\
\hline $\begin{array}{l}\text { Comp B-3/Comp B-3 } \\
1 \\
2\end{array}$ & & $\begin{array}{l}0.31 \\
0.265\end{array}$ & $\begin{array}{l}0.30 \\
0.25\end{array}$ & & $\begin{array}{l}0.28 \\
0.24\end{array}$ & & 0.31 & $\begin{array}{l}0.30 \\
0.27\end{array}$ & & 0.29 & & & $\begin{array}{l}0.33 \\
0.285\end{array}$ & & \\
\hline $\begin{array}{l}\mathrm{LX}-04 / \mathrm{Al} \\
\quad 1 \\
2\end{array}$ & & $\begin{array}{l}0.75 \\
0.63\end{array}$ & $\begin{array}{l}0.71 \\
0.59\end{array}$ & $\begin{array}{l}0.69 \\
0.56\end{array}$ & & & $\begin{array}{l}0.73 \\
0.61\end{array}$ & $\begin{array}{l}0.71 \\
0.56\end{array}$ & 0.69 & & & $\begin{array}{l}0.73 \\
0.61\end{array}$ & $\begin{array}{l}0.72 \\
0.58\end{array}$ & & \\
\hline $\begin{array}{l}\mathrm{LX}-04 / \mathrm{LX}-04 \\
1 \\
2\end{array}$ & & $\begin{array}{l}1.1 \\
0.92\end{array}$ & $\begin{array}{l}0.91 \\
0.89\end{array}$ & & & & 0.89 & & & & & 0.86 & & & \\
\hline $\begin{array}{l}\mathrm{PBX}-9011 / \mathrm{Al} \\
\quad 1 \\
2\end{array}$ & & $\begin{array}{l}0.71 \\
0.57\end{array}$ & 0.51 & & & & $\begin{array}{l}0.70 \\
0.57\end{array}$ & 0.50 & & & & $\begin{array}{l}0.72 \\
0.54\end{array}$ & 0.52 & & \\
\hline $\begin{array}{l}\text { PBX-9011/PBX-9011 } \\
1 \\
2\end{array}$ & $\begin{array}{l}1.0 \\
0.90\end{array}$ & $\begin{array}{l}0.98 \\
0.89\end{array}$ & & & & 0.89 & & & & & & & & & \\
\hline
\end{tabular}



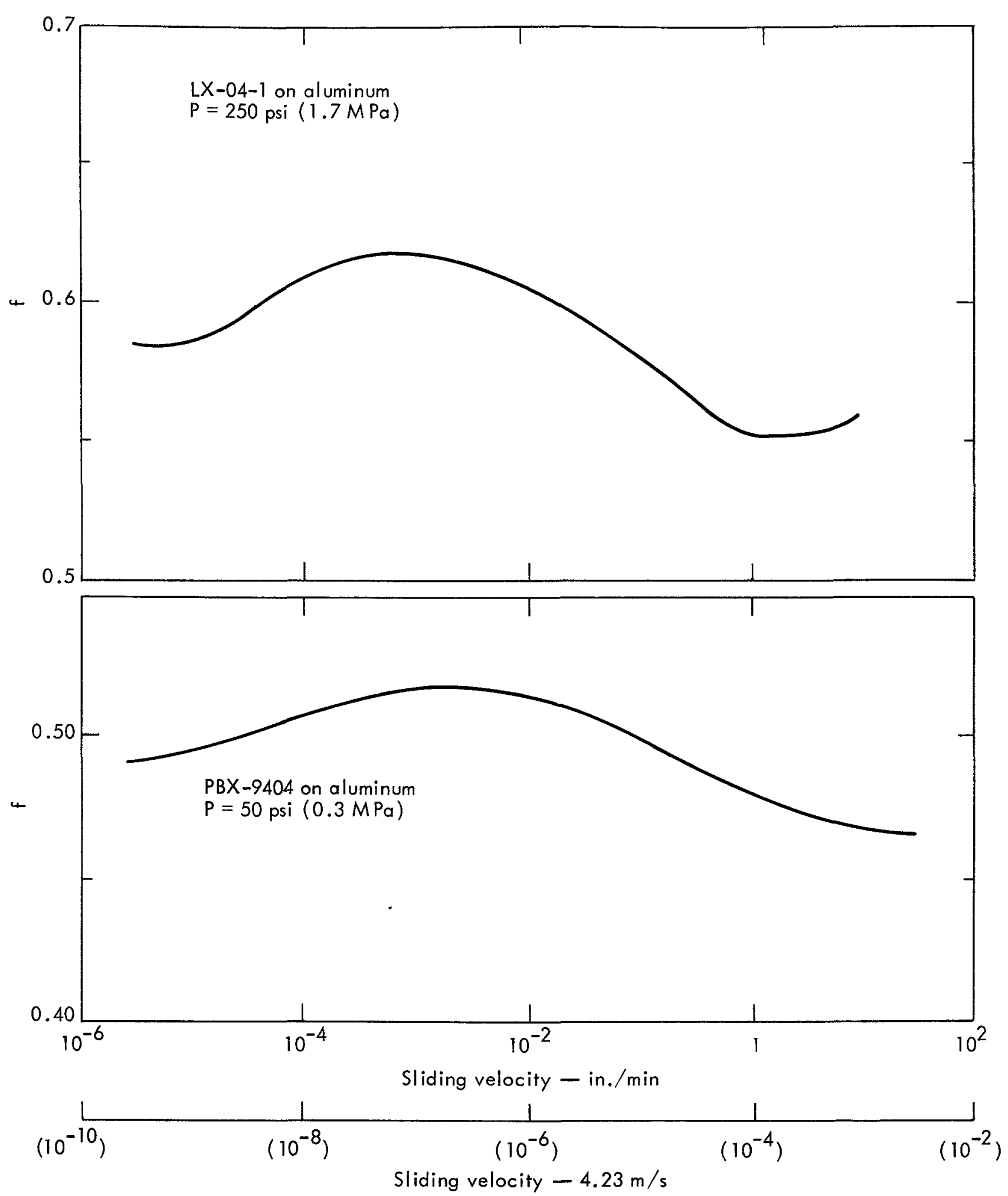

Fig. 7-10. Coefficients of friction $\mathrm{f}$ as a function of sliding velocity $\nu$ for two explosives calculated for a reduced temperature $\mathrm{T}_{\mathrm{r}}$ of $22^{\circ} \mathrm{C}(295 \mathrm{~K}) .^{5}$ Conversion factor: $1 \mathrm{in} . / \mathrm{min}=4.233 \times 10^{-4} \mathrm{~m} / \mathrm{s}$. 


\section{Complex Shear}

The complex shear modulus G, or rather two of its components, shear storage and shear loss, have been determined ${ }^{8}$ for LX-04 at various frequencies $(0.0004$ to $1 \mathrm{~Hz}$ over the temperature range -15 to $125^{\circ} \mathrm{F}(247$ to $325 \mathrm{~K})$ ). This material can be considered to be representative of the family of homogeneous, isotropic, linear viscoelastic and thermorheologically simple polymeric materials of which HEs are members.

Figure 7-11 shows the observed shear storage and shear loss moduli of LX-04 reduced to a temperature $\mathrm{T}_{r}$ of $22^{\circ} \mathrm{C}(295 \mathrm{~K})$ by the WLF empirical equation.

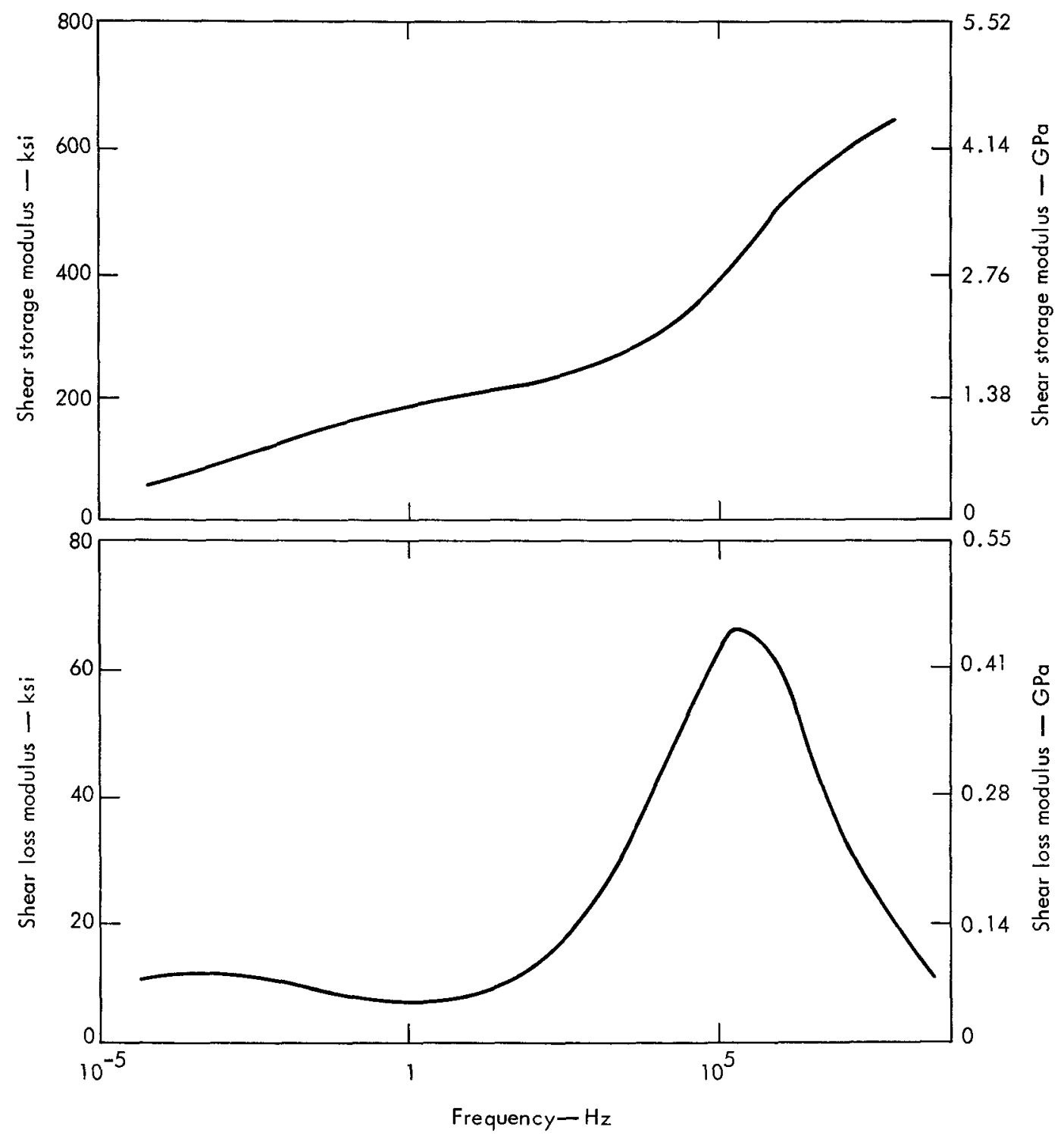

Fig. 7-11. Complex shear moduli of LX-04 at frequencies from 0.0004 to $1 \mathrm{~Hz}$ measured and calculated for $\operatorname{T}_{\mathrm{r}}$ of $22^{\circ} \mathrm{C}(295 \mathrm{~K})$ over the temperature range -15 to $125^{\circ} \mathrm{F}(247$ to $325 \mathrm{~K})$. Conversion factor: 1 psi $=6.894757 \mathrm{kPa}$. 


\section{Dynamic Mechanical Properties}

\section{Compressive Stress Strain and Tensile Strength}

The Hopkinson split-bar technique was used to determine compressive stressstrain and ultimate tensile strength of a number of explosives and related materials at strain rates up to $5000 \mathrm{sec}^{-1}$. Hugoniot curves for the unreacted materials were obtained from a gun experiment with aluminum flyer plates.

Table 7-2 (from Ref. 2 and 6) gives dynamic ultimate tensile strength compared to static strength. Other dynamic mechanical properties obtained with the Hopkinson split-bar technique are shown in Fig. 7-12..$^{1}$ The figure also shows the ultrasonically determined modulus $\mathrm{E}_{\mathrm{u}}$, which provides an upper bound for modulus values.

Table 7-2. Dynamic and static tensile strengths.

\begin{tabular}{|c|c|c|c|c|}
\hline \multirow[b]{2}{*}{ Material } & \multirow{2}{*}{$\begin{array}{l}\text { Strain } \\
\text { rate } \\
\left(\sec ^{-1}\right)\end{array}$} & \multicolumn{2}{|c|}{$\begin{array}{c}\text { Ultimate } \\
\text { stress }\end{array}$} & \multirow{2}{*}{$\begin{array}{l}\text { Type of } \\
\text { fracture }\end{array}$} \\
\hline & & (psi & $(\mathrm{MPa}))$ & \\
\hline \multirow[t]{5}{*}{$L X-04-1$} & $10^{-4}$ & 340 & $(2.34)$ & Slightly ductile \\
\hline & 850 & 1500 & $(10.34)$ & Slightly ductile \\
\hline & 1100 & 1780 & $(12.27)$ & Slightly ductile \\
\hline & 1550 & 1750 & $(12.07)$ & Brittle \\
\hline & 3100 & 2100 & $(14.48)$ & Slightly ductile \\
\hline \multirow[t]{3}{*}{$\mathrm{LX}-14-0$} & $10^{-5}$ & 450 & $(3.1)$ & Brittle \\
\hline & $10^{-4}$ & 540 & $(3.7)$ & Brittle \\
\hline & $10^{-3}$ & 580 & $(4.0)$ & Brittle \\
\hline \multirow[t]{4}{*}{ PBX -9011} & $10^{-4}$ & 340 & $(2.34)$ & Slightly ductile \\
\hline & 1050 & 1300 & $(8.96)$ & Brittle \\
\hline & 1100 & 1450 & $(10.00)$ & Brittle \\
\hline & 1300 & 1400 & $(9.65)$ & Brittle \\
\hline \multirow[t]{5}{*}{ PBX-9404 } & $10^{-4}$ & 330 & $(2.28)$ & Slightly ductile \\
\hline & 950 & 1200 & $(8.27)$ & Brittle \\
\hline & 1070 & 1500 & $(10.34)$ & Slightly ductile \\
\hline & 1100 & 1340 & $(9.24)$ & Brittle \\
\hline & 1850 & 1510 & $(10.41)$ & Brittle \\
\hline \multirow[t]{7}{*}{ PETN } & $10^{-3}$ & 160 & $(1.10)$ & Brittle \\
\hline & $10^{-2}$ & 215 & $(1.48)$ & Brittle \\
\hline & $10^{-1}$ & 215 & $(1.48)$ & Brittle \\
\hline & 1000 & 720 & $(4.96)$ & Brittle \\
\hline & 1120 & 700 & $(4.83)$ & Brittle \\
\hline & 1300 & 785 & $(5.41)$ & Brittle \\
\hline & 2600 & 840 & $(5.79)$ & Brittle \\
\hline
\end{tabular}




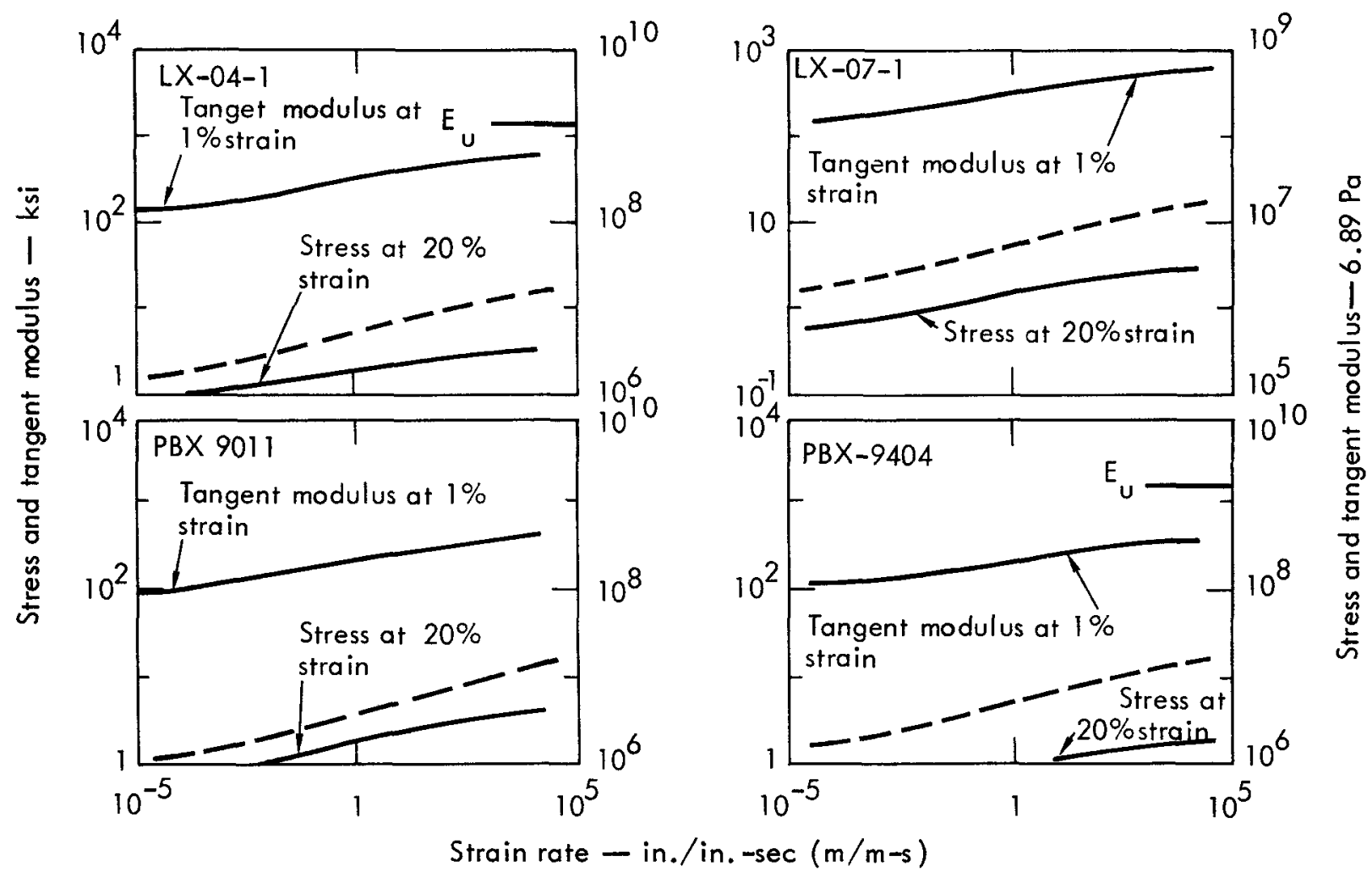

Fig. 7-12. Stress and tangent moduli of several explosives as a function of strain rate. The dashed line represents ultimate stress. The plots for LX-04-1 and PBX-9404 show the ultrasonically determined modulus $\mathrm{E}_{\mathrm{u}}$. Conversion factor: 1 psi $=6.894757 \mathrm{kPa}$. 


\section{Hugoniot Data}

Narrow-pulse and sustained shock-loading effects obtained with the flyer-plate technique are shown in Fig. $7-13 .{ }^{9}$ The transducer data were normalized to a plateimpact velocity of $0.3 \mathrm{~mm} / \mu \mathrm{sec}(0.3 \mathrm{~km} / \mathrm{s})$.

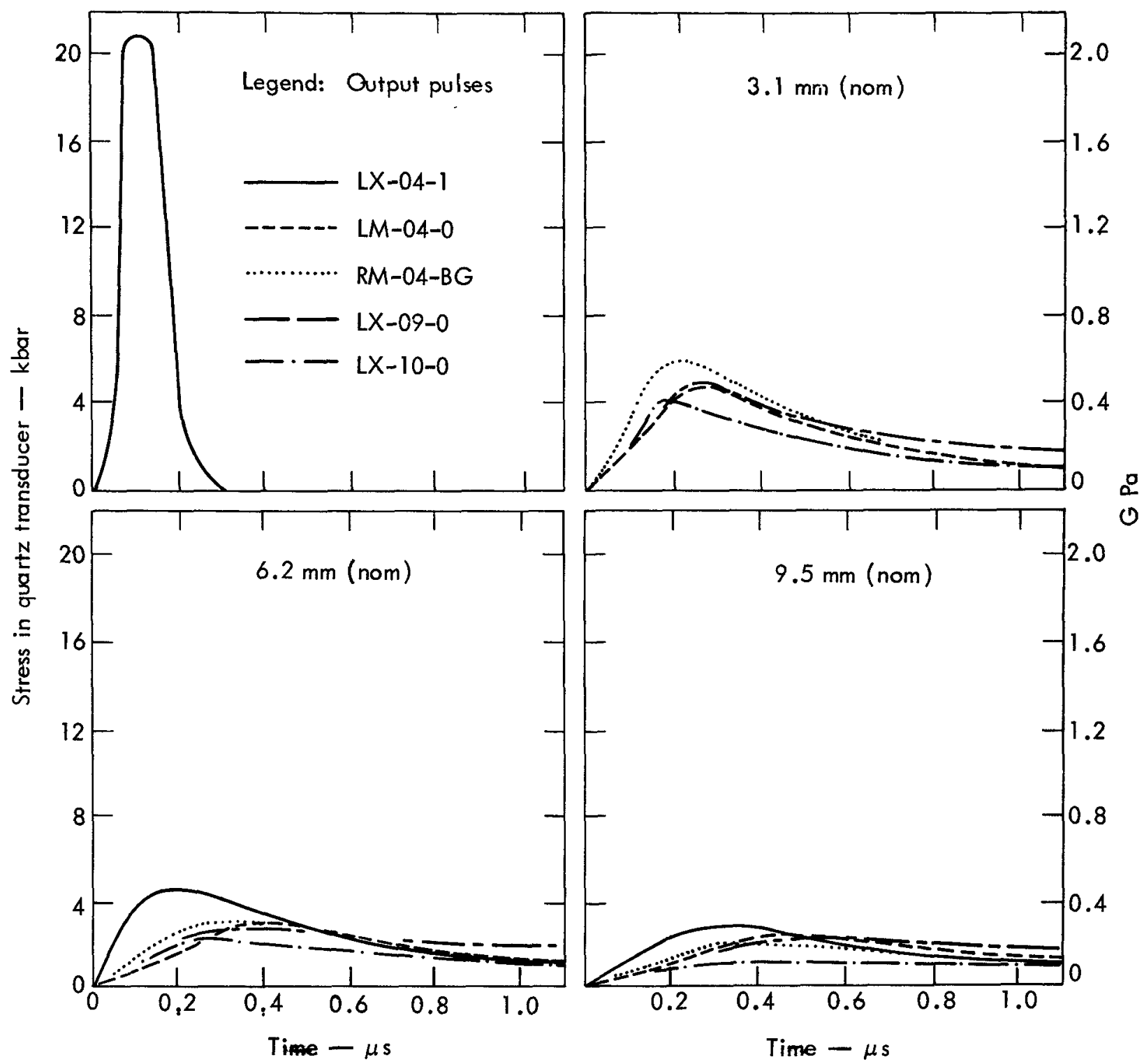

Fig. 7-13. Input and output pulses generated experimentally ${ }^{9}$ at three depths in various materials by a $0.28-\mathrm{mm}$-thick (nominal) aluminum driver plate backed with foam. Conversion factor: $1 \mathrm{bar}=10^{5} \mathrm{~Pa}$. 
The Hugoniot of unreacted HEs can also be expressed by a simple least squares relationship

$$
\mathrm{U}_{\mathrm{S}}=\mathrm{A}+\mathrm{BU} \mathrm{p}
$$

where

$$
\mathrm{U}_{\mathrm{s}}=\text { shock velocity in } \mathrm{km} / \mathrm{s} \text {, }
$$

$\mathrm{A}, \mathrm{B}=$ material constants,

$$
\mathrm{U}_{\mathrm{p}}=\text { particle velocity in } \mathrm{km} / \mathrm{s} \text {. }
$$

The data (at ambient temperature) have been compiled from various sources for the compositions listed in Table 3-1 to $3-3$. The Grüneisen constant $\Gamma$ is expressed as

$$
\Gamma=\frac{\partial \mathrm{P}}{\partial \mathrm{E}} \mathrm{v}
$$

where

\begin{tabular}{|c|c|c|c|c|c|}
\hline Explosive & $\frac{\rho_{0}}{\left(\mathrm{~g} / \mathrm{cm}^{3}\left(\mathrm{Mg} / \mathrm{m}^{3}\right)\right)}$ & Equation & Range $^{a}$ & $\Gamma$ & Ref. \\
\hline \multirow[t]{2}{*}{ Baratol } & 2.611 & $\begin{array}{l}\mathrm{U}_{\mathrm{S}}=2.40+1.66 \mathrm{U}_{\mathrm{p}} \\
\mathrm{U}_{\mathrm{s}}=1.5+2.16 \mathrm{U}_{\mathrm{p}}\end{array}$ & $\left.\begin{array}{l}c_{0} \leq U_{s} \leq 3.66 \\
3.66 \leq U_{s} \leq 4.0\end{array}\right\}$ & & 10 \\
\hline & 2.63 & $U_{s}=2.79+1.25 U_{p}$ & & & 11 \\
\hline \multirow[t]{2}{*}{ Comp B } & 1.70 & $\mathrm{U}_{\mathrm{s}}=2.95+1.58 \mathrm{U}_{\mathrm{p}}$ & & & 11 \\
\hline & 1.710 & $\mathrm{U}_{\mathrm{s}}=1.20+2.81 \mathrm{U}_{\mathrm{p}}$ & $4.40 \leq \mathrm{U}_{\mathrm{S}} \leq 5.04$ & & 12 \\
\hline $\begin{array}{l}\text { Comp } B \\
\text { (cast) }\end{array}$ & 1.700 & $\mathrm{U}_{\mathrm{s}}=2.49+1.99 \mathrm{U}_{\mathrm{p}}$ & $3.57 \leq U_{\mathrm{s}} \leq 5.02$ & & 12 \\
\hline \multirow[t]{4}{*}{ Comp B-3 } & 1.70 & $\mathrm{U}_{\mathrm{s}}=3.03+1.73 \mathrm{U}_{\mathrm{p}}$ & & & 11 \\
\hline & 1.70 & $\mathrm{U}_{\mathrm{s}}=2.88+1.60 \mathrm{U}_{\mathrm{p}}$ & $\left.\begin{array}{l}4.24 \leq \mathrm{U}_{\mathrm{s}}<7.01 \\
\mathrm{c}_{0}=2.93\end{array}\right\}$ & & 12 \\
\hline & 1.72 & $\mathrm{U}_{\mathrm{s}}=2.71+1.86 \mathrm{U}_{\mathrm{p}}$ & $3.42 \leq \mathrm{U}_{\mathrm{S}} \leq 4.45$ & & 12 \\
\hline & 1.723 & $\mathrm{U}_{\mathrm{s}}=.1 .23+2.81 \mathrm{U}_{\mathrm{p}}$ & $4.42 \leq \mathrm{U}_{\mathrm{s}} \leq 5.07$ & & 12 \\
\hline $\begin{array}{l}\text { Comp } B-3 \\
\text { (cast) }\end{array}$ & 1.680 & $\mathrm{U}_{\mathrm{s}}=2.710+1.860 \mathrm{U}_{\mathrm{p}}$ & $\left.\begin{array}{l}3.387 \leq \mathrm{U}_{\mathrm{S}} \leq 4.469 \\
\mathrm{c}_{0}=2.736\end{array}\right\}$ & 0.947 & $\begin{array}{l}12, \\
13\end{array}$ \\
\hline Cyclotol & 1.729 & $\mathrm{U}_{\mathrm{s}}=2.02+2.36 \mathrm{U}_{\mathrm{p}}$ & $4.67 \leq \mathrm{U}_{\mathrm{s}} \leq 5.22$ & & 12 \\
\hline DATB & 1.780 & $\mathrm{U}_{\mathrm{s}}=2.449+1.892 \mathrm{U}_{\mathrm{p}}$ & $\left.\begin{array}{l}3.159 \leq \mathrm{U}_{\mathrm{s}} \leq 4.492 \\
\mathrm{c}_{\ell}=2.660\end{array}\right\}$ & 1.76 & $\begin{array}{l}12 \\
13\end{array}$ \\
\hline
\end{tabular}

$$
\begin{aligned}
& P=\text { pressure }, \\
& E=\text { energy, } \\
& \mathrm{V}=\text { volume. }
\end{aligned}
$$

Least squares relationships for unreacted Hugoniots are given in Table 7-3.

Table 7-3. Least squares fits for Hugoniots of unreacted HEs. 
Table 7-3. (continued)

\begin{tabular}{|c|c|c|c|c|c|}
\hline Explosive & $\frac{\rho_{0}}{\left(\mathrm{~g} / \mathrm{cm}^{3}\left(\mathrm{Mg} / \mathrm{m}^{3}\right)\right)}$ & Equation & Range $^{a}$ & $\Gamma$ & Ref. \\
\hline $\mathrm{H}-6$ (cast) & 1.76 & $\mathrm{U}_{\mathrm{s}}=2.654+1.984 \mathrm{U}_{\mathrm{p}}$ & $\mathrm{U}_{\mathrm{s}}<3.7$ & & 14 \\
\hline $\mathrm{H}-6$ (cast) & 1.760 & $\mathrm{U}_{\mathrm{s}}=2.832+1.695 \mathrm{U}_{\mathrm{p}}$ & $\left.\begin{array}{l}2.832 \leq \mathrm{U}_{\mathrm{s}} \leq 4.535 \\
\mathrm{c}_{0}=2.759\end{array}\right\}$ & & $\begin{array}{l}12, \\
13\end{array}$ \\
\hline \multirow[t]{2}{*}{ HNS } & 1.38 & $\mathrm{U}_{\mathrm{s}}=0.61+2.77 \mathrm{U}_{\mathrm{p}}$ & $1.44 \leq \mathrm{U}_{\mathrm{S}} \leq 1.995$ & & 15 \\
\hline & 1.57 & $\mathrm{U}_{\mathrm{s}}=1.00+3.21 \mathrm{U}_{\mathrm{p}}$ & $\left.\begin{array}{l}1.00 \leq \mathrm{U}_{\mathrm{s}} \leq 3.18 \\
\mathrm{c}_{0}=1.00\end{array}\right\}$ & & 15 \\
\hline $\mathrm{Kel}-\mathrm{F}$ & 2.10 & $\mathrm{U}_{\mathrm{s}}=1.73+1.61 \mathrm{U}_{\mathrm{p}}$ & $2.65 \leq \mathrm{U}_{\mathrm{S}} \leq 3.78$ & & 12 \\
\hline $\mathrm{LX}-04-1$ & $\begin{array}{r}1.860- \\
1.863\end{array}$ & $\mathrm{U}_{\mathrm{s}}=2.36+2.43 \mathrm{U}_{\mathrm{p}}$ & $2.61 \leq \mathrm{U}_{\mathrm{s}} \leq 3.24$ & & 12 \\
\hline$L X-09-0$ & 1.839 & $\mathrm{U}_{\mathrm{s}}=2.43+2.90 \mathrm{U}_{\mathrm{p}}$ & & & 16 \\
\hline \multirow[t]{2}{*}{$\mathrm{NM}$} & 1.13 & $\mathrm{U}_{\mathrm{s}}=2.00+1.38 \mathrm{U}_{\mathrm{p}}$ & $2.83 \leq \mathrm{U}_{\mathrm{s}} \leq 4.40$ & & 12 \\
\hline & $\begin{array}{l}1.123- \\
1.128\end{array}$ & $\begin{aligned} \mathrm{U}_{\mathrm{S}} & =1.560+1.721 \mathrm{U}_{\mathrm{p}} \\
& +1.082\left(1.125-\rho_{0}\right)\end{aligned}$ & $2.918 \leq \mathrm{U}_{\mathrm{S}} \leq 4.639$ & & 12 \\
\hline Octol & 1.80 & $\mathrm{U}_{\mathrm{s}}=3.01+1.72 \mathrm{U}_{\mathrm{p}}$ & & & 11 \\
\hline Octol (cast) & 1.803 & $\mathrm{U}_{\mathrm{s}}=2.21+2.51 \mathrm{U}_{\mathrm{p}}$ & $3.24 \leq \mathrm{U}_{\mathrm{S}} \leq 4.97$ & & 12 \\
\hline PBX-9011-06 & 1.790 & $\mathrm{U}_{\mathrm{s}}=2.225+2.644 \mathrm{U}_{\mathrm{p}}$ & $4.1 \leq \mathrm{U}_{\mathrm{S}} \leq 6.1$ & & 10 \\
\hline \multirow[t]{4}{*}{ PBX-9404-03 } & 1.721 & $\mathrm{U}_{\mathrm{s}}=1.89+1.57 \mathrm{U}_{\mathrm{p}}$ & $2.4 \leq U_{p} \leq 3.7$ & & 10 \\
\hline & 1.840 & $\mathrm{U}_{\mathrm{S}}=2.494+2.09 \mathrm{U}_{\mathrm{p}}$ & $2.9 \leq \mathrm{U}_{\mathrm{s}} \leq 6.7$ & & 10 \\
\hline & 1.84 & $\mathrm{U}_{\mathrm{s}}=2.310+2.767 \mathrm{U}_{\mathrm{p}}$ & $\left.\begin{array}{l}\mathrm{U}_{\mathrm{s}}<3.2 \\
\mathrm{c}_{\mathrm{b}}=2.310\end{array}\right\}$ & & 14 \\
\hline & 1.84 & $\mathrm{U}_{\mathrm{S}}=2.45+2.48 \mathrm{U}_{\mathrm{p}}$ & $\left.\begin{array}{l}2.45 \leq \mathrm{U}_{\mathrm{S}} \leq 6.05 \\
c_{0}=2.60\end{array}\right\}$ & & 15 \\
\hline PBX-9407 & 1.60 & $\mathrm{U}_{\mathrm{s}}=1.328+1.993 \mathrm{U}_{\mathrm{p}}$ & $2.11 \leq \mathrm{U}_{\mathrm{s}} \leq 3.18$ & & 17 \\
\hline PBX-9501-01 & 1.844 & $\mathrm{U}_{\mathrm{S}}=2.683+1.906 \mathrm{U}_{\mathrm{p}}$ & $2.9 \leq \mathrm{U}_{\mathrm{s}} \leq 4.4$ & & 10 \\
\hline \multirow[t]{2}{*}{ Pentolite } & 1.67 & $\mathrm{U}_{\mathrm{s}}=2.83+1.91 \mathrm{U}_{\mathrm{p}}$ & & & 11 \\
\hline & 1.676 & $\mathrm{U}_{\mathrm{S}}=0.885+3.20 \mathrm{U}_{\mathrm{p}}$ & $4.52 \leq \mathrm{U}_{\mathrm{S}} \leq 5.25$ & & 12 \\
\hline \multirow[t]{3}{*}{ PETN } & 1.59 & $\mathrm{U}_{\mathrm{s}}=1.33+2.18 \mathrm{U}_{\mathrm{p}}$ & $\left.\begin{array}{l}1.40 \leq \mathrm{U}_{\mathrm{s}} \leq 2.14 \\
\mathrm{c}_{0}=2.45\end{array}\right\}$ & & 15 \\
\hline & & $\mathrm{U}_{\mathrm{s}}=0.64+4.19 \mathrm{U}_{\mathrm{p}}$ & $\left.\begin{array}{l}1.86 \leq \mathrm{U}_{\mathrm{s}} \leq 2.65 \\
\mathrm{c}_{0}=2.45\end{array}\right\}$ & & 15 \\
\hline & 1.60 & $\mathrm{U}_{\mathrm{S}}=1.32+2.58 \mathrm{U}_{\mathrm{p}}$ & $1.89 \leq \mathrm{U}_{\mathrm{S}} \leq 2.56$ & 0.77 & 19 \\
\hline $7 / 74$ & & $7-19$ & & & \\
\hline
\end{tabular}


Table 7-3. (continued)

\begin{tabular}{|c|c|c|c|c|c|}
\hline Explosive & $\frac{\rho_{0}}{\left(\mathrm{~g} / \mathrm{cm}^{3}\left(\mathrm{Mg} / \mathrm{m}^{3}\right)\right)}$ & Equation & Range $^{a}$ & $\Gamma$ & Ref. \\
\hline & 1.72 & $\mathrm{U}_{\mathrm{s}}=2.326+2.342 \mathrm{U}_{\mathrm{p}}$ & $\left.\begin{array}{l}2.83 \leq U_{s} \leq 3.18 \\
c_{b}=2.326\end{array}\right\}$ & & 18 \\
\hline & & $\mathrm{U}_{\mathrm{s}}=1.83+3.45 \mathrm{U}_{\mathrm{p}}$ & $\left.\begin{array}{l}2.52 \leq U_{s} \leq 3.87 \\
c_{b}=2.24\end{array}\right\}$ & 0.77 & 19 \\
\hline Polystyrene & 1.05 & $\mathrm{U}_{\mathrm{s}}=2.40+1.637 \mathrm{U}_{\mathrm{p}}$ & $3.87 \leq \mathrm{U}_{\mathrm{s}} \leq 6.493$ & & 12 \\
\hline \multirow[t]{3}{*}{$\mathrm{RDX}$} & 1.64 & $\mathrm{U}_{\mathrm{s}}=1.93+0.666 \mathrm{U}_{\mathrm{p}}$ & $\left.\begin{array}{l}2.00 \leq \mathrm{U}_{\mathrm{S}} \leq 2.16 \\
\mathrm{c}_{0}=2.80\end{array}\right\}$ & & 15 \\
\hline & & $\mathrm{U}_{\mathrm{s}}=0.70+4.11 \mathrm{U}_{\mathrm{p}}$ & $\left.\begin{array}{l}2.14 \leq \mathrm{U}_{\mathrm{s}} \leq 2.63 \\
\mathrm{c}_{0}=2.80\end{array}\right\}$ & & 15 \\
\hline & 1.80 & $\mathrm{U}_{\mathrm{s}}=2.87+1.61 \mathrm{U}_{\mathrm{p}}$ & $4.21 \leq \mathrm{U}_{\mathrm{s}} \leq 5.45$ & & 10 \\
\hline \multirow[t]{2}{*}{ TATB } & 1.847 & $\mathrm{U}_{\mathrm{s}}=2.340+2.316 \mathrm{U}_{\mathrm{p}}$ & $\left.\begin{array}{l}3.125 \leq U_{S} \leq 5.629 \\
c_{0}=2.050\end{array}\right\}$ & 1.60 & $\begin{array}{l}11,12 \\
13,16\end{array}$ \\
\hline & 1.876 & $\begin{array}{l}\mathrm{U}_{\mathrm{s}}=1.46+3.68 \mathrm{U}_{\mathrm{p}} \\
\mathrm{U}_{\mathrm{s}}=2.037+2.497 \mathrm{U}_{\mathrm{p}}\end{array}$ & $\begin{array}{l}\mathrm{c}_{0} \leq \mathrm{U}_{\mathrm{s}} \leq 3.23 \\
3.23 \leq \mathrm{U}_{\mathrm{s}} \leq 5.9\end{array}$ & & 10 \\
\hline \multirow[t]{5}{*}{ Tetryl } & 1.30 & $\mathrm{U}_{\mathrm{S}}=2.1620+1.4271 \mathrm{U}_{\mathrm{p}}$ & $\left.\begin{array}{l}2.58 \leq \mathrm{U}_{\mathrm{S}} \leq 4.16 \\
\mathrm{c}_{\ell}=1.1\end{array}\right\}$ & & 20 \\
\hline & 1.40 & $\mathrm{U}_{\mathrm{s}}=1.6111+1.9658 \mathrm{U}_{\mathrm{p}}$ & $\left.\begin{array}{l}2.20 \leq \mathrm{U}_{\mathrm{s}} \leq 4.07 \\
\mathrm{c}_{\ell}=1.13\end{array}\right\}$ & & 20 \\
\hline & 1.50 & $\mathrm{U}_{\mathrm{S}}=2.1674+1.6225 \mathrm{U}_{\mathrm{p}}$ & $\left.\begin{array}{l}2.63 \leq \mathrm{U}_{\mathrm{s}} \leq 4.17 \\
\mathrm{c}_{\ell}=1.36\end{array}\right\}$ & & 20 \\
\hline & 1.60 & $\mathrm{U}_{\mathrm{S}}=2.3621+1.5285 \mathrm{U}_{\mathrm{p}}$ & $\left.\begin{array}{l}2.86 \leq U_{s} \leq 4.25 \\
c_{\ell}=1.66\end{array}\right\}$ & & 20 \\
\hline & 1.70 & $\mathrm{U}_{\mathrm{s}}=2.4763+1.4160 \mathrm{U}_{\mathrm{p}}$ & $\left.\begin{array}{l}3.08 \leq \mathrm{U}_{\mathrm{s}} \leq 4.17 \\
\mathrm{c}_{\ell}=2.035\end{array}\right\}$ & & 20 \\
\hline \multirow[t]{3}{*}{ TNT } & 1.582 & $\mathrm{U}_{\mathrm{s}}=2.52+1.69 \mathrm{U}_{\mathrm{p}}$ & $4.46 \leq \mathrm{U}_{\mathrm{S}} \leq 4.8 \dot{9}$ & 0.737 & 12 \\
\hline & 1.62 & $\mathrm{U}_{\mathrm{s}}=3.09+1.29 \mathrm{U}_{\mathrm{p}}$ & $4.17 \leq \mathrm{U}_{\mathrm{S}} \leq 5.22$ & & 12 \\
\hline & $\begin{array}{r}1.643- \\
1.648\end{array}$ & $\mathrm{U}_{\mathrm{s}}=2.372+2.16 \mathrm{U}_{\mathrm{p}}$ & $\left.\begin{array}{l}2.78<U_{s} \\
c_{0}=2.30 \\
2.345 \leq U_{s} \leq 3.375\end{array}\right\}$ & & 12 \\
\hline \multirow[t]{2}{*}{ TNT (cast) } & 1.62 & $\begin{array}{l}\mathrm{U}_{\mathrm{s}}=2.274+2.652 \mathrm{U}_{\mathrm{p}} \\
\mathrm{U}_{\mathrm{s}}=2.987+1.363 \mathrm{U}_{\mathrm{p}}\end{array}$ & $\left.\begin{array}{c}\mathrm{U}_{\mathrm{S}}<3.7 \\
3.7<\mathrm{U} \\
\mathrm{c}_{\ell}=2.297\end{array}\right\}$ & & 14 \\
\hline & & $7-20$ & & \multicolumn{2}{|c|}{$7 / 74$} \\
\hline
\end{tabular}


Table 7-3. (continued)

\begin{tabular}{|c|c|c|c|c|c|}
\hline Explosive & $\frac{\rho_{0}}{\left(\mathrm{~g} / \mathrm{cm}^{3}\left(\mathrm{Mg} / \mathrm{m}^{3}\right)\right)}$ & Equation & Range $^{a}$ & $\Gamma$ & Ref. \\
\hline & 1.614 & $\mathrm{U}_{\mathrm{s}}=2.390+2.050 \mathrm{U}_{\mathrm{p}}$ & $\left.\begin{array}{l}3.034<U_{s}<5.414 \\
c_{0}=2.572\end{array}\right\}$ & 0.737 & $\begin{array}{l}12, \\
13\end{array}$ \\
\hline & 1.63 & $\mathrm{U}_{\mathrm{s}}=2.57+1.88 \mathrm{U}_{\mathrm{p}}$ & $c_{l}=2.572$ & & 11 \\
\hline $\begin{array}{l}\text { TNT (liquid) } \\
\left(82^{\circ} \mathrm{C}\right)\end{array}$ & 1.472 & $\mathrm{U}_{\mathrm{s}}=2.14+1.57 \mathrm{U}_{\mathrm{p}}$ & $\left.\begin{array}{l}3.49 \leq \mathrm{U}_{\mathrm{s}} \leq 4.65 \\
\mathrm{c}_{0}=1.37\end{array}\right\}$ & & $\begin{array}{l}12 \\
13\end{array}$ \\
\hline Tritonal (cast) & 1.73 & $\mathrm{U}_{\mathrm{s}}=2.313+2.769 \mathrm{U}_{\mathrm{p}}$ & $\mathrm{U}_{\mathrm{s}}<3.8$ & & 14 \\
\hline XTX-8003 & 1.53 & $\mathrm{U}_{\mathrm{S}}=1.49+3.30 \mathrm{U}_{\mathrm{p}}$ & $2.38 \leq \mathrm{U}_{\mathrm{S}} \leq 4.06$ & 0.77 & 19 \\
\hline
\end{tabular}

\footnotetext{
${ }^{a}$ Sound velocities through the sample are in $\mathrm{km} / \mathrm{s} ; \mathrm{c}_{0}=$ initial sound velocity, $c_{\ell}=$ longitudinal sound velocity, $c_{b}=$ bulk sound velocity.
}

\section{Sound Velocity}

Longitudinal and transverse shear sound velocities were measured by Marsh of LASL in $1971^{21}$ for materials with large acoustic attenuation. The arrival times of signals traveling through different thicknesses of stacked samples were measured and the sound velocities were determined by a differential technique, i.e., by measuring the transit times of the signals through the measured thicknesses of the samples.

The bulk sound velocities $c_{b}$ were determined from the expression for isotropic materials:

$$
c_{b}=\sqrt{c_{l}^{2}-\frac{4}{3} c_{s}} \text {, }
$$

and are compiled in Table $7-4 .^{17,21,22}$ 
Table 7-4. Sound velocities, $c_{\ell^{\prime}} c_{s}$, and $c_{b}$.

\begin{tabular}{lcccc}
\hline $\begin{array}{c}\text { Explosive } \\
\text { and preparation }\end{array}$ & $\begin{array}{c}\rho \\
\left(\mathrm{Mg} / \mathrm{m}^{3}\right)\end{array}$ & $\begin{array}{c}\mathrm{c}_{\ell} \\
(\mathrm{km} / \mathrm{s})\end{array}$ & $\begin{array}{c}\mathrm{c}_{\mathrm{s}} \\
(\mathrm{km} / \mathrm{s})\end{array}$ & $\begin{array}{c}\mathrm{c}_{\mathrm{b}} \\
(\mathrm{km} / \mathrm{s})\end{array}$ \\
\hline Baratol (cast) & 2.538 & 2.95 & 1.48 & 2.40 \\
Comp B-3 (cast) & 1.726 & 3.12 & 1.71 & 2.42 \\
Cyclotol (cast) & 1.752 & 3.12 & 1.69 & 2.43 \\
DATB (pressed) & 1.78 & 2.99 & 1.55 & 2.40 \\
Octol (cast) & 1.80 & 3.14 & 1.66 & 2.49 \\
PBX-9010-02 & 1.78 & 2.72 & 1.47 & 2.13 \\
PBX-9011-04 & 1.77 & 2.89 & 1.38 & 2.41 \\
PBX-9404 & 1.83 & 2.90 & 1.57 & 2.26 \\
PBX-9407 & 1.78 & 3.04 & 1.70 & 2.32 \\
TATB (pressed) & 1.87 & 1.98 & 1.16 & 1.46 \\
Tetryl (pressed) & 1.68 & 2.27 & 1.24 & 1.76 \\
TNT (pressed) & 1.61 & 2.48 & 1.34 & 1.94 \\
TNT (pressed) & 1.632 & 2.58 & 1.35 & 2.08 \\
TNT (molten) & 1.47 & & & 2.1 \\
\hline
\end{tabular}




\section{References}

1. K. G. Hoge, Appl. Polym. Symp. 5, 19-40 (1967).

2. D. Breithaupt, Lawrence Livermore Laboratory, personal communication (1974).

3. R. C. Murray, Lawrence Livermore Laboratory, personal communication (1970).

4. G. L. Goudreau, Lawrence Livermore Laboratory, personal communication (1970).

5. J. D. Ferry, Viscoelastic Properties of Polymers (J. Wiley and Sons, Inc., New York, 1970), 2nd ed.

6. K. G. Hoge, Explosivstoffe 18, 39-41 (1970).

7. K. G. Hoge, Frictional and Viscoelastic Properties of Highly Filled Polymers: Plastic-Bonded Explosives, Lawrence Livermore Laboratory, Rept. UCRL-70588 Rev. 1 (1968).

8. M. A. Hamstead, Complex Shear Modulus of a High Explosive, Lawrence Livermore Laboratory, Rept. UCRL-50357 (1967).

9. R. J. Wasley and R. H. Valentine, Shock-Pulse Attenuation and Hugoniot Studies of Three Explosives and Three Mock Explosives, Lawrence Livermore Laboratory, Rept. UCRL-50950 (1970).

10. B. G. Craig, Los Alamos Scientific Laboratory, personal communication (1974).

11. V. M. Boyle, R. L. Jameson, and M. Sultanoff, "Determination of Shock Hugoniots for Several Condensed Phase Explosives," in Proc. 4 th Symp. (Intern.) on Detonation, U.S. Office of Naval Research, Washington, D. C., Rept. ACR-126 (1965) pp. 241-247.

12. M. Van Thiel, Compendium of Shock Wave Data, Vol. 2, Lawrence Livermore Laboratory, Livermore, California, Rept. UCRL-50108, Vol. 2 (1967).

13. N. L. Coleburn and T. P. Liddiard, Jr., J. Chem. Phys. 44, 1929-1936 (1966).

14. V. M. Boyle, W. G. Smothers, and L. H. Ervin, "The Shock Hugoniot of Unreacted Explosives"; in Proc. 5th Symp. (Intern.) on Detonation, U.S. Office of Naval Research, Washington, D. C., Rept. ACR-184 (1970) pp. 251-257.

15. J. Roth, "Shock Sensitivity and Shock Hugoniots of High-Density Granular Explosives," in Proc. 5th Symp. (Intern.) on Detonation, U.S. Office of Naval Research, Washington, D. C., Rept. ACR-184 (1970) pp. 219-230.

16. L. G. Green, Lawrence Livermore Laboratory, personal communication (1971).

17. J. E. Lindstrom, J. Appl. Phys. 37, 4873-4880 (1966).

18. J. Wackerle and J. O. Johnson, Pressure Measurements on the Shock-Induced Decomposition of High-Density PETN, Los Alamos Scientific Laboratory, Rept. LA-5131 (1973).

19. D. Stirpe, J. O. Johnson, and J. Wackerle, J. Appl. Phys. 41, 3884-3893 (1970).

20. J. E. Lindstrom, J. Appl. Phys. 41, 337-350 (1970).

21. S. Marsh, Los Alamos Scientific Laboratory, personal communication (1974).

22. J. B. Ramsey, Los Alamos Scientific Laboratory, personal communication (1974). 


\section{PERFORMANCE}

This section contains tables of detonation velocities, detonation velocity equations, Chapman-Jouguet detonation pressures, cylinder-test measurements of explosive energies, equation-of-state parameters, and detonation energies.

\section{Detonation Velocity}

Table 8-1. Measured detonation velocities $D$ characteristic of the materials at nominal composition and density $\rho$, under ambient conditions in large charges at LLL, unless otherwise indicated. (See also Table 8-2.)

\begin{tabular}{|c|c|c|c|}
\hline Explosive & $\left(\mathrm{g} / \mathrm{cm}^{3} \stackrel{\rho}{\left.\left(\mathrm{Mg} / \mathrm{m}^{3}\right)\right)}\right.$ & $\begin{array}{c}\mathrm{D} \\
(\mathrm{mm} / \mu \mathrm{sec}(\mathrm{km} / \mathrm{s}))^{\mathrm{a}}\end{array}$ & Ref. \\
\hline Baratol & 2.55 & 4.87 & \\
\hline Boracitol & 1.55 & 4.86 & \\
\hline BTE & 1.859 & 8.485 & \\
\hline Comp B, Grade A (pressed) & 1.72 & 7.99 & \\
\hline Comp B-3 (cast) & 1.62 & 7.70 & \\
\hline Comp C-4 & 1.59 & 8.04 & \\
\hline Cyclotol $75 / 25$ & 1.76 & 8.30 & \\
\hline DA TB & 1.79 & 7.52 & \\
\hline DIPAM & 1.76 & 7.40 & 1 \\
\hline$E L-506 \mathrm{~A}$ & 1.48 & 7.2 & \\
\hline$E L-506 C$ & 1.48 & 7.0 & \\
\hline$H-6$ & 1.72 & $\begin{array}{c}7.5-7.7 \\
\left(-65 \text { to } 77^{\circ} \mathrm{F}\right. \\
(219 \text { to } 298 \mathrm{~K}))\end{array}$ & 2 \\
\hline $\mathrm{HMX}$ & 1.89 & 9.11 & \\
\hline HNAB IJ & 1.77 & $\begin{array}{l}7.6-7.7 \\
\text { (1n } 0.1-0.3 \mathrm{in} \text {, } \\
\text { diam column }\end{array}$ & 3,4 \\
\hline HNS & 1.70 & 7.00 & 1 \\
\hline L.X-01 & 1.24 & 6.84 & \\
\hline$L X-02$ & 1.44 & 7.37 & \\
\hline$L X-04$ & 1.86 & 8.46 & \\
\hline LX $-07-2$ & 1.87 & 8.64 & \\
\hline$L X-08$ & 1.42 & 6.56 & \\
\hline $\mathrm{LX}-09$ & 1.84 & 8.81 & \\
\hline$L X-10-0$ & 1.86 & 8.82 & \\
\hline$L X-10-1$ & 1.87 & 8.847 & \\
\hline $\mathrm{LX}-11$ & 1.87 & 8.32 & \\
\hline$L X-13$ & See XTX-8003 & & \\
\hline$L X-14$ & 1.833 & 8.837 & 5 \\
\hline MEN-II & 1.02 & 5.49 & \\
\hline $\mathrm{NC}(13.45 \% \mathrm{~N})$ & 1.20 & 7.30 & \\
\hline NG & 1.60 & 7.70 & \\
\hline NM & 1.13 & 6.32 & 6 \\
\hline$N Q$ & 1.55 & 7.65 & \\
\hline Octol & 1.81 & 8.48 & \\
\hline $\mathrm{PBX}-9007$ & 1.64 & 8.09 & \\
\hline PBX -9010 & 1.78 & 8.37 & \\
\hline PBX-9011 & 1.77 & 8.50 & \\
\hline PBX-9205 & 1.67 & 8.17 & \\
\hline PBX -9404 & 1.84 & 8.80 & \\
\hline PBX -9407 & 1.60 & 7.91 & \\
\hline$P B X-9501$ & 1.84 & 8.83 & 7 \\
\hline Pentolite $50 / 50$ & 1.67 & 7.47 & \\
\hline PETN & 1.76 & 8.26 & \\
\hline $\operatorname{RDX}$ & 1.77 & 8.70 & \\
\hline TACOT & 1.85 & 7.25 & \\
\hline ТATB & 1.88 & 7.76 & \\
\hline Tetryl & 1.71 & 7.85 & \\
\hline TNM & 1.6 & $\begin{array}{c}6.4 \\
\left(15 \text { to } 20^{\circ} \mathrm{C}\right. \\
(288 \text { to } 298 \mathrm{~K}))\end{array}$ & 8 \\
\hline TNT & 1.64 & 6.93 & \\
\hline$X T X-8003$ & $\approx 1.53$ & 7,30 & \\
\hline
\end{tabular}




\section{Estimation}

One method for estimating the detonation velocity and pressure of an organic $\mathrm{C}-\mathrm{H}-\mathrm{N}-\mathrm{O}$ explosive from its chemical structure was devised by Kamlet and Jacobs of the U.S. Naval Ordnance Laboratory. ${ }^{9}$ Detonation pressures $\mathrm{P}$ in kbars and detonation velocities $D$ in $\mathrm{km} / \mathrm{s}$ of $\mathrm{C}-\mathrm{H}-\mathrm{N}-\mathrm{O}$ explosives at initial densities above $1.0 \mathrm{~g} / \mathrm{cm}^{3} \mathrm{can}$ be calculated by means of the simple empirical equations

$$
\mathrm{P}=\mathrm{K} \rho_{0}^{2} \phi
$$

and

$$
\mathrm{D}=\mathrm{A} \phi^{1 / 2}\left(1+\mathrm{B} \rho_{0}\right), \quad \phi=\mathrm{NM}^{1 / 2} \mathrm{Q}^{1 / 2},
$$

where

$$
\begin{aligned}
\mathrm{K} & =15.58, \\
\rho_{0} & =\text { initial density of } \mathrm{HE}\left(\mathrm{g} / \mathrm{cm}^{3}\right), \\
\mathrm{A} & =1.01, \\
\mathrm{~B} & =1.30, \\
\mathrm{~N} & =\text { moles of gaseous detonation products per gram of } \mathrm{HE}(\mathrm{mol} \mathrm{gas} / \mathrm{g} \mathrm{HE}), \\
\mathrm{M} & =\text { average molecular weight of detonation product gas }(\mathrm{g} \mathrm{gas} / \mathrm{mol} \mathrm{gas}), \\
\mathrm{Q} & =\text { chemical energy of the detonation reaction (cal } / \mathrm{g}) .
\end{aligned}
$$

Values of $\mathrm{N}, \mathrm{M}$, and $\mathrm{Q}$ can be estimated from the $\mathrm{H}_{2} \mathrm{O}-\mathrm{CO}_{2}$ decomposition assumption. The other input parameters are the elemental composition, the $\Delta \mathrm{H}_{\mathrm{f}}$ in $\mathrm{kcal} / \mathrm{mol}$, and the loading density of the $\mathrm{HE}$.

$$
\mathrm{C}_{\mathrm{a}} \mathrm{H}_{\mathrm{b}} \mathrm{N}_{\mathrm{c}} \mathrm{O}_{\mathrm{d}} \rightarrow \frac{\mathrm{c}}{2} \mathrm{~N}_{2}+\frac{\mathrm{b}}{2} \mathrm{H}_{2} \mathrm{O}+\left(\frac{\mathrm{d}}{2}-\frac{\mathrm{b}}{4}\right) \mathrm{CO}_{2}+\left(\mathrm{a}-\frac{\mathrm{d}}{2}+\frac{\mathrm{b}}{4}\right) \mathrm{C} \text {. }
$$

Then,

$$
\begin{aligned}
N & =\frac{2 c+2 d+b}{48 a+4 b+56 c+64 d}, \\
M & =\frac{56 c+88 d-8 b}{2 c+2 d+b}, \\
Q & =-\Delta H_{0}=\frac{\Delta H_{f}\left(\text { detonation products) }-\Delta H_{f}(H E)\right.}{\text { formula weight }} \\
& =\frac{28.9 b+47.0\left(d-\frac{b}{2}\right)+\Delta H_{f}(H E)}{12 a+b+14 c+16 d} .
\end{aligned}
$$

Another simple empirical equation was demonstrated by Urizar at LASL in the late 1940s, and gives good agreement with measured detonation velocities of mixtures. The detonation velocity of a mixture or formulation can be estimated or predicted as the sum of the detonation or shock velocities of the components weighted by their 
individual volume fractions. Table 8-2 gives values of characteristic velocities $\mathrm{D}_{\mathrm{i}}$ for use in the equation

$$
\mathrm{D}=\sum\left(\mathrm{V}_{\mathrm{i}} \mathrm{D}_{\mathrm{i}}\right)
$$

where $\mathrm{D}$ is the detonation velocity of the mixture of infinite diameter, $\mathrm{V}$ is the volume fraction, and subscript $i$ refers to each of the $i$ components including void space. Consult Table 8-1 for D of explosives not listed here.

Table 8-2. Characteristic velocities $D_{i}$.

\begin{tabular}{|c|c|c|c|}
\hline Material & $\left(\mathrm{g} / \mathrm{cm}^{3} \stackrel{\rho}{\left.\left(\mathrm{Mg} / \mathrm{m}^{3}\right)\right)}\right.$ & $\underset{(\mathrm{mm} / \mu \sec (\mathrm{km} / \mathrm{s}))}{\mathrm{D}_{\mathrm{i}}}$ & Ref. \\
\hline \multicolumn{4}{|c|}{ Polymers and plasticizers } \\
\hline Adiprene L & 1.15 & 5.69 & 10 \\
\hline AFNOL & 1.48 & 6.35 & 11 \\
\hline Beeswax & 0.96 & 5.46 & 10 \\
\hline BDNPF & 1.55 & 6.50 & 10 \\
\hline BDNPF/BDNPA (50/50 wt\% eutectic) & 1.39 & 6.31 & 11 \\
\hline $\mathrm{CEF}$ & 1.45 & 5.15 & 10 \\
\hline DNPA & 1.47 & 6.10 & 11 \\
\hline EDNP & 1.28 & 6.30 & 10 \\
\hline Estane $5740-\mathrm{X} 2$ & 1.2 & 5.52 & 10 \\
\hline Exon-400 XR61 & 1.7 & 5.47 & 10 \\
\hline Exon-454 (85/15 wt $\%$ PVC/PVA) & 1.35 & 4.90 & 11 \\
\hline FEFO (as constituent to $\sim 35 \%$ ) & 1.60 & 7.20 & 11 \\
\hline Fluoronitroso rubber & 1.92 & 6.09 & 11 \\
\hline Halowax 1014 & 1.78 & 4.22 & 10 \\
\hline Kel-F wax & & 5.62 & 10 \\
\hline Kel-F elastomer & 1.85 & 5.38 & 10 \\
\hline $\mathrm{Kel}-\mathrm{F} 800 / 827$ & 2.00 & $5.83^{\mathrm{a}}$ & 10 \\
\hline $\mathrm{Kel}-\mathrm{F} 800$ & 2.02 & 5.50 & 11 \\
\hline Neoprene CNA & 1.23 & 5.02 & 10 \\
\hline $\mathrm{NC}$ & 1.5 & 6.70 & 10 \\
\hline Paracril BJ (Buna-N nitrile rubber) & 0.97 & 5.39 & 10 \\
\hline Polyethylene & 0.93 & 5.55 & 11 \\
\hline Polystyrene & 1.05 & 5.28 & 10 \\
\hline Saran F-242 & & 5.55 & 10 \\
\hline Silastic 160 & & 5.72 & 10 \\
\hline Sylgard 182 & 1.05 & 5.10 & 11 \\
\hline Teflon & 2.15 & 5.33 & 10 \\
\hline Viton A & 1.82 & 5.39 & 10,11 \\
\hline $7 / 74$ & $8-3$ & & \\
\hline
\end{tabular}


Table 8-2 (continued)

\begin{tabular}{|c|c|c|c|}
\hline Material & $\left(\mathrm{g} / \mathrm{cm}^{3} \stackrel{\rho}{\left.\left(\mathrm{Mg} / \mathrm{m}^{3}\right)\right)}\right.$ & $\stackrel{\mathrm{D}_{\mathrm{i}}}{(\mathrm{mm} / \mu \sec (\mathrm{km} / \mathrm{s}))}$ & Ref. \\
\hline \multicolumn{4}{|c|}{ Inorganic additives } \\
\hline Air or void & & 1.5 & 10 \\
\hline $\mathrm{Al}$ & 2.70 & 6.85 & 11 \\
\hline $\mathrm{Ba}\left(\mathrm{NO}_{3}\right)_{2}$ & 3.24 & 3.80 & 10 \\
\hline $\mathrm{KClO}_{4}$ & 2.52 & 5.47 & 11 \\
\hline $\mathrm{LiClO}_{4}$ & 2.43 & 6.32 & 11 \\
\hline $\mathrm{LiF}$ & 2.64 & 6.07 & 11 \\
\hline $\mathrm{Mg}$ & 1.74 & 7.2 & 11 \\
\hline $\mathrm{Mg} / \mathrm{Al}$ alloy $(61.5 / 38.5 \mathrm{wt} \%)$ & 2.02 & 6.9 & 11 \\
\hline $\mathrm{NH}_{4} \mathrm{ClO}_{4}$ & 1.95 & 6.25 & 11 \\
\hline $\mathrm{SiO}_{2}(\mathrm{Cab}-\mathrm{O}-\mathrm{Sil})$ & 2.2 & 4.0 & 11 \\
\hline \multicolumn{4}{|c|}{ Pure explosives at TMD } \\
\hline DATB & 1.84 & 7.52 & 10 \\
\hline FEFO (invalid when $<35 \%$ present) & 1.61 & 7.50 & 11 \\
\hline HMX & 1.90 & 9.15 & 11 \\
\hline NQ & 1.72 & 8.74 & 10 \\
\hline PETN & 1.77 & 8.28 & 11 \\
\hline $\mathrm{RDX}$ & 1.81 & 8.80 & 10 \\
\hline ТАТВ & 1.94 & 8.00 & 10 \\
\hline TNT & 1.65 & 6.97 & 10 \\
\hline
\end{tabular}

${ }^{a}$ One shot only. 


\section{Equations}

To calculate detonation velocities at conditions other than those specified in Table 8-1, the equations in Table 8-3 were developed to take into account composition and density of the explosive, charge diameter, and temperature.

Table 8-3. Detonation velocity equations. Symbols and units are: $D=$ detonation velocity in $\mathrm{mm} / \mu$ sec $(\mathrm{km} / \mathrm{s}), \rho=$ density in $\mathrm{g} / \mathrm{cm}^{3}\left(\mathrm{~kg} / \mathrm{m}^{3}\right), \quad \mathrm{R}=$ charge radius in $\mathrm{cm}(\mathrm{m}), W=$ composition in $\mathrm{wt} \%, \mathrm{~V}=$ composition in vol\%, $\mathrm{T}=$ temperature in ${ }^{\circ} \mathrm{C}(\mathrm{K})$. Values or equations in parentheses are in SI units.

\begin{tabular}{|c|c|c|c|c|}
\hline Explosive & Equation & & Condition & Ref. \\
\hline Baratol & $\mathrm{D}=4.96-(0.454 / \mathrm{R})$ & $\left(4.96-\left[\left(4.54 \times 10^{-3}\right) / R\right]\right)$ & $27 \%$ TNT, $\rho \sim 2.60,2.5<\mathrm{R}<10$ & 12 \\
\hline Boracitol & $\mathrm{D}=5.15-(6.25 / \mathrm{R})$ & $\left(5.15-\left[\left(62.5 \times 10^{-3}\right) / \mathrm{R}\right]\right)$ & $R>5(0.05)$ & 12 \\
\hline BTF & $\mathrm{D}=4.265+2.27 \rho$ & $\left(4.265+\left(2.27 \times 10^{-3} \rho \mathrm{E}\right)\right)$ & & 11 \\
\hline $\begin{array}{l}\text { Comp B, } \\
\text { Grade A }\end{array}$ & $\begin{array}{l}\mathrm{D}=7.99-\left[\left(75.6 \times 10^{-3}\right) / \mathrm{R}\right] \\
\Delta \mathrm{D} / \Delta \mathrm{T}=-0.5 \times 10^{-3}\end{array}$ & $\left(7.99-\left[\left(0.756 \times 10^{-3}\right) / \mathrm{R}\right]\right)$ & $\rho=1.715$ & 12 \\
\hline Cyclotol & $\mathrm{D}=8.298-\left[\left(57.7 \times 10^{-3}\right) / \mathrm{R}\right]$ & $\left(8.298-\left[\left(0.577 \times 10^{-3}\right) / R\right]\right)$ & $77 \%$ RDX, $\rho=1.755$ & 12 \\
\hline DATB & $\begin{array}{l}D=7.52-\left[\left(52.76 \times 10^{-3}\right) / R\right] \\
D=2.495+2.834 \rho\end{array}$ & $\begin{array}{l}\left(7.52-\left[\left(0.528 \times 10^{-3}\right) / \mathrm{R}\right]\right) \\
\left(2.495+\left(2.834 \times 10^{-3} \rho\right)\right)\end{array}$ & $\rho=1.788$ & 13 \\
\hline$L X-01-0$ & $\Delta \mathrm{D} / \Delta \mathrm{T}=-3.8 \times 10^{-3}$ & & & \\
\hline LX -02 & $D=7.44-\left[\left(4.31 \times 10^{-3}\right) / R\right]$ & $\left(7.44-\left[\left(43.1 \times 10^{-6}\right) / R\right]\right)$ & $\begin{array}{l}\text { Brass confinement; } \\
\text { varies with confinement. }\end{array}$ & \\
\hline LX $-04-1$ & $\begin{array}{l}D^{\infty}=1.733+3.62 \beta \\
D^{\infty}=8.46-\left[\left(24.015 \times 10^{-3}\right) / R\right] \\
\Delta D / \Delta T=-1.55 \times 10^{-3} \\
\Delta D / \Delta W=-38 \times 10^{-3}(W=\text { wt } \% \text { Viton })\end{array}$ & $\begin{array}{l}\left(1.733+\left(3.62 \times 10^{-3} \rho\right)\right\} \\
\left(8.46-\left[\left(0.24 \times 10^{-3}\right) / \mathbf{R}\right]\right)\end{array}$ & $\begin{array}{l}\rho=1.86 \\
-54 \text { to } 74^{\circ} \mathrm{C}(219-347 \mathrm{~K})\end{array}$ & \\
\hline $\mathrm{LX}-07$ & $\begin{array}{l}\Delta \mathrm{D} / \Delta \mathrm{T}=-1.55 \times 10^{-3} \\
\Delta \mathrm{D} / \Delta \mathrm{W}=-35 \times 10^{-3}(\mathrm{~W}=\mathrm{wt} \% \mathrm{HMX})\end{array}$ & & -54 to $74^{\circ} \mathrm{C}(219-347 \mathrm{~K})$ & \\
\hline $\mathrm{LX}-08$ & $\Delta \mathrm{D} / \Delta \mathrm{T}=-3.56 \times 10^{-3}$ & & -36 to $23^{\circ} \mathrm{C}(237-296 \mathrm{~K})$ & \\
\hline$L X-09$ & $\Delta \mathrm{D} / \Delta \mathrm{T}=-3.31 \times 10^{-3}$ & & & 14 \\
\hline $\mathrm{LXX}-13$ & See XTX-8003 & & & \\
\hline NM & $\begin{array}{l}\Delta \mathrm{D} / \Delta \mathrm{T}=-3.7 \times 10^{-3} \\
\Delta \mathrm{D} / \Delta \mathrm{P}=0.197 \times 10^{-3} \mathrm{~mm} / \mathrm{\mu sec}-\mathrm{atm}\end{array}$ & $(19.96 \mathrm{~km} / \mathrm{s}-\mathrm{Pa})$ & $4^{\circ} \mathrm{C}(277 \mathrm{~K})$, infinite diam & 15 \\
\hline NQ & $\mathrm{D}=1.44+4.015 \rho$ & $\left(1.44+\left(4.015 \times 10^{-3}\right) \rho\right)$ & $0.4 \leq \rho \leq 1.63$ & 13 \\
\hline Octol & $\mathrm{D}=8.48-\left[\left(64.97 \times 10^{-3}\right) / \mathrm{R}\right]$ & $\left(8.48-\left[\left(0.65 \times 10^{-3}\right) / R\right]\right)$ & $77 \%$ HMX, $\rho=1.814$ & 12 \\
\hline PBX -9010 & $\begin{array}{l}D=2.843+3.1 \rho \\
D=8.371-\left[\left(10.16 \times 10^{-3}\right) / R\right]\end{array}$ & $\begin{array}{l}\left(2.843+\left(3.1 \times 10^{-3} \rho\right)\right) \\
\left(8.371-\left[\left(0.1016 \times 10^{-3}\right) / \mathrm{R}\right]\right)\end{array}$ & $\rho=1.781$ & 11 \\
\hline PBX-9205 & $\begin{array}{l}\mathrm{D}=2.41+3.44 \rho \\
\mathrm{D}=4.995+\left(36.54 \times 10^{-3} \mathrm{~V}\right)(\mathrm{V}=\mathrm{vol} \%\end{array}$ & $\frac{\left(2.41+\left(3.44 \times 10^{-3} \rho\right)\right)}{\operatorname{RDX})}$ & $\rho=97.5 \% \mathrm{TMD}$ & \\
\hline PBX-9404 & $\begin{array}{l}\mathrm{D}=8.8-\left[\left(24.12 \times 10^{-3}\right) / \mathrm{R}\right] \\
\mathrm{D}=2.176+3.6 \rho \\
\Delta \mathrm{D} / \Delta \mathrm{T}=-1.165 \times 10^{-3}\end{array}$ & $\begin{array}{l}\left(8.8-\left[\left(0.24 \times 10^{-3}\right) / R\right]\right) \\
\left(2.176+\left(3.6 \times 10^{-3} \rho\right)\right)\end{array}$ & -54 to $74^{\circ} \mathrm{C}(219-347 \mathrm{~K})$ & \\
\hline Pentolite & $\Delta \mathrm{D} / \Delta \mathrm{T}=-0.4 \times 10^{-3}$ & & & \\
\hline PETN & $\begin{array}{l}\mathrm{D}=2.14+2.84 \rho \\
\mathrm{D}=3.19+3.7(\rho-0.37) \\
\mathrm{D}=7.92+3.05(\rho-1.65)\end{array}$ & $\left(2.14+\left(2.84 \times 10^{-3} \rho\right)\right)$ & $\begin{array}{l}\rho \leq 0.37 \\
0.37 \leq \rho \leq 1.65 \\
\rho \geq 1.65\end{array}$ & 16 \\
\hline RDX & $\mathrm{D}=2.56+3.47 \rho$ & $\left(2.56+\left(3.47 \times 10^{-3} \rho\right)\right)$ & $\rho>1.0$ & 17 \\
\hline TA TB & $\begin{array}{l}\mathrm{D}=0.343+3.94 \rho \\
\mathrm{D}=7.79-\left[\left(16.8 \times 10^{-3}\right) / \mathbf{R}\right]\end{array}$ & $\begin{array}{l}\left(0.343+\left(3.94 \times 10^{-3} \rho\right)\right) \\
\left(7.79-\left[\left(0.168 \times 10^{-3}\right) / \mathrm{R}\right]\right)\end{array}$ & $\begin{array}{l}\rho>1.2 \\
\rho=1.876\end{array}$ & 12 \\
\hline TNT & $\begin{aligned} D_{\infty} & =1.873+3.187 \rho \\
D_{\infty} & =6.763+3.187(\rho-1.534)-25.1(\rho \\
& +115.1(\rho-1.534)^{3}\end{aligned}$ & $\begin{array}{c}\left(1.873+\left(3.187 \times 10^{-3} \rho\right)\right) \\
\rho-1.534)^{2}\end{array}$ & $\begin{array}{l}0.9<\rho<1.534 \\
1.534<\rho<1.636\end{array}$ & 18 \\
\hline $\mathrm{XTX}-8003$ & $\begin{array}{l}\mathrm{D}=7.26-3.02 \times 10^{-3} / \mathrm{R} \\
\mathrm{D}=3.68+\left(44.8 \times 10^{-3} \mathrm{~W}\right)(\mathrm{W}=\mathrm{wt} \% \mathrm{Pl} \\
\Delta \mathrm{D} / \Delta \mathrm{T}=-2.34 \times 10^{-3}\end{array}$ & $\begin{array}{l}\left(7.26-\left[\left(30.2 \times 10^{-6}\right) / \mathrm{R}\right]\right) \\
\mathrm{ETN})\end{array}$ & $\begin{array}{l}\rho \simeq 1.53 \\
-54 \text { to } 74^{\circ} \mathrm{C}(219-347 \mathrm{~K})\end{array}$ & 14 \\
\hline
\end{tabular}




\section{Chapman-Jouguet Detonation Pressure}

In idealized detonation theory, a detonation front consists of several regions: (1) The leading surface is a shock front, chemically unreactive, with a discontinuous high pressure. (2) Following the shock front is the reaction zone where chemical reactions take place and release the bulk of the detonation energy; its thickness is estimated to be of the order of $10^{-1} \mathrm{~mm}$ for some pure explosives, but may vary by several powers of 10 depending on the HE. (3) The surface at the rear of the reaction zone is called the Chapman-Jouguet $(\mathrm{C}-\mathrm{J})$ plane. Complete thermodynamic equilibrium is assumed to exist at the $\mathrm{C}-\mathrm{J}$ plane, and the detonation products are said to be at the $\mathrm{C}-\mathrm{J}$ state. Detonation pressure normally refers to the pressure in the $\mathrm{C}-\mathrm{J}$ state; it is somewhat lower than the pressure at the shock front.

Experimentally, C-J pressures (Table 8-4) are measured by various indirect hydrodynamic methods. These measurements may span a range of $10-20 \%$, and their exact interpretation is uncertain. Calculated $C-J$ pressures (Table 8-4) are obtained with the RUBY hydrodynamic-thermodynamic computer code, which combines the Rankine-Hugoniot conservation equations, the $\mathrm{C}-\mathrm{J}$ condition, the density and enthalpy of formation $\Delta \mathrm{H}_{\mathrm{f}}$ of the explosive, the laws of chemical thermodynamic equilibrium, and the Brinkley-Kistiakowsky-Wilson (BKW) equation of state for the gaseous products. The code parameters are normalized with measured detonation velocities and $\mathrm{C}-\mathrm{J}$ pressures of several explosives. 
Table 8-4. Chapman-Jouguet detonation pressures $P_{\mathbf{C J}}$.

\begin{tabular}{|c|c|c|c|}
\hline \multirow[b]{2}{*}{ Explosive } & \multirow[b]{2}{*}{$\left(\mathrm{g} / \mathrm{cm}^{3} \stackrel{\rho}{\left.\left(\mathrm{Mg} / \mathrm{m}^{3}\right)\right)}\right.$} & \multicolumn{2}{|c|}{$P_{C J}\left(k b a r\left(10^{-1} \mathrm{GPa}\right)\right)^{a}$} \\
\hline & & Measured & $\begin{array}{l}\text { Calculated, } \\
\text { RUBY code }\end{array}$ \\
\hline Baratol & 2.61 & 140 & --- \\
\hline $\mathrm{BTF}$ & 1.882 & --- & 294 \\
\hline Comp B, Grade A & 1.717 & $295^{b}$ & $-\cdots$ \\
\hline Comp B-3 & 1.715 & 287 & 286 \\
\hline Comp C -4 & 1.59 & --- & 257 \\
\hline Cyclotol $(77 / 23)$ & 1.752 & 316 & -- \\
\hline DATB & 1.78 & 259 & 250 \\
\hline HMX & 1.90 & --- & 387 \\
\hline$L X-01$ & 1.31 & 1.56 & 177 \\
\hline$L X-04$ & 1.865 & 350 & 330 \\
\hline$L X-07-2$ & 1.865 & $\cdots$ & 346 \\
\hline$L X-09-0$ & 1.837 & 377 & 373 \\
\hline$L X-10$ & 1.860 & 375 & 360 \\
\hline$L X-11$ & 1.87 & $\cdots$ & 310 \\
\hline$L X-13$ & See XTX-8003 & & \\
\hline $\mathrm{LX}-14$ & 1.833 & 370 & -- \\
\hline MEN-II & 1.017 & --- & 113 \\
\hline $\mathrm{NC}(12.0 \% \mathrm{~N})$ & 1.58 & $\ldots$ & 200 \\
\hline $\mathrm{NC}(13.35 \% \mathrm{~N})$ & 1.58 & -- & 210 \\
\hline NG & 1.60 & 253 & 251 \\
\hline $\mathrm{NM}$ & 1.135 & 130 & 144 \\
\hline Octol $(77.6 / 22.4)$ & 1.821 & 342 & $-\cdot$ \\
\hline PBX-9007 & 1.60 & 265 & --- \\
\hline PBX -9010 & 1.783 & $328 \pm 5$ & -- \\
\hline PBX-9011 & 1.767 & $324 \pm 5$ & 298 \\
\hline PBX-9205 & 1.69 & -- & 288 \\
\hline PBX-9404 & 1.840 & 375 & 354 \\
\hline PBX-9407 & 1.60 & 287 & 300 \\
\hline Pentolite $(50 / 50)$ & 1.66 & -- & 280 \\
\hline PETN & $\begin{array}{l}1.77 \\
1.67 \\
0.99\end{array}$ & $\begin{array}{r}340 \\
300 \\
87\end{array}$ & $\begin{array}{l}326 \\
280 \\
100\end{array}$ \\
\hline RDX & 1.767 & 338 & 348 \\
\hline TACOT & 1.61 & --- & 181 \\
\hline TATB & 1.88 &.-- & 291 \\
\hline Tetryl & 1.71 & -- & 260 \\
\hline TNM & 1.65 & --- & 144 \\
\hline TNT & 1.630 & 190 & 207 \\
\hline $\mathrm{XTX}-8003$ & 1.546 & 170 & 210 \\
\hline \multicolumn{4}{|c|}{$\begin{array}{l}{ }^{2} \text { One } \mathrm{GPa}=10 \mathrm{kbar} . \\
\mathrm{b}_{\mathrm{Pressure}} \text { can be corrected for small changes in } \% \mathrm{RDX} \text { and density by the formula } \\
\mathrm{P}=295+1.57(\% \mathrm{RDX}-64)+678.5\left[\left(\rho_{0}-1.717\right) / \rho_{0}\right] .\end{array}$} \\
\hline
\end{tabular}




\section{Cylinder Test Measurements of Explosive Energy}

The cylinder test gives a measure of the hydrodynamic performance of an explosive. The test geometry is based on a constant volume of HE. The test system consists of an explosive charge $1 \mathrm{in.}(25.4 \mathrm{~mm})$ in diameter and $12 \mathrm{in}$. $(0.31 \mathrm{~m})$ long in a tightly fitting copper tube with a wall $0.1022 \mathrm{in}$. $(2.6 \mathrm{~mm})$ thick. The charge is initiated at one end. The radial motion of the cylinder wall is measured at about $8 \mathrm{in} .(0.2 \mathrm{~m})$ from the initiated end with a streak camera technique. Detailed radius-time data are available from the Organic Materials Division.

The kinetic energy imparted to the copper wall in a fixed geometry leads to a simple way of expressing the performance of the explosive. Two extreme geometric arrangements have been considered for the transfer of explosive energy to adjacent metal in this range of mass ratio of explosive to metal: (1) detonation normal or headon to the metal, and (2) detonation tangential or sideways to the metal. The effective explosive energy is frequently different for the two cases, even on a relative basis, because of the effects of the equations of state of the detonation products. The cylinder test provides a measure of the relative effective explosive energy for both head-on and tangential detonation. The radial wall velocity at 5-6 $\mathrm{mm}$ wall displacement, expressed as volume ratio $\left(\mathrm{V}=\mathrm{V} / \mathrm{V}_{0} \simeq 2\right)$ is indicative of explosive energy in head-on geometry. The wall velocity at $19 \mathrm{~mm}$ displacement, $\mathrm{V} / \mathrm{V}_{0} \approx 7$, is indicative of performance in tangential geometry.

Table 8-5 lists the specific wall kinetic energies at $6 \mathrm{~mm}$ and $19 \mathrm{~mm}$ wall displacement; these are characteristic of head-on and tangential detonation, respectively. Terminal wall velocities at breakup are about 7-10\% higher. Approximately 50\% of the detonation energy is transferred to the cylinder wall. 
Table 8-5. Cylinder-test measurements of explosive energy. ${ }^{11}$ Specific kinetic energy $\mathrm{E}_{\text {cyl }}$ delivered to the copper cylinder wall in geometries characterized by head-on (6 $\mathrm{mm}$ displacement) and tangential (19 $\mathrm{mm}$ displacement).

\begin{tabular}{lccc}
\hline & & \multicolumn{2}{c}{$E_{\text {cyl }}\left(\frac{(\mathrm{mm} / \mu \mathrm{sec})^{2}}{2}(\mathrm{MJ} / \mathrm{kg})\right)$} \\
\cline { 2 - 4 } Explosive & $\left(\mathrm{g} / \mathrm{cm}^{3}\left(\mathrm{Mg} / \mathrm{m}^{3}\right)\right)$ & $\begin{array}{c}\text { Head-on } \\
6 \mathrm{~mm}\end{array}$ & $\begin{array}{c}\text { Tangential } \\
19 \mathrm{~mm}\end{array}$ \\
\hline BTF & 1.859 & 1.305 & 1.680 \\
Comp B, Grade A & 1.717 & 1.035 & 1.330 \\
Cyclotol 77/23 & 1.754 & 1.140 & 1.445 \\
HMX & 1.894 & 1.410 & 1.745 \\
LX-04 & 1.865 & 1.170 & 1.470 \\
LX-07-1 & 1.857 & 1.250 & 1.575 \\
LX-09-0 & 1.836 & 1.320 & 1.675 \\
LX-10 & 1.862 & 1.315 & 1.670 \\
LX-11 & 1.876 & 1.105 & 1.360 \\
LX-13 & XTX-8003 & & \\
NM & $\left.1.11-15^{\circ} \mathrm{C}\right)$ & 0.560 & 0.745 \\
Octol 78/22 & $(284-288 \mathrm{~K})$ & & 1.535 \\
PBX-9010 & 1.813 & 1.215 & 1.470 \\
PBX-9011 & 1.788 & 1.160 & 1.415 \\
PBX-9404 & 1.777 & 1.120 & 1.620 \\
PBX-95016 & 1.843 & 1.295 & 1.656 \\
Pentolite 50/50 & 1.843 & 1.288 & 1.260 \\
PETN & 1.696 & 0.960 & 1.575 \\
TNT & 1.765 & 1.255 & 0.975 \\
XTX-8003 & 1.630 & 0.735 & 0.950 \\
\hline
\end{tabular}




\section{Equation of State}

The Jones-Wilkins-Lee (JWL) equation of state has been used to describe accurately the pressure-volume-energy behavior of the detonation products of explosives in applications of metal acceleration. All values are valid only for large charges. 19,20 The equation for pressure $P$ is

$$
P=A\left(1-\frac{\omega}{R_{1} V}\right) e^{-R_{1} V}+B\left(1-\frac{\omega}{R_{2} V}\right) e^{-R_{2} V}+\frac{\omega E}{V}
$$

and that for $\mathrm{P}_{\mathrm{S}}$, pressure as a function of volume at constant entropy (i. e., the isentrope), is

$$
P_{S}=A e^{-R_{1} V}+B e^{-R_{2} V}+C V^{-(\omega+1)},
$$

where $A, B$, and $C$ are linear coefficients (in Mbar (GPa)); $R_{1}, R_{2}$, and $\omega$ are nonlinear coefficients; $\mathrm{V}=\mathrm{V} / \mathrm{V}_{0}$ (volume of detonation products/volume of undetonated $\mathrm{HE}$ ); $\mathrm{P}$ and $\mathrm{P}_{\mathrm{S}}$ are in Mbar ( $\left.\mathrm{GPa}\right)$, and $\mathrm{E}$, the detonation energy per unit volume is in $\left(\mathrm{Mbar}-\mathrm{cm}^{3}\right) /$ $\mathrm{cm}^{3}\left(\left(\mathrm{GPa}-\mathrm{m}^{3}\right) / \mathrm{m}^{3}\right)$.

Some explosives have been subjected to a rigorous comparison in which coefficients are determined by matching the equation with experimental $\mathrm{C}-\mathrm{J}$ conditions, calorimetric data, and expansion behavior - usually cylinder-test data. These explosives are listed in Table 8-6 without additional notation. It has proved very useful to estimate coefficients for which only limited data are available; for these HEs the estimated parameters are listed as noted. The best estimates are for those explosives for which cylinder-test data are available. In many instances, $P_{C J}$ is estimated by assuming that $2.7<\Gamma<2.8$, where $\Gamma$ is the adiabatic coefficient of expansion. Where data were extremely limited, estimates were made from RUBY code calculations for $P_{C J}, D$, and $E_{0} ; R_{1}, R_{2}$, and $\omega$ were estimated. 


\begin{tabular}{|c|c|c|c|c|c|c|c|c|c|c|c|c|}
\hline \multirow[b]{4}{*}{ Explosive ${ }^{b}$} & \multirow{4}{*}{$\begin{array}{c}\text { Composition } \\
(\text { wt } \%)\end{array}$} & \multicolumn{5}{|c|}{$\mathrm{C}-\mathrm{J}$ parameters ${ }^{\mathrm{c}}$} & \multirow{2}{*}{\multicolumn{6}{|c|}{ Equation-of-state parameters }} \\
\hline & & \multirow{3}{*}{$\frac{\rho_{0}}{\left(\mathrm{~g} / \mathrm{cm}^{3}\right)}$} & \multirow{3}{*}{$\frac{P}{\left(\begin{array}{l}\text { (Mbar }) \\
(100 \mathrm{GPa})\end{array}\right.}$} & \multirow{3}{*}{ 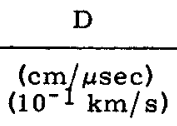 } & \multirow{3}{*}{ 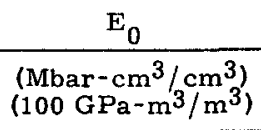 } & \multirow[t]{3}{*}{$\Gamma$} & & & & & & \\
\hline & & & & & & & A & $\mathrm{B}$ & $\mathrm{C}$ & \multirow[b]{2}{*}{$\mathrm{R}_{1}$} & \multirow[b]{2}{*}{$\mathrm{R}_{2}$} & \multirow[b]{2}{*}{$\omega$} \\
\hline & & & & & & & \multicolumn{3}{|c|}{$(\mathrm{Mbar}(100 \mathrm{GPa}))$} & & & \\
\hline & Benzotrifuroxan & 1.859 & $0.360^{*}$ & 0.848 & 0.1150 & 2.717 & 8.407 & 0.14960 & 0.01368 & 4.60 & 1.20 & 0.30 \\
\hline$\underset{\text { Grade A }}{\text { Comp }}$ & $\mathrm{RDX} / \mathrm{TNT} 64 / 36$ & 1.717 & 0.295 & 0.798 & 0.0850 & 2.706 & 5.242 & 0.07678 & 0.01082 & 4.20 & 1.10 & 0.34 \\
\hline Cyclotol & RDX/TNT $77 / 23$ & 1.754 & 0.320 & 0.825 & $0.0920 *$ & 2.731 & 6.034 & 0.09924 & 0.01075 & 4.30 & 1.10 & 0.35 \\
\hline DIPAM** & $\begin{array}{l}\text { Diamino-hexanitro } \\
\text { biphenyl }\end{array}$ & 1.550 & $0.180^{*}$ & 0.670 & $0.0620 *$ & 2.842 & 4.254 & 0.08007 & 0.01175 & 4.70 & 1.30 & 0.39 \\
\hline$E L-506 A *$ & $\mathrm{PETN} / \mathrm{CH}_{2} 85 / 15$ & 1.480 & $0.205 *$ & 0.720 & $0.0700 *$ & 2.752 & 3.738 & 0.03647 & 0.01138 & 4.20 & 1.10 & 0.30 \\
\hline EL-506C & $\mathrm{PETN} / \mathrm{NC} / \mathrm{CH}_{2} 63 / 8 / 29$ & 1.480 & $0.195^{*}$ & 0.700 & $0.0620 *$ & 2.719 & 3.490 & 0.04524 & 0.00854 & 4.10 & 1.20 & 0.30 \\
\hline HMLX & Tetranitrotetrazacyclooctane & 1.891 & $0.420 *$ & 0.911 & 0.1050 & 2.740 & 7.783 & 0.07071 & 0.00643 & 4.20 & 1.00 & 0.30 \\
\hline HNS** & Hexanitrostilbene & 1.540 & $0.175^{*}$ & 0.660 & $0.0600 *$ & 2.885 & 4.469 & 0.08358 & 0.01010 & 4.80 & 1.30 & 0.39 \\
\hline$L X-01 * *$ & TNM/NM/INP $33.3 / 52 / 14.7$ & 1.230 & 0.155 & 0.684 & $0.0610 *$ & 2.711 & 3.110 & 0.04761 & 0.01039 & 4.50 & 1.00 & 0.35 \\
\hline$L X-04-1$ & HMX/Viton $85 / 15$ & 1.865 & 0.340 & 0.847 & 0.0950 & 2.936 & 8.498 & 0.15277 & 0.01159 & 4.65 & 1.30 & 0.35 \\
\hline $\mathrm{LX}-07$ & HMX/Viton $90 / 10$ & 1.865 & 0.355 & 0.864 & $0.1000 *$ & 2.921 & 8.710 & 0.13896 & 0.00891 & 4.60 & 1.15 & 0.30 \\
\hline $\mathrm{L} X-09-0$ & HMX/DNPA/FEFO 93/4.6/2.4 & 1.838 & 0.373 & 0.884 & $0.1050 *$ & 2.851 & 8.684 & 0.18711 & 0.00729 & 4.60 & 1.25 & 0.25 \\
\hline LX-10 & HMX/Viton $95 / 5$ & 1.860 & 0.375 & 0.882 & $0.1040 *$ & 2.861 & 8.802 & 0.17437 & 0.00809 & 4.60 & 1.20 & 0.30 \\
\hline LX-11 & HMX/Viton $80 / 20$ & 1.875 & 0.330 & 0.832 & $0.0900 *$ & 2.930 & 7.791 & 0.10668 & 0.00885 & 4.50 & 1.15 & 0.30 \\
\hline LX-13 & See XTX-8003 & & & & & & & & & & & \\
\hline NM & Nitromethane & 1.128 & 0.125 & 0.628 & 0.0510 & 2.538 & 2.092 & 0.05689 & 0.00770 & 4.40 & 1.20 & 0.30 \\
\hline Octol & HMX/TNT 78/22 & 1.821 & 0.342 & 0.848 & $0.0960 *$ & 2.830 & 7.486 & 0.13380 & 0.01167 & 4.50 & 1.20 & 0.38 \\
\hline PBX-9010 & RDX/KEL F 90/10 & 1.787 & 0.340 & 0.839 & 0.0900 & 2.700 & 5.814 & 0.06801 & 0.00234 & 4.10 & 1.00 & 0.35 \\
\hline PBX-9011 & HMX/Estane 90/10 & 1.777 & 0.340 & 0.850 & $0.0890 *$ & 2.776 & 6.347 & 0.07998 & 0.00727 & 4.20 & 1.00 & 0.30 \\
\hline PBX-9404-3 & $\mathrm{HMX} / \mathrm{NC} / \mathrm{CEF} 94 / 3 / 3$ & 1.840 & 0.370 & 0.880 & 0.1020 & 2.850 & 8.545 & 0.20493 & 0.00754 & 4.60 & 1.35 & 0.25 \\
\hline PBX-9407 & RDX/EXON 94/6 & 1.600 & 0.265 * & 0.791 & $0.0860 *$ & 2.513 & 5.73187 & 0.146390 & 0.01200 & 4.60 & 1.40 & 0.32 \\
\hline Pentolite & $\mathrm{TNT} / \mathrm{PETN} 50 / 50$ & 1.670 & $0.250 *$ & 0.747 & 0.0800 & 2.727 & 4.911 & 0.09061 & 0.00876 & 4.40 & 1.10 & 0.30 \\
\hline PETN*** & $\begin{array}{l}\text { Pentaerythritol } \\
\text { tetranitrate }\end{array}$ & $\begin{array}{l}1.770 \\
1.500 \\
1.260 \\
0.880\end{array}$ & $\begin{array}{l}0.335 \\
0.220 \\
0.140 \\
0.062\end{array}$ & $\begin{array}{l}0.830 \\
0.745 \\
0.654 \\
0.517\end{array}$ & $\begin{array}{l}0.1010 \\
0.0856 * \\
0.0719 * \\
0.0502 *\end{array}$ & $\begin{array}{l}2.640 \\
2.788 \\
2.831 \\
2.668\end{array}$ & $\begin{array}{l}6.170 \\
6.253 \\
5.731 \\
3.486\end{array}$ & $\begin{array}{l}0.16926 \\
0.23290 \\
0.20160 \\
0.11288\end{array}$ & $\begin{array}{l}0.00699 \\
0.01152 \\
0.01267 \\
0.00941\end{array}$ & $\begin{array}{l}4.40 \\
5.25 \\
6.00 \\
7.00\end{array}$ & $\begin{array}{l}1.20 \\
1.60 \\
1.80 \\
2.00\end{array}$ & $\begin{array}{l}0.25 \\
0.28 \\
0.28 \\
0.24\end{array}$ \\
\hline Tetryl ** & Trinitrophenylmethylnitramine & 1.730 & 0.285 & 0.791 & 0.0820 & 2.798 & 5.868 & 0.10671 & 0.00774 & 4.40 & 1.20 & 0.28 \\
\hline TNT & Trinitrotoluene & 1.630 & 0.210 & 0.693 & 0.0600 & 2.727 & 3.738 & 0.03747 & 0.00734 & 4.15 & 0.90 & 0.35 \\
\hline $\mathrm{XTX}-8003$ & PETN/Sylgard $80 / 20$ & 1.540 & 0.170 & 0.735 & $0.0660 *$ & 3.894 & 27.140 & 0.17930 & 0.01202 & 7.00 & 1.60 & 0.35 \\
\hline
\end{tabular}

\footnotetext{
${ }^{\mathrm{a}}$ One $\mathrm{Mbar}=100 \mathrm{GPa}$.

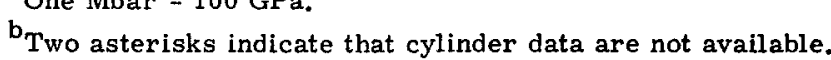

$c_{V a l u e s}$ followed by one asterisk are estimated quantities.
} 


\section{Detonation Energy}

Detonation energies $^{21}$ (as measured by metal acceleration in the cylinder test) of formulations containing mostly HMX can be correlated with the volume fraction of additives by a simple linear relationship

$$
E=E_{H M X}\left(1-\sum S_{i} v_{i}\right)
$$

where

$$
\begin{aligned}
\mathrm{E}= & \text { detonation energy per unit volume of a formulation at its loaded } \\
& \text { density, } \\
\mathrm{E}_{\mathrm{HMX}}= & \text { detonation energy per unit volume of pure } \mathrm{HMX} \text { at its theoretical } \\
& \text { maximum density }(\mathrm{TMD}) \text { of } 1.90 \mathrm{~g} / \mathrm{cm}^{3}\left(\mathrm{Mg} / \mathrm{m}^{3}\right) . \text { The reference } \\
& \text { value is (wall velocity) at } 19 \mathrm{~mm} \text { displacement in the cylinder } \\
& \text { test corrected to } \mathrm{TMD} \text {. The corrected wall velocity is } \\
& 1.872 \mathrm{~mm} / \mu \mathrm{sec}(\mathrm{km} / \mathrm{s}) . \\
\mathrm{S}_{\mathrm{i}}= & \text { characteristic energy decrement for each diluent, } \\
\mathrm{V}_{\mathrm{i}}= & \text { volume fraction of each additive. }
\end{aligned}
$$

The energy decrement for a fixed combination of two or more ingredients is readily computed as

$$
\mathrm{S}_{\mathrm{b}}=\frac{\sum \mathrm{S}_{\mathrm{i}} \mathrm{v}_{\mathrm{i}}}{\sum \mathrm{v}_{\mathrm{i}}} \quad \text { and } \quad \mathrm{v}_{\mathrm{b}}=\sum \mathrm{v}_{\mathrm{i}} \text {, }
$$

where the subscript $b$ denotes the fixed combination. The quantity $\mathrm{S}_{\mathrm{b}} \mathrm{V}_{\mathrm{b}}$ for the combination becomes one of the terms in Eq. 8-1. An $S_{i} V_{i}$ term for air or void takes account of porosity in the actual explosive. A convenient form of Eq. 8-1 gives relative energy as a percentage of HMX energy, $\mathrm{E}_{\operatorname{Rel} \%}$, and as a function of the volume percent,

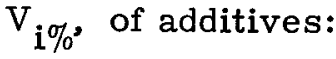

$$
\mathrm{E}_{\operatorname{Re} 1 \%}=\frac{100 \mathrm{E}}{\mathrm{E}_{\mathrm{HMX}}}=100-\sum \mathrm{S}_{\mathrm{i}} \mathrm{V}_{\mathrm{i} \%} \text {. }
$$

The characteristic $S_{i}$ can be recognized as a percent energy degradation from pure HMX for each volume percent of the additive. The $S_{i}$ values for a number of additives are given in Table 8-7. Neither the applicable range of composition nor the exact linearity of Eq. 8-1 has been tested, but all formulations contained at least $70 \mathrm{wt} \%$ HMX. 
Table 8-7. Characteristic energy decrement $S_{i}$ from pure HMX for additives to HMX.

\begin{tabular}{lc|lc}
\hline Additive $^{2}$ & $\begin{array}{c}\mathrm{S}_{\mathrm{i}} \\
\left(\mathrm{E}_{\mathrm{Rel} \%} / \mathrm{V}_{\mathrm{i}}\right)\end{array}$ & Additive & $\begin{array}{c}\mathrm{S}_{\mathrm{i}} \\
\left(\mathrm{E}_{\mathrm{Rel} \%} / \mathrm{V}_{\mathrm{i}}\right)\end{array}$ \\
\hline AFNOL & 0.75 & FEFO & 0.3 \\
Air & 1.3 & Graphite & 1.3 \\
BEAF & 0.75 & $*$ HNS & 0.5 \\
BDNPA & 0.75 & Kel F & 1.0 \\
BDNPF & 0.75 & NC & 0.75 \\
CAB & 1.3 & $*$ NG & 0.3 \\
CEF & 1.3 & Nitrosorubber & 0.75 \\
*DATB & 0.5 & $*$ NONA & 0.5 \\
DFTNB & 0.25 & Polyethylene & 1.3 \\
*DIPAM & 0.5 & Sylgard & 1.3 \\
BDNPA/BDNPF 50/50 & 0.75 & $*$ TACOT & 0.5 \\
DNPA & 0.75 & $*$ TATB & 0.5 \\
DNPN & 0.75 & Teflon & 1.0 \\
EDNP & 0.75 & TNT & 0.5 \\
Estane & 1.3 & Viton & 1.0 \\
EXON (polyvinyl chloride/ & 1.0 & Void & 1.3 \\
polyvinyl alcohol 85/15 & & Wax & 1.3 \\
\hline
\end{tabular}

${ }^{a}$ An asterisk denotes materials not actually tested; values estimated with RUBY code. 


\section{References}

1. E. E. Kilmer, J. Spacecr. Rockets 5, 1216-1219 (1968).

2. U.S. Material Command, Engineering Design Handbook, Explosives Series, Properties of Explosives of Military Interest, Army Material Command, Rept. A MCP-706-177 (1967).

3. E. E. Kilmer, Naval Ordnance Laboratory, White Oak, Md., personal communication (1966).

4. A. C. Schwartz, Application of Hexanitrostilbene (HNS) in Explosive Components, Sandia Laboratories, Albuquerque, N. Mex., Rept. SC-RR-710673 (1972).

5. J. R. Humphrey, Lawrence Livermore Laboratory, personal communication (1974).

6. A. W. Campbell, M. E. Malin, T. J. Boyd, and J. A. Hull, Rev. Sci. Instrum. 27, $567-574$ (1956).

7. T. M. Benziger, X-0242: A High-Energy Plastic-Bonded Explosive, Los Alamos Scientific Laboratory, N. Mex., Rept. LA-4872 (1972).

8. A. N. Dremin, Combust. Explos. Shock Waves 2 (4), 45-51 (1966).

9. M. J. Kamlet and S. J. Jacobs, J. Chem. Phys. 48, 23-35 (1968).

10. J. B. Panowski, Los Alamos Scientific Laboratory, N. Mex., personal communication (1974).

11. H. C. Hornig, Lawrence Livermore Laboratory, personal communication (1972).

12. A. Popolato, Los Alamos Scientific Laboratory, N. Mex., personal communication (1957).

13. D. Price and A. R. Clairmont, Jr., "Explosive Behavior of Nitroguanidine," in Symp. (Intern.) on Combustion, 12th, Combustion Institute, Pittsburgh (1969).

14. M. Finger, Lawrence Livermore Laboratory, personal communication (1971).

15. A. W. Campbell, M. E. Malin, and T. E. Holland, J. Appl. Phys. 27, 963 (1965).

16. H. C. Hornig, E. L. Lee, M. Finger, and K. E. Kurrle, "Equation of State of Detonation Products," in Proc. 5th Symp. (Intern.) on Detonation, U.S. Office of Naval Research, Washington, D.C., Rept. ACR-184 (1970), pp. 503-512.

17. E. L. Lee, Lawrence Livermore Laboratory, personal communication (1971).

18. M. J. Urizar, E. James, Jr., and L. C. Smith, Phys. Fluids 4, 262-274 (1961).

19. E. L. Lee and M. Finger, Lawrence Livermore Laboratory, personal communication (1972).

20. E. L. Lee, H. C. Hornig, and J. W. Kury, Adiabatic Expansion of High Explosive Detonation Products, Lawrence Livermore Laboratory, Rept. UCRL-50422 (1968).

21. J. W. Kury, H. C. Hornig, E. L. Lee, J. L. McDonnel, D. L. Ornellas, M. Finger, F. M. Strange, and M. L. Wilkins, "Metal Acceleration by Chemical . Explosives," in Proc. 4th Symp. (Intern.) on Detonation, U.S. Office of Naval Research, Washington, D. C., Rept. ACR-126 (1965), pp. 3-13. 


\section{SENSITIVITY AND INITIATION}

Several tests have been designed to evaluate the sensitivity of HEs to different kinds of impact under varying conditions. This aspect of the characterization of explosives is treated here in some detail in descriptions of drop-weight impact, Susan, skid, and gap tests. The sensitivity of liquid explosives can be assessed through determination of their low-velocity detonation (LVD) and high-velocity detonation (HVD) characteristics as established by a gap test. Some critical energies for shock initiation are given.

\section{Drop-Weight Test}

The drop-weight machine, or drop hammer, offers one means of evaluating impact sensitivity. In the test, a 2.5 - or 5 - kg weight is dropped from a preset height onto a small ( 35-mg) sample of explosive. A series of drops is made from different heights, and explosion or nonexplosion is recorded. The criterion for "explosion" is an arbitrarily set level of sound produced by the explosive on impact. The result of the test is summarized as $\mathrm{H}_{50}$, the height in $\mathrm{cm}(\mathrm{m})$ at which the probability of explosion is $50 \%$.

Values in Table 9-1 were determined on a machine patterned after the one designed at the Explosives Division, Atomic Weapons Research Establishments (AWRE) at the time of World War II. Because of the extremely complicated process involved in initiation by impact, these drop-hammer data serve only as approximate indications

of sensitivity. The $\mathrm{H}_{50}$ values are quite dependent on the anvil surface. Two surfaces are usually used: sandpaper (type 12 tooling) and roughened steel (type 12B tooling).

In general, values below $25 \mathrm{~cm}(0.25 \mathrm{~m})$ usually indicate relative sensitivity to impact. Values of 25 to $70 \mathrm{~cm}(0.25$ to $0.70 \mathrm{~m})$ indicate a material of moderate sensitivity that possibly can be handled in accordance with standard procedures. Values above $70 \mathrm{~cm}(0.70 \mathrm{~m})$ usually indicate relative insensitivity to impact.

The indications of sensitivity given by the drop-hammer test are always verified by large-scale testing (see the succeeding tests in this section) for any material to be handled in large quantities. 
Table 9-1. Sensitivities of explosives as indicated by the drop-weight impact test.

\begin{tabular}{|c|c|c|c|}
\hline \multirow[b]{2}{*}{ Explosive } & \multicolumn{3}{|c|}{$\mathrm{H}_{50}\left(\mathrm{~cm}\left(10^{-2} \mathrm{~m}\right)\right)$} \\
\hline & $\begin{array}{l}\text { Type 12 } \\
\text { tooling }\end{array}$ & $\begin{array}{l}\text { Type 12B } \\
\text { tooling }\end{array}$ & 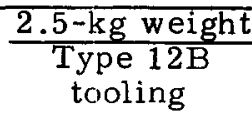 \\
\hline Baratol & 95 & -- & -- \\
\hline Boracitol & $>177$ & -- & -- \\
\hline BTF & 11 & -- & -- \\
\hline Comp B, Grade A & 45 & -- & -- \\
\hline Comp B-3 & 29 & 65 & -- \\
\hline Cyclotol 75/25. & 33 & -- & -- \\
\hline DATB & $>177$ & $>177$ & -- \\
\hline DIPA $M^{1}$ & 95 & -- & -- \\
\hline DNPA & $>177$ & -- & -- \\
\hline$E L-506 A$ & 59 & -- & -- \\
\hline $\mathrm{EL}-506 \mathrm{C}$ & 54 & -- & -- \\
\hline FEFO & 28 & -- & -- \\
\hline $\mathrm{H}-6$ & 60 & - & -- \\
\hline $\mathrm{HMX}$ & 33 & 40 & -- \\
\hline $\mathrm{LX}-02-1$ & 80 & -- & -- \\
\hline $\mathrm{LX}-04-1$ & 41 & 55 & -- \\
\hline LX X-07-2 & 38 & -- & -- \\
\hline$L X-09-0$ & 32 & -- & -- \\
\hline $\mathrm{LX}-10-0$ & 35 & -- & 40 \\
\hline $\mathrm{LX}-11-0$ & 59 & -- & -- \\
\hline$L X-13$ & See XTX-8002 & & \\
\hline $\mathrm{LX}-14-0$ & & & 51 \\
\hline $\mathrm{NQ}$ & $>177$ & -- & -- \\
\hline Octol & 41 & -- & -- \\
\hline PBX-9007 & 35 & 28 & -- \\
\hline PBX-9010 & 30 & 45 & -- \\
\hline PBX-9011 & 44 & 98 & -- \\
\hline PBX-9205 & 42 & 36 & -- \\
\hline PBX-9404 & 34 & 35 & 40 \\
\hline PBX-9407 & 33 & 30 & -- \\
\hline PBX $-9501^{2}$ & 44 & 80 & -- \\
\hline Pentolite 50/50 & $\sim 35$ & -- & -- \\
\hline PETN & 11 & -- & - \\
\hline RDX & 28 & -- & -- \\
\hline TATB & $>100$ & -- & -- \\
\hline Tetryl & 28 & -- & - \\
\hline TNT & 80 & $>177$ & -- \\
\hline $\begin{aligned} \mathrm{XTX}-8003 & \begin{array}{l}\text { (uncured) } \\
\text { (cured) }\end{array}\end{aligned}$ & $\begin{array}{l}25 \\
21\end{array}$ & -- & -- \\
\hline
\end{tabular}




\section{Susan Test}

The Susan Sensitivity Test ${ }^{2}$ is a projectile impact test with the projectile shown in Fig. 9-1. The weight of explosive in the projectile head is about $1 \mathrm{lb}(0.45 \mathrm{~kg})$. The

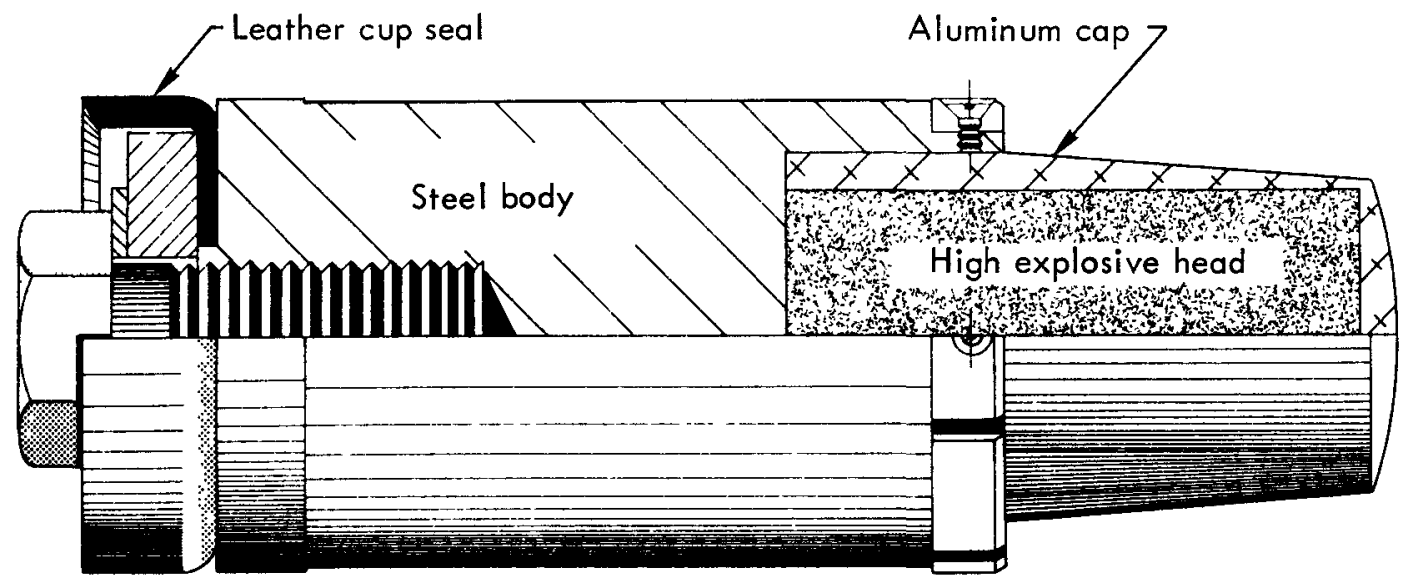

Fig. 9-1. The Susan projectile. Scaled drawing; the high explosive head is 4 in. long by 2 in. in diameter $(0.102 \mathrm{~m} \times 0.051 \mathrm{~m})$.

target is armor-plate steel. The results of the tests are expressed in terms of a "sensitivity" curve in which the relative "point-source detonation energy" released by the explosive as a result of the impact is plotted against the velocity of the projectile. The relative point-source detonation energy can be derived from a transit-time measurement of the air shock from the point of impact to a pressure gauge $10 \mathrm{ft}(3.1 \mathrm{~m})$ away. The results determined in this manner are somewhat subjective, particularly when the reaction level shows a large but relatively slow increase with time. The preferred way to get at the "point-source detonation energy" at present is to relate it to the overpressure measured $10 \mathrm{ft}(3.1 \mathrm{~m})$ from the impact. This results in much more reproducible data and is not subject to many of the errors of the transit-time measurements.

On the figures in this section the energy scale has been set to range from zero for no chemical reaction to approximately 100 for the most violent detonation-like reactions (all explosive consumed) for the most energetic explosives. Less violent burning reactions that appear to consume all of the explosive can give values on the scale as low as 40; the energy equivalent of TNT fully reacted as a point source, would register at 70 on the scale. For each explosive considered, comments are made on the details of the impact process that seem to bear on the impact safety of an explosive. Remarks about probabilities of large reactions are relevant to unconfined charges in the $25-1 b(11.3-\mathrm{kg})$ class. Smaller unconfined charges show a trend of decreasing reaction level as the charge size gets smaller. 
References to the "pinch" stage of the impact refer to the terminal stage when the nose cap has been completely split open longitudinally and peeled back to the steel projectile body, which is rapidly being brought to a halt. 


\section{Comp B-3}

Comp B-3 (RDX/TNT 60/40) behaves reasonably well in the standard Susan test (Fig. 9-2). Ignition is observed only after extensive splitting and deformation of the projectile nosecap, more or less at the beginning of the "pinch" stage of impact. This results in a threshold velocity of about $180 \mathrm{ft} / \mathrm{sec}(55 \mathrm{~m} / \mathrm{sec})$. The reaction level is quite dependent on impact velocity; it never rises to its full potential even at an impact velocity of $1500 \mathrm{ft} / \mathrm{sec}(457 \mathrm{~m} / \mathrm{sec})$. Any reaction enhancement is seen quite soon after initial ignition. Comp B-3 should be considered as generally rather difficult to ignite by mechanical means and as having a low probability for violent reaction once ignited, provided the relative confinement is rather low. It has given substantially larger reactions in the Mod-IA projectile than in the standard Mod I; the important difference between the two projectiles appears to be the exceptionally straight flight of the Mod-IA, which results in higher pressures on the explosive and more effective confinement. Comp B-3 has been observed to detonate in impact geometries where there was good inertial confinement at the time of ignition, and where it has been subjected to mechanical work by the impact.

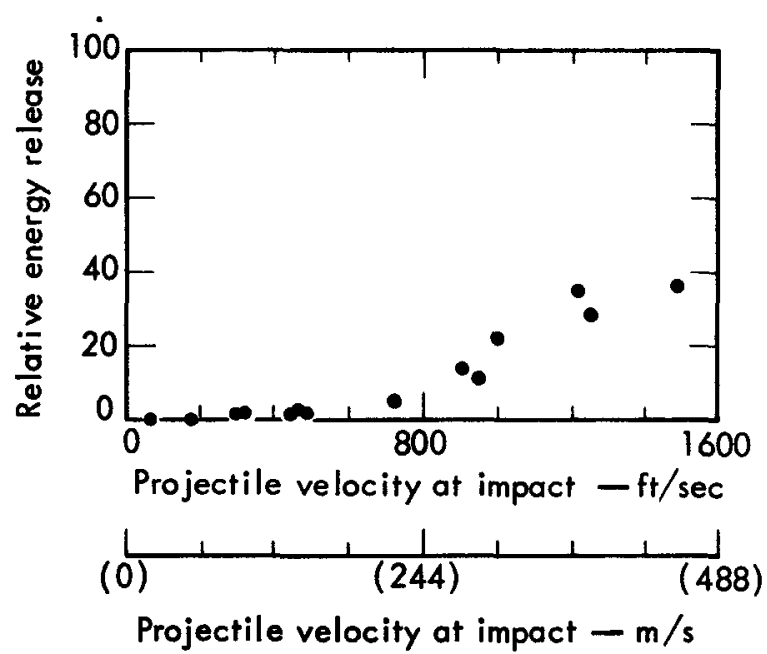

Fig. 9-2. Susan test: Comp B-3. Conversion factor: $1 \mathrm{ft} / \mathrm{sec}=3.048 \times 10^{-1} \mathrm{~m} / \mathrm{s}$. 


\section{Cyclotol 75/25}

Cyclotol 75/25 (RDX/TNT 75/25) has both good and bad properties as measured by the Susan test (Fig. 9-3). The threshold velocity for reaction is probably about $180 \mathrm{ft} / \mathrm{sec}(55 \mathrm{~m} / \mathrm{sec})$, which is rather typical of the TNT-bonded cast explosives and higher than most plastic-bonded explosives. On the other hand, reaction levels generally are moderately high at relatively low velocity and on occasion are considerably higher. Cyclotol 75/25 should be considered as generally rather difficult to ignite by mechanical means but capable of a large reaction once ignited. Note should be taken of the very low drop height for ignition in the 14-deg (0.24-rad) skid test (Table 9-2).

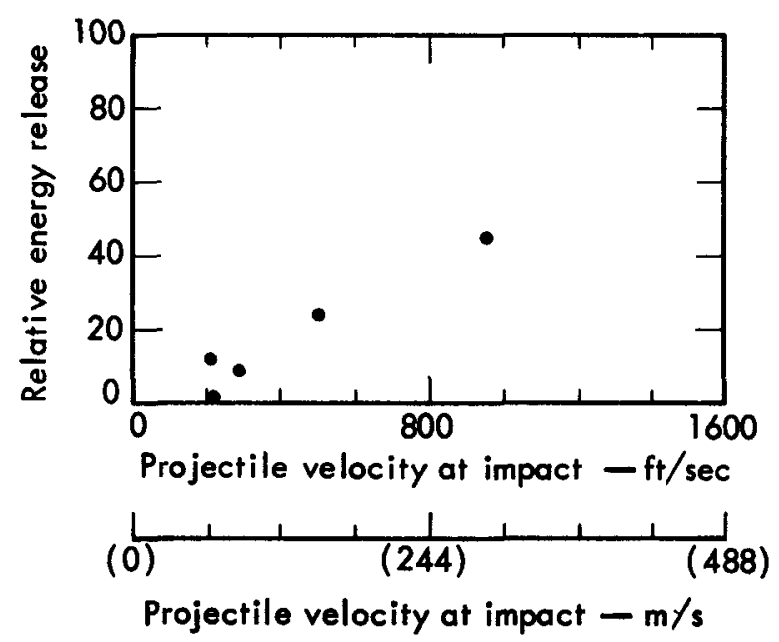

Fig. 9-3. Susan test: Cyclotol 75/25. Conversion factor: $1 \mathrm{ft} / \mathrm{sec}=3.048 \times 10^{-1} \mathrm{~m} / \mathrm{s}$. 
$\underline{L X-02-1}$

LX-02-1 (PETN/butyl rubber/acetyltributyl citrate/Cab-O-Sil 73.5/17.6/6.9/2.0) appears more difficult to ignite in the Susan test than XTX-8003, but the exact threshold value is poorly defined due to the very small reactions observed and the limited number of tests (Fig. 9-4). Even at $505 \mathrm{ft} / \mathrm{sec}(154 \mathrm{~m} / \mathrm{s})$, the reaction level was very low. The very limited data indicate that LX-02-1 has a very small probability of building to a violent reaction from an accidental ignition where there is relatively little or no confinement.

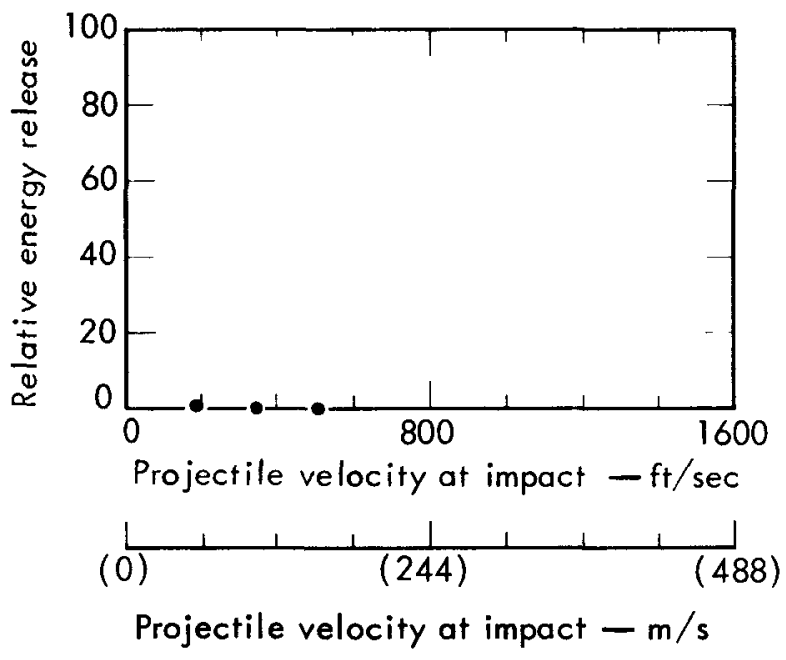

Fig. 9-4. Susan test: LX-02-1. Conversion factor: $1 \mathrm{ft} / \mathrm{sec}=3.048 \times 10^{-1} \mathrm{~m} / \mathrm{s}$. 


\section{LX-04-1}

LX-04-1 (HMX/Viton 85/15) is moderately easy to ignite in the Susan test (Fig. 9-5), requiring an impact velocity of 140 to $150 \mathrm{ft} / \mathrm{sec}(43$ to $46 \mathrm{~m} / \mathrm{s})$. At impact velocities higher than threshold, the nosecap deforms about an inch before ignition is observed. Reaction levels are dependent on impact velocity, rising very slowly to three or four energy units from threshold out to about $350 \mathrm{ft} / \mathrm{sec}(107 \mathrm{~m} / \mathrm{s})$ and then rising more rapidly as impact velocity increases to 40 or 50 energy units at $1000 \mathrm{ft} / \mathrm{sec}$ $(305 \mathrm{~m} / \mathrm{s})$. Thus, while LX-04-1 is moderately easy to ignite from mechanical impact, it has a low probability of building to a violent reaction or detonation from a minor ignition where there is little or no confinement. Note that LX-04-1 frequently has been observed to detonate high-order in other impact test geometries where the effective confinement was rather good and the explosive was well pulverized to give a large surface area at the time of ignition.

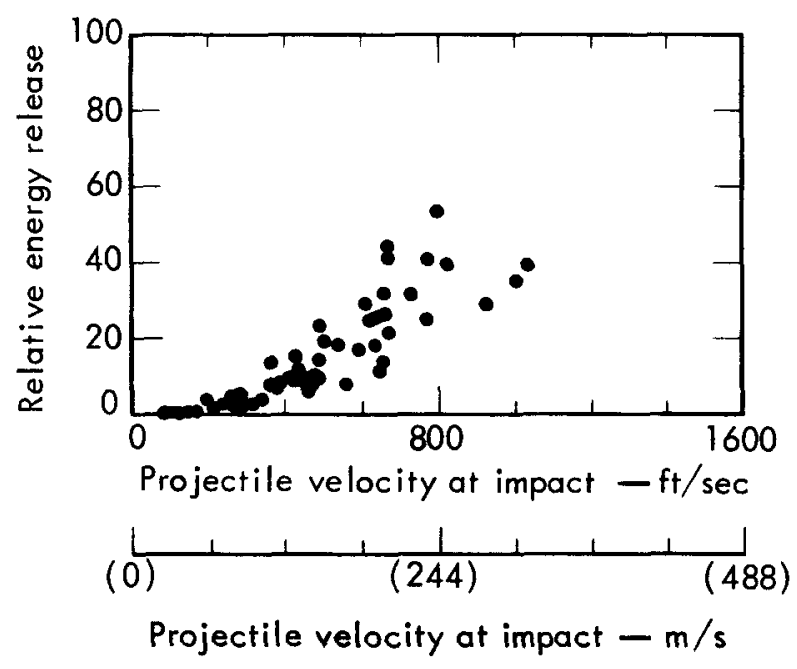

Fig. 9-5. Susan test: LX-04-1. Conversion factor: $1 \mathrm{ft} / \mathrm{sec}=3.048 \times 10^{-1} \mathrm{~m} / \mathrm{s}$. 


\section{$\underline{\text { LX-07-2 }}$}

LX-07-2 (HMX/Viton 90/10) is intermediate in sensitivity between PBX-9404 and LX-04-1. The threshold for reaction is about $125 \mathrm{ft} / \mathrm{sec}(38 \mathrm{~m} / \mathrm{s})$, and the reaction level, while dependent upon impact velocity, becomes large at a rather low velocity (Fig. 9-6). Small changes in manufacturing variables can affect the extent of reaction in the Susan test. The LX-07-2 initially tested was a handmade batch that gave appreciably larger reactions than previously tested LX-07-type explosives. Figure 9-6 also shows the results for RX-07-BA, manufactured at the Holston Army Ammunition Plant, which meets the LX-07-2 specifications and, based on the results of three shots, appears to be more like the previous LX-07-type explosives. Thus, LX-07-2 has a low threshold for reaction but only a moderate rate of buildup to violent reaction. It appears that accidental mechanical ignition of LX-07-2 would have a moderate probability of building to violent deflagration or detonation where the relative confinement was rather low.

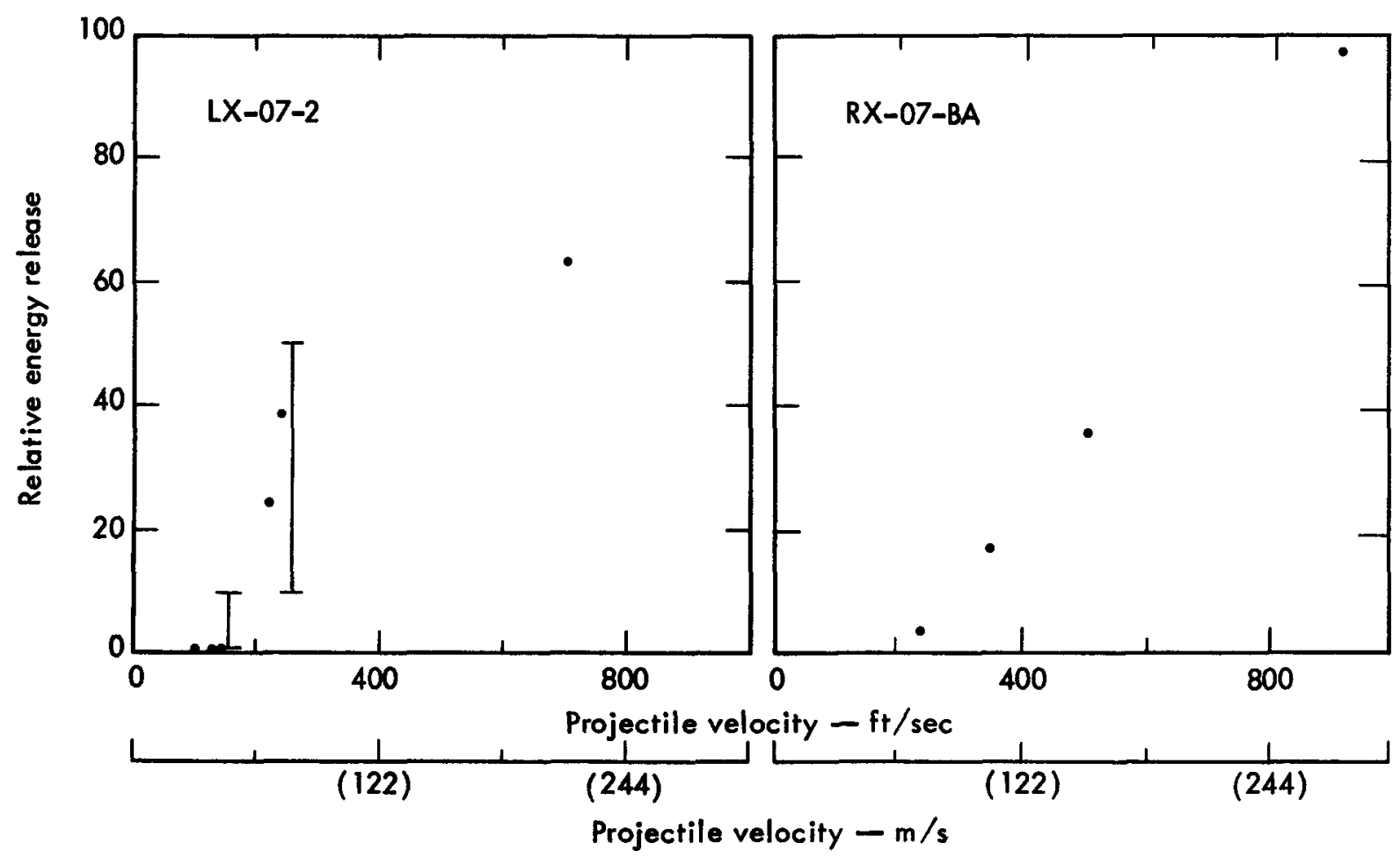

Fig. 9-6. Susan test: LX-07-2 and RX-07-BA. Conversion factor: $1 \mathrm{ft} / \mathrm{sec}=3.048$ $\times 10^{-1} \mathrm{~m} / \mathrm{s}$. 


\section{$\underline{L X-09-0}$}

LX-09-0 (HMX/pDNPA/FEFO 93/4.6/2.4) displays some very undesirable properties in the Susan test (Fig. 9-7); it is very similar to PBX-9404 in many respects. -Ignition is seen after about $0.5-\mathrm{in}$. $(13-\mathrm{mm})$ deformation of the projectile nosecap, which is consistent with the very low threshold velocity of $110 \mathrm{ft} / \mathrm{sec}(34 \mathrm{~m} / \mathrm{s})$. As with PBX-9404, "pinch"-stage enhancement of the reaction is observed only at impact velocities greater than about $200 \mathrm{ft} / \sec (51 \mathrm{~m} / \mathrm{s})$. At lower-impact velocities, reactions build to violent levels with sufficient rapidity that no "pinch" stage enhancement is observed. The reaction levels observed are generally quite high and independent of impact velocity. Thus, LX-09-0 exhibits both low-threshold velocity for reaction and rapid buildup to violent reaction. Any accidental mechanical ignition has a large probability of building to a violent deflagration or detonation.

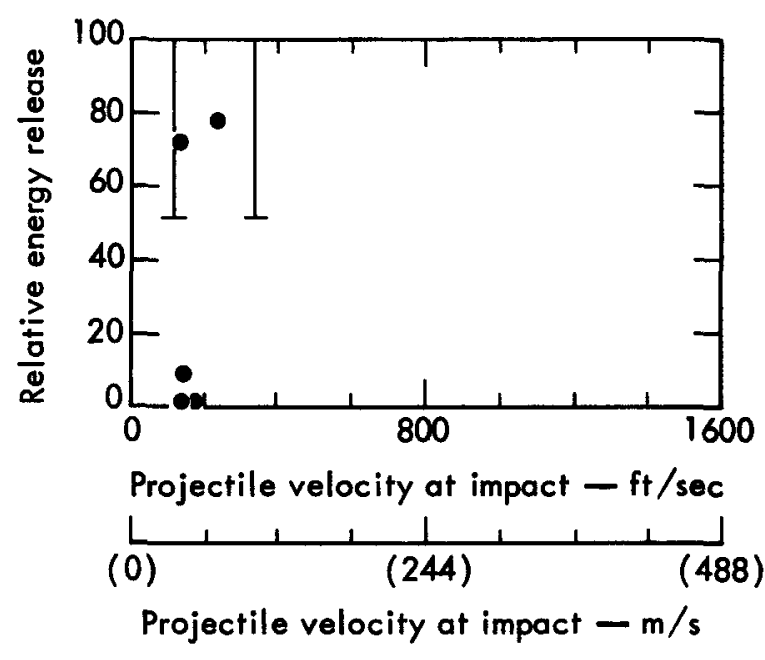

Fig. 9-7. Susan test: LX-09-0. Conversion factor: $1 \mathrm{ft} / \mathrm{sec}=3.048 \times 10^{-1} \mathrm{~m} / \mathrm{s}$. 
LX-10-0 (HMX/Viton 95/5) displays some very undesirable properties in the Susan Test (Fig. 9-8). Ignition is observed after about 0.6-in. (15 mm) of projectile nosecap deformation, which is consistent with the low threshold velocity of about $120 \mathrm{ft} / \mathrm{sec}(37 \mathrm{~m} / \mathrm{s})$. The reaction levels observed are generally quite high and independent of impact velocity. The reaction buildup is sufficiently rapid that no "pinch" stage enhancement of the reaction is observed. LX-10-0 exhibits both a low threshold for reaction and an extremely rapid buildup to violent reaction. Any accidental mechanical ignition of LX-10-0 has a very large probability of building to violent deflagration or detonation.

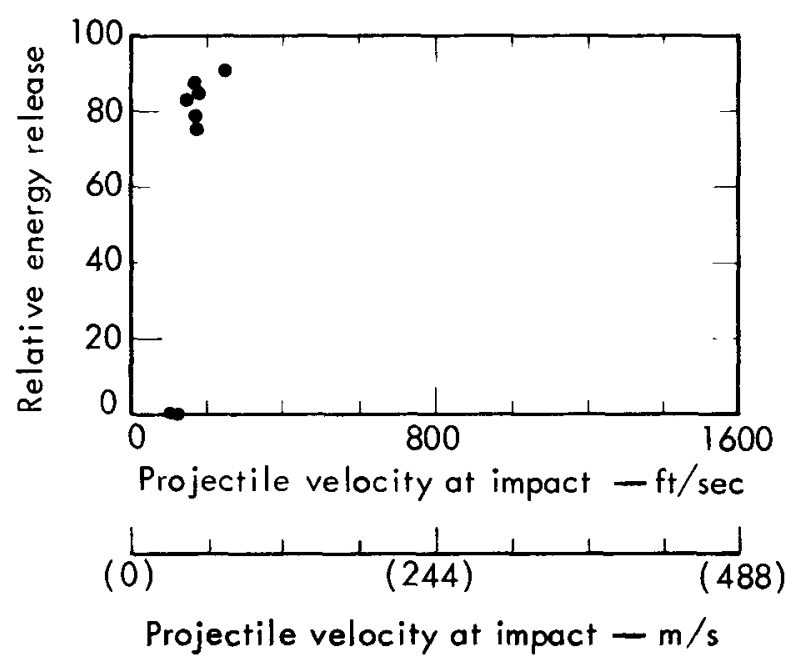

Fig. 9-8. Susan test: LX-10-0. Conversion factor: $1 \mathrm{ft} / \mathrm{sec}=3.048 \times 10^{-1} \mathrm{~m} / \mathrm{s}$. 
$\underline{L X}-11-0$

LX-11-0 ( $\mathrm{HMIX} /$ Viton $80 / 20$ ) is among the least reactive of the PBXs tested in the Susan test (Fig. 9-9). The threshold for reaction is probably about $170 \mathrm{ft} / \mathrm{sec}$ $(52.8 \mathrm{~m} / \mathrm{s})$, judging from the nosecap deformation of 1.8 to $1.9 \mathrm{in}$. (46 to $49 \mathrm{~mm}$ ) at the time ignitions were observed for the higher velocity shots. Most TNT-containing cast explosives require even more deformation for ignition; however, the reaction level is quite dependent on impact velocity and is generally lower than that observed for LX-04-1, although not as low as that observed for Comp B-3. The rather high value of 44 energy units at $612 \mathrm{ft} / \mathrm{sec}(187 \mathrm{~m} / \mathrm{s})$ is considered atypical and possibly due to axisymmetric impact. Reaction enhancement is observed at the "pinch" stage of the impact. LX-11-0 should be considered as moderately difficult to ignite by mechanical means and as having very low probability of building to violent reaction from a minor ignition where there is relatively little confinement.

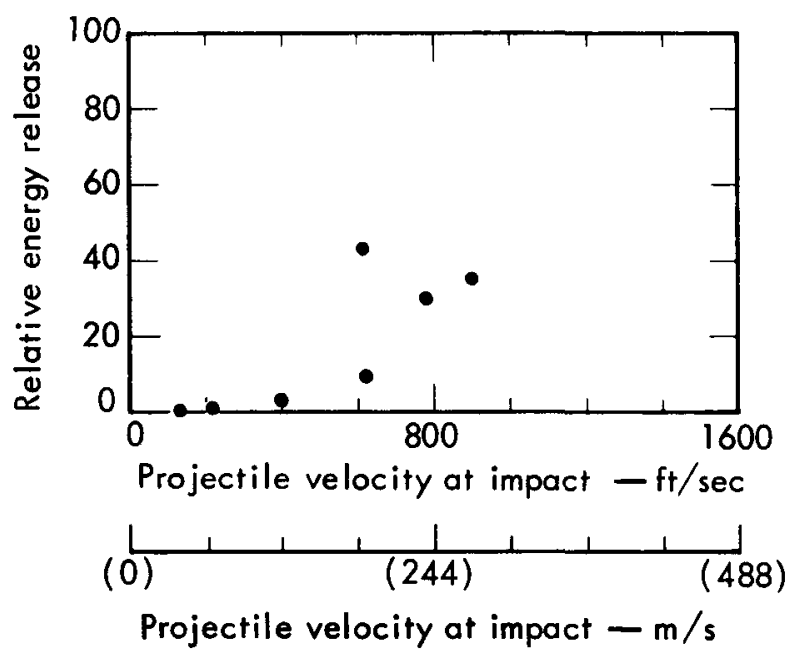

Fig. 9-9. Susan test: LX-11-0. Conversion factor: $1 \mathrm{ft} / \mathrm{sec}=3.048 \times 10^{-1} \mathrm{~m} / \mathrm{s}$. 
$\underline{\mathrm{LX}-14-0}$

LX-14-0 (HMX/Estane 95.5/4.5) is moderately easy to ignite in the Susan test, requiring an impact velocity of about $48 \mathrm{~m} / \mathrm{s}$.(Fig. $9-10$ ). This is slightly higher than that required for LX-04-1. Nosecap deformation is generally greater than $25 \mathrm{~mm}$ before ignition is observed. Reaction levels tend to be somewhat large and erratic once the threshold velocity is exceeded, somewhat like those of LX-07-2. In support of this tendency skid test results on LX-14 are intermediate in reaction level between LX-04-1 and LX-07-2. It appears that accidental mechanical ignition of LX-14-0 would have a moderately low probability of building to a violent reaction or detonation where there was little or no confinement.

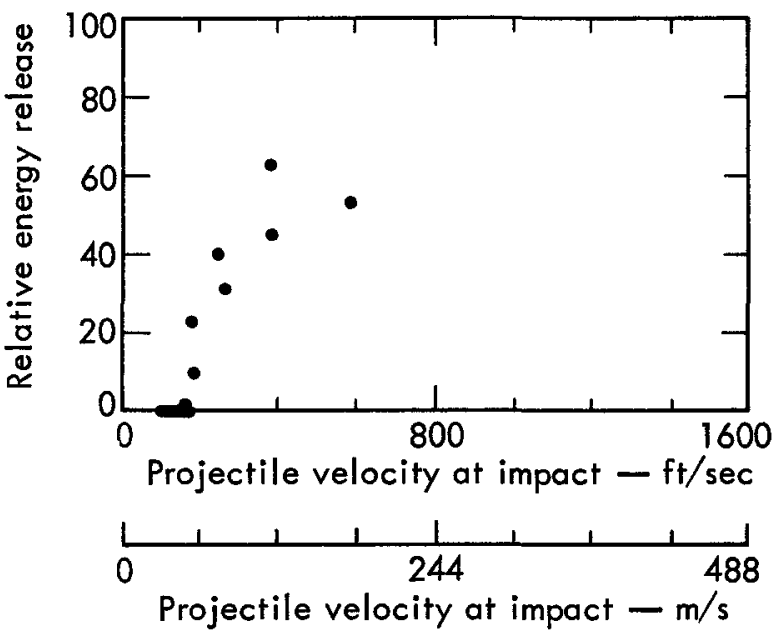

Fig. 9-10. Susan test: LX-14-0. Conversion factor $=1 \mathrm{ft} / \mathrm{sec}=3.048 \times 10^{-1} \mathrm{~m} / \mathrm{s}$. 


\section{Octol $75 / 25$}

Octol 75/25 (HMX/TNT 75/25) has both good and bad properties as measured by the Susan test (Fig. 9-11). The threshold velocity for reaction is probably about $180 \mathrm{ft} / \mathrm{sec}(55 \mathrm{~m} / \mathrm{s})$, which is rather typical of the TNT-bonded cast explosives and higher than most plastic-bonded explosives. On the other hand, reaction levels become moderately high, generally at relatively low velocity. The variability of results is less than that observed with Cyclotol 75/25. Octol 75/25 should be considered as rather difficult to ignite accidentally by mechanical means but capable of a large reaction once ignited under certain conditions.

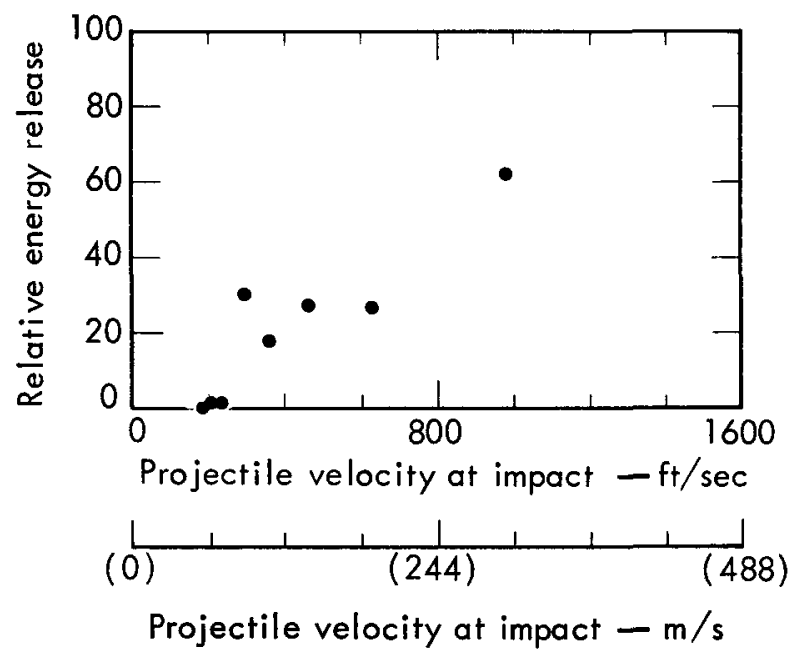

Fig. 9-11. Susan test: Octol 75/25. Conversion factor: $1 \mathrm{ft} / \mathrm{sec}=3.048 \times 10^{-1} \mathrm{~m} / \mathrm{s}$. 
PBX-9010 (RDX/Kel F 90/10) displays some very undesirable properties in the Susan test (Fig. 9-12). Ignition is observed after about $0.5-\mathrm{in}$. (13 mm) of projectile nosecap deformation, which would make the threshold velocity for reaction about $110 \mathrm{ft} / \mathrm{sec}(34 \mathrm{~m} / \mathrm{s})$. The reaction levels observed are high and independent of impact geometry. The observed energy release is not as high as that often seen with the more energetic explosives PBX-9404, LX-09-0, and LX-10-0, but intrinsic energy content does not completely explain the difference; geometric factors at the time of maximum reaction are thought to also contribute to the observed results. The reaction buildup is sufficiently rapid that no "pinch" stage enhancement of the reaction is observed. PBX-9010 exhibits both a low threshold for reaction and sufficient reactivity to indicate a very large probability of violent reaction or detonation from any accidental mechanical ignition.

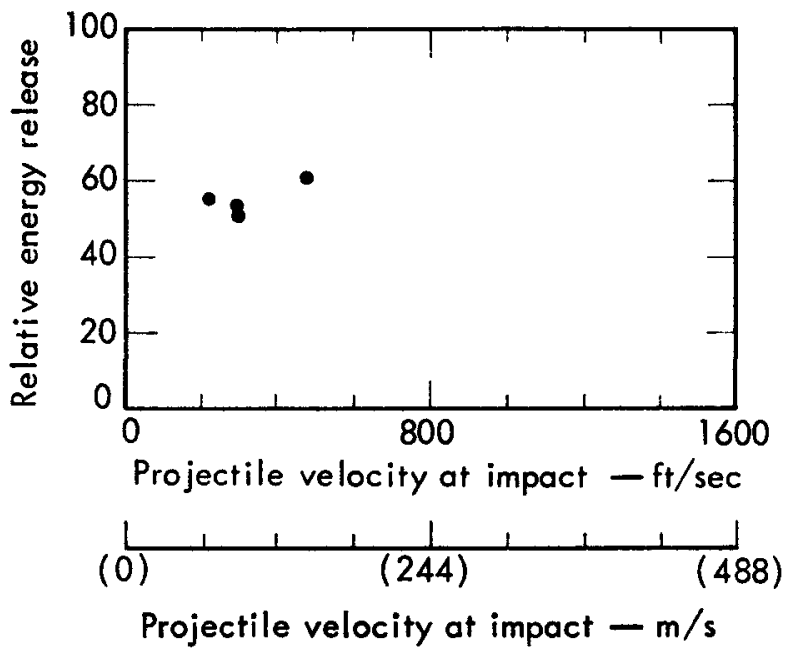

Fig. 9-12. Susan test: PBX-9010. Conversion factor: $1 \mathrm{ft} / \mathrm{sec}=3.048 \times 10^{-1} \mathrm{~m} / \mathrm{s}$. 
PBX-9011 (HMX/estane 90/10) is among the least reactive of the PBXs tested in the Susan test (Fig. 9-13). The threshold for reaction is probably about $165 \mathrm{ft} / \mathrm{sec}$ $(50 \mathrm{~m} / \mathrm{s})$, judging from the nosecap deformation of about $1.7-\mathrm{in}$. $(43 \mathrm{~mm})$ at the time of observed ignition for the higher-velocity shots. The reaction level is quite dependent on the impact velocity; it is generally somewhat lower than that observed for LX-04-1 but not as low as for Comp B-3. Reaction enhancement is observed only at the "pinch" stage of the impact. PBX-9011 should be considered as moderately difficult to ignite by mechanical impact and as having very low probability of building to violent reaction from a minor ignition where there is relatively little confinement. PBX-9011 has given only mild reactions in other impact geometries that often give detonations with explosives such as LX-04-1.

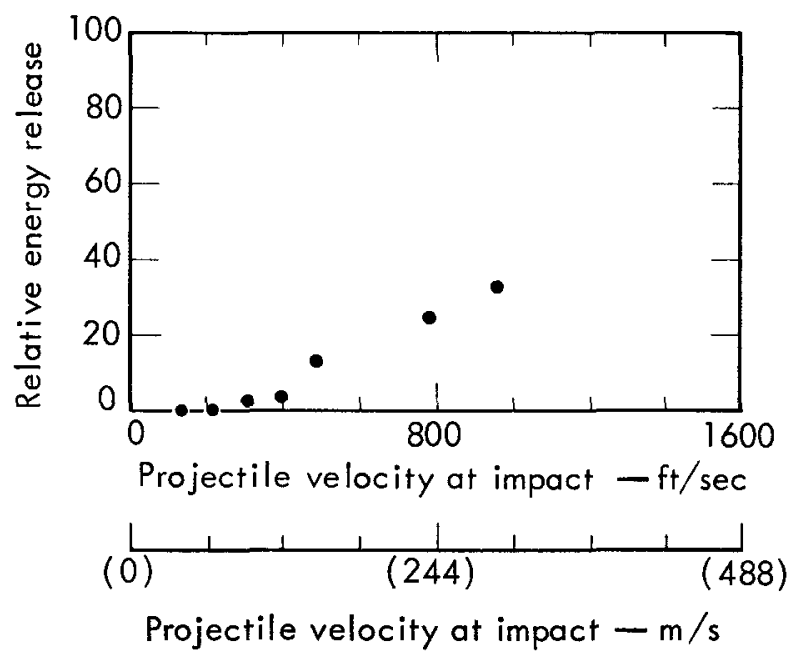

Fig. 9-13. Susan test: PBX-9011. Conversion factor: $1 \mathrm{ft} / \mathrm{sec}=3.048 \times 10^{-1} \mathrm{~m} / \mathrm{s}$. 
$\underline{\mathrm{PBX}-9205}$

PBX-9205 (RDX/polystyrene/di-2-ethylhexylphthalate $92 / 6 / 2$ ) is similar to LX-07-2 in some of its properties (Fig. 9-14). The threshold velocity for reaction is probably about $120 \mathrm{ft} / \mathrm{sec}(37 \mathrm{~m} / \mathrm{s})$, judging from the nosecap crush-up at the time of observed ignition with higher-velocity impacts. As with LX-07-2, the response is dependent on impact velocity and is intermediate between that of PBX-9404 and LX-04-1. Thus, PBX -9205 has a low threshold for reaction but only a moderate rate of buildup to violent reaction. It appears that accidental mechanical ignition of PBX-9205 would have a moderate probability of building to violent deflagration or detonation.

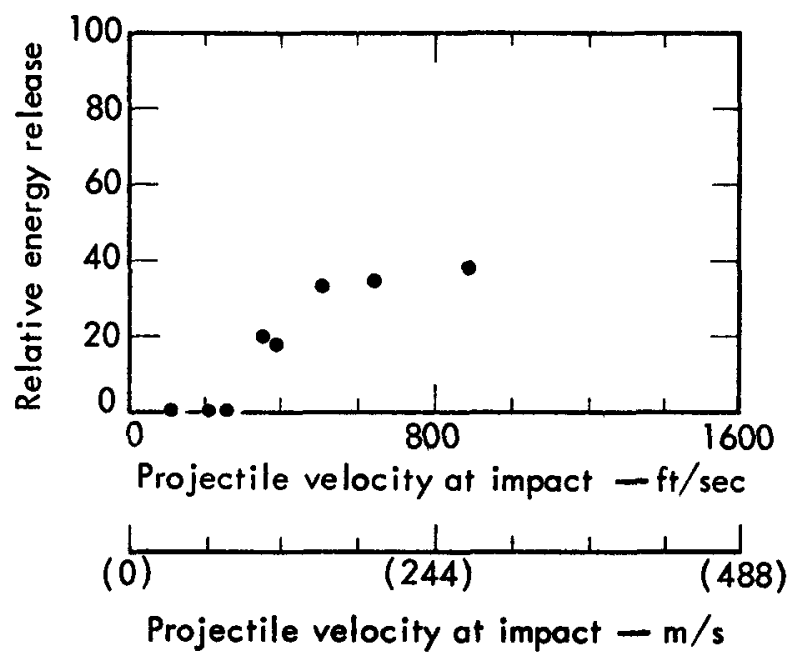

Fig. 9-14. Susan test: PBX-9205. Conversion factor: $1 \mathrm{ft} / \mathrm{sec}=3.048 \times 10^{-1} \mathrm{~m} / \mathrm{s}$. 
PBX-9404 (HMX/NC/tris- $\beta$-chloroethyl phosphate $94 / 3 / 3$ ) displays some very undesirable properties in the Susan test (Fig, 9-15). Ignition is seen after only about 0.35-in. $(8.9 \mathrm{~mm})$ of deformation of the projectile nosecap, which is consistent with the very low threshold velocity of $105 \mathrm{ft} / \mathrm{sec}(32 \mathrm{~m} / \mathrm{s})$. The reaction levels are generally quite high for impacts in the range of 105 to $200 \mathrm{ft} / \mathrm{sec}(32$ to $61 \mathrm{~m} / \mathrm{s})$. These reactions build to violent levels with sufficient rapidity that no "pinch" stage enhancement of the reaction is observed. At higher impact velocities, the reaction level. seems to depend somewhat on impact velocity, but it is always at least moderately high. "Pinch" stage enhancement of the reaction at these higher-impact velocities is very noticeable. PBX-9404 exhibits both a very low threshold velocity for reaction and rapid buildup to violent reaction. Any mechanical ignition of PBX-9404 has a very large probability of building to violent deflagration or detonation.

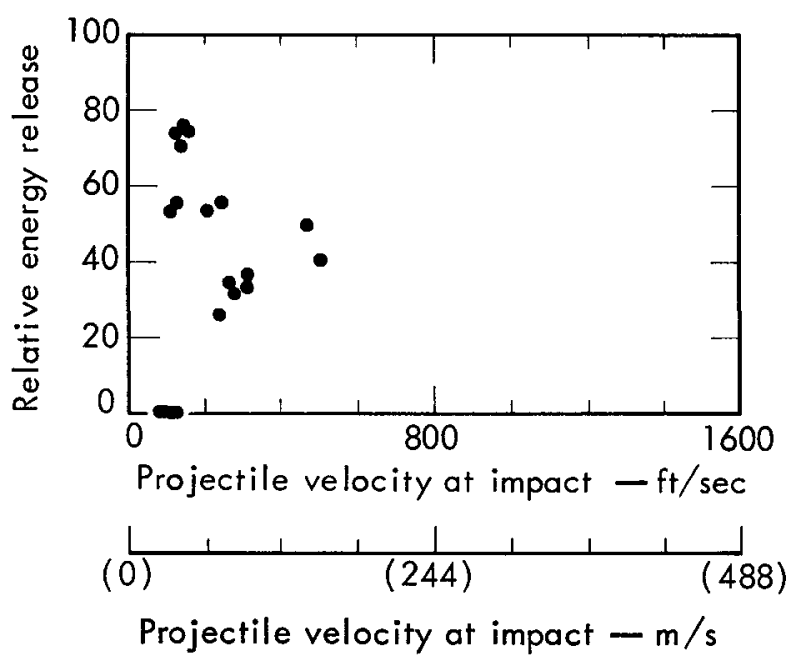

Fig. 9-15. Susan test: PBX-9404. Conversion factor: $1 \mathrm{ft} / \mathrm{sec}=3.048 \times 10^{-1} \mathrm{~m} / \mathrm{s}$. 
PBX-9501 (HMX/estane/DNPAF 95/2.5/2.5) is a high-energy explosive with low impact sensitivity for an explosive of its power (Fig. 9-16). The threshold velocity for reaction is about $200 \mathrm{ft} / \mathrm{sec}(61 \mathrm{~m} / \mathrm{s})$, which is higher than that for most PBXs and about equal to that for many TNT-based explosives. Reactions start after about 2.52 in. $(6.4 \mathrm{~cm})$ of projectile deformation, which is consistent with the observed threshold velocity. Once threshold velocity is exceeded, reactions become violent over a rather narrow velocity range. Small reactions do not automatically grow to large reactions as they do in many other high-energy PBXs. Skid-test ignitions, for example, give very low reactions.

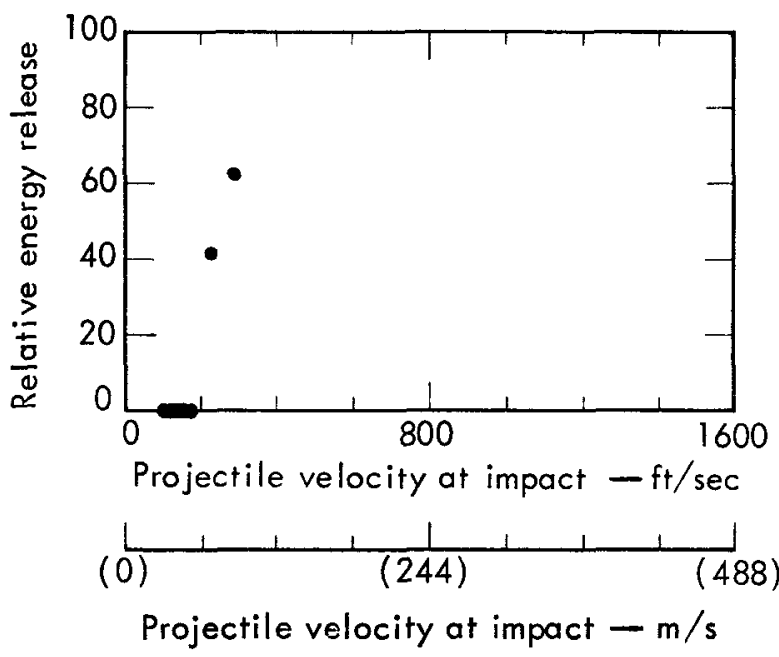

Fig. 9-16. Susan test: PBX-9501. Conversion factor: $1 \mathrm{ft} / \mathrm{sec}=3.048 \times 10^{-1} \mathrm{~m} / \mathrm{s}$. 
TNT shows no undesirable properties by the Susan test (Fig. 9-17). Minor ignitions are seen down to about $235 \mathrm{ft} / \mathrm{sec}(72 \mathrm{~m} / \mathrm{s})$ impact velocity but only after extensive splitting of the projectile nosecap and abrupt halt of the projectile at the final or "pinch" stage of impact. No violent reactions are observed even at impact velocities above $1200 \mathrm{ft} / \mathrm{sec}(366 \mathrm{~m} / \mathrm{s})$. Further, the TNT response is independent of whether it is cast or is a high- or medium-density pressing. TNT should be considered very difficult to ignite accidentally by mechanical means; any reaction from such an ignition should be regarded as having an extremely low probability of building to violent levels where there is relatively little confinement.

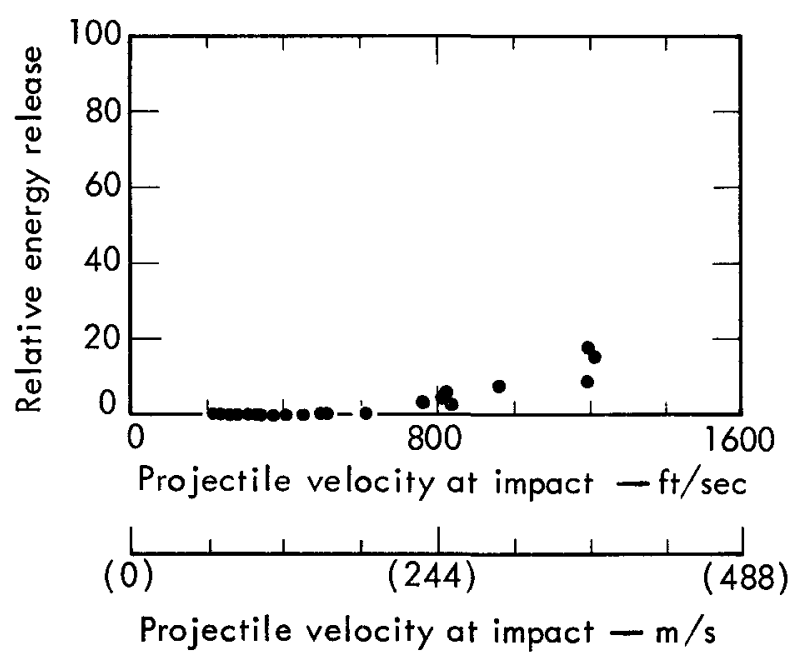

Fig. 9-17. Susan test: TNT. Conversion factor:

$1 \mathrm{ft} / \mathrm{sec}=3.048 \times 10^{-1} \mathrm{~m} / \mathrm{s}$. 


\section{$\underline{\mathrm{XTX}-8003}$}

XTX-8003 (PETN/silicone rubber 80/20) is moderately difficult to ignite in the Susan test (Fig. 9-18), requiring an impact velocity of about $160 \mathrm{ft} / \mathrm{sec}(49 \mathrm{~m} / \mathrm{s})$, judging from the 1.4-in. (36 mm) of projectile nosecap deformation at the time of observed ignition. Reaction levels ranged from quite low to moderately low over the velocity range tested. While the number of tests is limited, it appears that XTX-8003 has a very small probability of building to violent reaction from an accidental ignition where there is relatively little or no confinement.

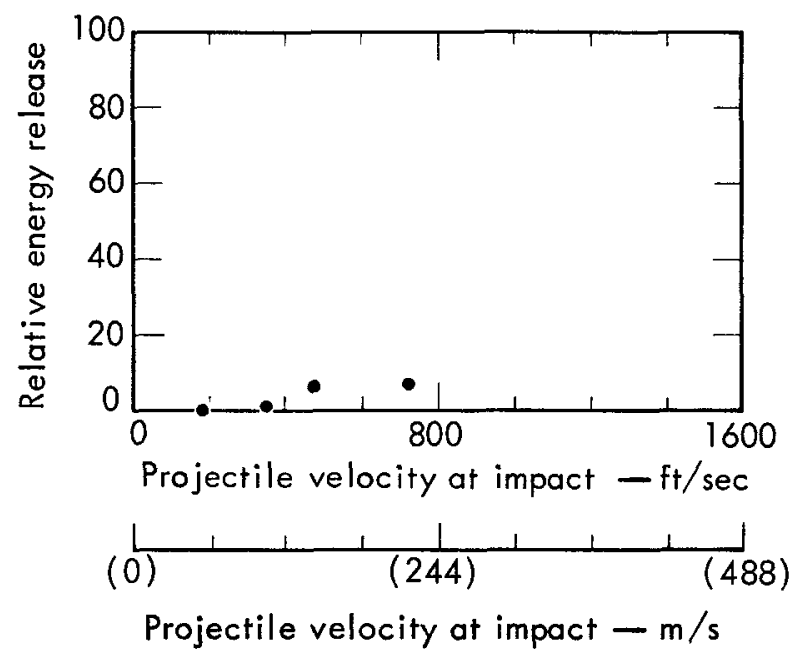

Fig. 9-18. Susan test: XTX-8003. Conversion factor: $1 \mathrm{ft} / \mathrm{sec}=3.048 \times 10^{-1} \mathrm{~m} / \mathrm{s}$. 


\section{Skid Test}

Results from a sliding impact sensitivity test (skid test) with large hemispherical billets of HE have proved valuable for evaluating the plant-handling safety of HEs. 4,5 The test was developed at AWRE in England.

In the LLL-Pantex version of this test, the explosive billet, supported on a pendulum device, is allowed to swing down from a preset height and strike at an angle on a sand-coated steel target plate. Impact angles employed are $14 \mathrm{deg}(0.24 \mathrm{rad})$ and $45 \mathrm{deg}(0.79 \mathrm{rad})$ (defined as the angle between the line of billet travel and the horizontal target surface; the heights vary). The spherical surface of the billet serves to concentrate the force of the impact in a small area; the pendulum arrangement gives the impact both a sliding or skidding component as well as a vertical one. The results of the test (Table 9-2) are expressed in terms of the type of chemical event produced by the impact as a function of impact angle and vertical drop. Chemical events are defined as follows:

0 No reaction; charge retains integrity.

1 Burn or scorch marks on HE or target; charge retains integrity.

2 Puff of smoke, but no flame or light visible in high-speed photography. Charge may retain integrity or may be broken into large pieces.

3 Mild low-order reaction with flame or light; charge broken up and scattered.

4 Medium low-order reaction with flame or light; major part of $\mathrm{HE}$ consumed.

5 Violent deflagration; virtually all HE consumed.

6 Detonation.

The sliding-impact test results are significant indications of plant-handling safety because the drop heights and impact angles used in the test are quite within the limits one might find for the accidental drop of an explosive billet. The test is used not only to evaluate the relative sensitivity of different explosives, using the sand-coated target as a reference surface (Table $9-2$ ), but also to evaluate typical plant floor coverings, using PBX-9010 as a reference explosive (Table 9-3 and 9-4). 
Table 9-2. Standard LLL-Pantex skid test with hemispheres of explosive $11 \mathrm{in.}(0.28 \mathrm{~m})$ in diameter and weighing $23 \mathrm{lb}(10.4 \mathrm{~kg})$. a

\begin{tabular}{|c|c|c|c|c|c|}
\hline \multirow[b]{2}{*}{ Explosive } & \multicolumn{2}{|c|}{ Impact angle } & \multicolumn{2}{|c|}{ Vertical drop } & \multirow[b]{2}{*}{ Chemical event } \\
\hline & $(\mathrm{deg})$ & (rad) & $(\mathrm{ft})$ & $(\mathrm{m})$ & \\
\hline Comp B-3 & $\begin{array}{l}14 \\
14 \\
14 \\
45\end{array}$ & $\begin{array}{l}(0.24) \\
(0.24) \\
(0.24) \\
(0.79)\end{array}$ & $\begin{array}{r}3.5 \\
5.0 \\
7.1 \\
28.0\end{array}$ & $\begin{array}{l}(1.07) \\
(1.52) \\
(2.16) \\
(8.53)\end{array}$ & $\begin{array}{l}0 \\
1,0,4 \\
2 \\
0\end{array}$ \\
\hline Cyclotol 75/25 & $\begin{array}{l}14 \\
14 \\
14 \\
45 \\
45 \\
45\end{array}$ & $\begin{array}{l}(0.24) \\
(0.24) \\
(0.24) \\
(0.79) \\
(0.79) \\
(0.79)\end{array}$ & $\begin{array}{l}0.62 \\
0.88 \\
1.75 \\
7.1 \\
14.0 \\
28.0\end{array}$ & $\begin{array}{l}(0.19) \\
(0.27) \\
(0.53) \\
(2.16) \\
(4.27) \\
(8.53)\end{array}$ & $\begin{array}{l}0 \\
4 \\
3 \\
0 \\
0 \\
0\end{array}$ \\
\hline $\mathrm{LX}-04-1$ & $\begin{array}{l}14 \\
14 \\
14 \\
45 \\
45 \\
45 \\
45 \\
45\end{array}$ & $\begin{array}{l}(0.24) \\
(0.24) \\
(0.24) \\
(0.79) \\
(0.79) \\
(0.79) \\
(0.79) \\
(0.79)\end{array}$ & $\begin{array}{r}1.75 \\
2.5 \\
14.1 \\
3.5 \\
5.0 \\
7.1 \\
10.0 \\
14.1\end{array}$ & $\begin{array}{l}(0.53) \\
(0.76) \\
(4.30) \\
(1.07) \\
(1.52) \\
(2.16) \\
(3.05) \\
(4.30)\end{array}$ & $\begin{array}{c}0 \\
2 \\
2,1 \\
0,0 \\
3,0 \\
1,0 \\
2 \\
3\end{array}$ \\
\hline$L X-07-1$ & $\begin{array}{l}14 \\
14 \\
14 \\
14 \\
45 \\
45 \\
45 \\
45\end{array}$ & $\begin{array}{l}(0.24) \\
(0.24) \\
(0.24) \\
(0.24) \\
(0.79) \\
(0.79) \\
(0.79) \\
(0.79)\end{array}$ & $\begin{array}{l}0.88 \\
1.25 \\
1.75 \\
2.5 \\
2.5 \\
3.5 \\
5.0 \\
7.1\end{array}$ & $\begin{array}{l}(0.27) \\
(0.38) \\
(0.53) \\
(0.76) \\
(0.76) \\
(1.07) \\
(1.52) \\
(2.16)\end{array}$ & $\begin{array}{c}0,0,0,0 \\
0,0,0 \\
0,0,0 \\
6,4,3 \\
0,0 \\
0,0,0,0,0 \\
0,0,0 \\
5,0,0,0,0,0,0\end{array}$ \\
\hline$L X-09-0$ & $\begin{array}{l}14 \\
14 \\
45 \\
45 \\
45\end{array}$ & $\begin{array}{l}(0.24) \\
(0.24) \\
(0.79) \\
(0.79) \\
(0.79)\end{array}$ & $\begin{array}{l}0.88 \\
1.25 \\
3.5 \\
5.0 \\
7.1\end{array}$ & $\begin{array}{l}(0.27) \\
(0.38) \\
(1.07) \\
(1.52) \\
(2.16)\end{array}$ & $\begin{array}{c}0,0,0,0 \\
6,0,0 \\
0,0,0 \\
6,0,0,0 \\
0\end{array}$ \\
\hline$L X-10-0$ & $\begin{array}{l}14 \\
45 \\
45\end{array}$ & $\begin{array}{l}(0.79) \\
(0.79)\end{array}$ & $\begin{array}{l}0.88 \\
\\
2.5 \\
3.5\end{array}$ & $\begin{array}{l}(0.76) \\
(1.07)\end{array}$ & $\begin{array}{c}0,0,0,0,0 \\
0,0,0,0 \\
0,0,0 \\
6,6,0,0,0 \\
0,0,0,0,0 \\
0,0,0,0,0\end{array}$ \\
\hline Octol $75 / 25$ & $\begin{array}{l}14 \\
14\end{array}$ & $\begin{array}{l}(0.24) \\
(0.24)\end{array}$ & $\begin{array}{l}2.5 \\
3.5\end{array}$ & $\begin{array}{l}(0.76) \\
(1.07)\end{array}$ & $\begin{array}{l}0,0 \\
6,6\end{array}$ \\
\hline PBX-9010 & $\begin{array}{l}14 \\
14 \\
14 \\
14\end{array}$ & $\begin{array}{l}(0.24) \\
(0.24) \\
(0.24) \\
(0.24)\end{array}$ & $\begin{array}{l}0.88 \\
1.25 \\
1.5 \\
1.75\end{array}$ & $\begin{array}{l}(0.27) \\
(0.38) \\
(0.46) \\
(0.53)\end{array}$ & $\begin{array}{c}0 \\
6,0,0,0 \\
0 \\
0,0\end{array}$ \\
\hline PBX-9011 & $\begin{array}{l}14 \\
14 \\
14 \\
45 \\
45\end{array}$ & $\begin{array}{l}(0.24) \\
(0.24) \\
(0.24) \\
(0.79) \\
(0.79)\end{array}$ & $\begin{array}{r}7.1 \\
10.0 \\
20.0 \\
14.1 \\
20.0\end{array}$ & $\begin{array}{l}(2.16) \\
(3.05) \\
(6.10) \\
(4.30) \\
(6.10)\end{array}$ & $\begin{array}{l}0 \\
0 \\
2 \\
0 \\
0\end{array}$ \\
\hline PBX-9205 & $\begin{array}{l}14 \\
14 \\
14 \\
45 \\
45 \\
45\end{array}$ & $\begin{array}{l}(0.24) \\
(0.24) \\
(0.24) \\
(0.79) \\
(0.79) \\
(0.79)\end{array}$ & $\begin{array}{l}0.88 \\
1.25 \\
1.75 \\
1.25 \\
1.75 \\
2.5\end{array}$ & $\begin{array}{l}(0.27) \\
(0.38) \\
(0.53) \\
(0.38) \\
(0.53) \\
(0.76)\end{array}$ & $\begin{array}{l}0 \\
2 \\
3 \\
0 \\
0 \\
4\end{array}$ \\
\hline PBX- 9404 & $\begin{array}{l}14 \\
14 \\
14 \\
45 \\
45 \\
45 \\
45 \\
\\
45\end{array}$ & $\begin{array}{l}(0.24) \\
(0.24) \\
(0.24) \\
(0.79) \\
(0.79) \\
(0.79) \\
(0.79)\end{array}$ & $\begin{array}{l}0.88 \\
1.25 \\
1.75 \\
1.75 \\
2.5 \\
3.5 \\
\\
5.0\end{array}$ & $\begin{array}{l}(0.27) \\
(0.38) \\
(0.53) \\
(0.53) \\
(0.76) \\
(1.07) \\
(1.52)\end{array}$ & $\begin{array}{c}0,0,0,0 \\
6,6,6,0 \\
6,6 \\
0,0,0,0,0,0 \\
0,0,0 \\
6,0,0,0, \\
0,0,0,0 \\
6,6,6,6,0 \\
0,0,0,0 \\
6,6\end{array}$ \\
\hline PBX-9501 & $\begin{array}{l}14 \\
14 \\
14 \\
45 \\
45\end{array}$ & $\begin{array}{l}(0.24) \\
(0.24) \\
(0.24) \\
(0.79) \\
(0.79)\end{array}$ & $\begin{array}{r}1.25 \\
5.0 \\
10.0 \\
5.0 \\
10.0\end{array}$ & $\begin{array}{l}(0.38) \\
(1.52) \\
(3.05) \\
(1.52) \\
(3.05)\end{array}$ & $\begin{array}{ll}0,0,0 \\
0 \\
3 \\
0,0,0 \\
0,0,0\end{array}$ \\
\hline
\end{tabular}

aOne in. $=2.540 \times 10^{-2} \mathrm{~m} ; 1 \mathrm{lb}=4.535924 \times 10^{-1} \mathrm{~kg} ; 1 \mathrm{ft}=3.048 \times 10^{-1} \mathrm{~m}$;

$1 \mathrm{deg}=1.745329 \times 10^{-2} \mathrm{rad}$. 
Table 9-3. Nonstandard skid tests of interest. Target: standard sand-coated steel (1/4-in. $(6.375-\mathrm{mm}))$ bonded to concrete. ${ }^{2}$

\begin{tabular}{|c|c|c|c|c|c|c|c|c|}
\hline \multirow[b]{2}{*}{ Explosive } & & \multicolumn{2}{|c|}{ Weight } & \multicolumn{2}{|c|}{ Impact angle } & \multicolumn{2}{|c|}{ Vertical drop } & \multirow{2}{*}{$\begin{array}{c}\text { Chemical } \\
\text { event }\end{array}$} \\
\hline & & (lb) & $(\mathrm{kg})$ & $(\mathrm{deg})$ & $(\mathrm{rad})$ & $(\mathrm{ft})$ & $(\mathrm{m})$ & \\
\hline Comp B & & 50 & $(22.7)$ & 14 & $(0.24)$ & 5.0 & $(1.52)$ & 4 \\
\hline LX $-04-0$ & $\begin{array}{l}-57^{\circ} \mathrm{F}(224 \mathrm{~K}) \\
60^{\circ} \mathrm{F}(290 \mathrm{~K}) \\
235^{\circ} \mathrm{F}(385 \mathrm{~K})\end{array}$ & $\begin{array}{l}23 \\
23 \\
23 \\
23 \\
23 \\
23 \\
23 \\
50\end{array}$ & $\begin{array}{l}(10.4) \\
(10.4) \\
(10.4) \\
(10.4) \\
(10.4) \\
(10.4) \\
(10.4) \\
(22.7)\end{array}$ & $\begin{array}{l}45 \\
14 \\
14 \\
45 \\
45 \\
14 \\
45 \\
45\end{array}$ & $\begin{array}{l}(0.79) \\
(0.24) \\
(0.24) \\
(0.79) \\
(0.79) \\
(0.24) \\
(0.79) \\
(0.79)\end{array}$ & $\begin{array}{c}3.5 \\
1.25 \\
1.75 \\
3.5 \\
5.0 \\
5.0 \\
14.1 \\
7.1\end{array}$ & $\begin{array}{l}(1.07) \\
(0.38) \\
(0.53) \\
(1.07) \\
(1.52) \\
(1.52) \\
(4.30) \\
(2.16)\end{array}$ & $\begin{array}{l}2 \\
0 \\
2 \\
0 \\
3 \\
0 \\
0 \\
0\end{array}$ \\
\hline LX $-04-1$ & & $\begin{array}{l}298 \\
298 \\
298\end{array}$ & $\begin{array}{l}(135.2) \\
(135.2) \\
(135.2)\end{array}$ & $\begin{array}{l}45 \\
45 \\
45\end{array}$ & $\begin{array}{l}(0.79) \\
(0.79) \\
(0.79)\end{array}$ & $\begin{array}{l}0.88 \\
1.25 \\
1.75\end{array}$ & $\begin{array}{l}(0.27) \\
(0.38) \\
(0.53)\end{array}$ & $\begin{array}{l}0 \\
0 \\
5\end{array}$ \\
\hline L.X-09-0 & $\begin{array}{l}\text { Aged } 11 \text { months; } \\
70^{\circ} \mathrm{C}(343 \mathrm{~K}) \\
\text { Control for aged sample }\end{array}$ & $\begin{array}{l}28 \\
28 \\
28 \\
28 \\
28 \\
28\end{array}$ & $\begin{array}{l}(12.7) \\
(12.7) \\
(12.7) \\
(12.7) \\
(12.7) \\
(12.7)\end{array}$ & $\begin{array}{l}14 \\
45 \\
45 \\
14 \\
45 \\
45\end{array}$ & $\begin{array}{l}(0.24) \\
(0.79) \\
(0.79) \\
(0.24) \\
(0.79) \\
(0.79)\end{array}$ & $\begin{array}{l}0.88 \\
2.5 \\
3.5 \\
0.88 \\
2.5 \\
3.5\end{array}$ & $\begin{array}{l}(0.27) \\
(0.76) \\
(1.07) \\
(0.27) \\
(0.76) \\
(1.07)\end{array}$ & $\begin{array}{c}0 \\
0 \\
6,0 \\
6 \\
0 \\
0,0\end{array}$ \\
\hline$L X-10-0$ & $\begin{array}{l}\text { Made with Fluorel } \\
\text { With } 48 \mathrm{lb}(21.8 \mathrm{~kg}) \text { of } \\
\text { steel plate on } \mathrm{HE} \text { equator }\end{array}$ & $\begin{array}{l}23 \\
23 \\
69 \\
70\end{array}$ & $\begin{array}{l}(10.4) \\
(10.4) \\
(31.3) \\
(31.8)\end{array}$ & $\begin{array}{l}14 \\
45 \\
14 \\
14\end{array}$ & $\begin{array}{l}(0.24) \\
(0.79) \\
(0.24) \\
(0.24)\end{array}$ & $\begin{array}{l}0.88 \\
3.5 \\
0.44 \\
0.66\end{array}$ & $\begin{array}{l}(0.27) \\
(1.07) \\
(0.13) \\
(0.20)\end{array}$ & $\begin{array}{l}0,0,0 \\
0,0,0 \\
0 \\
6\end{array}$ \\
\hline $\mathrm{LX}-14-0$ & & $\begin{array}{l}291 \\
292 \\
291 \\
290 \\
290 \\
290\end{array}$ & $\begin{array}{l}(132) \\
(132.4) \\
(132) \\
(131.6) \\
(131.6) \\
(131.6)\end{array}$ & $\begin{array}{l}45 \\
45 \\
45 \\
45 \\
45 \\
45\end{array}$ & $\begin{array}{l}(0.79) \\
(0.79) \\
(0.79) \\
(0.79) \\
(0.79) \\
(0.79)\end{array}$ & $\begin{array}{l}0.88 \\
1.25 \\
1.50 \\
1.75 \\
2.5 \\
5.0\end{array}$ & $\begin{array}{l}(0.27) \\
(0.38) \\
(0.46) \\
(0.53) \\
(0.76) \\
(1.52)\end{array}$ & $\begin{array}{l}0 \\
0 \\
0 \\
0 \\
0 \\
6\end{array}$ \\
\hline PBX-9404 & & $\begin{array}{l}296 \\
292 \\
296 \\
296 \\
298 \\
293 \\
291 \\
297 \\
295 \\
296\end{array}$ & $\begin{array}{l}(134.3) \\
(132.4) \\
(134.3) \\
(134.3) \\
(135.2) \\
(132.9) \\
(132.0) \\
(134.7) \\
(133.8) \\
(134.3)\end{array}$ & $\begin{array}{l}14 \\
14 \\
14 \\
45 \\
45 \\
45 \\
45 \\
45 \\
45 \\
45\end{array}$ & $\begin{array}{l}(0.24) \\
(0.24) \\
(0.24) \\
(0.79) \\
(0.79) \\
(0.79) \\
(0.79) \\
(0.79) \\
(0.79) \\
(0.79)\end{array}$ & $\begin{array}{l}0.25 \\
0.33 \\
0.48 \\
0.33 \\
0.44 \\
0.60 \\
0.63 \\
1.23 \\
1.83 \\
2.5\end{array}$ & $\begin{array}{l}(0.08) \\
(0.10) \\
(0.15) \\
(0.10) \\
(0.13) \\
(0.18) \\
(0.19) \\
(0.38) \\
(0.56) \\
(0.76)\end{array}$ & $\begin{array}{l}0 \\
6 \\
6 \\
0 \\
0 \\
0 \\
0 \\
0 \\
0 \\
0\end{array}$ \\
\hline PBX-9501 & $\begin{array}{l}-34^{\circ} \mathrm{C}(239 \mathrm{~K}) \\
16^{\circ} \mathrm{C}(289 \mathrm{~K}) \\
16^{\circ} \mathrm{C}(289 \mathrm{~K}) \\
-34^{\circ} \mathrm{C}(239 \mathrm{~K}) \\
-34^{\circ} \mathrm{C}(239 \mathrm{~K}) \\
-34^{\circ} \mathrm{C}(239 \mathrm{~K}) \\
-34^{\circ} \mathrm{C}(239 \mathrm{~K}) \\
-34^{\circ} \mathrm{C}(239 \mathrm{~K}) \\
-34^{\circ} \mathrm{C}(239 \mathrm{~K}) \\
16^{\circ} \mathrm{C}(289 \mathrm{~K}) \\
16^{\circ} \mathrm{C}(289 \mathrm{~K}) \\
16^{\circ} \mathrm{C}(289 \mathrm{~K}) \\
16^{\circ} \mathrm{C}(289 \mathrm{~K}) \\
16^{\circ} \mathrm{C}(289 \mathrm{~K}) \\
71^{\circ} \mathrm{C}(344 \mathrm{~K}) \\
71^{\circ} \mathrm{C}(344 \mathrm{~K}) \\
71^{\circ} \mathrm{C}(344 \mathrm{~K}) \\
71^{\circ} \mathrm{C}(344 \mathrm{~K})\end{array}$ & $\begin{array}{l}23 \\
23 \\
23 \\
23 \\
23 \\
23 \\
23 \\
23 \\
23 \\
23 \\
23 \\
23 \\
23 \\
23 \\
23 \\
23 \\
23 \\
23\end{array}$ & $\begin{array}{l}(10.4) \\
(10.4) \\
(10.4) \\
(10.4) \\
(10.4) \\
(10.4) \\
(10.4) \\
(10.4) \\
(10.4) \\
(10.4) \\
(10.4) \\
(10.4) \\
(10.4) \\
(10.4) \\
(10.4) \\
(10.4) \\
(10.4) \\
(10.4)\end{array}$ & $\begin{array}{l}14 \\
14 \\
14 \\
45 \\
45 \\
45 \\
45 \\
45 \\
45 \\
45 \\
45 \\
45 \\
45 \\
45 \\
45 \\
45 \\
45 \\
45\end{array}$ & $\begin{array}{l}(0.24) \\
(0.24) \\
(0.24) \\
(0.79) \\
(0.79) \\
(0.79) \\
(0.79) \\
(0.79) \\
(0.79) \\
(0.79) \\
(0.79) \\
(0.79) \\
(0.79) \\
(0.79) \\
(0.79) \\
(0.79) \\
(0.79) \\
(0.79)\end{array}$ & $\begin{array}{l}0.62 \\
0.88 \\
1.25 \\
0.88 \\
1.25 \\
1.75 \\
2.5 \\
3.5 \\
5.0 \\
2.5 \\
3.5\end{array}$ & $\begin{array}{l}(0.19) \\
(0.27) \\
(0.38) \\
(0.27) \\
(0.38) \\
(0.53) \\
(0.76) \\
(1.07) \\
(1.52) \\
(0.76) \\
(1.07)\end{array}$ & $\begin{array}{c}6 \\
0,0,0,0,0 \\
6,6,0 \\
0 \mathrm{~b} \\
0^{\mathrm{b}} \\
0^{\mathrm{b}} \\
0^{\mathrm{b}} \\
0^{\mathrm{b}} \\
6 \\
0,0,0 \\
6,0,0,0 \\
6,0,0,0 \\
0,0,0,0,0 \\
0,0,0 \\
0 \\
0 \\
0 \\
0\end{array}$ \\
\hline
\end{tabular}

${ }^{\mathrm{a}}$ One in. $=2.540 \times 10^{-2} \mathrm{~m} ; 1 \mathrm{lb}=4.535924 \times 10^{-1} \mathrm{~kg} ; 1 \mathrm{ft}=3.048 \times 10^{-1} \mathrm{~m} ; 1 \mathrm{deg}=1.745329 \times 10^{-2} \mathrm{rad}$.

${ }^{b}$ Acrid or burnt odor noticed after test. 
Table 9-4. Evaluation of plant floorings by LLL-Pantex test with 50-1b $(22.7-\mathrm{kg})$ hemispheres of PBX-9010 and, except where otherwise noted, $45 \mathrm{deg}(0.79 \mathrm{rad})$ impact angle. ${ }^{a}$

\begin{tabular}{|c|c|c|c|c|c|}
\hline \multirow[b]{2}{*}{ Floor Material } & \multicolumn{2}{|c|}{ Thickness } & \multicolumn{2}{|c|}{ Vertical drop } & \multirow[b]{2}{*}{ Chemical event } \\
\hline & (in.) & $(\mathrm{mm})$ & $(\mathrm{ft})$ & $(\mathrm{m})$ & \\
\hline \multicolumn{6}{|l|}{$\begin{array}{l}\text { Corrugated rubber } \\
\text { floor covering }\end{array}$} \\
\hline $\begin{array}{l}\text { Against grain } \\
\text { With grain }\end{array}$ & & & $\begin{array}{l}10 \\
10 \\
20\end{array}$ & $\begin{array}{l}(3.05) \\
(3.05) \\
(6.10)\end{array}$ & $\begin{array}{c}0,0 \\
0 \\
0\end{array}$ \\
\hline Linoleum & $1 / 8$ & $(3.18)$ & $\begin{array}{r}7.1 \\
10.0 \\
14.1 \\
20.0\end{array}$ & $\begin{array}{l}(2.16) \\
(3.05) \\
(4.30) \\
(6.10)\end{array}$ & $\begin{array}{l}0 \\
0 \\
0 \\
0\end{array}$ \\
\hline $\begin{array}{l}\text { Poly-Con }{ }^{\mathrm{b}} \\
14 \text { deg }(0.24 \mathrm{rad}) \\
\text { impact angle }\end{array}$ & & & $\begin{array}{l}2.5 \\
3.5 \\
5.0 \\
7.1 \\
1.25 \\
1.75 \\
2.5 \\
3.5 \\
5.0\end{array}$ & $\begin{array}{l}(0.76) \\
(1.07) \\
(1.52) \\
(2.16) \\
(0.38) \\
(0.53) \\
(0.76) \\
(1.07) \\
(1.52)\end{array}$ & $\begin{array}{l}0 \\
0 \\
0 \\
6 \\
0 \\
0 \\
0 \\
0 \\
6\end{array}$ \\
\hline $\begin{array}{l}\text { Polyurethane } \\
\text { (Adiprene L-100) }\end{array}$ & $5 / 64$ & $(1.98)$ & $\begin{array}{r}7.1 \\
14.1 \\
24.0\end{array}$ & $\begin{array}{l}(2.16) \\
(4.30) \\
(7.32)\end{array}$ & $\begin{array}{l}0 \\
0 \\
0\end{array}$ \\
\hline Sanded steel & & & $\begin{array}{l}1.75 \\
2.5\end{array}$ & $\begin{array}{l}(0.53) \\
(0.76)\end{array}$ & $\begin{array}{c}0 \\
6,6\end{array}$ \\
\hline Torginal (Torga-Deck) & $\begin{array}{c}1 / 16 \\
3 / 16 \\
\text { to } \\
1 / 4\end{array}$ & $\begin{array}{c}(1.59) \\
(4.76 \\
\text { to } \\
6.35)\end{array}$ & $\begin{array}{l}14.0 \\
20.0 \\
20.0 \\
28.0\end{array}$ & $\begin{array}{l}(4.27) \\
(6.10) \\
(6.10) \\
(8.53)\end{array}$ & $\begin{array}{l}0 \\
6 \\
0 \\
1\end{array}$ \\
\hline $\begin{array}{l}14 \mathrm{deg}(0.24 \mathrm{rad}) \\
\text { impact angle }\end{array}$ & $\begin{array}{c}3 / 32 \\
1 / 8\end{array}$ & $\begin{array}{l}(2.38) \\
(3.18)\end{array}$ & $\begin{array}{l}10 \\
14.1 \\
20 \\
10 \\
14.1 \\
20 \\
20.0\end{array}$ & $\begin{array}{l}(3.05) \\
(4.30) \\
(6.10) \\
(3.05) \\
(4.30) \\
(6.10) \\
(6.10)\end{array}$ & $\begin{array}{l}0 \\
0 \\
0 \\
0 \\
0 \\
0 \\
0\end{array}$ \\
\hline Vinyl & & & $\begin{array}{l}5.0 \\
7.1\end{array}$ & $\begin{array}{l}(1.52) \\
(2.16)\end{array}$ & $\begin{array}{l}0,0 \\
6,6\end{array}$ \\
\hline
\end{tabular}

${ }^{\mathrm{a}}$ One in. $=2.540 \times 10^{-2} \mathrm{~m} ; 1 \mathrm{lb}=4.535924 \times 10^{-1} \mathrm{~kg} ; 1 \mathrm{ft}=3.048 \times 10^{-1} \mathrm{~m}$; $1 \mathrm{deg}=1.745329 \times 10^{-2} \mathrm{rad}$.

${ }^{b}$ A poured polyurethane floor covering. 


\section{Gap Test}

The gap test gives a measure of the shock sensitivity of an explosive. The values are obtained by measuring the thickness of inert spacer material (expressed in "cards" or inches) that will just produce $50 \%$ probability of detonation when placed between the test explosive and a standard detonating charge. In general, the larger the spacer gap the more shock-sensitive is the HE. The numbers, however, depend on test size and geometry as well as on the particular lot, its method of preparation, and density or percent voids. They are, therefore, only approximate indications of relative shock sensitivity. Two tests were developed at LASL for different amounts of solid HE; they are identified as the large-scale and the small-scale gap tests. ${ }^{6}$

In the small-scale gap test the acceptors (samples) are pellets $1 / 2$ in. $(12.7 \mathrm{~mm}$ ) in diameter and $1-1 / 2$ in. (38.1 mm) long; the spacers (constituting the gap) are brass shims in 0.1 in. $(2.54 \mathrm{~mm})$ increments. The donors are modified SE-1 detonators with PBX-9407 pellets $0.300 \mathrm{in.}(7.62 \mathrm{~mm})$ in diameter and $0.207 \mathrm{in}$. $(5.26 \mathrm{~mm})$ long. Detonation of the acceptor charge is ascertained by the dent produced in a $6-\mathrm{in}$. (152 $\mathrm{mm}$ ) square, 2-in. (102-mm) thick witness plate. The values in Table 9-5 were obtained at LASL and at Pantex.

Results from the large-scale gap test at LASL are given in Table 9-6. This test differs from the small-scale test in the following respects:

1. The acceptors are pellets $1-5 / 8 \mathrm{in} .(41.3 \mathrm{~mm})$ in diameter and 4 in. $(102 \mathrm{~mm})$ long.

2. The donors are $1-5 / 8$ in. $(41.3 \mathrm{~mm})$ diameter by 4 in. $(102 \mathrm{~mm})$ long $P B X-9205$ pellets.

3. The spacers are $1-5 / 8$ in. $(41.3 \mathrm{~mm})$ diameter disks of 2020-T4 Dural (aluminum). 
Table 9-5. Small-scale gap-test sensitivities of various explosives. ${ }^{a}$

\begin{tabular}{|c|c|c|c|c|c|}
\hline \multirow[b]{2}{*}{ Explosive } & \multirow[b]{2}{*}{ Preparation } & $\rho$ & \multirow{2}{*}{$\begin{array}{c}\text { Percent } \\
\text { voids } \\
(\%)\end{array}$} & \multicolumn{2}{|c|}{ Expected gap range } \\
\hline & & $\left(\mathrm{g} / \mathrm{cm}^{3}\left(\mathrm{Mg} / \mathrm{m}^{3}\right)\right)$ & & (mils) & $(\mathrm{mm})$ \\
\hline Baratol & Cast & 2.565 & 2.6 & \multicolumn{2}{|c|}{ Failed at 0} \\
\hline Comp B, Grade A & Cast & 1.710 & 1.1 & $16-26$ & $(0.41 \div 0.66)$ \\
\hline Comp B-3 & Cast & 1.721 & 1.8 & $44-54$ & $(1.1-1.4)$ \\
\hline Cyclotol $75 / 25$ & Cast & 1.753 & 1.1 & $10-16$ & $(0.25-0.41)$ \\
\hline DA TB & Hot-pressed & 1.801 & 2.1 & $11-17$ & $(0.28-0.43)$ \\
\hline $\begin{aligned} \text { LX-04-1 } & (\text { pre-6/65) } \\
& (\text { post-6/65) }\end{aligned}$ & $\begin{array}{l}\text { Hot-pressed } \\
\text { Hot-pressed }\end{array}$ & $\begin{array}{l}1.865 \\
1.865\end{array}$ & $\begin{array}{l}1.3 \\
1.3\end{array}$ & $\begin{array}{l}60-80 \\
40-60\end{array}$ & $\begin{array}{l}(1.5-2.0) \\
(1.0-1.5)\end{array}$ \\
\hline$L X-07-1$ & Hot-pressed & 1.857 & 1.8 & $70-90$ & $(1.8-2.3)$ \\
\hline $\mathrm{LX}-07-2$ & Hot-pressed & 1.859 & 1.3 & $70-90$ & $(1.8-2.3)$ \\
\hline$L X-09-0$ & Hot-pressed & 1.835 & 1.3 & $75-105$ & $(1.9-2.7)$ \\
\hline$L X-10-0$ & Hot-pressed & 1.872 & 1.7 & $80-100$ & $(2.0-2.5)$ \\
\hline$L X-11-0$ & Hot-pressed & 1.867 & 0.3 & $45-65$ & $(1.1-1.7)$ \\
\hline $\mathrm{LX}-13$ & See XTX-8003 & & & & \\
\hline $\mathrm{LX}-14$ & Hot-pressed & 1.833 & 0.9 & $60-80$ & $(1.5-2.0 !$ \\
\hline 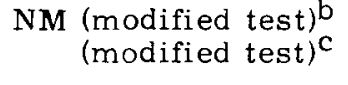 & & & & $\begin{array}{l}7-17 \\
2-8\end{array}$ & $\begin{array}{l}(0.18-0.43) \\
(0.05-0.20)\end{array}$ \\
\hline Octol $75 / 25$ & Cast & 1.810 & 1.1 & $22-28$ & $(0.56-0.71)$ \\
\hline $\begin{array}{l}\text { PBX }-9007 \\
\quad(0.8 \% \text { graphite })\end{array}$ & Hot-pressed & 1.665 & 1.8 & $45-55$ & $(1.1-1.4)$ \\
\hline PBX-9010-02 & Hot-pressed & 1.783 & 1.7 & $75-95$ & $(1.9-2.4)$ \\
\hline PBX-9011-03 & Hot-pressed & 1.783 & 0.7 & $55-70$ & $(1.4-1.8)$ \\
\hline PBX-9205 & Hot-pressed & 1.682 & 1.6 & $25-35$ & $(0.64-0.89)$ \\
\hline PBX -9404-03 & Hot-pressed & 1.850 & 0.9 & 85-105 & $(2.2-2.7)$ \\
\hline PBX-9407 & $\begin{array}{l}\text { Hot-pressed } \\
\text { Hot-pressed }\end{array}$ & $\begin{array}{l}1.600 \\
1.770\end{array}$ & $\begin{array}{r}11.3 \\
1.8\end{array}$ & $\begin{array}{r}180-210 \\
90-120\end{array}$ & $\begin{array}{l}(4.6-5.3) \\
(2.3-3.1)\end{array}$ \\
\hline PBX-9501 & Hot-pressed & 1.843 & 0.6 & $50-70$ & $(1.3-1.8)$ \\
\hline Pentolite $50 / 50$ & $\begin{array}{l}\text { Hot-pressed } \\
\text { Cast }\end{array}$ & $\begin{array}{l}1.676 \\
1.700\end{array}$ & $\begin{array}{l}2.0 \\
0.6\end{array}$ & $\begin{array}{c}105-140 \\
30-38\end{array}$ & $\begin{array}{l}(2.7-3.6) \\
(0.76-0.97)\end{array}$ \\
\hline PETN & Hot-pressed & 1.757 & 0.8 & $190-220$ & $(4.8-5.6)$ \\
\hline $\mathrm{RDX}$ & Hot-pressed & 1.735 & 4.1 & $190-220$ & $(4.8-5.6)$ \\
\hline TA TB & Hot-pressed & 1.872 & 2.5 & 2-8 & $(0.05-0.2)$ \\
\hline Tetryl & Hot-pressed & 1.684 & 2.7 & $135-165$ & $(3.4-4.2)$ \\
\hline TNT & Hot-pressed & 1.624 & 1.8 & $8-16$ & $(0.20-0.41)$ \\
\hline XTX-8003 & $\begin{array}{l}\text { Uncured } \\
\text { Cured }\end{array}$ & $\begin{array}{l}1.53 \\
1.53\end{array}$ & $\begin{array}{l}1.7 \\
1.7\end{array}$ & $\begin{array}{l}160-190 \\
130-160\end{array}$ & $\begin{array}{l}(4.1-4.8) \\
(3.3-4.1)\end{array}$ \\
\hline
\end{tabular}

${ }^{\mathrm{a}}$ One mil $=2.540 \times 10^{-2} \mathrm{~mm}$.

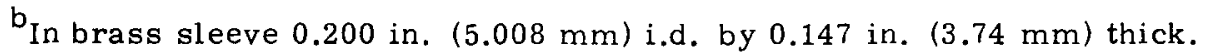

${ }^{c}$ In brass sleeve $0.400 \mathrm{in}$. $(10.2 \mathrm{~mm})$ i.d. by $0.43 \mathrm{in.}(10.9 \mathrm{~mm})$ thick. 
Table 9-6. Large-scale gap test sensitivities.

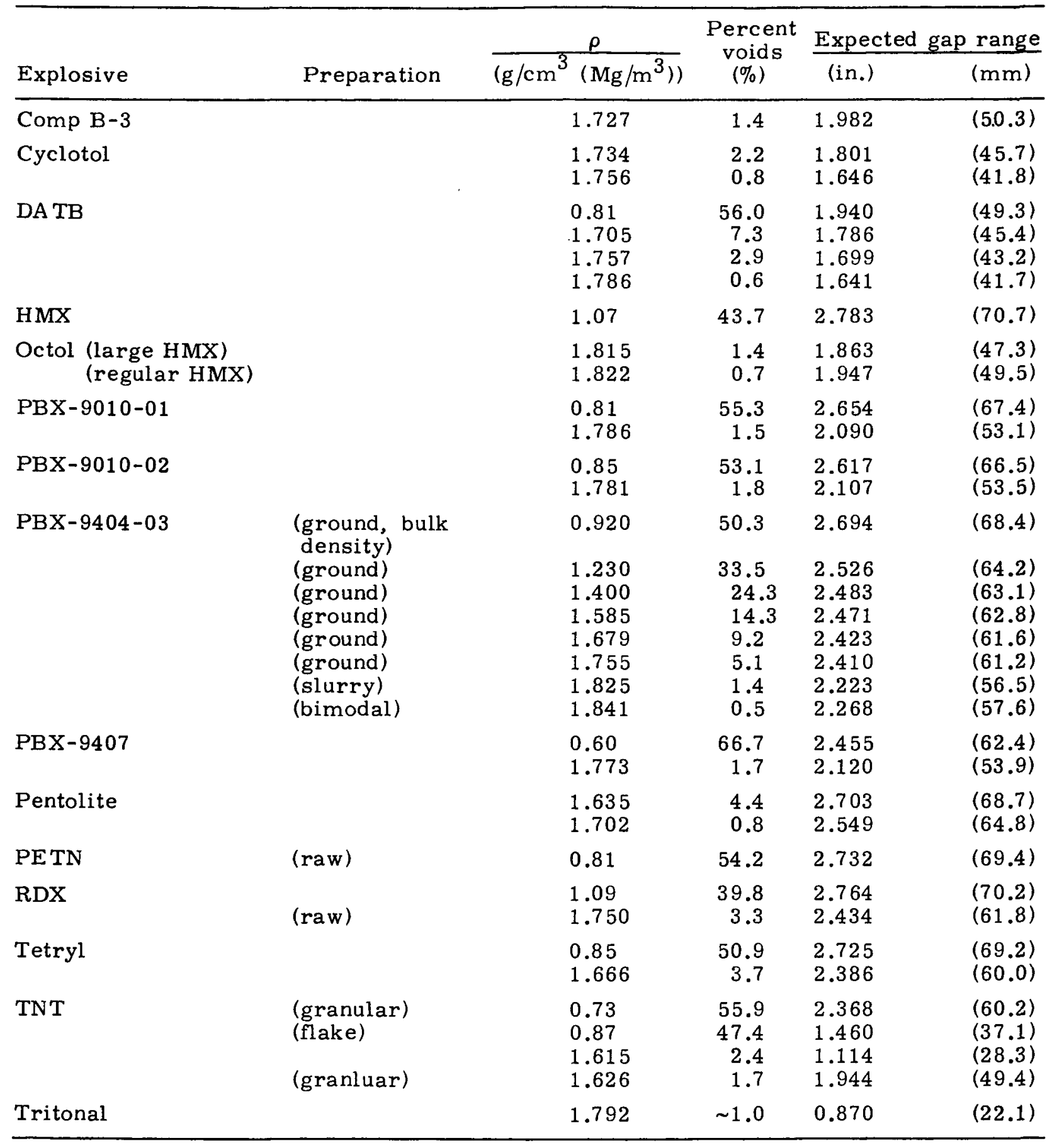

The values in Table 9-7 were obtained at Stanford Research Institute with a gap test for liquid explosives. ${ }^{6}$ The acceptors are steel tubes of $1 / 2$ in. $(12.7 \mathrm{~mm})$ i.d. $\times 0.1$ in. $(2.54 \mathrm{~mm})$ thick $\times 4$ in. $(101.6 \mathrm{~mm})$ long. The spacers are cellulose acetate disks ("cards") 10 mils $(0.25 \mathrm{~mm})$ thick and $1-5 / 8 \mathrm{in.}(41.4 \mathrm{~mm})$ in diameter, used here as a unit of measurement. The donors are two tetryl pellets $1-5 / 8 \mathrm{in}$. (41.4 $\mathrm{mm}$ ) in diameter and $1 / 2$ in. $(12.7 \mathrm{~mm})$ long, each weighing $\sim 50 \mathrm{~g}$. Detonation is detected on a witness plate $1 / 16 \mathrm{in.}(1.6 \mathrm{~mm})$ thick for $L V D$ and $3 / 8 \mathrm{in.}(9.6 \mathrm{~mm})$ thick for HVD. 
Table 9-7. Gap test sensitivities of liquid explosives. ${ }^{7}$

\begin{tabular}{lcccccc}
\hline & \multicolumn{2}{c}{ LVD gap } & & \multicolumn{2}{c}{ HVD gap } & HVD velocity \\
Explosive & (cards) & $(\mathrm{mm})$ & & (cards) & $(\mathrm{mm})$ & $(\mathrm{km} / \mathrm{s})$ \\
\hline FEFO & $1500-1800$ & $(381-457)$ & 77 & $(19.6)$ & 7.2 \\
NG/EGDN 50/50 & 11,000 & $(2790)$ & 180 & $(45.7)$ & 7.61 \\
NM & $-{ }^{2}$ & - & $20-44$ & $(5.1-10.2)$ & 6.3 \\
NM/TNM 50/50 & $354-394$ & $(90-100)$ & 40 & $(10)$ & 7.4 \\
\hline
\end{tabular}

${ }^{a}$ None in this geometry.

Shock Initiation

\section{Critical Energy}

Data from a number of sources show that there is a rather strict boundary between shock initiation and noninitiation of an explosive as a function of the energy fluence of the shock wave. Each explosive studied has a specific critical energy fluence value. Critical energy as a function of pressure and time has not been explored widely, but the data to date indicate that the critical energy fluence for initiation is probably reasonably constant over the initiation pressure ranges of interest. A critical energy equation has been derived from the conservation and Hugoniot relationships. The equation is

$$
\mathrm{E}_{\mathrm{c}}=\frac{t \mathrm{P}^{2}}{\rho \mathrm{U}_{\mathrm{s}}},
$$

where $\mathrm{E}_{\mathrm{c}}$ is the critical energy in cal $/ \mathrm{cm}^{2}\left(\mathrm{~J} / \mathrm{m}^{2}\right), \mathrm{t}$ is the pulse-width of the incident shock in $\mu \mathrm{s}, \mathrm{P}$ is the shock pressure in kbar $(\mathrm{GPa}), \rho$ is the density of the explosive in $\mathrm{g} / \mathrm{cm}^{3}\left(\mathrm{Mg} / \mathrm{m}^{3}\right)$, and $\mathrm{U}_{\mathrm{S}}$ is the shock velocity in $\mathrm{cm} / \mu \mathrm{s}\langle\mathrm{km} / \mathrm{s})$ in the explosive at pressure $\mathrm{P}$. Table $9-8$ gives the $\mathrm{E}_{\mathrm{c}}$ values for several HEs. 
Table 9-8. Critical energies. ${ }^{a}$

\begin{tabular}{|c|c|c|c|}
\hline \multirow[b]{2}{*}{ Explosive } & $\rho$ & \multicolumn{2}{|l|}{$\mathrm{E}_{\mathrm{c}}$} \\
\hline & $\left(\mathrm{g} / \mathrm{cm}^{3}\left(\mathrm{Mg} / \mathrm{m}^{3}\right)\right)$ & $\left(\mathrm{cal} / \mathrm{cm}^{2}\left(\mathrm{~kJ} / \mathrm{m}^{3}\right)\right)$ & Ref. \\
\hline Comp B & 1.715 & $35(-1500)^{b}$ & 8 \\
\hline Comp B-3 & 1.727 & $-29(1250)$ & 8 \\
\hline HNS-I & 1.555 & $<34(<1422)$ & 9 \\
\hline LX -04 & 1.865 & $26(1090)$ & 8 \\
\hline LX-09 & 1.84 & $23(962)$ & 10 \\
\hline NM & 1.13 & $404.7(17,000)$ & 8 \\
\hline PBX-9404 & $\begin{array}{l}1.84 \\
1.842\end{array}$ & $\begin{array}{l}15(630) \\
15(644)\end{array}$ & $\begin{array}{l}8 \\
11\end{array}$ \\
\hline PETN & $\begin{array}{r}\simeq 1.0 \\
1.0 \\
\approx 1.6\end{array}$ & $\begin{array}{c}\sim 2(\sim 84) \\
2.7(120) \\
\sim 4(\sim 167)\end{array}$ & $\begin{array}{l}8 \\
8 \\
8\end{array}$ \\
\hline TA TB & 1.93 & $226(9500)$ & 8 \\
\hline Tetryl & 1.655 & $10(420)$ & 12 \\
\hline $\begin{array}{l}\text { TNT (cast) } \\
\text { (pressed) }\end{array}$ & $\begin{array}{l}1.6 \\
1.645\end{array}$ & $\begin{array}{c}100(* 4200) \\
34(1420)\end{array}$ & $\begin{array}{l}13 \\
8\end{array}$ \\
\hline
\end{tabular}

\section{Initial Shock Pressure}

Shock initiation experiments, such as wedge tests, provide records of initial shock pressure-distance histories characteristic to each $\mathrm{HE}$. The $\log P-\log \mathbf{x}$ equations in Table 9-9 represent least squares fits in the pressure ranges indicated. The $P-x^{-1}$ equations in the table represent least square fits for runs ( $x$ ) of less than $25 \mathrm{~mm}$. Some of the fits are shown graphically in Fig. 9-19.

Table 9-9. Least squares fits for shock initiation data.

\begin{tabular}{|c|c|c|c|c|}
\hline Explosive & $\left(\mathrm{Mg} / \mathrm{m}^{3}\right)$ & Equation & Range & Ref. \\
\hline Baratol & 2.611 & $\left\{\begin{array}{l}\log P=1.2352-0.3383 \log x \\
P=5.44+22.47 x^{-1}\end{array}\right.$ & $\begin{array}{l}6.8 \leq \mathrm{P} \leq 12 \\
6.8 \leq \mathrm{P} \leq 12\end{array}$ & $\begin{array}{l}14 \\
14\end{array}$ \\
\hline PBX-9011-06 & 1.790 & $\left\{\begin{array}{l}\log P=1.1835-0.6570 \log x \\
P=2.59+13.55 x\end{array}\right.$ & $\begin{array}{l}4.8 \leq P \leq 16 \\
4.8 \leq P \leq 16\end{array}$ & $\begin{array}{l}14 \\
14\end{array}$ \\
\hline PBX -9404 & $\begin{array}{l}1.840 \\
1.721\end{array}$ & $\begin{array}{l}\left\{\begin{array}{l}\log P=1.1192-0.6696 \log x \\
P=2.17+9.88 x^{-i}\end{array}\right. \\
\left\{\begin{array}{l}\log P=0.9597-0.7148 \log x \\
P=1.09+8.71 x^{-i}\end{array}\right.\end{array}$ & $\begin{array}{l}2 \leq \mathrm{P} \leq 25 \\
3 \leq \mathrm{P} \leq 25 \\
1.2 \leq \mathrm{P} \leq 6.3 \\
2.0 \leq \mathrm{P} \leq 6.3\end{array}$ & $\begin{array}{l}14 \\
14 \\
14 \\
14\end{array}$ \\
\hline PBX-9501-01 & $\left\{\begin{array}{l}1.833 \\
1.844\end{array}\right.$ & $\begin{array}{l}\log P=1.0999-0.5878 \log x \\
\log P=1.1029-0.5064 \log x\end{array}$ & $\begin{array}{l}2.5 \leq \mathrm{P} \leq 6.9 \\
2.5 \leq \mathrm{P} \leq 7.2\end{array}$ & $\begin{array}{l}14 \\
14\end{array}$ \\
\hline PETN & $\left\{\begin{array}{l}1.72 \\
1.60 \\
1.0\end{array}\right.$ & $\begin{array}{l}\log P=0.6526-0.5959 \log x \\
\log P=0.3872-0.5038 \log x \\
\log P=0.3855-0.2916 \log x\end{array}$ & $\begin{array}{l}2.0 \leq \mathrm{P} \leq 4.2 \\
1.2 \leq \mathrm{P} \leq 2.0 \\
0.2 \leq \mathrm{P} \leq 0.5\end{array}$ & $\begin{array}{l}15 \\
15 \\
16\end{array}$ \\
\hline ТА ТВ & 1.876 & $\left\{\begin{array}{l}\log P=1.4170-0.4030 \log x \\
P=8.24+26.01 x^{-1}\end{array}\right.$ & $\begin{array}{l}11 \leq P \leq 16 \\
11 \leq P \leq 16\end{array}$ & $\begin{array}{l}14 \\
14\end{array}$ \\
\hline $\mathrm{XTX}-8003$ & 1.53 & $\log P=0.7957-0.463 \log x$ & $3.0 \leq \mathrm{P} \leq 5.0$ & 16 \\
\hline
\end{tabular}

${ }^{a} x=d_{i s t a n c e}$ of run to transition to high order in $\mathrm{mm}$

${ }^{b} P=1 n i t i a l$ shock pressure in GPa. 


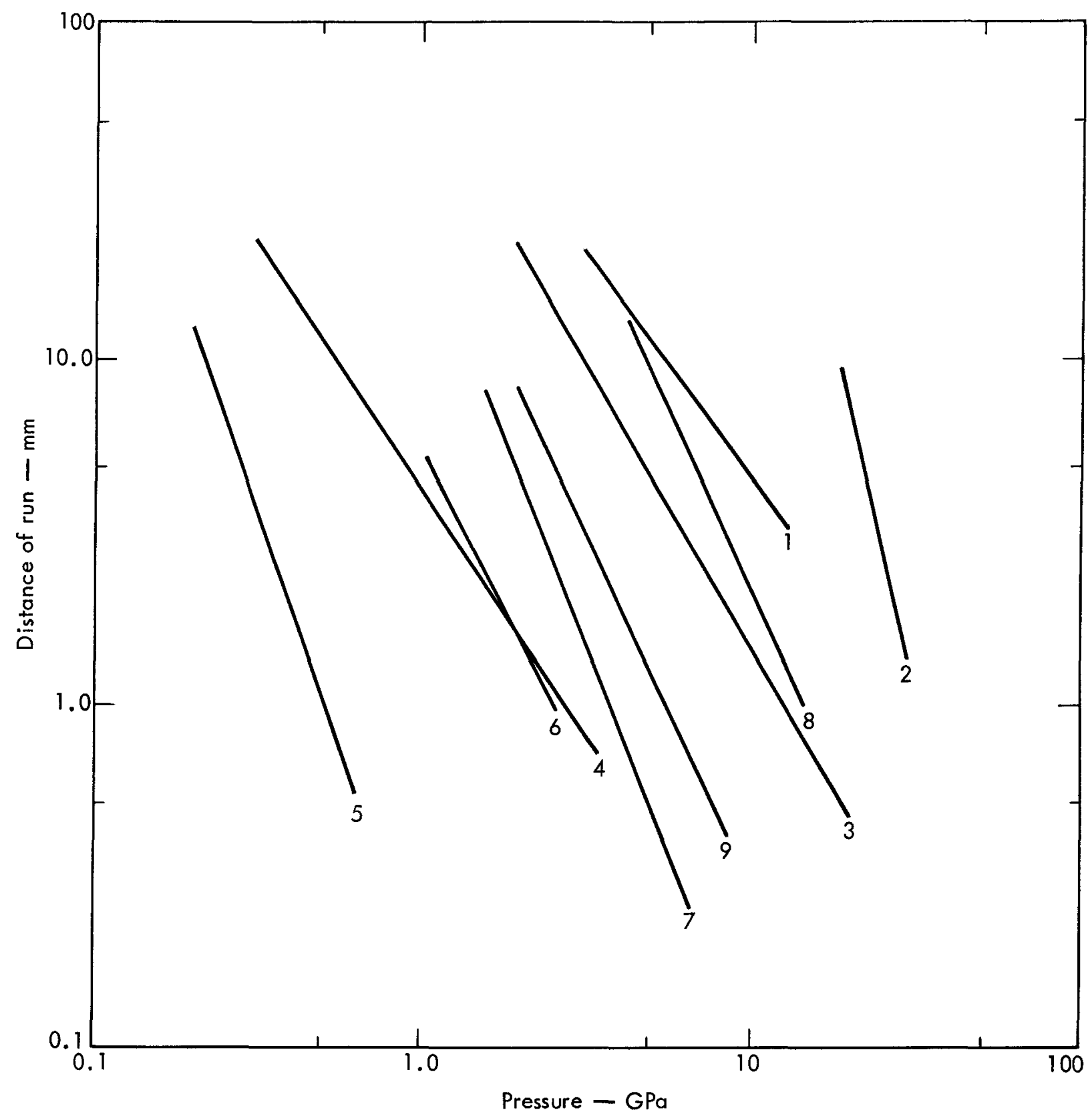

\begin{tabular}{clcc} 
Curve No. & Explosive & $\rho\left(\mathrm{Mg} / \mathrm{m}^{3}\right)$ & Ref. \\
\hline 1 & Comp B & 1.72 & 17 \\
2 & NQ & 1.69 & 17 \\
3 & PBX-9404 & 1.83 & 17 \\
4 & PBX-9407 & 1.60 & 18 \\
5 & PETN & 1.0 & 17 \\
6 & PETN & 1.60 & 16 \\
7 & PETN & 1.72 & 16 \\
8 & TNT & 1.63 & 17 \\
9 & XTX-8003 & 1.53 & 16 \\
\hline
\end{tabular}

Fig. 9-19. Log-Log plots of distance of run to detonation vs initial shock pressure of various explosives. 


\section{$\underline{\text { References }}$}

1. E. E. Kilmer, J. Spacecr. Rockets 5, 1216-1219 (1968).

2. T. M. Benziger, X-0242, A High-Energy Plastic-Bonded Explosive, Los Alamos Scientific Laboratory, N. M., Rept. LA-4872-MS (1972).

3. L. G. Green and A. M. Weston, Data Analysis of the Reaction Behavior of Explosive Materials Subjected to Susan Test Impacts, Lawrence Livermore Laboratory, Rept. UCRL-13480 (1970).

4. L. G. Green, A. M. Weston, and J. H. van Velkinburg, Mechanical Behavior of Flastic-Bonded Explosives Vertically Dropped on a Smooth, Rigid, Steel Target Surface, Lawrence Livermore Laboratory, Rept. UCRL-51022 (1971).

5. L. G. Green, A. M. Weston, and J. H. van Velkinburg, Mechanical and Functional Behavior of Skid Test Hemispherical Billets, Lawrence Livermore Laboratory, Rept. UCRL-51085 (1971).

6. M. J. Urizar and L. C. Smith, Los Alamos Scientific Laboratory, N. M., personal communication (1970).

7. R. W. Woolfolk, Stanford Research Institute, Menlo Park, Calif., personal communication (1970).

8. F. W. Walker, Lawrence Livermore Laboratory, to be published (1974).

9. D. Price, U.S. Naval Ordnance Laboratory, White Oak, Md., personal communication (1967)

10. L. G. Green, Lawrence Livermore Laboratory, personal communication (1972).

11. L. G. Green, E. J. Nidick, Jr., and F. E. Walker, Critical Shock Initiation of PBX-9404, A New Approach, Lawrence Livermore Laboratory, Rept. UCRL51522 (1974).

12. L. G. Green, E. J. Nidick, Jr., and F. E. Walker, Critical Energy for Shock Initiation of Tetryl and A-5, Lawrence Livermore Laboratory, Rept. UCID16469 (1974).

13. M. L. Schimmel, QUEST-Quantitative Understanding of Explosive Stimulus Transfer, Summary Report - Tasks 1 thru 6. McDonnell Aircraft Co., St. Louis, Mo., Rept. MDC-A-1021 (1971).

14. B. G. Craig, Los Alamos Scientific Laboratory, N. M., personal communication (1974).

15. J. Wackerle and J. O. Johnson, Pressure Measurements on the Shock-Induced Decomposition of High-Density PETN, Los Alamos Scientific Laboratory, N. M., Rept. LA-5131 (1973).

16. D. Stirpe, J. O. Johnson, and J. Wackerle, J. Appl. Phys. 41, 3884-3893 (1970).

17. J. B. Ramsey and A. Popolato, "Analysis of Shock Wave and Initiation Data for Solid Explosives," in Proc. 4th Symp. (Intern.) on Detonation, U.S. Office of Naval Research, Washington, D. C., Rept. ACR-126 (1965), pp. 233-238.

18. I. E. Lindstrom, J. Appl. Phys. 37, 4873-3880 (1966). 


\section{ELECTRICAL PROPERTIES}

Like other polymeric materials, the secondary HEs discussed here are good electrical insulators. They are not considered to be sensitive to accidental initiation from electric sparks.

\section{Dielectric Constant}

The dielectric constant $\epsilon$, also called relative permittıvity, is density-dependent; it is defined as the ratio of the capacitance of a condenser filled with the sample material to the capacitance of the condenser with a vacuum between its plates. The dielectric constants of several explosives are given in Table 10-1. An empirical, logarithmic relationship has been established for two-component HEs composed of the same materials in different proportions. ${ }^{1}$ Figure 10-1 illustrates this mixing rule for TNT/RDX compositions. The relationship is expressed as

$$
\log \mathrm{k}_{\mathrm{t}}=\theta_{1} \log \mathrm{K}_{1}=\theta_{2} \log \mathrm{k}_{2} \text {, }
$$

where

$$
\begin{aligned}
\mathrm{k}_{\mathrm{t}} & =\text { relative permittivity of the mixture, } \\
\mathrm{k}_{1}, \mathrm{k}_{2} & =\text { relative permittıvities of components, and }
\end{aligned}
$$$$
\theta_{1}, \theta_{2}=\text { volume ratios of components. }
$$

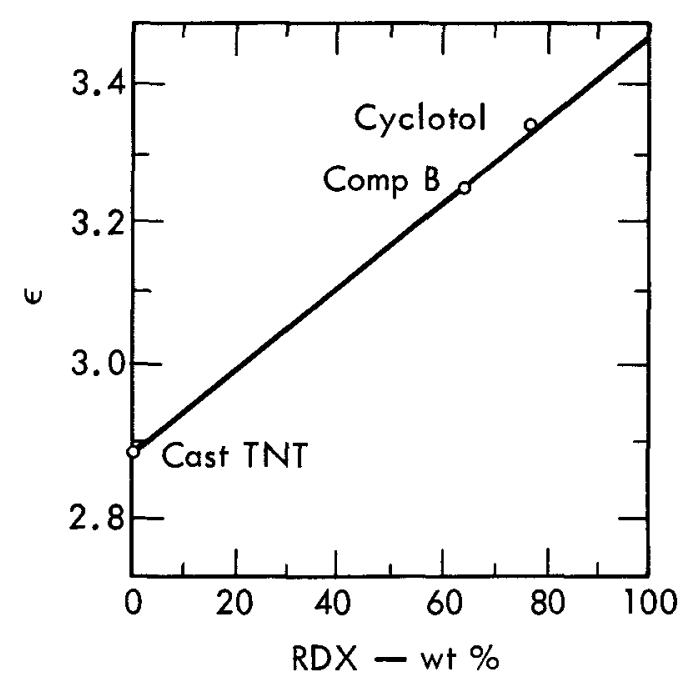

Fig. 10-1. Logarithmic mixing rule applied to TNT-RDX mixtures. 1 
Table 10-1. Dielectric constants, $\epsilon$.

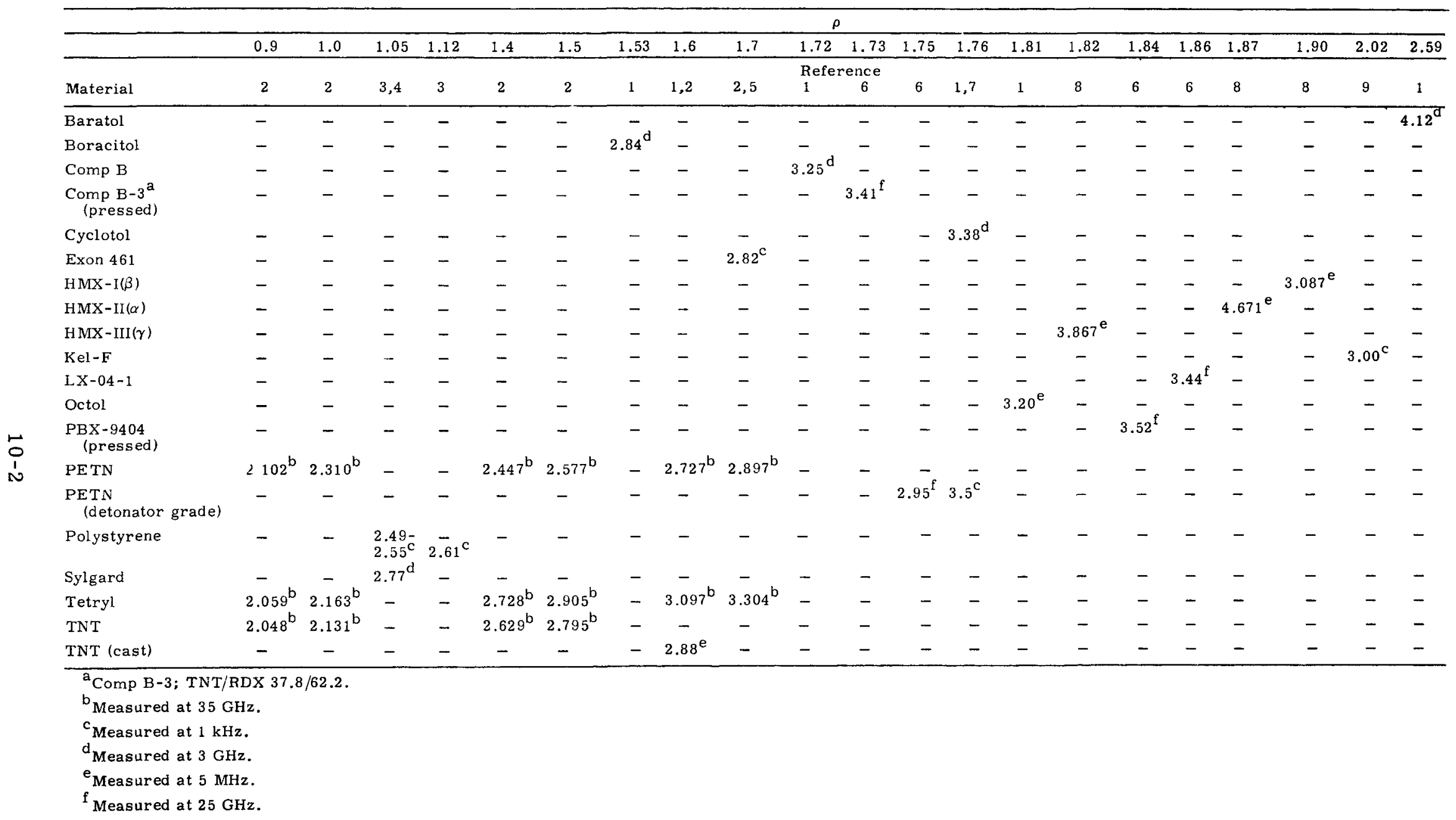




\section{References}

1. B. Hayes, Los Alamos Scientific Laboratory, N. M., personal communication (1956).

2. G. F. Cawsey, J. L. Farrands, and S. Thomas, Proc. Roy. Soc. (London) 248A, 499-521 (1958).

3. J. Brandrup and E. H. Immergut, eds., Polymer Handbook, Interscience, N.Y. (1966).

4. Dow Corning, Hemlock, Mich., Information About Electronic Materials, Bulletin 07-123 (May 1964).

5. Firestone Plastics Company, Exon, Sales Service Bulletin No. 20 (1956).

6. K. Ernst, Lawrence Livermore Laboratory, personal communication (1972).

7. M. Fulk, Lawrence Livermore Laboratory, personal communication (1972).

8. M. Bedard, H. Huber, J. L. Myers, and G. F. Wright, Can. J. Chem. $\underline{40}$, 2278-2299 (1962).

9. Minnesota Mining and Manufacturing Co., St. Paul, Minn., Kel-F Elastomer Properties and Applications, Service Bulletin (no date). 
$10-4$ 


\section{TOXICITY}

Toxic symptoms can result from exposure to some HEs and components by inhalation of the dust or vapor, by ingestion, or by contact with the skin. Most explosives are not highly toxic, but careless handling could result in systemic poisoning, usually affecting the bone marrow (blood-cell-producing system) and the liver.

The following general precautions (LLL standard operating procedures) should be observed on all HEs:

1. The material should be handled only in a well-ventilated area.

2. Skin contact should be avoided. Explosives can be absorbed through the skin, or they may cause skin rash (the most common symptom among explosives handlers). Daily baths and clean clothing are recommended for persons engaged in $\mathrm{HE}$ processing.

Toxicities, where known, are listed in Table 11-1.

Table 11-1. Health hazards of explosives.

\begin{tabular}{ll}
\hline Explosive & \multicolumn{1}{c}{ Toxicity $^{1}$} \\
\hline BDNPA/BDNPF & None $^{1}$ \\
Cab-O-Sil & Low $^{2}$ \\
Comp C-4 & Moderate $^{3}$ \\
DIPAM & Moderate $^{4}$ \\
DOP & Low $^{5}$ \\
Estane & None $^{6}$ \\
Exon 461 & Slight $^{7}$ \\
FEFO & High $^{8}$ \\
HNAB & Slight $^{9}$ \\
HNS & Slight $^{9}$ \\
NC & None $^{4}$ \\
NG & Very high $^{4}$ \\
NM & Moderate $^{4}$ \\
NQ & Slight $^{4}$ \\
PETN & High $^{4}$ \\
RDX & Slight $^{10}$ \\
TEF & High $^{4}$ \\
Tetryl & Very high $^{4}$ \\
TNM & Moderate $^{4}$ \\
TNT &
\end{tabular}


1. M. Finger, Properties of Bis(2,2-dinitropropyl)acetal and Bis(2,2dinitropropyl)formal, Eutectic Mixture, Lawrence Livermore Laboratory, Rept. UCID-16088 (1972).

2. H. G. Hammond, Lawrence Livermore Laboratory, personal communication (1974).

3. A. J. Hollander, Mil. Med. 134, 1529-1530 (1969).

4. N. I. Sax, Dangerous Properties of Industrial Materials (Reinhold, New York, 1968).

5. M. Radeva and S. Dinoeva, Khig. Zdraveopazvane, 9(5), 510-16 (1966). (Cited in Chem. Abstr. 66, Abstr. 103632 (1967).

6. B. F. Goodrich Company, Cleveland, Ohio, Estane Polyurethane Solution Systems, TSR 64-18 (1964).

7. Firestone Plastics Co., Pottstown, Pa., Sales Service Bulletin No. 20 (nd).

8. B. J. Mechalas and P. H. Allen, Toxicology Screening of FEFO, Lawrence Livermore Laboratory, Rept. UCRL-13372 (1968).

9. A. C. Schwarz, Applications of Hexanitrostilbene (HNS) in Explosive Components, Sandia Laboratories, Albuquerque, N. Mex., Rept. SC-RR-710673 (1972).

10. A. S. Kaplan, C. F. Berghout, and A. Peczenik, Arch. Environ. Health 10, $877-883$ (1965).

11. Celanese Corporation, Chemical Division, New York, N. Y., Celluflex CEF, Products Bulletin N-46-2 (1955). 


\section{Mock Explosives}

\section{INTRODUCTION}

It is often convenient for test purposes to have materials that duplicate compositional, mechanical, or other properties of an HE but lacks its hazards. A series of mock materials has been formulated for these purposes. Characteristics and properties of these mocks are summarized in this section according to the same scheme used for HEs in the preceding sections.

A mock $\mathrm{HE}$ is a nonexplosive equivalent of a particular explosive formulation. The approved all-purpose mock for LX-04-1 might naturally be called LM-04-1. However, mocks do not always (in fact, they seldom do) pair in one-to-one relation with the corresponding $\mathrm{HE}$. For PBX-9404, for example, there are three separate mocks: a compositional mock, a physical-property mock, and a thermal mock. For this and other reasons too involved to detail here, no attempt is made to achieve correspondence beyond the class designation. Thus, there may be an LM-04-5 that mocks the thermalexpansion characteristics of LX-04-2, or an RM-06-H that mocks the density of RX-06-AA, etc.

Selection of the best mock HE for a specific purpose involves the following steps:

- Selection of the properties to be mocked. Some examples:

1. Atomic composition

2. Density

3. Thermal properties

Coefficient of thermal expansion

Heat transfer properties (Table 15-1 shows how to select the properties for a specific boundary condition)

4. Mechanical properties

Elastic behavior

Viscoelastic behavior

Failure behavior

- Comparison with the HE of interest over the appropriate temperature range, either by direct comparison of properties or by comparison of results from analytical calculations. 
12-2

$12 / 72$ 


\section{NAMES AND FORMULATIONS}

Table 13-1. Formulations of mock explosives.

\begin{tabular}{|c|c|c|c|c|}
\hline \multirow{2}{*}{$\frac{\text { Mock }}{10010}$} & \multirow{2}{*}{$\begin{array}{l}\begin{array}{c}\text { Hxplosive properties } \\
\text { mocked }\end{array} \\
\text { P'BX-9404: mechanical } \\
\text { properties }\end{array}$} & \multicolumn{2}{|c|}{$\underset{\left(w^{0} / \mu\right)}{\left.C^{\circ}\right)}$} & \multirow[t]{2}{*}{ Molecular formula ${ }^{b}$} \\
\hline & & $\begin{array}{l}\text { Pentaerythritol } \\
\mathrm{Ba}\left(\mathrm{NO}_{3}\right)_{2} \\
\mathrm{NC} \\
\mathrm{CEF}\end{array}$ & $\begin{array}{r}48.0 \\
46.0 \\
2.8 \\
3.2\end{array}$ & \\
\hline 90503 & $\begin{array}{l}\text { PBX-9404 and } L X-10: \\
\text { atomic composition }\end{array}$ & $\begin{array}{l}\text { Cyanuric acid } \\
\text { Melamine } \\
\text { NC } \\
\text { ClF }\end{array}$ & $\begin{array}{r}60 \\
32 \\
4 \\
4\end{array}$ & $\mathrm{C}_{2.32} \mathrm{H}_{3.18} \mathrm{~N}_{2.96} \mathrm{O}_{1.60} \mathrm{Cl}_{0.04} \mathrm{P}_{0.01}$ \\
\hline LM - 04-0 & $\begin{array}{l}\text { LX-04: atomic com- } \\
\text { position }{ }^{\mathrm{C}}\end{array}$ & $\begin{array}{l}\text { Cyanuric acid } \\
\text { Melamine } \\
\text { Viton } \mathrm{A}\end{array}$ & $\begin{array}{l}59.7 \\
23.5 \\
16.8\end{array}$ & $\mathrm{C}_{2.34} \mathrm{H}_{2.66} \mathrm{~N}_{2.51} \mathrm{O}_{1.39} \mathrm{~F}_{0.63}$ \\
\hline $\mathrm{RM}-04-13 \mathrm{G}$ & $\begin{array}{l}\text { L } \lambda \text {-04: mechanical } \\
\text { properties-static } \\
\text { and dynamic }\end{array}$ & $\begin{array}{l}\text { Cyanuric acid } \\
\left.\text { Ba( } \mathrm{NO}_{3}\right)_{2} \\
\text { Viton } \mathrm{A}\end{array}$ & $\begin{array}{l}70.5 \\
14.5 \\
15\end{array}$ & $\mathrm{C}_{2.02}{ }^{\mathrm{H}}{ }_{1.86} \mathrm{~N}_{1.75} \mathrm{O}_{1.97} \mathrm{~F}_{0.54}{ }^{\mathrm{Ba}}{ }_{0.06}$ \\
\hline
\end{tabular}

"Approximately $0.05 "$ ", of a red pigment is also added to these formulations.

${ }^{b}$ Molecular weights of these mixtures are arbitrarily taken as 100 .

${ }^{C}$ Although designed as an atomic-composition mock, LM-04-0 can also be used as an approximate mock of the mechanical properties of LX-04-1 at ambient conditions. 
13-2 
14. PHYSICAL PROPERTIES

Table 14-1. Physical states and densities. ${ }^{1}$

\begin{tabular}{lccc}
\hline Mock HE & $\begin{array}{c}\text { Physical } \\
\text { state }\end{array}$ & $\begin{array}{c}\text { TMD, } \rho \\
\left(\mathrm{g} / \mathrm{cm}^{3}\left(\mathrm{Mg} / \mathrm{m}^{3}\right)\right)\end{array}$ & $\begin{array}{c}\text { Nominal } \\
\text { density, } \rho \\
\left(\mathrm{g} / \mathrm{cm}^{3}\left(\mathrm{Mg} / \mathrm{m}^{3}\right)\right)\end{array}$ \\
\hline 90010 & Solid & 1.89 & 1.88 \\
90503 & Solid & 1.68 & 1.57 \\
LM-04-0 & Solid & 1.727 & 1.70 \\
RM-04-BG & Solid & 1.914 & 1.87 \\
\hline
\end{tabular}

Mock HE 90010 has been widely used for many years, both at LLL and at LASL, where it was originally formulated. However, it could be considered a very low-grade propellant, since it contains a fair amount of $\mathrm{BaNO}_{3}$. It burns in air with a sooty flame. Decomposition at $250^{\circ} \mathrm{C}(523 \mathrm{~K})$ results in about $117 \mathrm{ml}$ of gas evolved per gram of material. RUBY calculations were made for approximations of volume burn. The identity of the solid products of combustion is not clear; they could be either $\mathrm{BaCO}_{3}$ or $\mathrm{BaO}$. If we assume that the more energetic $\mathrm{BaCO}_{3}$ is a product, the calculated energy equivalent is about one-third that for TNT. Many differential thermal analyses have been made; they all show a characteristic exotherm. Mock HE 90010 is difficult to ignite and will not propagate a detonation, but it is definitely an exothermic material. It is strongly recommended that 90010 no longer be used in experiments involving fissile materials. 2

$\mathrm{RM}-04-\mathrm{BG}$ contains relatively much less $\mathrm{BaNO}_{3}$. Its RUBY calculations for volume burn indicate that the greater heat input would be required to decompose it than would be obtained from the final oxidation; nevertheless it does show a small exotherm at $400^{\circ} \mathrm{C}(673 \mathrm{~K})$. Clearly it presents less of a potential hazard than mock 90010, but it also should not be used for experiments with fissile materials. ${ }^{2}$

\section{$\underline{\text { References }}$}

1. R. C. Murray, Lawrence Livermore Laboratory, personal communication (1972).

2. E. James, Jr., Lawrence Livermore Laboratory, personal communication (1973). 
14-2 


\section{THERMAL PROPERTIES}

This section contains information on the selection of heat transfer properties, thermal conductivities $k$, coefficients of thermal expansion CTE, glass transition points $\mathrm{T}_{\mathrm{g}}$ and specific heats $\mathrm{C}_{\mathrm{p}}$.

Table 15-1 shows how to select the appropriate heat-transfer properties to be mocked. This table is based on mocking the temperature under specific conditions. In steady-state problems with insulated or prescribed-temperature boundary conditions, thermal properties have no significance and any material could be used.

Table 15-1. Criteria for selection of heat-transfer properties to be mocked.

\begin{tabular}{lcc}
\hline Boundary conditions & $\begin{array}{c}\text { Transient } \\
\text { problemsa }\end{array}$ & $\begin{array}{c}\text { Steady-state } \\
\text { problems }\end{array}$ \\
\hline $\begin{array}{l}\text { No heat generation } \\
\text { Insulated }\end{array}$ & $\alpha$ & - \\
Prescribed temperature & $\alpha$ & - \\
Prescribed heat flux & $\alpha, \mathbf{k}$ & $\mathbf{k}$ \\
Convection & $\alpha, \mathbf{k}$ & $\mathbf{k}$ \\
Heat generation & & $\mathbf{k}$ \\
Insulated & $\alpha, \mathbf{k}$ & $\mathbf{k}$ \\
Prescribed temperature & $\alpha, \mathbf{k}$ & $\mathbf{k}$ \\
Prescribed heat flux & $\alpha, \mathbf{k}$ & $\mathbf{k}$ \\
Convection & $\alpha, \mathbf{k}$ & \\
\hline
\end{tabular}

${ }^{2}$ Here $k=$ thermal conductivity, $\alpha=k / \rho C_{p}=$ thermal diffusivity.

\section{Thermal Conductivity and Specific Heat}

Specific heats were determined by an ice calorimetry technique. Data are given in Table 15-2 and Figs. 15-1 and 15-2.

Table 15-2. Thermal conductivities $k$ and specific heats $C_{p}$.

\begin{tabular}{|c|c|c|c|c|c|}
\hline \multirow[b]{3}{*}{ Mock HE } & \multirow{2}{*}{\multicolumn{3}{|c|}{$\mathrm{k}$ (Ref, 1) }} & \multicolumn{2}{|c|}{$C_{p}$ (Ref. 2) } \\
\hline & & & & \multirow{2}{*}{$\begin{array}{l}\mathrm{BTU} / \mathrm{lb}-^{\circ} \mathrm{F} \\
\text { or } \mathrm{cal} / \mathrm{g}-^{\circ} \mathrm{C}\end{array}$} & \multirow[b]{2}{*}{$(\mathbf{k J} / \mathrm{kg}-\mathrm{K})^{\mathrm{b}}$} \\
\hline & $\left(\mathrm{BTU} / \mathrm{hr}-\mathrm{ft}-{ }^{\circ} \mathrm{F}\right)$ & $\left(10^{-4} \mathrm{cal} / \mathrm{sec}^{-}{ }^{\circ} \mathrm{C}\right)$ & $(W / m-K)^{2}$ & & \\
\hline 90010 & 0.31 & $(12.8)$ & $(0.54)$ & 0.23 & $(0.96)$ \\
\hline 90503 & 0.36 & $(14.9)$ & $(0.62)$ & 0.29 & $(1.21)$ \\
\hline LM-04-0 & 0.59 & $(24.3)$ & $(1.02)$ & 0.28 & $(1.17)$ \\
\hline RM-04-BG & 0.66 & $(27.2)$ & $(1.14)$ & 0.24 & $(1.004)$ \\
\hline
\end{tabular}

${ }^{\mathrm{a}} \mathrm{One} \mathrm{cal} / \mathrm{cm}-\mathrm{sec}^{\circ}{ }^{\circ} \mathrm{C}=4.184 \times 10^{2} \mathrm{~W} / \mathrm{m}-\mathrm{K} ; 1 \mathrm{BTU} / \mathrm{hr}-\mathrm{ft}-{ }^{\circ} \mathrm{F}=0.004135 \mathrm{cal} / \mathrm{cm}-\mathrm{sec}-{ }^{\circ} \mathrm{C}$ $=1.729577 \mathrm{~W} / \mathrm{m}-\mathrm{K}$.

${ }^{\mathrm{b}}$ One $\mathrm{BTU} / \mathrm{bb}-{ }^{\circ} \mathrm{F}=1 \mathrm{cal} / \mathrm{g}-{ }^{\circ} \mathrm{C}=4.184 \mathrm{~kJ} / \mathrm{kg}-\mathrm{K}$. 


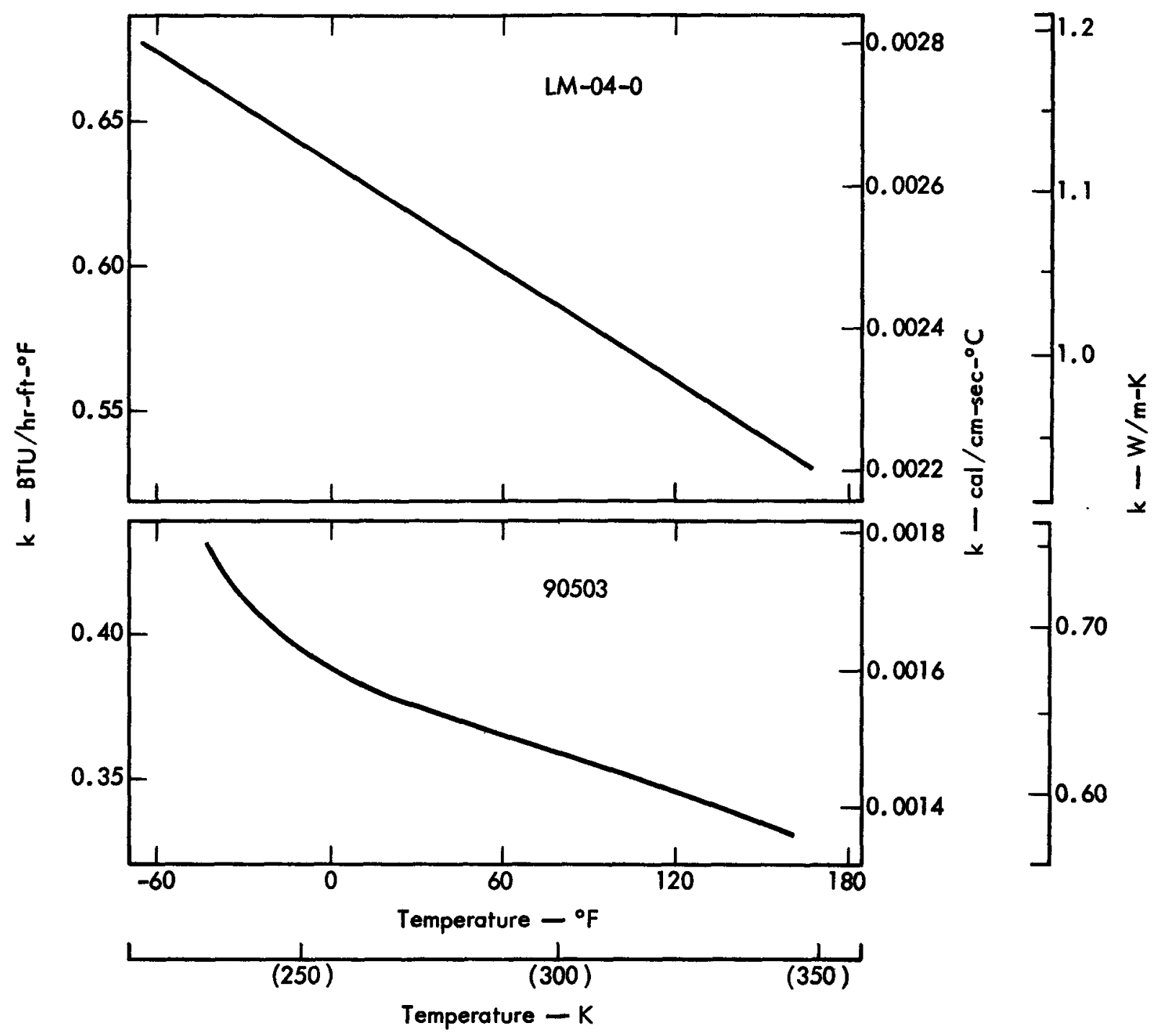

Fig. 15-1. Thermal conductivity $\mathbf{k}$ as a function of temperature. Conversion factors:

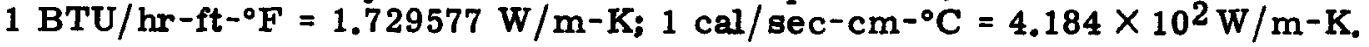




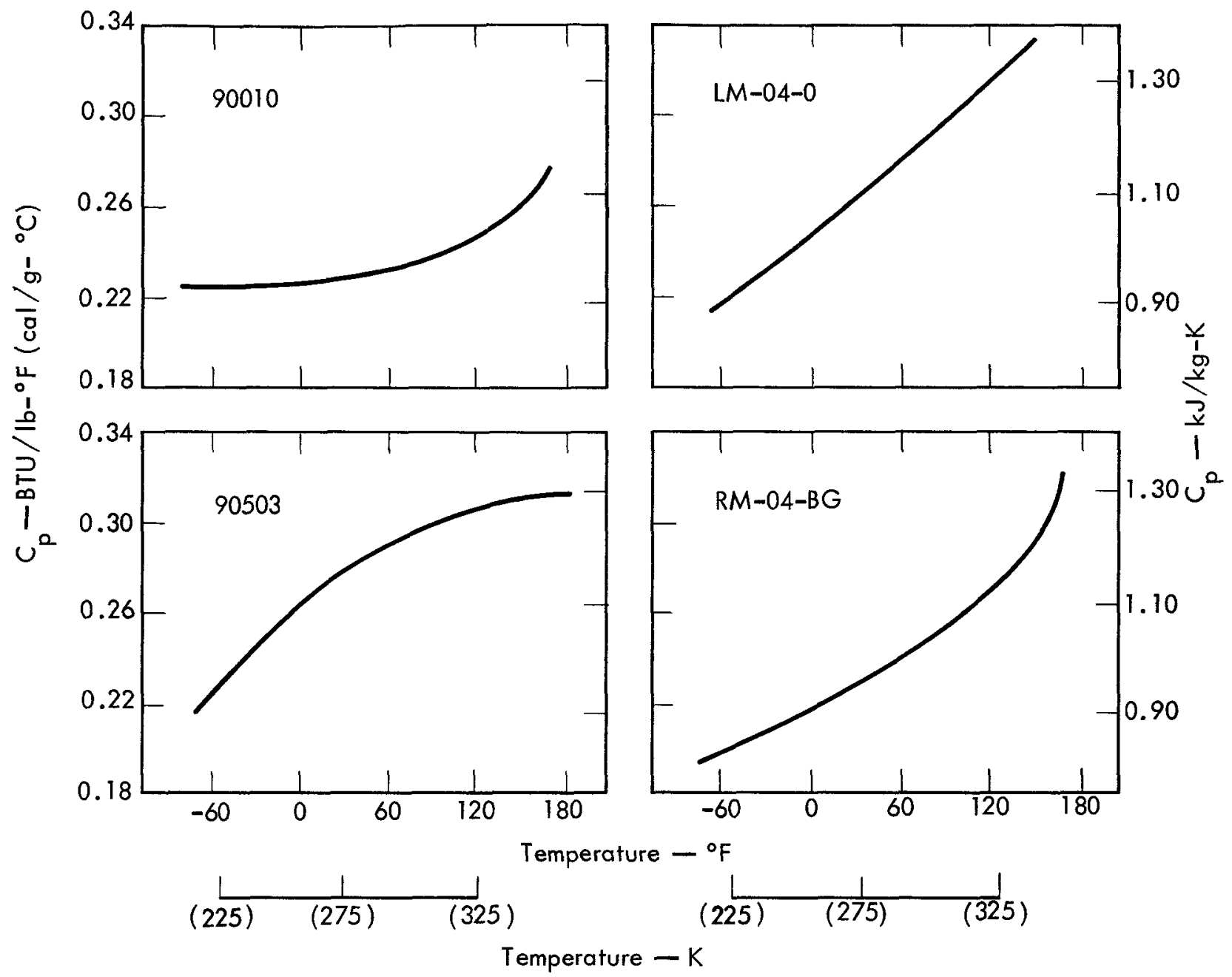

Fig. 15-2. Specific heat $C_{p}$ as a function of temperature. Conversion factor: $1 \mathrm{BTU} / 1 \mathrm{~b}-{ }^{\circ} \mathrm{F}=1 \mathrm{cal} / \mathrm{g}{ }^{\circ} \mathrm{C}=4.184 \mathrm{~kJ} / \mathrm{kg}-\mathrm{K}$. 


\section{Thermal Expansion}

Early CTE data for cyanuric-acid-type mock HEs were affected by surface chalking and growth; this is now prevented by a parylene coating. CTE data are given in Table 15-3.

Table 15-3. Coefficients of thermal expansion $\mathrm{CTE}^{\mathrm{a}, 3}$ and glass transition temperatures $\mathrm{T}_{\mathrm{g}}$.

\begin{tabular}{|c|c|c|c|c|c|c|c|c|c|c|}
\hline \multirow[b]{3}{*}{ Mock HE } & \multicolumn{5}{|c|}{ Lunear CTE $(\alpha)$} & \multicolumn{2}{|c|}{ Cubic CTF $(\beta)$} & \multirow{2}{*}{\multicolumn{2}{|c|}{$\mathrm{I}_{\mathrm{g}}$}} & \multirow{3}{*}{$\frac{\text { Pressed density } \rho}{\left(\mathrm{g} / \mathrm{cm}^{3}\left(\mathrm{Mg} / \mathrm{m}^{3}\right)\right)}$} \\
\hline & \multirow[b]{2}{*}{$\left(10^{-6}\right.$} & \multirow[b]{2}{*}{ In. $/\left(n,-^{\circ} \mathrm{F}\right)$} & \multirow{2}{*}{$\begin{array}{c}\left(10^{-6} \mathrm{~cm} / \mathrm{cm}-^{\circ} \mathrm{C}\right. \\
(\mu \mathrm{m} / \mathrm{m}-\mathrm{K}))\end{array}$} & \multicolumn{2}{|c|}{ Temperature } & \multirow{2}{*}{$\begin{array}{c}\left(10^{-6} \mathrm{cmcm}\right)^{\circ} \mathrm{C} \\
(\mu \mathrm{mm} m))\end{array}$} & \multirow{2}{*}{$\frac{\text { Temperature }}{\left({ }^{\circ} \mathrm{C}(\mathrm{K})\right)}$} & & & \\
\hline & & & & $\left({ }^{\circ} \mathrm{F}\right)$ & (K) & & & & $(\mathrm{K}))$ & \\
\hline 90010 & & $\begin{array}{l}155 \\
233\end{array}$ & $\begin{array}{l}(27.9) \\
(41.9)\end{array}$ & $\begin{array}{l}-65 \text { to }-30 \\
-10 \text { to } 165\end{array}$ & $\begin{array}{l}(219-239) \\
(250-347)\end{array}$ & & & -18 & $(245)$ & $1.880-1882$ \\
\hline 90503 & & $\begin{array}{l}20.8 \\
29.5\end{array}$ & $\begin{array}{l}(37.4) \\
(53.1)\end{array}$ & $\begin{array}{r}-65 \text { to }-10 \\
10 \text { to } 165\end{array}$ & $\begin{array}{l}(219-250) \\
(261-347)\end{array}$ & & & -18 & $(245)$ & $1.574-1.589$ \\
\hline$L M-04-0$ & & $\begin{array}{l}21.5 \\
43.9\end{array}$ & 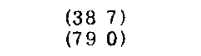 & $\begin{array}{r}-65 \text { to }-24 \\
10 \text { to } 165\end{array}$ & $\begin{array}{l}(219-243) \\
(261-347)\end{array}$ & & & -18 & $(245)$ & $1705-1.715$ \\
\hline $\mathrm{RM}-04-\mathrm{BG}$ & & $\begin{array}{l}19.2 \\
37.5\end{array}$ & $\begin{array}{l}(34.6) \\
(67.5)\end{array}$ & $\begin{array}{r}-65 \text { to }-20 \\
0 \text { to } 165\end{array}$ & $\begin{array}{l}(219-244) \\
(255-347)\end{array}$ & $\begin{array}{l}1994 \text { meas. } \\
\text { 198 calc }\end{array}$ & $\begin{array}{l}-30 \text { to } 70 \\
(243-343)\end{array}$ & -18 & $(245)$ & 1.80 \\
\hline
\end{tabular}

${ }^{a}$ One $1 \mathrm{n} . / \mathrm{nn},{ }^{\circ} \mathrm{F}-1.8 \mathrm{~cm} / \mathrm{cm}-{ }^{\circ} \mathrm{C}-1.8 \mathrm{~m} / \mathrm{m}-\mathrm{k}$.

\section{References}

1. R. C. Murray, Lawrence Livermore Laboratory, personal communication (1972).

2. T. Hoheisel, Lawrence Livermore Laboratory, personal communication (1969).

3. R. C. Murray, Lawrence Livermore Laboratory, personal communication (1968).

4. M. Finger, Lawrence Livermore Laboratory, personal communication (1965). 


\section{MECHANICAL PROPERTIES}

The data presented here ${ }^{1}$ are for each mock HE without comparison with the corresponding live HE. A mechanical mock can best be selected by selecting the appropriate mechanical property to be mocked and then making a comparison with the available data for the HE.

Figure 16-1 shows the stress-strain relationship in compression for RM-04-BG.

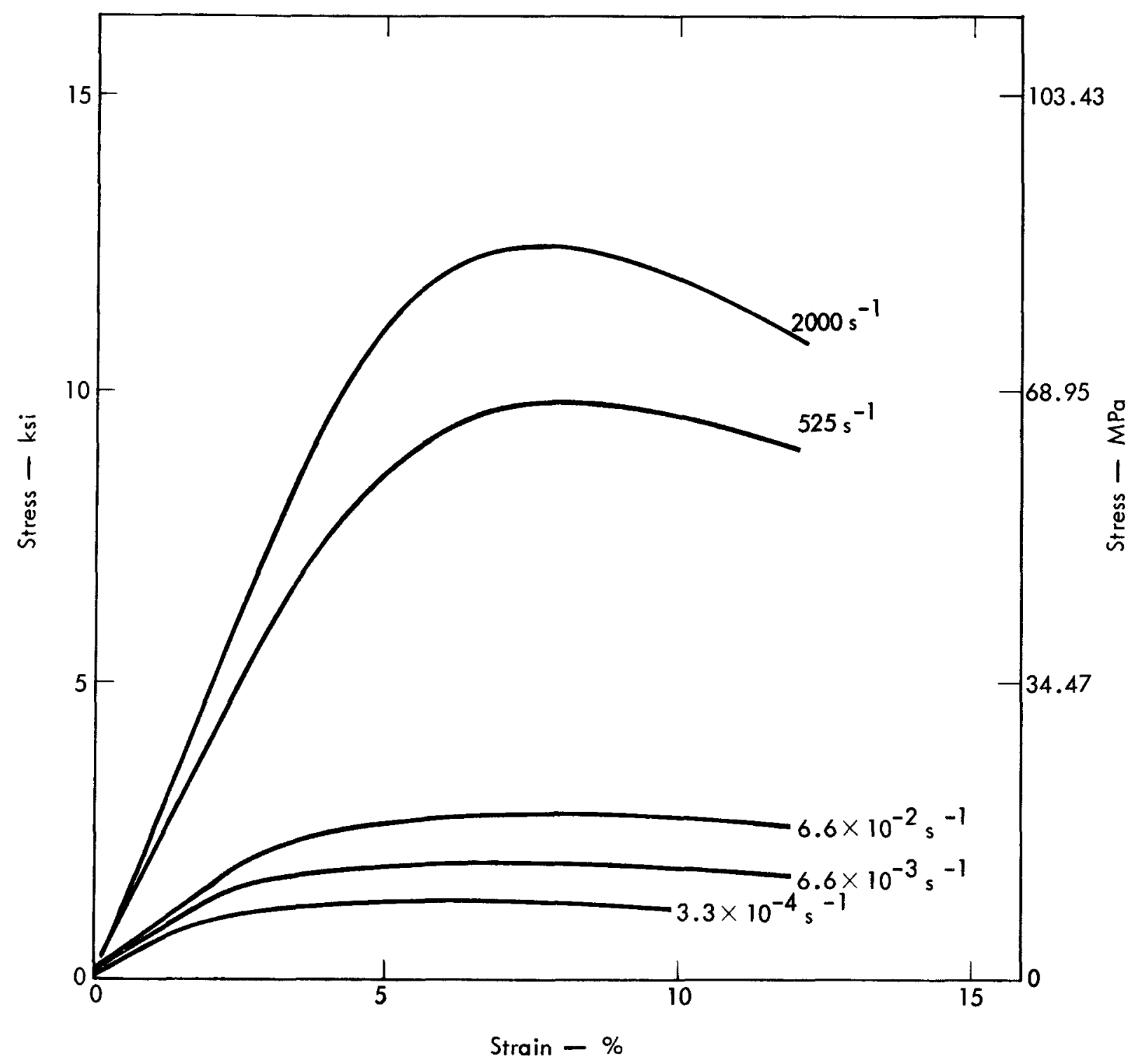

Fig. 16-1. Compressive stress strain curves for RM-04-BG at various strain rates. ${ }^{2}$ 


\section{Static Mechanical Properties}

Included here afe data on initial modulus $\mathrm{E}_{\boldsymbol{\alpha}}$ tension creep, failure envelope, and coefficient of friction $\mathrm{f}^{3}$

Initial Modulus

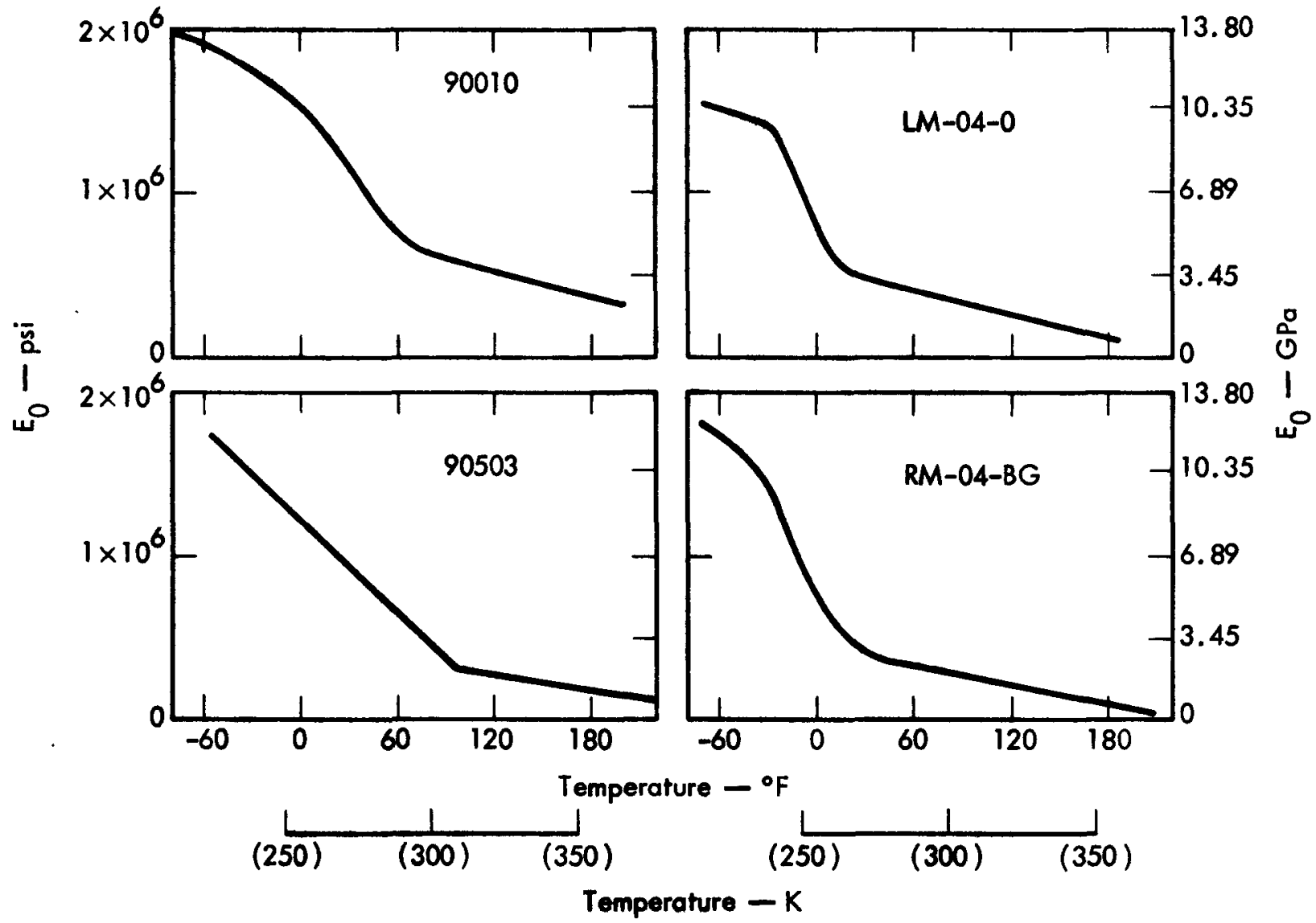

Fig. 16-2. Initial longitudinal modulus $\mathrm{E}_{0}$ vo temperature. Conversion factor: $1 \mathrm{psi}=6.894757 \mathrm{kPa}$. 


\section{Tension Creep}

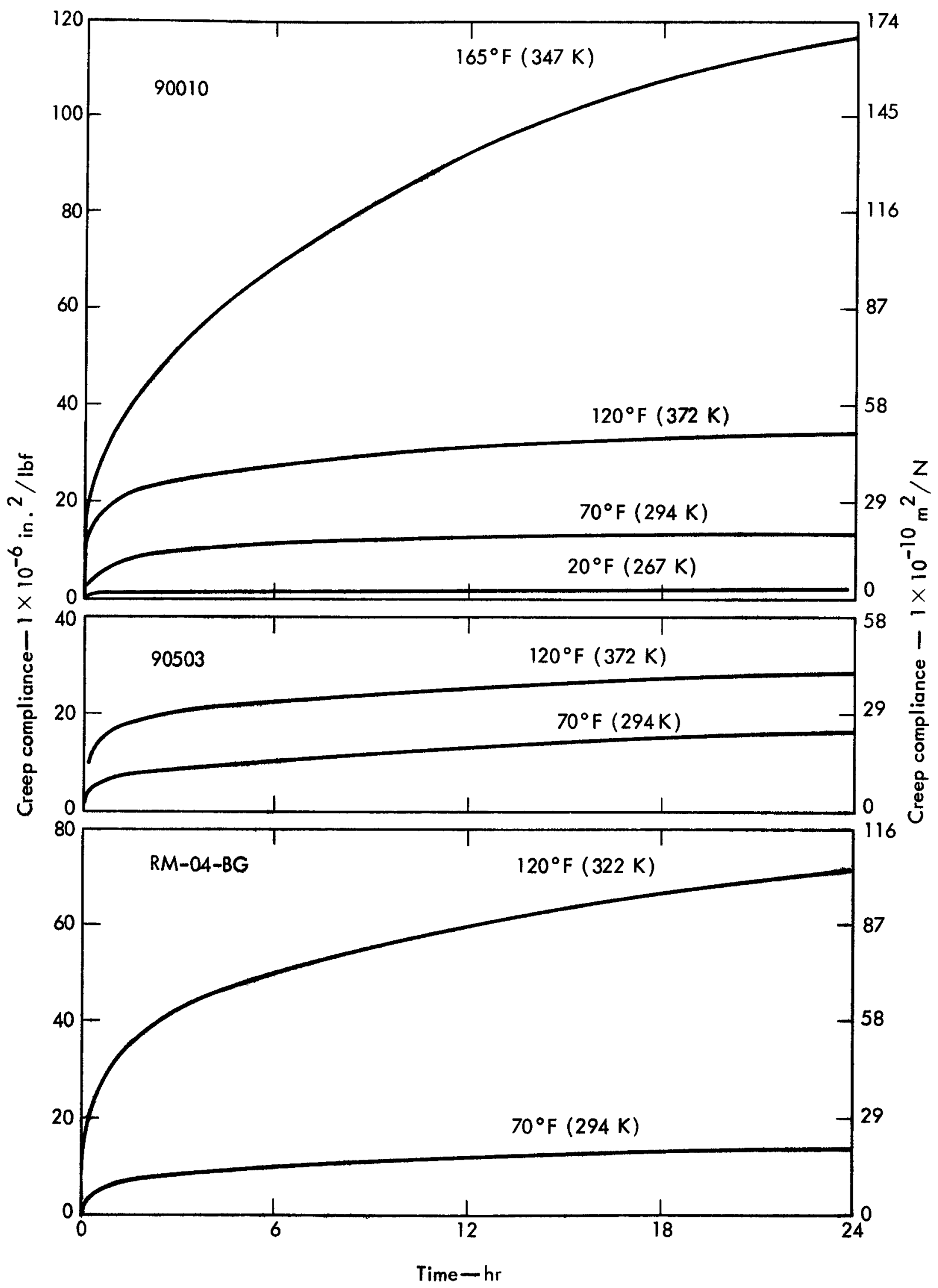

Fig. 16-3. Tension creep data. Conversion factor: $1 \mathrm{in}^{2} / \mathrm{lbf}=1.450377 \times 10^{-4} \mathrm{~m}^{2} / \mathrm{N}$. 


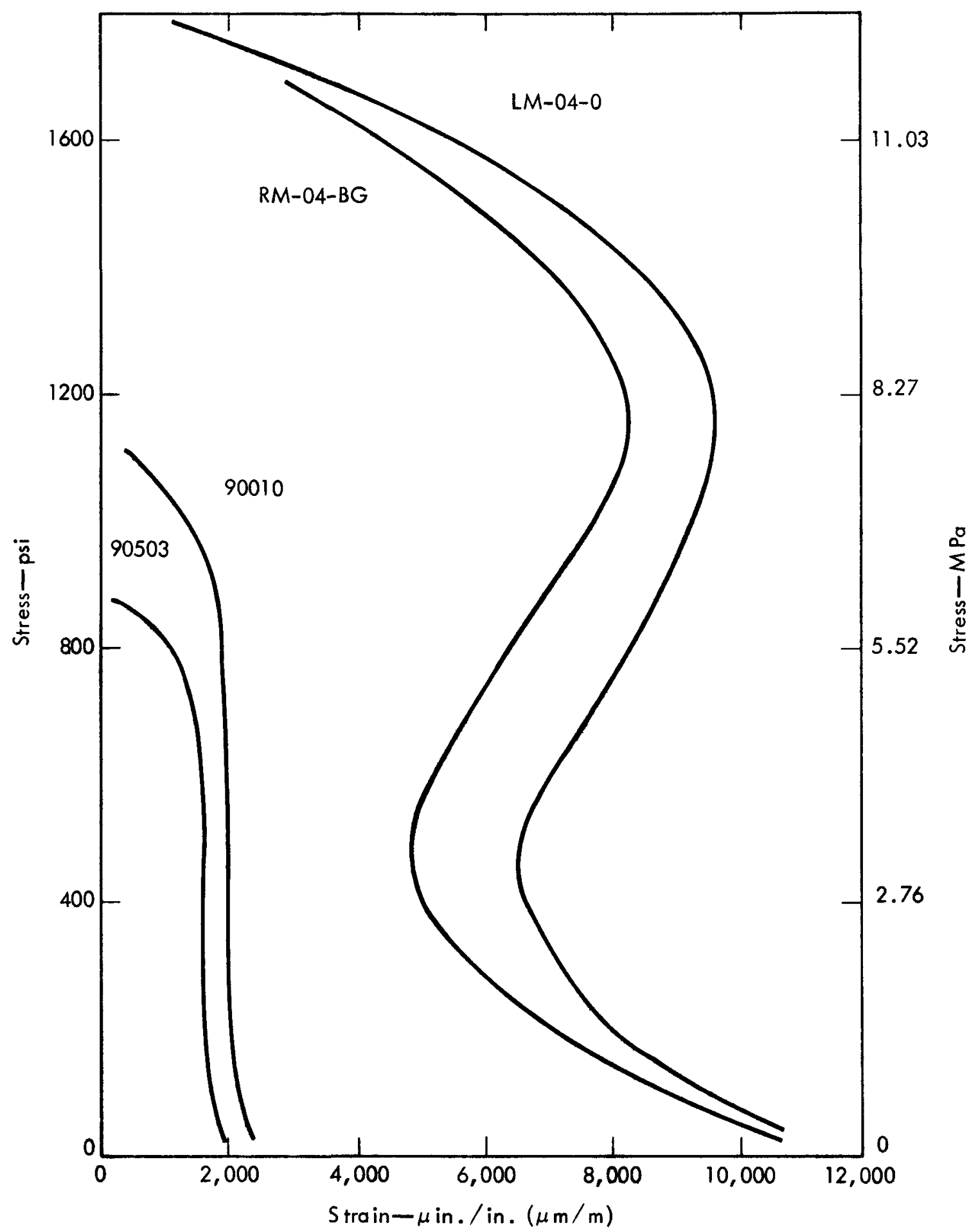

Fig. 16-4. Failure envelopes. Conversion factor: 1 psi $=6.894757 \mathrm{kPa}$. 


\section{Friction}

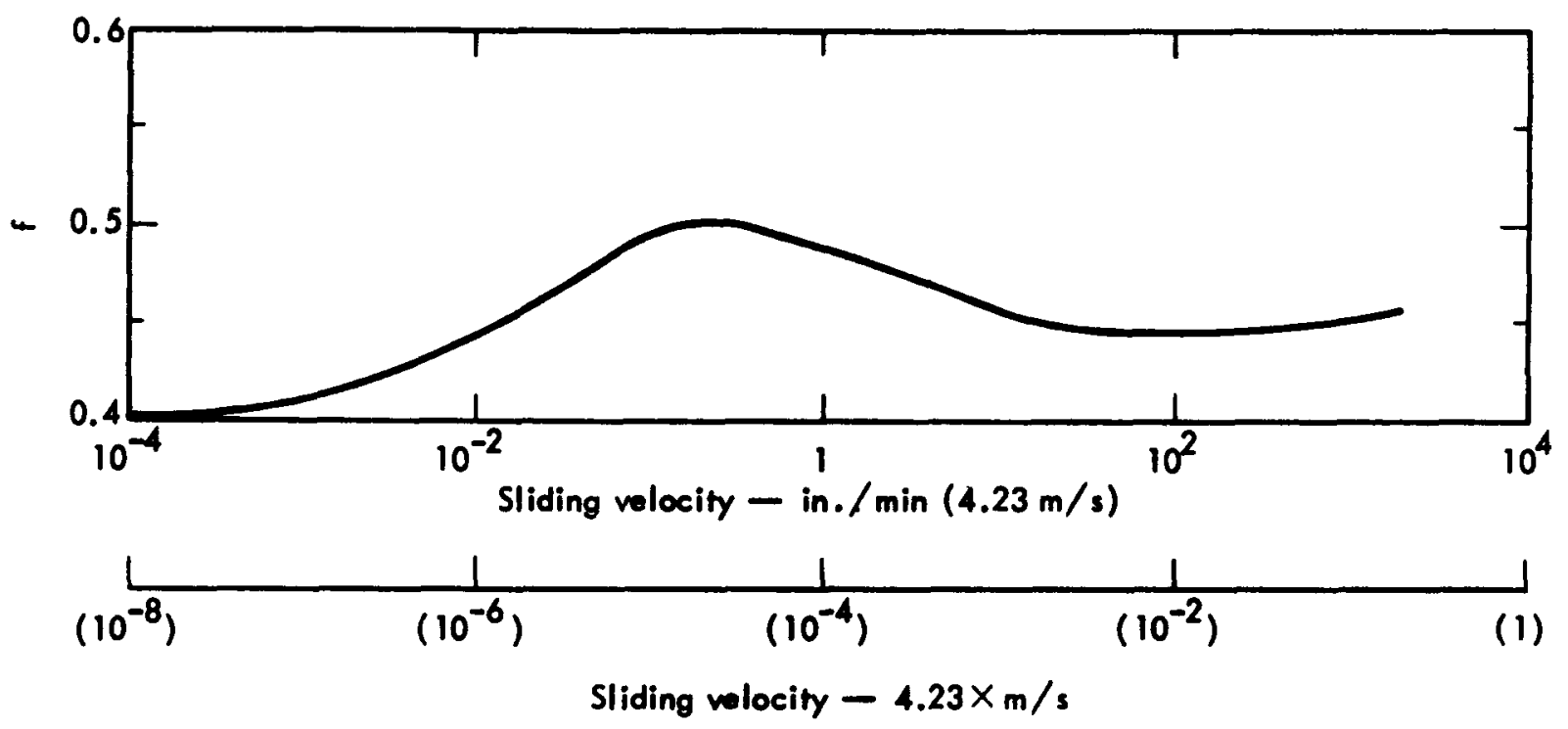

Fig. 16-5. Coefficient of friction $f$ as a function of sliding velocity $\nu$. Conversion factor: $1 \mathrm{in} / \mathrm{min}=4.23 \times 10^{-4} \mathrm{~m} / \mathrm{s}$. 


\section{Dynamic Mechanical Properties}

\section{Compressive Stress-Strain}

The Hopkinson split-bar technique was used to determine the compressive stressstrain properties of mock HE and Viton. The results are shown in Fig. 16-6.

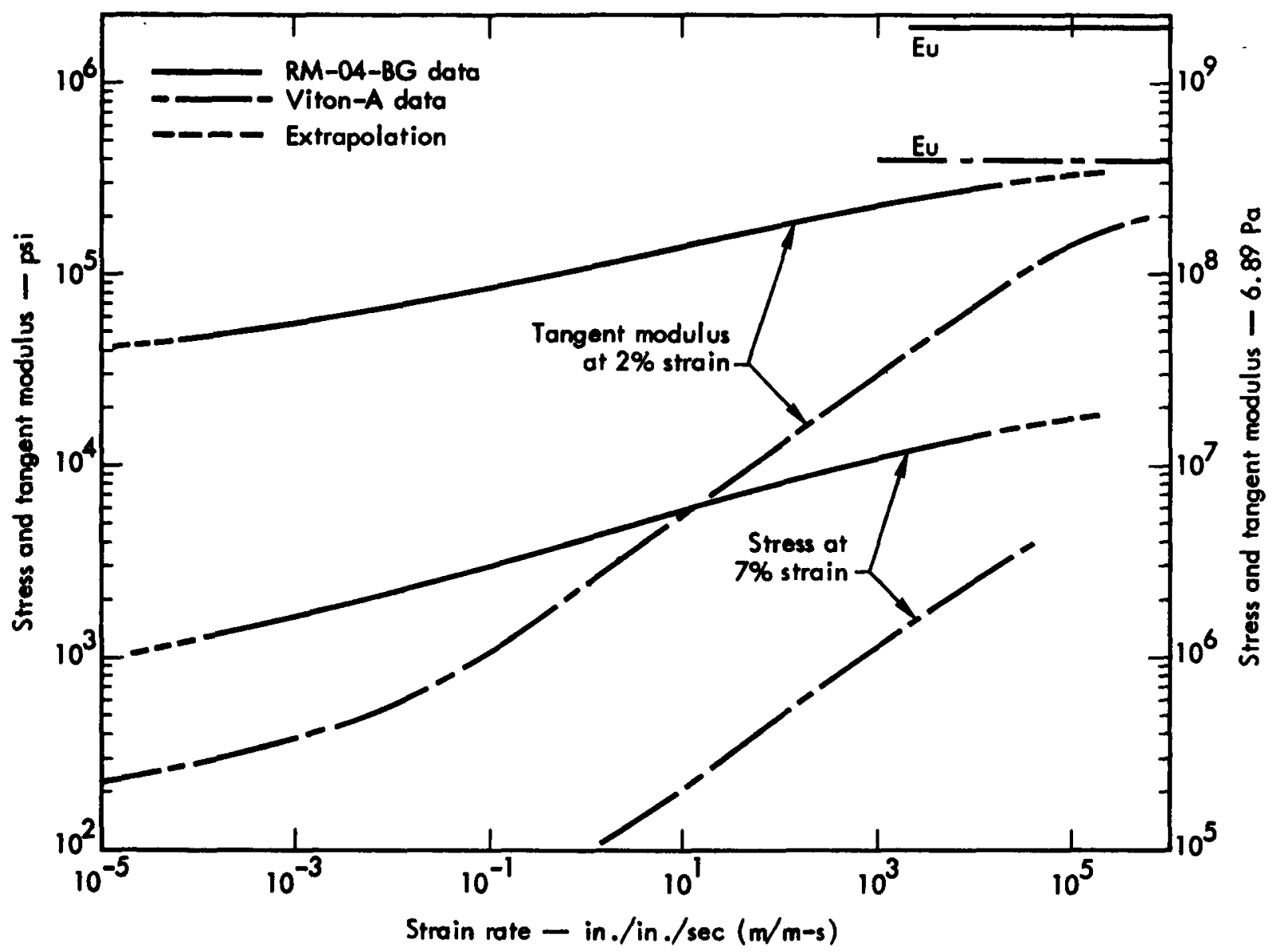

Fig. 16-6. Stregs and tangent modull for RM-04-BG and Viton as a function of strain rate. ${ }^{2}$ Also shown is the ultrasonically determined modulus $\mathrm{E}_{\mathrm{u}}$. Conversion factor: $1 \mathrm{psi}=6.894757 \mathrm{kPa}$. 


\section{$\underline{\text { Hugoniot Data }}$}

The Hugoniots of unreacted mock HEs were determined from Marsh's measured sound velocities ${ }^{5}$ (Tables 7-4 and 16-1), and are summarized in Table 16-2.

Table 16-1. Sound velocities.

\begin{tabular}{lcccc}
\hline Mock & $\begin{array}{c}\rho \\
\left(\mathrm{Mg} / \mathrm{m}^{3}\right)\end{array}$ & $\begin{array}{c}\mathrm{c}_{\ell} \\
(\mathrm{km} / \mathrm{s})\end{array}$ & $\begin{array}{c}\mathrm{c}_{\mathrm{s}} \\
(\mathrm{km} / \mathrm{s})\end{array}$ & $\begin{array}{c}\mathrm{c}_{\mathrm{b}} \\
(\mathrm{km} / \mathrm{s})\end{array}$ \\
\hline 90010 & 1.84 & 3.22 & 1.56 & 2.67 \\
90503 & 1.61 & 2.70 & 1.48 & 2.09 \\
\hline
\end{tabular}

Table 16-2. Least squares fits for Hugoniots of unreacted mock HEs.

\begin{tabular}{lccc}
\hline Mock & $\begin{array}{c}\rho \\
\left(\mathrm{Mg} / \mathrm{m}^{3}\right)\end{array}$ & Equation & Range \\
\hline 90010 & 1.84 & $\mathrm{U}_{\mathrm{S}}=2.70+1.62 \mathrm{U}_{\mathrm{p}}$ & $\mathrm{U}_{\mathrm{S}}<6.28$ \\
90503 & 1.61 & $\left\{\begin{array}{l}\mathrm{U}_{\mathrm{S}}=2.67+1.57 \mathrm{U}_{\mathrm{p}} \\
\mathrm{U}_{\mathrm{S}}=3.39+1.25 \mathrm{U}_{\mathrm{p}}\end{array}\right.$ & $\mathrm{U}_{\mathrm{s}}>6.27$ \\
\hline
\end{tabular}

The flyer-plate data for mock HEs are shown in Fig. 16-7; compare with Figs.7-13 through 7-15. See also the section on Dynamic Mechanical Properties of HEs (p. 7-15). 


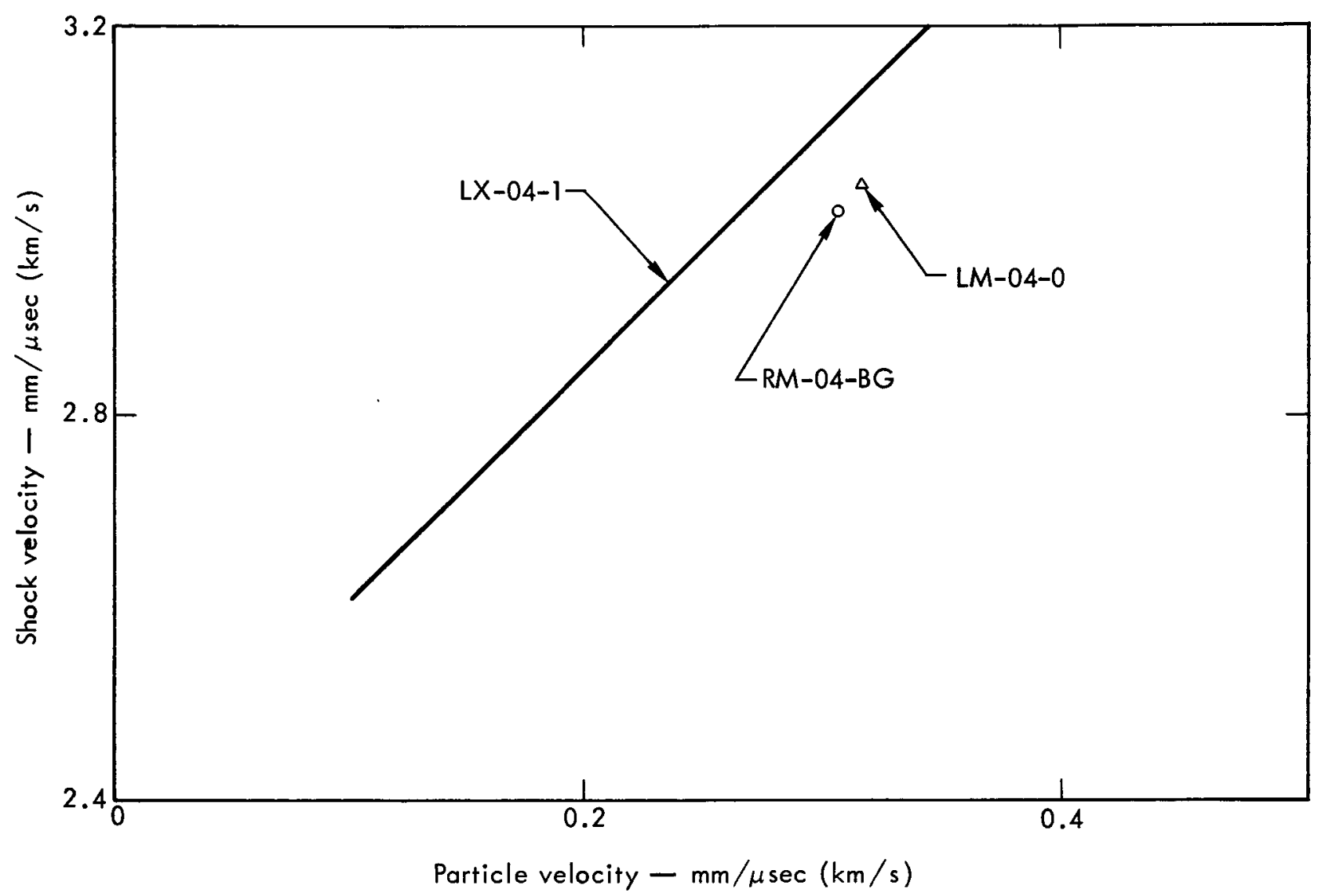

Fig. 16-7. Hugoniot data for LM-04-0 and RM-04-BG, compared with LX-04-1. ${ }^{6}$

\section{References}

1. R. C. Murray, Lawrence Livermore Laboratory, personal communication (1970).

2. K. G. Hoge, Applied Polymer Symposia 5, 19-40 (1967).

3. K. G. Hoge, "Friction and Viscoelastic Properties of Highly Filled Polymers: Plastic-Bonded Explosives," in Developments in Theoretical and Applied Mechanics, Vol. 4 (Pergamon Press, Oxford, 1970), pp. 371-392.

4. K. G. Hoge, Explosivstoffe 18, 39-41 (1970).

5. S. Marsh, Los Alamos Scientific Laboratory, N. M., personal communication (1974).

6. R. J. Wasley and R. H. Valentine, Shock-Pulse Attenuation and Hugoniot Studies of Three Explosives and Three Mock Explosives, Lawrence Livermore Laboratory, Rept. UCRL-50950 (1970). 


\section{Code Designations}

This section defines and describes the codes now in use at LLL and LASL for designating explosive materials. Three categories of explosives are covered. LLL formulations in production, LLL research formulations and LASL PBX designations. The code for each type is distinctive and easily recognized.

\section{LLL CODE DESIGNATIONS}

\section{Formulations in Production (LX Code)}

A specific code designation in this category is assigned to an explosive when the state of development of its formulation has reached the point where

(1) a set of reasonable manufacturing specifications can be written for the developed formulation,

(2) the evaluation of the material's chemical, physical, explosive properties and sensitivity is essentially complete,

(3) the material has a definite application.

This code consists of the two letters LX followed by a dash, two digits, a second dash, and finally a single digit. The first pair of digits is merely an arbitrary serial number assigned in sequence. The last digit denotes a subclass in the series. Thus we have LX-01-0, LX-02-1, .., LX-05-0, etc. The last digit provides for the small changes in manufacturing specifications that inevitably occur. For example, when LX-04-0 has undergone a revision of explosive particle size, new lots, manufactured under the revised specification, are identified as LX-04-1.

LX-01-A liquid material, characterized by a wide liquid range $\left(-65^{\circ}\right.$ to $+165^{\circ} \mathrm{F}$ $(219-347 \mathrm{~K}))$, moderate energy release, and good stability and sensitivity properties. CAUTION: The TNM component is moderately volatile and highly toxic.

LX-02-A material of puttylike texture characterized by ability to propagate in very small diameters. LX-02 is derived from a series of DuPont formulations, the EL-506 series. Its immediate predecessor in development, called EL-506 L-3, represented one of several LLL modifications to DuPont's EL-506D. EL-506 L-3 became LX-02-0, and differed from the composition above by the inclusion of a few tenths of a percent of a red dye (DuPont Oil Red). Later, the dye was omitted because it tends to migrate out of the explosive under certain conditions. 
LX-04-A solid explosive characterized by excellent mechanical and compatibility properties, an energy release about $9 \%$ less than LX-09, and sensitivity properties much superior to LX-09.

$\underline{\mathrm{LX}-07-2}-\mathrm{A}$ modification of LX-04 with a higher energy release $(5 \%$ less than LX-09-0) obtained at the expense of some degradation in the mechanical properties (less elongation, etc.) and in sensitivity.

LX-08-An extrudable, curable explosive developed for use in Dautriche timing tests.

LX-09-Similar to the LASL explosive PBX-9404, but with significantly improved thermal stability and slightly poorer physical properties.

$\underline{\mathrm{LX}-10}$ - In the same energy class as LX-09 and PBX-9404, but utilizing HMX and Viton A like LX-04, and having excellent thermal characteristics. It also exhibits high creep resistance but may be somewhat more sensitive than the others.

$\underline{\mathrm{LX}-11}$ - Like LX-04 but intentionally degraded in energy by adding an additional $5 \%$ binder.

$\underline{\mathrm{LX}-13}-\mathrm{A}$ variant of the LASL explosive XTX-8003.

A master log kept in the office of the Organic Materials Division contains the current listing of LX number assignments. The listing includes a detailed description of each LX explosive. 


\section{Research Explosives (RX Code)}

A great variety of explosive formulations that never enter "production" are generated as the result of various research and development programs. These materials are designated "research" explosives and identified by a code patterned after the LX code. The code is applied to all materials that are formulated in large amounts or that are handled by large numbers of people outside the Organic Materials Division (either in- or outside the Laboratory).

The RX-code consists of the letters RX followed by a dash, two digits, another dash, and finally two capital alphabetic characters. Thus we might have RX-01-AA, $\mathrm{RX}-13-\mathrm{XD}$, etc. The two digits, assigned arbitrarily in sequence, define a general class of formulation. Thus, RX-01 refers to nitromethane liquid formulations, RX-02 to PETN extrudable formulations, etc. The two final letters in the code, also assigned arbitrarily in sequence ( $A A, A B$, etc.) refer to a specific formulation within that general class.

$\underline{\mathrm{RX}-01}-\mathrm{A}$ series of liquid materials containing nitromethane.

$\underline{\mathrm{RX}-02}-\mathrm{A}$ series of extrudable materials containing PETN.

$\underline{\mathrm{RX}-03}-\mathrm{A}$ series of solid, plastic-bonded materials containing DATB or TATB.

RX-04-A series of solid, plastic-bonded materials composed of HMX and fluorocarbon elastomer. A specific example is RX-04-AB (HMX/Viton A 85/15); the HMX is defined as Holston's Class $A$. This material is for research purposes only, it is very much more sensitive than LX-04 with the identical chemical composition.

$\underline{\mathrm{RX}-05}-\mathrm{A}$ series of solid, plastic-bonded materials based on HMX and polystyrene.

RX-06-A series of extrudable materials based on HMX/4,4-dinitropentanoic acid ester formulations.

RX-07-A Series: A series of cyclotols (RDX/TNT) containing various additives. B Series: A series of LX-07-type explosives.

$\underline{\mathrm{RX}-08}-\mathrm{A}$ series of research explosives based on formulations of HMX, energetic liquids, and polymers. They are primarily for use in polymerization/pressure-casting experiments.

$\underline{\mathrm{RX}-09}$ - A series of research explosives based on formulations of HMX and energetic binders. The binders are primarily based on plasticized poly (2, 2-dinitropropylacrylate). These explosives are intended to be high-energy formulations replacing PBX-9404. 
$\underline{\mathrm{RX}-10}-\mathrm{A}$ series of rigid plastic-bonded explosives containing RDX and a fluorocarbon binder. They are primarily designed as insensitive replacements of PBX-9010.

$\underline{\mathrm{RX}-11}$ - A series of rigid plastic-bonded explosives containing HMX and a light metal perchlorate.

$\underline{\mathrm{RX}-12}-\mathrm{A}$ series of inert metal-loaded formulation of HMX/Viton.

$\underline{\mathrm{RX}-13}$ - Potentially explosive materials compounded to produce color changes from the heat produced upon impact.

$\underline{\mathrm{RX}-14}-\mathrm{A}$ series of HMX/polyethylene formulations. These explosives possess a very high degree of insensitivity, even though they are formulated with relatively low volume percentages of binder.

RX-15-PETN- or BTF-based rigid PBXs for booster applications.

$\underline{\mathrm{RX}}-16-\mathrm{HMX} /$ silicone formulations made in paste or putty form using a spray-on catalyst.

$\underline{\mathrm{RX}-17}-\mathrm{A}$ series of HMX-based rigid explosives using various binders and energetic plasticizers.

$\underline{\mathrm{RX}-18}$ - A series of paste explosives containing HMX and a perchlorate. The carrier fluid is energetic, for example, EDNP or FEFO.

RX-19-An extrudable explosive consisting of class-E HMX and water with a reinforcing agent, such as milled glass fibers, and a wetting agent.

$\underline{\mathrm{RX}-20}-\mathrm{A}$ series of research explosives based on HMX and an energetic binder (NFPATVOPA). These are primarily formulations to replace PBX-9404.

$\underline{\mathrm{RX}-21}$ - A series of research explosives based on $\mathrm{HMX}$, a perchlorate, and energetic binders.

$\underline{\mathrm{RX}-22}-\mathrm{A}$ series of research explosives for exploring advanced energy concepts.

$\underline{\mathrm{RX}-23}-\mathrm{A}$ series of liquid explosives based on hydrazine. 
$\underline{\mathrm{RX}-24}-\mathrm{A}$ series of research explosives containing HMX, PVC/PVA, and graphite.

$\underline{\mathrm{RX}-25}-\mathrm{A}$ series of research explosives based on HMX, a light metal, a perchlorate, and a binder.

$\underline{\mathrm{RX}-26}-\mathrm{A}$ series of high-temperature composite explosives based on TATB.

$\underline{\mathrm{RX}-27}-\mathrm{A}$ series of high-temperature explosives based on TACOT.

$\underline{\mathrm{RX}-28}-\mathrm{A}$ series of conventional high-temperature plastic-bonded explosives.

$\underline{\mathrm{RX}-29}-\mathrm{A}$ series of explosives consisting of separate components which are nondetonable until mixed.

$\underline{\mathrm{RX}-30}-\mathrm{A}$ series of research explosives based on gelled nitromethane and various perchlorates.

A master log kept in the office of the Organic Materials Division (Bldg. 222) lists and describes in detail each RX explosive. No correlation exists between RX and LX code number sequences. 


$$
\text { 17-6 }
$$




\section{LASL CODE DESIGNATIONS}

The Los Alamos Scientific Laboratory has a number code for designating PBX materials that reach the stage of pilot or full-scale production. The code consists of four digits, a dash, and two more digits (for example, 9010-02). The first two digits give the weight percentage of the major explosive ingredient in the formulation. The next two digits represent an arbitrary serial number, assigned in sequence as materials are developed. The digits following the dash represent a second arbitrarily assigned serial number to designate different modifications of a given formulation. Thus, PBX9010-02 is a material that contains 90 weight percent of the major explosive ingredient, is the tenth $90 \%$ material to be developed, and is the second modification of that particular composition.

The last two digits are often deleted in references to LASL materials. Thus, production PBX-9404 should, strictly speaking, be designated PBX-9404-03. The -03 designates a product manufactured in Holston equipment from HMX with a particular particle-size distribution.

LASL research explosives carry the designation $X$ followed by a four-digit number. 
17-8 


\section{Data Sheets: Collected Properties of Explosives and Energetic Materials}

This section contains the assembled data sheets of properties of individual explosives and related materials of continuing interest to this Laboratory. For details, conversion factors, and references, please refer to Section I.

The symbols and units used in these data sheets are listed below for your convenience.

\begin{tabular}{|c|c|c|}
\hline Property & Symbol & Unit \\
\hline Boiling point & b.p. & ${ }^{\circ} \mathrm{C}(\mathrm{K})$ \\
\hline Chapman-Jouguet pressure & $\mathrm{P}_{\mathrm{CJ}}$ & $\operatorname{kbar}(\mathrm{GPa})$ \\
\hline $\begin{array}{l}\text { Coefficient of thermal } \\
\text { expansion - linear }\end{array}$ & $\alpha$ & $\mathrm{m} / \mathrm{m}-\mathrm{K}$ \\
\hline cubical & $\beta$ & $\mathrm{m} / \mathrm{m}-\mathrm{K}$ \\
\hline Creep compliance & - & $\mathrm{m}^{2} / \mathrm{N}$ \\
\hline Crystal data & - & $\AA$ \\
\hline Density & $\rho$ & $\mathrm{g} / \mathrm{cm}^{3}$ \\
\hline Detonation velocity & $\mathrm{D}$ & $\mathrm{mm} / \mu \mathrm{sec}(\mathrm{km} / \mathrm{s})$ \\
\hline Dielectric constant & $\epsilon$ & - \\
\hline Drop weight sensitivity & $\mathrm{H}_{50}$ & $\mathrm{~cm}\left(10^{-2} \mathrm{~m}\right)$ \\
\hline Energy - cylinder test & $\mathrm{E}_{\mathrm{cyl}}$ & $(\mathrm{mm} / \mu \mathrm{sec})^{2} / 2(\mathrm{MJ} / \mathrm{kg})$ \\
\hline Gap test ( $1 / 2$ in.) & Gap & $\operatorname{mil}(\mathrm{mm})$ \\
\hline Glass transition point & $\mathrm{T}_{\mathrm{g}}$ & ${ }^{\circ} \mathrm{F}(\mathrm{K})$ \\
\hline Heat of detonation & $\Delta \stackrel{\mathrm{s}}{\mathrm{det}}$ & $\mathrm{kcal} / \mathrm{g}(\mathrm{kJ} / \mathrm{kg})$ \\
\hline Heat of formation & $\Delta \mathbf{H}_{\mathrm{f}}$ & $\mathrm{kcal} / \mathrm{mol}(\mathrm{kJ} / \mathrm{mol})$ \\
\hline Initial modulus & $\mathrm{E}_{\mathrm{o}}$ & $\mathrm{GPa}$ \\
\hline Melting point & m.p. & ${ }^{\circ} \mathrm{C}(\mathrm{K})$ \\
\hline Molecular refraction & $\mathrm{R}$ & 一 \\
\hline Molecular weight & MW & - \\
\hline Refractive index & $\mathrm{n}$ & - \\
\hline Skid test & Skid & ft $(\mathrm{m})$ \\
\hline Solubility & sol. & - \\
\hline Specific heat & $\mathrm{C}_{\mathrm{p}}$ & $\mathrm{cal} / \mathrm{g}-{ }^{\circ} \mathrm{C}(\mathrm{kJ} / \mathrm{kg}-\mathrm{K})$ \\
\hline \multirow[t]{2}{*}{ Thermal conductivity } & $\mathrm{k}$ & $\mathrm{cal} / \mathrm{sec}-\mathrm{cm}-{ }^{\circ} \mathrm{C}(\mathrm{W} / \mathrm{m}-\mathrm{K})$ \\
\hline & & $\mathrm{BTU} / \mathrm{hr}-\mathrm{ft}-{ }^{\circ} \mathrm{F}(\mathrm{W} / \mathrm{m}-\mathrm{K})$ \\
\hline Vapor pressure & v.p. & $\mathrm{mm} \mathrm{Hg}(\mathrm{Pa})$ \\
\hline
\end{tabular}


18-2 


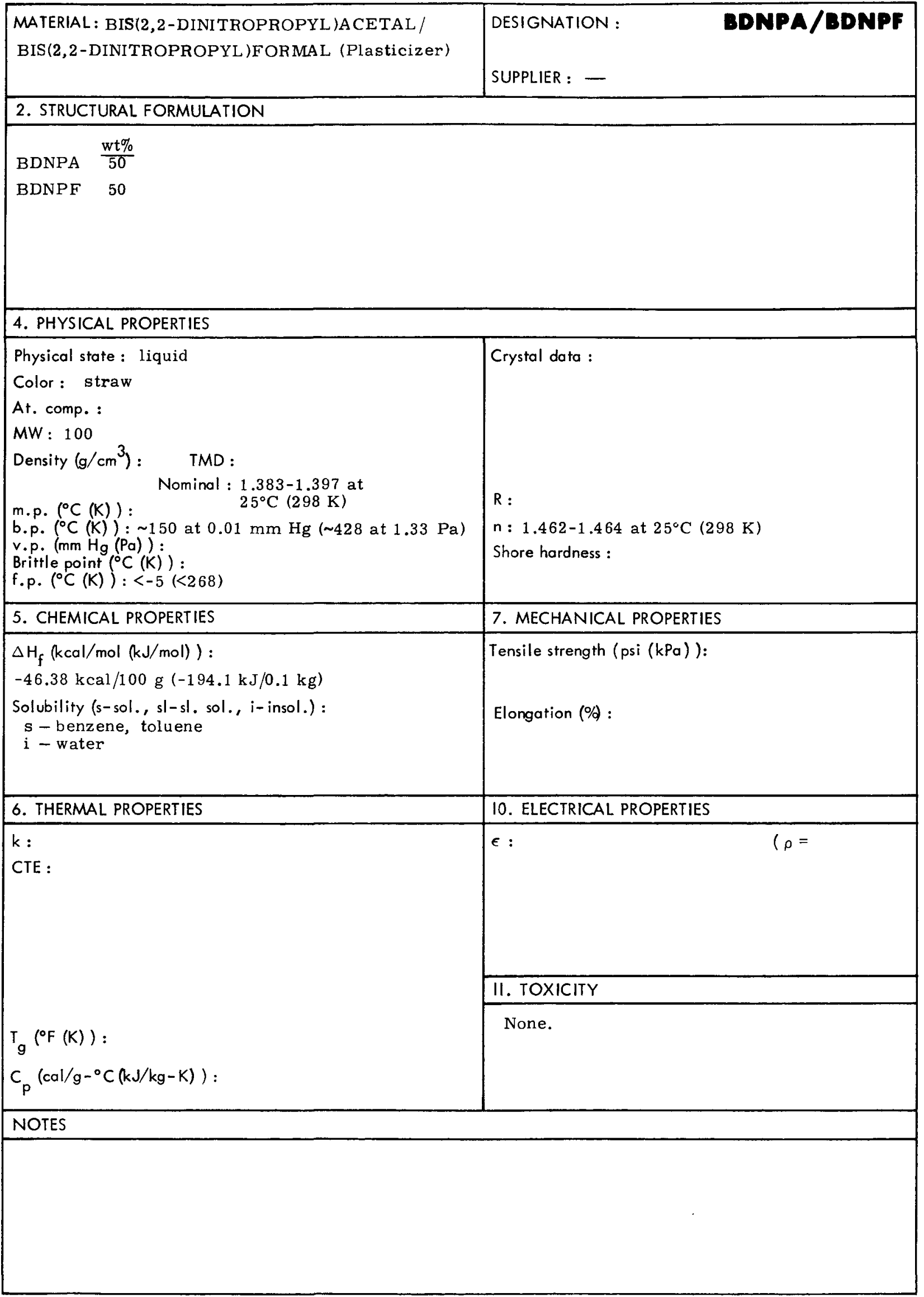




BDNPA/BDNPF

18-4 


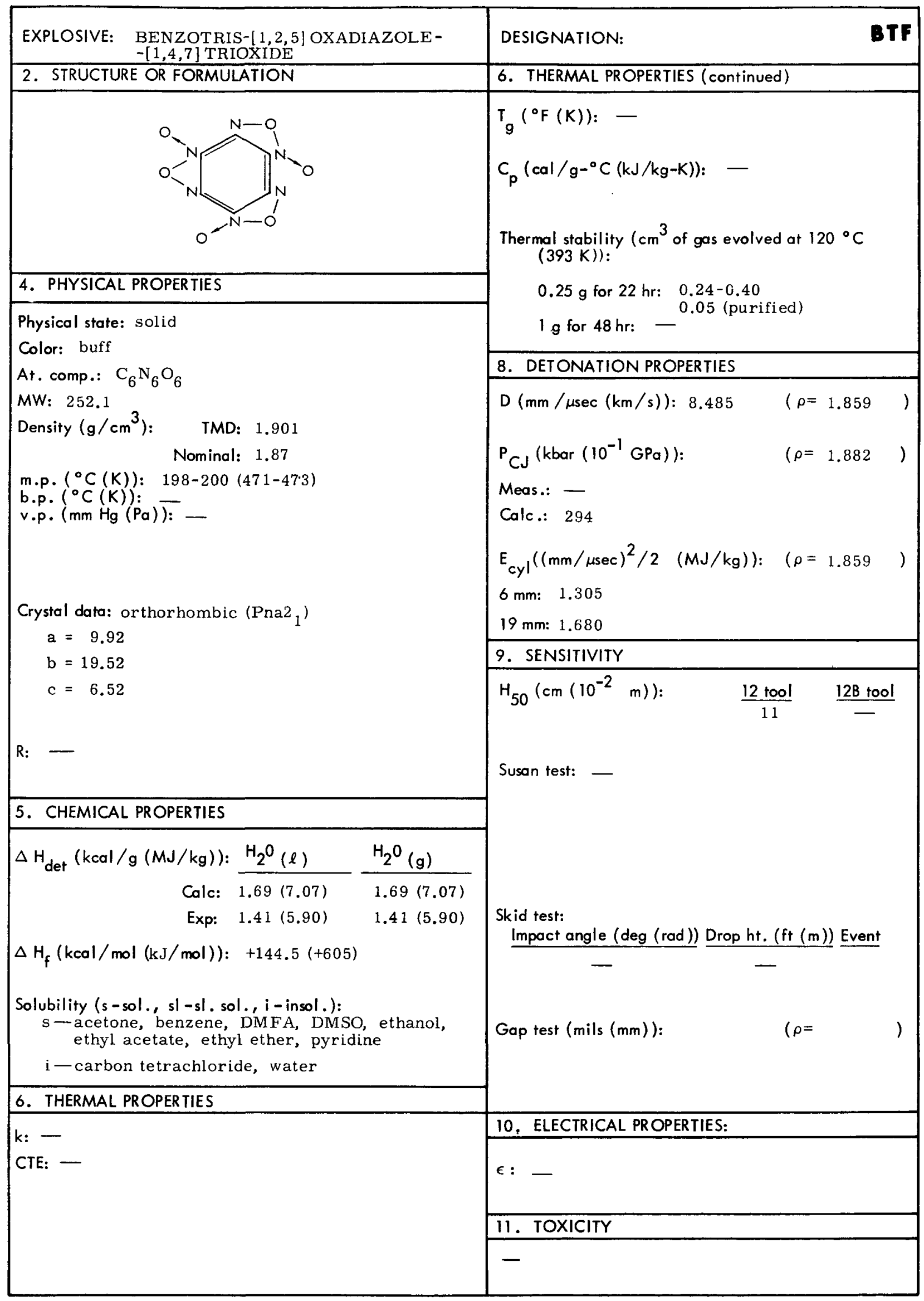




BTF BENZOTRIS- $[1,2,5]$ OXADIAZOLE $-[1,4,7]$ TRIOXIDE

7. MECHANICAL PROPERTIES

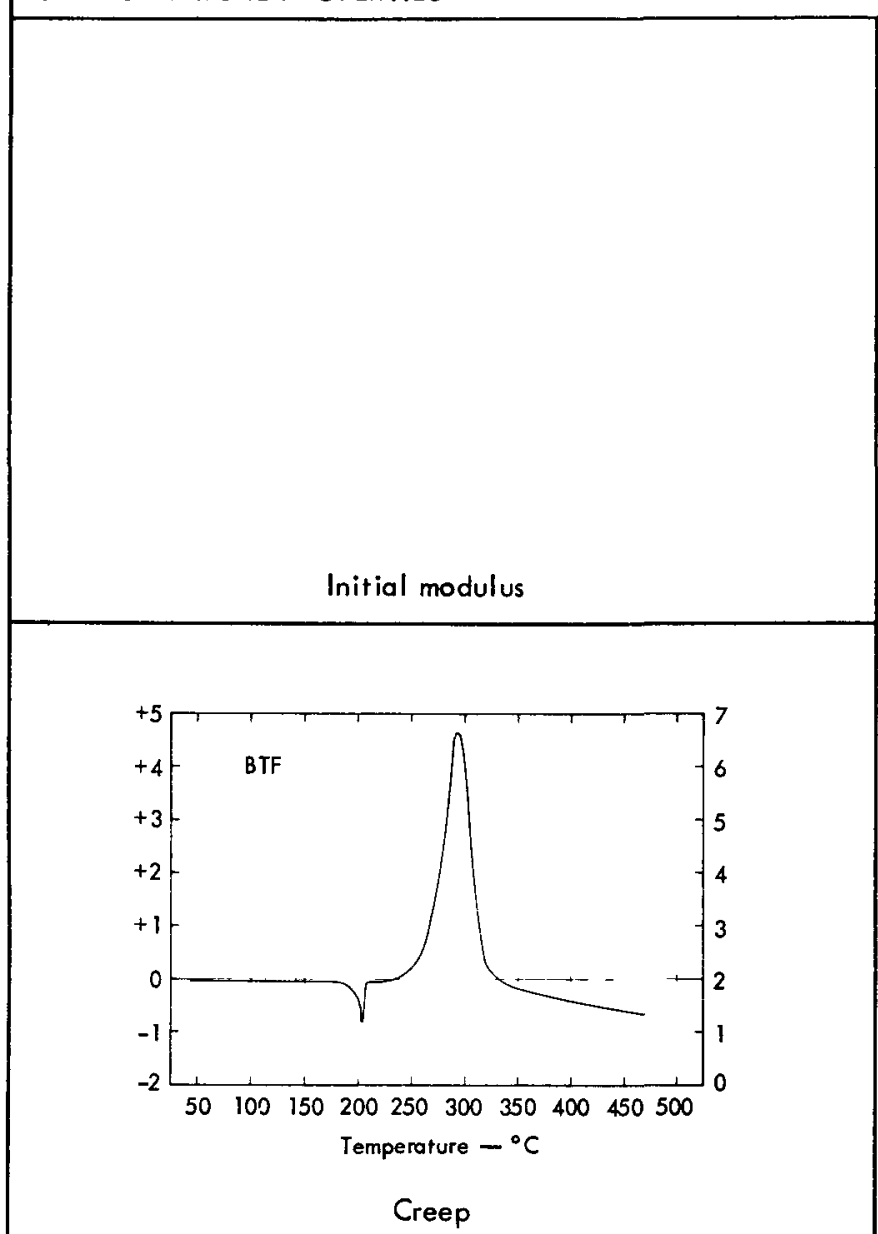

NOTES

Failure envelope 


\begin{tabular}{|c|c|}
\hline $\begin{array}{l}\text { MATERIAL: A MORPHOUS SILICON OXIDE } \\
\text { (Gelling agent) }\end{array}$ & $\begin{array}{l}\text { DESIGNATION: } \mathbf{C a b - O - S i l ~ M - s} \\
\text { SUPPLIER : Cabot Corp. }\end{array}$ \\
\hline \multicolumn{2}{|l|}{ 2. STRUCTURAL FORMULATION } \\
\hline \multicolumn{2}{|l|}{$\mathrm{O}-\mathrm{Si}-\mathrm{O}$} \\
\hline \multicolumn{2}{|l|}{ 4. PHYSICAL PROPERTIES } \\
\hline 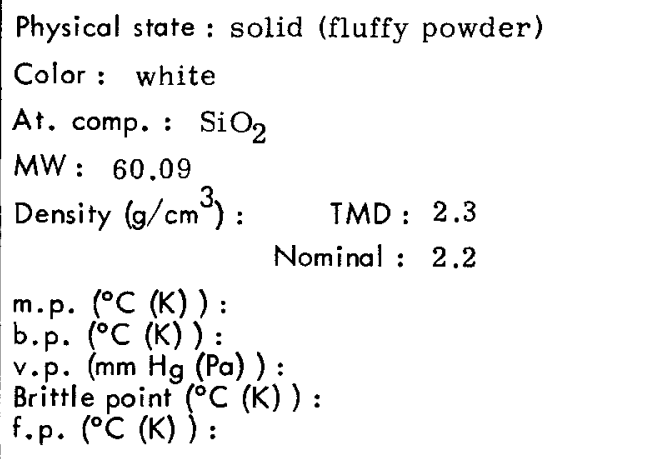 & $\begin{array}{l}\text { Crystal data: amorphous } \\
R: \\
\mathrm{R}: 1.46 \\
\text { Shore hardness : }\end{array}$ \\
\hline 5. CHEMICAL PROPERTIES & 7. MECHANICAL PROPERTIES \\
\hline $\begin{array}{l}\Delta H_{f}(\mathrm{kcal} / \mathrm{mol}(\mathrm{kJ} / \mathrm{mol})):-215.94(-903.5) \\
\text { Solubility (s-sol., sl-sl. sol., i- insol.): }\end{array}$ & $\begin{array}{l}\text { Tensile strength (psi }(\mathrm{kPa})) \text { : } \\
\text { Elongation }(\%):\end{array}$ \\
\hline 6. THERMAL PROPERTIES & 10. ELECTRICAL PROPERTIES \\
\hline $\begin{array}{l}k: \\
\text { CTE : }\end{array}$ & $\epsilon:$ \\
\hline & 11. TOXICITY \\
\hline $\begin{array}{l}\mathrm{T}_{g}\left({ }^{\circ} \mathrm{F}(\mathrm{K})\right): \\
\mathrm{C}_{\mathrm{p}}\left(\mathrm{cal} / \mathrm{g}-{ }^{\circ} \mathrm{C}(\mathrm{kJ} / \mathrm{kg}-\mathrm{K})\right):\end{array}$ & Low. \\
\hline NOTES & \\
\hline
\end{tabular}




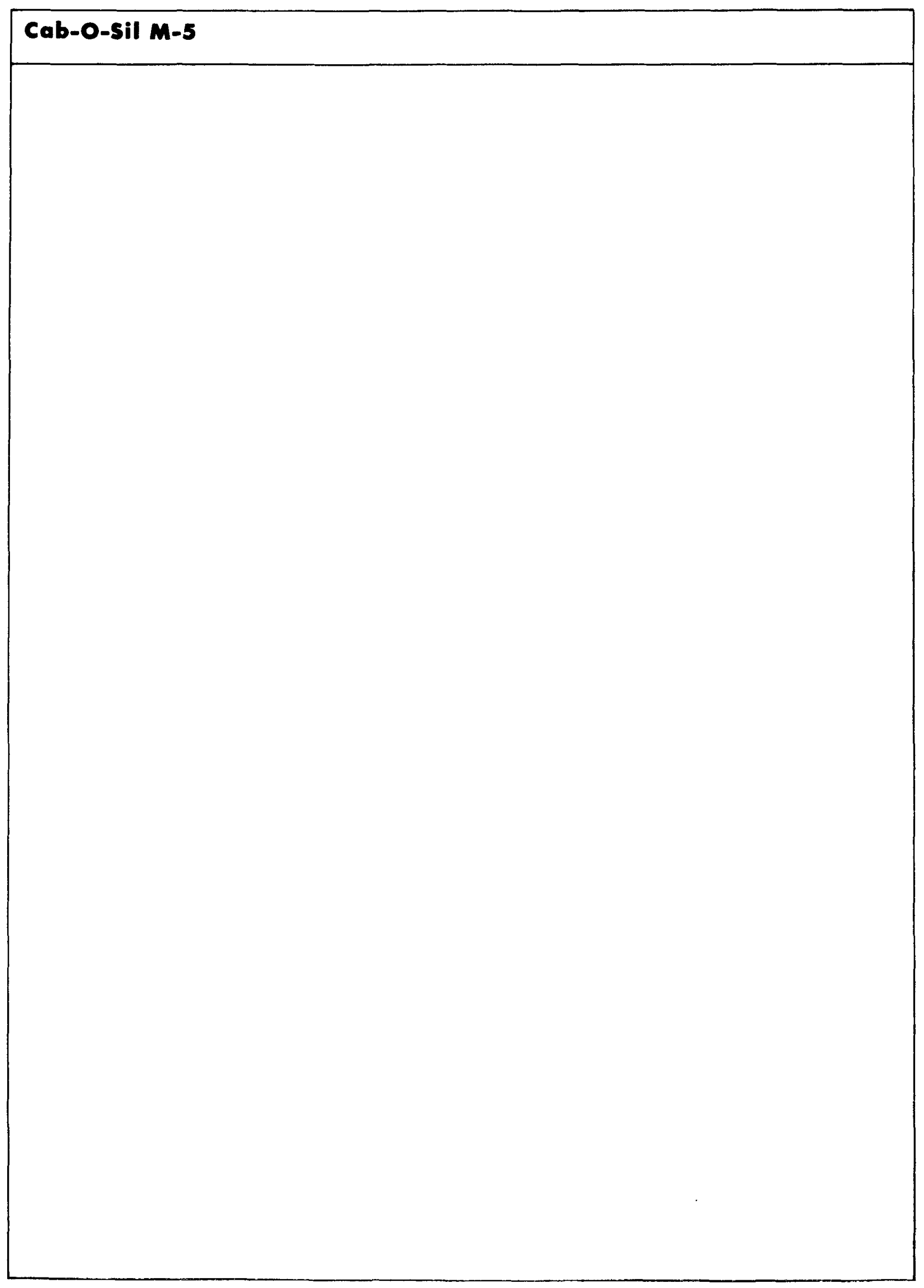

18-8

$7 / 74$ 


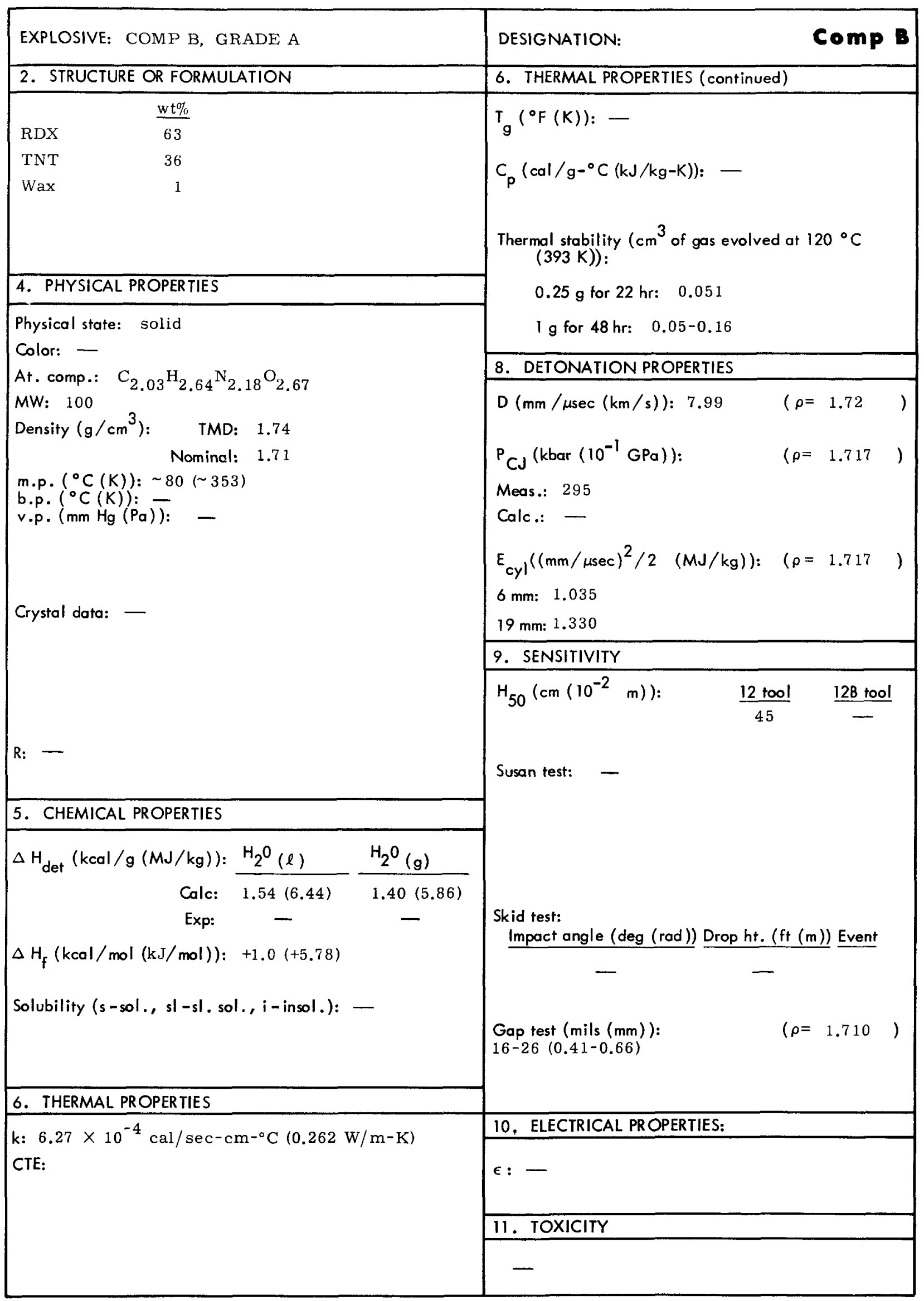




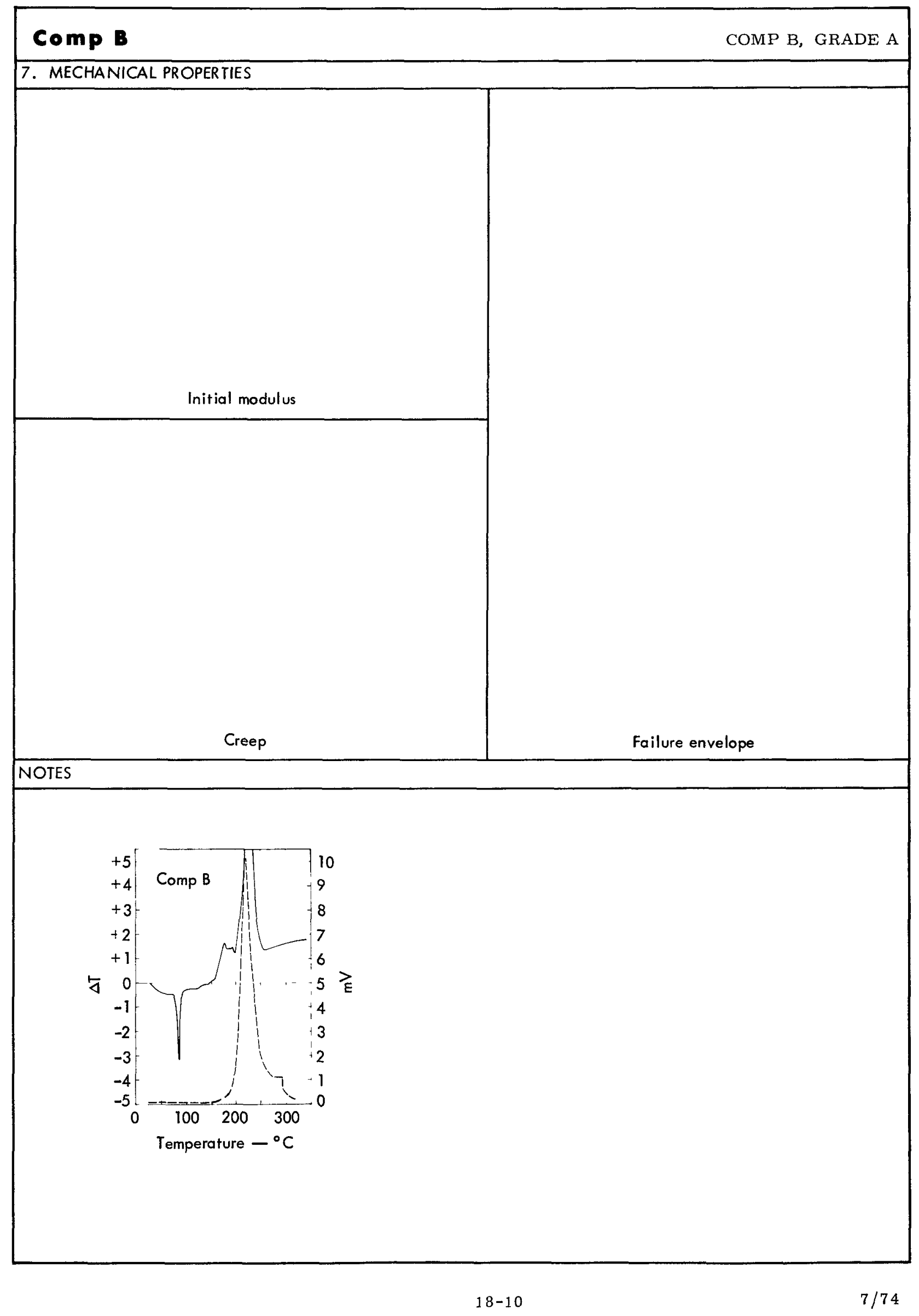




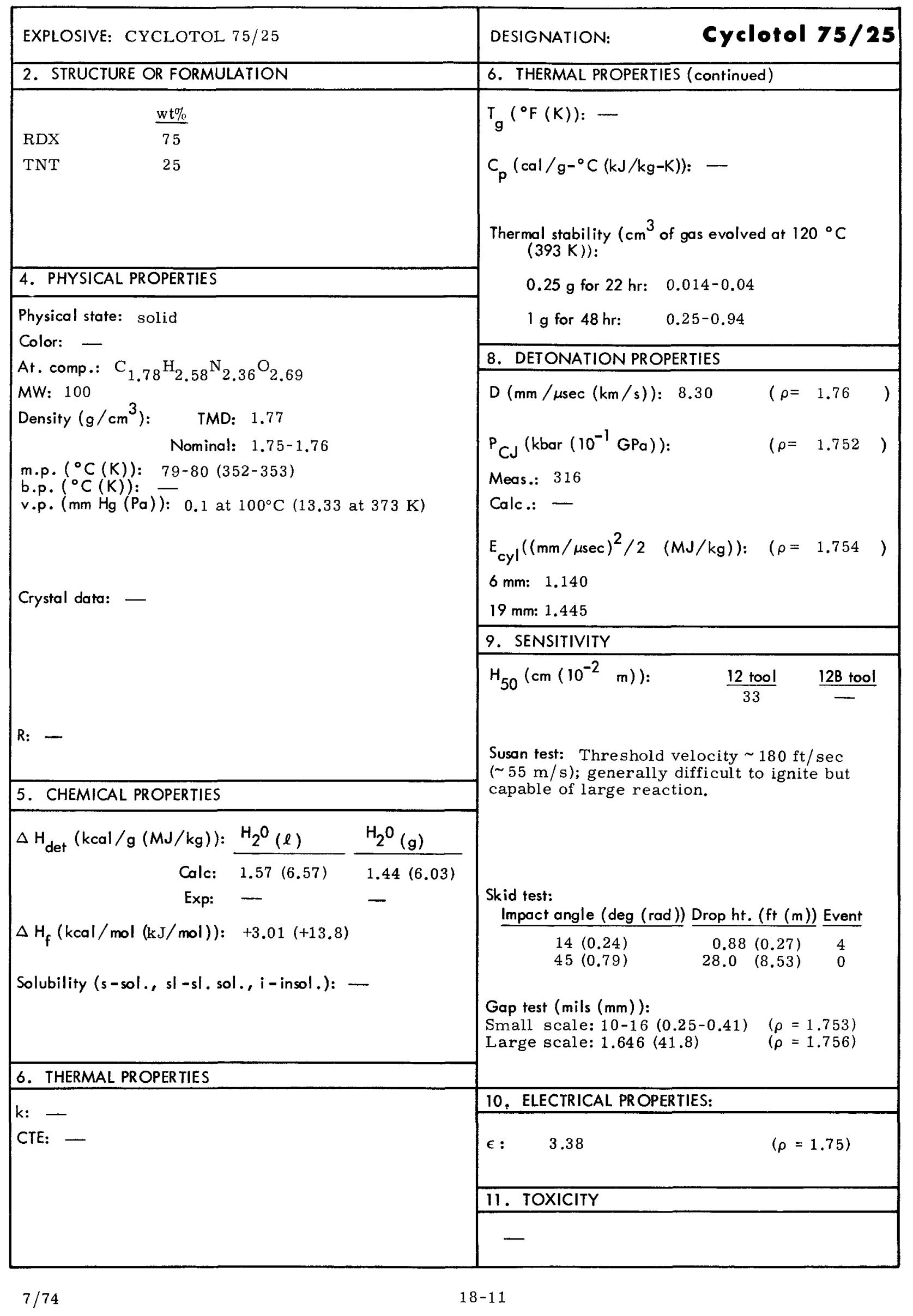




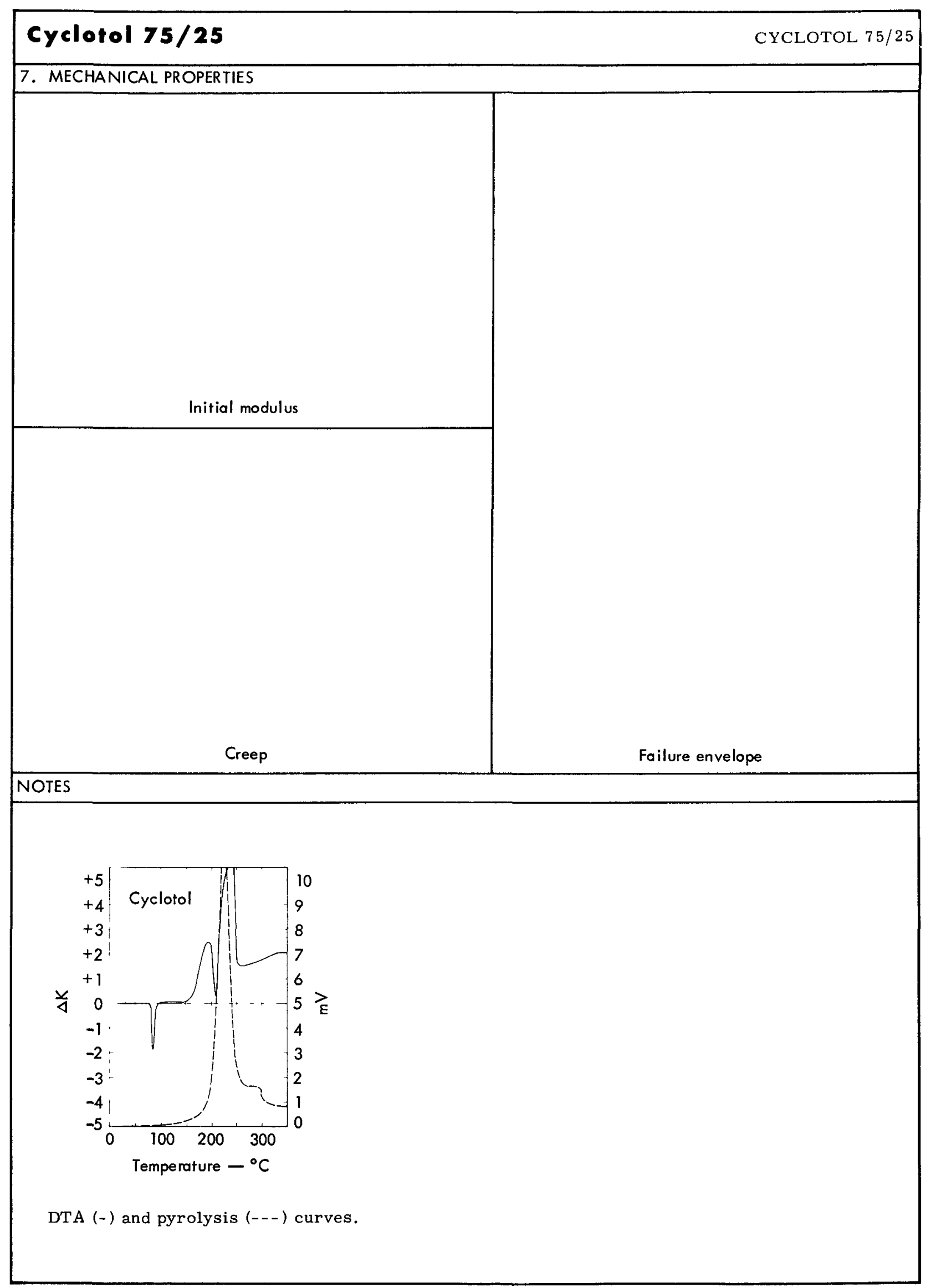




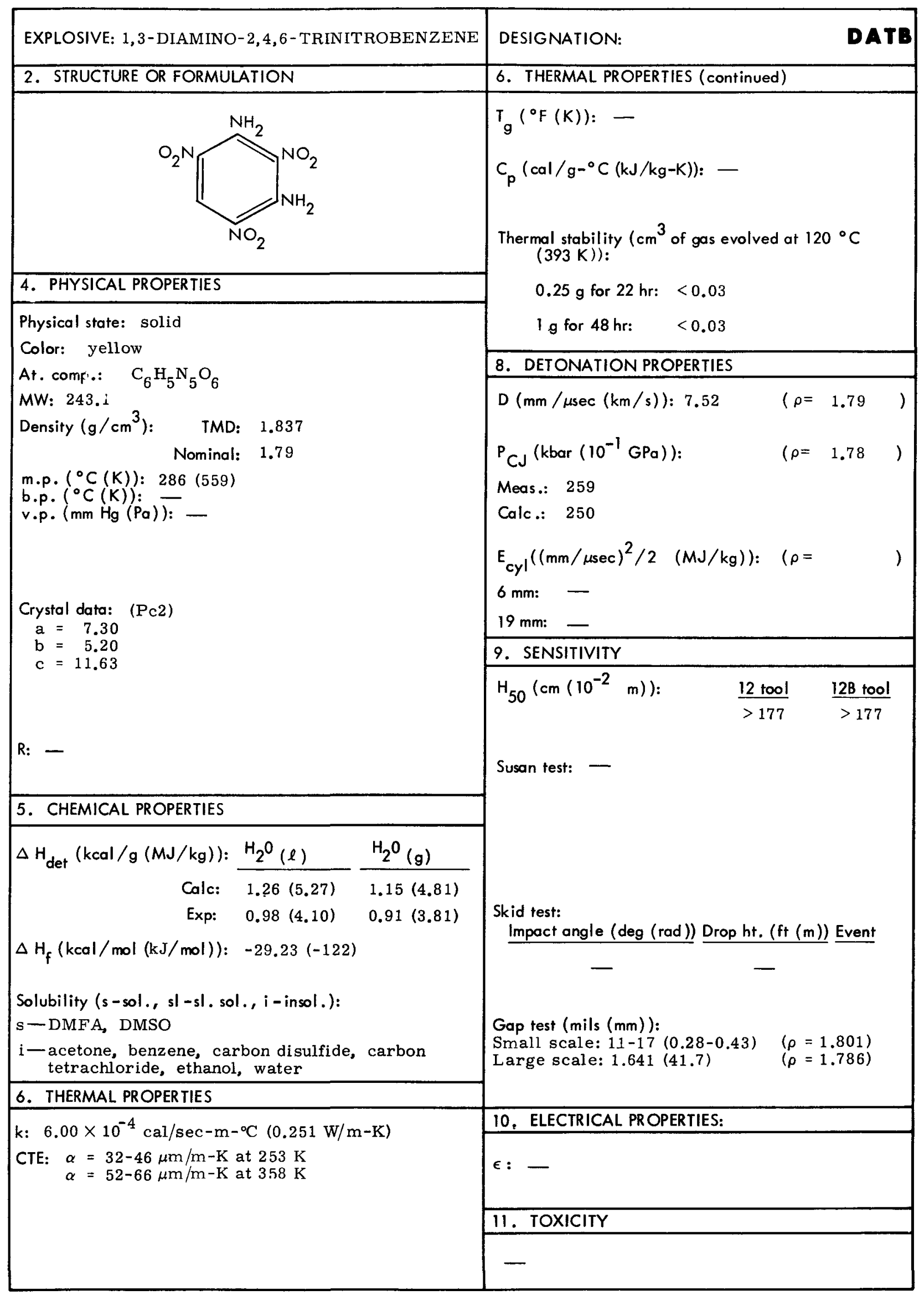




\section{MECHANICAL PROPERTIES}

Initial modulus

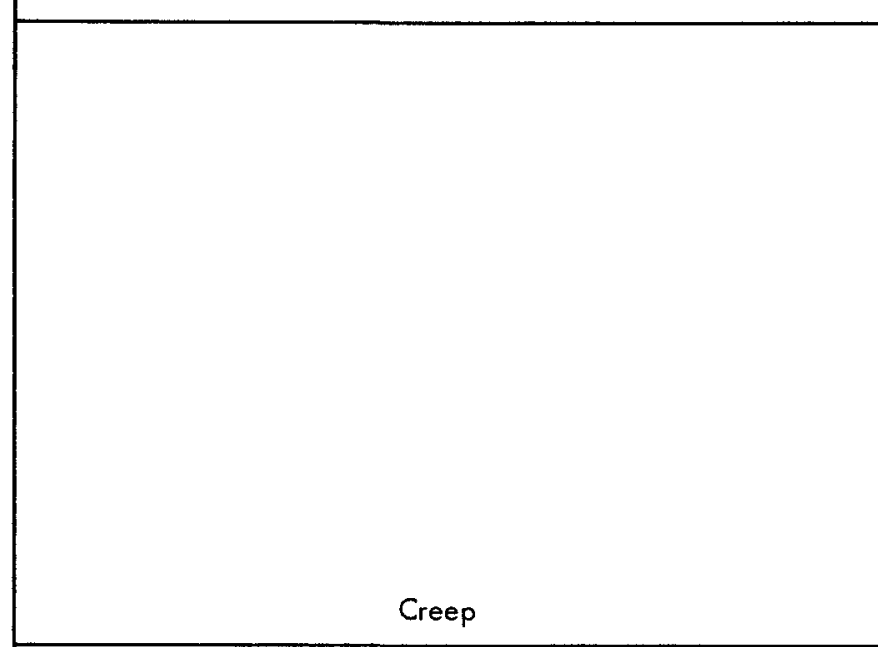

Failure envelope

\section{NOTES}

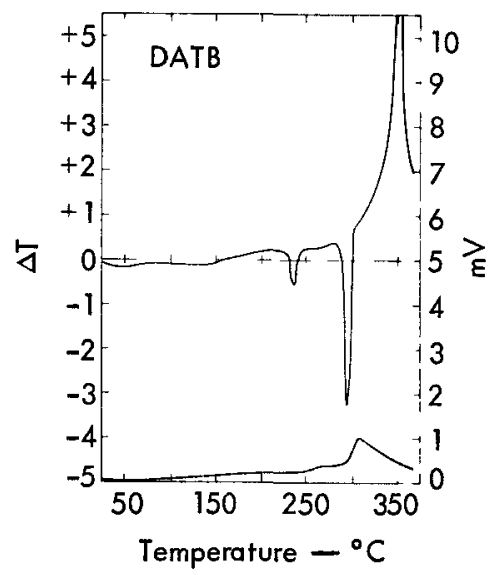

DTA (-) and pyrolysis (---) curves. 


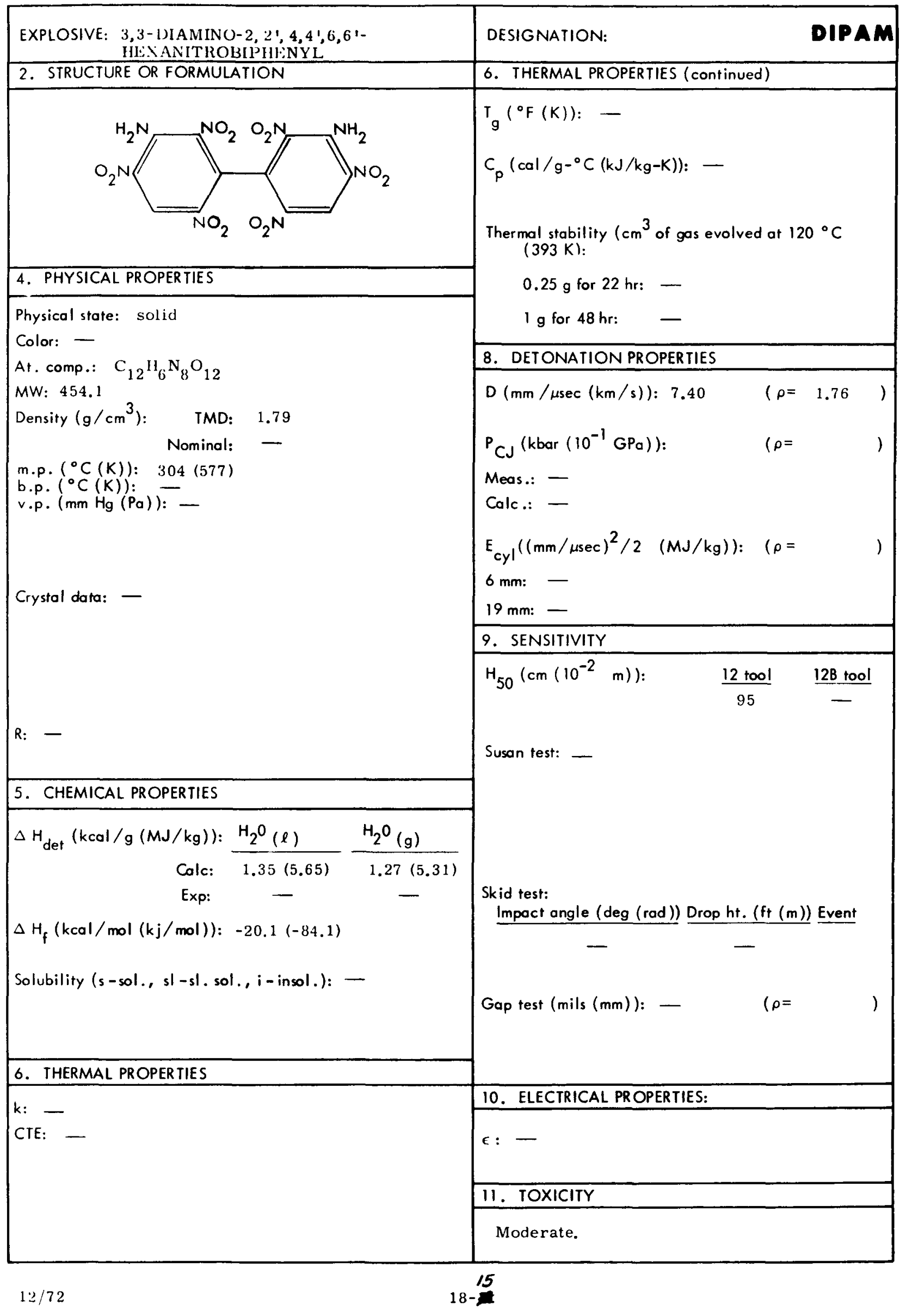




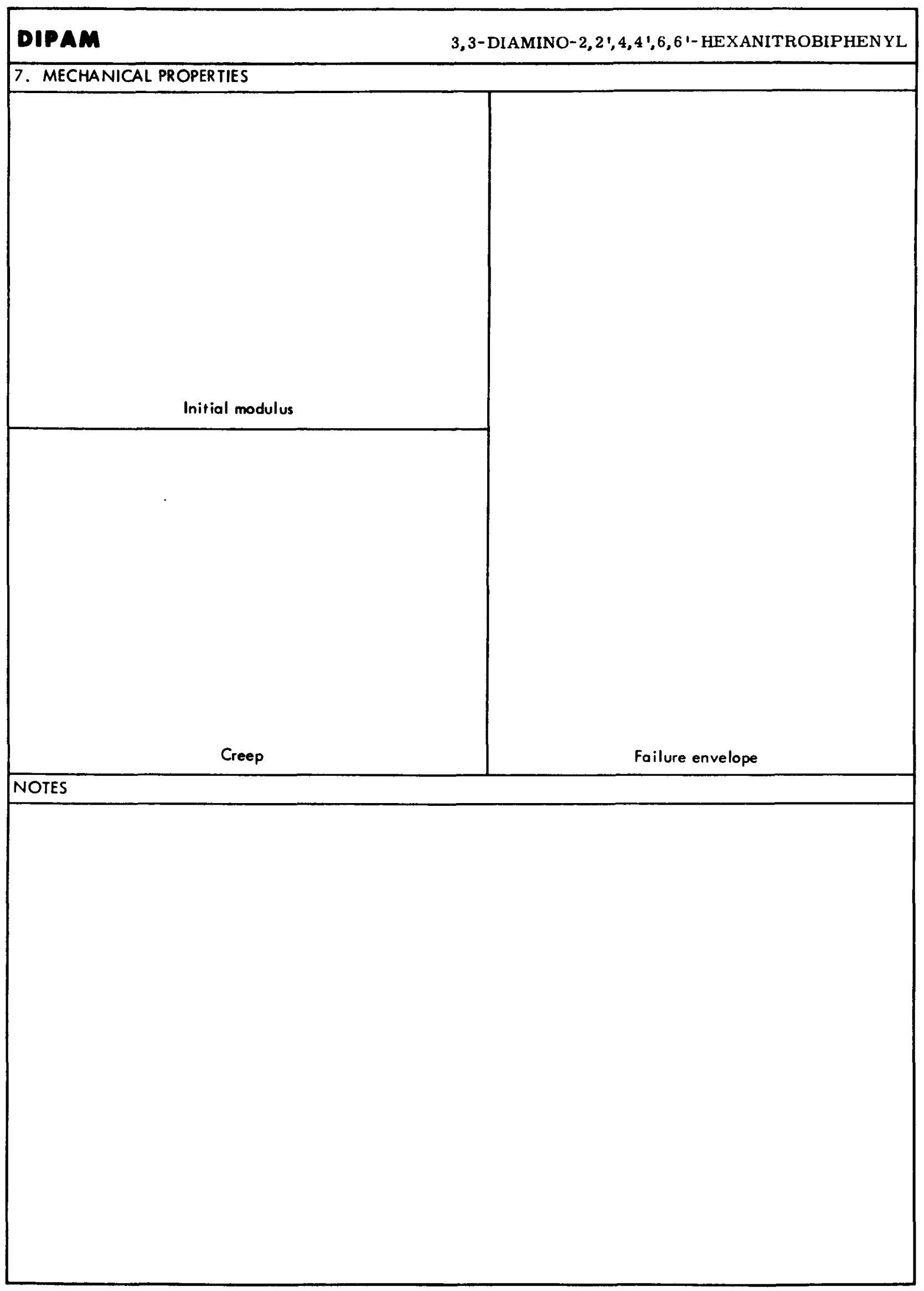

$18-16$

$12 / 72$ 


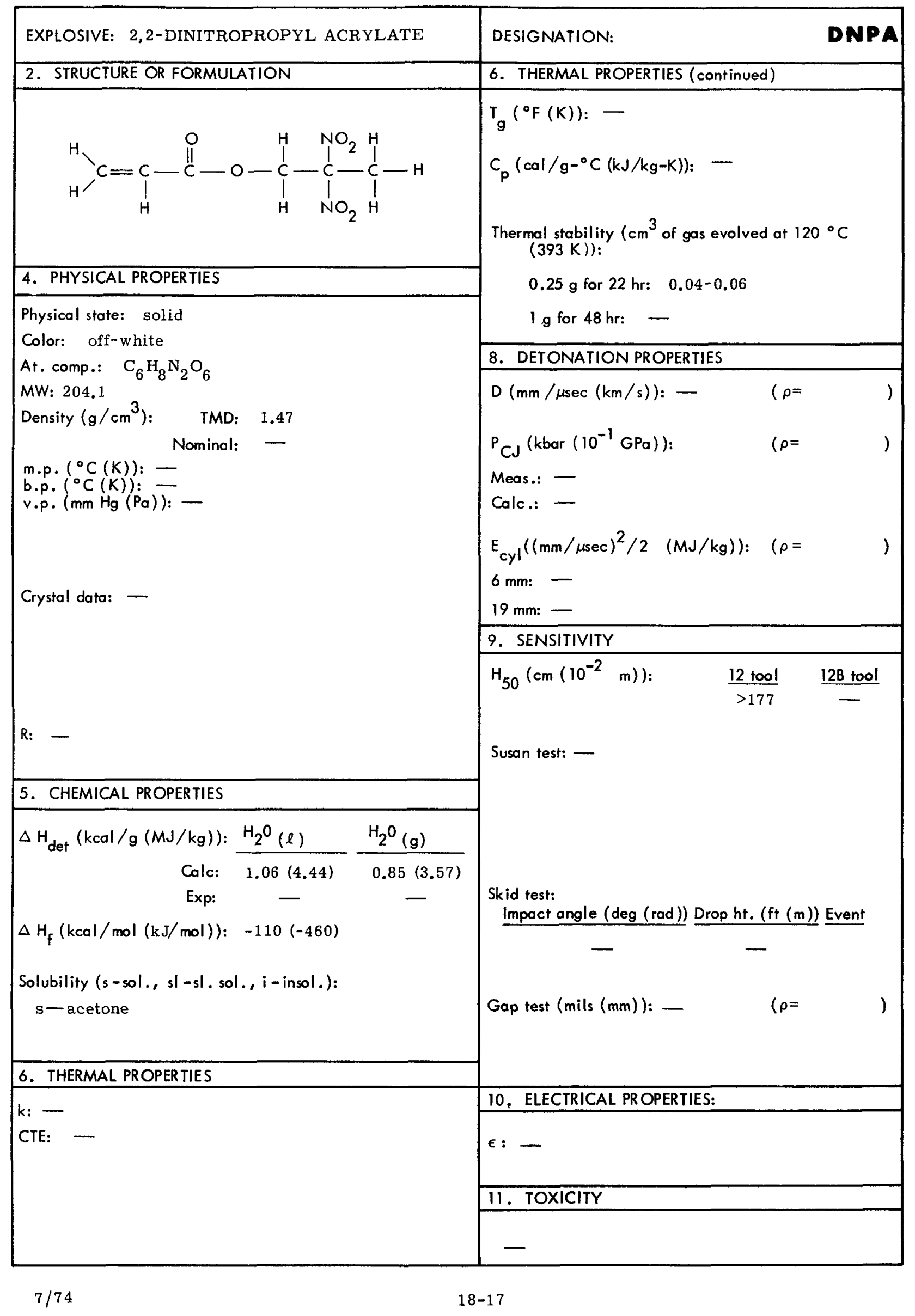



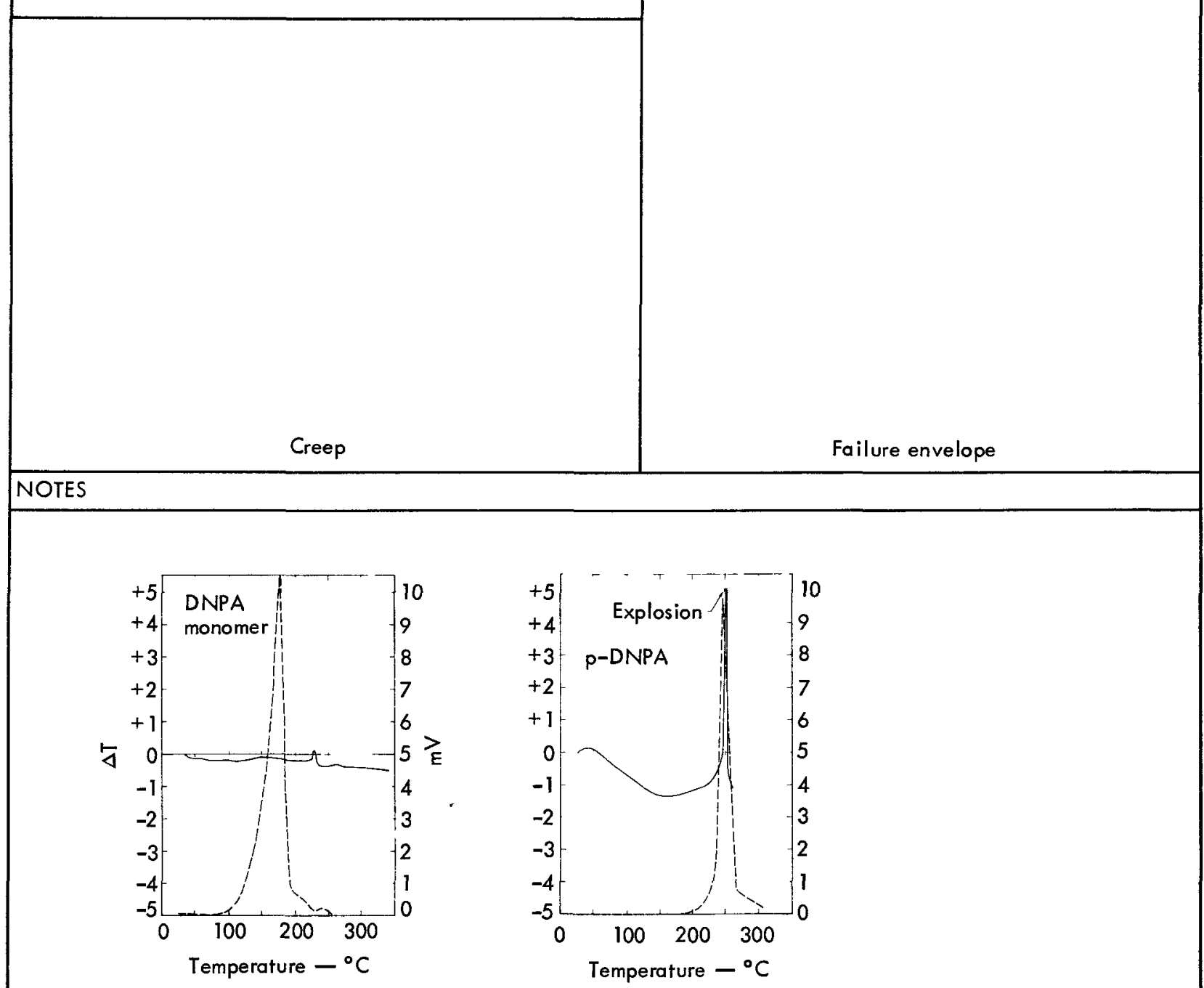

DTA (-) and pyrolysis (---) curves. 
MATERIAL: DI-2-ETHYLHEXYL PHTHALATE

DESIGNATION :

(Plasticizer)

SUPPLIER :

2. STRUCTURAL FORMULATION

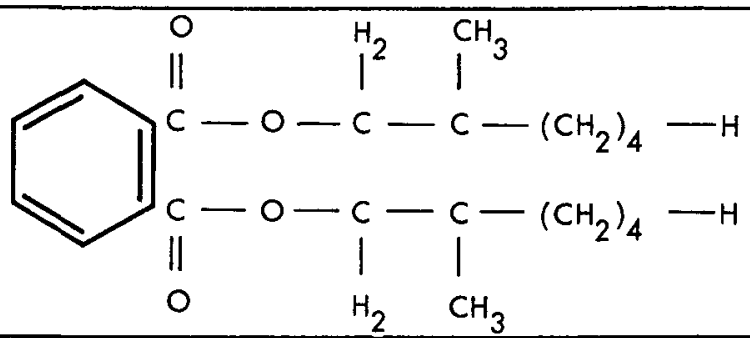

4. PHYSICAL PROPERTIES

Physical state : liquid

Color : clear

At. comp. : $\mathrm{C}_{24} \mathrm{H}_{38} \mathrm{O}_{4}$

MW: 390.57

Density $\left(\mathrm{g} / \mathrm{cm}^{3}\right): \quad$ TMD $: 0.9861$

Nominal

m.p. $\left({ }^{\circ} \mathrm{C}(\mathrm{K})\right)$ :

b.p. $\left({ }^{\circ} \mathrm{C}(\mathrm{K})\right)$ : $222-230(495-503)$

v.p. $(\mathrm{mm} \mathrm{Hg}(\mathrm{Pa})):<0.06$ at $150^{\circ} \mathrm{C}(<8.0$ at $423 \mathrm{~K})$

Brittle point $\left({ }^{\circ} \mathrm{C}(\mathrm{K})\right)$.

f.p. $\left({ }^{\circ} \mathrm{C}(\mathrm{K})\right):-55(218)$

5. CHEMICAL PROPERTIES

$R$ :

$\mathrm{n}: \quad 1.485$ at $25^{\circ} \mathrm{C}(298 \mathrm{~K})$

Shore hardness :

$\Delta H_{f}(\mathrm{kcal} / \mathrm{mol}(\mathrm{kJ} / \mathrm{mol})):-268.2\left(\begin{array}{ll}-122) \\ 12\end{array}\right.$

. MECHANICAL PROPERTIES

Tensile strength ( $\mathrm{psi}(\mathrm{kPa})$ ):

Solubility (s-sol., sl-sl. sol., i-insol.) :

$\mathrm{s}$ - gasoline, mineral oil

Elongation $(\%)$ :

Crystal data :

i- glycerine, water

6. THERMAL PROPERTIES

$k$ :

CTE : $74 \mu \mathrm{m} / \mathrm{m}$ at $10-40^{\circ} \mathrm{C}(283-313 \mathrm{~K})$

$\mathrm{T}_{\mathrm{g}}\left({ }^{\circ} \mathrm{F}(\mathrm{K})\right):$

$C_{p}\left(\mathrm{cal} / \mathrm{g}-{ }^{\circ} \mathrm{C}(\mathrm{kJ} / \mathrm{kg}-\mathrm{K})\right)$ :

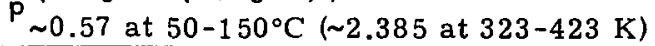

NOTES
10. ELECTRICAL PROPERTIES

$\epsilon$ :

$\zeta \rho=$

\section{TOXICITY}

None. 


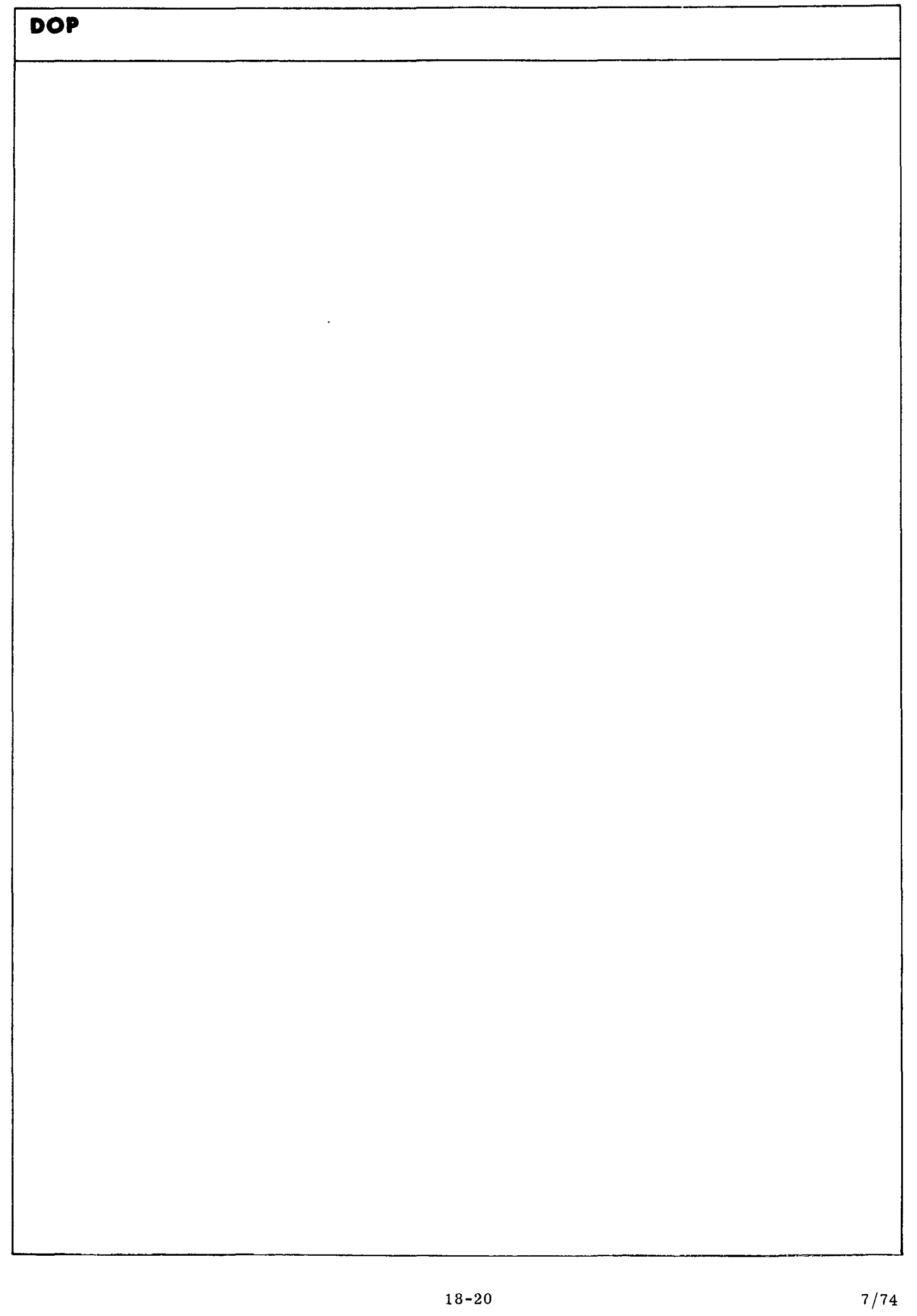




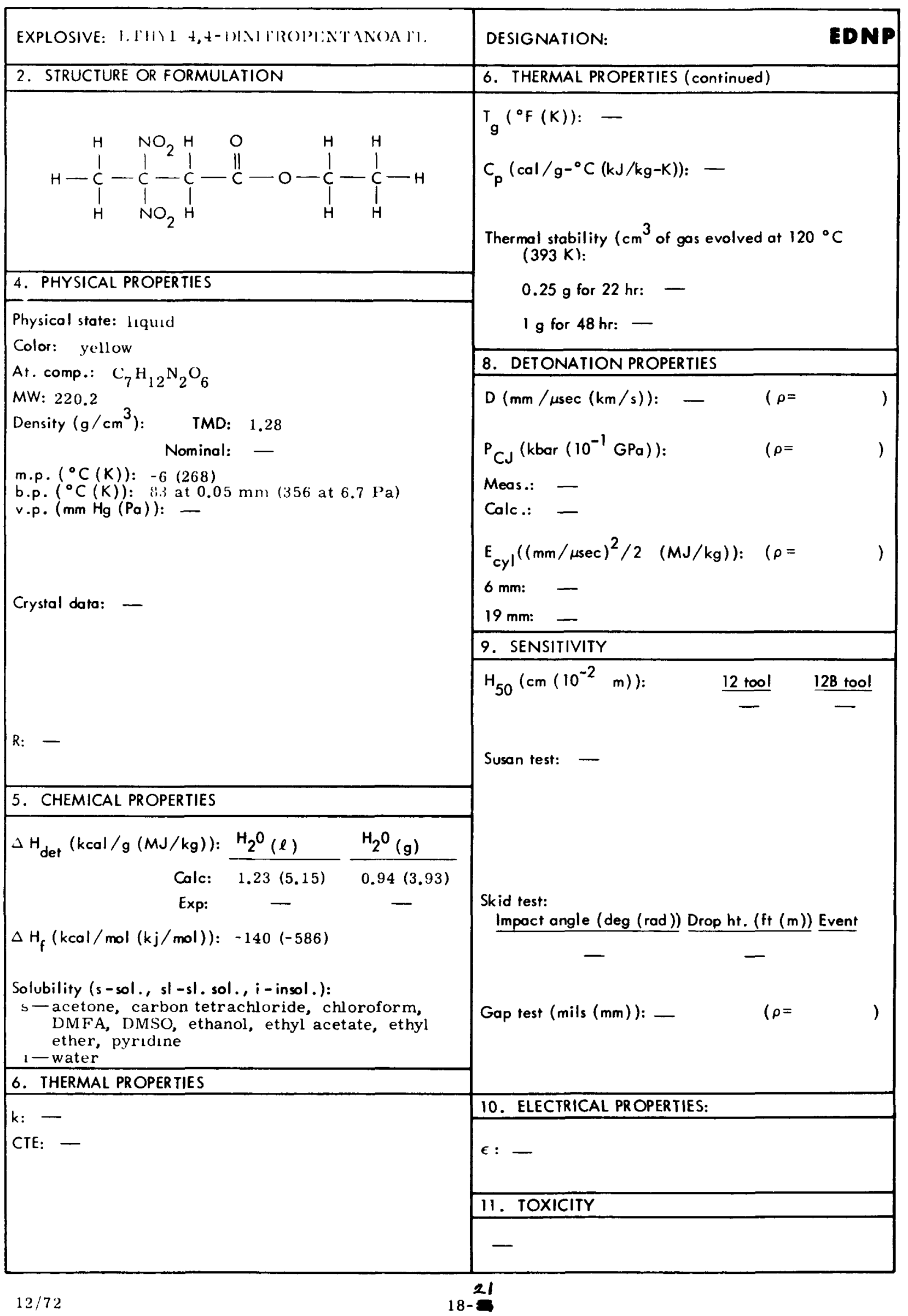




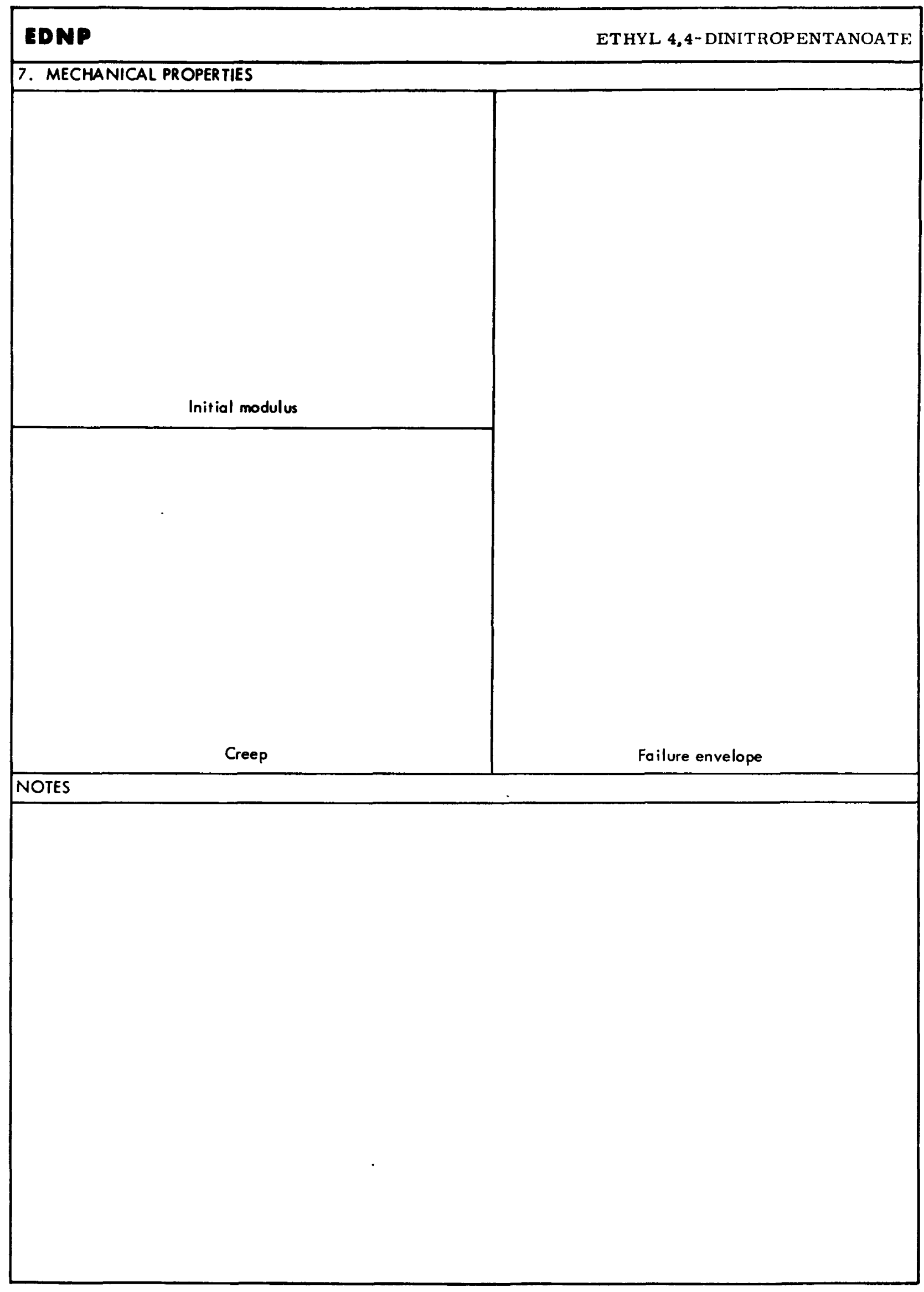

$18-22$

$12 / 72$ 
MATERIAL: POL YURETHANE SOLUTION SYSTEM

DESIGNATION :

Estane 5702-F1

(Binder)

SUPPLIER : B. F. Goodrich

2. STRUCTURAL FORMULATION

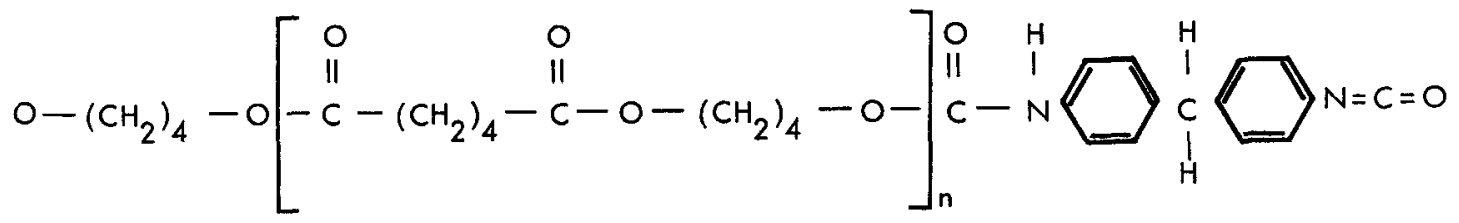

$n=5-10$

\section{PHYSICAL PROPERTIES}

Physical state : rubbery solid

Crystal data :

Color: light amber

At. comp. : $\left(\mathrm{C}_{5.137} \mathrm{H}_{7.500} \mathrm{~N}_{0.187} \mathrm{O}_{1.758}\right)_{\mathrm{n}}$

MW : 100

Density $\left(\mathrm{g} / \mathrm{cm}^{3}\right): \quad$ TMD :

Nominal : 1.18

m.p. $\left({ }^{\circ} \mathrm{C}(\mathrm{K})\right)$ :

b.p. $\left({ }^{\circ} \mathrm{C}(\mathrm{K})\right)$ :

v.p. $(\mathrm{mm} \mathrm{Hg}(\mathrm{Pa}))$ :

Brittle point $\left({ }^{\circ} \mathrm{C}(\mathrm{K})\right)$ :

R:

f.p. $\left({ }^{\circ} \mathrm{C}(\mathrm{K})\right)$ :

5. CHEMICAL PROPERTIES

7. MECHANICAL PROPERTIES

$\Delta H_{f}(\mathrm{kcal} / \mathrm{mol}(\mathrm{kJ} / \mathrm{mol})):-95(-397)$

Tensile strength (psi $(k P a))$ :

Solubility (s-sol., sl-sl. sol., i-insol.) :

s - acetone, dichloroethane, DMFA, DMSO, MEK, MIBK, THF

\section{THERMAL PROPERTIES}

10. ELECTRICAL PROPERTIES

$\mathrm{k}$ :

CTE :

$\epsilon:$

$(\rho=$

$\mathrm{T}_{\mathrm{g}}\left({ }^{\circ} \mathrm{F}(\mathrm{K})\right):-31(242)$

Elongation $(\%)$ :

$C_{p}\left(\mathrm{cal} / \mathrm{g}-{ }^{\circ} \mathrm{C}(\mathrm{kJ} / \mathrm{kg}-\mathrm{K})\right):$

NOTES 
Estane 5702-F1

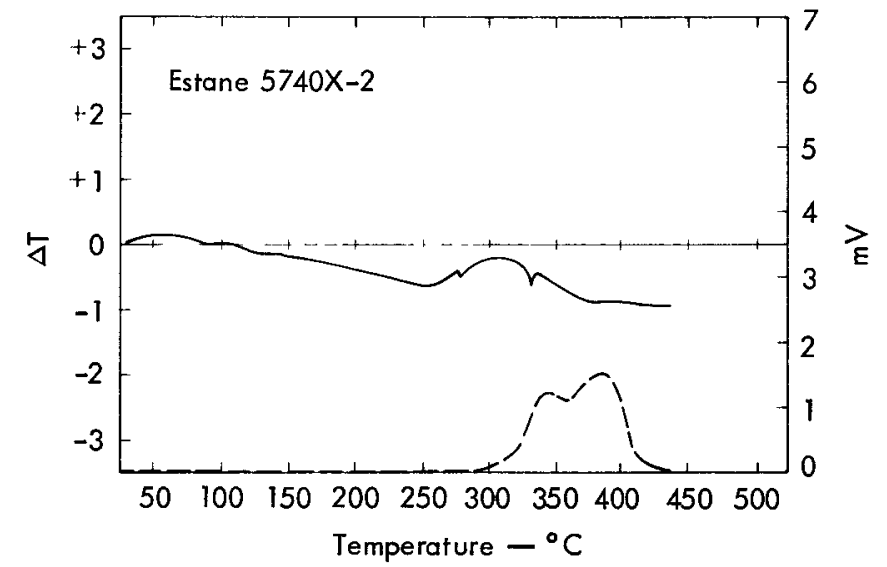

DTA (-) and pyrolysis (---) curves. 


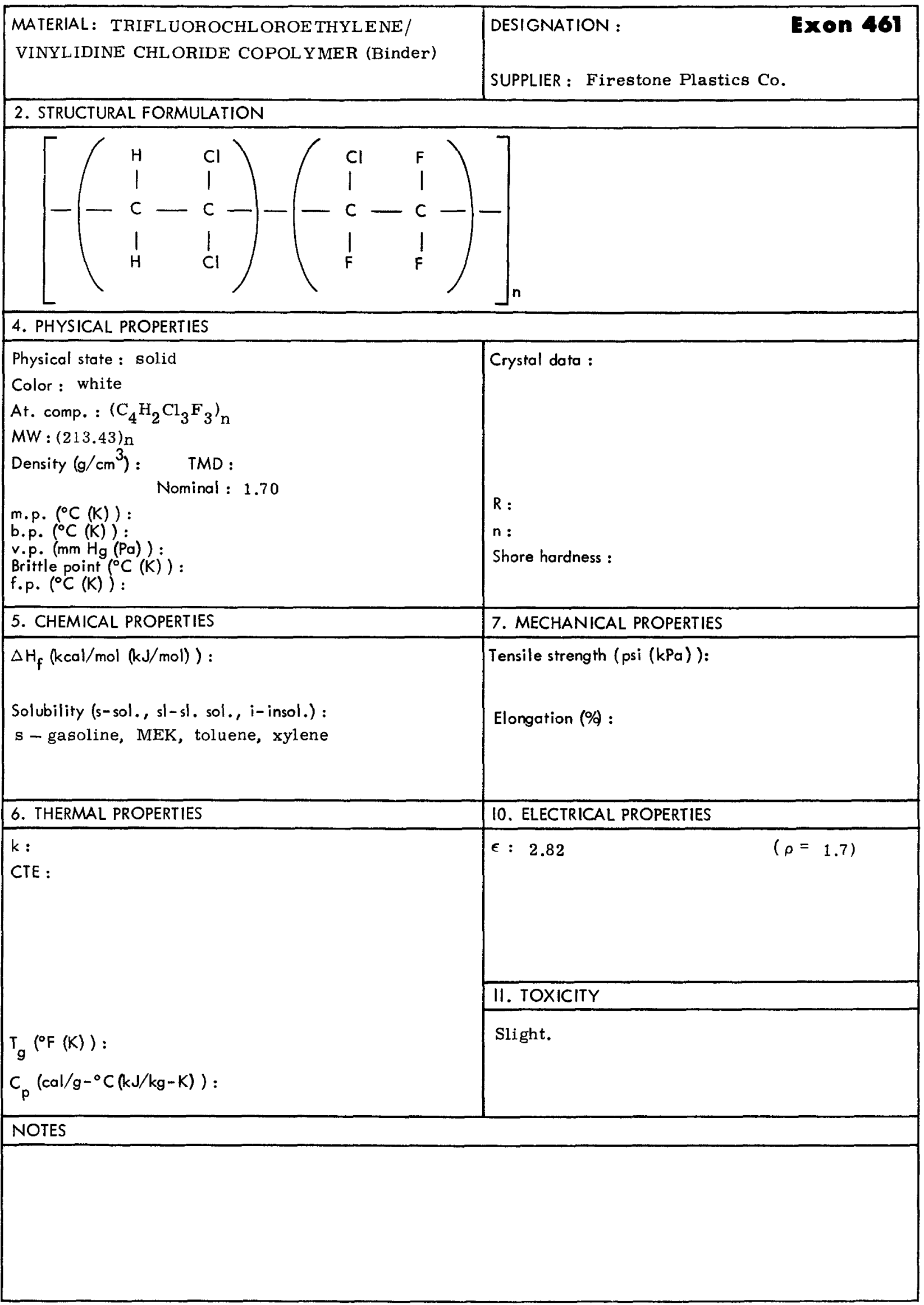


Exon 461

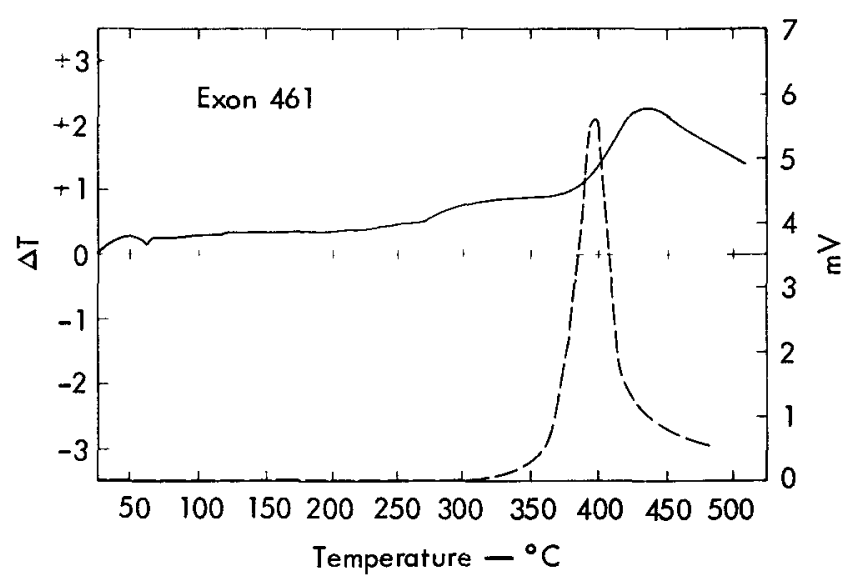

DTA (-) and pyrolysis (---) curves. 


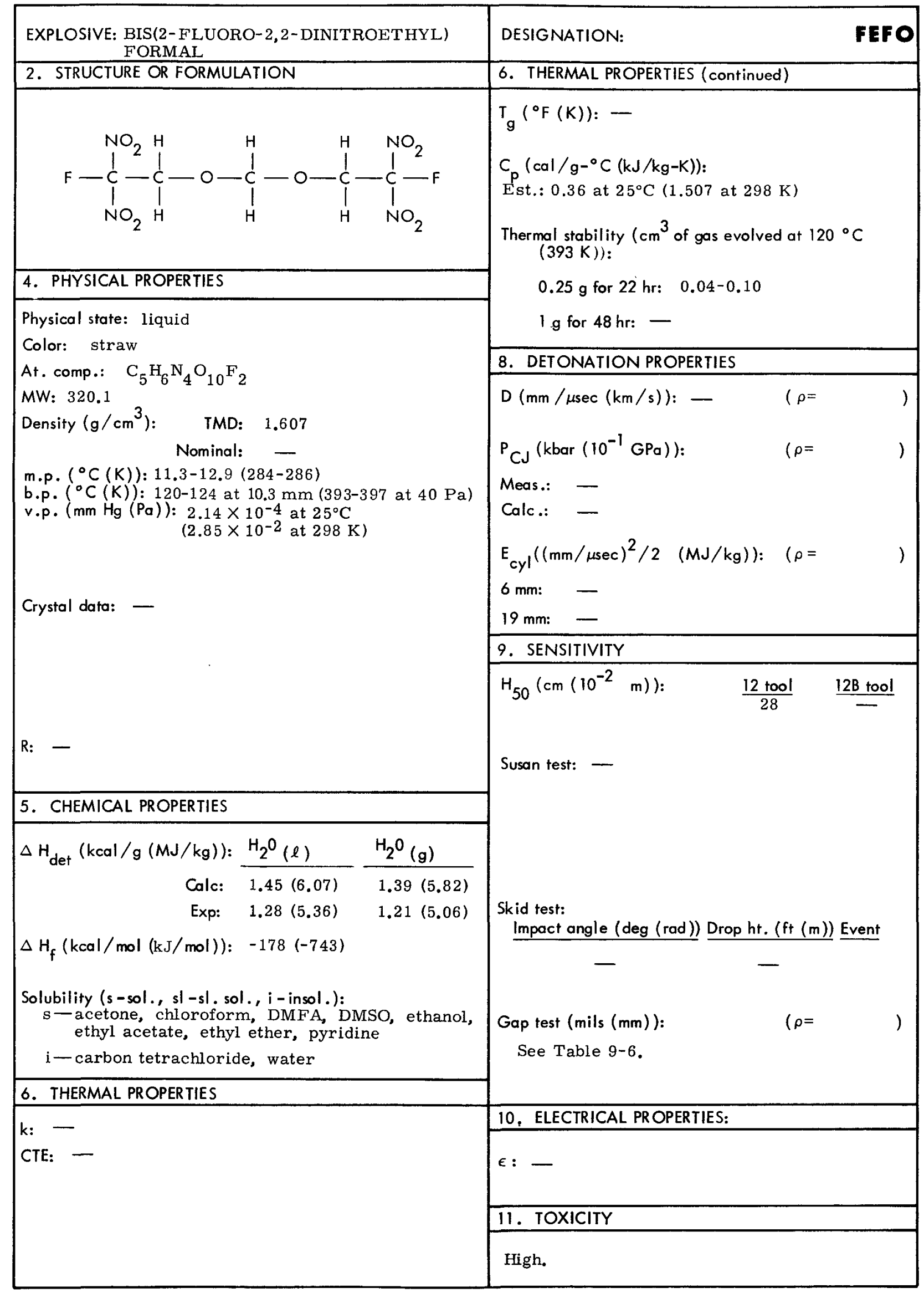




FEFO BIS(2-FLUORO-2,2-DINITROETHYL)FORMAL

7. MECHANICAL PROPERTIES

Initial modulus

\begin{tabular}{r|r} 
Creep & Failure envelope
\end{tabular}

NOTES

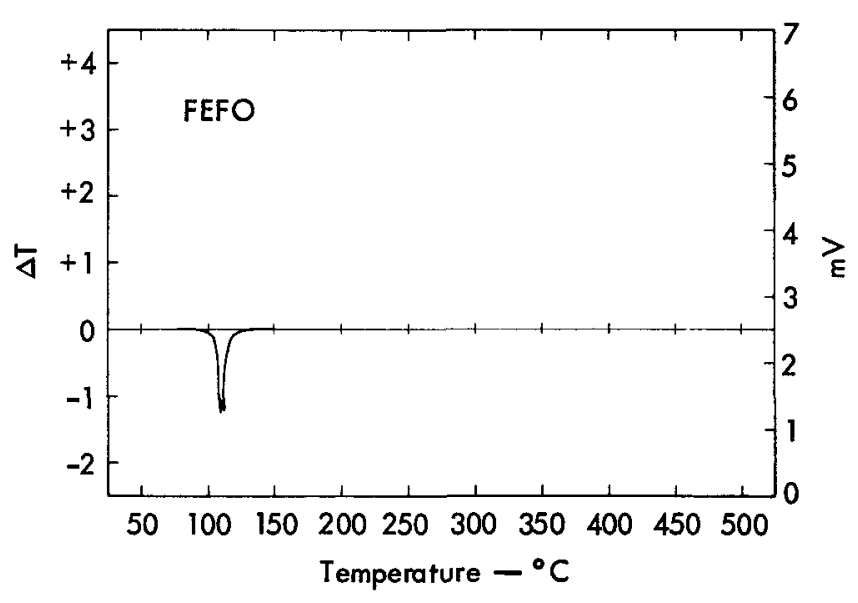

DTA (-) and pyrolysis (---) curves. 


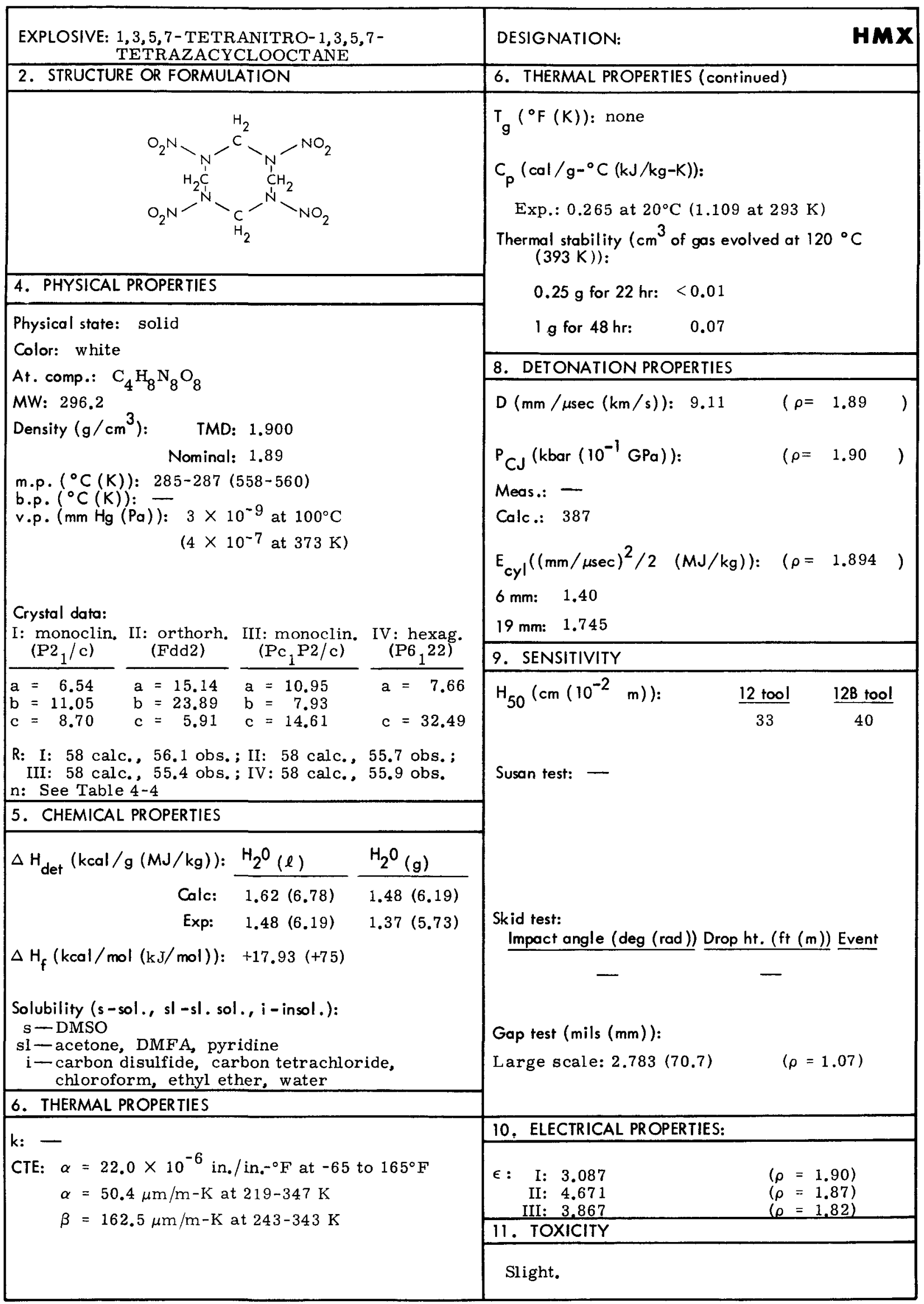




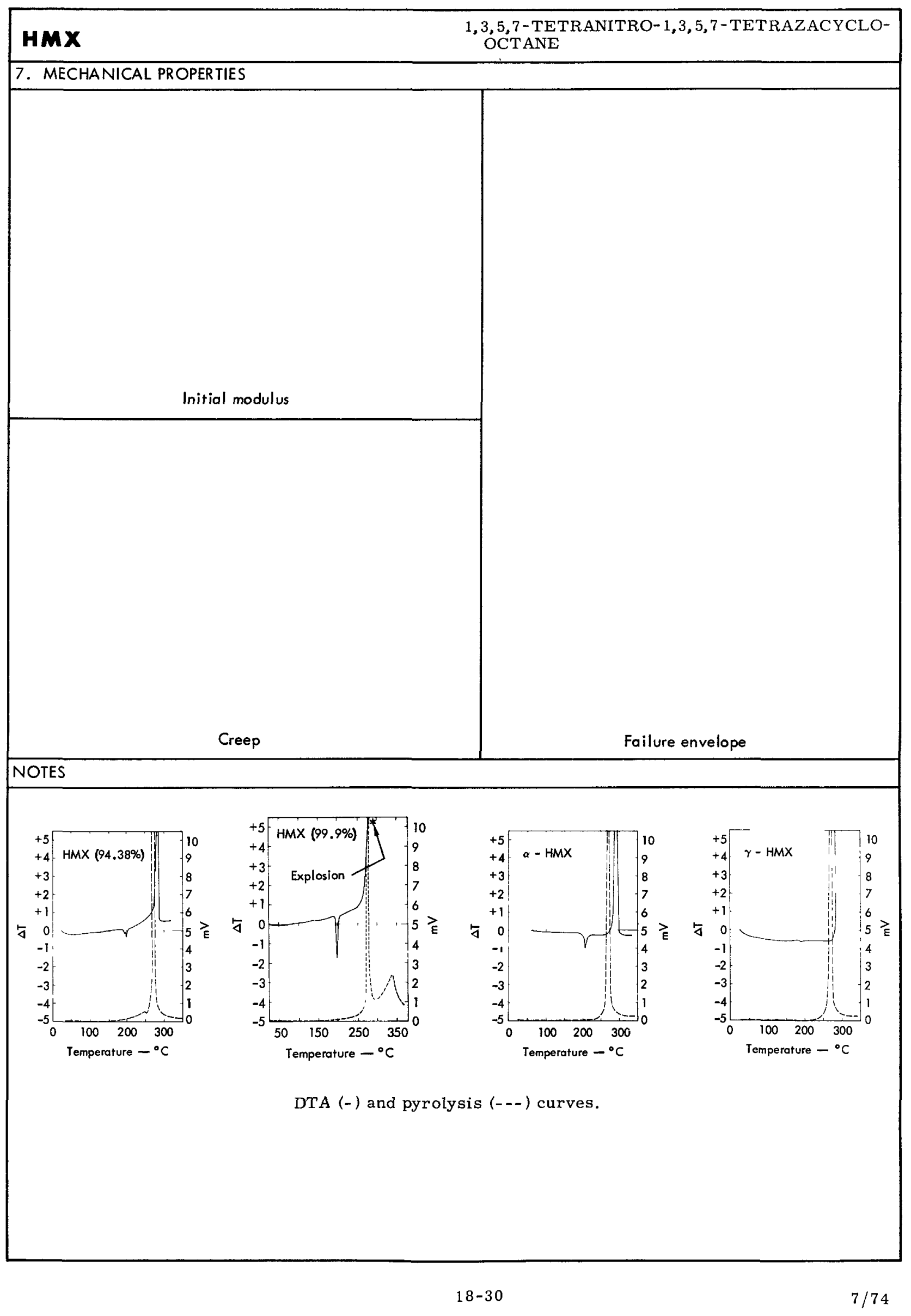




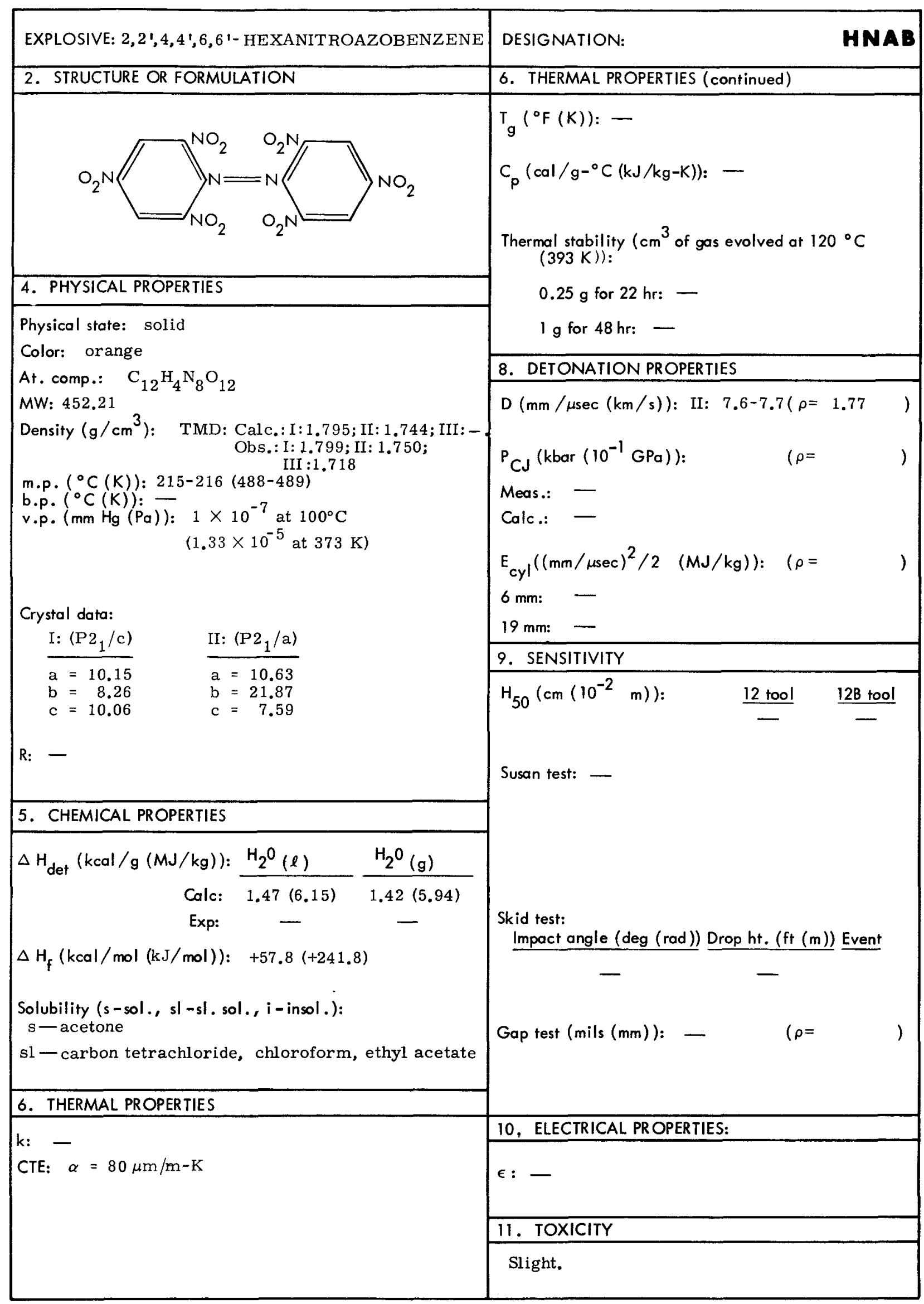




\section{HNAB}

$2,2^{\prime}, 4,4^{\prime}, 6,6^{\prime}$-HEXANITROAZOBENZENE

\section{MECHANICAL PROPERTIES}

Initial modulus

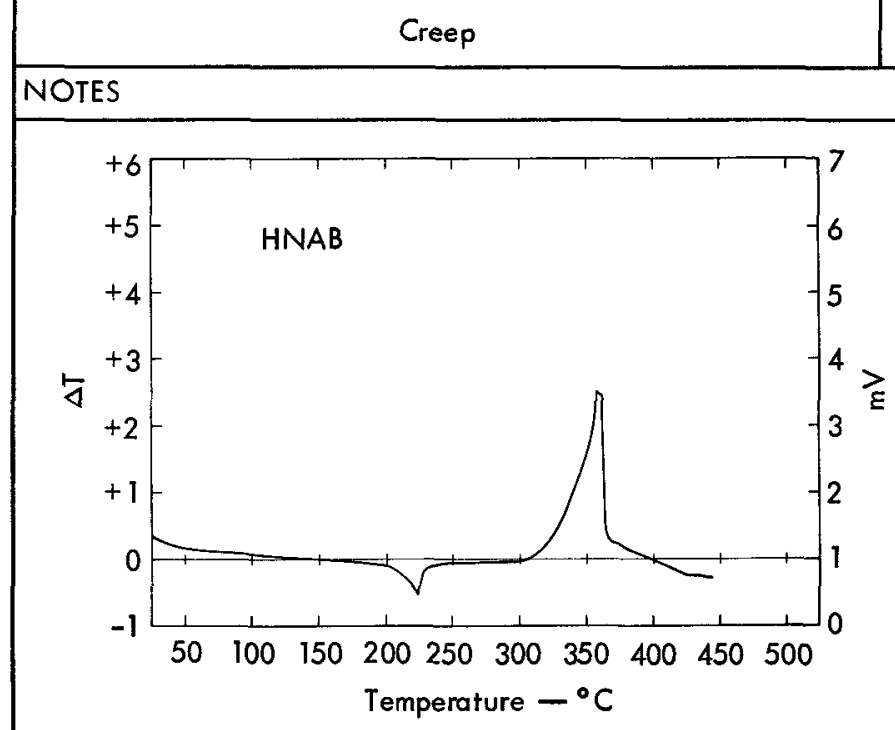

DTA (-) and pyrolysis (-- ) curves. 


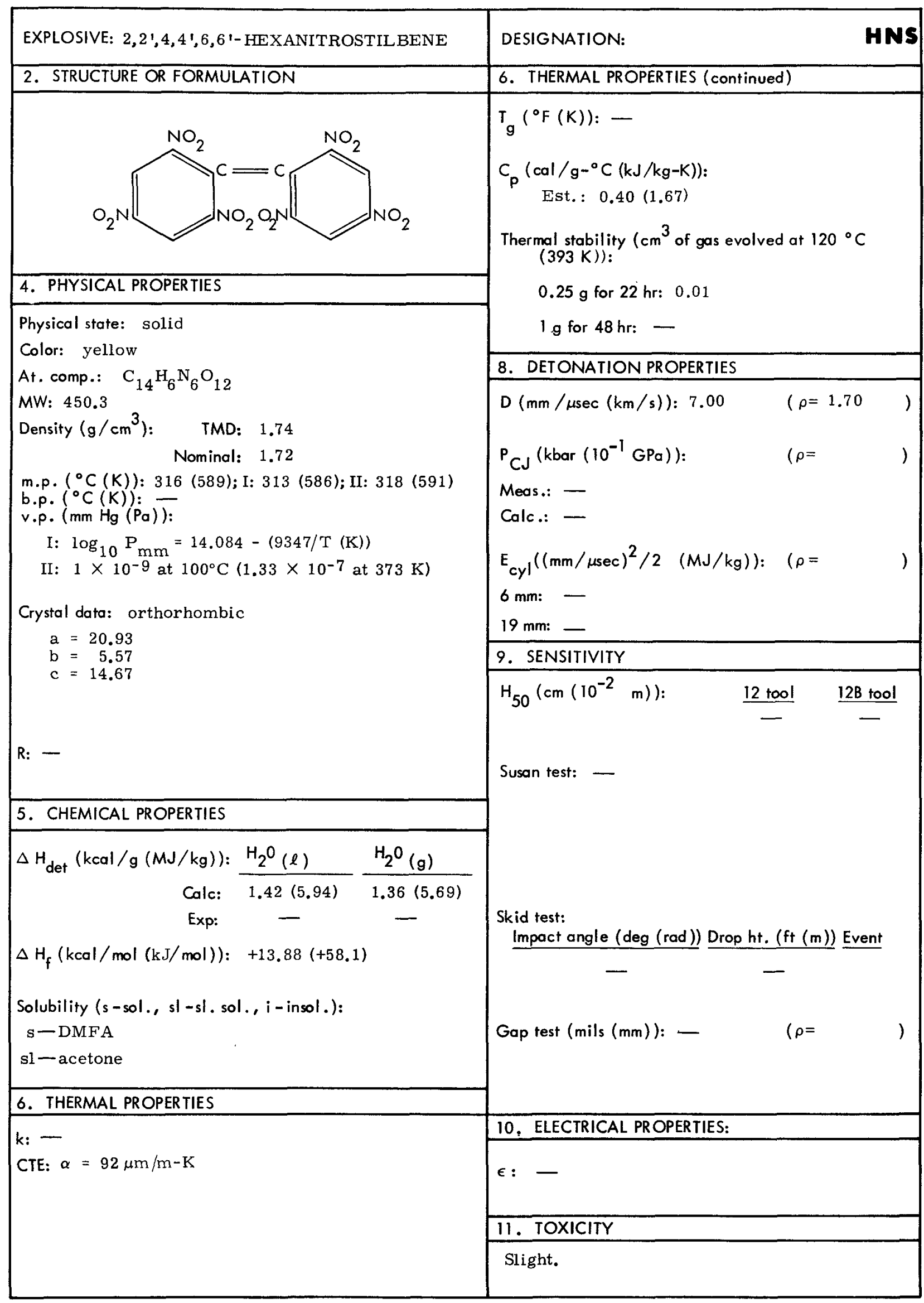




\section{HNS}

$2,21,4,4 !, 6,61$-HEXANITROSTILBENE

7. MECHANICAL PROPERTIES

Initial modulus

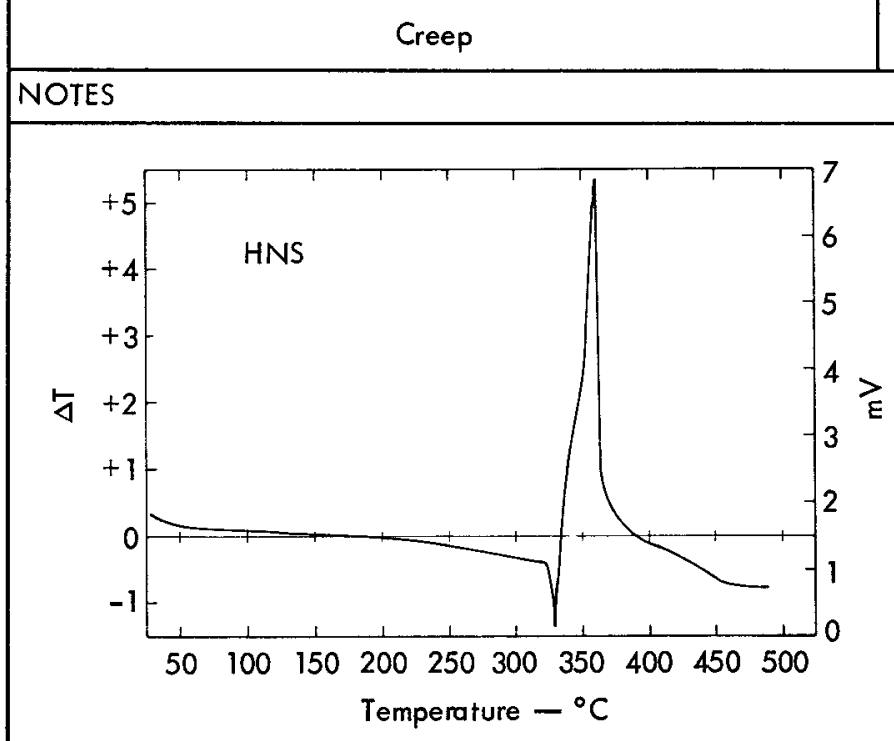

DTA (-) and pyrolysis (---) curves. 


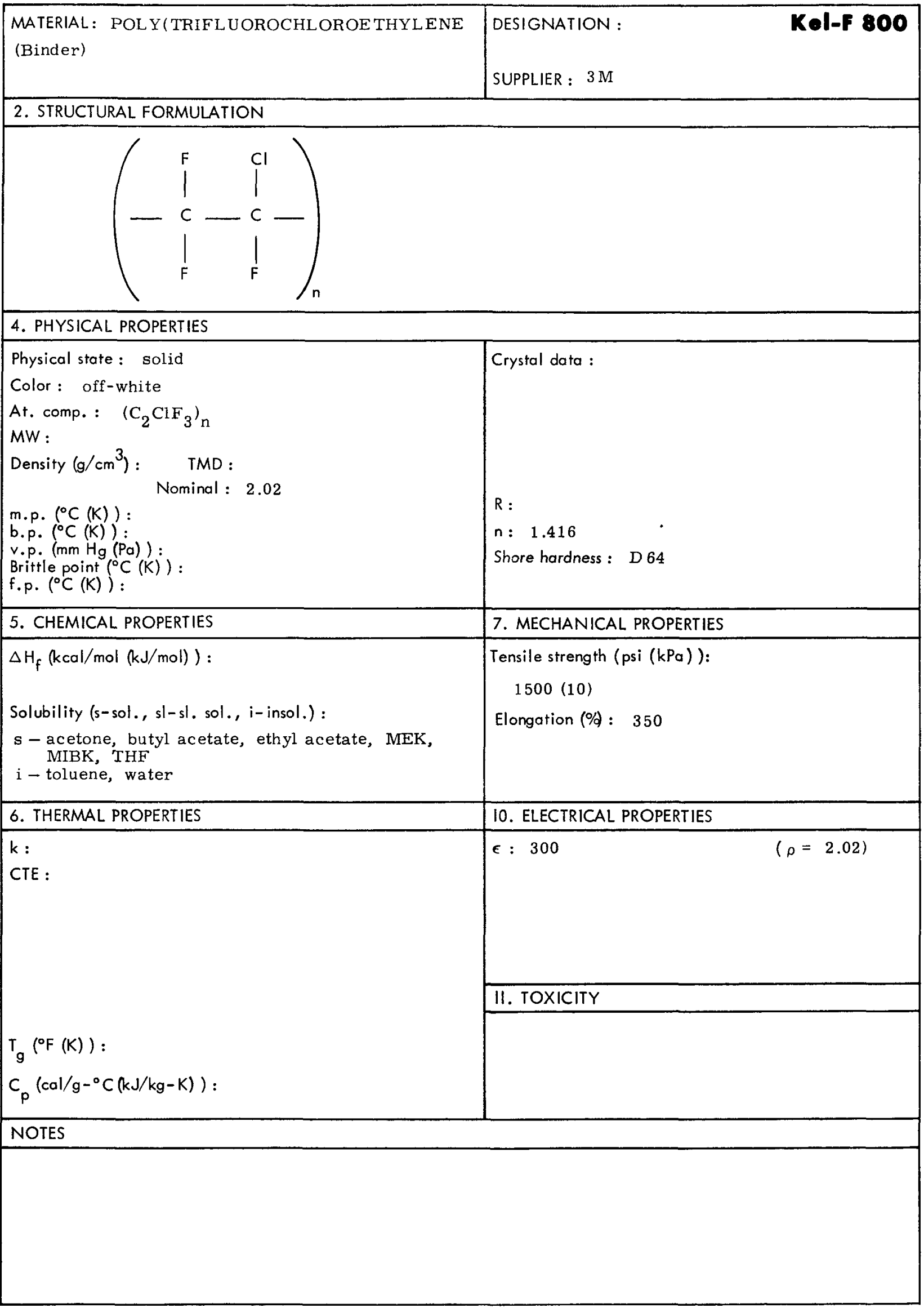




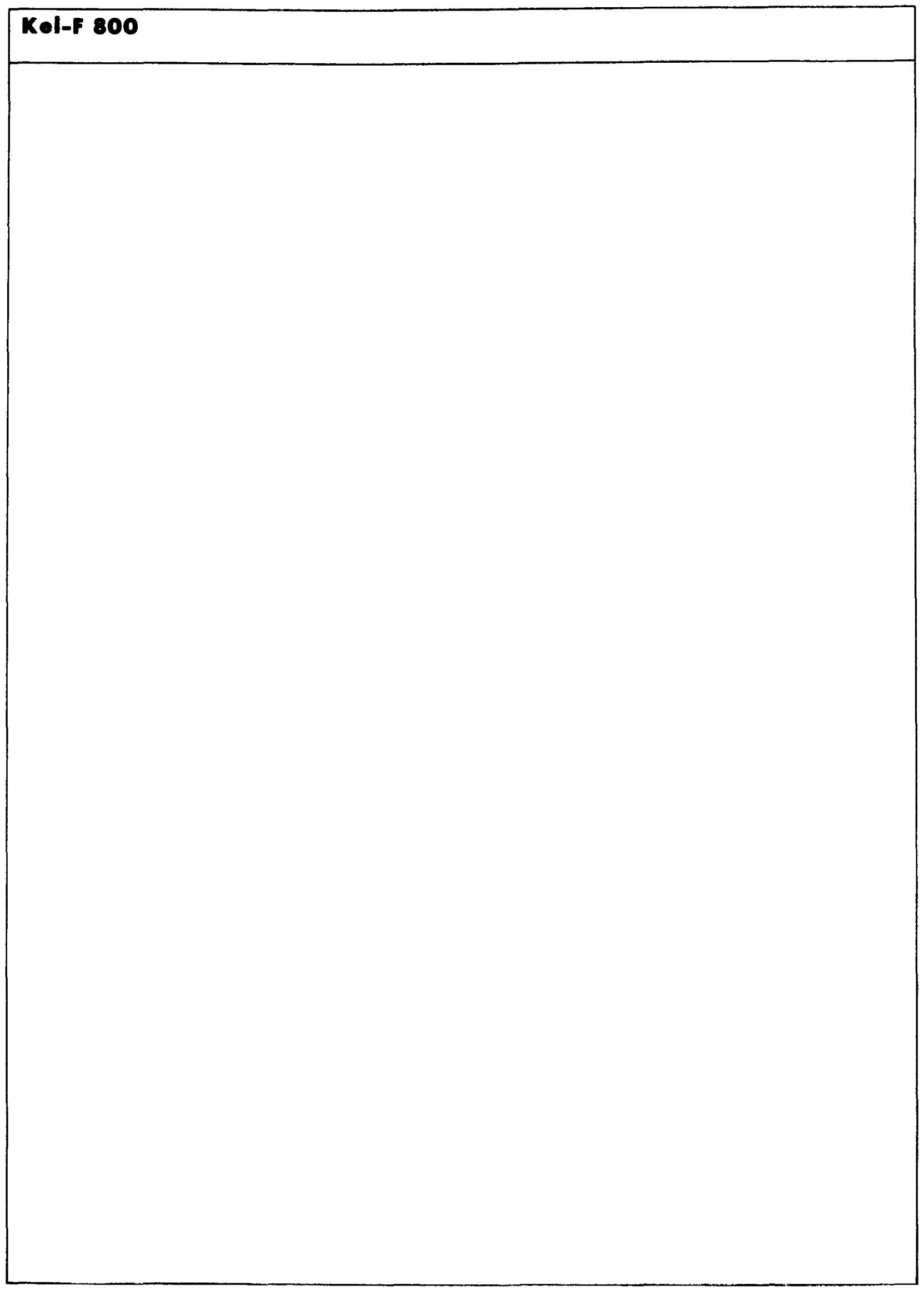

$18-36$

$7 / 74$ 


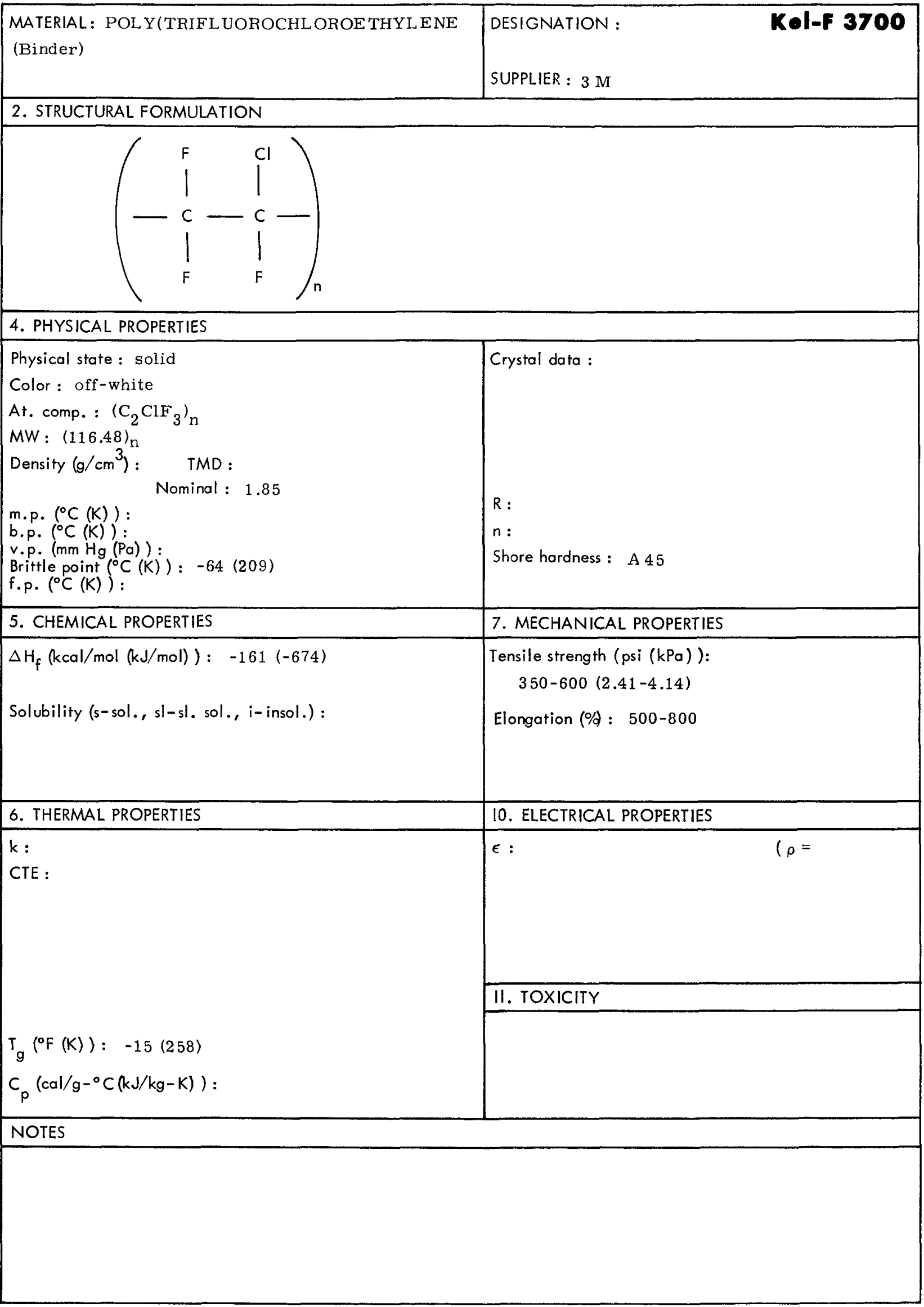


Kel-F 3700

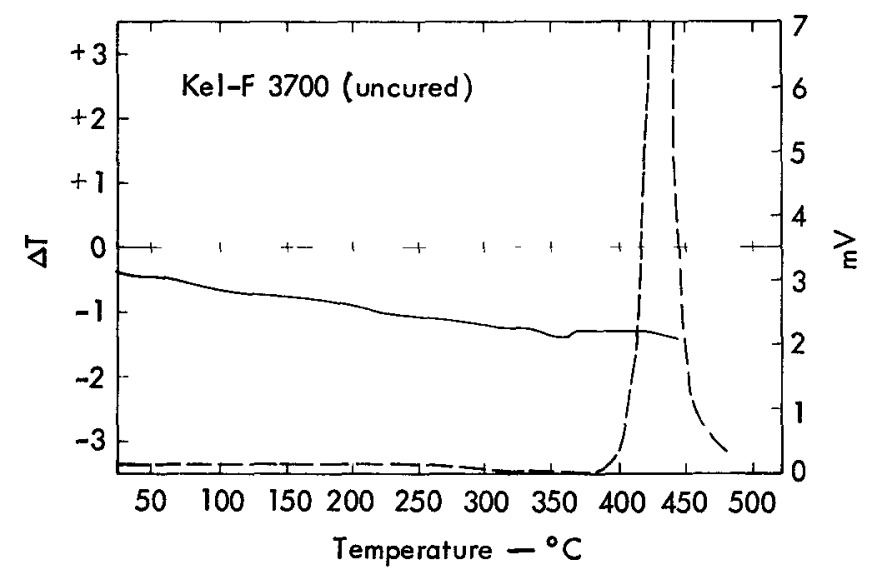

DTA (-) and pyrolysis (---) curves. 


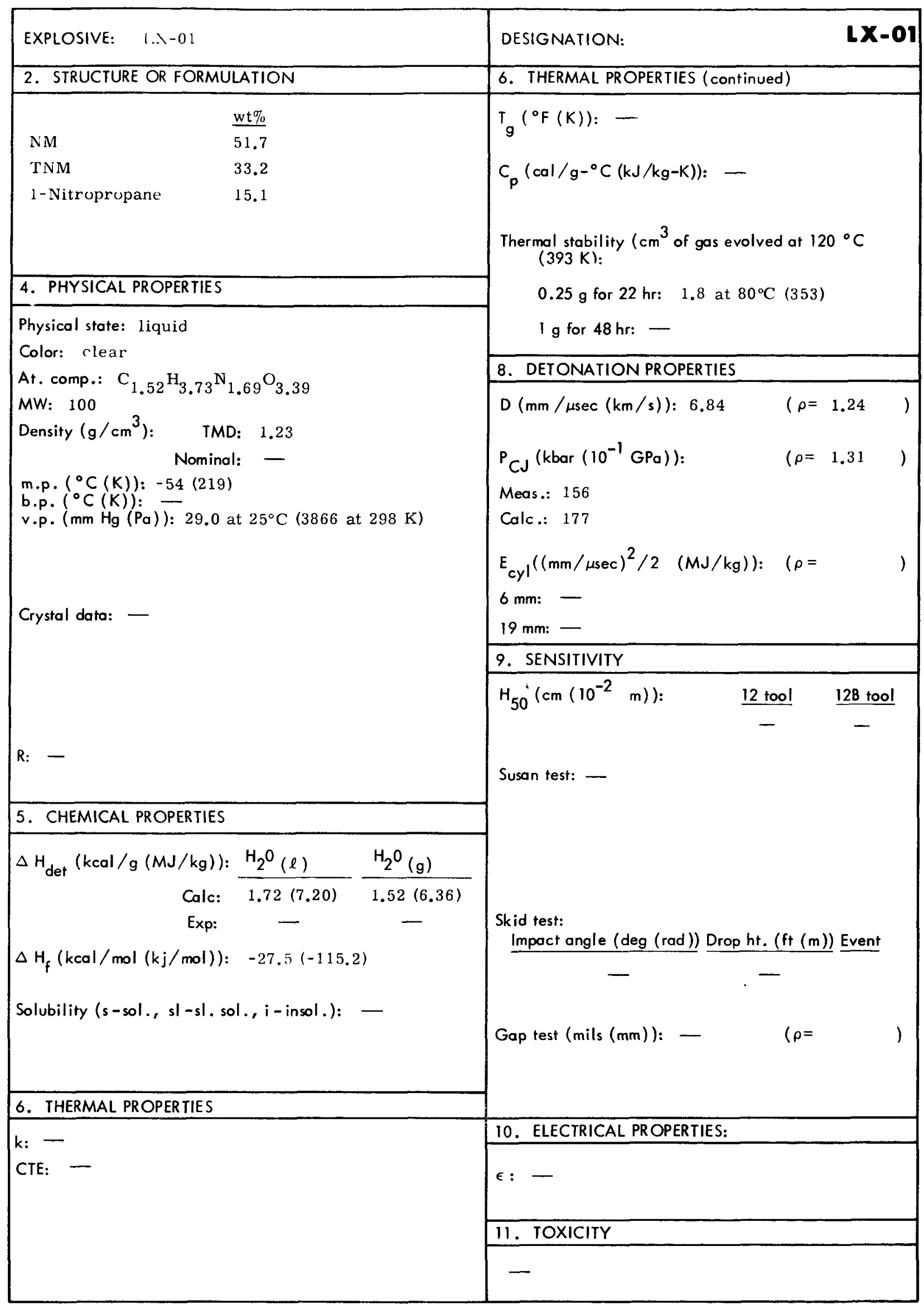




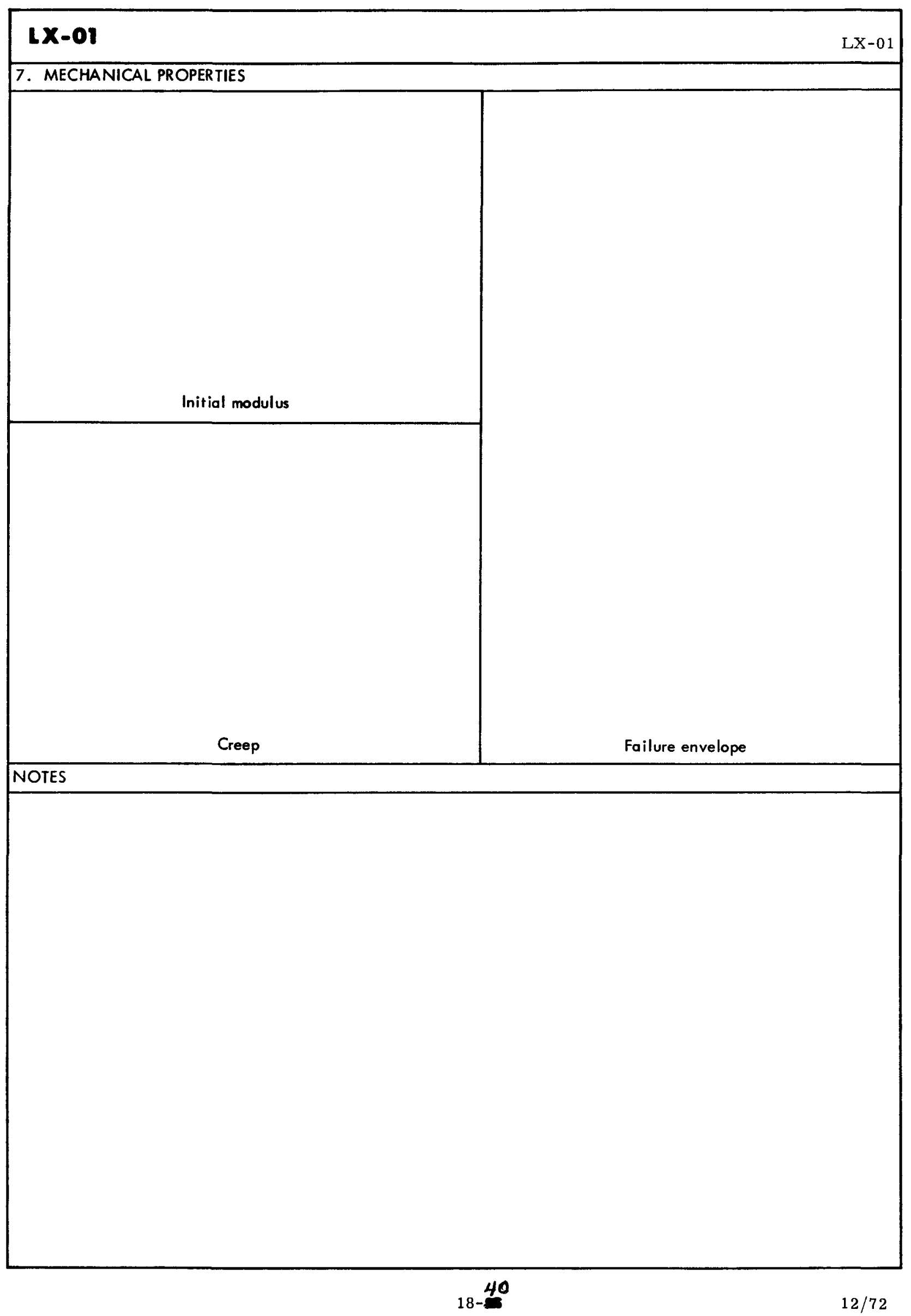




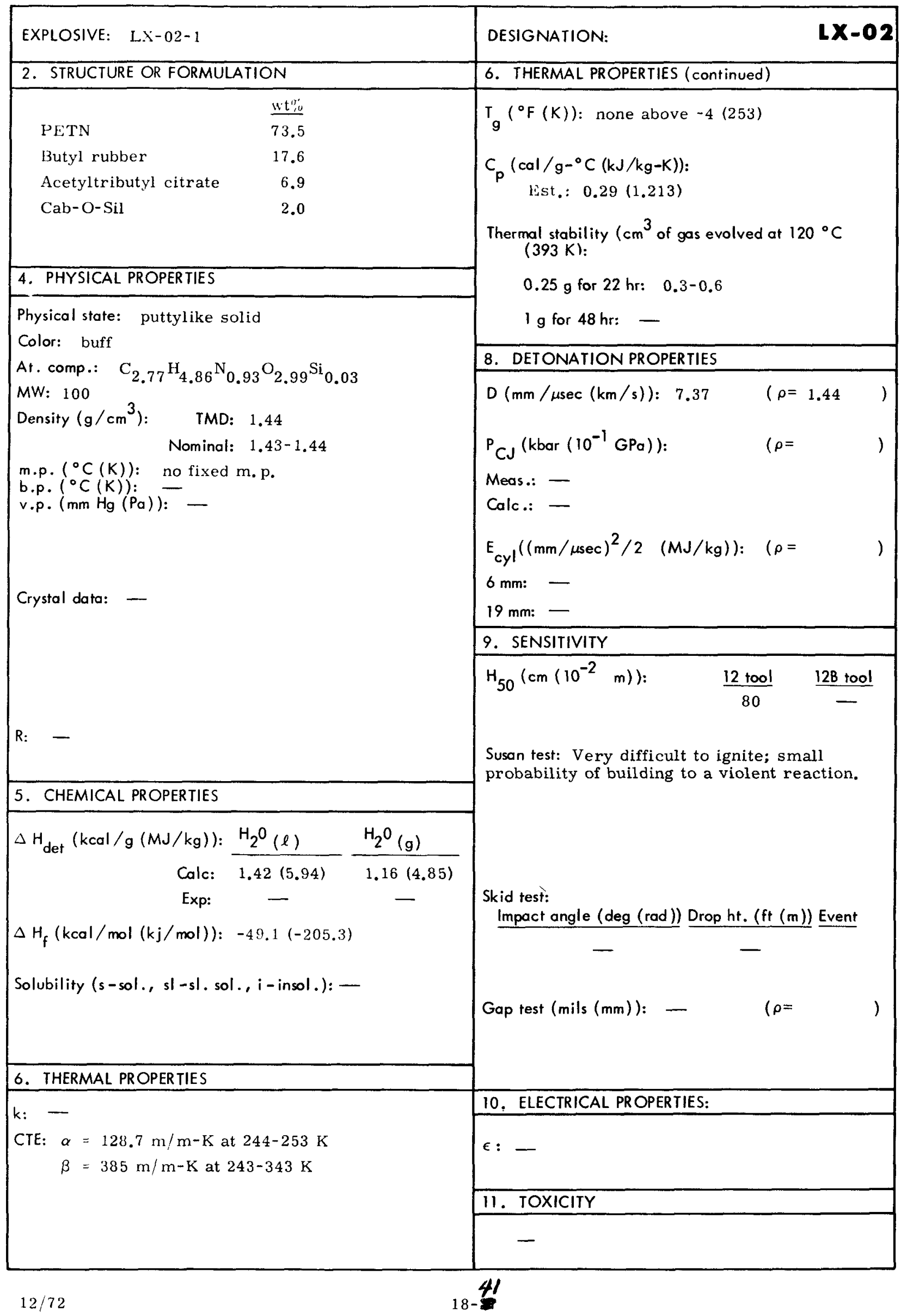




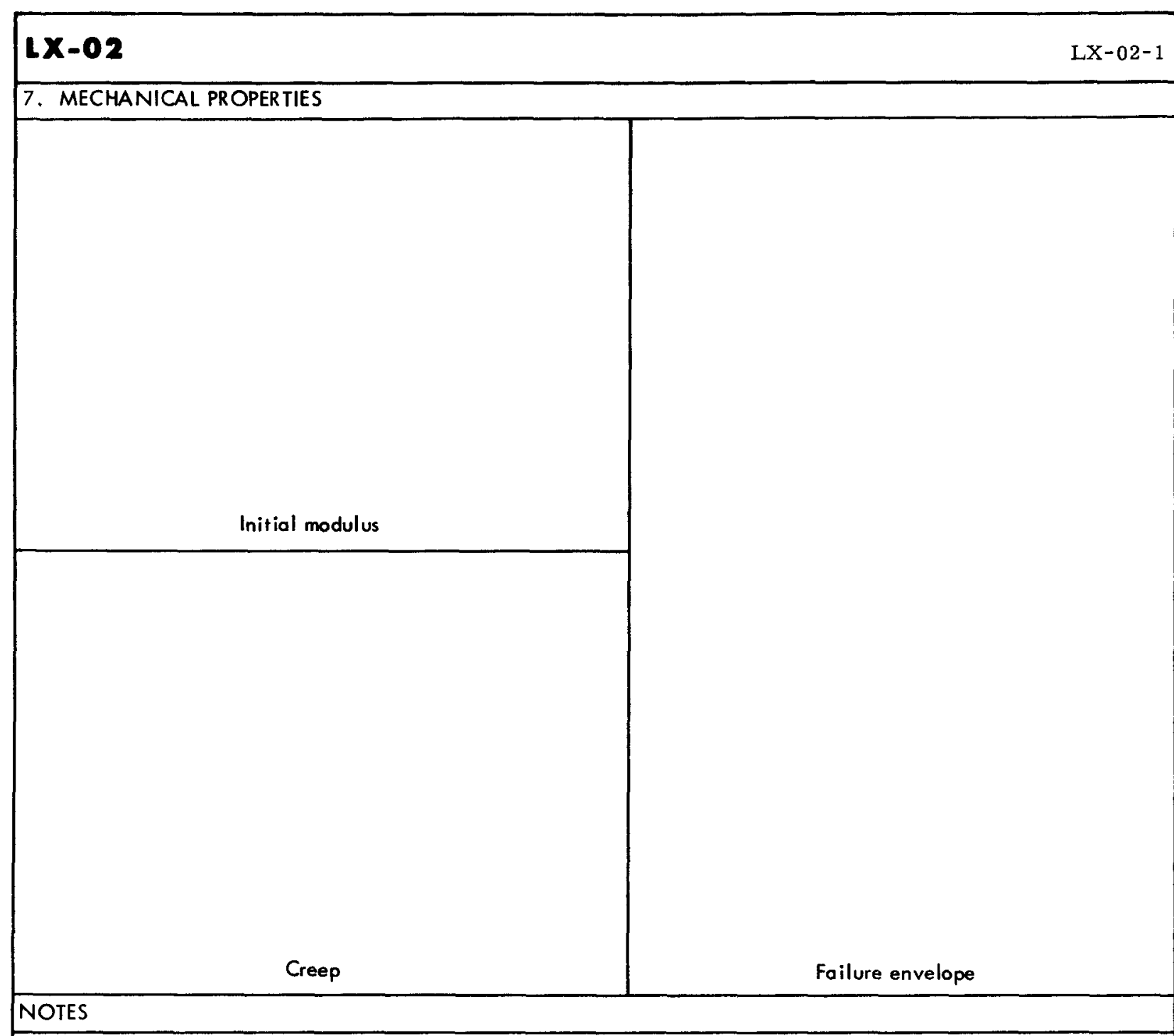




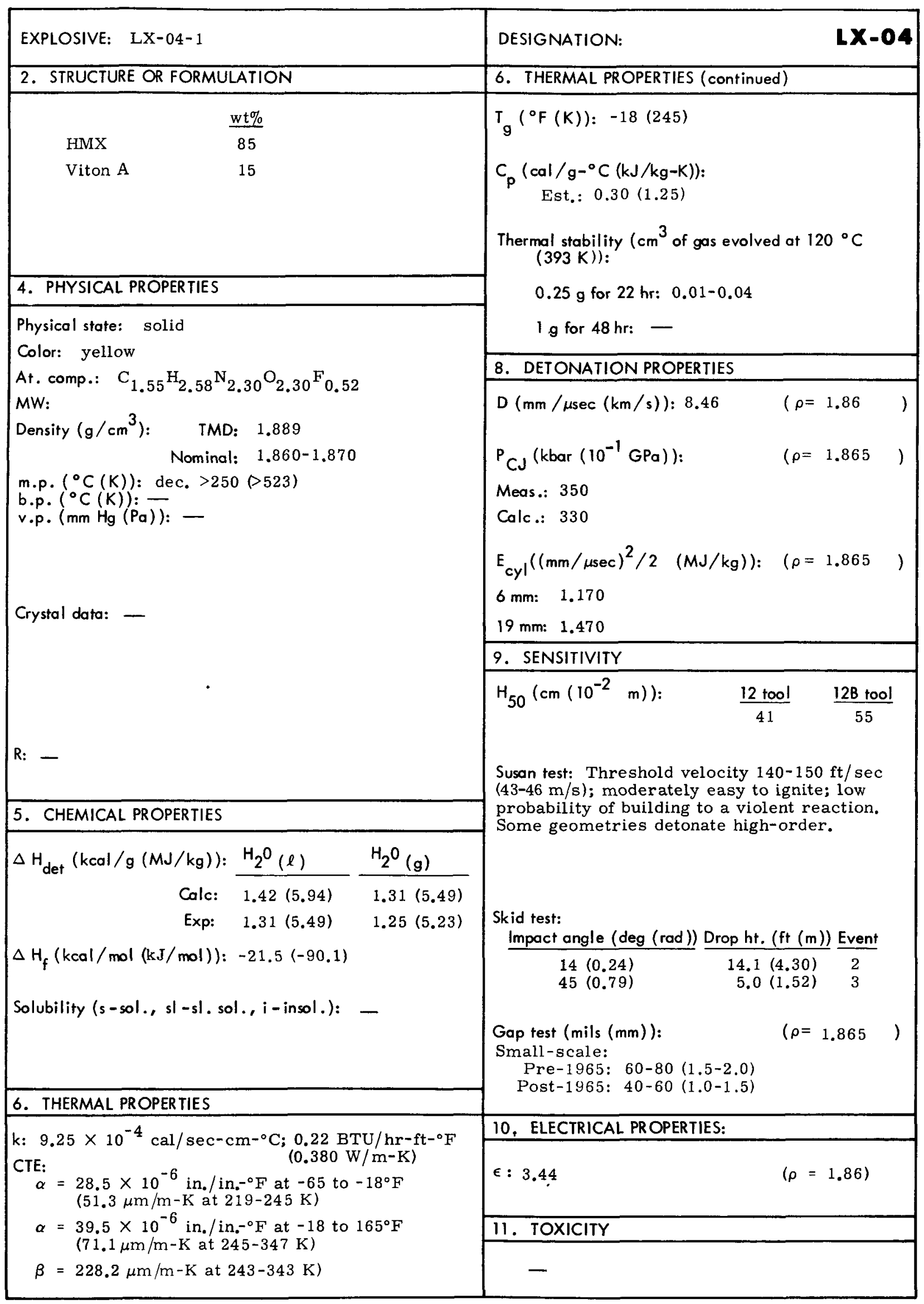




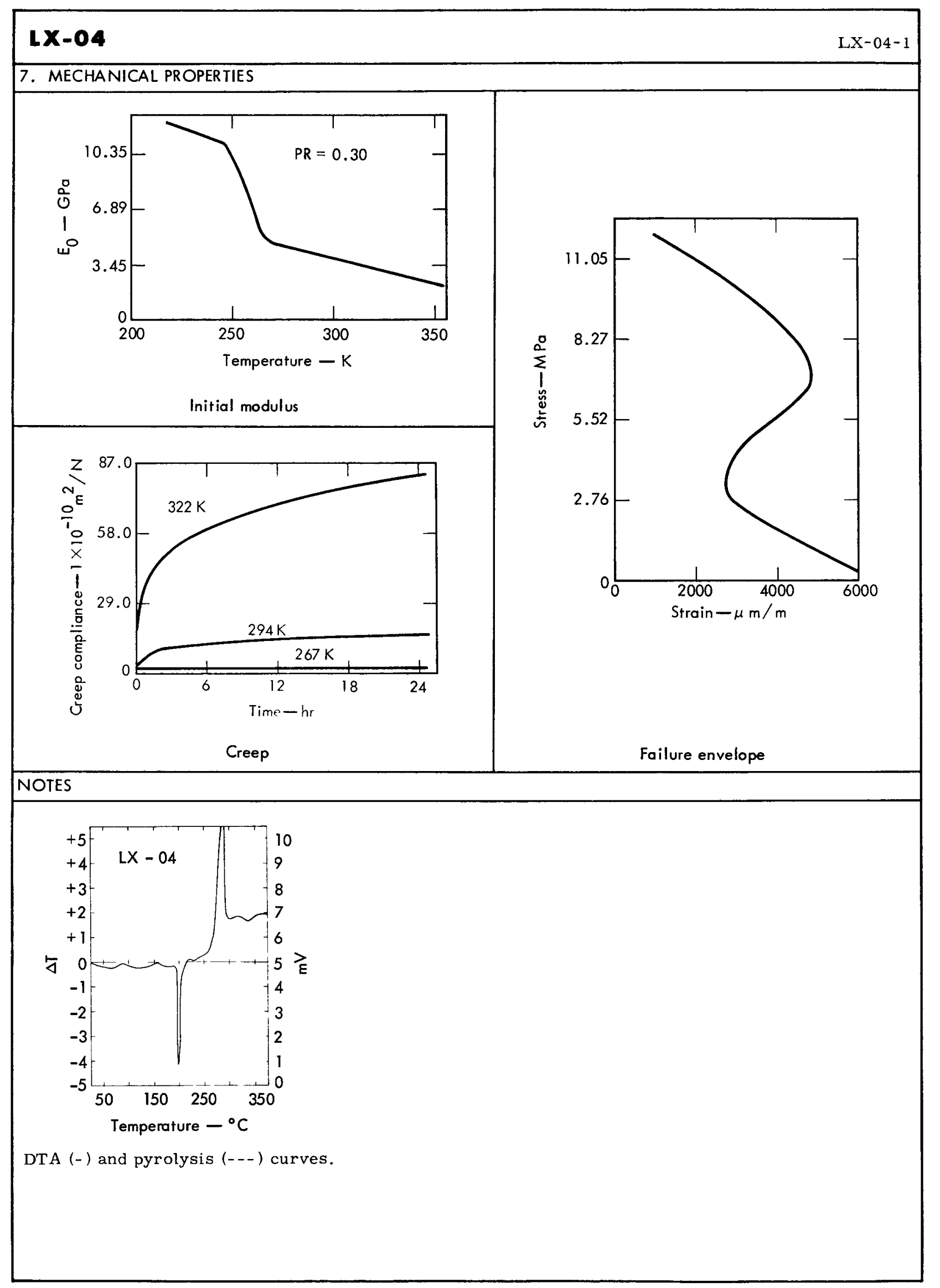




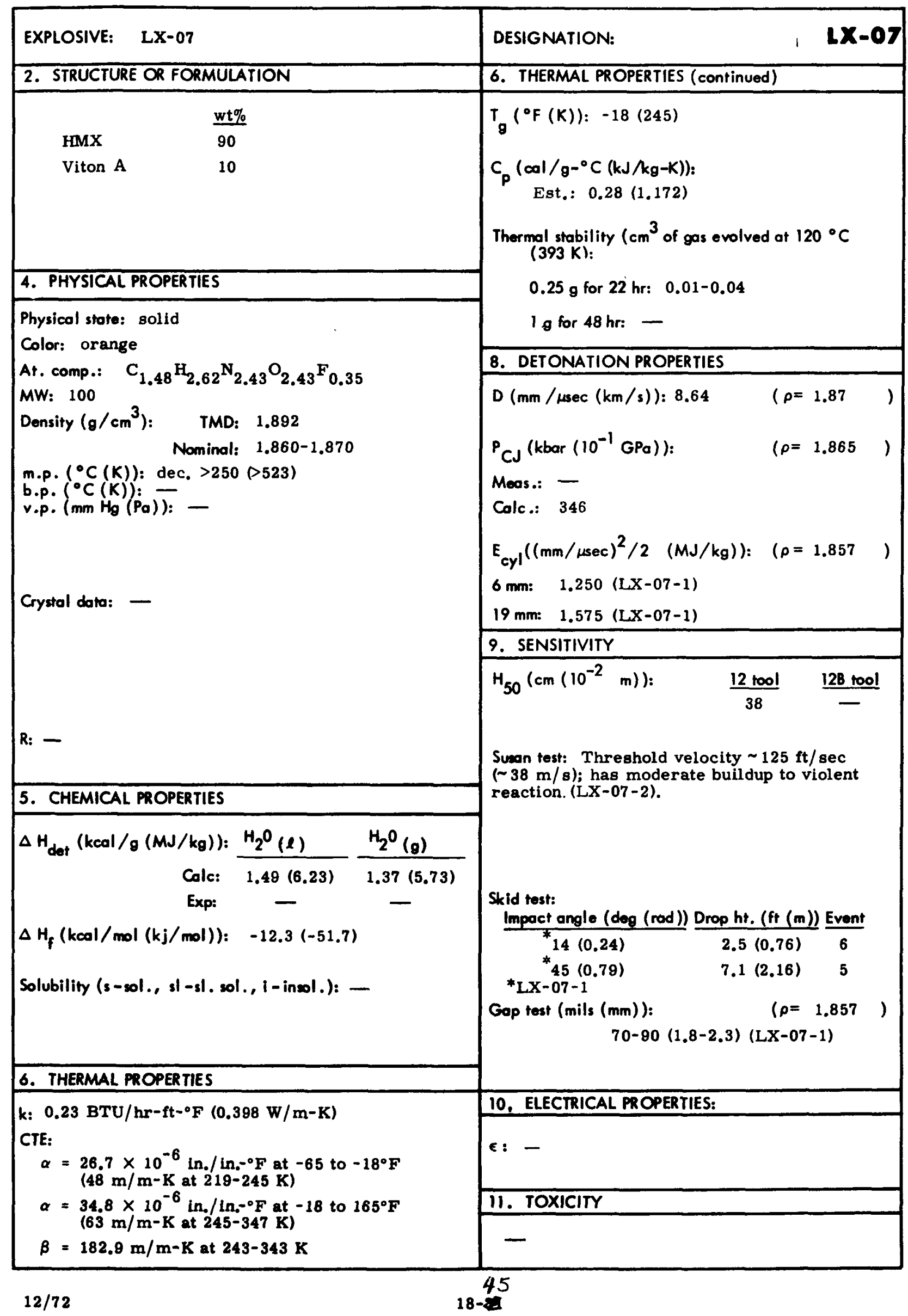




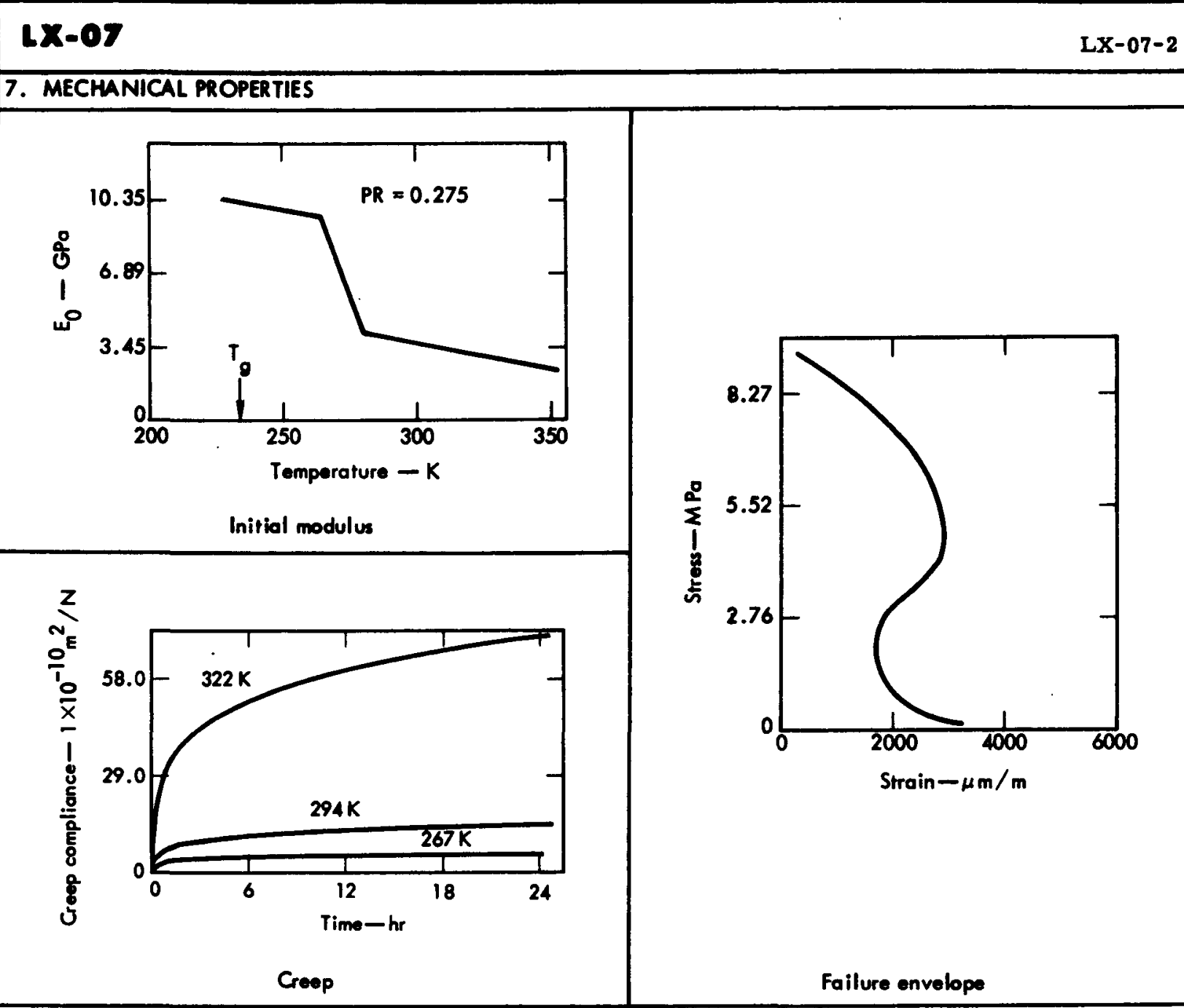

NOTES 


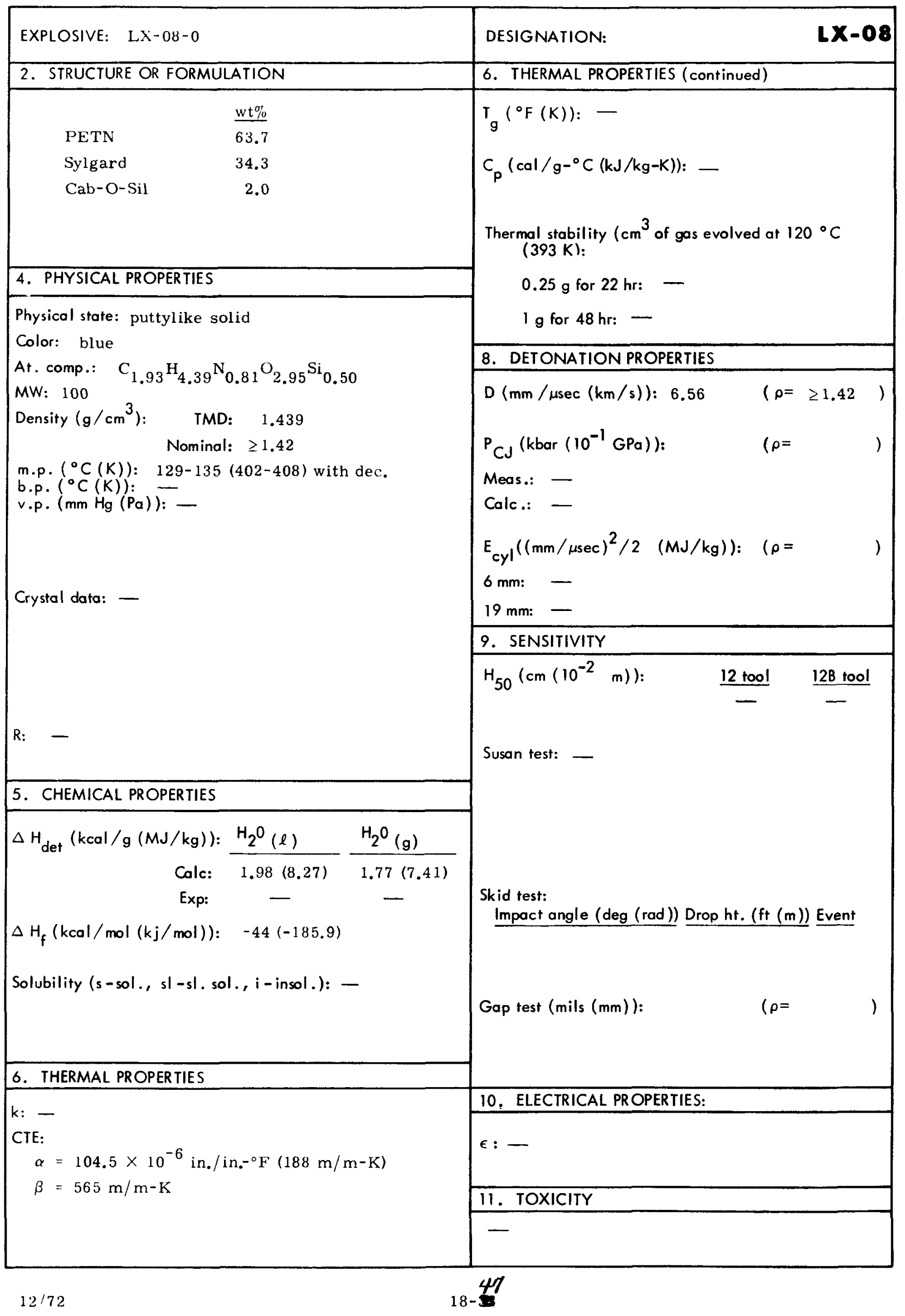




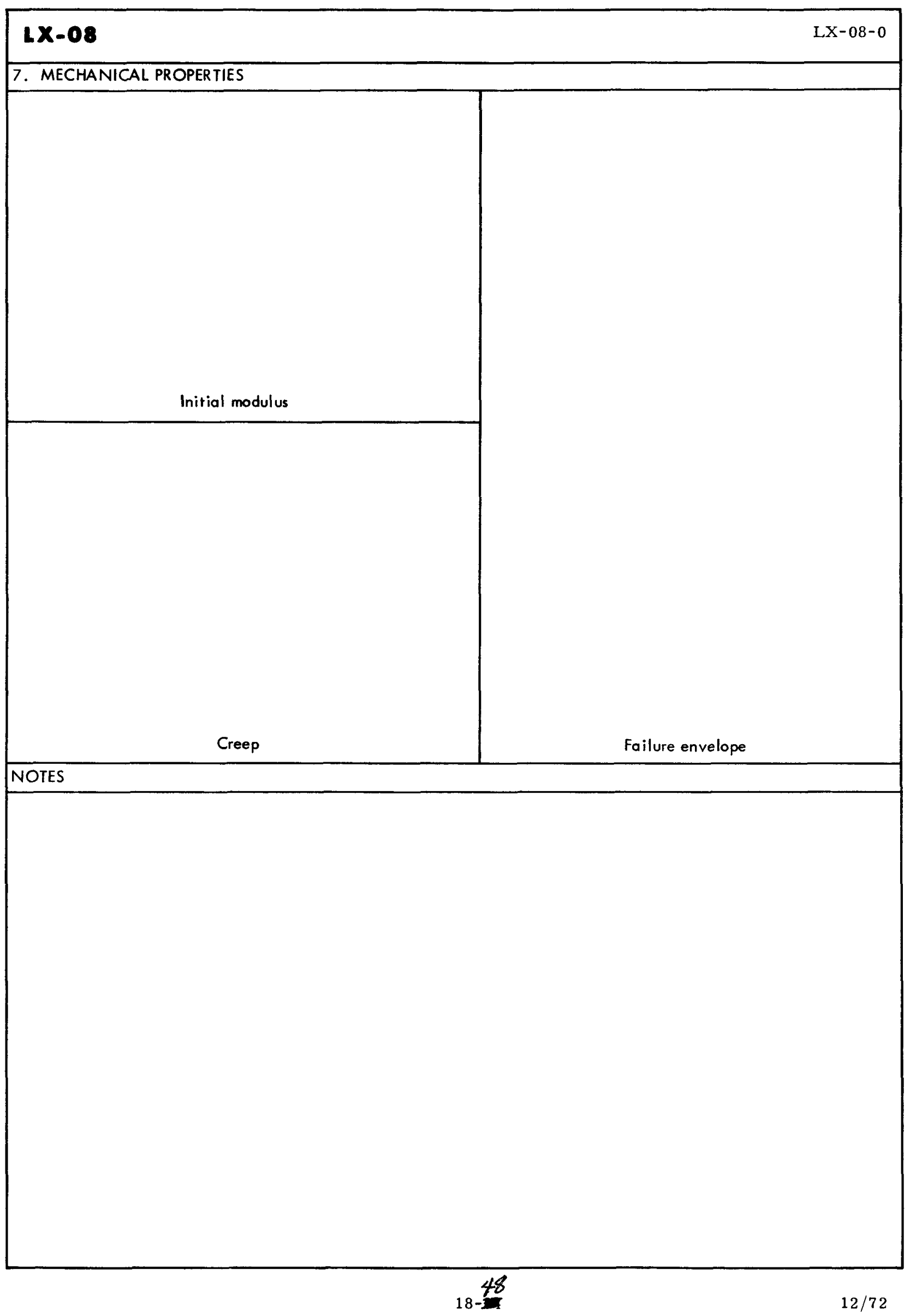




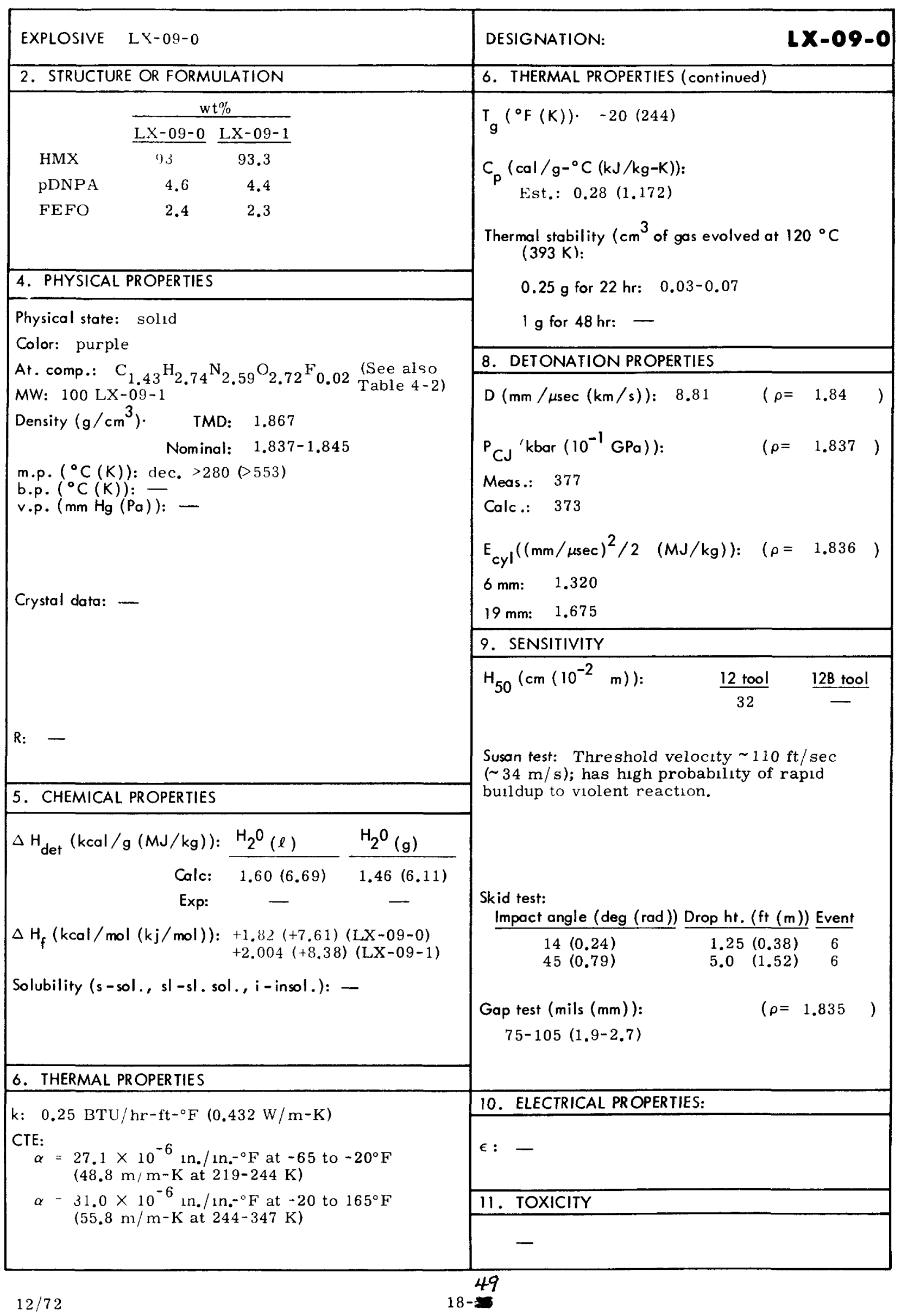




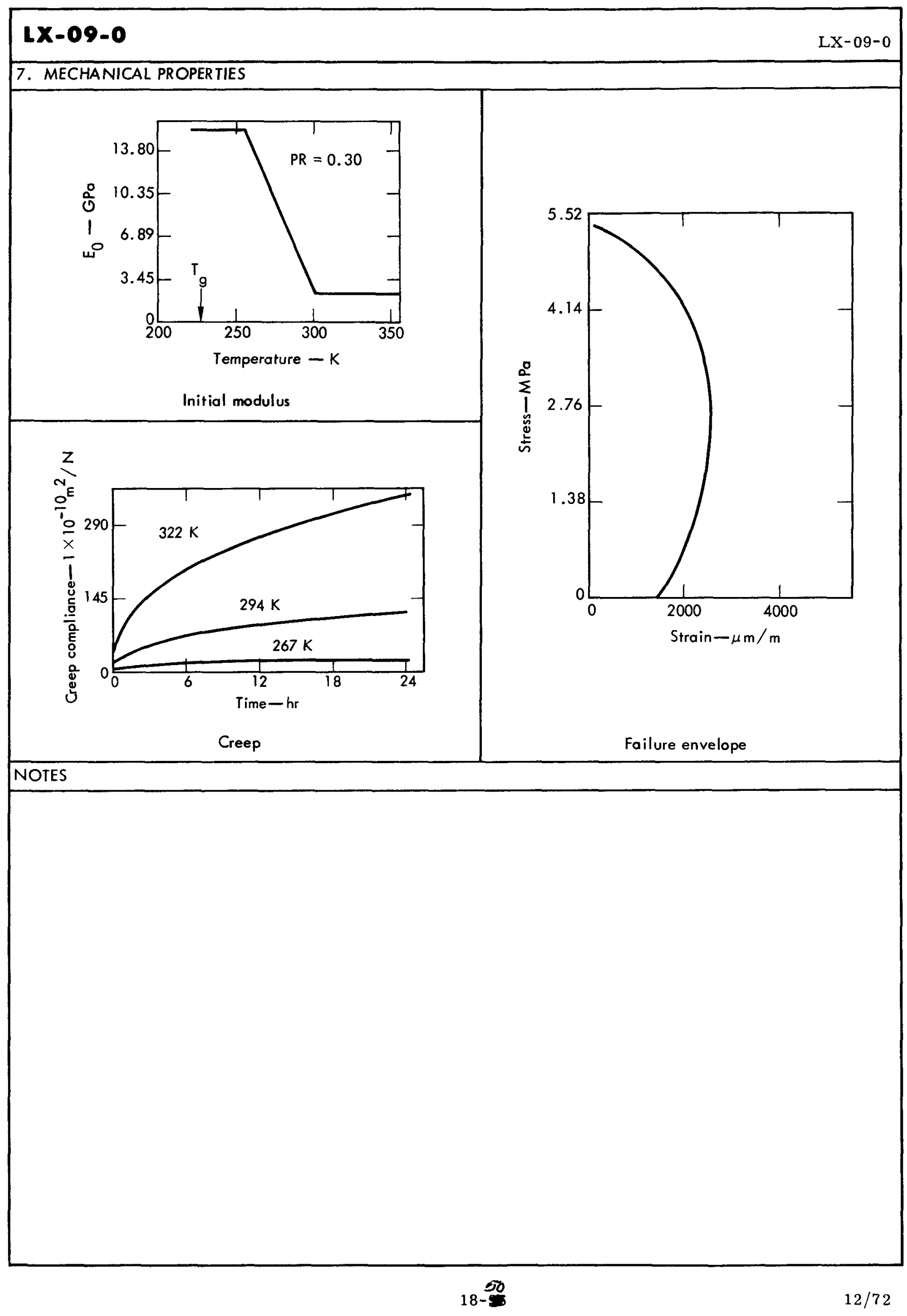




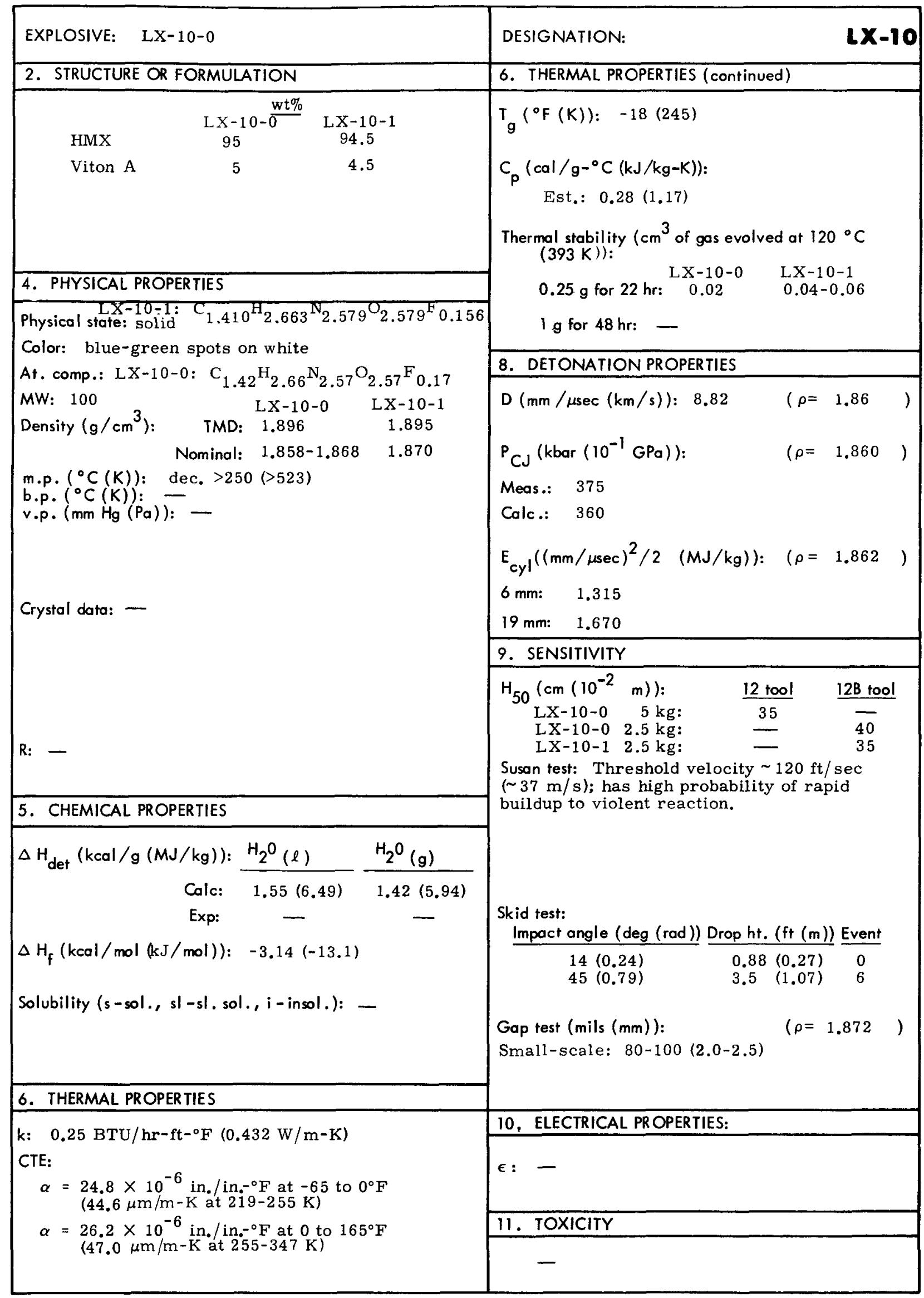




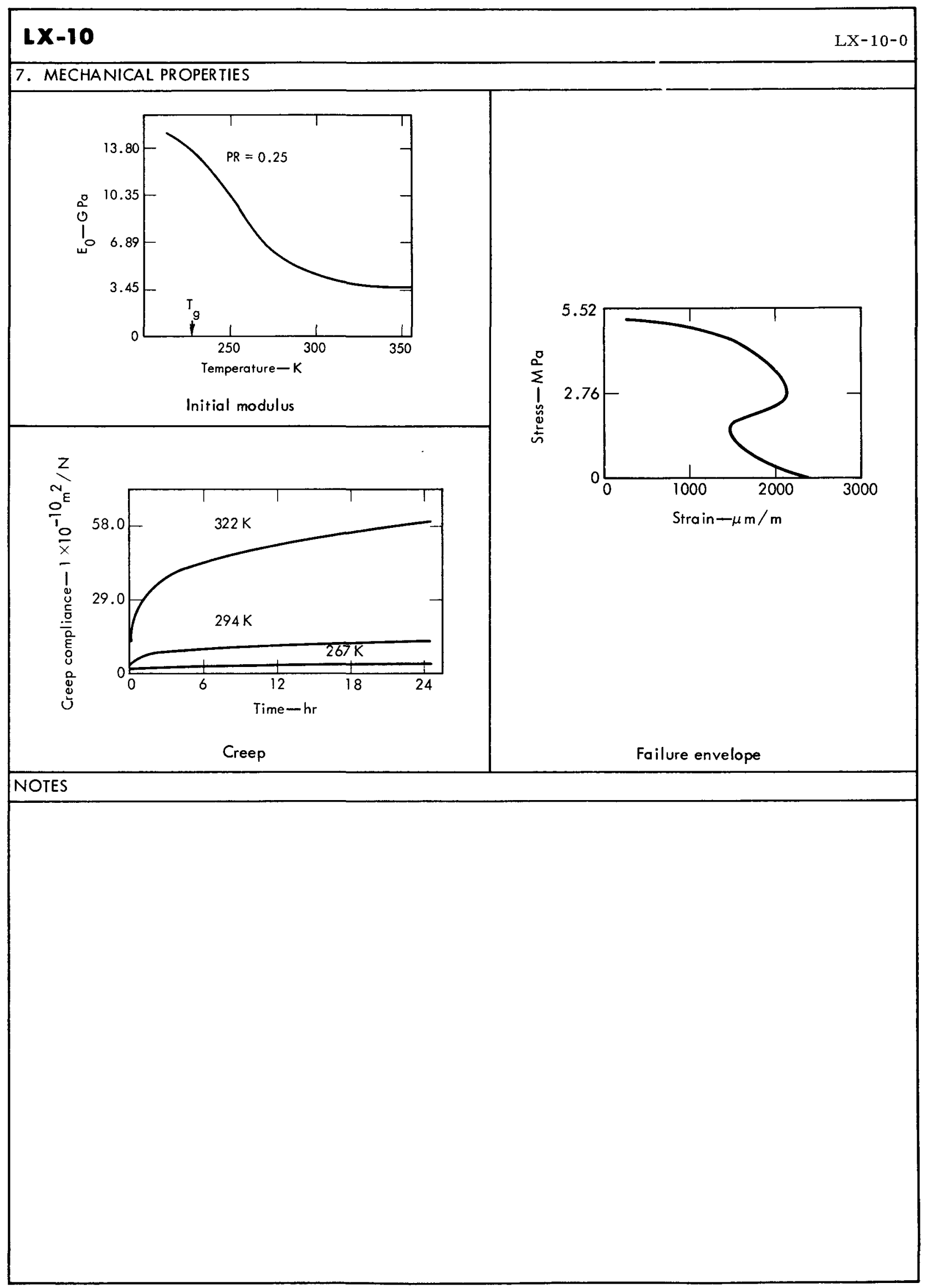




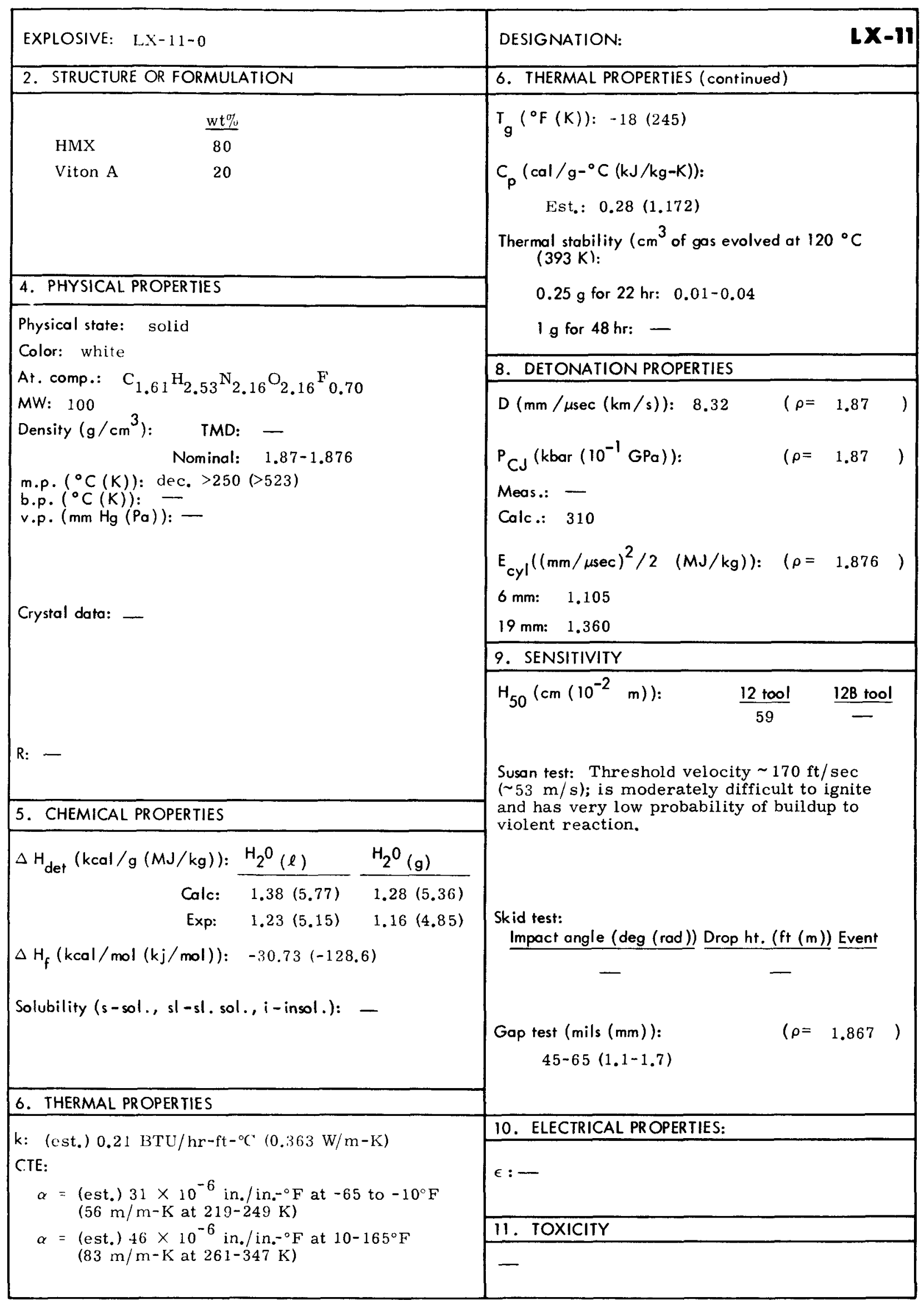




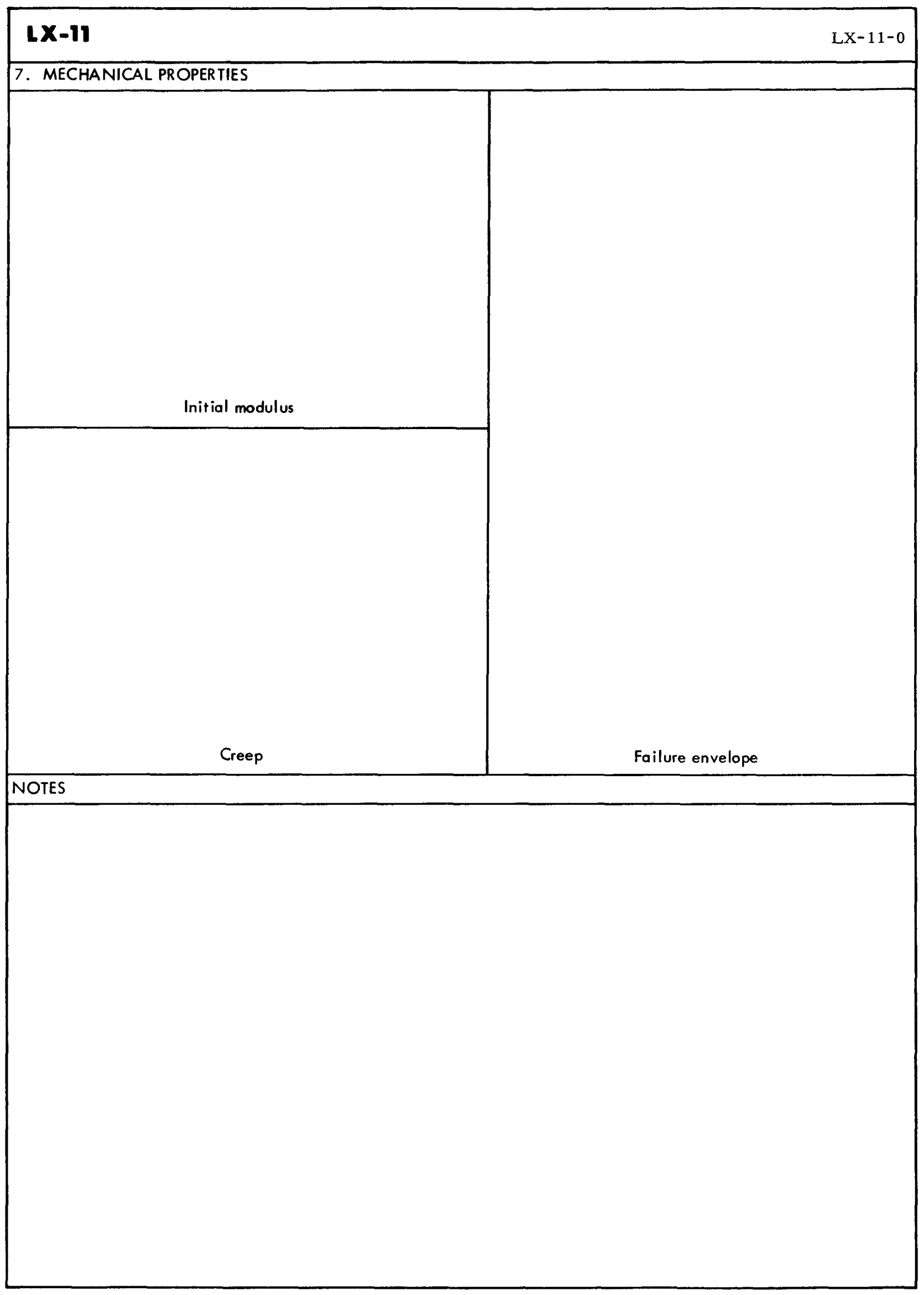




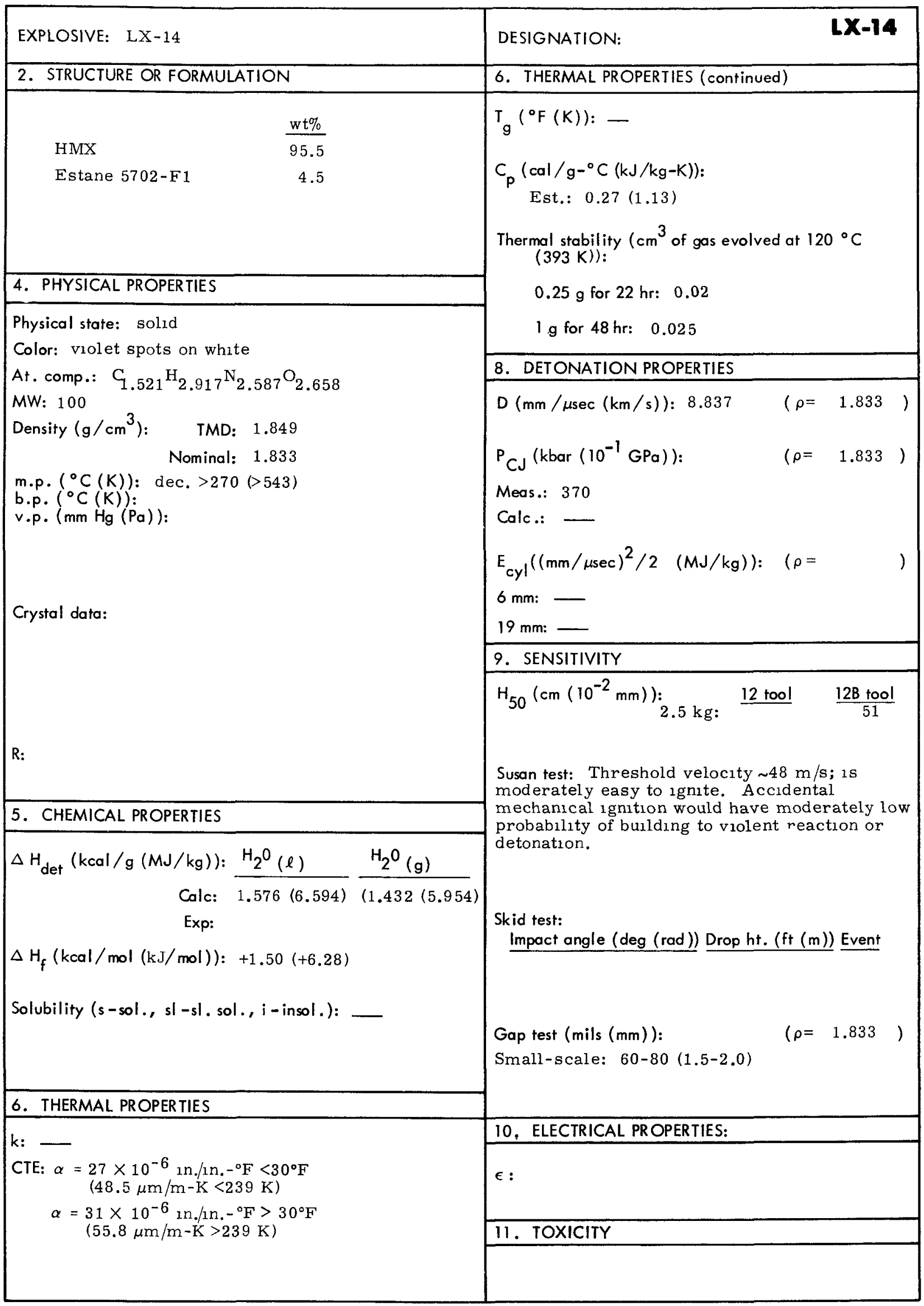




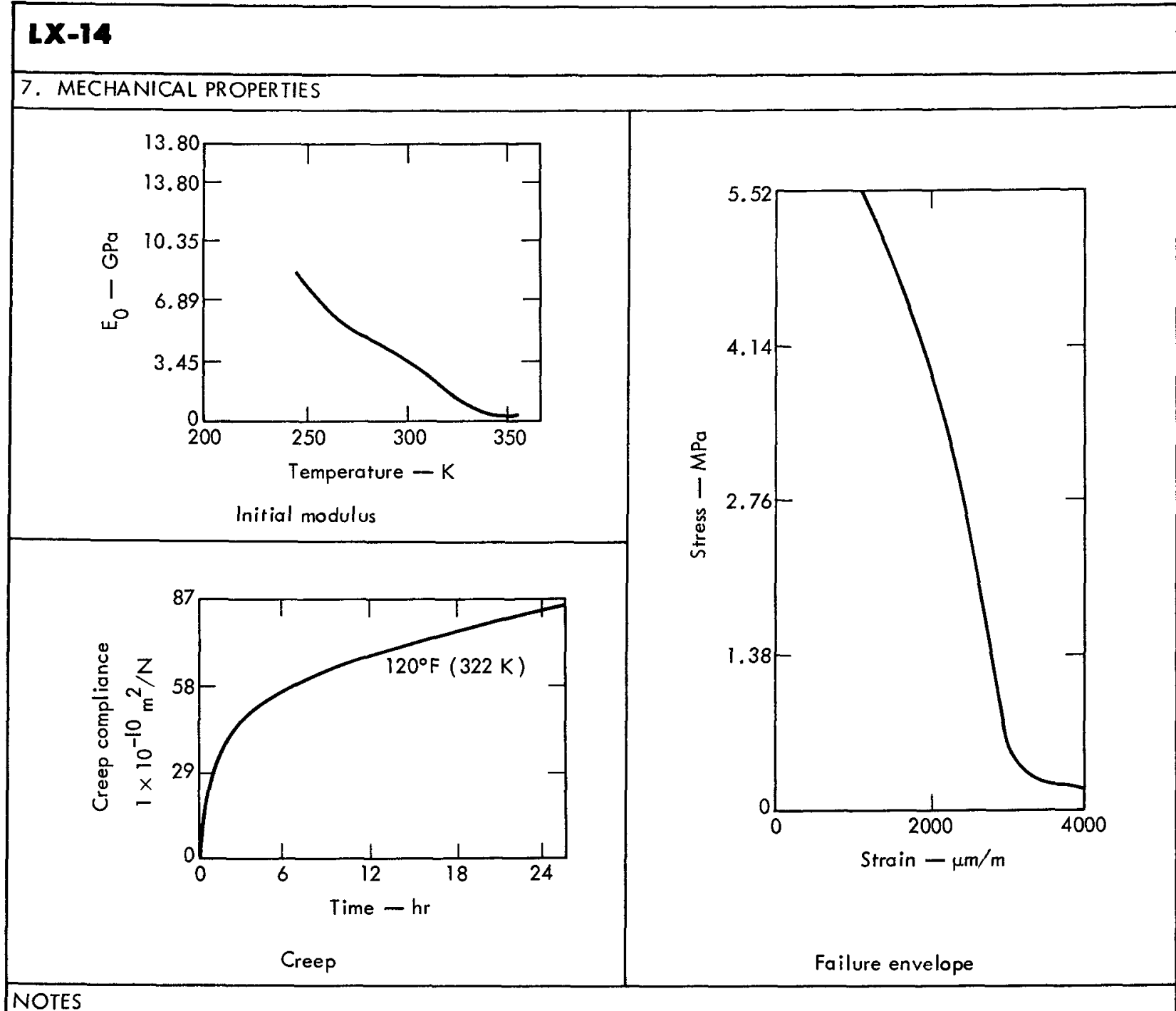

NOTES 


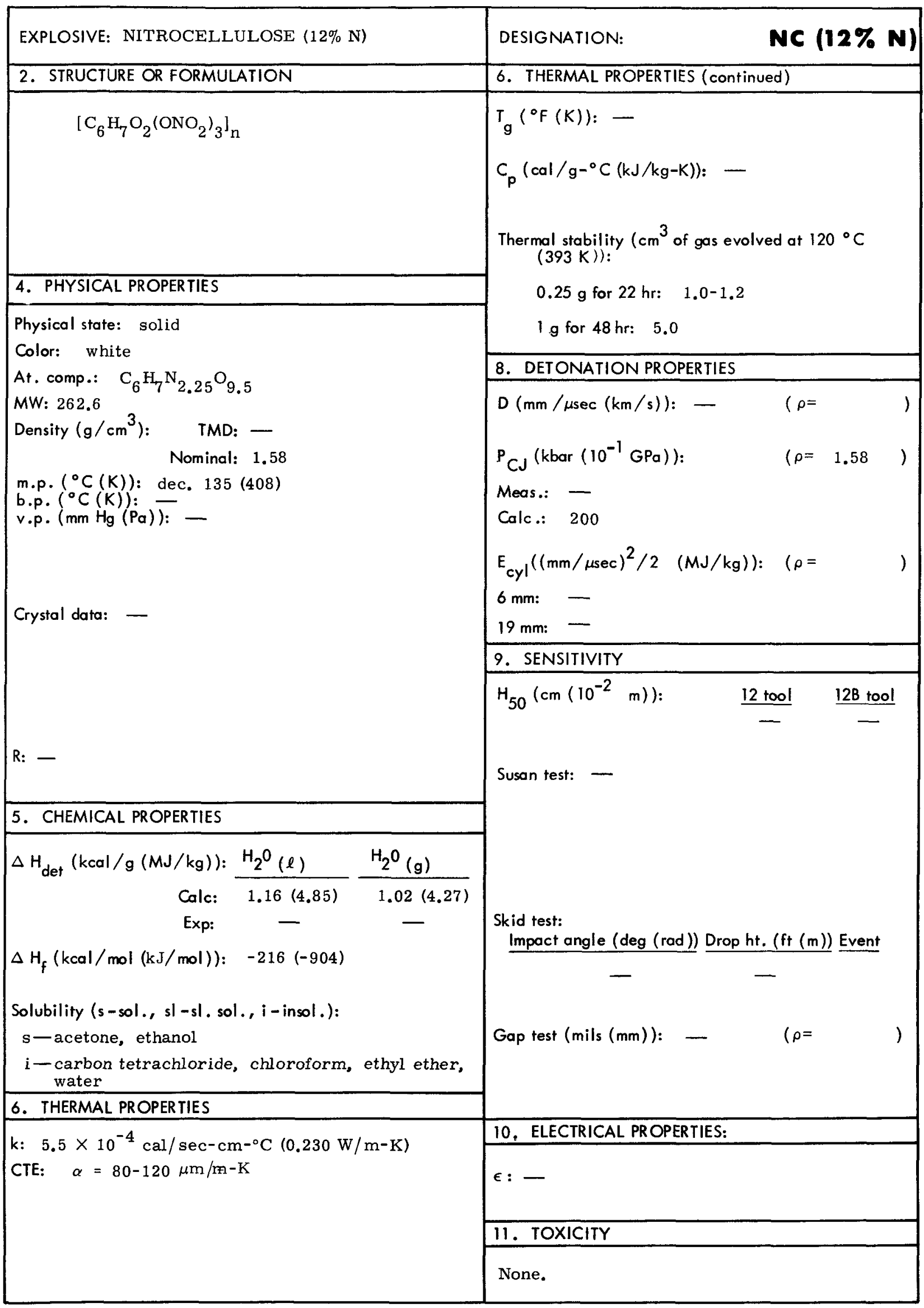




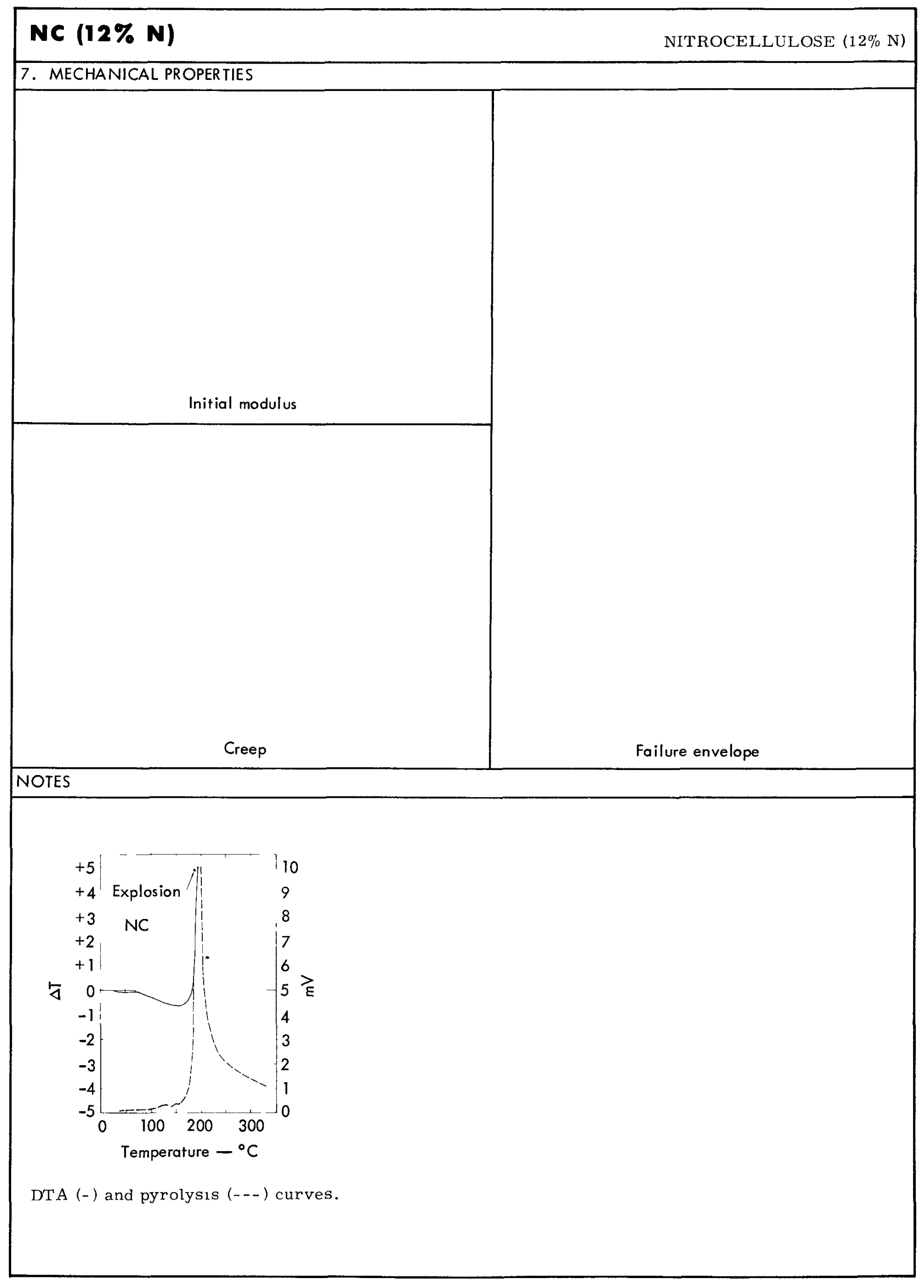




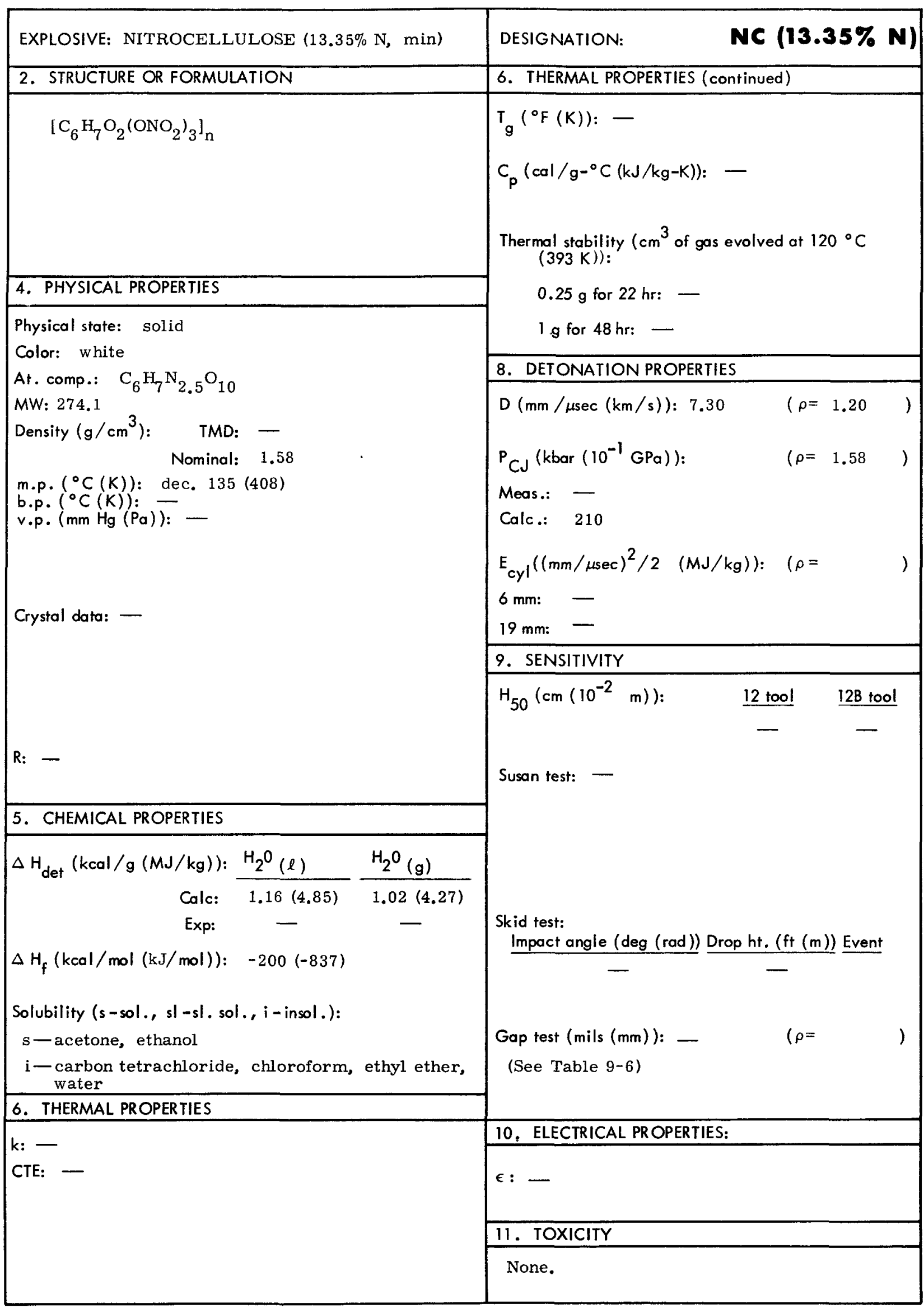




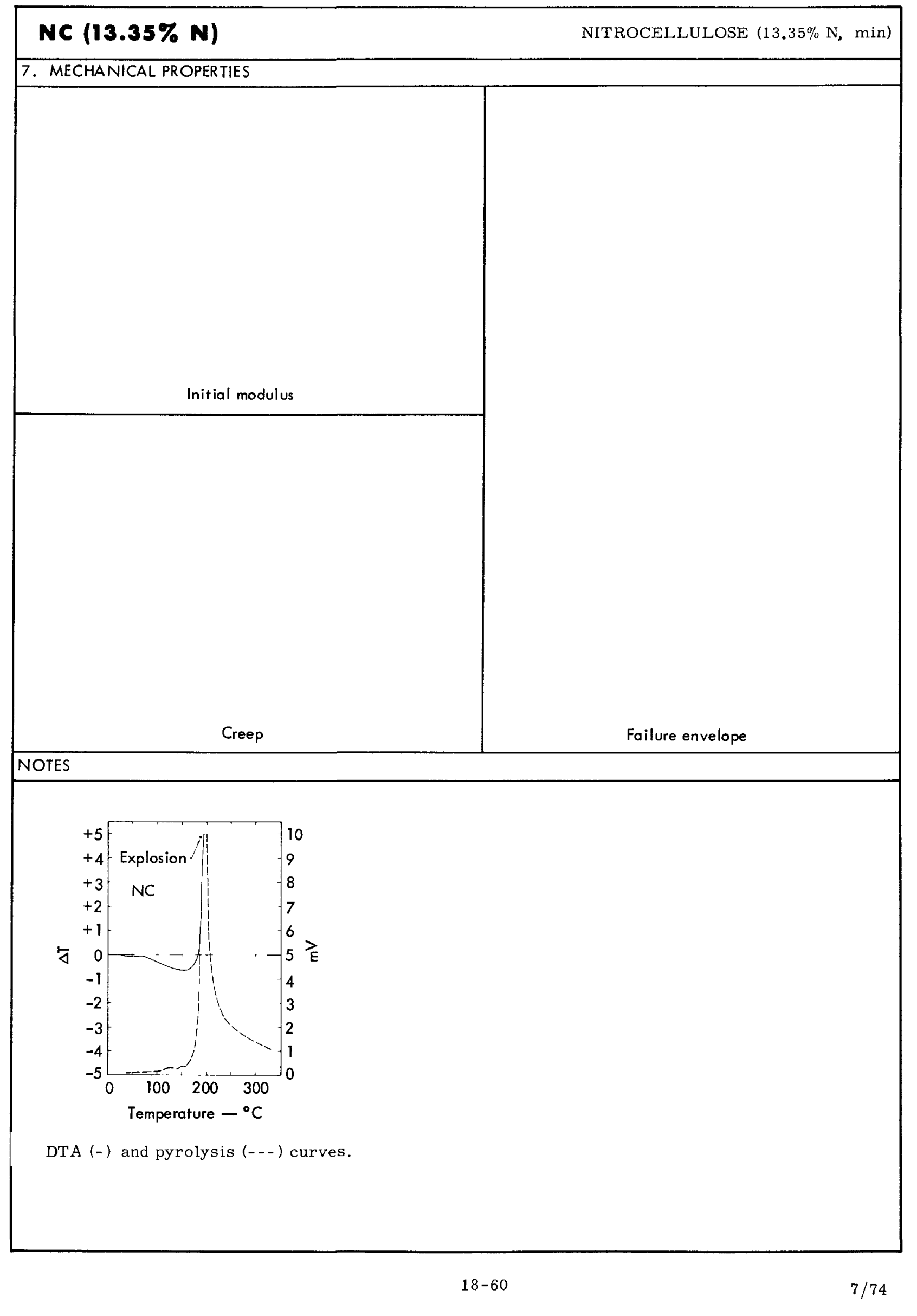




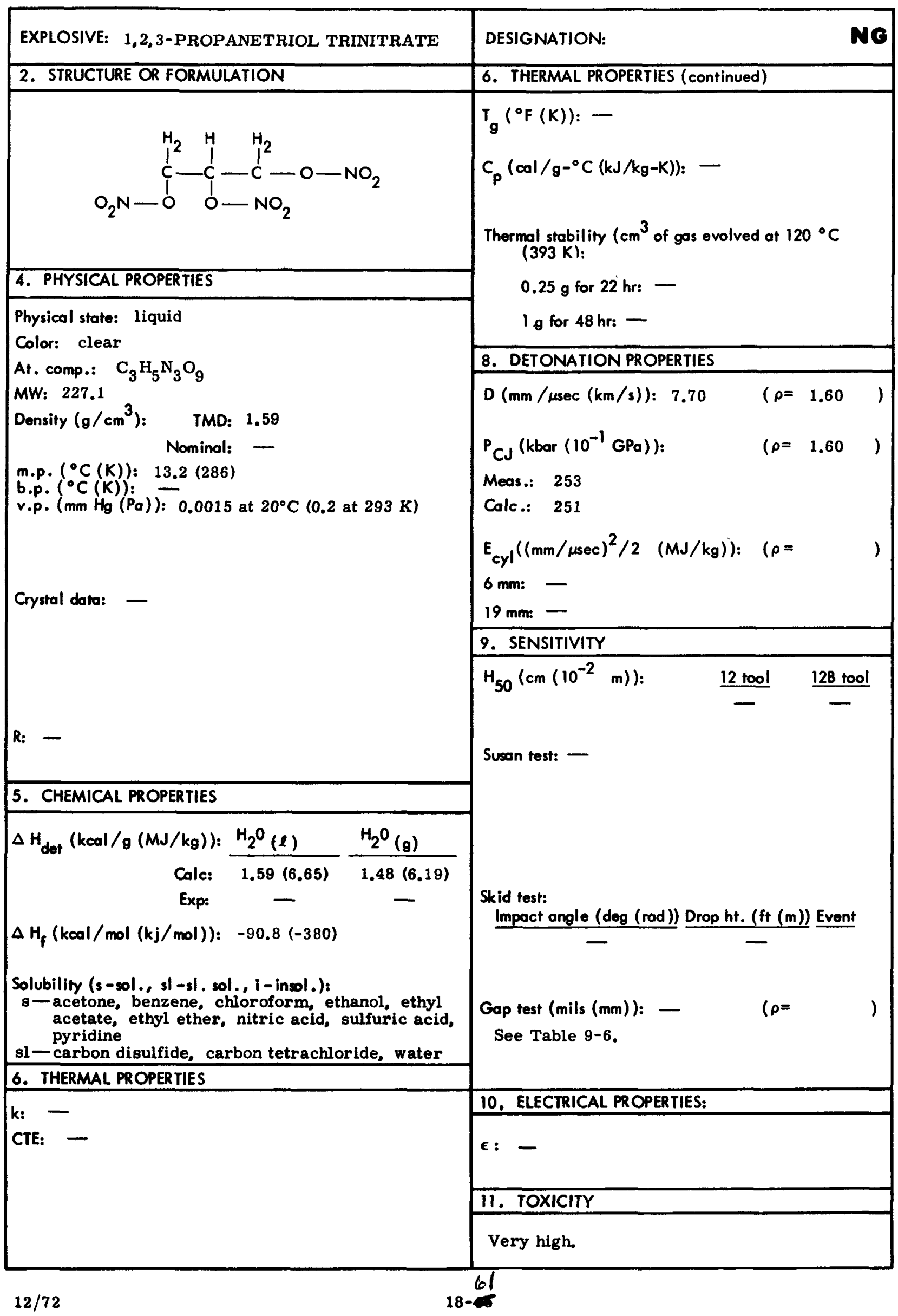




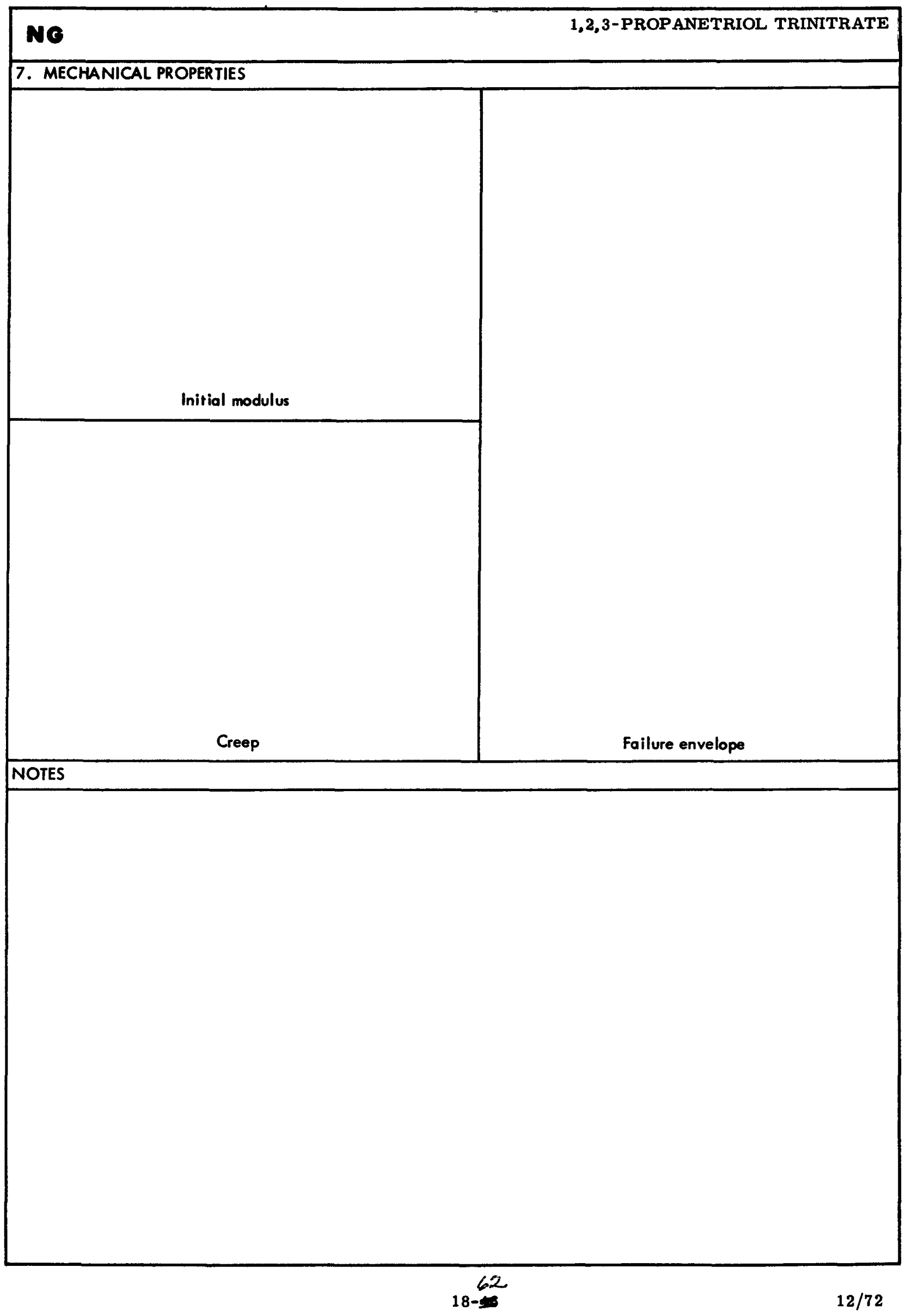




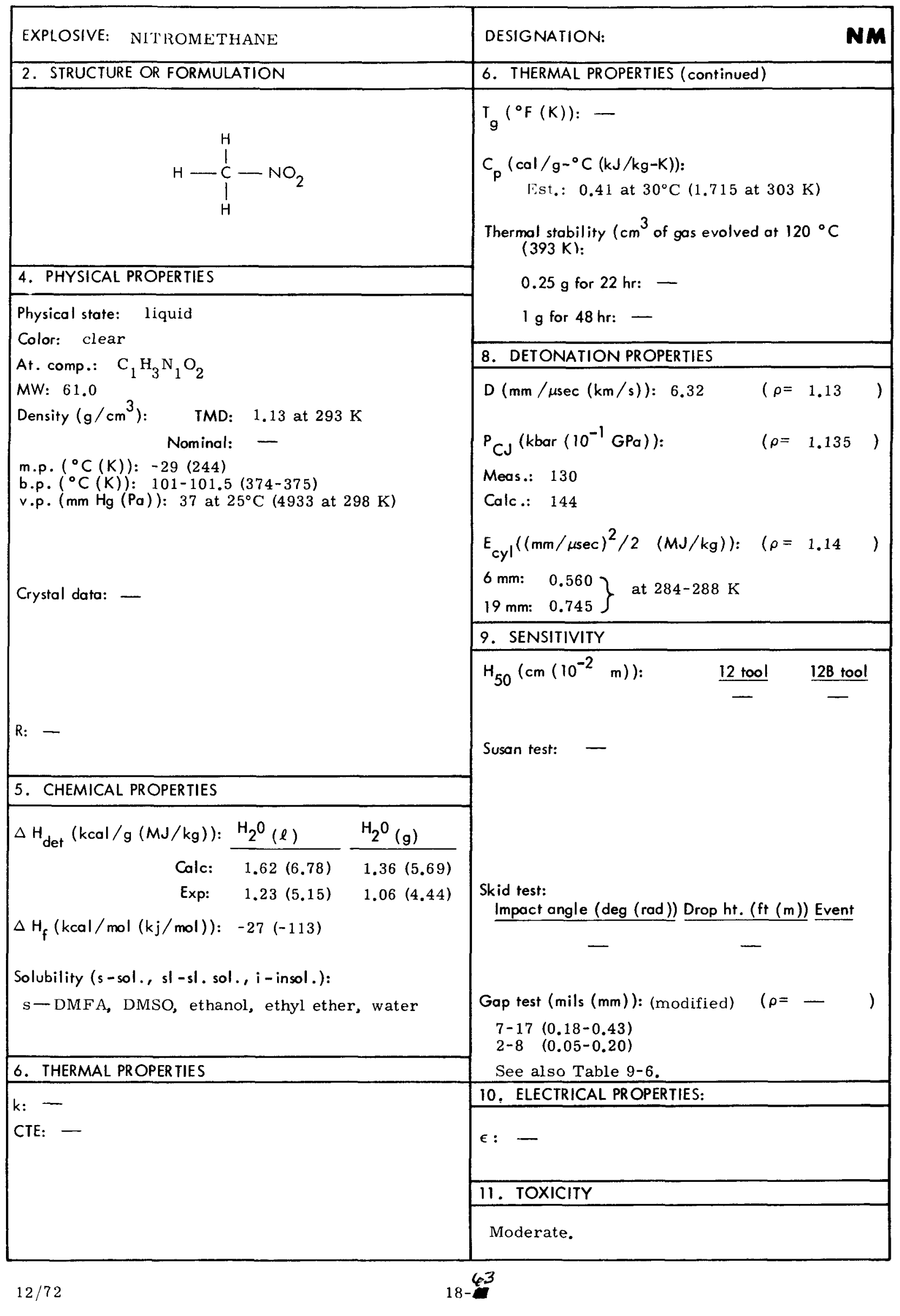




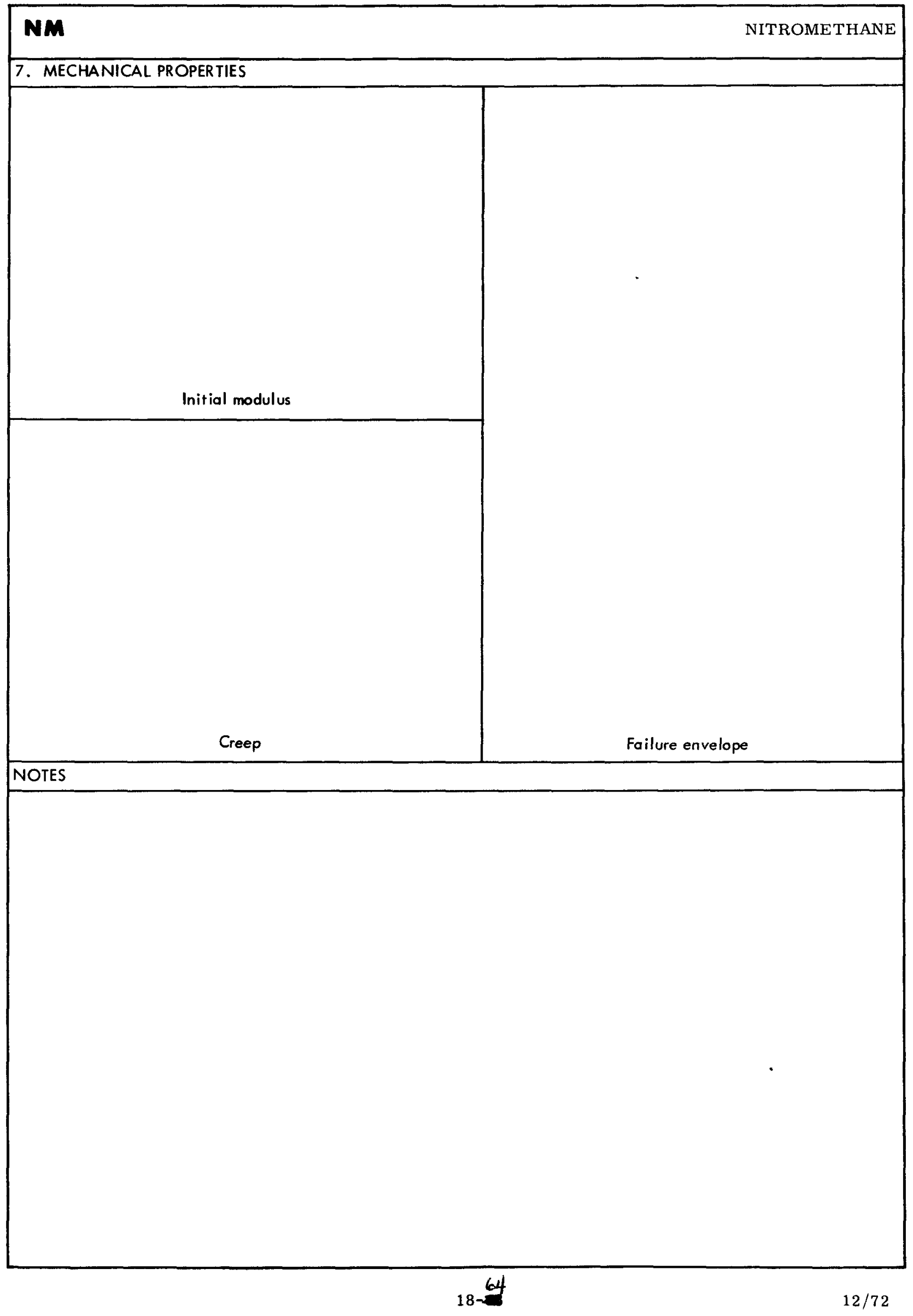




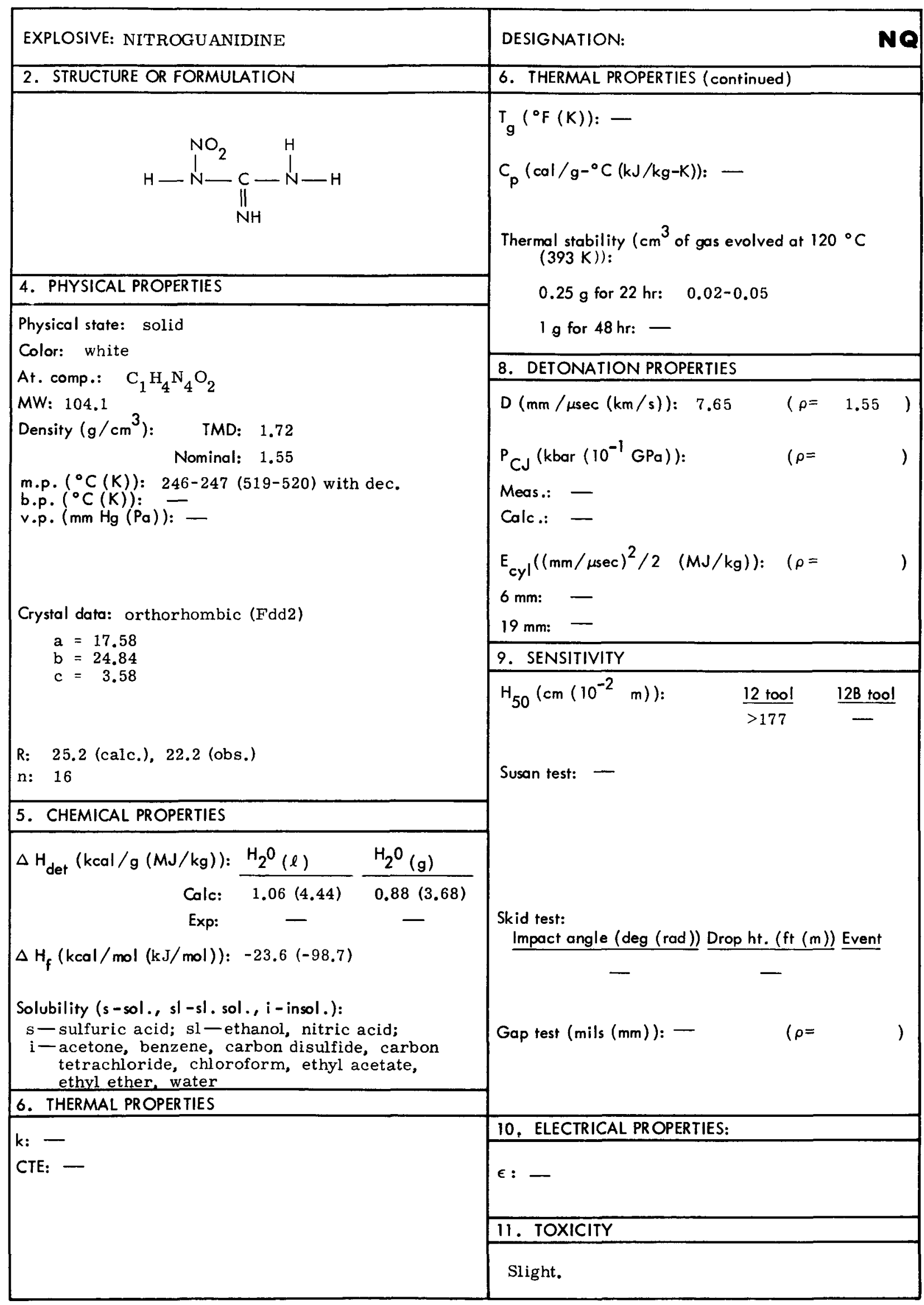




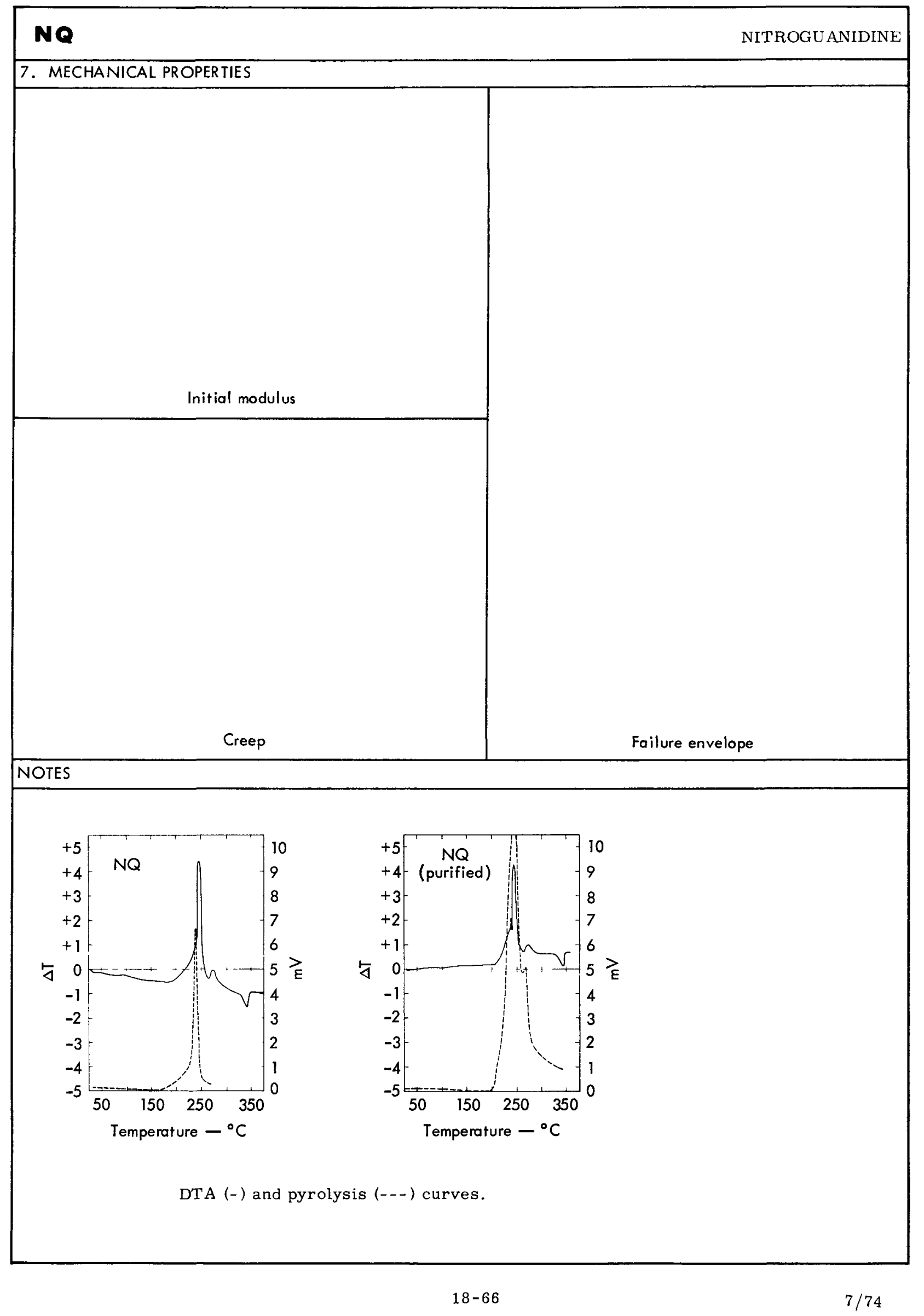




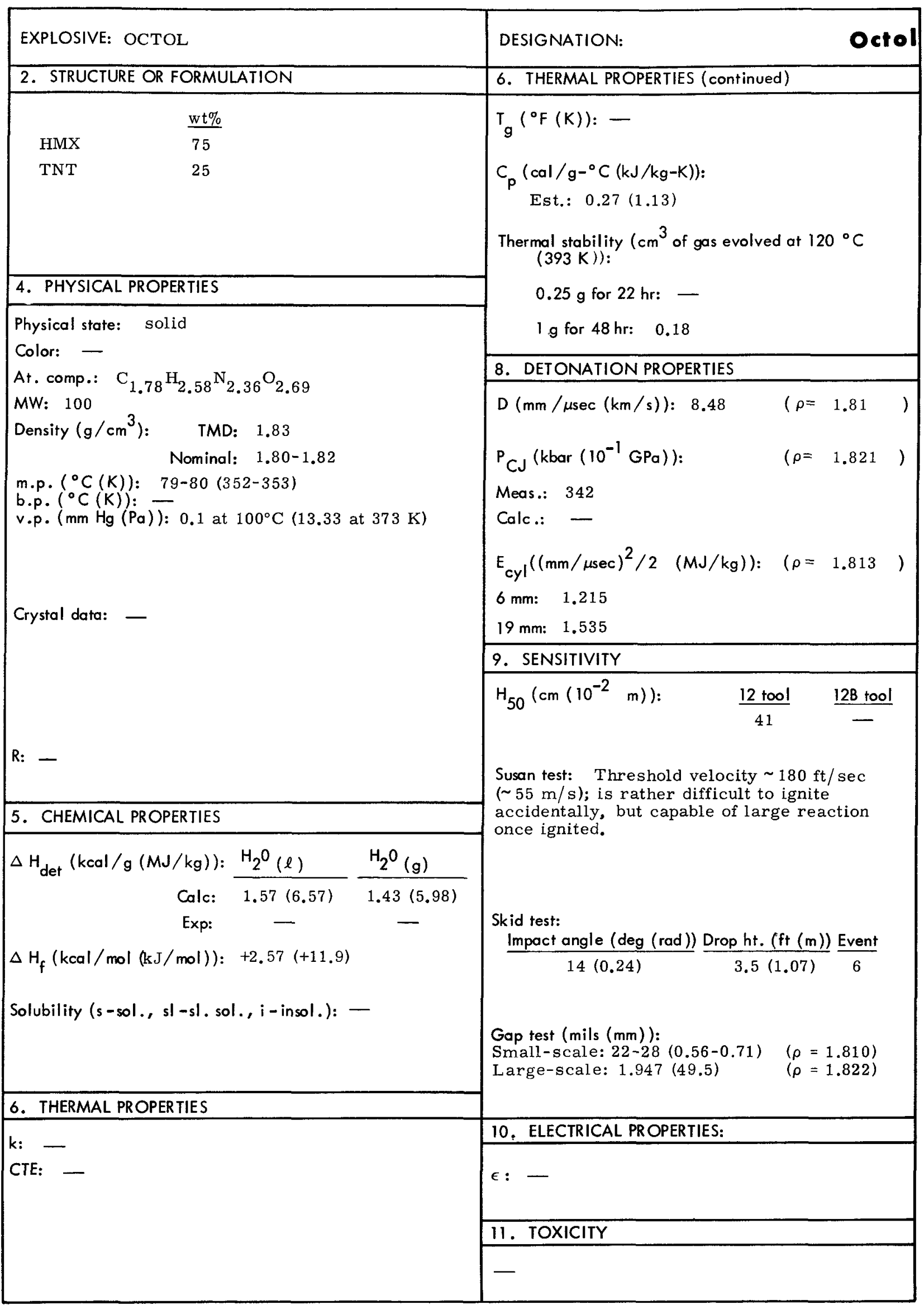




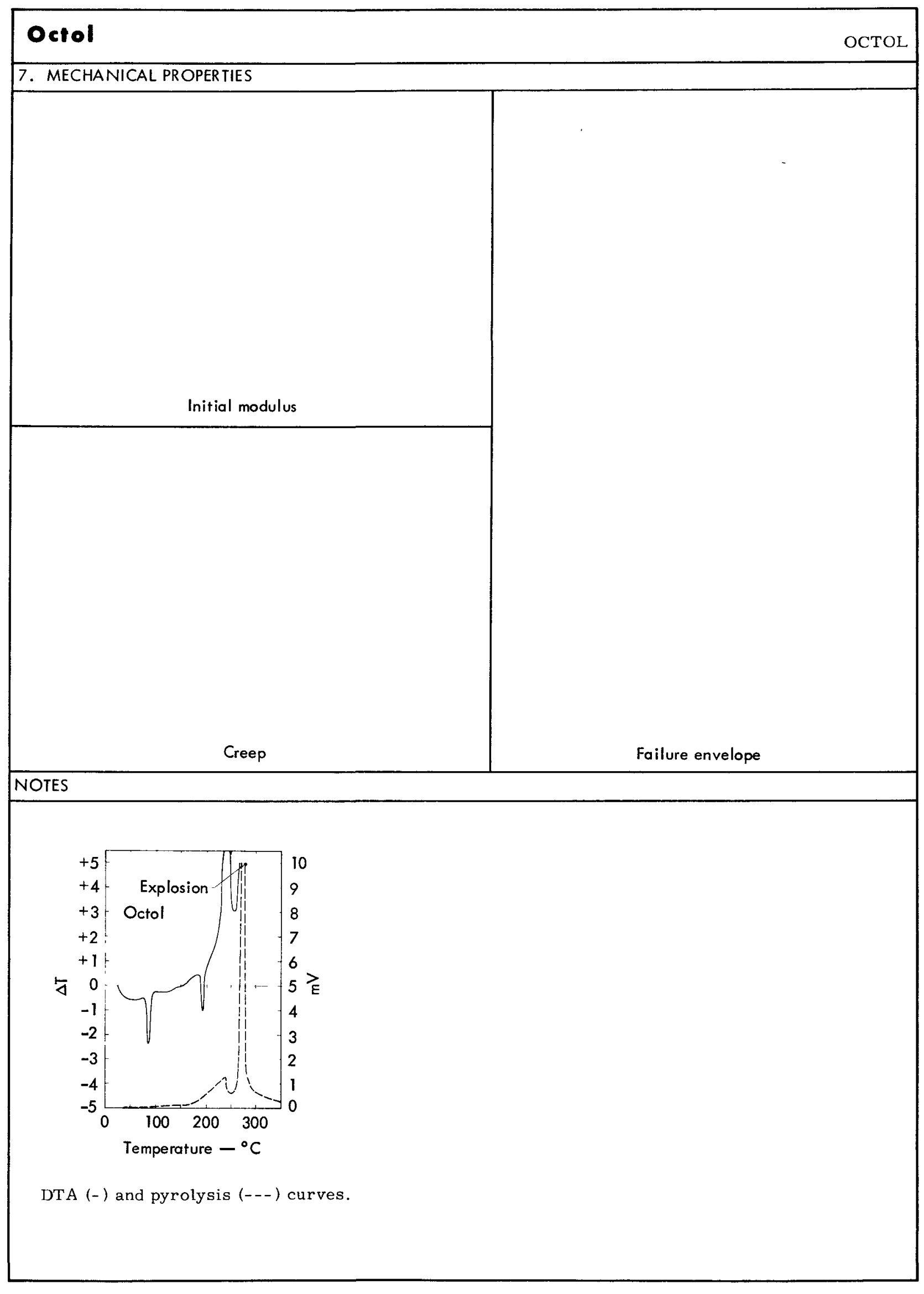




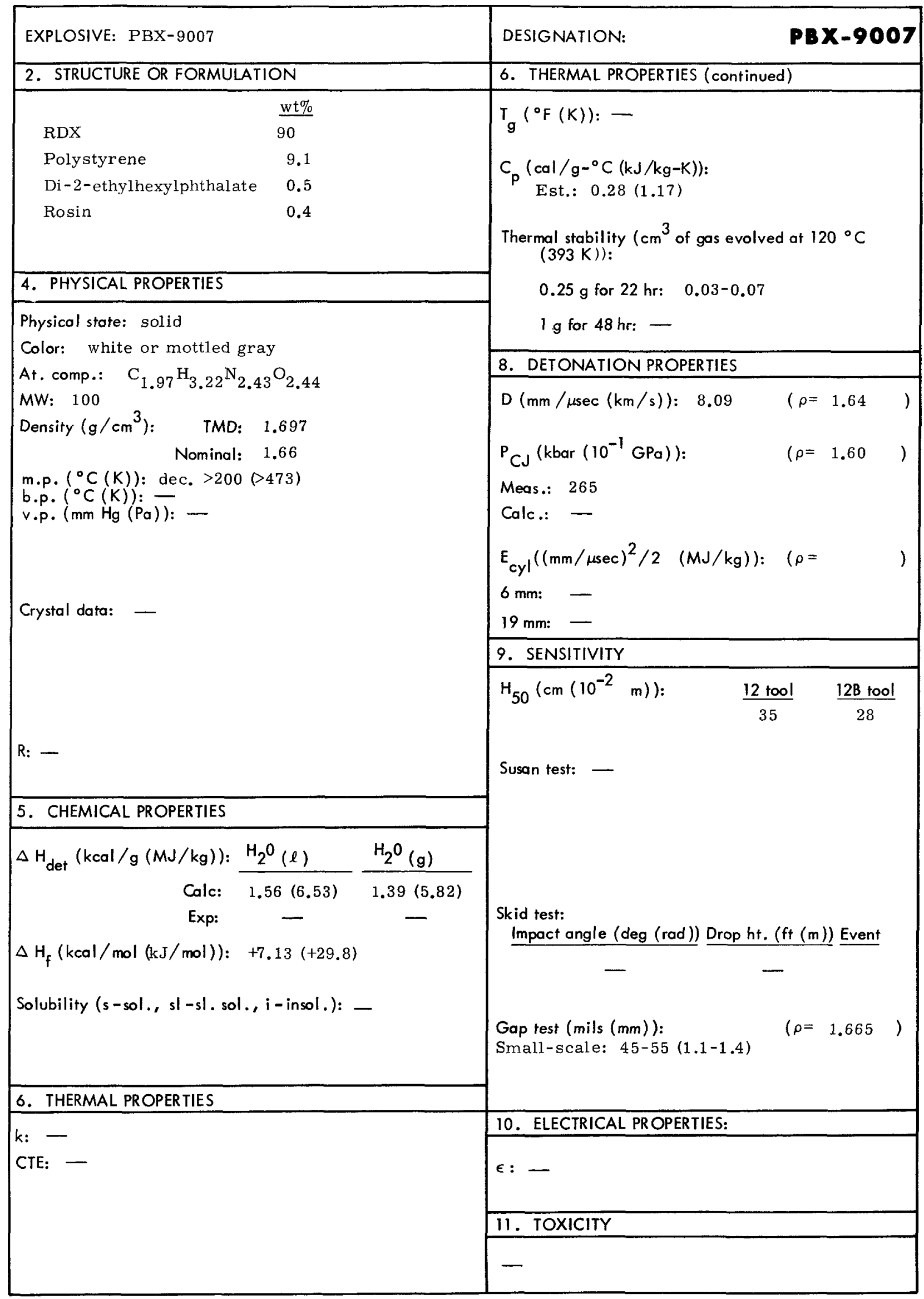




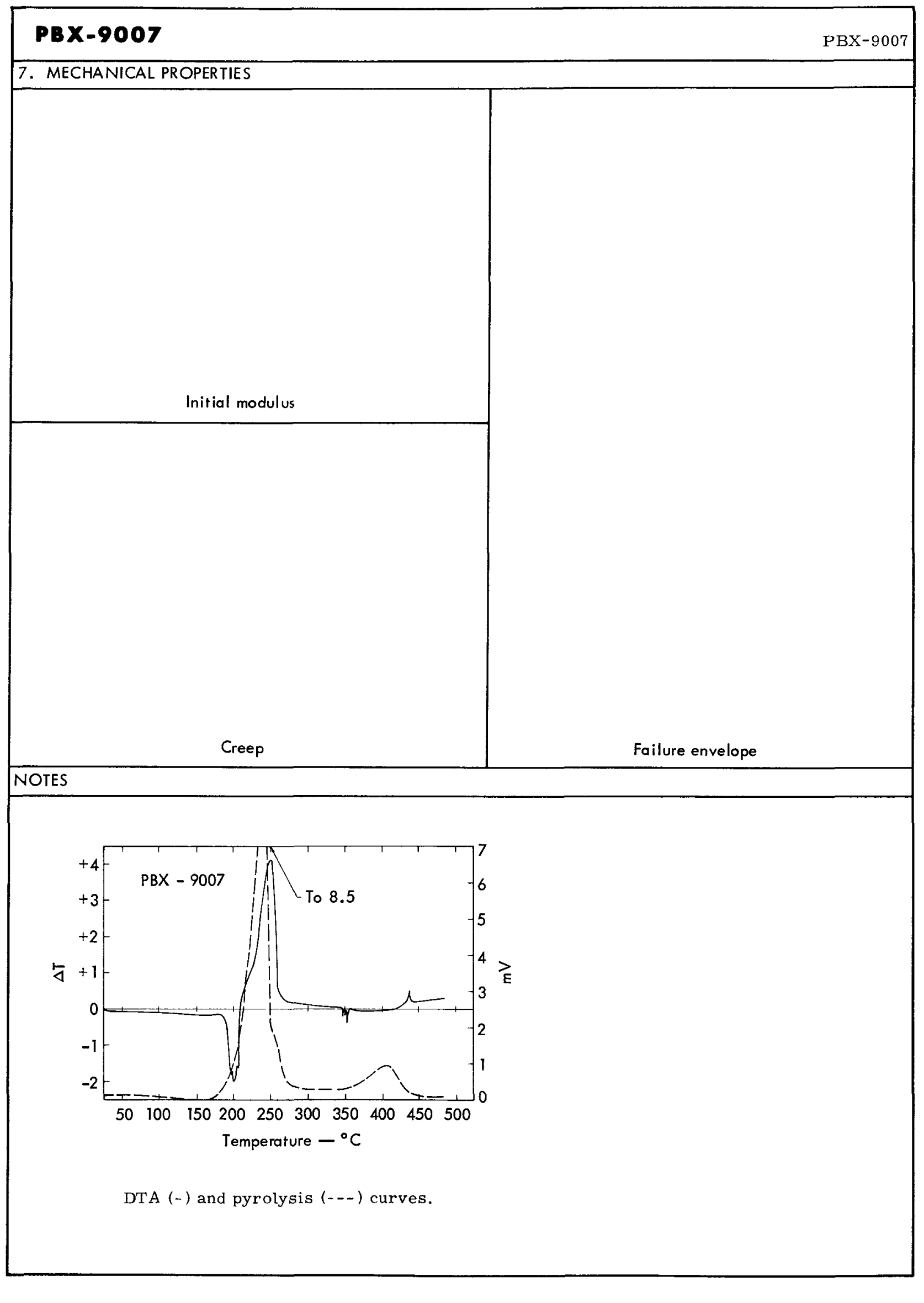




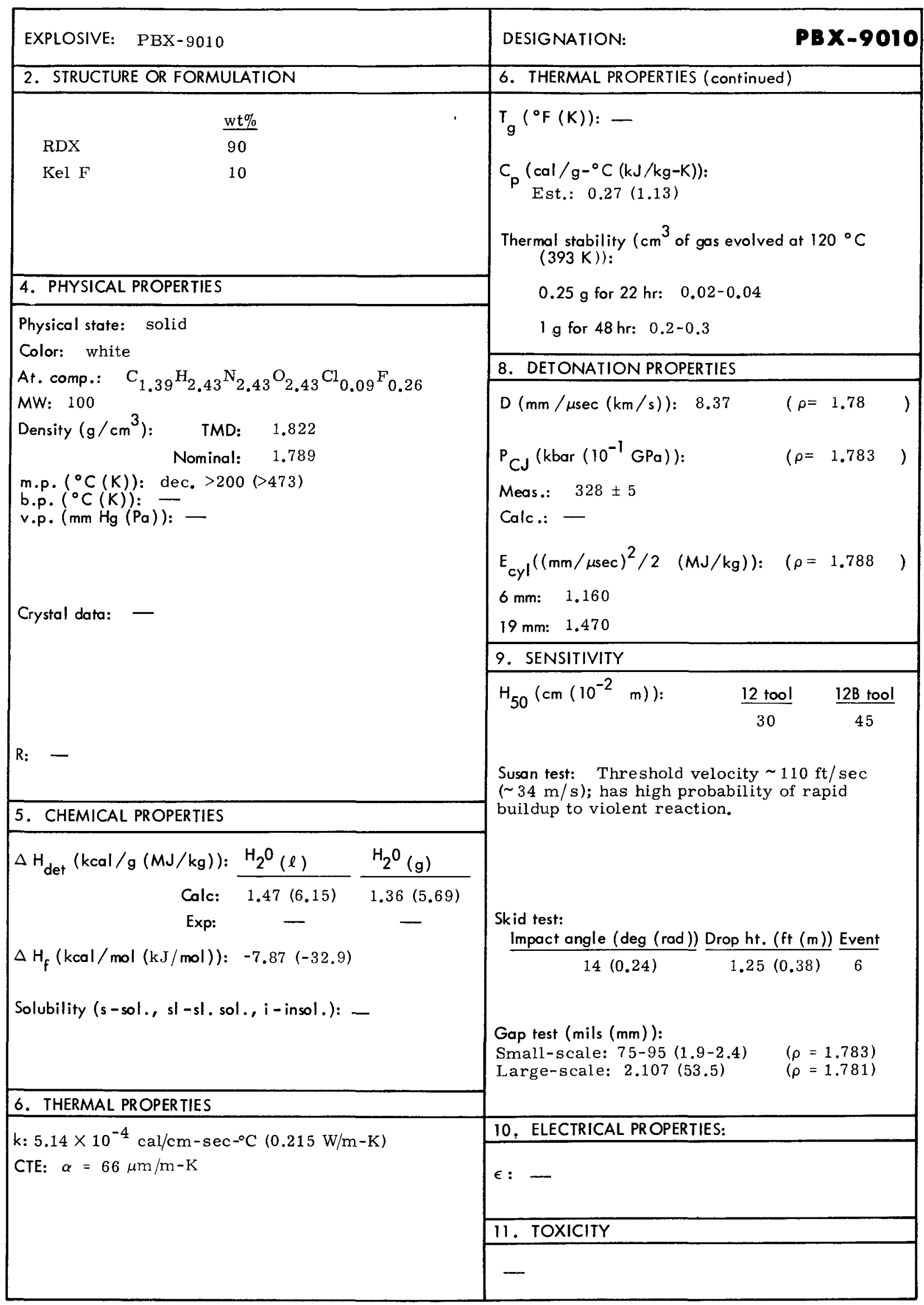




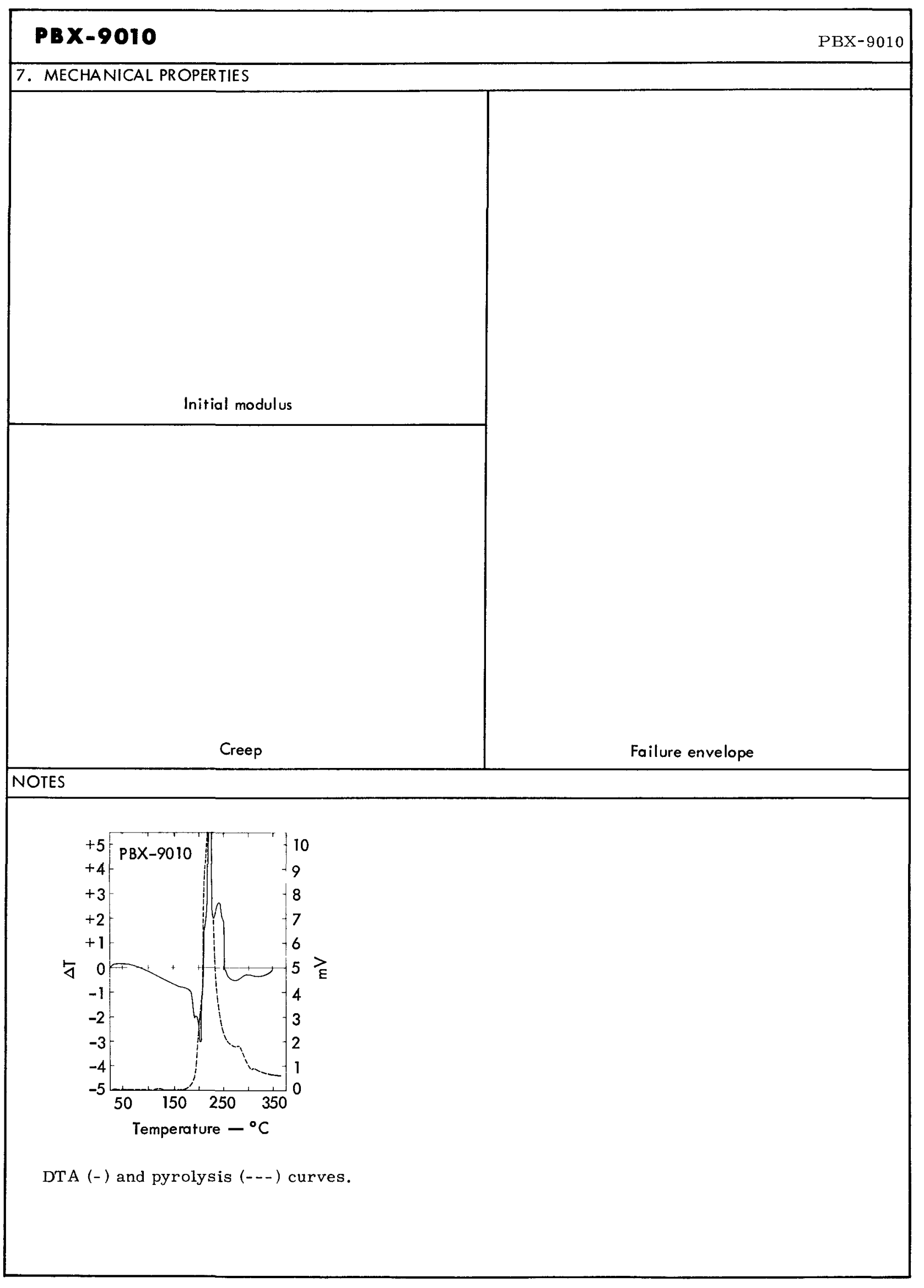




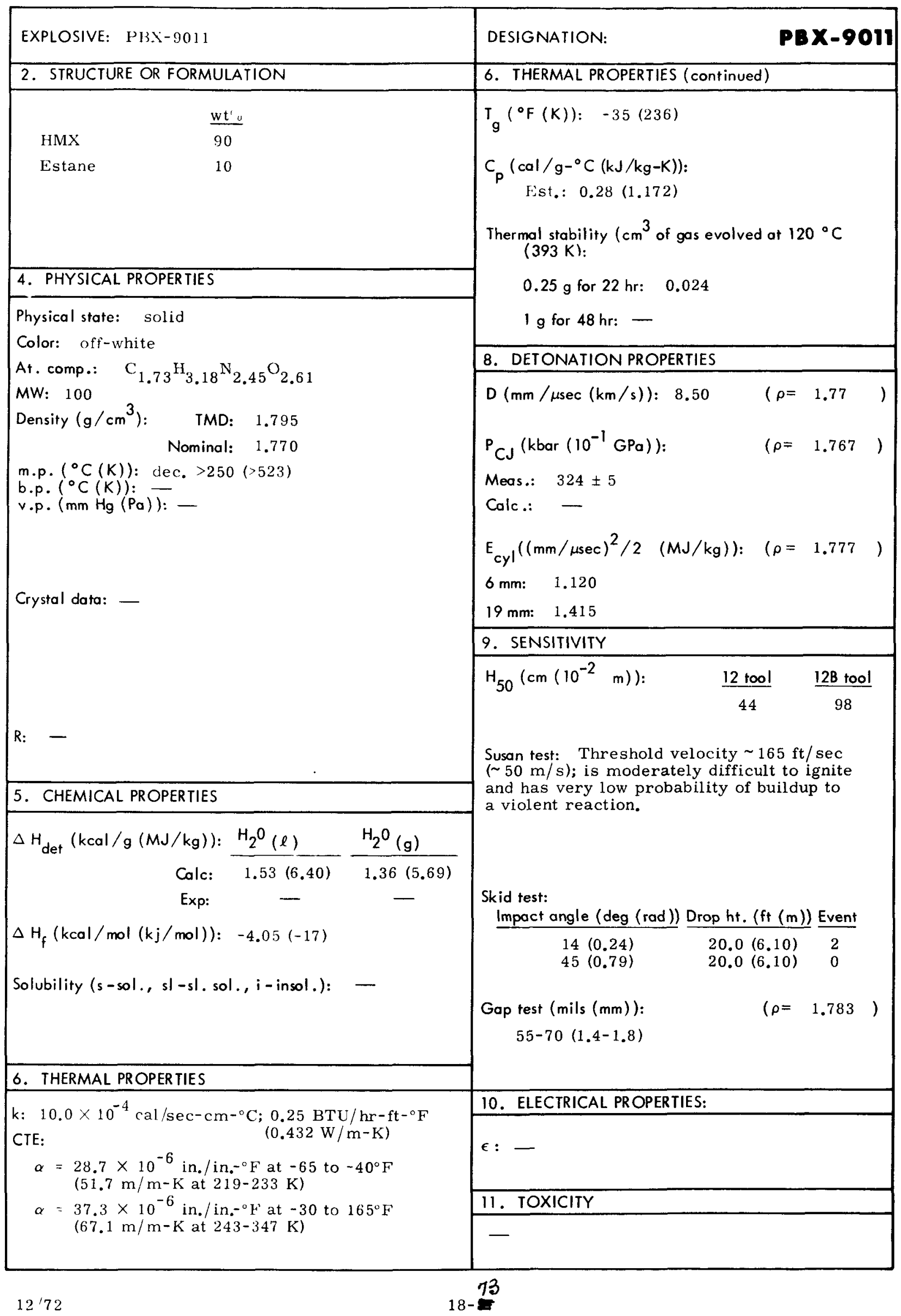




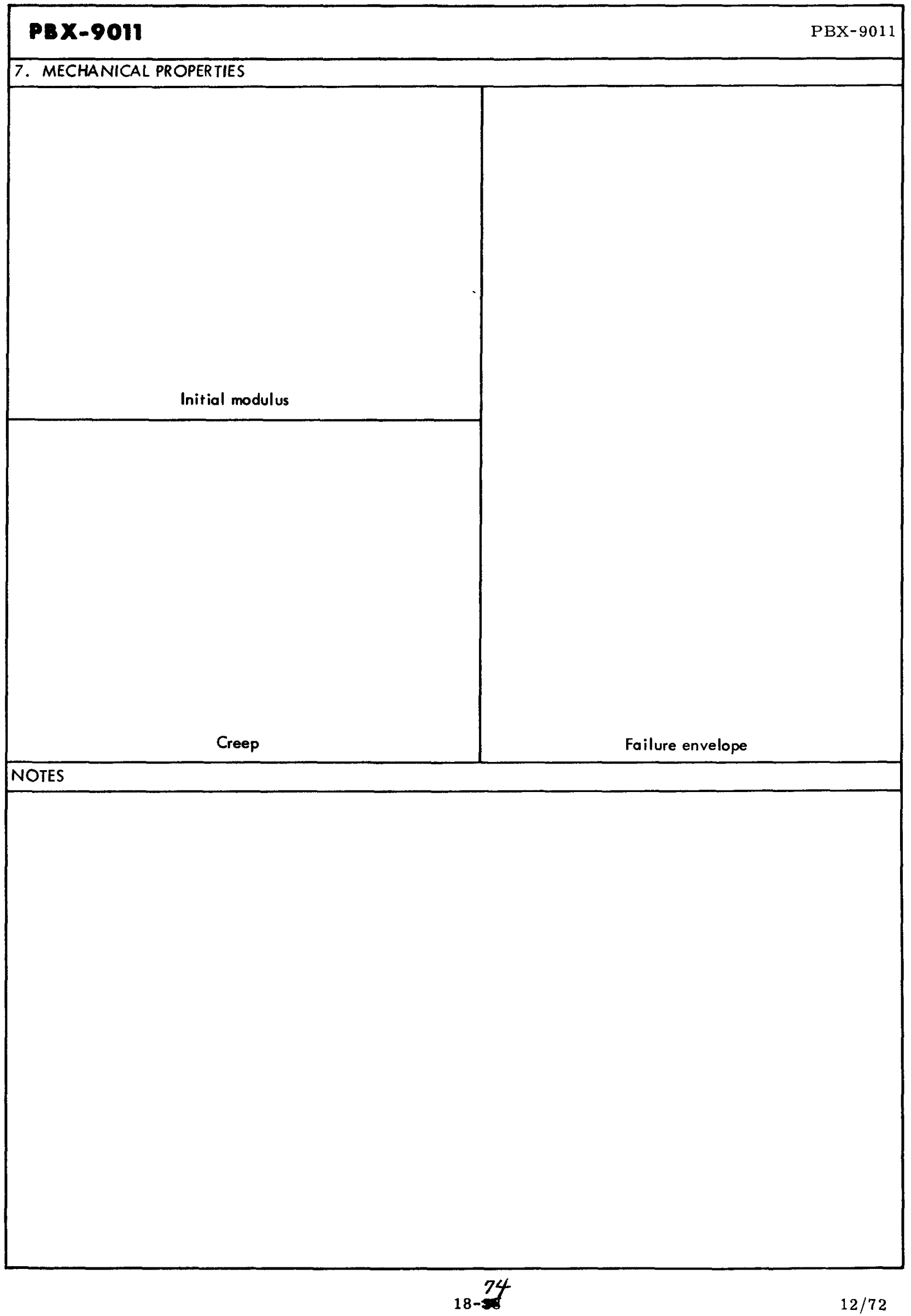




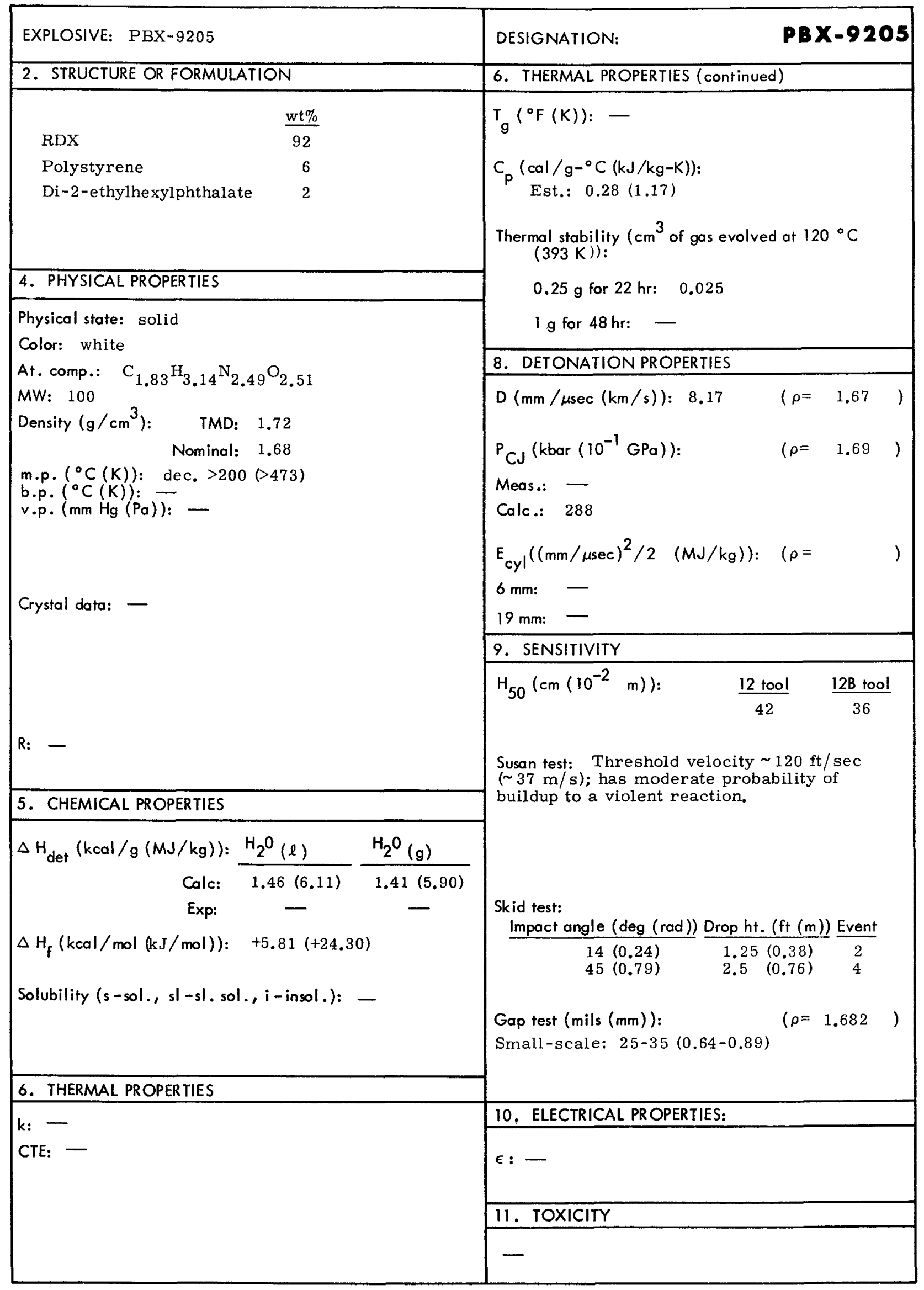




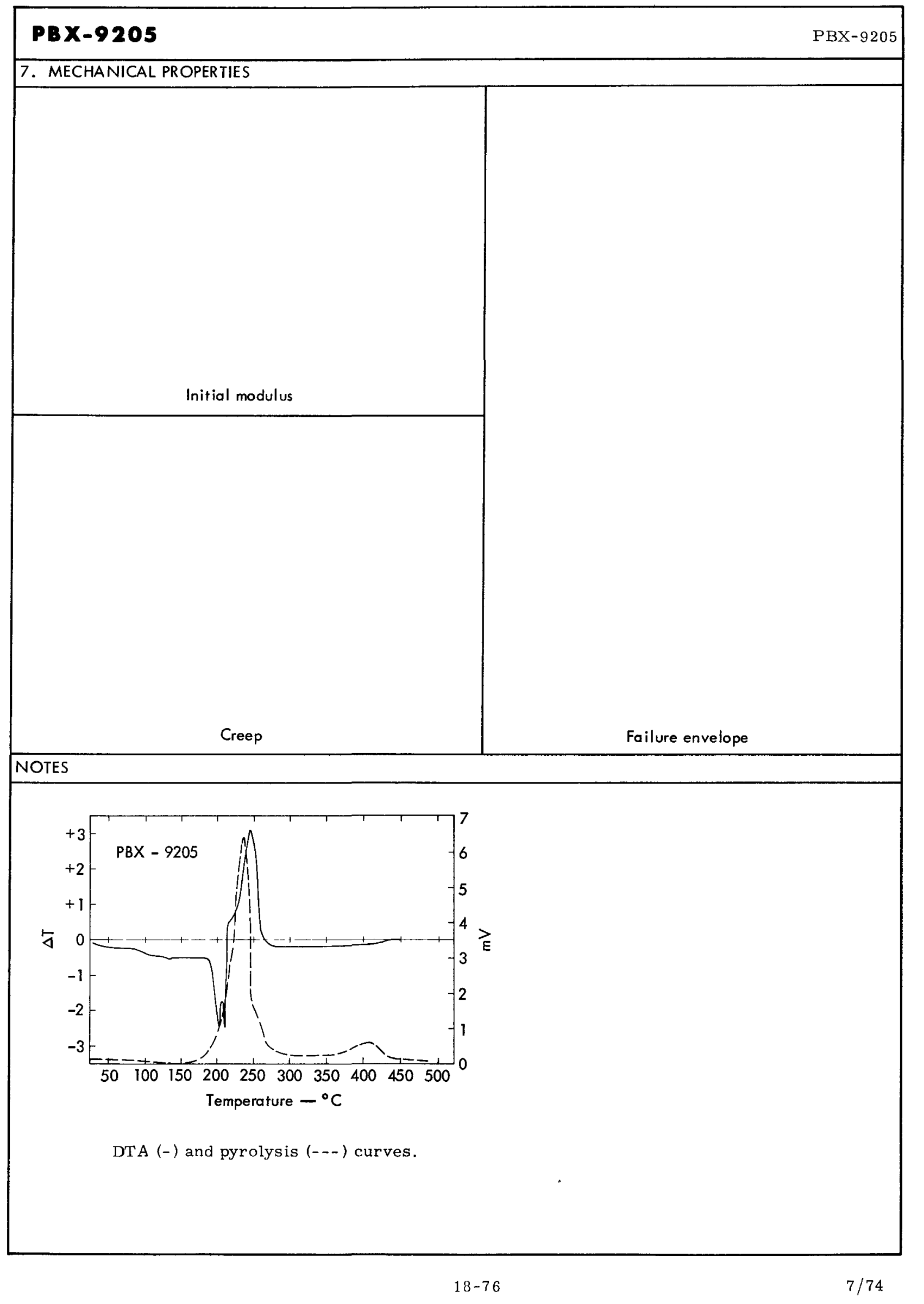




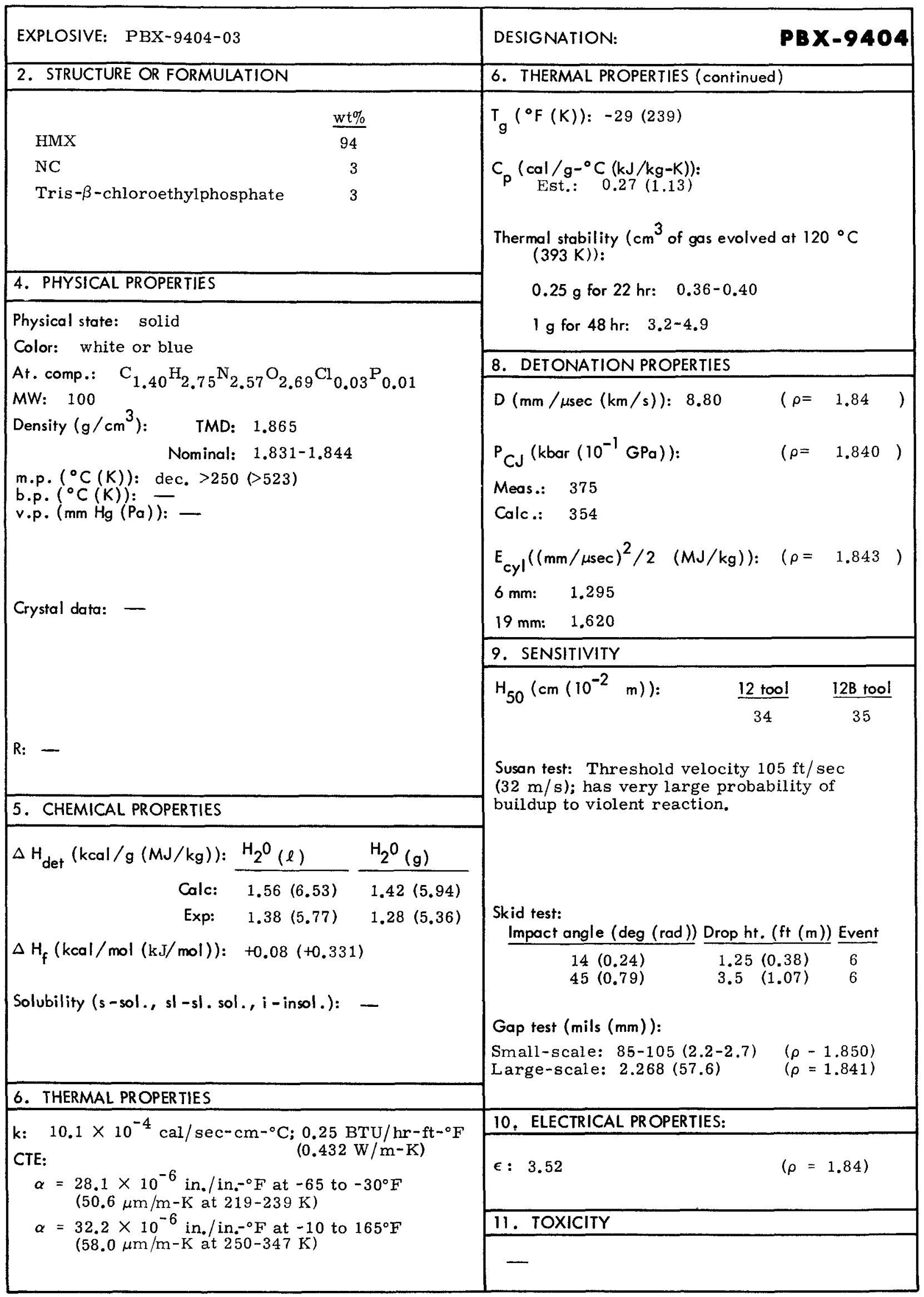




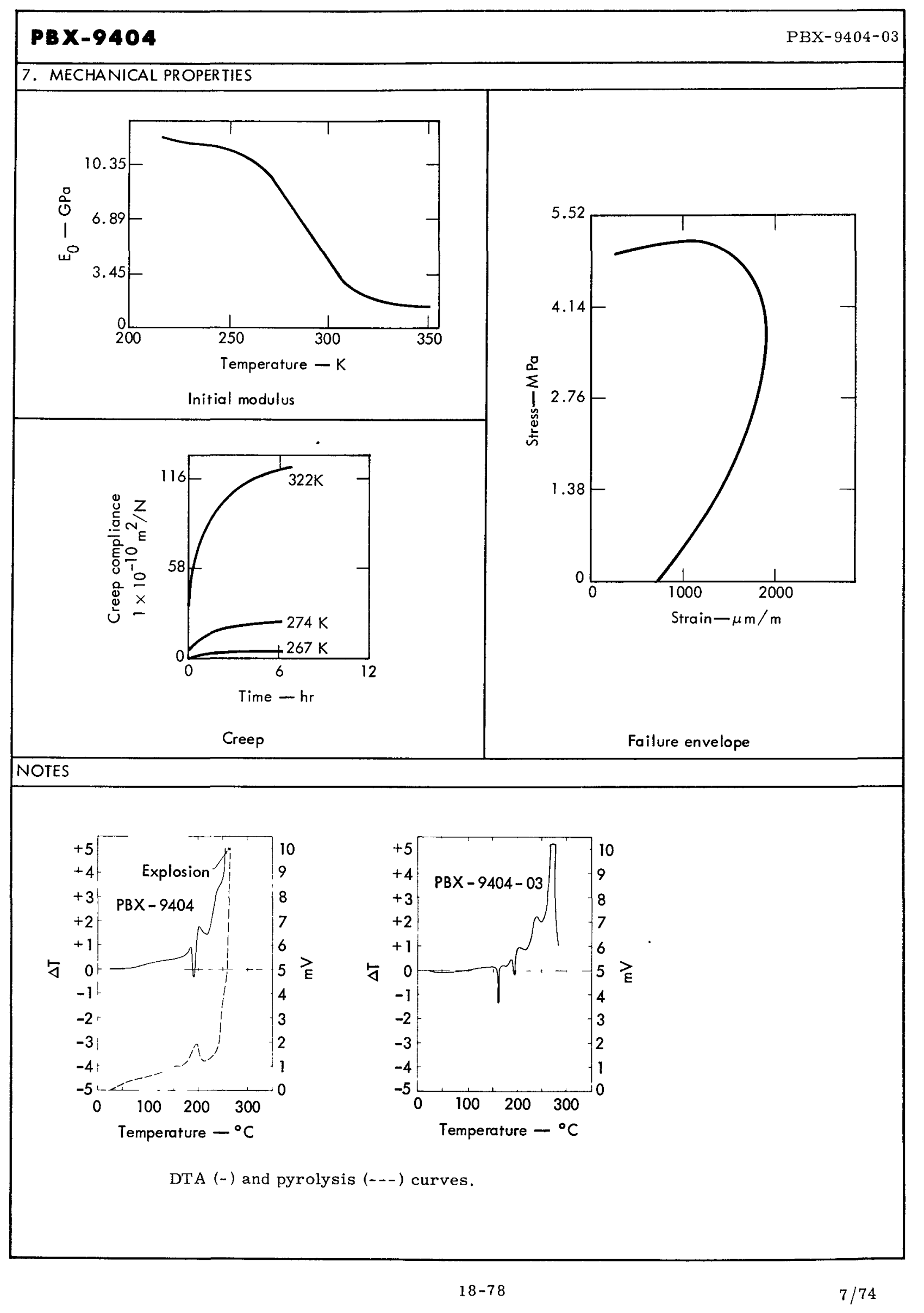




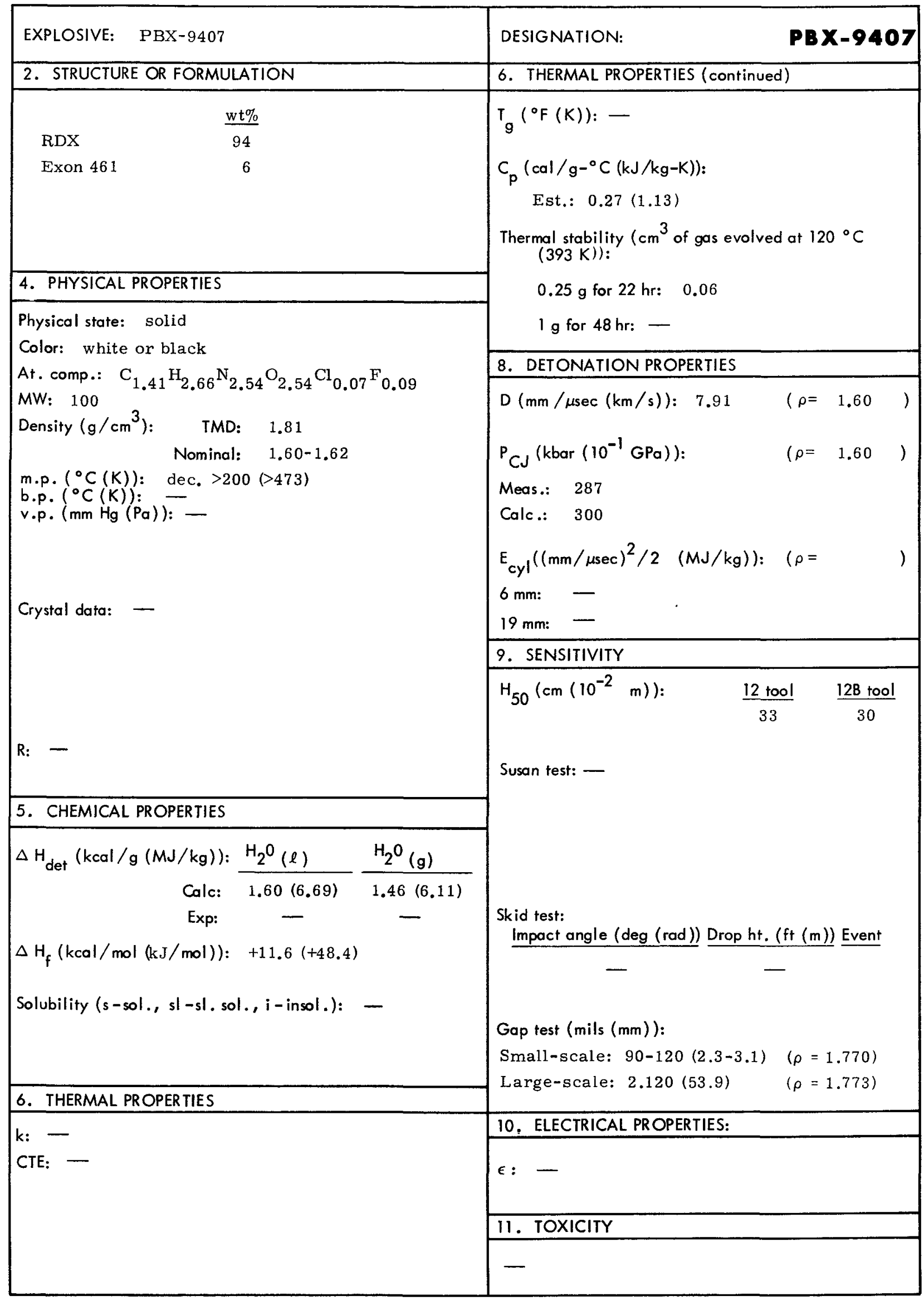




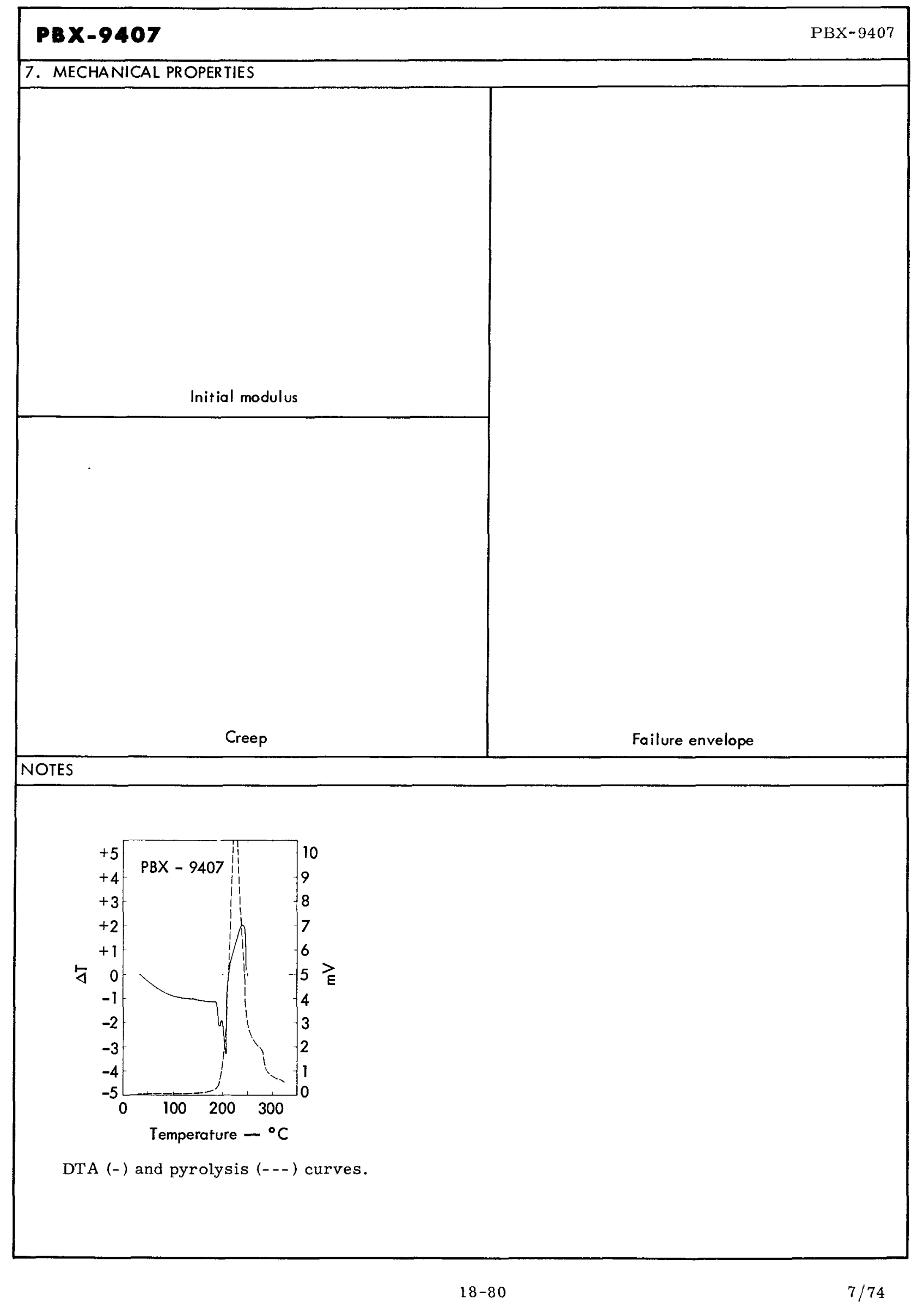




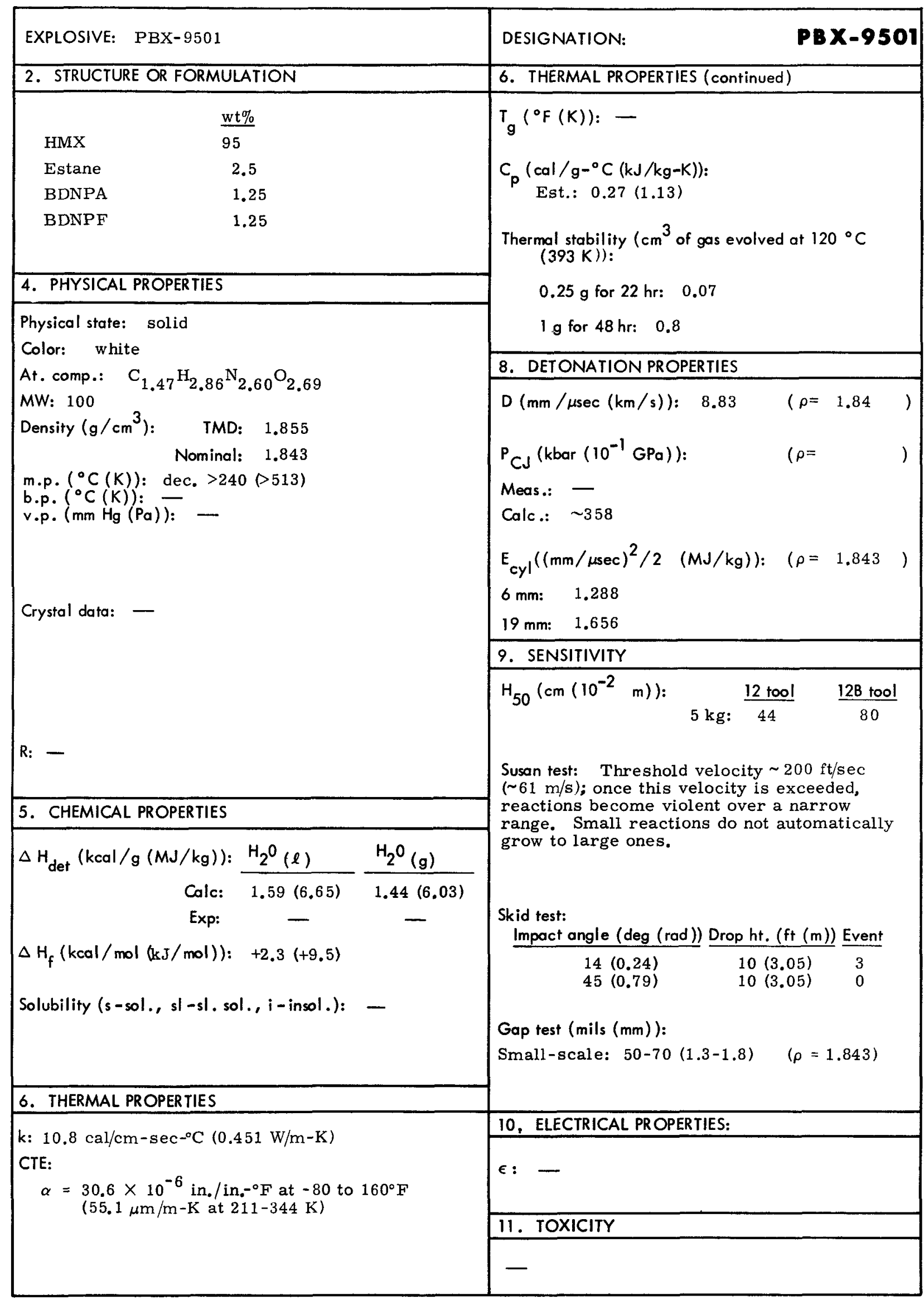




\section{MECHANICAL PROPERTIES}

\section{Initial modulus}

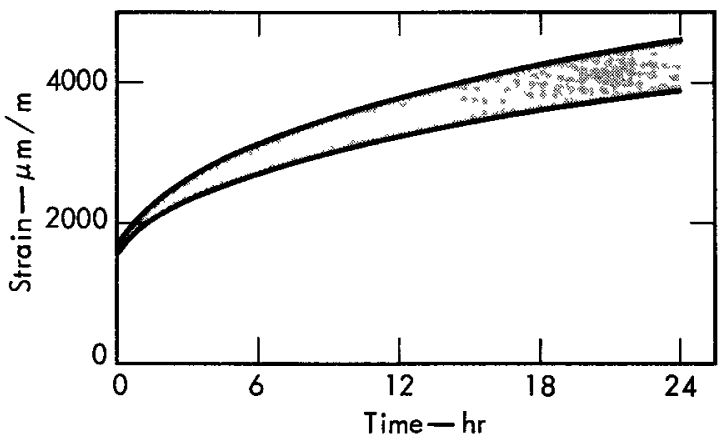

Creep

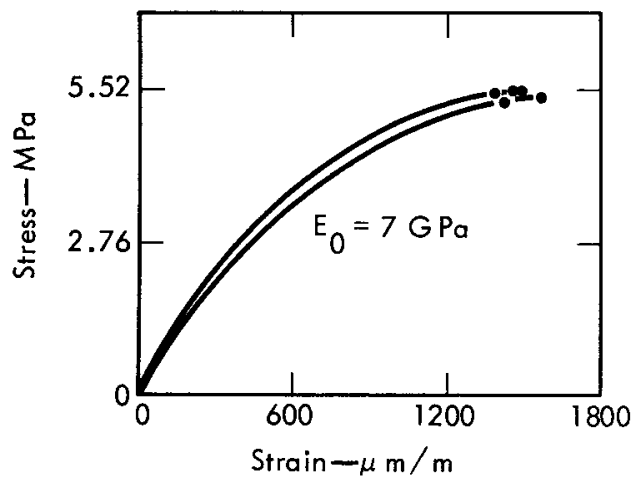

Failure envelope

\section{NOTES}

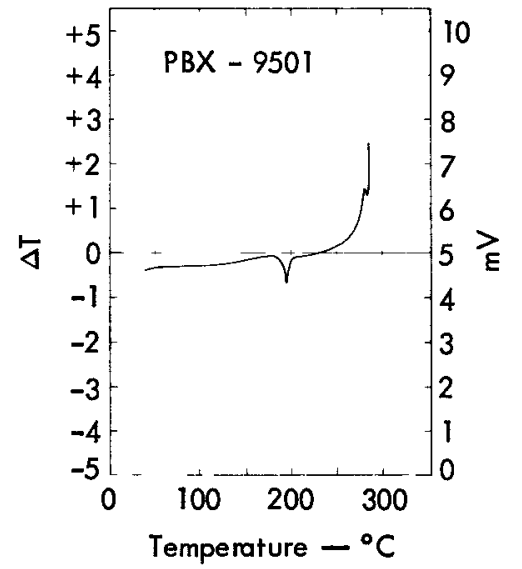

DTA (-) and pyrolysis (---) curves. 


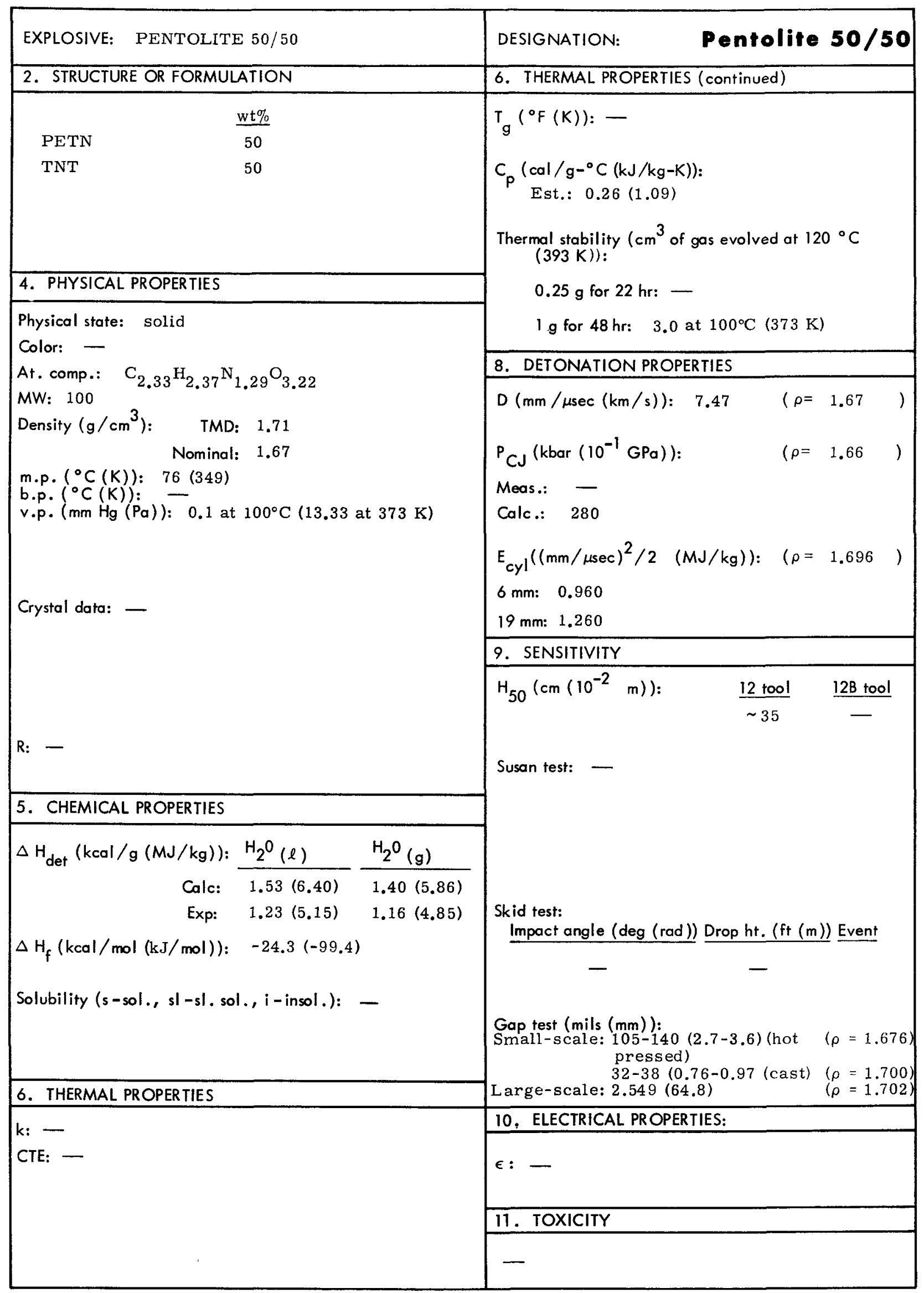




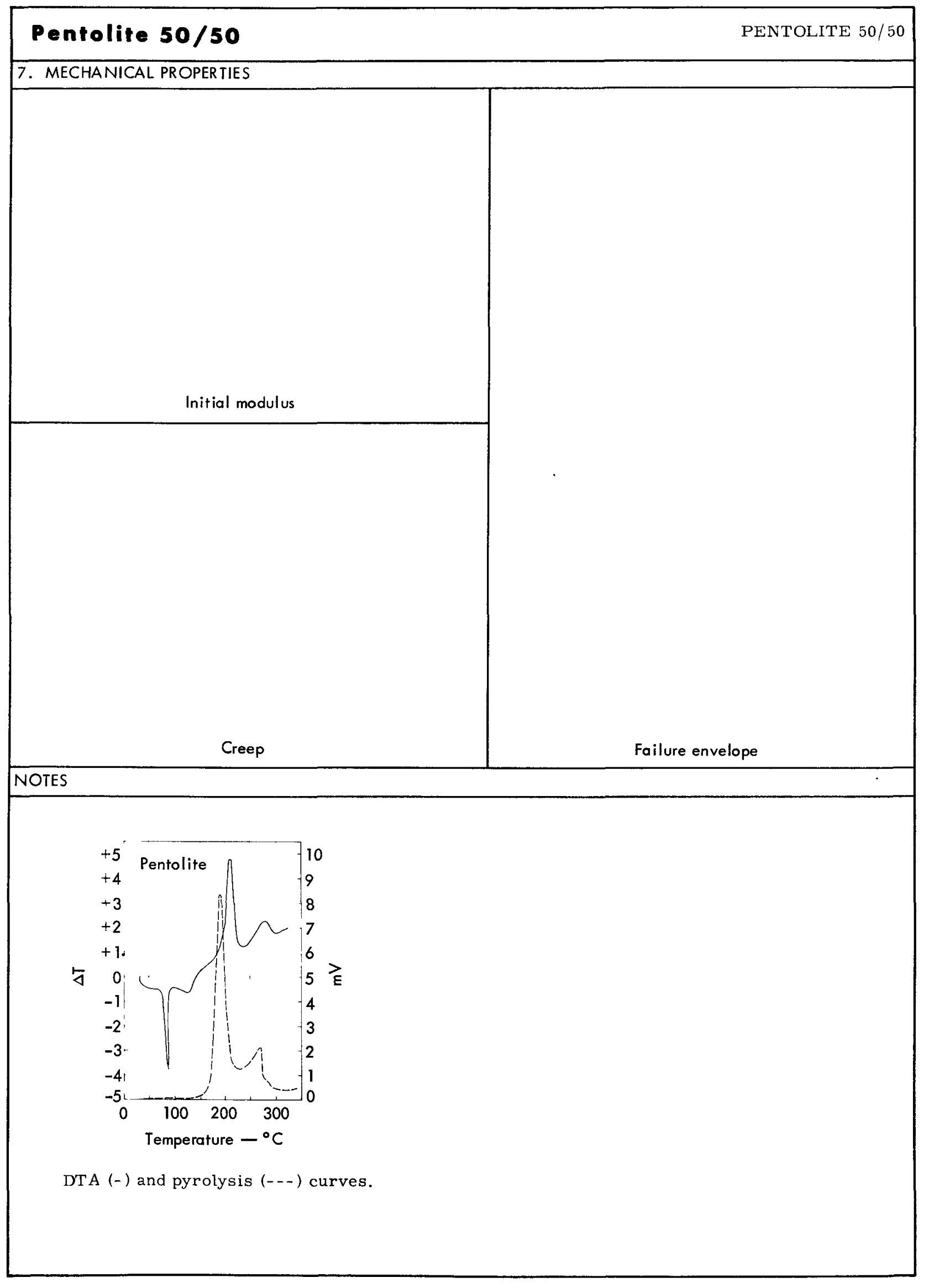




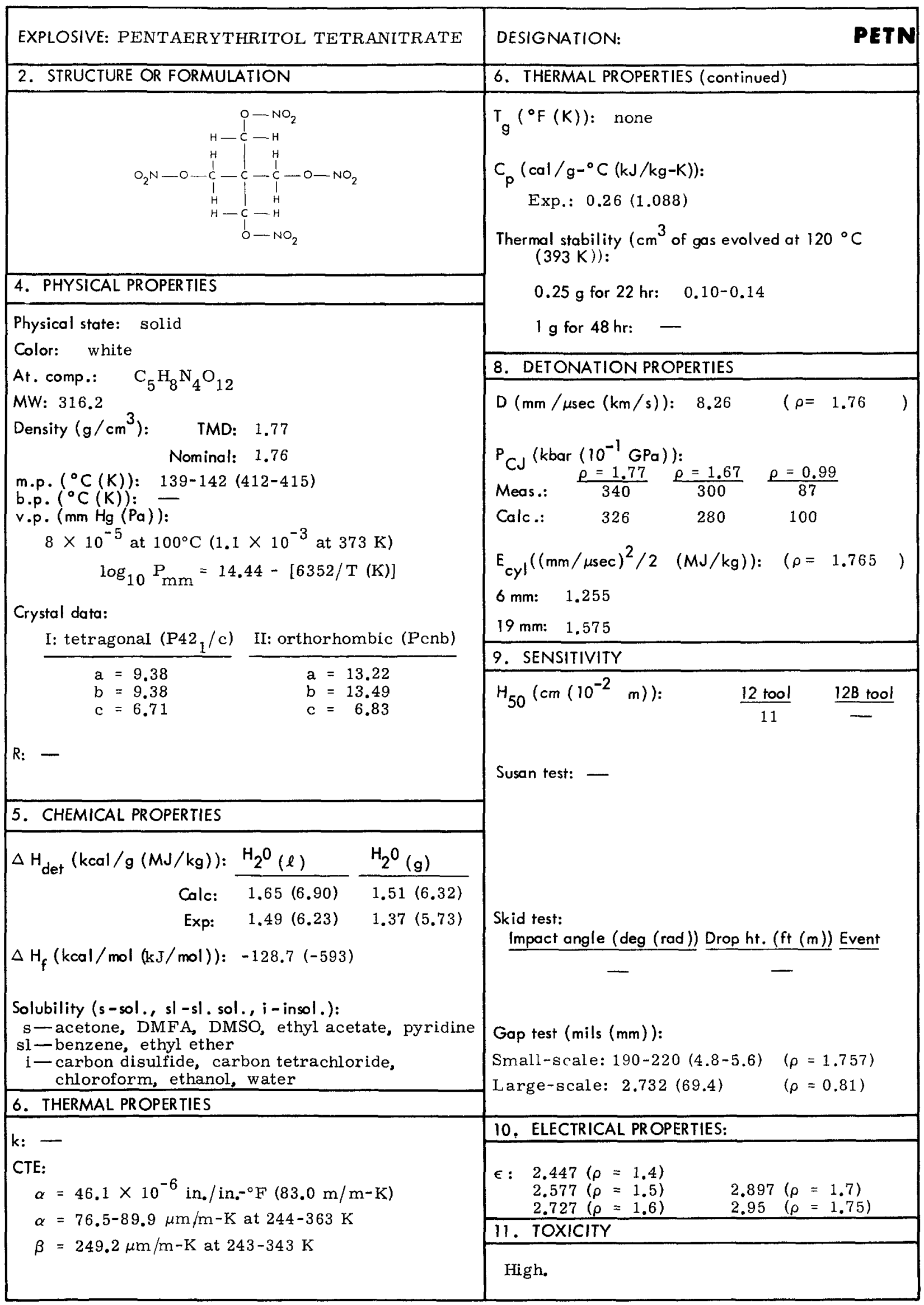




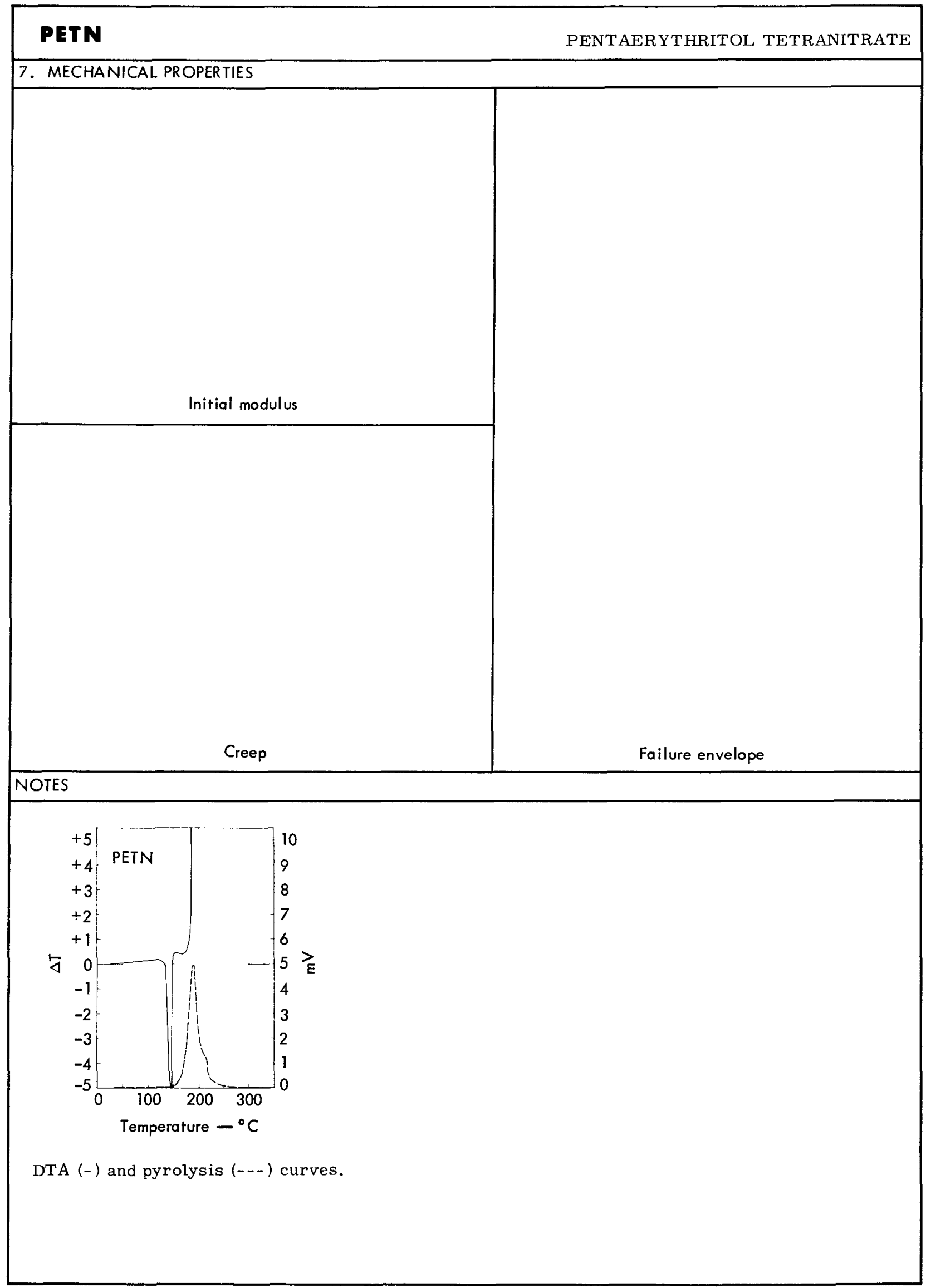




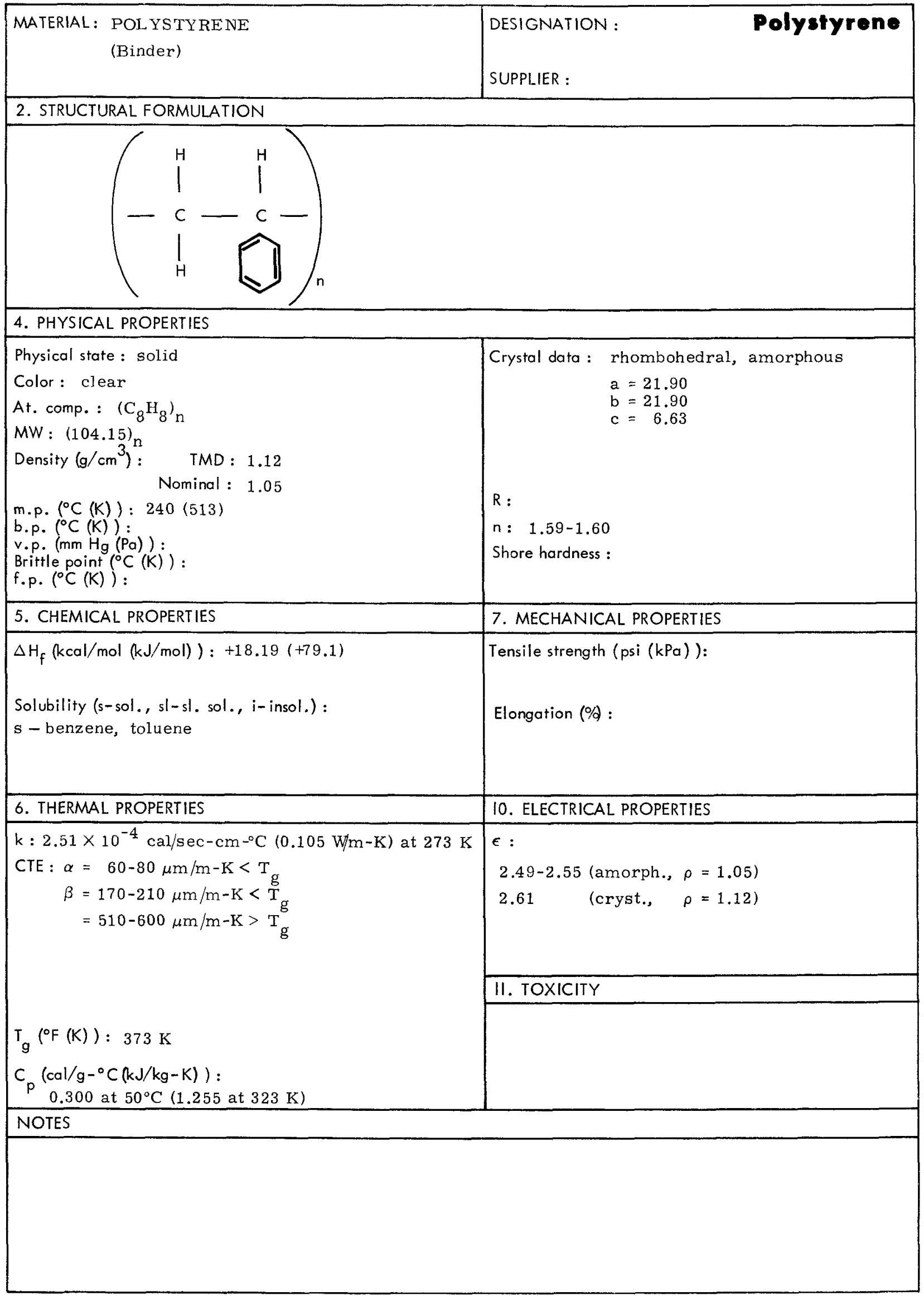




\section{Polystyrene}

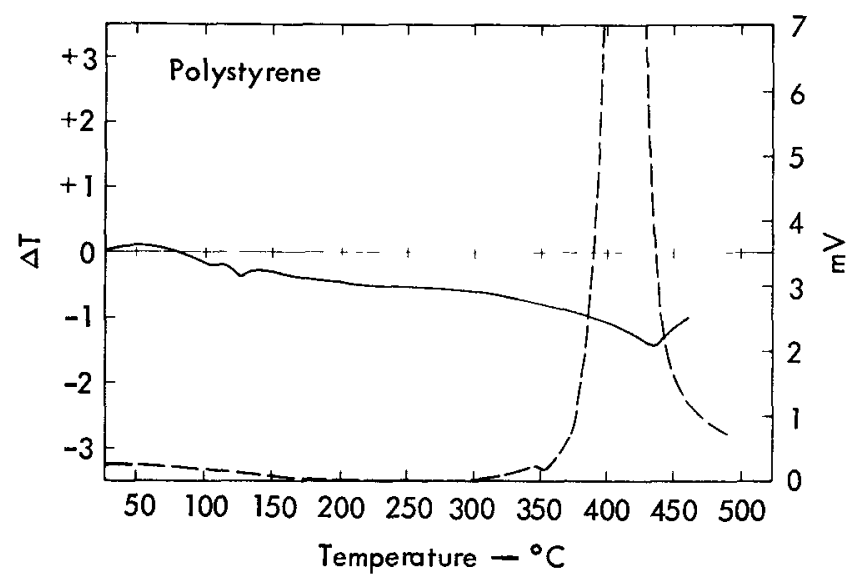




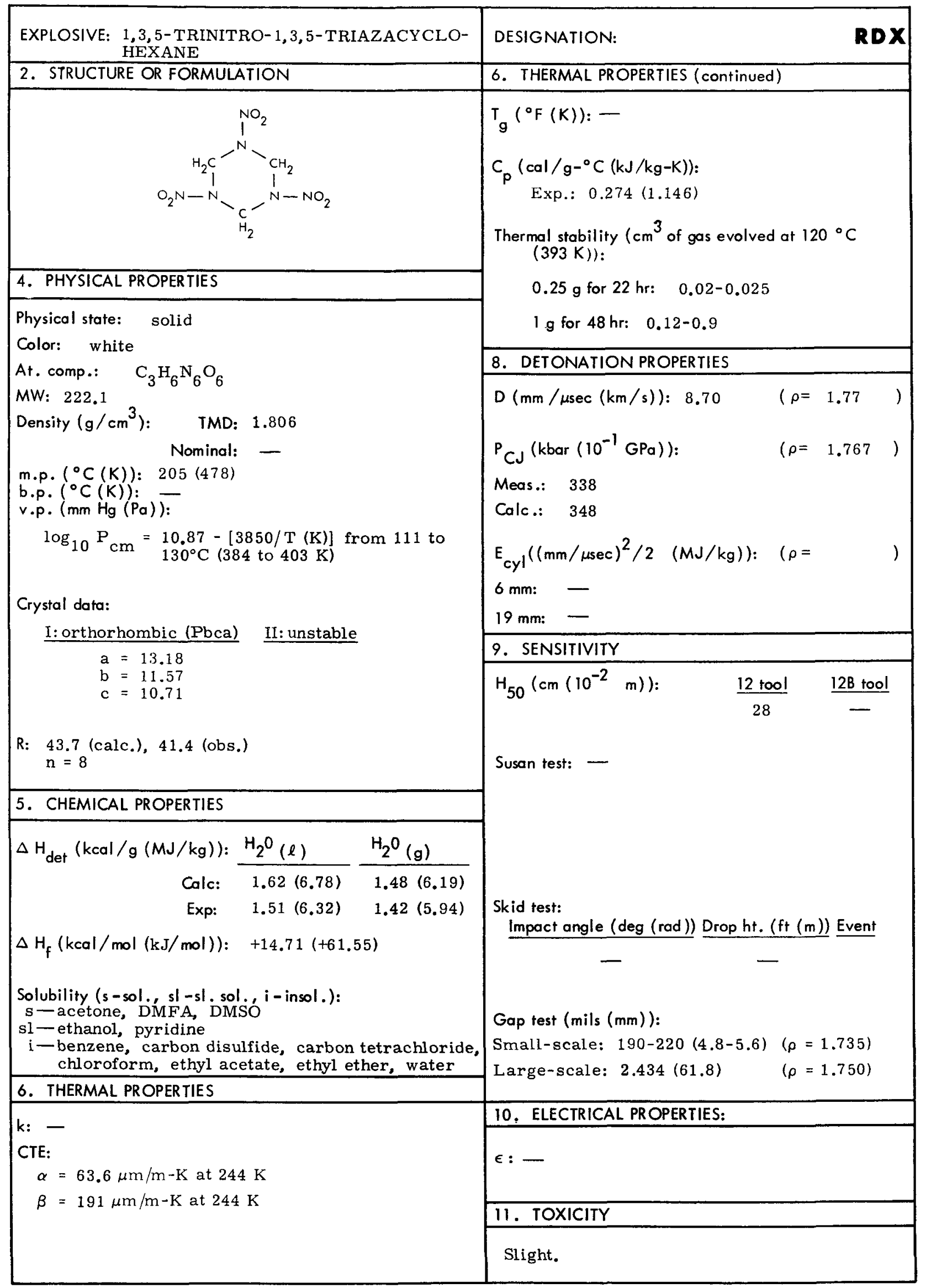




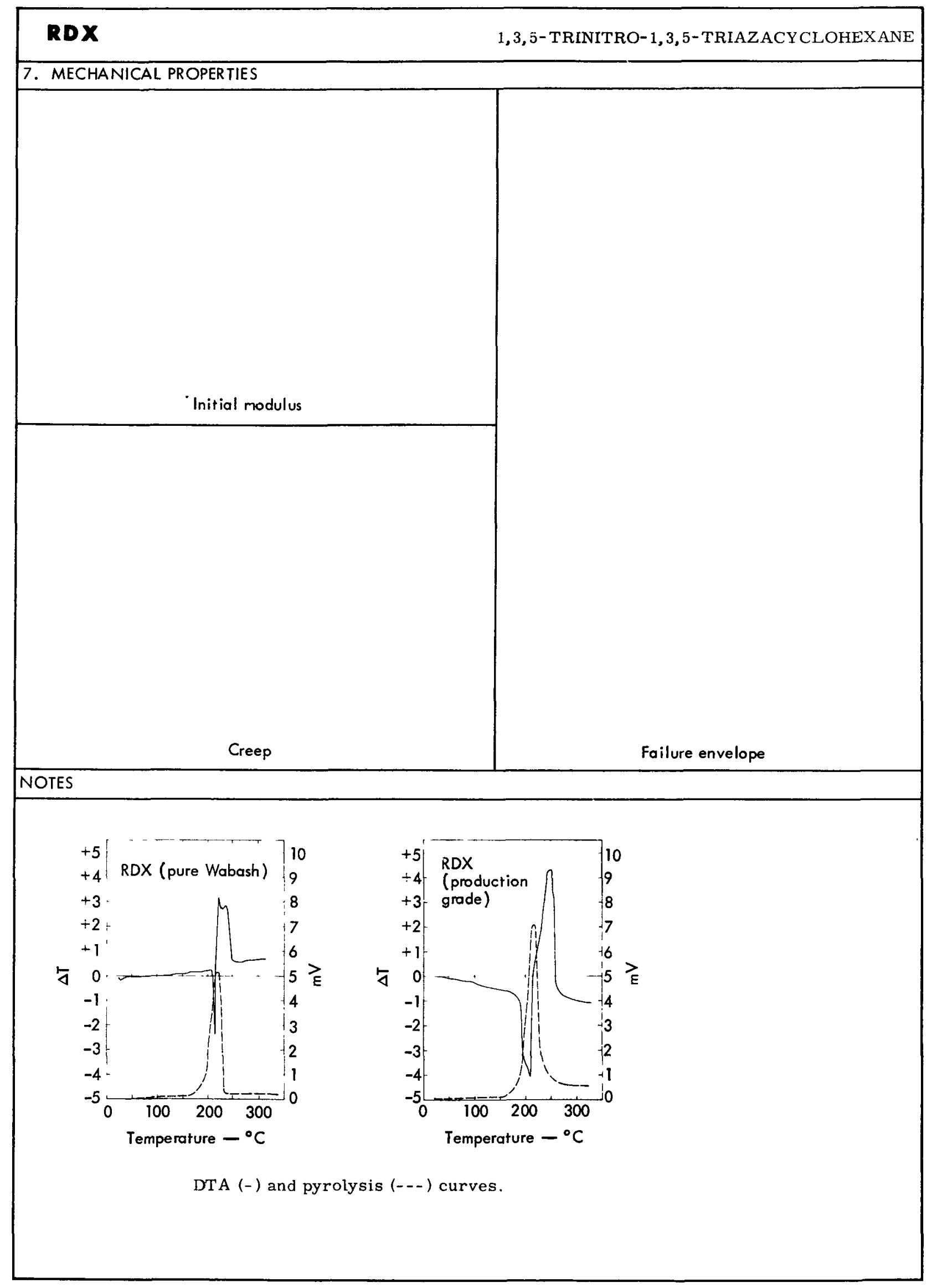




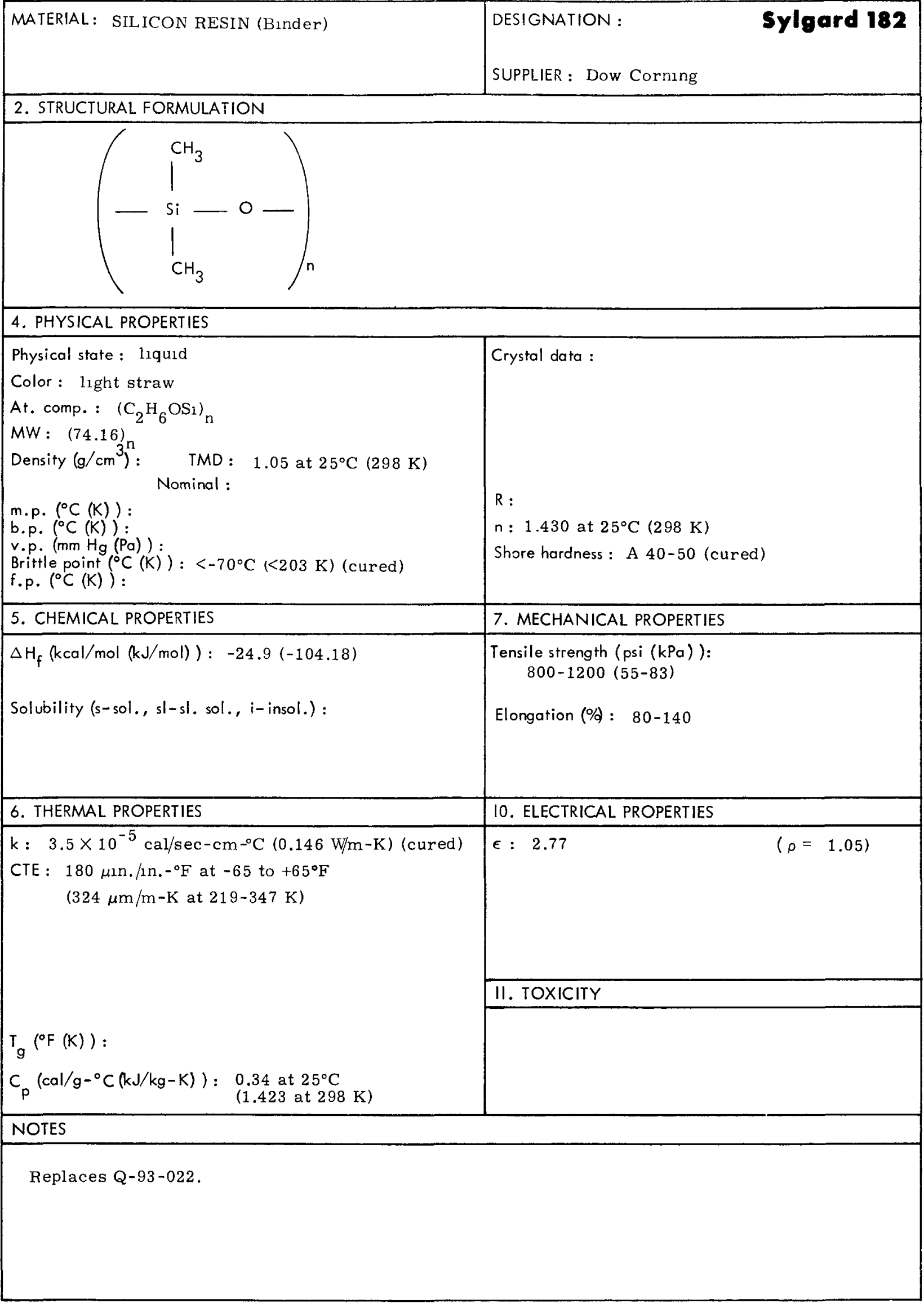




\section{Sylgard 182}




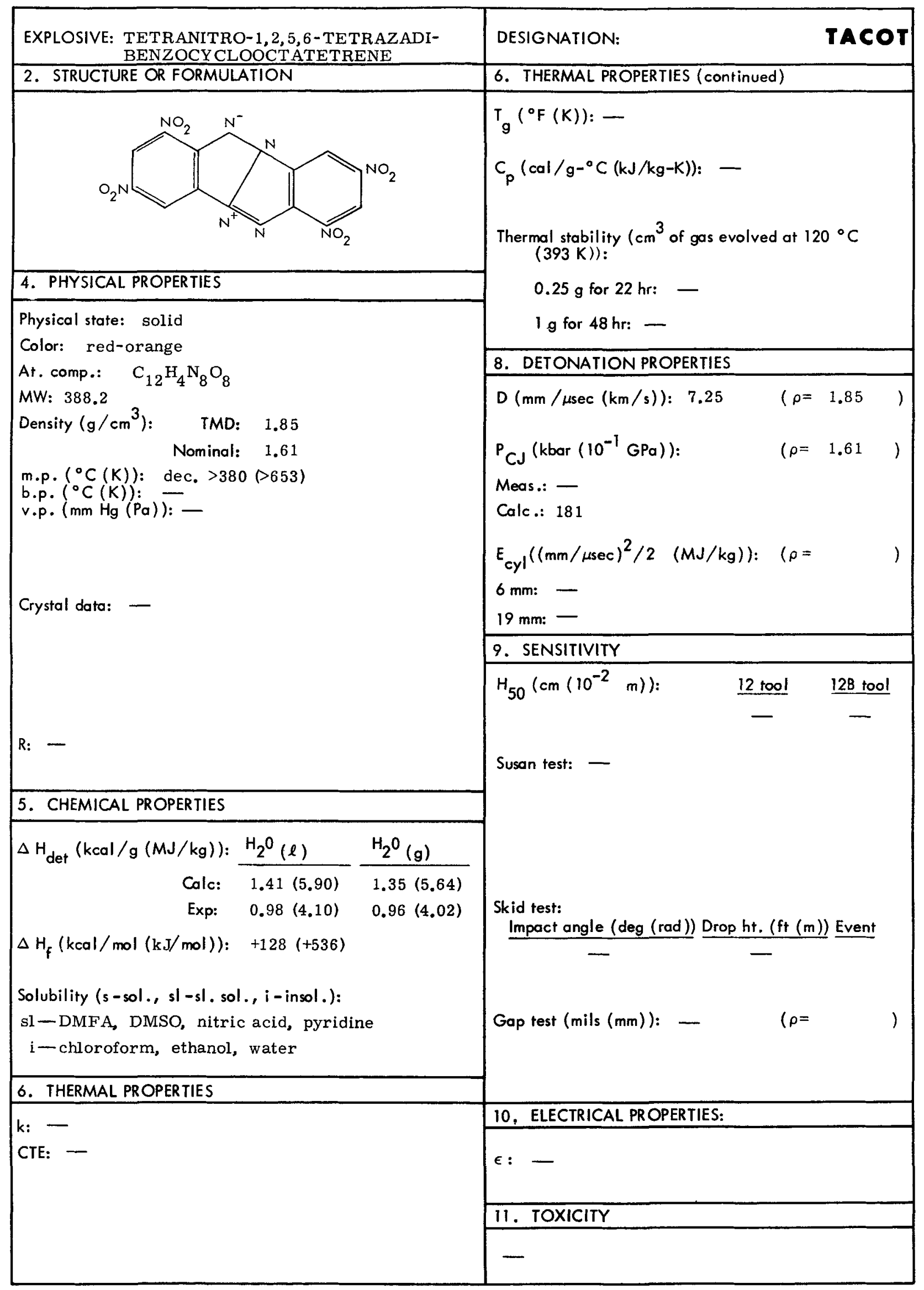




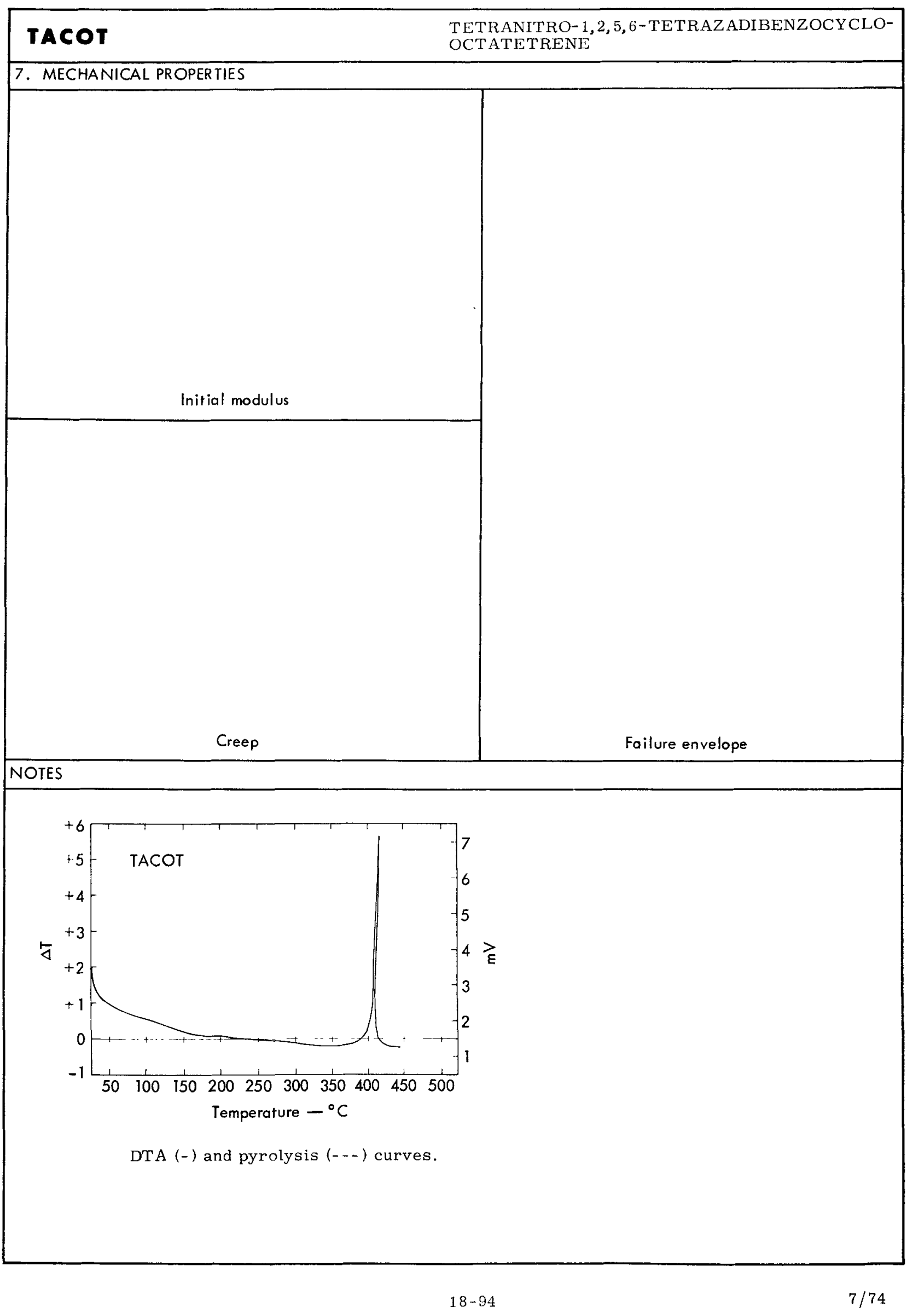




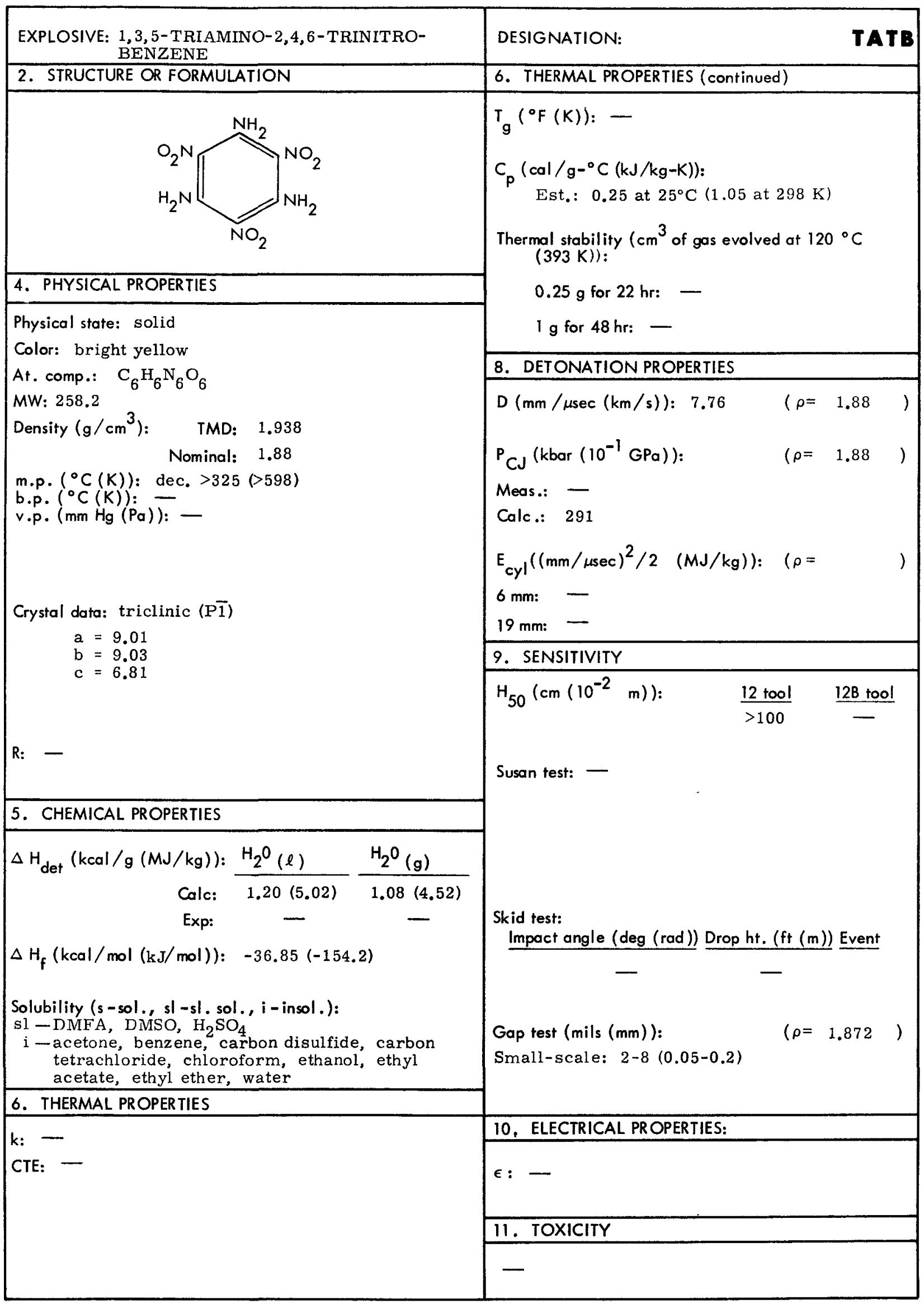


TATB 1,3,5-TRIAMINO-2,4,6-TRINITROBENZENE

7. MECHANICAL PROPERTIES

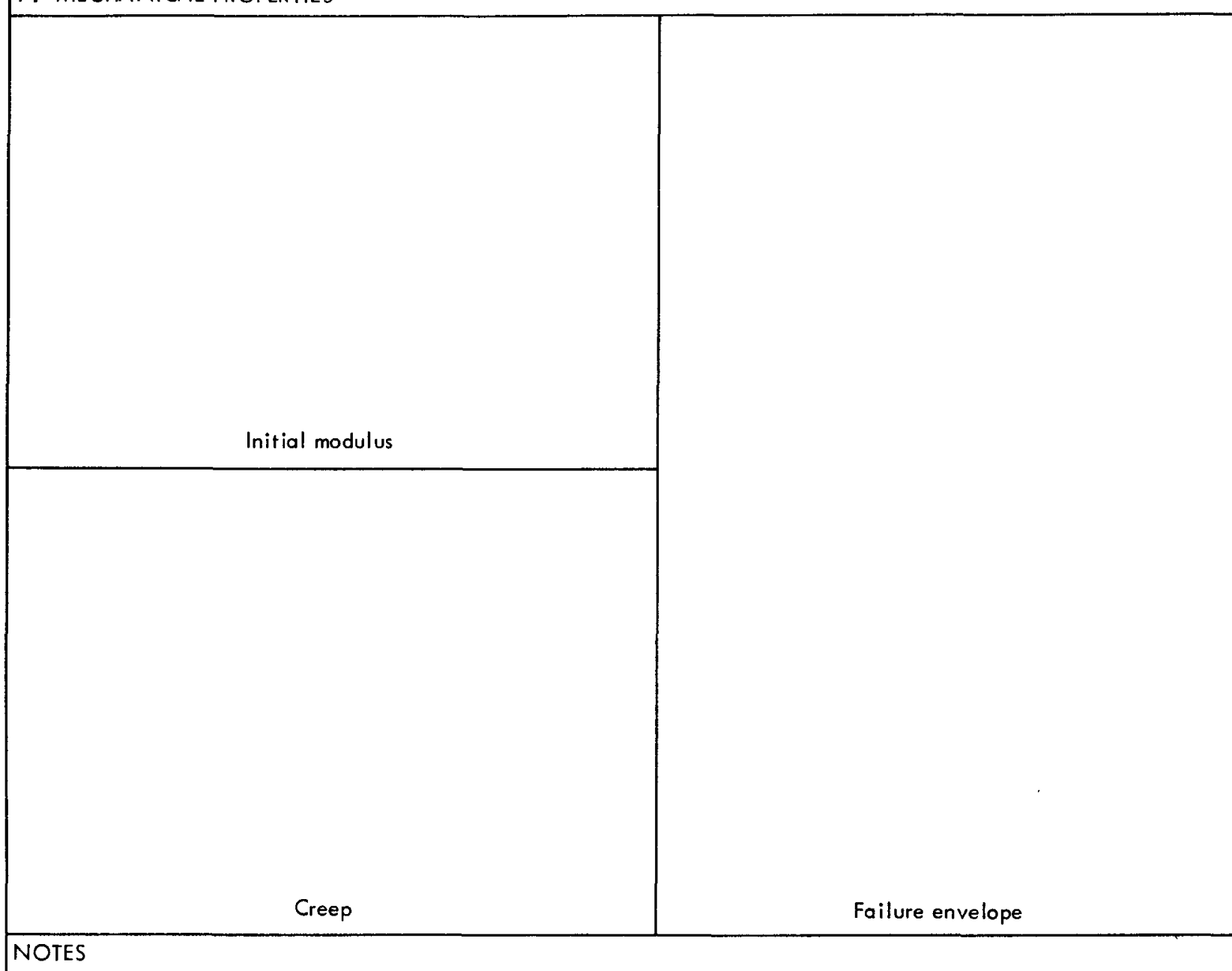

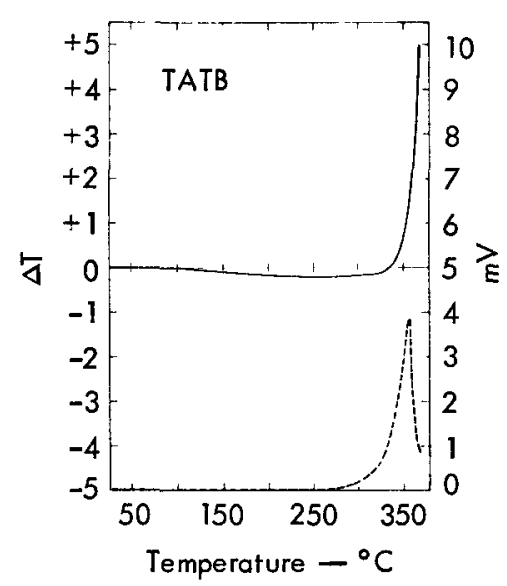

DTA (-) and pyrolysis (---) curves. 
MATERIAL: TRIS- $\beta-$ CHLOROETHYL PHOSPHA TE

\section{STRUCTURAL FORMULATION}

$$
\mathrm{O}=\mathrm{P}-\left(\mathrm{O}-\mathrm{CH}_{2}-\mathrm{CH}_{2} \mathrm{Cl}\right)_{3}
$$

\section{PHYSICAL PROPERTIES}

Physical state : liquid

Color : clear

At. comp. : $\mathrm{C}_{6} \mathrm{H}_{12} \mathrm{Cl}_{3} \mathrm{O}_{4} \mathrm{P}$

$M W: 285.5$

Density $\left(\mathrm{g} / \mathrm{cm}^{3}\right): \quad$ TMD $: 1.425$

$$
\text { Nominal : }
$$

m.p. $\left({ }^{\circ} \mathrm{C}(\mathrm{K})\right)$ :

b.p. $\left({ }^{\circ} \mathrm{C}(\mathrm{K})\right): 203(476)$

v.p. $(\mathrm{mm} \mathrm{Hg}(\mathrm{Pa}))$ :

Brittle point $\left({ }^{\circ} \mathrm{C}(\mathrm{K})\right):-60(213 \mathrm{~K})$

f.p. $\left({ }^{\circ} \mathrm{C}(\mathrm{K})\right)$ :

5. CHEMICAL PROPERTIES

$\Delta H_{f}(\mathrm{kcal} / \mathrm{mol}(\mathrm{kJ} / \mathrm{mol})):-300(-1255)$

Solubility (s-sol., sl-sl. sol., i-insol.) :

$\mathrm{s}$ - alcohols, benzene, carbon tetrachloride, chloroform, esters, ethers, ketones, toluene, xylene

sl - water ${ }_{\text {i aliphatic hydrocarbons }}$

6. THERMAL PROPERTIES

$\mathrm{k}:$

CTE : $\beta=840 \mu \mathrm{m} / \mathrm{m}-\mathrm{K}$

$T_{g}\left({ }^{\circ} F(K)\right):$

$C_{p}\left(\mathrm{cal} / \mathrm{g}-{ }^{\circ} \mathrm{C}(\mathrm{kJ} / \mathrm{kg}-\mathrm{K})\right):$
Crystal data :

$R$ :

$n:$

Shore hardness :

7. MECHANICAL PROPERTIES

Tensile strength ( $\mathrm{psi}(\mathrm{kPa})$ ):

Elongation (\%) :

10. ELECTRICAL PROPERTIES

$\epsilon: \quad(\rho=$

II. TOXICITY

Low.

NOTES 
TEF

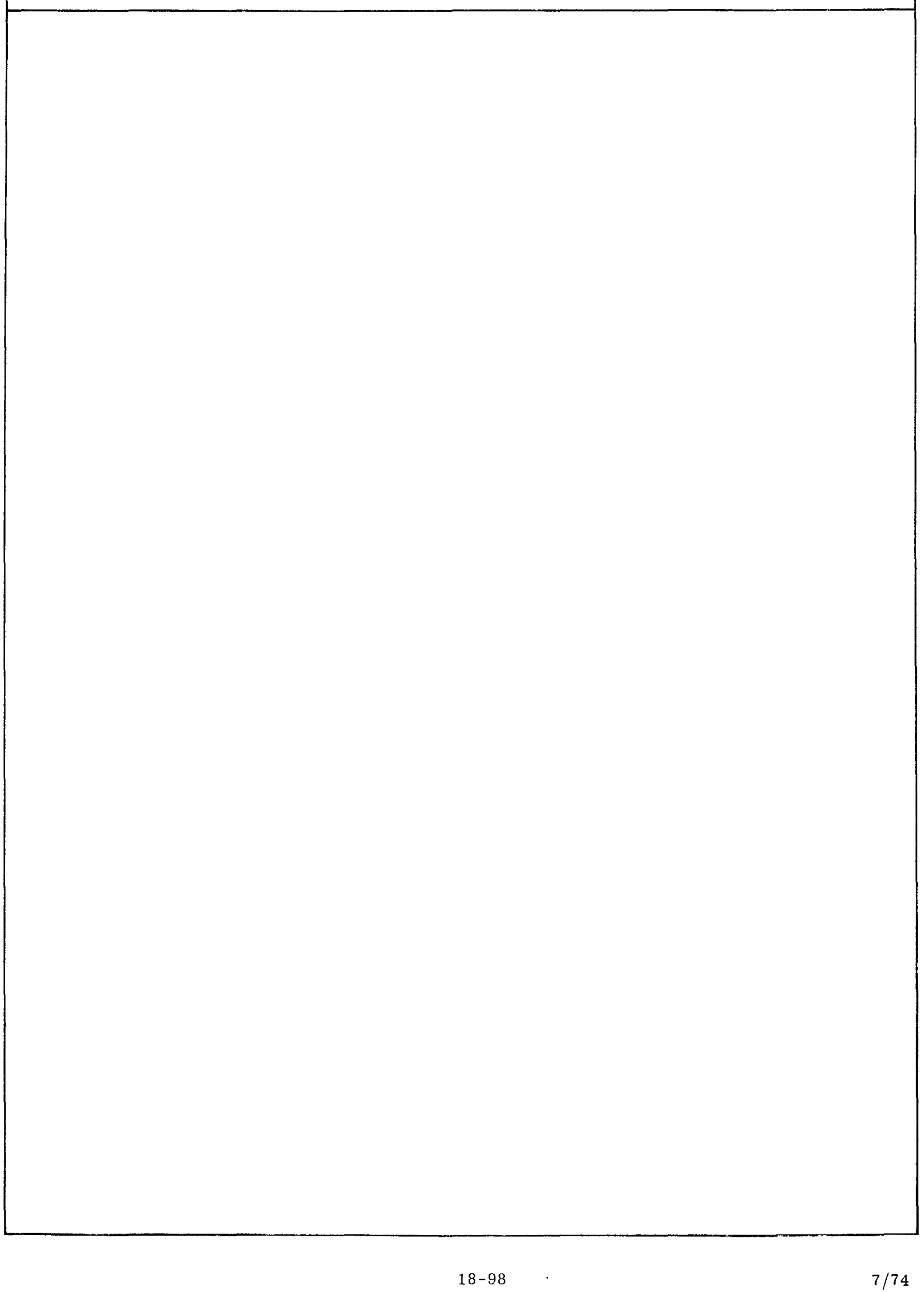

$18-98 \cdot 7 / 74$

$t$ 


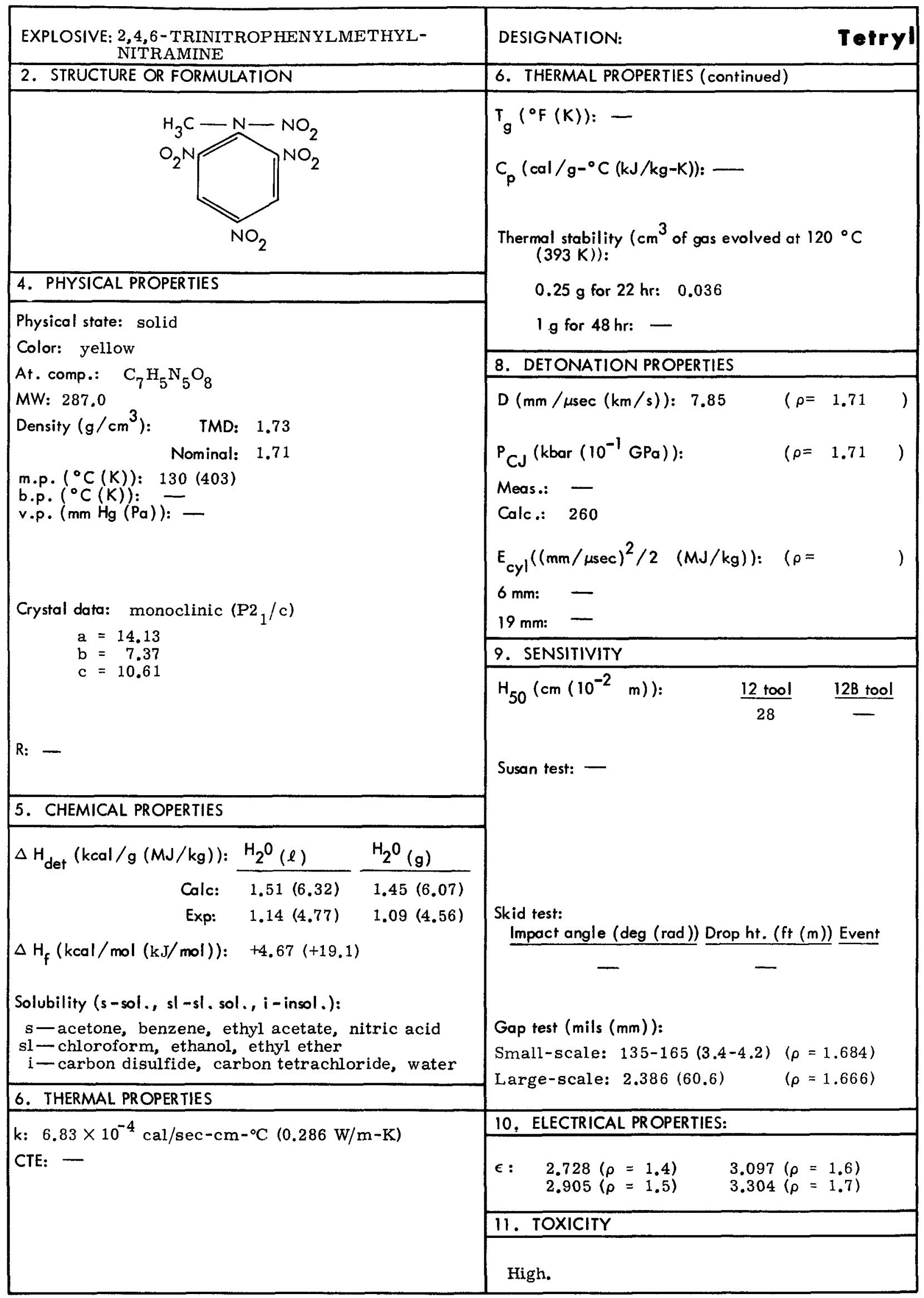




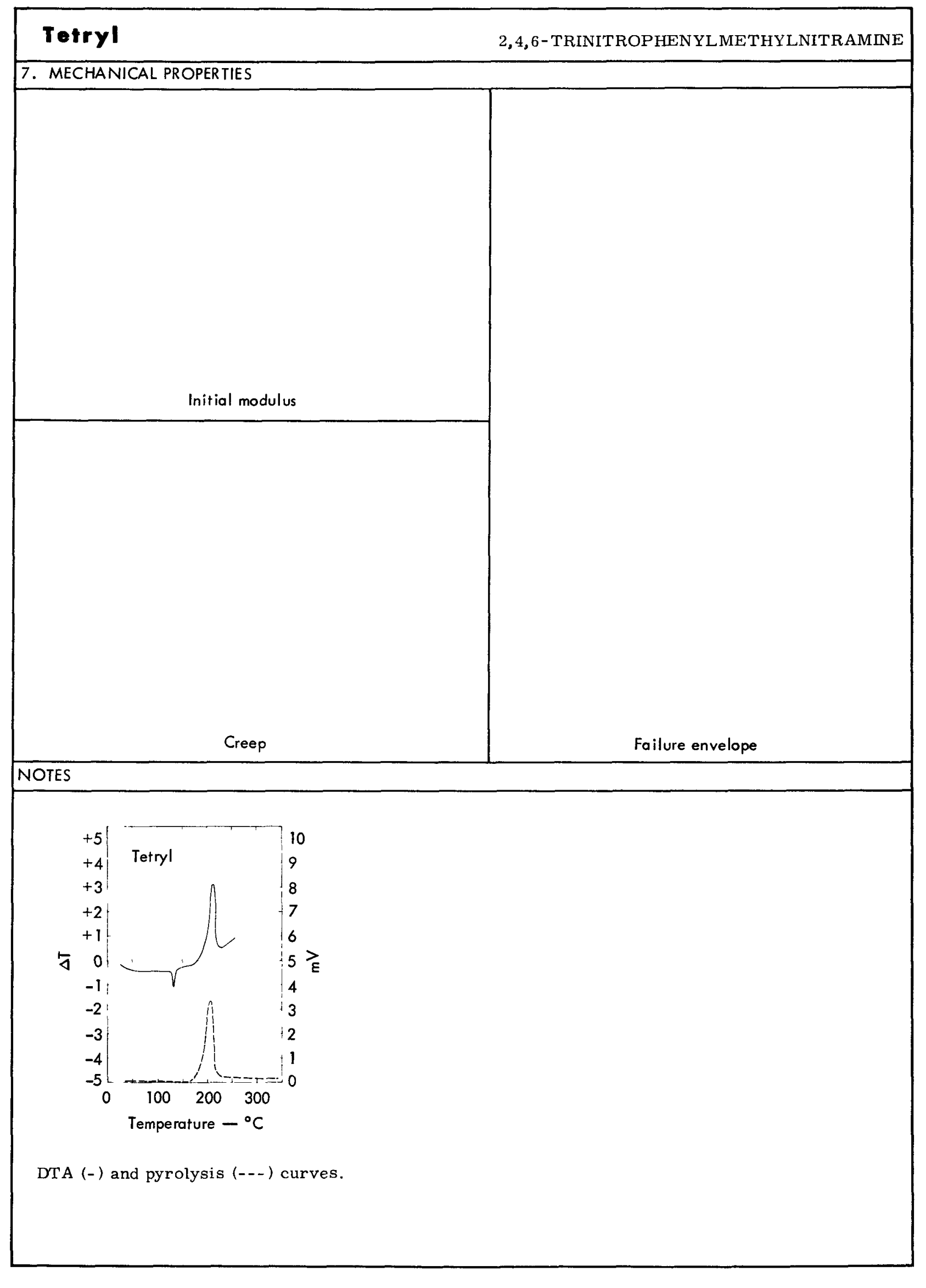




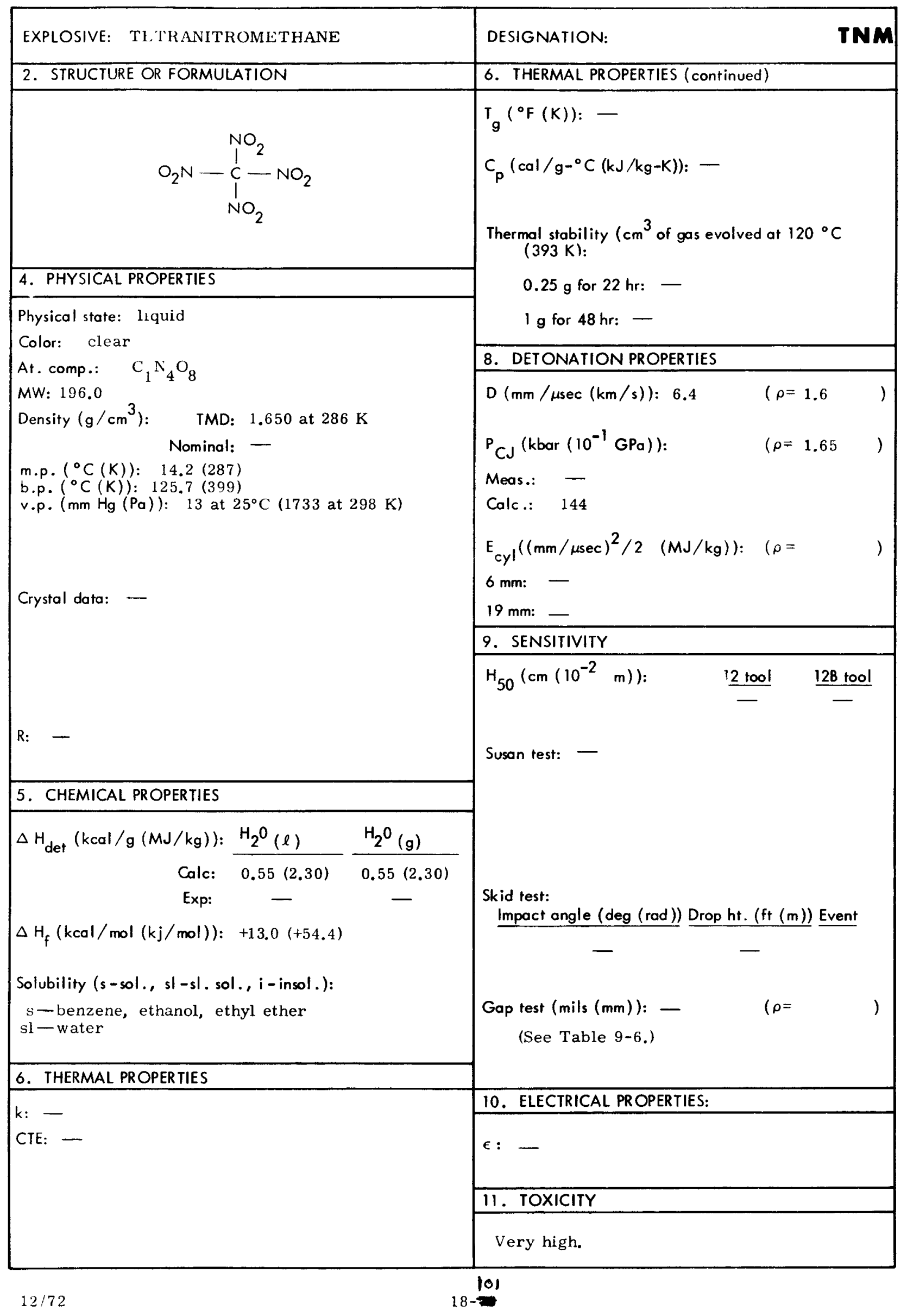




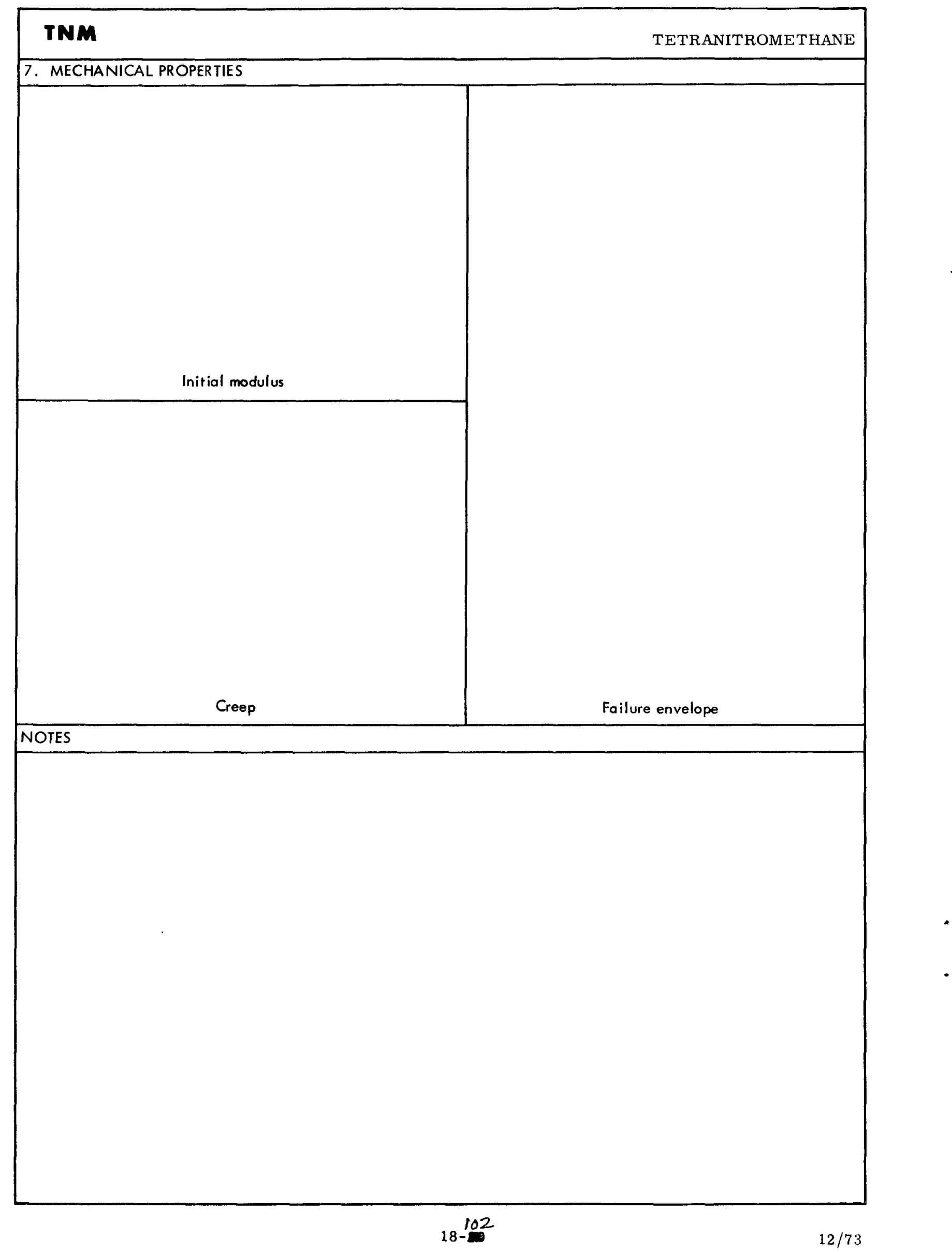




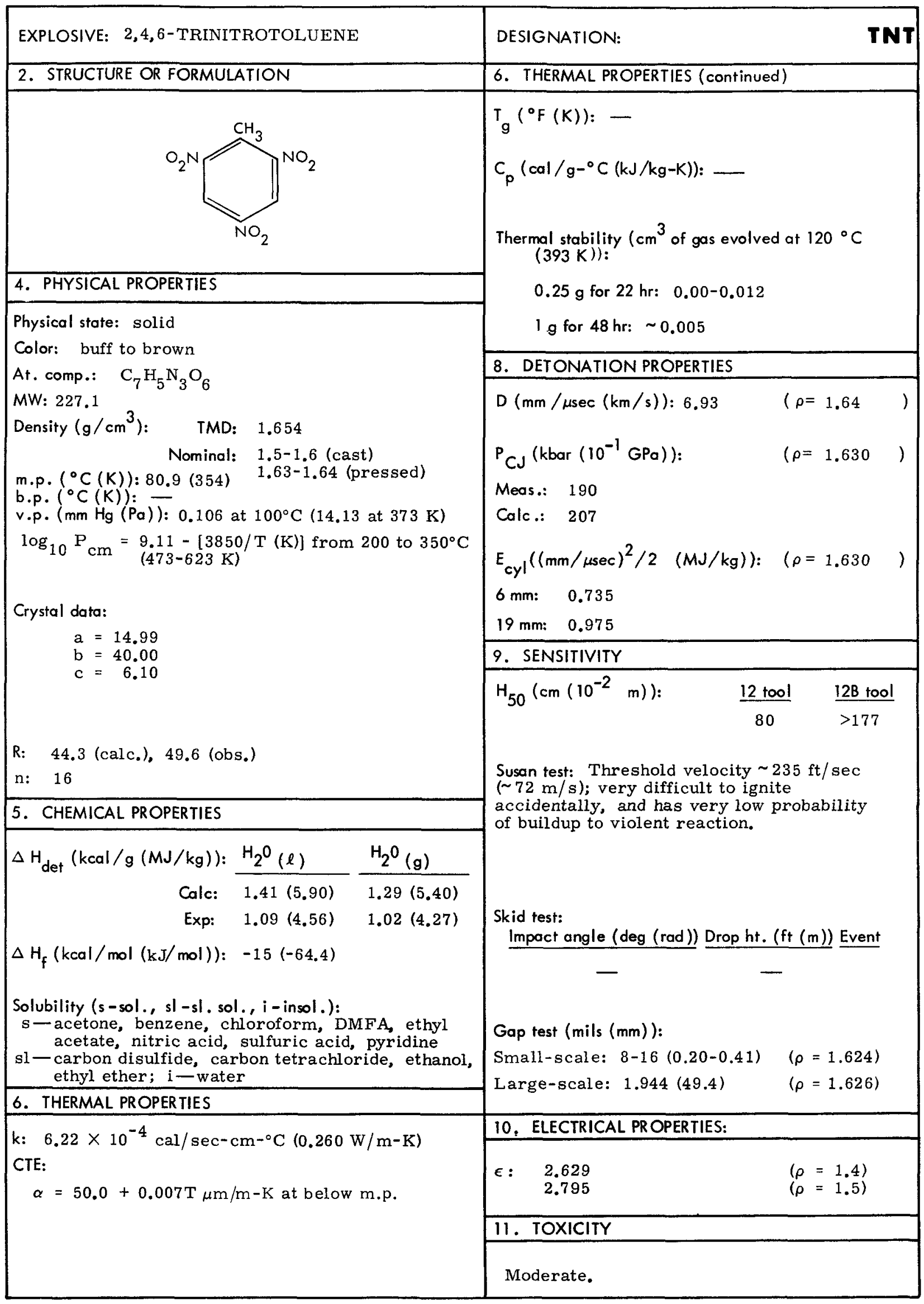




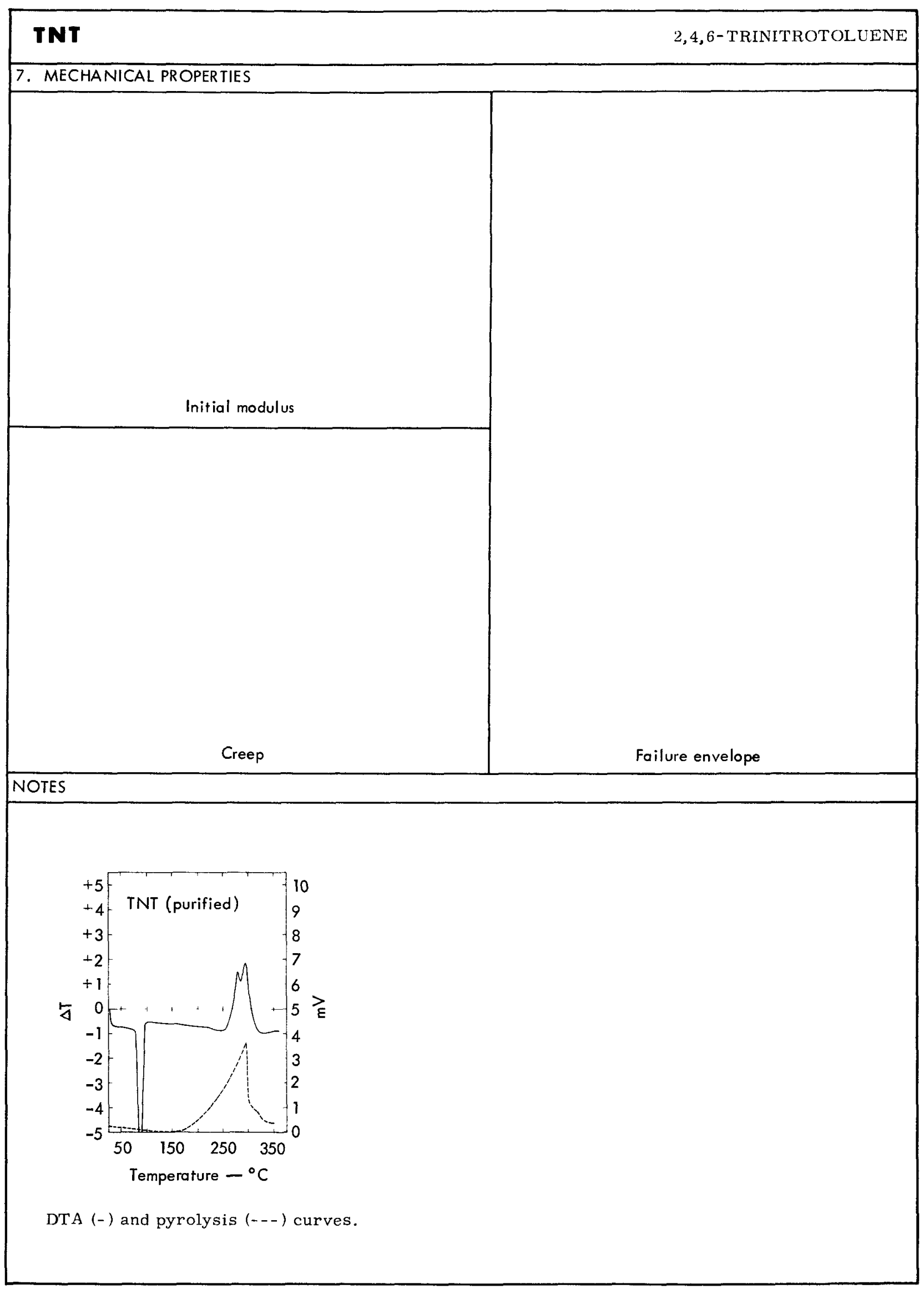

$18-104$

$7 / 74$ 


\begin{tabular}{|l|ll}
\hline MATERIAL: HEXAFLUOROPROPYLENE/ & VESIGNATION : & ifon A \\
VINYLIDINE FLUORIDE $1: 2$ (Binder) & SUPPLIER : DuPont \\
\hline
\end{tabular}

\section{STRUCTURAL FORMULATION}

$$
\left.\left[\begin{array}{cc}
\mathrm{F} & \mathrm{F} \\
\mathrm{I} & \mathrm{I} \\
\mathrm{C}-\mathrm{C}-( \\
\mathrm{I} & \mathrm{I} \\
\mathrm{CF}_{3} & \mathrm{~F}
\end{array}\right)_{1}-\left(\begin{array}{ccc}
\mathrm{H} & \mathrm{F} \\
\mathrm{I} & 1 \\
\mathrm{C}-\mathrm{C}- & - \\
\mathrm{I} & 1 \\
\mathrm{H} & \mathrm{F}
\end{array}\right)_{2}\right]
$$

\section{PHYSICAL PROPERTIES}

Physical state: rubbery solid

Color: white

At. comp. : $\left(\mathrm{C}_{5} \mathrm{H}_{3.5^{\mathrm{F}}} 6.5\right)_{\mathrm{n}}$

MW: $(187.08)_{n}$

Density $\left(\mathrm{g} / \mathrm{cm}^{3}\right):$ TMD :

Nominal : 1.815

m.p. $\left({ }^{\circ} \mathrm{C}(\mathrm{K})\right)$ :

b.p. $\left({ }^{\circ} \mathrm{C}(\mathrm{K})\right)$ :

v.p. $(\mathrm{mm} \mathrm{H} \mathrm{g}(\mathrm{Pa}))$ :

Brittle point $\left({ }^{\circ} \mathrm{C}(\mathrm{K})\right)$ :

f.p. $\left({ }^{\circ} \mathrm{C}(\mathrm{K})\right)$ :

\begin{tabular}{|l|l}
\hline 5. CHEMICAL PROPERTIES & T. \\
\hline $\mathrm{H}_{f}(\mathrm{kcal} / \mathrm{mol}(\mathrm{kJ} / \mathrm{mol})):-332.7(-1392)$ & \\
Solubility (s-sol., sl-sl. sol., i-insol.) : \\
s- acetone, MEK, MIBK, n-butyl acetate, THF
\end{tabular}

Crystal data :

$R$ :

n :

Shore hardness : A 40-60 (71 cured)

7. MECHANICAL PROPERTIES

Tensile strength ( $p s i(\mathrm{kPa}))$ :

Elongation $(\%)$ :

10. ELECTRICAL PROPERTIES

$\epsilon: \quad(\rho=$

II. TOXICITY

$\mathrm{T}_{\mathrm{g}}\left({ }^{\circ} \mathrm{F}(\mathrm{K})\right):-27^{\circ} \mathrm{C}(246 \mathrm{~K})$

$C_{p}\left(\mathrm{cal} / \mathrm{g}-{ }^{\circ} \mathrm{C}(\mathrm{kJ} / \mathrm{kg}-\mathrm{K})\right): 0.35(1.464)$

NOTES 


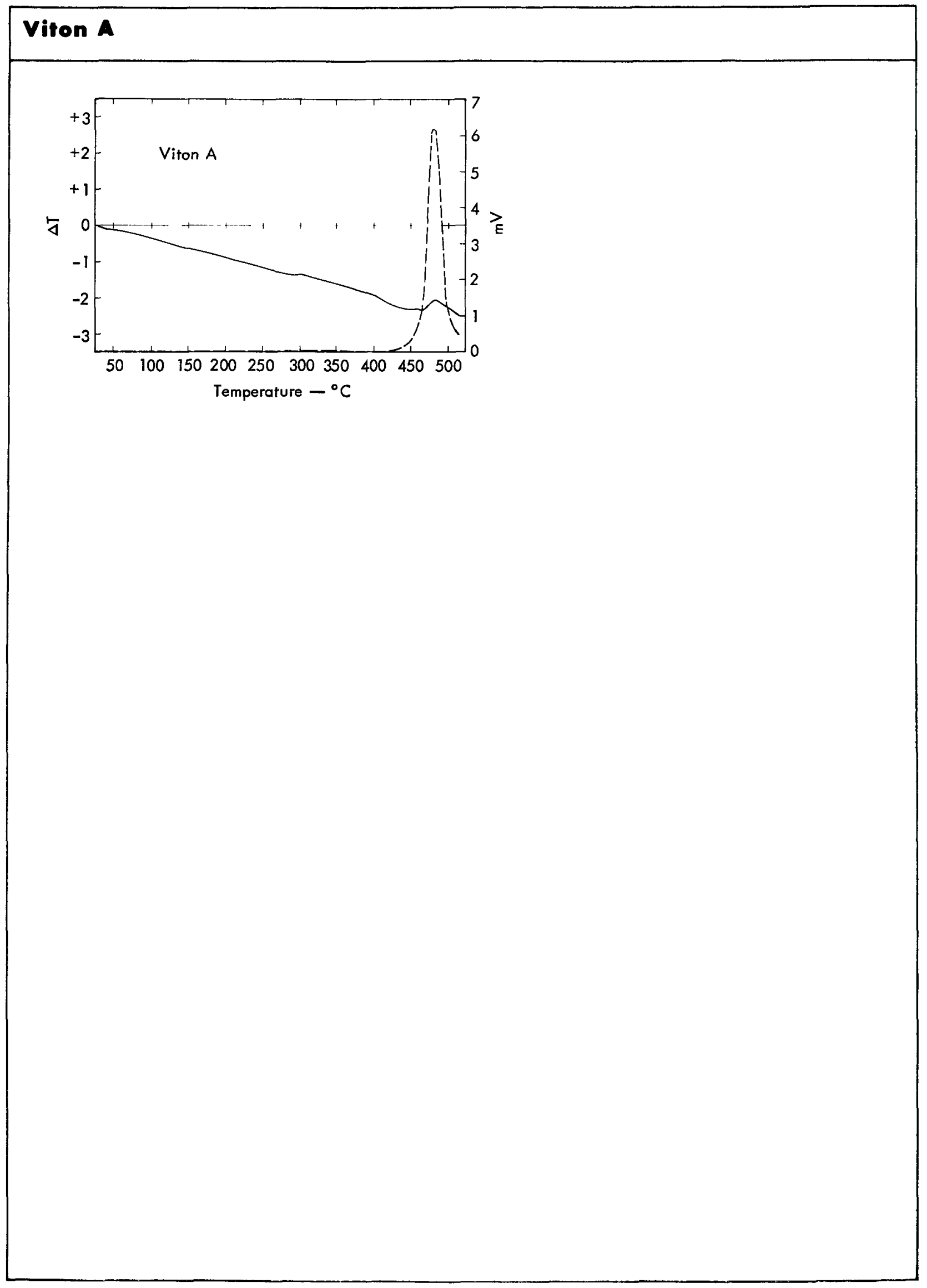

18-106

, GPO

$7 / 74$ 


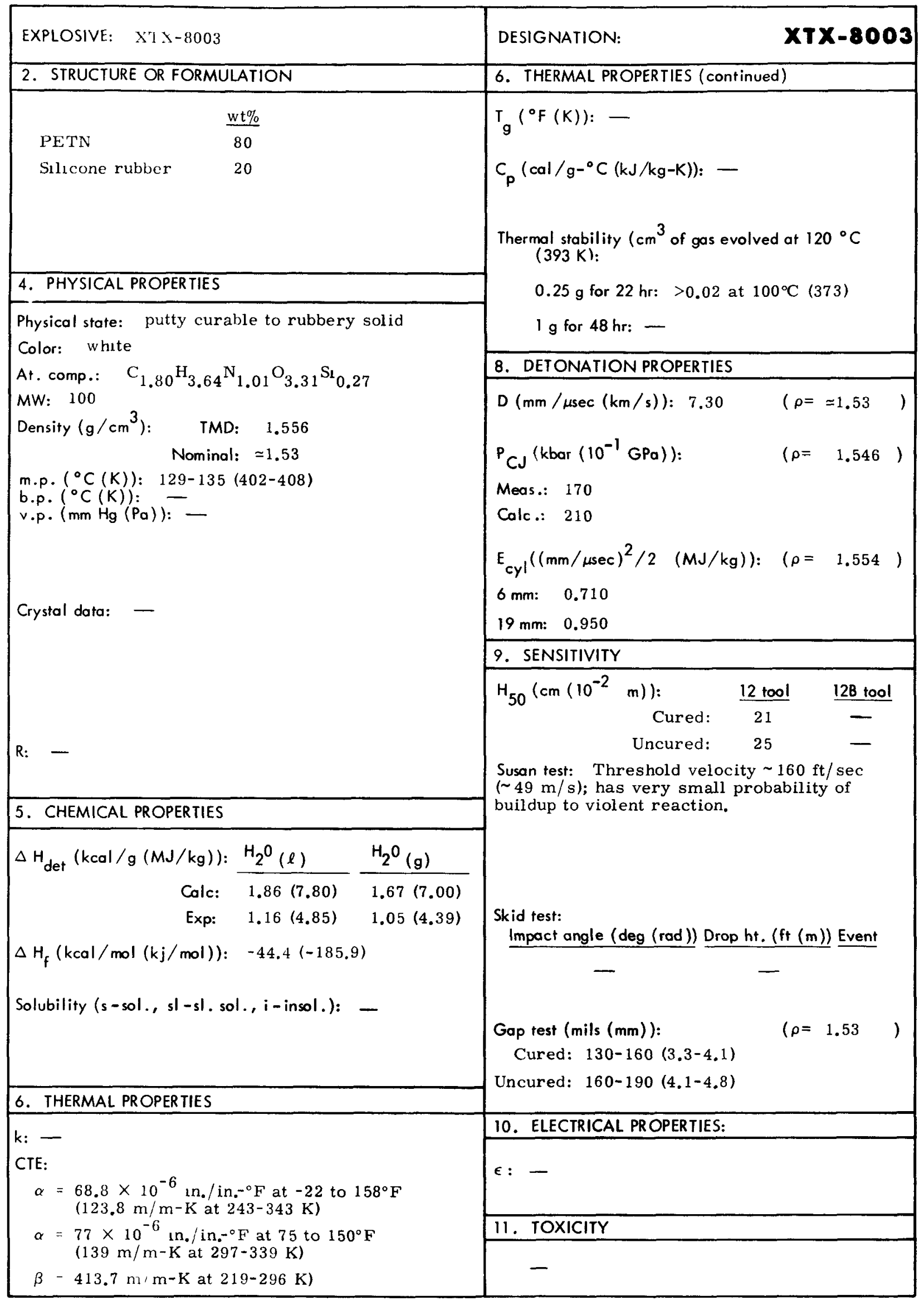




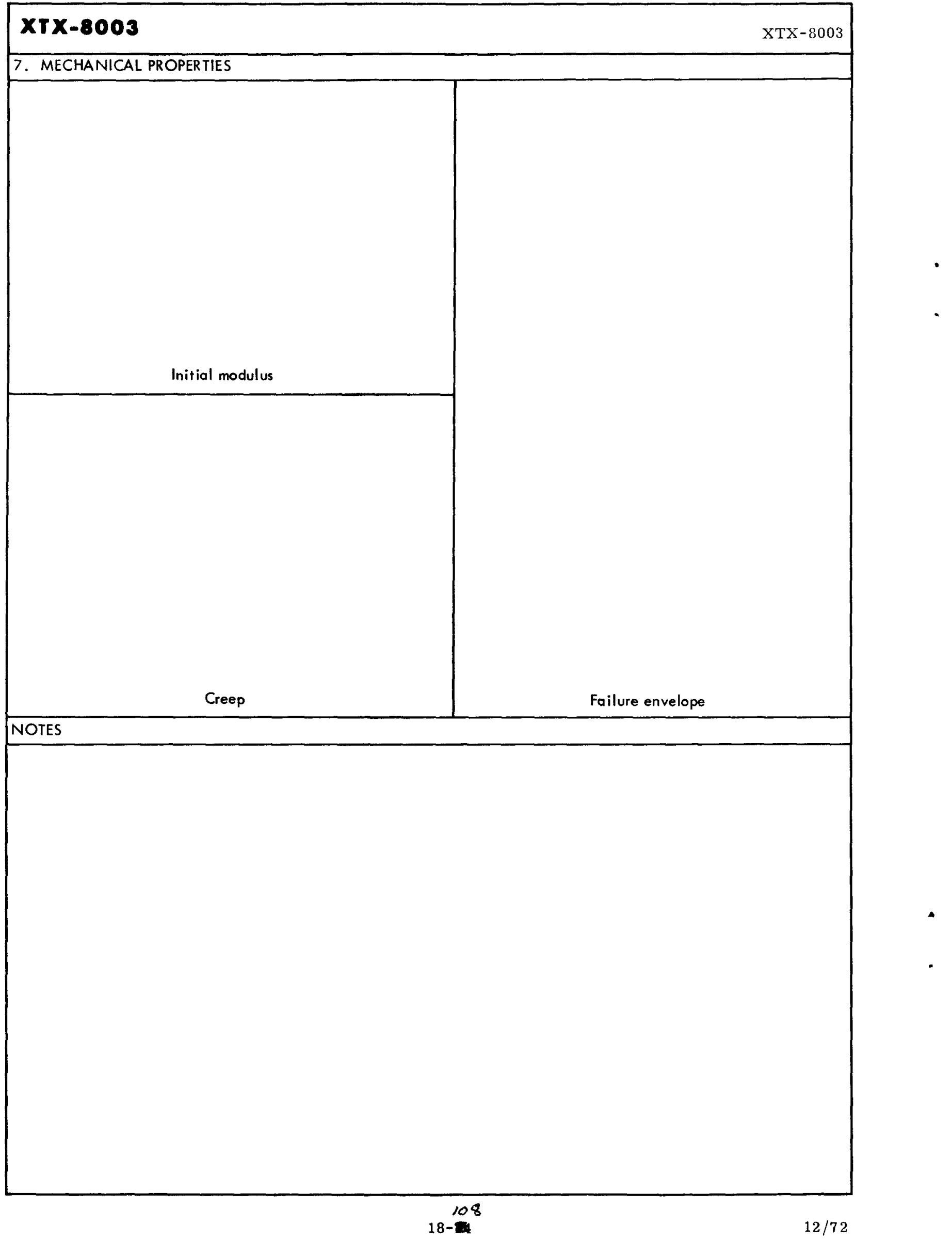




\title{
V. Bibliography
}

\author{
CHEMICAL ANALYSIS
}

Anderson, D. M., F. B. Kistner, and M. J. Schwarz, The Mass Spectra of Volatile Constituents in Military Explosives, Cold Regions Research and Engineering Lab., Hanover, N. H. , Final Rept. AD-699325 (1969).

Chasan, D. E., and G. Norwitz, Qualitative Analysis of Primers, Tracers, Igniters, Incendiaries, Boosters, and Delay Compositions on a Micro Scale by Use of Infrared Spectroscopy, Department of the Army, Frankford Arsenal, Philadelphia, Pa., Rept. T-71-6-1 (AD-729337) (1971).

Crossman, G. L., and W. Selig, A Rapid Determination of Tris(chloroethylphthalate) in PBX-9404 Explosive, Lawrence Livermore Laboratory, Rept. UCID-15444 (1969).

Doali, J. O. and A.A. Juhasz, High Speed Liquid Chromatographic Separations of Thermally Labile High Energy Compounds. Part I. Application of High Speed Liquid Chromatography to the Qualitative Analysis of Compounds of Propellant and Explosives Interest, Ballistic Research Laboratories, Aberdeen, Md., Rept. BRL-1644 (1973).

Hoffsommer, J.C., and J. M. Rosen, U1tramicroanalysis of Explosives in Seawater, U. S. Naval Ordnance Lab., White Oak, Md., NOL-TR-71-151, AD-730444 (1971).

Jenkins, R., and H. J. Gallop, "The Identification of Explosives in Trace Quantities on Objects near an Explosion," Explosivstoffe 18, 139-141 (1970).

Kegler, W., and D. Grune, Determining the Synthetic Content of Explosive Synthetic Mixtures, Institut Franco-Allemand de Recherches, St. Louis, France, Rept. ISL-N-8/67 (1967). (In German.)

Norwitz, G., Spectrophotometric Determination of Sulfate in Propellants and Nitrocellulose, U.S. Dept of the Army, Frankford Arsenal, Philadelphia, Pa., Rept. FA-TR-T-70-10-1 (1970).

Pristera, F. and W. E. Fredericks, Compilation of Infrared Spectra of Ingredients of Propellants and Explosives, Picatinny Arsenal, Dover, N.J., Rept. PA-TM-1887 (AD-859846) (1969).

Schubert, H., F. Volk, and H. Roszinski, "Analytical Study of RDX-HMX Mixtures," Explosivstoffe 14, 265-273 (1966).

Selig, W. . Some Analytical Methods for Explosives and Explosive Simulants, Lawrence Livermore Laboratory, Rept. UCRL-7873 (1964); Pt. 2 (1965); Pt.3 (1969); Pt. 4 (1973).

Selig, W., The Analysis of FEFO in Plastic-Bonded Explosives, Lawrence Livermore Laboratory, Rept. UCID-5118 (1966). 
Selig, W., Fluorine Analysis of Plastic-Bonded Explosives and Plastics, Fresenius Z. Anal. Chem. 234, 261-269 (1968).

Selig, W., The Semimicro Determination of Fluorine in Plastic-Bonded Explosives, Lawrence Livermore Laboratory, Rept. UCD-15074 (1967).

Selig, W., The Analysis of Cyclomethylenetetranitramine (HMX) and Ammonium Perchlorate in Plastic-Bonded Explosives, Lawrence Livermore Laboratory, Rept. UCID-15173 (1967).

Selig, W., The Infrared Determination of Poly(2,2,-dinitropropyl Acrylate) in LX-09, Lawrence Livermore Laboratory, Rept. UCID-15202 (1967).

Selig, W., The Analysis of 1,3,5,7-Tetranitro-1,3,5,7-tetrazacyclooctane (HMX) and Potassium Perchlorate in Plastic-Bonded Explosives, Lawrence Livermore Laboratory, Rept. UCID-15208 (1967).

Selig, W., The Analysis of the Explosive LX-09-0, Lawrence Livermore Laboratory, Rept. UCID-15330 (1968).

Selig, W. , The Analysis of Bis(2,2-dinitro-2-fluoroethyl) Formal (FEFO) in LX-09-0, Lawrence Livermore Laboratory, Rept. UCID-15452 (1969).

Selig, W., "Microdetermination of Chloride and Azide by Sequential Titration," Mikrochim. Acta 1971, 46-53 (1971).

Snell, F. D., and L. S. Ehre, Eds., Encyclopedia of Industrial Chemical Analys is (Interscience, New York, 1971), Vol. 12, pp. 405-471.

Wright, I., "The Rapid Micro Combustion Determination of Carbon, Hydrogen, and Nitrogen in High Explosives," Explosivstoffe 16, 176-178 (1968). 
Agard Combustion and Combustion Panel, The Chemistry of Propellants (Pergamon Press, London, 1959).

Alder, B., S. Fernbach, and M. Rotenberg, Methods in Computational Physics, Vol. 3 of Fundamental Methods in Hydrodynamics, Academic Press, New York, 1964).

Altshuler, L.V., "Use of Shock Waves in High-Pressure Physics," Sov. Phys.-Uspekhi 8, 52-91 (1965).

Andreev, K. K., and A. F. Belyaev, Theory of Explosive Substances, Transl. AD-643597 (1966).

Army Materiel Command, Principles of Explosives Behavior, U.S. Army Materiel Command, Rept. AMCP-706-180 (1972).

Army Materiel Command, Properties of Explosives of Military Interest, U. S. Army Materiel Command, Rept. AMCP-706-177 (1967). (Supersedes W. R. Tomlinson, Jr., Picatinny Arsenal Rept. PA-TR-1740 (1958)).

Ascani, D. C., "Literature of Explosives," in Advances in Chemistry Ser. . No. 78, pp. 565-580 (1968).

Avanesov, D. S., Manual of Physical and Chemical Testing of Explosives, Gosndarstvennoe Izdatel. Oboron. Promyshl. (Transl. by H. G. Condor, U. K. Atomic Energy Authority, Rept. AWRE-TRANS-30 (1962)).

Beach, N. E., M. C. St. Cyr, and V. K. Canfield, Compatibility of Explosives with Polymers I Picatinny Arsenal, Dover, N. J., Rept. PA-TR-2595 (AD-207076, PB-168175, 1959).

Beach, N. E., M. C. St. Cyr, and V.K. Canfield, Compatibility of Explosives with Polymers II, Picatinny Arsenal, Dover, N. J., Plastec Rept. 33 (AD-672061) (1968).

Beach, N. E., M. C. St. Cyr, and V. K. Canfield, Compatibility of Explosives with Polymers III Picatinny Arsenal, Dover, N. J., Plastec Rept. 40 (AD-721004) (1971).

Bebie, J., Manual of Explosives, Military Pyrotechnics, and Chemical Warfare Agents, (MacMillan, New York, 1943).

Berger, J., and J. Viard, Physics of Solid Explosives (Dunod, Paris, 1962). (In French.)

Bowden, F. P., and A. D. Yoffe, Fast Reactions in Solids (Butterworths, London, 1858).

Bradley, J. N., Flame and Combustion Phenomena (Methuen, London, 1969).

Bradley, J. N., Shock Waves in Chemistry and Physics (Wiley, London, 1962).

Bradley, R. S., High Pressure Physics and Chemistry, Vols. 1 and 2 (Academic Press, New York, 1963).

Coates, A. D., E. Freedman, and L. P. Kuhn, Characteristics of Certain Military Explosives, Ballistic Research Laboratories, Aberdeen Proving Ground, Md., Rept. BRL-1507 (1970).

Cook, M. A., The Science of High Explosives (Reinhold, New York, 1958). 
Cook, S. G., J. M. Rosen, and C. N. Bernstein, Manual for Ammunition Quality Evaluation Surveillance Laboratories (U. S. Naval Powder Factory, Indian Head, Md., 1964).

Combustion Institute, Symposium on Combustion, Vols. 1- (Academic Press, New York, 1929-).

Davis, T. L., The Chemistry of Powder and Explosives (Wiley, New York, 1953).

Department of the Army, Military Explosives, Dept. of the Army, Rept. TM-9-1910 (1955). (Identical to Dept. of Air Force Rept. TO-11-A-1-34).

Dunston, I., "Chemistry in the Technology of Explosives and Propellants," Chem. in Britain 7, 62-79 (1971).

DuPont De Nemours, E. I., and Company, Blasters Handbook, 15th ed., (E. I. DuPont De Nemours and Company, Wilmington, Del., 1967).

Elban, W. L., Development of Inert Simulants for Castable Plastic Bonded Explosives, U.S. Naval Ordnance Laboratory, White Oak, Md., Rept. NOL-TR-71-192 (1971).

Ellern, H., Military and Civilian Pyrotechnics (Chemical Publishing Company, New York, 1968).

Ellern, H., Modern Pyrotechnics (Chemical Publishing Company, New York, 1961).

Evans, B. L., A. D. Yoffe, and P. Gray, "Physics and Chemistry of the Organic Azides," Chem. Rev. 59, 515-568 (1959).

Fedoroff, B. T., Encyclopedia of Explosives and Related Items, Vols. 1- (Picatinny Arsenal, Dover, N. J., 1960-).

Fordham, S., High Explosives and Propellants (Pergamon Press, New York, 1966).

Frank-Kamenetskii, D. A., Diffusion and Heat Exchange in Chemical Kinetics (Plenum Press, New York, 1969).

Hammann, S. D., "The Use of Explosions in High Pressure Research," Rev. Pure Appl. Chem. 10, 139-168 (1960).

Hammer, W., Explosions and Explosives, Norton Air Force Base, Calif., Rept. AD-839310 (1968).

Hayes, T. J., Elements of Ordnance-A Textbook for Use of Cadets of the United States Military Academy (Wiley, New York, 1938).

Jacobs, S. J., "Recent Advances in Condensed Media Detonations," Am. Rocket Soc. J. 30, 151-158 (1960).

Jaffe, B., A Primer on Ferroelectricity and Piezoelectric Ceramics (Clevite Corporation, Cleveland, Ohio, 1960).

Johansson, C. H., and P.A. Persson, Detonics of High Explosives (Academic Press, New York, 1970).

Kantz, M. R., Pentaerythritol Tetranitrate: A Bibliography, Mound Laboratory, Miamisburg, Ohio, Rept. MLM-1252 (1965).

Khitrin, L. N., Physics of Combustion and Explosion (National Science Foundation, Washington, D. C. , 1962).

Kirk-Othmer Encyclopedia of Chemical Technology, 2nd ed., Vol. 8, pp. 581-719 (Interscience, New York, 1965). 
Levich, V.G., Physicochemical Hydrodynamics (Prentice-Hall, Englewood Cliffs, N. J., 1962).

Lewis, B. T., and G. Von Elbe, Combustion, Flames, and Explosions of Gases, 2nd ed. (Academic Press, New York, 1961).

Arthur D. Little, Inc., Punch Card Recording of Data on Explosives, Final Report 1961, AD-275022, AD-275023, AD-275024, AD-329073, Vols. 1-4 (1961). (Vol. 2 CDI).

Mason, C. M., and E. G. Aiken, Methods for Evaluating Explosives and Hazardous Materials, Pittsburgh Mining and Safety Research Center, Bureau of Mines, Pittsburgh, Pa., Rept. BM-IC-8541 (1972).

McGarry, W. F., and T.W. Stevens, Detonation Rates of the More Important Military Explosives at Several Different Temperatures (Picatinny Arsenal, Dover, N. J., 1956).

Marshall, A., Explosives, Vols. 1-3 (Churchill, London, Vols. 1, 2, 1917, Vol. 3, 1932).

Muraour, H., Poudres et Explosifs (Presses Universitaires de France, 1947). (In French.)

Office of Naval Research, Symposium on Detonation, No. 1-, Office of Naval Research, Arlington, Va. (1951, 1955, 1960, 1965, 1970-). (Some volumes are classified.)

Ordnance Technical Intelligence Agency, Encyclopedia of Explosives, Ordnance Technical Intelligence Agency, Durham, N. C., Rept. AD-274026 (1960).

Orlova, Y. Y., The Chemistry and Technology of High Explosives (Moscow, 1960).

Paushkin, Y. M., The Chemistry of Reaction Fuels, Transl., Foreign Technology Division Air Force Systems Command, Wright-Patterson Air Force Base, Ohio (1962).

Pokrovskiy, G. I., The Explosion and Its Utilization (Moscow, 1910; Joint Publications Research Service, Washington, D. C., 1960).

Porzel, F.B., A.Unified Theory of Explosions (UTE), U.S. Naval Ordnance Laboratory, White Oak, Md., Rept. NOL-TR-72-209 (AD-758000) (1972).

Ribaud, G., Detonation Waves (Centre National des Recherches Scientifiques, Paris, France, 1962). (In French.)

Rogers, J. T., Physical and Chemical Properties of RDX and HIXX, Holston Defense Corporation, Kingston, Tenn., Rept. HD-20-P-26 (1962).

Rosen, J. M., and C. Dickenson, Vapor Pressures and Heats of Sublimation of Some High Melting Organic Explosives, U.S. Naval Ordnance Laboratory, White Oak, Md., Rept. NOL-TR-69-67 (1969).

Tavernier, P., Powders and Explosives (Presses Universitaires de France, 1969). (In French.)

Urbanski, T., Chemistry and Technology of Explosives, Vols, 1-3 (McMillan, New York, 1964-1967). 
Urbanski, T., ed., Nitro Compounds (McMillan, New York, 1964).

Walbrecht, E. E., Dielectric Properties of Some Common High Explosives, Picatinny Arsenal, Dover, N. J., Rept. PA-TM-1170 (1963).

Warren, F.A., Rocket Propellants (Reinhold, New York, 1958).

Weich, R. E., Fundamentals of Rocket Propulsion (Reinhold, New York, 1960).

Zaehringer, A. J., "Solid Propellant Bibliography," Jet Propulsion 27, 900-927 (1957).

Zeldovich, Ya. B., "On the Theory of Combustion of Powder and Explosives," $\mathrm{Zh}$.

Eksper. Teoret. Fiz. 12, 498-524 (1942); transl. PA-TM-1597, AD-486286. 
Armed Services Explosives Safety Board, Explosives Safety Seminars, Minutes (Armed Services Explosives Safety Board, Washington, D. C., 1958-).

Cohen, E., Ed., "Prevention of and Protection against Accidental Explosion of Munitions, Fuels and Other Hazardous Materials," Ann. N. Y. Acad. Sci. 152, $1-913$ (1968).

Cook, M. A., "Explosives and the Hazards and Testing of Explosives," Ind. Eng. Chem. 56 (2), 31-35 (1964).

Deichmann, W. B., and H. W. Gerarde, Toxicity of Drugs and Chemicals (Academic Press, New York, 1969).

Dodrill, J. P., C. E. Green, J. F. Hester, and C. R. Wells, An Evaluation of Safety Devices for Laboratories Handling Explosive Compounds, Redstone Arsenal Branch, Rohm and Haas, Huntsville, Ala. (1961).

Hallam, J. S., and K. J. Scribner, Explosion during Pressing of LX-04-1 at Site 300 on October 17, 1968, Lawrence Livermore Laboratory, Rept. UCRL-50567 (1969).

Hanna, H. A., and J. R. Polson, Investigation of Static Electrical Phenomena in Lead Azide Handling, Mason and Hanger, Silas Mason Co., Inc. Burlington AEC Plant, Burlington, Iowa, Rept. IAAP-TR-98-A (1967).

Mason and Hanger, Silas Mason Co., Inc., Recommended Safe Handling Methods for Plastic Bonded Explosives 9010 and 9404 (1961).

McGill, R., Explosives, Propellants, and Pyrotechnic Safety Covering Laboratory, Pilot Plant and Production Operations, U. S. Naval Ordnance Lab., White Oak, Md., Rept. NOL-TR-61-138 (AD-272424) (1962).

McNamara, B. P., H. P. Averill, E. J. Owens, J. F. Callaghan, D. G. Fairchild, H. P. Ciuchta, R. H. Rengstorff, and R. K. Biskup, The Toxicology of Cyclotrimethylenetrinitramine (RDX) and Cyclotetramethylenetetranitramine (HMX) Solutions in Dimethylsulfoxide (DMSO), Cyclohexanone, and Acetone, Edgewood Arsenal, Md. (1970).

Picatinny Arsenal, Manual for Design of Protective Structures Used in Explosive Processing and Storage Facilities, Picatinny Arsenal, Dover, N. J., Rept. AD-834465 (1968).

Pryde, A. W., and I. Dunston, "Processing of Dangerous Chemicals," Chem. Ind. (London) 1972 (2), 67-69 (1972).

Sax, N. I. , Dangerous Properties of Industrial Materials (Reinhold Publishing Company, 1968).

Sensitiveness Collaboration Committee, Explosives Hazard Assessment, U. K. Explosives Research and Development Establishment, Waltham Abbey, Essex, Rept. SCC-3 (1969). 
Skaar, K. S. , Fundamentals of Safety for Processing, Handling, and Storage of HighEnergy Materials, U.S. Naval Ordnance Testing Station, China Lake, Calif., Rept. NOTS-TP-2866 (1962).

Sunshine, I., Ed., Handbook of Analytical Toxicology (The Chemical Rubber Company, Cleveland, Ohio, 1969). 


\section{INITIATION AND SENSITIVITY}

Africano, A., Maximum Rate Theory of Impact Sensitivity (Space Technology Laboratories, Inc., Los Angeles, 1959).

Barbarisi, M. J., and E. G. Kessler, Initiation of Secondary Explosives by Means of Laser Radiation, Picatinny Arsenal, Dover, N.J., Rept. PA-TR-3861 (AD-688585) (1969).

Bowden, F. P., discussion leader, "A Discussion of the Initiation and Growth of Explosions in Solids," Proc. Roy. Soc. (London) A246, 145-297 (1958).

Bowden, F. P., and A.D. Yoffe, Initiation and Growth of Explosions in Liquids and Solids (Cambridge University Press, Cambridge, 1952).

Brownlee, K. A., J. L. Hodges, and M. Rosenblatt, "The Up-and-Down Method with Small Samples," J. Am. Statist. Assoc. $\underline{43}, 262-277$ (1953).

Campbell, A. W., W. C. Davis, and J. R. Travis, "Shock Initiation of Detonation in Liquid Explosives," Phys. Fluids 4, 498-510 (1961).

Campbell, A. W., W. C. Davis, J. B. Ramsey, and J. R. Travis, "Shock Initiation of Solid Explosives," Phys. Fluids 4, 511-521 (1961).

Chaiken, R. F., "Comments on Hypervelocity Wave Phenomena in Condensed Explosives," J. Chem. Phys, 33, 760-761 (1960).

Chase, W.E., and H. K. Moore, eds., Exploding Wires, Vols. 1- (Plenum Press, New York, 1959-).

Clear, A. J., Standard Laboratory Procedures for Determining Sensitivity, Brisance, and Stability of Explosives, Picatinny Arsenal, Dover, N. J., Rept. PA-TR-3278 (1965).

Dixon, W. J., and F. J. Massey, Introduction to Statistical Analysis, 2nd ed., (McGrawHill, New York, 1957).

Dorough, G. D., L. G. Green, and D. T. Gray, The Susan Test for Evaluating the Impact Safety of Explosive Materials, Lawrence Livermore Laboratory, Rept. UCRL-7394 (1965).

Enig, J. W., and F. T. Metcalf, Theoretical Calculations on the Shock Initiation of Liquid TNT, U.S. Naval Ordnance Laboratory, White Oak, Md., Rept. NOLTR-62-159 (1962).

Evans, M. W., "Detonation Sensitivity and Failure Diameter in Homogeneous Condensed Materials," J. Chem. Phys. 36, 193-200 (1962).

Grant, R. L. , A Combination Statistical Design for Sensitivity Testing, U. S. Bureau of Mines, Pittsburgh, Pa., Rept. BM-IC-8324 (1967).

Green, L. G., and G. D. Dorough, "Further Studies on the Ignition of Explosives," in Proc. 4th Symp. (Intern.) on Detonation, U.S. Office of Naval Research, Washington, D.C., Rept. ACR-126 (1965), pp. 477-486. 
Green, L. G., R. J. Wasley, and P. E. Kramer, Shock Initiation of LX-04-1 and LX-09-0, Lawrence Livermore Laboratory, Rept. UCRL-50672 (1969).

Green, L. G., R. J. Wasley, and P. E. Kramer, Shock Initiation of LX-07-2 and LX-10-0, Lawrence Livermore Laboratory, Rept. UCRL-50851 (1970).

Green, L. G. , and A. M. Weston, Data Analysis of the Reaction Behavior of Explosive Materials Subjected to Susan Test Impacts, Lawrence Livermore Laboratory, Rept. UCRL-13480 (1970).

Green, L. G., A. M. Weston, and J. H. Van Velkinburg, Mechanical Behavior of Hemispherical Billets of Plastic-Bonded Explosives Vertically Dropped on a Smooth, Rigid, Steel Target Surface, Lawrence Livermore Laboratory, Rept. UCRL-51022 (1971).

Green, L. G., A. M. Weston, and J. H. Van Velkinburg, Mechanical and Frictional Behavior of Skid Test Hemispherical Billets, Lawrence Livermore Laboratory, Rept. UCRL-51085 (1971).

Hubbard, H. W., and M. H. Johnson, "Initiation of Detonation," J. Appl. Phys. $\underline{30}$, 765-769 (1959).

Jaffe, I., G. Roberson, and J. Toscana, Calibration for the Gap Test with a Pentolite Donor, U.S. Naval Ordnance Laboratory, White Oak, Md., Rept. NOL-TR-63-19 (1963).

Jones, M. M., and H. J. Jackson, "Heat Sensitization of Explosives," Explosivstoffe 7, 177-183 (1959).

Liddiard, T. P., and D. Price, Recalibration of the Standard Card-Gap Test, U. S. Naval Ordnance Laboratory, White Oak, Md., Rept. NOL-TR-65-43 (1965).

Lindstrom, I. E., "The Planar Shock Initiation of Porous Tetryl,: J. Appl. Phys. 41, $337-350$ (1970).

Macek, A., "Sensitivity of Explosives," Chem. Rev. 62, 41-63 (1962).

Mader, C., A Hydrodynamic Hot Spot Calculation, Los Alamos Scientific Laboratory, N. Mex., Rept. LA-2703 (1962).

Mason, C. M., R.W. Van Dolah, and M. L. Weiss, Drop Weight Testing of Explosive Liquids, Explosives Research Center, U.S. Bureau of Mines, Pittsburgh, Pa., Rept. BM-RI-6799 (1966).

Napadensky, H. , Experimental Studies of the Effects of Impact Loading on PlasticBonded Explosive Materials, Armour Research Foundation, Ilinois Institute of Technology, Chicago, Ill., Rept. DASA-1391 (1963).

Price, D., and T. P. Liddiard, Jr., The Small Scale Gap Test-Calibration and Comparison with the Large Scale Gap Test, U.S. Naval Ordnance Laboratory, White Oak, Md., Rept. NOL-TR-66-87 (AD-487353) (1966). 
Schimmel, M. L., QUEST-Quantitative Understanding of Explosive Stimulus Transfer, Summary Report-Task 1 through 6, McDonnell Aircraft Company, St. Louis, Mo., Rept. MDC-A-1021 (1971).

Sensitiveness Collaboration Committee, Manual of Explosive Safety Certificate Sensi-

tiveness Tests, U. K. Explosives Research and Development Establishment, Waltham Abbey, Essex, Rept. WAC-158-06 with suppl., WAE-325-03 with suppl. (1963).

Slade, D. C., and J. Dewey, High Order Initiation of Two Military Explosives, Ballistic Research Laboratories, Aberdeen Proving Ground, Md., Rept. BRL-1021 (1957).

Statistical Research Group, Princeton University, Statistical Analysis for a New Procedure in Sensitivity Experiments, Naval Defense Research Committee, Office of Scientific Research and Development, Washington, Rept. OSRD-4040 (1944).

Tucker, T. J., "Spark Initiation Requirements of a Secondary Explosive," Ann. N. Y. Acad, Sci. 152, 643-653 (1968).

Walker, F. E., and R. J. Wasley, "Critical Energy for Shock Initiation of Heterogeneous Explosives," Explosivstoffe 17, 9-13 (1969).

Walker, F.E., and R. J. Wasley, "Initiation of Nitromethane with Relatively LongDuration, Low-Amplitude Shock Waves," Combust. Flame 15, 233-246 (1970). 
Archibald, P. B., "Isostatic Solvent Pressing," Ind. Eng. Chem. 53, 737-738 (1961).

Bryden, J. H., The Density of Crystalline Cyclotetramethylenetetranitramine (HMX), U.S. Naval Ordnance Test Station, China Lake, Calif., Rept. NOTS-1652, (NAVORD-5398) (1957).

Goldsmith, W., and T. A. Reitter, Static and Dynamic Properties of Two Explosive Materials, U.S. Naval Weapons Center, China Lake, Calif., Rept. NWC-TP4805, (AD-864750) (1970).

Hamstad, M. A., Complex Shear Modulus of a High Explosive, Lawrence Livermore Laboratory, Rept. UCRL-50357 (1967).

Hoge, K. G. , Friction and Wear of Explosive Materials, Lawrence Livermore Laboratory, Rept. UCRL-50134 (1966).

Hoge, K. G., "The Behavior of Plastic-Bonded Explosives under Dynamic Compressive Loads," in Appl. Polymer Symp. 5, 19-40 (1967).

Hoge, K. G., "Friction and Viscoelastic Properties of Highly Filled Polymers-PlasticBonded Explosives," 4th Southeastern Conf, on Theoretical and Applied Mechanics, New Orleans, Feb. 29-Mar. 1, 1968.

Murray, R. C., and W. G. Moen, The Linear Viscoelastic Response of LX-07-1, Lawrence Livermore Laboratory, Rept. UCRL-50751 (1969).

Murray, R. C., and R. Jaeger, Mechanical Properties Testing of High Explosives, Lawrence Livermore Laboratory, Rept. (16-mm color sound film (1969)).

Scribner, K., A Physical Properties Mock for LX-04-1, Lawrence Livermore Laboratory, Rept. UCID-15495 (1965).

Wasley, R. J., and F.E. Walker, "Dynamic Compressive Rheological Behavior of a Brittle, Strain Rate Sensitive, Polycrystalline, Organic Solid," J. Appl Phys. $\underline{40}$, 2639-2648 (1969).

Wasley, R. J., and F.E. Walker, A Method for the Numerical Analysis of Pressure Transducer Records, Lawrence Livermore Laboratory, Rept. UCRL-50233 (1967).

Wasley, R. J., K. G. Hoge, and J. C. Cast, "Combined Strain Gauge-Quartz Crystal Instrumented Hopkinson Split Bar," Rev. Sci. Instr. 40, 889-894 (1969).

Wilkins, M. L., and R. Giroux, The Calculation of Stress Waves in Solids, Lawrence Livermore Laboratory, Rept. UCRL-7271 (1963). 


\section{PERFORMANCE}

Adler, J., and J.W. Enig, The Critical Conditions in Thermal Explosions Theory for Nth Order Reactions, U. S. Naval Ordnance Laboratory, White Oak, Md., Rept. NOL-TR-64-180 (1964).

Brinkley, S. R., and E. B. Wilson, Revised Method of Predicting the Detonation Velocities in Solid Explosives, Office of Scientific Research and Development, National Defense Research Committee, Washington, D. C., Rept. OSRD-905 (1942).

Burnham, M. W. Investigation of Flow Kinematics of Detonating Explosive Slabs, Falcon Research Corp., Denver, Colo., Rept. AFATL-TR-67-33 (1967).

Burnham, M. W., Research on Detonation Wave Mechanics, Falcon Research Corp., Denver, Colo., Rept. ARL-TR-66-2 (1966).

Campbell, A. W., M. E. Malin, T. J. Boyd, Jr., and J. A. Hull, "Precision Measurement of Detonation Velocities in Liquid and Solid Explosives," Rev. Sci. Instr. 27. 567-574 (1956).

Catalano, E., and H. C. Hornig, Time-Resolved Emission Spectra of the Detonation Products of PETN, Lawrence Livermore Laboratory, Rept. UCRL 50328 (1967).

Christian, E. A., and H. G. Snay, Analysis of Experimental Data on Detonation Velocities, U.S. Naval Ordnance Laboratory, White Oak, Md., Rept. NAVORD-1508 (1956).

Cole, R., Underwater Explosions, Princeton University Press, Princeton, NJ (1948).

Coleburn, N. L., Chapman-Jouguet Pressures of Several Pure and Mixed Explosives, U.S. Naval Ordnance Laboratory, White Oak, Md., Rept. NOL-TR-64-58 (1964).

Cook, M. A. , Detonation Velocities of "Ideal" Explosives with Inert Additives, University of Utah, Salt Lake City, Rept. AD-16380 (1953).

Cook, M. A., Velocity-Diameter Measurements and Reaction Rates of PETN, RDX, and EDNA, University of Utah, Salt Lake City, Rept. AD-44634 (1954).

Cook, M. A., R. I. Keyes, and W. O. Ursenbach, Measurements of Shock and Detonation Pressures, University of Utah, Salt Lake City, Rept. AD-258201 (1961).

Cook, M. A., R. I. Keyes, and W. O. Ursenbach, "Measurement of Detonation Pressure," J. Appl. Phys. 33, 3413-3421 (1962).

Cowperthwaite, M., Theoretical Studies of Detonation, Final Report, February 1966-February 1971, Stanford Research Institute, Menlo Park, Calif., Rept. $\mathrm{AD}-730642$ (1971).

Courant, R., and K. O. Friedrichs, Supersonic Flow and Shock Waves (Interscience, New York, 1948).

Cowan, R. D., and W. Fickett, "Calculation of the Detonation Properties of Solid Explosives with the Kistiakowsky-Wilson Equation of State," J. Chem. Phys. 24, 932-939 (1956).

Crouch, M. R., and N. E. Hoskin, "Detonation of Explosive Slabs of Finite Dimensions," J. Appl. Phys. 42, 264-267 (1971). 
Deal, W. E., "Measurement of Chapman-Jouguet Pressure for Explosives," J. Chem. Phys. 27, 796-800 (1957).

Deal, W.E., "Measurement of Reflected Shock Hugoniot and Isentrope for Explosive Reaction Products," Phys. Fluids 1, 523-527 (1958).

Derzhavets, A.S., "Increased Susceptibility of Explosives to a Detonation Impulse," in Termostoikie Vzryvchatye Veshchestva ikh Deistvie v Glubokikh Skavzhinakh, F. A. Baum, Ed. (1969), pp. 37-52 (Transl, by H. J. Dahlby, Los Alamos Scientific Laboratory, N. Mex., Rept. LA-TR-71-32 (1971)).

Dremin, A. N., and K. K. Shvedov, "Determination of the Chapman-Jouguet Pressure and the Reaction Duration in a Shock Wave of High Power Explosives," $\mathrm{Zh}$ Priklad. Mekh Tekh. Fiz. 3, 139-144 (1964). (Transl. PA-TT-15 (AD-688247).)

Duff, R.E., and E. Houston, "Measurement of the Chapman-Jouguet Pressure and Reaction Zone Length in a Detonating High Explosive," J. Chem. Phys. 23, 1268-1273 (1955).

Enig, J.W., and F. J. Petrone, On Equations of State in Shock Initiation Problems, U.S. Naval Ordnance Laboratory, White Oak, Md., Informal Rept. (1964).

Evans, M. W., and C. M. Ablow, "Theories of Detonation," Chem, Rev. 61, 129-178 (1961).

Evans, M. W., C. M. Ablow, B. O. Reese, and A. B. Amster, Shock Sensitivity of Low Density Granular Explosives, Stanford Research Institute, Menlo Park, Calif., Rept. AD-417863 (1963).

Eyring, H., R. E. Powell, G. H. Duffy, and R. B. Parlin, "The Stability of Detonation," Chem. Rev. 45, 69-181 (1949).

Fickett, W., Detonation Properties of Condensed Explosives Calculated with an Equation of State Based on Intermolecular Potentials, Los Alamos Scientific Laboratory, N. Mex., Rept. LA-2712 (1962).

Fickett, W., and W. W. Wood, "A Detonation-Product Equation of State Obtained from Hydrodynamic Data," Phys. Fluids $1,528-534$ (1958).

Finger, M., H. C. Hornig, E. L. Lee, and J.W. Kury, "Metal Acceleration by Composite Explosives," in Proc. 5th Symp. (Intern.) on Detonation, Office of Naval Research, Arlington, Va., Rept. ACR-184 (1970), pp. 137-151.

Garn, W. B., "Detonation Pressure of Liquid TNT," J. Chem. Phys. 32, 653-655 (1960).

Gipson, R.W., and A. Macek, Transition from Slow Burning to Detonation-Flame Fronts and Compression Waves during Growth of Detonation, U. S. Naval Ordnance Laboratory, White Oak, Md., Rept. NAVORD-6759 (1959).

Goodman, H. J., Compiled Free-Air Blast Data on Bare Spherical Pentolite, Ballistic Research Laboratories, Aberdeen Proving Ground, Md., Rept. BRL-1092 (1960).

Goodman, H. J., and R. E. Shear, Pressure, Density and Internal Energy of Pentolite Explosion Products, Ballistic Research Laboratories, Aberdeen Proving Grovid, Md., Rept. BRL-1212 (1963). 
Gruschka, H. D., and F. Wecken, Gasdynamic Theory of Detonation (Gordon and Breach Science Publishers, New York, 1971).

Hauver, G. E., and P. H. Netherwood, Pressure Profiles of Detonating Baratol Measured with Sulphur Gauges, Ballistic Research Laboratories, Aberdeen Proving Ground, Md., Rept. BRL-TN-1452 (AD-276986) (1962).

Howe, P. M., Detonation Structure in Condensed Phase Explosives, Ballistic Research Laboratories, Aberdeen Proving Ground, Md., Rept. AD-713541 (1969).

Hurwitz, H., Calculation of Detonation Parameters with the RUBY Code, U. S. Naval Ordnance Laboratory, White Oak, Md., Rept. NOL-TR-63-205 (1965).

Hurwitz, H., and M. J. Kamlet, "The Chemistry of Detonations. V. A Simplified Method for Calculation of Pressures of $\mathrm{C}-\mathrm{H}-\mathrm{N}-\mathrm{O}$ Explosives on $\mathrm{K}-\mathrm{W}$ Isentrope," Israel J. Technol. 7, 431-430 (1969).

Jacobs, S. J., On the Equation of State of Compressed Liquids and Solids, U. S. Naval Ordnance Laboratory, White Oak, Md., Rept. NOL-TR-68-214 (1968).

Jacobs, S. J., "Equation of State for Detonation Products at High Density," 12th Symp. (Intern.) on Combustion, The Combustion Institute, Philadelphia, Pa. (1969), pp. 501-510.

Jacobs, S. J., T. P. Liddiard, Jr., and B. E. Drimmer, "The Shock-to-Detonation Transition in Solid Explosives," 9th Symp. (Intern.) on Combustion, The Combustion Institute, Philadelphia, Pa. (1963), pp. 499-516.

Jameson, R. L., and A. L. Hawkins, Detonation Pressure Measurements in TNT and Octol, Ballistic Research Laboratories, Aberdeen Proving Ground, Md., Rept. AD-713547 (1970).

Kamlet, M. J., and S. J. Jacobs, "The Chemistry of Detonations. I. A Simple Method for Calculating Detonation Properties of C-H-N-O Explosives," J. Chem. Phys. 48, 23-35 (1968).

Kamlet, M. J., and J. E. Ablard, "The Chemistry of Detonations, II. Buffered Equilibria," J. Chem. Phys. 48, 36-42 (1968).

Kamlet, M. J., and C. Dickinson, "The Chemistry of Detonations. III. Evaluation of the Simplified Calculational Method for Chapman-Jouguet Detonation Pressures on the Basis of Available Experimental Information," J. Chem. Phys. 48 , 43-50, (1968).

Kamlet, M. J., "The Chemistry of Detonation. IV. Evaluation of a Simple Predictional

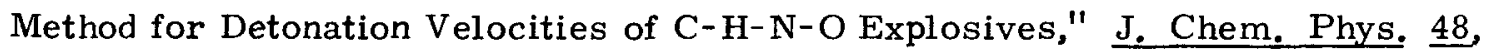
3685-3692 (1968).

Kamlet, M. J., see also H. Hurwitz.

Kandiner, H. J., and S. R. Brinkley, "Calculation of Complex Equilibrium Relations," Ind. Eng. Chem. 42, 850-855 (1949).

Kirkwood, K. G., and W.W. Wood, "Structure of a Steady-State Plane Detonation Wave with Finite Reaction Rate," J. Chem. Phys, 22, 1915-1919 (1954). 
Kury, J. W., H. C. Hornig, E. L. Lee, J. M. McDonnel, D. L. Ornellas, M. Finger, F. M. Strange, and M. L. Wilkins, "Metal Acceleration by Chemical Explosives," in 4 th Symp. (Intern.) on Detonation, U. S. Naval Ordnance Laboratory, White Oak, Md., Rept. ACR-126 (1965), pp. 3-13.

Lee, E. L., H. C. Hornig, and J. W. Kury, Adiabatic Expansion of High Explosive Detonation Products, Lawrence Livermore Laboratory, Rept. UCRL-50422 (1968).

Lee, E. L., and H. C. Hornig, "Equation of State of Detonation Product Gases," in 12th Symp. (Intern.) on Combustion, The Combustion Institute, Philadelphia, Pa. (1969), pp. 493-499.

Leger, E. G., and K. Park, A Zig-Zag Oscilloscope Presentation for Detonation Velocity Measurements in Explosives, Canadian Armament Research and Development Establishment, Rept. CARDE-TM-170-58 (1958).

Leopold, H.S., The Growth of Low Density Explosive Mixtures, U. S. Naval Ordnance Laboratory, White Oak, Md., Rept. NOL-TR-62-89 (1962).

Los Alamos Scientific Laboratory, Studies on Binders and Desensitizers (Los Alamos Scientific Laboratory, N. Mex., 1962).

Lutzky, M., The Flow Field behind a Spherical Detonation in TNT Using the LandauerStanyukovich Equation of State for Detonation Products, U. S. Naval Ordnance Laboratory, White Oak, Md., Rept. NOL-TR-64-40 (1964).

McGarry, W. F., and T.W. Stevens, Detonation Rates of the More Important Military Explosives at Several Different Temperatures, Picatinny Arsenal, Dover, N. J., Rept. PA-TR-2383 (1956).

Mader, C. L., Detonation Properties of Condensed Explosives Computed Using the Becker-Kistiakowsky-Wilson Equation of State, Los Alamos Scientific Laboratory, N. Mex., Rept. LA-2900 (1963).

Mader, C. L., FORTRAN BKW-A Code for Computing the Detonation Properties of Explosives, Los Alamos Scientific Laboratory, N. Mex., Rept. LA-3704 (1967).

Mader, C. L., The Time-Dependent Reaction Zone of Ideal Gases, Nitromethane, and Liquid TNT, Los Alamos Scientific Laboratory, N. Mex., Rept. LA-3764 (1967).

Melton, C. E., D. F. Strenzwilk, and P.D. Yedinak, Microscopic Theory of Detonation in Solids, Ballistic Research Laboratories, Aberdeen Proving Ground, Md., Rept. BRL-TN-1715 (AD-688869) (1969).

Minshall, D., "Properties of Elastic and Plastic Waves Determined by Pin Contactors and Crystals," J. Appl. Phys. 26, 463-469 (1955).

Ornellas, D. L., "Detonation Calorimeter and Results Obtained with Pentaerythritol Tetranitrate (PETN)," Rev. Sci. Instr. 37, 907-912 (1966).

Ornellas, D. L., "The Heat and Products of Detonation of Cyclotetramethylene Tetranitramine (HMX), 2,4,6-Trinitrotoluene (TNT), Nitromethane (NM), and Bis-(2, 2-dinitro-2-fluoroethyl)-formal (FEFO)," J. Phys. Chem. $\underline{72}$, 2390-2391 (1968). 
Pack, D. C., "The Reflection of a Detonation Wave at a Boundary," Phil. Mag. 2 , 182-188 (1957).

Palmer, R., Initiation of Detonation. I. Simple "Hubbard and Johnson" Model, U. K. Atomic Weapons Research Establishment, Rept. SSPD-USA-56 (1962).

Piacesi, D., Jr., Numerical Hydrodynamic Calculations of the Flow of the Detonation Products from a Point-Initiated Explosive Cylinder, U.S. Naval Ordnance Laboratory, White Oak, Md., Rept. NOL-TR-66-150 (AD-810470) (1967).

Price, D., "Dependence of Damage Effects on Detonation Parameters of Organic High Explosives," Chem. Rev. 59, 801-825 (1959).

Price, D., and F. J. Petrone, Detonation Initiated by High Pressure Loading of a Solid Explosive, U.S. Naval Ordnance, White Oak, Md., Rept. NOL-TR-63-103 (1963).

Price, D., J. F. Wehner, and G. E. Roberson, Transition from Slow Burning to Detonation - Further Studies of the Free Volume and the Low Velocity Regime in Cast Pentolite, U.S. Naval Ordnance Laboratory, White Oak, Md., Rept. NOL-TR-63-18 (1963).

Strange, F. M. , Equations of State for Six Explosives, Wm. Brobeck and Associates, Berkeley, Calif., Rept. WMBA-4500-95-2-R8 (1964).

Taylor, J., Detonation in Condensed Explosives (Oxford University Press, Oxford, 1952).

Taylor, J., "The Dynamics of the Combustion Products behind Plane and Spherical Detonation Fronts in Explosives," Proc. Roy. Soc. (London) Ser. A A200, 235-247 (1950).

Taylor, J., Solid Propellent and Exothermic Compositions (George Newnes, Ltd., London, 1959).

Taylor J., and P. F. Gay, British Coal Mining Explosives (George Newnes, Ltd., London, 1958).

Urizar, M. J., E. James, and L. C. Smith, "Detonation Velocity of Pressed TNT," Phys. Fluids $\underline{4}, 262-274$ (1961).

Villars, D.S., "A Method of Successive Approximations for Computing Combustion Equilibria on a High Speed Digital Computer," J. Am. Chem. Soc. 63, 521-525 (1959).

Von Neumann, J., and R. D. Richtmyer, "A Method for the Numerical Calculation of Hydrodynamic Shocks," J. Appl. Phys. 21, 232-237 (1950).

Walsh, J. M., and M. H. Rice, "Dynamic Compression of Liquids from Measurements on Strong Shock Waves," J. Chem. Phys. 26, 815-823 (1957).

Wasley, R. J., and R. H. Valentine, Shock Pulse Attenuation and Hugoniot Studies of One Explosive and Three Mock Explosives, Lawrence Livermore Laboratory, Livermore, Rept. UCRL-50950 (1970).

White, W. B., S. M. Johnston, and G. B. Dantzig, "Chemical Equilibrium in Complex Mixtures," J. Chem. Phys. 28, 751-755 (1958). 
Wilkins, M.L., J. French, and R. Giroux, A Computer Program for Calculating OneDimensional Hydrodynamic Flow - KO Code, Lawrence Livermore Laboratory, Rept. UCRL-6919 (1962).

Wilkins, M. L., B. Squier, and B. Halperin, The Equation of State of PBX-9404 and LX-04-1, Lawrence Livermore Laboratory, Rept. UCRL-7797 (1964).

Wilson, D. H., Hydrodynamics (Edward Arnold, Publ., London, 1959).

Wood, W. W., "Existence of Detonations for Small Values of the Rate Parameter," Phys. Fluids 4, 46-60 (1961).

Wood, W. W., "Existence of Detonations for Large Values of the Rate Parameter," Phys, Fluids 6, 1081-1090 (1963).

Wood, W. W., and J. G. Kirkwood, "Diameter Effect in Condensed Explosives - The Relation between Velocity and Radius of Curvature of the Detonation Wave," J. Chem. Phys. 22, 1920-1924 (1954).

Zeldovich, I. B., Theory of Detonation (Academic Press, New York, 1960).

Zovko, C. T. , The Mechanism of the Transition from Deflagration to Detonation in High Explosives, U.S. Naval Ordnance Laboratory, White Oak, Md., Rept: NAVWEPS-7393 (1961). 
Bolt, R. O., and G. J. Carroll, Eds., Radiation Effects on Organic Materials (Academic Press, New York, 1963).

Bowden, F. P., and H. M. Montagu-Pollock, "Slow Decomposition of Explosive Crystals and Their Damage by Fission Fragments," Nature 191, 556-559 (1961).

Cerny, J., M.S. Kirshenbaum, and R. C. Nichols, "Range-Energy Relations for Protons and Alpha-Particles in Various Explosives," Nature 198, 371-372 (1963).

Clark, D., and M. J. Daniels, The Proton Irradiation of High Explosives, U. K. Atomic Weapons Research Establishment, Aldermaston, Berks., U. K., Rept. ERN-25-64 (1964).

Dobratz, B. M. , Bibliography on Radiation Effects on Primary and Secondary Explosives and on Propellants, Lawrence Livermore Laboratory, Rept. UCID-16087 (1972).

Paitchel, J., J.E. Cockayne, R.S. Alger, R.T. Elsberry, W.B. Thomas, J. M. McSwain, J.P. Noonan, H. M. Shupp, and D. Wasler, Source Book of Radiation Effects on Propellants, Explosives and Pyrotechnics, Vol. 1, Picatinny Arsenal, Dover, N.J., Rept. DNA-2881F-1 (1974).

Ribaudo, C., J. Mallay, and H. J. Matsuguma, The Effects of Reactor Irradiation on the Chemical Characteristics of Solid Explosives, Picatinny Arsenal, Dover, N. J., Rept. PA-TR-3893 (1970).

Urizar, M. J., E. D. Loughran, and L. C. Smith, "The Effects of Nuclear Radiation on Organic Explosives," Explosivstoffe 4, 55-64 (1962). 

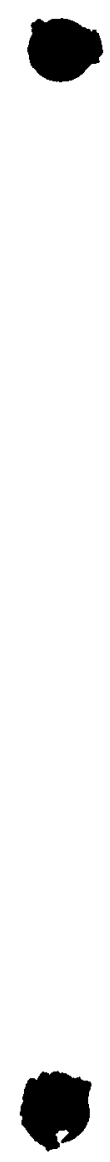

19-22 


\section{THERMAL PROPERTIES}

Andreev, K. K., Thermal Decomposition and Combustion of Explosives, 1st ed. (Moscow, 1960) (Transl. into German in Explosivstoffe (1960-1962); 2nd ed. (Moscow, 1966), Transl., Foreign Technology Div., Wright-Patterson AFB, Ohio, Transl. AD-693600 (1969)).

Aubertein, P., "Stability of Explosives," Mem. Poudr. 41, 111-125 (1959); in French (Transl. by F.E. Wallwork, U.K. Atomic Weapons Research Establishment, Aldermaston, Berks. U. K., Transl. AWRE-TRANS-24 (1961)).

Barrett, E.J., H.W. Hoyer, and A.V. Santoro, "Differential Thermal Analysis of . Rapid High Pressure Decompositions," Anal. Lett. 1, 285-289 (1968).

Buxton, R. J., and T. M. Massio, Compatibility of Explosives with Structural Materials of Interest, Sandia Laboratories, Albuquerque, N. Mex., Rept. SC-TM-70-355 (1970).

Cady, H. H., and W. H. Rogers, Enthalpy, Density and Thermal Coefficient of Cubical Expansion of TNT, Los Alamos Scientific Laboratory, N. Mex., Rept. LA-2696 (1962).

Clink, G. L., Corrosion Effects of the Interaction of 6061 Aluminum with Aqueous Mixtures and Solutions of Selected HE's, Mason and Hanger-Silas Mason Company, Inc., Pantex Plant, Amarillo, Texas, Rept. MHSMP-71-58 (1971).

Cook, M. A., and M. T. Abegg, "Isothermal Decomposition of Explosives," Ind. Eng. Chem. 48, 1090-1095 (1956).

Frazer, J.W., and K. Ernst, Chemical Reactivity Testing of Explosives, Lawrence Livermore Laboratory, Rept. UCRL-7438 (1963).

Hansson, J., Ed., Symposium on Chemical Problems Connected with Stability of Explosives, 1st, Swedish Detonic Research Foundation, Stockholm (1967); 2nd (1970): 3rd (1973).

Lee, E. L., R. H. Sanborn, and H. D. Stromberg, "Thermal Decomposition of High Explosives at Static Pressures 10-50 Kilobars," in Proc. 5th Symp. (Intern.) on Detonation, Office of Naval Research, Arlington, Va., Rept. ACR-184 (1970), pp. 331-337.

Maycock, J. N., Applications of Thermal Analysis-Explosives and Solid Propellant Ingredients (Martin-Marietta Corp./Mettler Instrument Corp. , Baltimore, Md., 1969).

Maycock, J. N., "Application of Thermal Analysis Methods to the Study of Unstable and Metastable Materials," Thermochim. Acta 4, 309-320 (1972).

Maycock, J. M., and V.R. Pai Verneker, "Characterization of Thermal and Photosublimation of Organic Explosives by Thermobarogravimetric Techniques," Thermochim. Acta 1, 191-198 (1970).

Murray, R. C., and T.E. Cooper, A Method of Measuring Thermal Diffusivity of High Explosive Materials, Lawrence Livermore Laboratory, Rept. UCRL-50827 (1970). 
Rogers, R. N., "The Simple Microscale Differential Thermal Analysis of Explosives," Microchem. J. 5, 91-99 (1961).

Rogers, R. N., S. K. Yasada, and J. Zinn, "Pyrolysis as an Analytical Tool," Anal. Chem. 32, 672-678 (1960).

Schuldt, H. S., and L. C. Myers, Time-to-Explosion Thermal Initiation Test for Explosives, Mason and Hanger-Silas Mason Company, Inc., Pantex Plant, Amarillo, Texas (1964).

Simmons, H. T., Sr., The Vacuum Thermal Stability Test for Explosives, U. S. Naval Ordnance Laboratory, White Oak, Md., Rept. NOL-TR-70-142 (1970).

Zinn, J., and C. L. Mader, "Thermal Initiation of Explosives," J. Appl. Phys. 31 , $323-328$ (1960). 


\section{Distribution}

LLL Internal Distribution

Roger E. Batzel

R. W. Anderson

C. G. Andre

P. B. Archibald

W. F. Arnold/E. R. McClure

R. H. Barlett

G. R. Baxter

C. F. Bender

W. P. Bennett

C. W. Berndt

E. R. Bissell

R. M. Boat

G. R. Bokanich

W. G. Boyle

R. D. Breithaupt

G. A. Broadman/C. R. Henry

W. L. Burden

R. I. Bystroff

R. B. Carr

J. C. Cast

E. Catalano

H. Cheung

W. E. Clements

J. P. Cramer

D. F. Cruff

v. E. Culler

J. D. Deligans

H. X. DiGrazia

G. L. Dittman

B. M. Dobratz

R. G. Dong

F. S. Eby

A. L. Edwards

R. E. Elson

R. B. Engle

K. Ernst

J. T. Ewing

D. B. Fields

M. Finger

P. G. Fleming
K. V. Fordyce

H. C. Forsberg

J. W. Frazer

J. L. Freiling

S. J. French

K. E. Froeschner

M. M. Fulk

R. Fyfe

B. L. Garner

L. S. Germain

E. Goldberg

10

H. A. Golopol

G. L. Goudreau

W. C. Grayson

L. G. Green

R. P. Guarienti

M. W. Guinan

W. A. Gummer

W. H. Gust

M. R. Gustavson

J. S. Hallam

H. G. Hammon

R. L. Heckman

F. H. Helm

G. H. Higgins

R. Henry

K. G. Hoge

B. E. Holder

A. C. Holt

A. C. Honodel

B. L. Hord

H. C. Hornig

J. R. Humphrey

W. S. Inouye

W. M. Isbell

E. James

F. W. Jessen

F. P. Johansen

C. V. Johnson III

M. Kamegai

V. N. Karpenko/C. E. Walter 
LLL Internal Distribution (continued)

R. N. Keeler

J. E. Keller

H. K. Kruger

J. W. Kury

A. Kusubov

J. K. Landauer

E. L. Lee

J. K. Lepper

W. A. Lokke

J. W. Lyle

A. Maimoni

L. L. Marino

R. L. McCleskey

C. A. McDonald

J. L. McDonnel

L. M. McGrew

W. R. McKinley

G. L. Moody

J. L. Morse

R. L. Morton

P. H. Moulthrop

J. H. Moyer

R. K. Mullins

R. C. Murray

R. C. Myers

W. B. Myers

W. E. Nelson

P. C. New comb

E. J. Nidick

D. C. Oakley

R. S. Paige

H. G. Palmer

J. M. Parker

R. K. Pearson

L. E. Peck

H. N. Perl

T. Perlman/G. B. Sabine

K. A. Peterman

H. E. Pfeifer

R. L. Remillard

G. W. Repp
H. L. Reynolds

F. Rienecker

K. H. Ristad

J. B. Robison

J. W. Routh

S. Sack

K. J. Scribner

D. L. Seaton

R. W. Seldon

W. Selig

L. L. Shaw

B. L. Shroyer

D. R. Speck

G. G. Staehle

D. J. Steinberg

J. S. Steller

E. A. Stisser

R. G. Stone

J. R. Stroud

C. A. Tatro

C. L. Teevan

J. F. Tinney

A. F. Todaro

O. A. Tveitmoe

5 P. A. Urtiew

R. E. Varosh

O. T. Vik

K. W. Volkman

R. L. Wagner

R. L. Waldron

F. E. Walker

D. H. Warner

R. J. Wasley

R. C. Weingart

H. Weiss

M. L. Wilkins

J. R. Wilson

F. R. Wondolowsky

C. D. Wood

R. J. Woodworth

D. L. Woods

D. L. Wooster 
LLL Internal Distribution (continued)

C. L. Wraith

M. Zaslawsky

TII) file

External Distribution

J. Choromokos, Jr.

Defense Nuclear Agency

Washington, D.C.

E. L. Brawley

Defense Nuclear Agency

Albuquerque, New Mexico

P. E. Koentap

G. Prassinos

Defense Nuclear Agency

Livermore, California

J. Bearden

S. Wright

Holston Army Ammunition Plant

Kingsport, Tennessee

J. Aragon

M. Brooks

A. W. Campbell

W. Deal

E. Eyster

W. Meyers

A. Popolato

R. H. Rogers

L. C. Smith

R. Spaulding

J. Travis

W. C. Davis

B. Craig

P. G. Salgado

B. Hayes

$\mathrm{T}$. Benziger

M. Urizer

W. Fickett

C. L. Mader

J. F. Barnes

Library

Los Alamos Scientific

Laboratory

Los Alamos, New Mexico

R. Holmberg

J. Polson

c. Poole

J. Kurrlee

J. Tash

Mason \& Hanger - Silas

Mason Co., Inc.

Burlington, Iowa
J. C. Drummond

J. Adams

I. Akst

R. Bailey

A. Duncan

R. Dunham

J. Higgins

L. Myers

G. Osborn

M. Ott

E. Poynor

J. Rigdon

A. Wilson

Mason \& Hanger - Silas

Mason Co., Inc.

Amarillo, Texas

R. Brinkman

D. Colman

L. Haw

P. J. Kiefer

Monsanto Research Corporation

Miamisburg, Ohio

D. Anderson

H. Barnett

W. Benedict

B. Grumley

J. C. King

E. Kjelgaard

J. Marron

C. H. Mauldin

C. McCampbell

T. Tucker

J. Weber

Library

Sandia Laboratories

Albuquerque, New Mexico

G. Anderson

C. R. Barncord

C. Schoenfelder

B. Worden

D. Gregson

L. Guiterrez

R. Meinken

Library

Sandia Laboratories

Livermore, California

D. M. Zimmer

V. Calbi

Air Force Systems Command

Eglin Air Force Base

Florida

H. Frazier

Ammunition Procurement and Supply Agency

Joliet, Illinois 
External Distribution (continued)

S. Taylor

R. Fichelberger

R. Karpp

P. Howe

Ballistic Research Laboratories Aberdeen Proving Ground

Maryland

A. M. Weston

William M. Brobeck

and Associates

Berkeley, California

G. Dorough

R. Thorkelsen

Department of Defense,

Research \& Engineering

Washington, D. C.

R. Roberts

Off $\downarrow$ ce of Naval Research

Washington, D. C.

J. Hershkowitz

H. Matsaguma

L. Saffian

R. Walker

N. Slagg

H. Fair

Picatinny Arsenal

Dover, New Jersey

J. Ablard

H. Heller

M. Kamlet

C. Misener

Library

U.S. Naval Ordnance Laboratory

Silver Spring, Maryland

H. Gryting

D. Lind

N. Rumpp

R. Sewall

B. Stott

U. S. Naval Ordnance Test Station

China Lake, California

A. Amster

B. Drimmer

R. Beauregard

Naval Ordnance Systems

Command

Washington, D. C.

J. Osborne

Air Force Weapons Laboratory

Kirtland AFB, New Mexico
J. Bell

U.S. Atomic Energy

Commission

Berkeley, California

C. H. Smith

Bendix Corporation

Kansas City, Missouri

H. Kite

Union Carbide Corporation

Oak Ridge, Tennessee

Manager

U.S. Atomic Energy

Commission

Albưquerque, New Mexico

I. G. Gwillim

Atomic Weapons Research

Establ ishment

Aldermaston, Reading

England

C. A. Beck

Explosives Research and Development Establishment

Waltham Abbey, Essex

England

N. Griffiths

Royal Armament Research \& Development Establishment

Fort Halstead, Kent

England

J. A. Bell

Defense Research \&

Development Staff

British Embassy

Washington, D. C.

D. B. Janisch

Atomic Coordinating Office

British Embassy

Washington, D. C.

Technical Information Center

Oak Ridge, Tennessee

$\mathrm{VJE} / \mathrm{md} / 1 \mathrm{c}$ 